\title{
VIVIENDA SOCIAL Y CIUDAD
}

La morfología del espacio residencial destinado a la población de bajos ingresos en Bogotá y Medellín

TESIS DOCTORAL

MARIA FERNANDA URIBE TAMI

Arquitecta 


\section{VIVIENDA SOCIAL Y CIUDAD}

La morfología del espacio residencial destinado a la población de bajos ingresos en Bogotá y Medellín

\section{TESIS DOCTORAL}

Autor:

MARIA FERNANDA URIBE TAMI, Arquitecta

Director:

JOSÉ MARÍA EZQUIAGA, Doctor Arquitecto Codirector.

DORIS TARCHÓPULOS, Doctor Arquitecta 


\section{INTRODUCCIÓN}

Consideraciones iniciales

Pág. 12

Objeto de estudio, pregunta de investigación, objetivos, hipótesis y problema de investigación.

Pertinencia del análisis morfológico

Pág. 18

Marco conceptual del espacio residencial

La vivienda objeto de estudio en Bogotá y Medellín

Pág. 23

Identificación y selección de las áreas de investigación.

\section{LA VIVIENDA SOCIAL, UN PROBLEMA HISTÓRICO Y CRECIENTE}

1.1 Características del espacio residencial, la vivienda

1.1.1 Formas de producción y tipología edificatoria

Pág. 31

1.1.2 Mecanismos de ocupación o distribución del suelo

Pág. 40

1.1.3 Densidad

Pág. 46

1.1.4 Determinantes de la población residente

Pág. 48

1.2 Características del espacio público residencial

1.2.1 Zonas de amenaza ambiental

Pág. 55

1.2.2 Prestación de servicios públicos domiciliarios

Pág. 56

1.2.3 Equipamientos y espacio público

Pág. 56

1.2.4 Cobertura malla vial

Pág. 59

1.3 El problema de la calidad. Conclusiones Parciales

1.3.1 Las condiciones de habitabilidad de la vivienda social

Pág. 61

1.3.2 1997 Una forma de actuar diferenciada, supuestamente.

Pág. 66

Rasgos generales de un modelo propuesto de ordenamiento territorial

1.3.3 Los proyectos de mejoramiento de barrio (MIB) a la luz de los

Pág. 72 desarrollos nuevos de vivienda. Planteamiento de una hipótesis.

\section{LA CALIDAD COMO OBJETIVO. UNA PROPUESTA METODOLÓGICA}

2.1 Aproximaciones a la calidad urbana

2.1.1 Calidad del espacio residencial

Pág. 76

2.1.2 Enfoque de necesidades y derechos

Pág. 79

Constitución política de Colombia

Pág. 81

2.1.3 Posicionamiento de esta investigación frente a la noción de calidad

Pág. 88

2.2 Iniciativa en la medición de la calidad

2.2.1 Análisis de nueve metodologías de evaluación

Pág. 90

2.2.2 Herramientas claves sobre la metodología

Pág. 117

2.3 Modelo de evaluación e indicadores

2.3.1 Modelo de análisis

Pág. 121

2.3.2 Parámetros para la medición de la calidad

Pág. 124

2.3.3 Precisiones metodológicas

Pág. 128 
El instrumento, su validación, fuente de información y procesamiento de datos

2.4 Relación de indicadores

Pág. 132

I01 Densidades

Pág. 133

102 Cesiones

Pág. 135

103 Centralidades y tiempos de desplazamiento

Pág. 138

104 Acceso a transporte público

Pág. 140

105 Trazado de vías

Pág. 142

106 Estado de las vías

Pág. 145

107 Porcentaje territorio cubierto por equipamientos

Pág. 146

108 Porcentaje espacio público

Pág. 148

109 Conexión servicios públicos domiciliarios

Pág. 150

110 Condiciones ambientales

Pág. 152

I11 Morfo-tipología de la vivienda

Pág. 153

I12 Complejidad Urbana

Pág. 155

\section{EL ANÁLISIS MORFOLÓGICO DEL ESPACIO RESIDENCIAL.}

\section{Aplicación del modelo de evaluación}

3.1 Estructura urbana y ordenación

3.1.1 Ocupación del suelo

Pág. 159

3.1.2 Accesibilidad

Pág. 163

3.1.3 Movilidad

Pág. 165

3.2 Dotaciones y servicios públicos

3.2.1 Equipamientos

Pág. 168

3.2.2 Zonas verdes. Espacio recreativo

Pág. 172

3.2.3 Servicios públicos domiciliarios

Pág. 174

3.3 Condiciones ambientales

Pág. 176

3.4 Oferta y configuración del conjunto habitacional

3.4.1 Morfo-tipología

Pág. 178

3.4.2 Complejidad urbana

Pág. 184

3.5 Síntesis transversal y conclusiones parciales

3.5.1 Análisis relativo a la escala de ciudad

Pág. 188

3.5.2 Análisis relativo a la escala de barrio-zonal

Pág. 188

3.5.3 Análisis relativo a la escala de bloque-vecindario

Pág. 190

3.5.4 Margen de cambio social

Pág. 192

\section{CONCLUSIONES Y RECOMENDACIONES SOBRE EL AMPLIO E IRRESOLUTO SENTIDO DE LA CALIDAD}

Sobre el modelo de análisis y su posible contribución a la disciplina

Pág. 201

Sobre los resultados asociados a la calidad de la vivienda social en los estudios de

Pág. 203 caso

Sobre la hipótesis planteada

Pág. 208

Búsqueda de condiciones de calidad adecuadas

Pág. 210 


\section{CARTILLA DE ESTUDIOS DE CASO ANALIZADOS}

1.Vivienda nueva: Ciudadela Nuevo Occidente. Medellín

Pág. 218

2.Vivienda nueva: Ciudadela El Porvenir. Bogotá

Pág. 233

3.MIB Sur Con Bogotá. Bogotá

Pág. 247

4.PUI Nororiental. Medellín

Pág. 263

5.MIB EI Lucero. Bogotá

Pág. 278

6.PUI Centroriental. Medellín

Pág. 292

BIBLIOGRAFÍA

Pág. 307

SIGLAS UTILIZADAS

Pág. 314

ÍNDICE DE TABLAS, GRÁFICOS Y PLANOS

Pág. 315 


\section{RESUMEN}

El deterioro cualitativo del espacio residencial destinado a la población de bajos ingresos en las dos principales ciudades de Colombia, Bogotá y Medellín, lleva a reflexionar sobre las lógicas de configuración que se producen en dicho territorio. La naturaleza del modelo de ciudad que se venía implantado, su forma de producción y ocupación, había generado un escenario de necesidad, deficiencia y fragmentación. Sin embargo, hacia el año 2000, dicho problema es enfocando por primera vez desde un nuevo marco normativo, ley 388/97, con los Planes de Ordenamiento Territorial. Este ordenamiento definiría, en lo esencial, un modelo de ciudad "más eficiente" determinado por sus carencias en materia de vivienda, espacio público, infraestructura o equipamientos. El espacio residencial, asumido como un elemento estructural de la ciudad, sería abordado desde dos principales actuaciones o tratamientos (según denominación normativa): el desarrollo de vivienda nueva y el mejoramiento de barrio. El primero iría dirigido a la construcción de unidades habitacionales dentro del suelo urbano o de expansión, con la novedad de ser urbanizaciones de gran escala y con condiciones de espacio público más proporcionado (mayores áreas y mejor ubicación según normativa). El segundo tratamiento, por su lado, sería orientado a la regularización y mejoramiento de las condiciones urbanas (espacio público fundamentalmente) de los asentamientos marginales.

Ambos tratamientos serían trabajados de manera simultánea en el territorio a través unas políticas encaminadas a una configuración, supuestamente, adecuada y digna del espacio y la vida urbana. Sin embargo, los resultados diez años después sobre el tejido urbano que se produce son diferentes y los principios de calidad implantados no son los mismos.

El trabajo de investigación que aquí se presenta, propone entonces avanzar en la comparación de las condiciones de habitabilidad de estos dos tratamientos: mejoramiento de barrio y desarrollo de vivienda nueva en seis estudios de caso en Bogotá y Medellín durante los años 2000 y 2010. Los proyectos a estudiar en la capital son: Ciudadela El Porvenir, como proyecto de vivienda nueva, y MIB Sur con Bogotá y MIB EI Lucero como tratamiento de mejoramiento de barrio. En la ciudad de Medellín como desarrollo de vivienda nueva se analiza Ciudadela Nuevo Occidente y como mejoramiento de barrio PUI Nororiental y PUI Centroriental.

El objetivo del análisis es reconocer en estos proyectos cuáles han sido las determinantes urbanas y normativas que han configurado dichos espacios, si esas formas de intervención son realmente novedosas y en definitiva, si realmente producen unas mejores condiciones urbana. Se parte del principio que en ninguno de los casos estudiados se cuenta con un escenario óptimo o mínimo de calidad pero se conjetura que en los proyectos de mejoramientos de barrio se llega a estándares superiores a los de desarrollo de vivienda nueva después de su intervención. Para medirlo, se propone un modelo de evaluación sobre las condiciones de calidad basado en indicadores urbanos que permitan determinar eficientemente el nivel de habitabilidad de cada estudio de caso y ayuden a comprobar la efectividad de las políticas públicas en materia de vivienda social. Así, este trabajo aporta una metodología de análisis que posibilita el monitoreo y la comprensión de los factores objetivos a determinar sobre los aspectos formales de la vivienda social y su entorno.

Conforme con lo expuesto, éste estudio hace entonces tres grandes aportaciones. El primero es el método analítico mencionado basado en instrumentos normativos de carácter nacional e 
internacional que demuestra solidez en la definición de los indicadores y validez a la hora de analizar las condiciones de calidad urbana de la vivienda social en Bogotá y Medellín. El segundo, la demostración en los estudios de caso que parte de la producción de vivienda gestionada por el Estado no cumple con los requisitos mínimos de dignidad y adecuación al no satisfacer las necesidades de sus habitantes. Por último, el tercero es avanzar en la contribución sobre la escasa literatura que reúne y analice la normativa colombiana sobre la configuración morfológica de la vivienda social.

Los resultados muestran cómo la vivienda social es una necesidad aun desatendida en donde se privilegia un producto, precario, sometido a intereses particulares y voluntades políticas. La normativa parece estar rezagada en cuanto a la forma en que se involucra la población en su vivienda y su entorno y tiene una comprensión limitada de sus impactos en la práctica. Finalmente, el documento identifica la necesidad de una mejor comprensión de los marcos de gobernanza que incluyan a una gama de actores que normalmente se asociarían con la "precariedad o pobreza ". 


\section{ABSTRACT}

The deterioration process of low-income residential areas that the two main cities in Colombia, Bogotá and Medellín, leads to reflect on the logic of configuration that takes place in that territory. The nature of the city model that had been implanted, production and occupation, had generated a scenario of need, deficiency and fragmentation. However, towards the year 2000, this problem became the focus of the urban planning legal framework (Territorial Organization Plans) with Public Act 388 of 1997. Essentially, this new structure defines a "more efficient" model of the city, which is determined by deficient housing, public space, infrastructure or community facilities. In this framework, residential space is considered a structural element of the city and tackled through two main interventions: new housing development and neighborhood improvement. The first intervention is aimed at construction of large scale housing schemes, either within urban boundaries or as sprawling suburban developments, paying more attention to public space design (larger areas and better locations, according to the legislation). The second intervention is designed to regulate and improve urban conditions in marginal settlements (mainly public space).

Both interventions have been carried out simultaneously through policies that were envisaged to configure space and urban life deemed adequately. However, they had diverse impacts on urban fabric and the implemented quality principles were not always the same.

The research contributes to the further comparison of habitability conditions that resulted from the two interventions - neighborhood improvement and new housing development - in six case studies in Bogotá and Medellin during the 2000 and 2010. The aim is to identify which urban conditions and legislation have shaped these spaces; whether these forms of intervention are really innovative and lastly, whether they actually lead to better urban conditions. It is assumed that none of the cases represented an optimal or minimum quality scenario and it is conjectured that neighborhood improvement projects would reach higher standards than new housing developments. Therefore, we have introduced an evaluation model based on a set of urban indicators to efficiently determine the quality of habitability in each case study. This research provides an analytical methodology that made it possible to understand the actual factors that influence formal aspects of social housing.

This study makes three major contributions. Firstly, the analytical method based on national and international normative instruments that demonstrate solidity in the definition of indicators and validity by analyzing the urban quality conditions of social housing in Bogotá and Medellin. Secondly, case studies show, in order to improve habitants 'living conditions, low-income residential areas managed by the State does not meet the minimum requirements of dignity and adequacy. Lastly, the third is to advance the contribution on the scarce literature that collects and analyzes the Colombian regulations on the morphological configuration of social housing.

Results show how social housing is an unattended need; a precarious product is privileged to particular interests and political wills. The regulations seem to be lagging behind in terms of the way in which the population is involved in their housing and their environment and has a limited understanding of their impacts in practice. Finally, the document identifies the need for a better understanding of governance frameworks that include a range of actors that would normally be associated with "precariousness or poverty" 


\section{PREFACIO}

La motivación de este trabajo de investigación surge al observar la forma indiscriminada en la que se impone un modelo de ciudad, producida con una normativa nacional o municipal bajo un esquema de mercado que poco específica sobre las condiciones de calidad que el alojamiento social debería contemplar. Las características formales, funcionales y constructivas de la vivienda han estado supeditadas, desde hace años ya, a un interés económico en donde unos pocos pueden participar. La realidad como ciudadana y como profesional, ha sido la de encontrarse constantemente por fuera de las posibilidades de intervenir en esa situación. La solución nunca ha parecido estar al alcance de las manos de los ciudadanos o de los profesionales del sector.

Así, con una profunda determinación como ciudadana pero también como arquitecta y urbanista, se aspira a que este trabajo de investigación no se convierta tan solo en un documento académico más sino que al menos ofrezca una herramienta para comprender el medio en el que se desarrolla el espacio residencial para la población menos favorecida. Se considera que cualquier esfuerzo encaminado en profundizar sobre las condiciones del alojamiento social en Colombia puede contribuir en el ámbito profesional, académico o público a generar una actitud crítica y activa en el necesario mejoramiento de la calidad urbana. 


\section{Introducción}

Consideraciones iniciales

Pertinencia del análisis morfológico

La vivienda objeto de estudio 


\section{CONSIDERACIONES INICIALES}

El presente trabajo de investigación nace del interés académico por reconocer las condiciones de calidad del alojamiento social producido para las clases menos favorecidas, bajo el contexto de los Planes de Ordenamiento Territorial (de ahora en adelante POT) ${ }^{1}$, en las ciudades de Bogotá y Medellín. En ellos se formula una nueva ordenación de barrios e intervenciones a gran escala que intenta apartarse de los modelos territoriales anteriores para reducir así las profundas deudas sociales y urbanas acumuladas durante décadas en las ciudades.

La situación de precariedad del parque habitacional y su entorno dado por las peores ubicaciones y lo que ello conlleva: difícil accesibilidad, sin saneamiento básico, escaza dotación de servicios públicos, relación de espacio libre versus espacio construido deficitario, densidad habitacional elevada y una valoración por parte de sus habitantes insatisfactoria en términos de seguridad, identidad y apropiación, es puesta en la mira de las políticas públicas para determinar -se supone ahora sí de una buena vez- los diferentes niveles y prioridades de intervención para resolver dicho escenario. Para ello se introduce un marco legislativo, definido por la ley 388 de 1997 de Desarrollo Territorial, en el cual se efectúa una reforma del papel del Estado mediante el proceso de descentralización fiscal, administrativa y política de las entidades territoriales a órdenes municipales y locales. Son ahora ellas, las entidades, las encargadas de determinar las carencias en materia de vivienda, equipamientos, espacio público e infraestructura y dar, por medio de los POT, una respuesta desde el punto de vista cuantitativo y técnico funcional ${ }^{2}$.

Dos tratamientos son implementados, como esas "nuevas" formas de actuar, en materia de vivienda social para cada ciudad: desarrollo de vivienda nueva y mejoramiento integral de barrio.

El programa de vivienda nueva se desarrolla en parcelas urbanizables localizadas en suelo urbano o de expansión. Como programa está destinado a cubrir a las familias con capacidad de compra y/o de ahorro, es decir está orientado bajo la perspectiva del subsidio a la demanda ${ }^{3}$. La gestión está a cargo del Estado y la construcción la realizan los promotores privados.

La novedad en el tratamiento está en que el área mínima de desarrollo para la ejecución de un proyecto es de 10 ha de suelo urbano y 20 ha de suelo de expansión; lo que supuestamente

\footnotetext{
${ }^{1}$ El análisis se basa principalmente en la primera generación de POT, es decir aquellos que fueron formulados seguidos a la ley 388/97 y su primera revisión.

${ }^{2}$ Las autonomías municipales desarrollan su propia regulación, a través de los planes de ordenamiento territorial, planes parciales o normas urbanas, en la cual definen las características urbanísticas, arquitectónicas y constructivas, es decir las características de calidad y habitabilidad de las viviendas y su entorno. Calidad que como se explicará en los capítulos siguientes está simplemente determinada por el precio de la vivienda en el mercado.

${ }^{3}$ El subsidio a la demanda está definido en Colombia como un "aporte estatal en dinero o en especia entregado por una sola vez a un hogar beneficiario, que no se restituye y que constituye un complemento para facilitar la adquisición de vivienda nueva, construcción en sitio propio o mejoramiento de vivienda. (MINVIVIENDA)
} 
garantiza un tamaño suficiente para lograr "condiciones de urbanismo adecuadas" (ancho de vías, elementos dotacionales, mobiliario, etc.) pero que inmediatamente, lo ubica en la periferia de la ciudad. El programa introduce también novedades en cuanto al espacio público y las áreas de cesión. Prohíbe la localización de cesiones en zonas inundables o de pendientes mayores de $25 \%$, aumenta el área de parques y equipamientos ( $25 \%$ de área neta urbanizable como mínimo con un $8 \%$ para equipamiento comunal público y un $17 \%$ restante para parques, plazas, plazoletas y alamedas) e incorpora varias categorías de vías.

La nueva mirada física se orienta por lo tanto, a responder simultáneamente a una cierta racionalidad del espacio determinada por un marco jurídico y normativo en el cual se inscriben por primera vez las nociones de estructura urbana, zonificación y normas mínimas ${ }^{4}$ que hacen énfasis en aspectos de estandarización y funcionalidad.

El mejoramiento integral de barrio (MIB) permite, por su lado, regularizar los asentamientos marginales con el mejoramiento de todos los elementos o atributos de un área con déficit crítico en la espacialidad privada y pública, con condiciones muy precarias en el urbanismo y ocupación ilegal del suelo para la integración a la estructura de la ciudad. Incluye en la dimensión territorial, la "participación" de la población como eje estructurante (según la administración) para la posible sostenibilidad de las actuaciones y los recursos invertidos.

Aquí la novedad está dada por la asistencia técnica desde el Estado para la coordinación entre las diferentes entidades que va a intervenir en el territorio y por la disminución en el tiempo de la titulación de las parcelas por medio del cual un poseedor puede llegar a ser propietario. La gestión y ejecución está a cargo del Estado, salvo por el mejoramiento de vivienda en su interior que corre por cuenta de los propietarios o poseedores.

Así ambos tratamientos son aplicados de forma simultánea en el territorio como solución para dar un techo nuevo o mejorar las condiciones urbanas de la población de bajos ingresos. Sin embargo, la configuración del tejido residencial que se termina consolidando y las condiciones de calidad habitacional, en cada uno de los tratamientos, como parecería obvio son completamente diferentes. ${ }^{5}$ Se cree, no por su condición legal-marginal o por su condición planeamiento-espontaneidad sino por la lógica de intervención en el territorio por parte del Estado. De ahí que se considere pertinente preguntar:

- ¿Bajo qué modelo de ciudad se ha venido configurando el espacio residencial para la población de bajos ingresos en las dos principales ciudades de Colombia y cuáles han sido sus determinantes urbanos?

- ¿Trae cada tratamiento realmente una nueva forma de actuar en el territorio? ¿Se ha buscado llegar a las mismas condiciones de calidad?

\footnotetext{
${ }^{4}$ Estas son realmente reguladas posteriormente, en el año 2004, bajo el decreto 2060 que contempla las normas mínimas para vivienda de interés social urbana.

${ }^{5}$ Es importante mencionar que a nivel de políticas nacionales, la protagonista siempre ha sido el tratamiento de vivienda nueva de interés social o para sectores de bajos ingresos. "Aunque planteada como solución estrella, esta propuesta es, paradójicamente, también la que más ha fracasado en términos de expectativas, pues las metas propuestas no se han cumplido y los costos proyectados han sido mucho mayores, tanto para el Estado, como para los pobladores beneficiados".(TORRES 2009: 66)

En cambio, los lineamientos políticos del MIB han tomado fuerza. A pesar de que en dicha política han persistido las dificultades frente al tipo de intervención, la escala a operar, la viabilidad de los proyectos, la fuente de financiación y los costos que debe asumir la comunidad, ésta se ha tratado como la única vía posible para solucionar el problema de vivienda para alguna parte de la población.
} 
¿Cómo satisfacer una condición urbana de calidad en un contexto político en donde se presentan unas fuerzas de poder desiguales?

¿A qué motivaciones o intereses responde cada tratamiento? ¿Para quién va realmente dirigido? ¿Qué procesos sociales genera cada proyecto: equidad, seguridad, bienestar, desarticulación, exclusión, etc.? ¿Cuán sostenibles son los proyectos que se realizan por parte de las instituciones del Estado? ¿Qué acciones públicas se han encaminado a mejorar las condiciones económicas de las familias, teniendo en cuenta que estas darán soporte a los procesos sociales y territoriales impulsados?

Para responder estas cuestiones se parte de las siguientes hipótesis: Se presume que se produce una mejor calidad del espacio residencial en los asentamientos marginales después de la intervención de mejoramiento de barrio que en los proyectos de construcción nueva siendo en los dos deficitario-. Aun cuando estos últimos, los proyectos de vivienda nueva, por "iniciar de cero", por partir de un planeamiento urbano podrían contar con condiciones arquitectónicas y urbanas mejores.

Técnicamente los desarrollos nuevos cuentan con las aprobaciones reglamentarias. Se cumplen los estándares en materiales, construcción, iluminación, ventilación y tamaño (relativamente ${ }^{6}$ ). Se supone cuentan también con un espacio libre suficiente y en óptimas condiciones para proveer a la comunidad de zonas verdes, equipamientos, área de parqueo, andenes transitables, etc. Pero a diferencia de los mejoramientos de barrios, no cuentan en muchos casos con una implicación por parte de los habitantes que allí van a alojarse. Estos proyectos son construidos como un objeto de mercado anónimo y para quien pueda económicamente acceder a ellos. El espacio público que les "corresponde" además es construido hasta el final de cada proyecto, cuando es construido, porque no va a cargo de los promotores privados y no representa ninguna posibilidad de lucro dentro del proyecto de vivienda como tal. Los mejoramientos de barrio, en cambio, pretender ser incluyentes incluyentes, eso sí de una población en absoluta pobreza a la que no siempre se le ofrece las mejores posibilidades para mejorar su calidad de vida en general-. Como proyecto procura incorporar a la población en su derecho a la ciudad. Para ello se construyen equipamientos y espacios públicos con una cierta calidad urbana, redes de transporte público por tierra y por aire o se amplían las coberturas de servicios domiciliarios, entre otras. Esto no se ha visto que se promueva en los planteamientos de vivienda nueva, por qué.

Esa disparidad de lógicas de configuración y condiciones de calidad son lo que motiva al trabajo de investigación a realizar un análisis morfológico comparativo. Se trata de encontrar regularidades o contrastes en los trazados urbanos más significativos y sus componentes básicos (tipologías, intensidad de uso, reparto del suelo, características funcionales, entre otras). Interesa centrar la mirada especialmente en las condiciones urbanas, entendidas como el espacio colectivo, que va más allá de las unidades de vivienda y son escenarios de encuentros y actividades.

Para ello se plantea un objetivo doble. Por un lado, caracterizar la nueva morfología residencial que los POT proponen bajo una comparación de las formas de configuración urbana de los dos

\footnotetext{
${ }^{6}$ En algunos РОт se ha establecido, además del precio de la vivienda, una condición física determinada por un área mínima de parcela (33m2), la cual ha sido entendida maliciosamente en algunos municipios como el máximo obligado por la ley.
} 
tipos de tratamiento. Para ello se determinan las condiciones territoriales en las que se han venido consolidando los espacios residenciales en las dos ciudades de Colombia y los agentes que en ella han participado desde su ubicación, gestión, progreso en el tiempo, etc.; se revisan las formulaciones normativas con las que se desarrollaron los proyectos; y finalmente se identifican las diferentes maneras de organización física de los espacios residenciales.

Y por otro lado, elaborar un perfil de las condiciones de calidad urbana de los proyectos de alojamiento para establecer cuáles son los factores que determinan dicha calidad. Para ello, se establecen indicadores objetivos que identifican los aspectos formales de la vivienda y su entorno asociados a la calidad de la misma en términos de habitabilidad. La comparación entre los diferentes estudios de caso es lo que permite valorar dichas condiciones y evaluar el modelo de ciudad con los que fueron construidos.

El aporte disciplinar que aquí se propone es entonces el diseño de una metodología para evaluar la habitabilidad de los proyectos de vivienda de interés social, particularmente aquellos realizados bajo la regulación de los POT. El propósito es el de desarrollar una propuesta técnica que permita de manera objetiva reconocer la calidad de la vivienda. Si bien, como se verá en el capítulo 02 , en Colombia se han elaborado recientemente mecanismos de evaluación y de seguimiento de proyectos, éstos han estado enfocados hacia un solo tratamiento, vivienda nueva o mejoramiento, y han estado "condicionados", en alguna medida por la primacía de las reglas del mercado. ${ }^{7}$ Además, la evaluación, en general, no ha sido considerada como indispensable para producir procesos adecuados de gestión, planificación o ejecución de proyectos, y aún menos de proyectos de vivienda social con "escasa" disposición de recursos.

Cabe advertir que la intención de este trabajo no es el de hacer un listado de los problemas de habitabilidad, bien sean legales, habitacionales o funcionales de los proyectos objeto de estudio. No hay interés en señalar cada metro cuadrado de espacio verde que se debió o no construir o de recalcar cuantas viviendas fueron o no legalizadas. No. El interés es, como se mencionó anteriormente, el de reconocer unas condiciones de calidad dadas por unas formas de intervención específicas en un territorio. De ahí la importancia de hacer un énfasis en el carácter morfológico pues se cree, desde el campo disciplinar de la arquitectura y el urbanismo, el análisis más plausible para dar cuenta o revelar dichas condiciones de habitabilidad.

No sobra indicar también, que en dicho análisis no se está promoviendo la idea que existen unas condiciones urbanas más adecuadas o mejores en los asentamientos de origen marginal que en la vivienda social promovida por el Estado. Como bien se ha planteado en la hipótesis se presume se produce una mejor calidad del espacio residencial en los asentamientos marginales una vez son intervenido con el tratamiento de mejoramiento de barrio. Allí el cambio fundamental se da cuando se mejora el espacio físico de estos territorios (cambios que podrían ser del todo mejorados si contemplaran otros aspectos culturales o sociales aparte de los físicos).

\footnotetext{
${ }^{7}$ El enfoque de las evaluaciones ha estado principalmente centrado en la relación costo-beneficio o en un modelo de evaluación de objetivos y logros. Esto no es muy difícil de entender cuando en Colombia, como lo mencionan varios autores Ceballos (2003), Fique (2006) no existe aún una definición conceptual de lo que es la vivienda social y menos aún de las características de calidad que debe cumplir.
} 
Dicho todo ello bajo las nociones antes mencionadas, la estructura de la investigación que orienta el trabajo y sus resultados se presenta entonces en cuatro grandes capítulos. El primero "La vivienda social, un problema histórico y creciente" en donde se explora el modelo de regulación y los problemas de calidad en la vivienda en Colombia, específicamente en Bogotá y Medellín en las zonas en donde se proponen realizar los proyectos de vivienda nueva y mejoramiento de barrio. En el apartado 1.1 se exponen las características del espacio residencial como tal. Se enfatiza en las formas de producción de la vivienda social, la tipología edificatoria, los mecanismos de ocupación del suelo y las densidades que se alcanzan. Adicionalmente se hace un breve análisis de la población objeto de los dos tratamientos en cuestión. En el apartado 1.2 se describe el espacio público de dicha vivienda. Se realiza un breve análisis sobre las amenazas, riesgos y coberturas en infraestructura y dotaciones. Y finalmente en el apartado 1.3 se presentan unas conclusiones parciales sobre el problema de la calidad de la vivienda social hasta la implementación de los POT en cada ciudad y los supuestos cambios o formas de actuar que éstos formulan. Se hace un recuento histórico de la normativa hasta el año 2010 con sus disposiciones y sus nuevos planteamientos basados en el ordenamiento territorial.

En el segundo capítulo, "La calidad como objetivo. Una propuesta metodológica" se desarrollan los criterios de evaluación y comparación entre los seis estudios de caso para valorar las condiciones de calidad de cada proyecto y de los tratamientos propuestos por los POT. En el apartado 2.1 se señalan las iniciativas existentes en la medición de la calidad de la vivienda social propuesta para América Latina. En el apartado que le sigue, apartado 2.2, se expone, como el componente propositivo de la investigación, el modelo de evaluación e indicadores implementados. Se indican además los criterios bajo los cuales fue desarrollado el análisis numérico para medir, en la forma urbana, unas condiciones de calidad habitacional adecuadas. Y posteriormente, en el aparatado 2.3 se explica el método de aplicación.

En el tercer capítulo "La morfología urbana del espacio residencial" se exponen los resultados del análisis sobre las condiciones de calidad de los seis estudios de caso. Se aplica el modelo de evaluación y el sistema de indicadores para equiparar cada proyecto y así poder posteriormente compararlos y extraer resultados algunos sobre los factores asociados a la calidad de la vivienda. Adicionalmente, se presenta una cartilla al final del documento con los estudios de caso analizados. El objetivo de dicha cartilla es mostrar el estudio pormenorizado y la elaboración gráfica y numérica de cada uno de los estudios de caso seleccionados. Como cartilla tiene un carácter básicamente documental; su valor es el de permitir observar de manera sencilla el trabajo de homogenización de cada análisis. Ésta está conformada por dos partes. Una primera en donde se hace un reconocimiento al análisis morfológico: se explica su localización, contexto, estructura urbana, la ocupación de las manzanas y tipología edificatoria que se construyó y la gestión del suelo que se desarrolló. Y una segunda parte en donde se recogen y agrupan, por medio de fichas, los datos numéricos de cada proyecto y la valoración de sus condiciones de habitabilidad.

En el cuarto y último capítulo se expone la síntesis del trabajo de investigación comparando las condiciones de calidad de las actuaciones del Estado para los dos tipos de tratamientos. "Confrontar la calidad resultante en -los desarrollos de vivienda nueva y los mejoramientos de barrio- aporta información sobre los condicionamientos relacionados con la gestión, la espacialidad y la progresividad -sostenibilidad- de la vivienda, que pueden incidir en la calidad 
en términos de habitabilidad." (Tarchópulos y Ceballos, 2003: 10) Y a su vez conocer las diferentes disposiciones de la planeación urbana que ayudan a explicar los rasgos fundamentales de cada configuración en el territorio y su evolución en el tiempo. La investigación termina con un apartado final en el cual se desarrollan una serie de reflexiones, a manera de conclusión, sobre el tema en cuestión. 


\section{PERTINENCIA DEL ANÁLISIS MORFOLÓGICO}

El ámbito urbano es posiblemente uno de los conceptos más impreciso y relativo sobre el cual sigue persistiendo un debate importante sobre su definición, marco disciplinario o proyección operativa. La literatura disponible sobre el tema es extensa y pluridisciplinaria. Los estudios en sociología han relacionado la forma el espacio con los procesos sociales y, en algunos casos, el desarrollo económico. Los geógrafos, a lo largo del siglo XX, han hecho aportes muy importantes sobre su evolución y percepción. Los historiadores, por su parte han contribuido con innumerables estudios de caso sobre su formación. Reseñar aquí todos los campos o aproximaciones disciplinarias sería una labor exhaustiva y demasiado amplia para el interés de la investigación. Horacio Capel en su libro: "La morfología de las ciudades" hace un recuento importante de ello. Aquí para efectos del presente trabajo va a ser definido como la manera en que se estructuran los elementos materiales físicos (el medio urbano), en relación con las lógicas de organización en el territorio, es decir con los procesos sociales y normativos que en él se desarrollan. Es al mismo tiempo, como lo describe Horacio Capel un ámbito con dimensiones físicas, sociales y político administrativas que cualifican, nombran, producen y configuran dicho espacio.

"Lo urbano tiene muchas facetas, y por ello mismo es difícil su caracterización y definición. La ciudad es al mismo tiempo la urbs, la civitas y la polis. Es, en efecto en primer lugar, el espacio construido, y que posee características morfológicas que, en general, fácilmente podemos reconocer como "urbanas"(los edificios, las calles, una fuerte densidad de equipamientos y de infraestructuras), es decir, todo lo que los romanos designaban con la expresión urbs. Pero es también una realidad social constituida por los ciudadanos que viven en la ciudad, a lo que los romanos aludían al hablar de las civitas. Y finalmente es una unidad político-administrativa, del municipio al área metropolitana, es decir aquello a lo que los griegos se referían al hablar de la polis. Abordar los problemas de la ciudad significa referirse a la vez a las dimensiones físicas, sociales y político-administrativas". (Capel, 2002:10)

La dimensión física, el medio urbano como se mencionaba anteriormente, está constituida por cuatro complejos distintos de elementos" i) las calles y su asociación mutua en un sistema viario; ii) las manzanas delimitadas por calles y formada por agrupaciones de iii) parcelas individuales que sirven de soporte a los edificios y iv) las plantas. Son cuatro complejos que no existen aislados sino que tienen una dimensión espacio-temporal. Además no son estáticos, sino que tienen un dinamismo que afecta de forma diferente a los elementos que lo componen, cada uno de los cuales condiciona las relaciones físicas y significados funcionales de los otros. (Capel, 2002:71) En su conjunto constituyen el tejido urbano, el tejido residencial para este caso de estudio, formado por el parque habitacional, el espacio público aledaño (calles, avenidas, plazas, jardines de barrio), los edificios de usos complementarios destinados a equipamientos (equipamientos escolares, sociales, deportivos, y comerciales) y dotaciones de servicios urbanos imprescindibles. Su importancia deriva de su relevancia espacial pues constituye la mayor parte del territorio de cada ciudad ${ }^{8}$.

\footnotetext{
${ }^{8}$ Bogotá cuenta con 7.363 .782 habitantes de los cuales el $52 \%$ viven en estratos 1 y 2 y el $84 \%$ viven en estratos 1,2 y 3 . Medellín por su lado Encuesta de: Calidad de vida. Secretaría Distrital de Planeación (SDP, 2007)
} 
La dimensión social es, por otra parte, la realidad construida por los habitantes que viven en la ciudad y las instituciones que la conforman. Son el resultado de la acción de los agentes urbanos: habitantes, propietarios, poseedores, empresas inmobiliarias o Estado.

Interesa en cuanto desvela el conjunto de procesos con los cuales la sociedad produce la vivienda y su entorno y en ellos, los procesos, las decisiones tomadas por los diversos actores, principalmente en la formulación de planes parciales, que conducen a obtener las condiciones de calidad habitacional que preocupan en este trabajo.

La dimensión político administrativa es definida como las lógicas de organización económicas y políticas en los procesos de ordenación del territorio. Son las regulaciones que determinan las actuaciones institucionales a nivel local, municipal o estatal en el caso colombiano.

Capel (2002) afirma que la legislación y la normativa no son neutras y dependen de las estrategias de los diversos agentes en la producción del espacio urbano. Es un hecho que las decisiones en políticas públicas inciden en la formación del espacio y en sus condiciones de calidad. Sin embargo, en Colombia éstas han sido abordadas de forma separada y con concepciones restringidas. Las condiciones de calidad se han concebido como consecuencia lineal de fenómenos causales aislados y las políticas como normas abstractas, sin antecedentes ni autores y, por tanto, sin implícitos e intereses concretos. (Fique, 2006:9)

Ahora bien, la distinción de cada dimensión es considerada como algo más artificial que real, pues las tres están relacionadas entre sí. "Las formas espaciales han de ser tratadas no como objetos inanimados dentro de los cuales se despliegan los procesos sociales, sino como cosas que contienen procesos sociales en la misma medida en que los procesos sociales son espaciales. (Harvey, 1973:3). Son un sistema que interactúa. No obstante, es la dimensión física, la forma espacial la que aparece como punto de partida, bajo el enfoque de esta investigación, desde el cual se pretende captar algunos aspectos sobresalientes sobre la calidad de la vivienda social. No es objeto de esta investigación el estudio profundizado sobre las organizaciones sociales y las estructuras políticas que la estructuran.

Se cree necesario ahondar específicamente en una dimensión si se quiere extraer información alguna. El hecho de escoger como punto de partida la forma espacial es simplemente una decisión tomada a partir de la disciplina del urbanismo y la arquitectura que parte ésta investigación. Es una estrategia para poder llegar a resultados en el análisis aun reconociendo los límites de su alcance. Con ello no pretende ser ni excluyente ni universal en su aplicación, simplemente pretende lograr un grado de conocimiento tal que pueda servir al menos como línea directriz a la hora de medir la calidad en viviendas, barrios y entornos con las características antes descritas. Como lo describe David Harvey "En la práctica no nos queda más remedio que utilizar conjeturas de este tipo. Pero es importante reconocer que viene a ser como utilizar frágiles puentes para salvar el enorme abismo de un problema. (Harvey, 1973:44)

Encuadrado de esta manera el estudio de la morfología urbana se plantea entonces como un análisis desde la dimensión física: el medio urbano, en relaciones con las lógicas de ordenación en el territorio: dimensión normativa y social, capaz de revelar claves sobre la calidad de dicho espacio como se mencionó anteriormente. La atención que se ha dedicado al análisis arquitectónico y urbanístico de la vivienda social y su entorno es muy escasa. Su forma de agrupación y el tipo edificatorio, sus trazados y conexiones, su distribución de actividades y 
usos o el carácter de los espacios públicos, entre otros, son aspectos que apenas conocemos o analizamos en los esquemáticos dibujos de los planes parciales. Como hitos concretos aparecen edificios, por lo general equipamientos, diseñados por reconocidos arquitectos, totalmente descontextualizados, como simples objetos aislados dentro de un territorio ignorado y despreciado; un territorio que precisamente para el caso de estudio es el de la periferia, el de la población de bajos ingresos. (López De Lucio, 2004)

Barrios en lo alto de los cerros, masas de casas y bloques, superficies libres sin programas (muchas veces contaminadas) y grandes zonas de servicios son "elementos urbanos" en las que se puede reconocer las características de una materialidad concreta y las condiciones de calidad que éstas aportan. Su análisis morfológico, el de esa superficie de la ciudad, permite reconocer los elementos básicos que la configuran. Se plantea la voluntad de abrir el análisis al reconocimiento del espacio como un campo estrictamente más amplio que el simplemente físico. No basta con mirar qué se ha hecho en cada actuación por parte del Estado. No solo es necesario compararlos entre sí. Es preciso reconocer cuáles han sido los intereses que han motivado cada tratamiento, cuáles han sido sus márgenes de transformación o qué avances en las condiciones de calidad se han alcanzado dentro del marco de acotación de la investigación ${ }^{10}$.

\section{La calidad del espacio residencial en el análisis morfológico}

Ligado al análisis de la forma de la ciudad se plantea el análisis de calidad urbana, entendido como el estudio de las condiciones satisfactorias de habitabilidad del espacio residencial ocupado. Su definición hace referencia a parámetros óptimos referentes al medio construido, es decir a lo edificado y su entorno: cantidad de espacio público, saneamiento básico, servicios domiciliarios, accesibilidad, densidad, tamaño, unidad de viviendas entre otros. Según como esté construido el tejido residencial o como estén relacionados esos cuatro elementos antes descritos de calles, manzanas, parcelas y edificaciones se llega a cumplir o no esa optimización de las condiciones físicas urbanas.

Ahora bien, como lo explica Julio Alguacil (1998), dicha calidad urbana o calidad ambiental como él la denomina, hace parte de una noción de orden mayor o principal y es la de calidad de vida. Para el autor cuando nos referimos al concepto de calidad de vida estamos haciendo referencia a una diversidad de circunstancias que incluirían tanto dimensiones mensurables (objetivas), como otras de más incierta cuantificación (subjetivas) ${ }^{11}$. Esas dimensiones son:

\footnotetext{
${ }^{9}$ Se hace referencia a "elementos urbanos" para distinguirlos de las "cosas urbanas" denominadas así por Solá-Morales. Para este arquitecto y urbanista el estudio de las forma urbanas tiene una cierta autonomía del proceso urbanizador (formal, de iniciativa, económico, local y geográfico) en sí mismo. Planteamiento dispar al que se ha esbozado en esta investigación.

10 Queda para desarrollar en fututas investigaciones, los actores con sus motivaciones y decisiones, los desarrollos institucionales, el detalle del marco normativo y tantos otros temas en el marco de la vivienda social que condicionan su desarrollo y su calidad. Aquí por límite de recursos y tiempo no se pudo desarrollar.

${ }^{11}$ Salvador Rueda (2013:12) define el término igualmente bajo dos tipos de criterios. Uno derivado de parámetros referentes al entorno mismo: cantidad de espacio público, saneamiento básico, servicios domiciliarios, accesibilidad, densidad, tamaño, unidad de viviendas, etc.). El segundo se relaciona con la condición social de los habitantes y su valoración en términos de satisfacción con respecto a la seguridad, la tenencia, la integración o la interacción en su territorio y la ciudad.
} 
calidad ambiental, bienestar e identidad. Todas ellas conforman parte de un conjunto de valores y hechos que no se pueden disociar.

El bienestar es la satisfacción en la provisión de los bienes y servicios definidos como básicos o imprescindibles, como lo son: el empleo, la salud, la cultura y la vivienda. Por lo general, estos están garantizados por las instituciones del Estado y desarrollados en legislaciones específicas. Su grado de satisfacción (relativa) se mide por comparación a un nivel de referencia dado (nivel de vida). Algunos los indicadores correspondientes a esta dimensión son: la provisión y calidad del Empleo, la asequibilidad a la vivienda, la accesibilidad de los bienes económicos o la calidad de la estructura urbana (cobertura en salud, educación).

La identidad es el grado de intervención y apropiación de los individuos sobre su medio. Incluye, como definición, la participación que la sociedad puede ejercer sobre su ciudad (derechos políticos) y el uso del tiempo y del espacio que puedan realizar (vínculos e interacción social). Su grado de satisfacción (subjetiva) depende de la cobertura de sus necesidades creadas. Algunos de los indicadores de esta dimensión son: participación en la producción del espacio, formación de redes sociales, tiempo libre disponible entre otros.

Y finalmente la que atañe la investigación, la calidad ambiental, antes definida como condición satisfactoria del medio construido y su relación con el entorno, entendido por el autor entorno como lugar próximo o global en donde se consumen los recursos naturales, suelo, energía, tratamientos de residuos o aire. Está delimitada a distintas escalas: El ámbito doméstico, la vivienda y el vecindario: calidad y accesibilidad; el barrio, como entorno próximo, representativo de lo local; la ciudad, como el espacio de máxima complejidad accesible; y la huella ecológica, síntesis de la relación de lo urbano con el medio del que depende ${ }^{12}$.

Un concepto importante surge de éste enunciado: la sostenibilidad. La calidad urbana lleva implícito la idea de poder mantener unas condiciones habitables por un largo tiempo sin agotar sus recursos o causar daño al medio ambiente. Es decir el espacio residencial no solo debe cumplir con condiciones óptimas en términos formales, funcionales y constructivos sino que estos deben perdurar en el espacio y en el tiempo. Dos factores manejados por el mercado en Colombia que los desdeña como se analizará más adelante.

En consecuencia, esta definición acota una concepción de calidad urbana como una construcción compleja y multifactorial. Para poderse aproximar a ella es necesario desarrollar algunas formas de medición objetivas a través de un modelo de evaluación y una serie de indicadores. Esto requiere el empleo de un procedimiento sistemático a partir del cual se produzcan datos válidos y confiables. El procedimiento consiste en una revisión de trabajos enmarcados en los enfoques mencionados como referentes para la aproximación a la calidad de la vivienda social y una elaboración de un análisis numérico propio para la evaluación y comparación de los proyectos.

\section{Método de investigación}

Se propone un posible modelo de análisis metodológico para el estudio de la morfología urbana, sabiendo que "la realidad resiste a veces fuertemente al análisis" (Panerai, 1999:134).

\footnotetext{
${ }^{12}$ Ver definición completa de calidad de vida desarrollado en ALGUACIL, Julio (1998) Calidad de vida y praxis urbana: nuevas iniciativas de gestión ciudadana en la periferia social de Madrid.
} 
Se insiste en este punto que el análisis morfológico que aquí se indaga es el de las formas espaciales consideradas a partir de su configuración en el territorio. Con ello no se pretende desconocer en absoluto los elementos fundamentales de dicha configuración: los procesos sociales, tan solo se intenta aproximar a ellos para captar la lógica en función de los elementos. Las investigaciones de Muratori, Aymonino, Parenai, así como otros trabajos más recientes, afirman la necesidad de un conocimiento del objeto antes de pasar a su interpretación.

Se trata de construir y validar un modelo de análisis que dé cuenta de la morfología del espacio y finalmente de su calidad basado en el análisis de las soluciones de vivienda nueva y los mejoramientos de barrio ubicados en la periferia de las dos ciudades en cuestión. Los elementos propuestos constituyen un punto de partida, una serie de aproximaciones que, examinadas bajos los estudios de caso de las dos ciudades colombianas, podrán suscitar nuevas observaciones y comparaciones.

El espacio urbano es comprendido dialécticamente como un todo al que se trata de observar, de desglosar, de ordenar y de recomponer, pero también como un conjunto de elementos al que se trata de reconocer, de reunir y de articular. Es en la continua interacción de estos dos puntos de vista donde se sitúan estos análisis, aunque la conveniencia de la exposición (y la estructura lineal del razonamiento) nos obligue a presentarlo sucesivamente. (Panerai, 1999:22)

El gráfico a continuación permite identificar las partes de cada uno de los elementos centrales del modelo de análisis de las características formales del medio urbano, así como de las condiciones de calidad que las origina.

Para finalizar, es necesario mencionar que las ideas que se han presentado a lo largo de este apartado hacen parte de las reflexiones del trabajo de investigación y por lo tanto, puestas a discusión. El modelo es una propuesta, como pueden existir otras, para comprender las condiciones de calidad originadas por unas características formales de un medio urbano determinado.

Gráfico 01 Modelo de análisis básico

LA COMPRENSIÓN DE LA CIUDAD DESDE LA FORMA URBANA

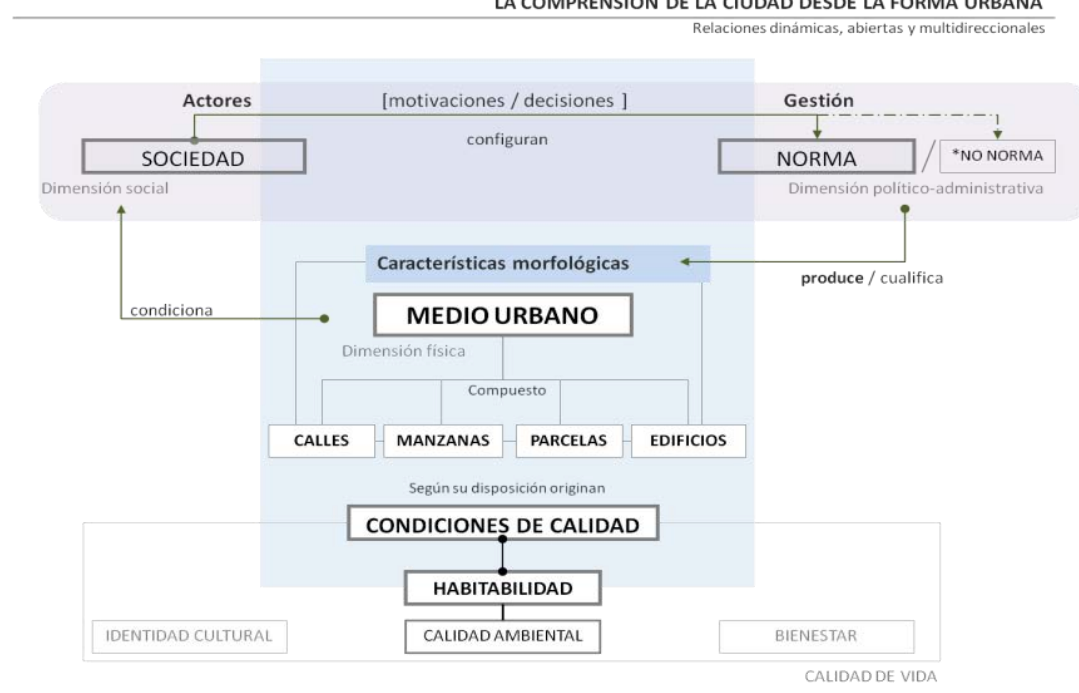

Elaboración propia 


\section{LA VIVIENDA OBJETO DE ESTUDIO}

El interés por trabajar la vivienda social en las dos principales ciudades de Colombia radica en el reconocimiento de su primacía urbana que a su vez repercute en su tamaño, términos demográficos, económicos y espaciales. Bogotá y Medellín, aparte de concentrar la mayor necesidad de alojamiento, originan una notable producción de vivienda (formal y marginal) y la canalización de recursos de una proporción considerable de los subsidios para los proyectos de vivienda nueva y mejoramiento de vivienda.

La capital colombiana es la ciudad con mayor población, cerca de 7 millones de habitantes, y mayor área del país con una superficie de $307,36 \mathrm{~km}^{2}$ en donde viven 1,9 millones de hogares en 1,7 millones de viviendas. Su población se divide territorialmente en estratos socioeconómicos $^{13}$ : los estratos altos representan el $18,4 \%$ y los estratos bajos, aquellos a quien va dirigida la vivienda social, representan el $81,6 \%$. Dicha mayoría de población es, en su conjunto, una población con bajos ingresos económicos no siempre capaz de hacer frente a los programas de crédito de vivienda nueva por parte del Estado y recurren, por lo tanto, a los asentamientos de origen marginal (equiparable prácticamente en su producción). Bogotá es la ciudad con la más alta densidad de personas con necesidades básicas insatisfechas (29,8\% de los hogares vive bajo el nivel de la pobreza y el $4 \%$ en la indigencia). El déficit habitacional para la ciudad es de 19,15\% (367.954hogares) (DANE, Censo 2005).

La producción formal de vivienda construye en promedio anual poco más de 19.000 unidades de vivienda social (VIS y VIP). Cifra que no alcanza a cubrir las necesidades de la ciudad pero que no por ello dejan de ser una gestión importante. Representa el $58 \%$ de la vivienda social construida en las principales ciudades de Colombia y se lleva casi el $70 \%$ de los subsidios. (CENAC - DANE, 2007)

Medellín, por su lado, es la segunda ciudad de Colombia según su tamaño de población, 2.499.080 habitantes según censo de 2005 y se disputa con Bogotá el primer lugar como centro industrial del país. Sin embargo, como en la capital, profundos problemas de desempleo, informalidad y exclusión social le impactan. Las cifras de los años recientes muestran el paulatino empobrecimiento de sus habitantes, donde la constante migración de desplazados por la violencia y la distribución inequitativa de los ingresos ha impactado negativamente a las comunidades, sobre todo de los sectores más pobres. $(12.07 \%$ de la población está por debajo de las necesidades básicas insatisfechas. (DANE, Censo 2005).

Para esta ciudad el déficit habitacional es de $14 \%$ (84.725 unidades de vivienda) y la producción de vivienda nueva es de 5.500 unidades correspondiente al 15\% de la producción principal del país y el $6 \%$ de los subsidios asignados por año. (CENAC - DANE 2007)

Dos escenarios con condiciones económicas, territoriales y sociales diferentes dentro de un país como Colombia pero que representan una situación de una población de bajos ingresos

\footnotetext{
13 Los estratos socioeconómicos en los que se pueden clasificar las viviendas y/o las parcelas son 6, denominados así: 1. Bajo-bajo 2. Bajo 3. Medio-bajo 4. Medio 5. Medio-alto 6. Alto. De éstos, los estratos 1, 2 y 3 corresponden a estratos bajos que albergan a los habitantes con menores recursos, los cuales son beneficiarios de subsidios en los servicios públicos domiciliarios y pueden acceder a subsidios para la vivienda social; el estrato 4 no es beneficiario de ningún subsidio; y los estratos 5 y 6 corresponden a estratos altos que albergan a los usuarios con mayores recursos económicos. La clasificación en cualquiera de los seis estratos es una aproximación a la diferencia socioeconómica jerarquizada de pobreza a riqueza. Fuente: DANE
} 
con una necesidad de vivienda social relativamente similar. Su comparación es posible dada la normativa estatal en materia de vivienda social que la regula, la ley 388 de 1997, a partir del cual se basa esta investigación.

\section{Selección de las áreas de estudio}

Para la selección de los estudios de caso se plantearon criterios que brindaran un panorama diverso, amplio y representativo de las condiciones de calidad de la vivienda social en las dos ciudades en cuestión y a su vez crearan una unidad de análisis posible para su evaluación y comparación. Así el enfoque adoptado para cada estudio delimitó que cada proyecto debía ser construido bajo un plan regulador (Plan Parcial o Plan Maestro) vinculado al POT de cada ciudad, Bogotá o Medellín, debía ser gestionado por parte del Estado y debía ser desarrollado como tratamiento de vivienda nueva o mejoramiento de barrio.

Plano 01 Ubicación casos de estudio Bogotá y Medellín

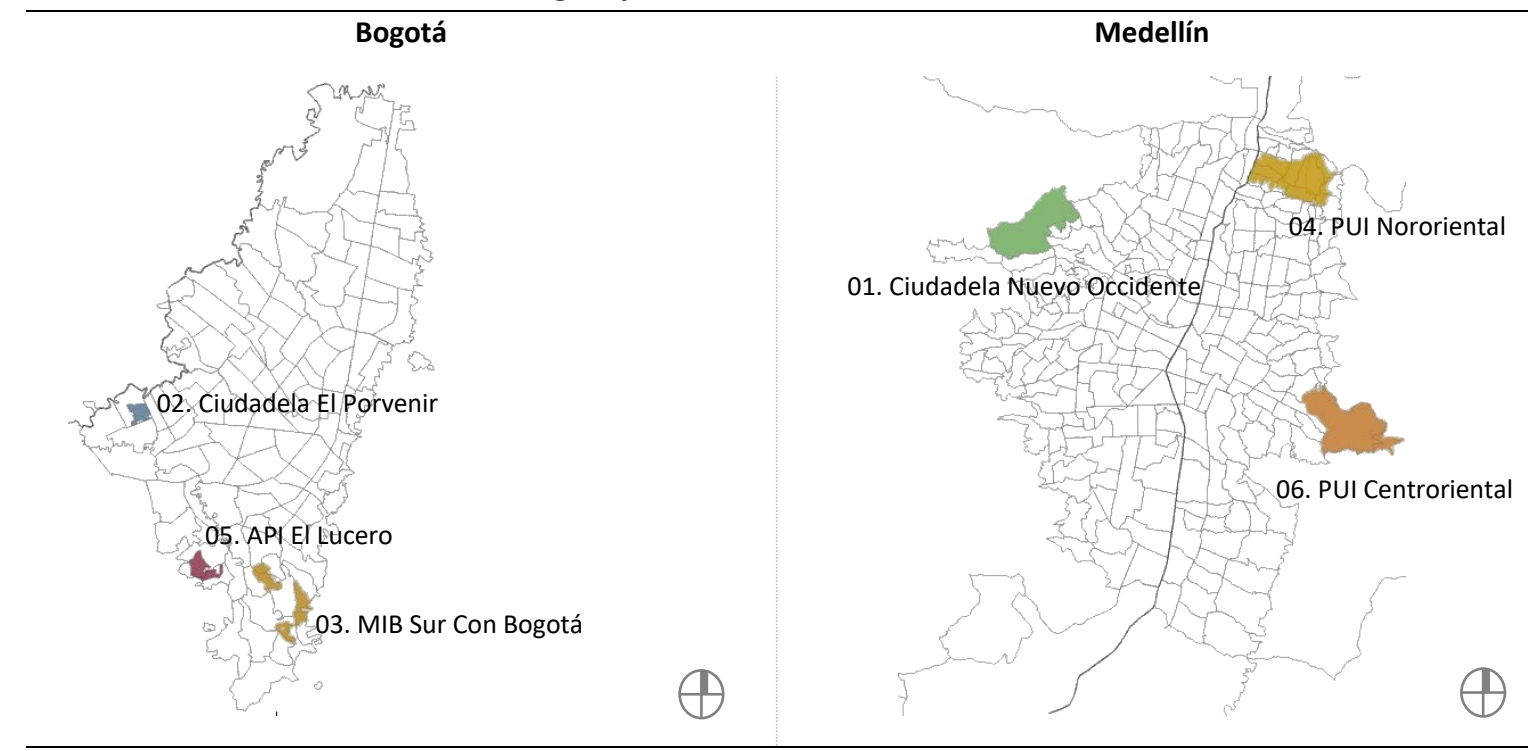

Elaboración propia

Para los proyectos de vivienda nueva, teniendo en cuenta las directrices promovidas por la Ley de Ordenamiento Territorial, de proyectos ubicados en parte en zonas de expansión, se seleccionó para Medellín la Ciudadela Nuevo Occidente y para Bogotá Ciudadela El Porvenir. Los rangos de elección para cada caso fueron i) La ubicación: periferia; ii) La magnitud del proyecto; iii) El rango económico de las soluciones de vivienda: vivienda de interés social (VIS) y vivienda de interés prioritaria (VIP); iv) Las tipologías edificatorias: unifamiliar, bifamiliar y/o multifamiliar y v) El grado de consolidación o ejecución del tratamiento mínimo del 50\%.

\section{La Ciudadela Nuevo Occidente}

La Ciudadela Nuevo Occidente está ubicada en la ladera occidental de Medellín en una zona de expansión urbana propiedad de la administración (dueña de hasta un $65 \%$ del terreno). Con un área de 236 hectáreas era un terreno con viviendas campestres, fincas de producción agrícola, parcelas sin uso y dos asentamientos marginales, Pedregal bajo y Pajarito Central. Su población aproximada, antes de la intervención, era de 2.000 personas de las cuales 1.845 se 
concentraban en los dos asentamientos. Actualmente cuenta con más de 20 urbanizaciones $^{14}$ con torres entre cinco y ocho niveles con apartamentos entre 45 y $47 \mathrm{~m} 2$ y más de 80.000 habitantes. La intervención contempla centros culturales, jardines infantiles, institutos académicos, un hospital y una red de infraestructura básica de malla vial (incluido metrocable) y servicios públicos domiciliarios.

El sector denominado Pajarito, a pesar de haber sido incorporado como parte del suelo urbano en el Acuerdo 01 de 1994, no se había urbanizado. Para ello se requería del desarrollo de una normativa territorial, Plan Parcial Pajarito (2002) y la voluntad administrativa para hacerlo. El suelo urbano para la urbanización se estaba agotando ${ }^{15}$, especialmente para los sectores de más bajos ingresos, y el sector de Pajarito era el terreno de expansión urbana más conveniente ${ }^{16}$.

El proyecto inició a principios del año 2002 y aún no ha sido terminado; muy posiblemente vaya tan solo en el $75 \%$ de su desarrollo. Durante todo este tiempo, éste ha sido enunciado en varios de los Planes de Desarrollo de los alcances elegidos y examinado por la modificación del POT en el año $2006^{17}$.

\section{Ciudadela El Porvenir}

Ciudadela El Porvenir se ubica en la localidad de Bosa, en el borde sur-occidental de la ciudad de Bogotá, sobre el margen del Río Bogotá. Su suelo, clasificado predominantemente como de expansión urbana, está conformado por 131,95 hectáreas distribuidas en 85 manzanas de las cuales 80 se destinan al desarrollo de vivienda unifamiliar y multifamiliar. Es un complejo urbanístico de grandes dimensiones proyectado para más de 85.000 moradores (en más de 21.000 unidades de vivienda) con plazoletas, parques, alamedas y equipamientos culturales y educativos.

La habilitación de su suelo, considerado antes del proyecto una reserva de tierras propiedad del Distrito destinada al desarrollo formal de vivienda social, implicó la ejecución de todas las obras de urbanismo que incluían vías de carácter urbano y local, la adecuación y construcción de las zonas verdes, la adecuación del suelo para los equipamientos y la construcción de las redes de servicios públicos (acueducto y alcantarillado sanitario y pluvial, las redes de gas, energía y teléfono). Dicha implicación era de carácter obligatorio pues el contexto de la ciudadela era principalmente residencial de origen marginal con grandes problemas de infraestructura, movilidad, déficit de espacio público y equipamientos urbanos

\footnotetext{
14 Dentro de urbanizaciones realizadas se encuentra La Villa Suramericana proyecto que fue concebido y desarrollado con un doble propósito: alojar a los aproximadamente 3.500 atletas y delegados que participaron en los IX Juegos Suramericanos Medellín en el año 2010 (como una Villa Olímpica) y convertirse posteriormente en el hogar de 621 familias (propietarios) de bajos ingresos. Como modelo innovador de gestión y financiamiento fue seleccionado en el Concurso de Buenas Prácticas patrocinado por Dubai en 2012, y catalogada como BEST. (Best Practices Database) En red: http://habitat.aq.upm.es/bpal/onu12/bp4439.html [Consultado: Octubre de 2015]

${ }^{15}$ De 1.513 hectáreas aptas para vivienda social en 1981, se pasó a 620 ha en 1984 y 257 ha en 1990.(Torres 2009:127)

${ }^{16}$ El territorio municipal asciende a 37.621 hectáreas y está compuesto por 10.210 ha. de suelo urbano (27,1\% del total), 401 ha. de áreas de expansión urbana $(1,1 \%)$ y 27.010 ha. de suelo rural $(71,8 \%)$, de acuerdo con la clasificación del suelo definida en el Plan de Ordenamiento Territorial. Para aquel entonces los suelos de expansión serían: Sector pajarito, El Rincón, Altos de Calasanz, El Noral, Altavista y el corregimiento de San Antonio de Prado.

${ }^{17}$ Modificado por el Acuerdo 46 de 2006 y Acuerdo 48 de 2014 (Departamento Administrativa de Planeación. Medellín)
} 
Todo el proceso de planeación, comercialización y ejecución ha estado regulado por el Plan Parcial El Porvenir (Decreto 395 de $2002^{18}$ ) y ha cumplido lo dispuesto en el POT (Decreto 619 de 2000$)^{19}$. Cabe aquí mencionar que éste es el primer proyecto distrital, gestionado por Metrovivienda, que se realiza por completo bajo las pautas técnicas, económicas y de gestión del POT. Si bien Metrovivienda ya había realizado dos proyectos anteriores, Ciudadela El Recreo y Nuevo Usme, éstos habían sido desarrollados bajo las normas del acuerdo 6 de 1990 y tan solo con el paso del tiempo y la entrada en vigor de la normativa territorial, se complementaron con las exigencias del POT.

Para los proyectos de mejoramiento de barrio se escogieron las experiencias locales de Medellín y Bogotá con mayor impacto que han sido consideradas exitosas a nivel nacional y en algunas ocasiones premiadas a nivel internacional. Cuatro estudios de caso fueron seleccionados, dos que hubieran entrado en vigor con los principios reguladores iniciales del POT de cada ciudad, PUI Nororiental en Medellín y Proyecto "Sur Con Bogotá" y dos que estuvieran siendo ejecutados actualmente, PUI Centroriental y API EI Lucero.

Los criterios de selección que se tuvieron en cuenta debían ser similares a los criterios de selección de vivienda nueva para permitir así su posible comparación posterior. Estos fueron: i) La ubicación: periferia de la ciudad; ii) La magnitud del proyecto; iii) El rango económico de la población en donde se realizara el mejoramiento de barrio); iv) El tipo de intervención: enfoque principalmente físico, y v) El grado de consolidación o ejecución del tratamiento. Adicionalmente, se supedito la selección a casos que fueran considerados de actuación o intervención primordial en las dos ciudades

\section{Proyecto de Mejoramiento Integral de Barrios "SUR con Bogotá"}

El proyecto MIB "Sur con Bogotá" fue una de las primeras experiencias de mejoramiento de gran escala ejecutadas entre el año 1997 y el 2006. Fue impulsada por el Departamento Administrativo de Planeación Distrital (DAPD) y la Empresa de Acueducto y Alcantarillado de Bogotá (EAAB) en cooperación con el Gobierno alemán, a través del Kreditanstaltfiir Wiederaufbau (KFW) para optar por la legalización de barrios. Su objetivo principal se planteó contribuir al mejoramiento sostenible de la calidad de vida de una población $(85.000$ habitantes) en altas condiciones de pobreza en 41 barrios próximos al Parque Entrenubes en las localidades de San Cristóbal, Usme y Rafael Uribe Uribe.

La intervención proponía, con una visión de áreas estratégicas a nivel físico, social e institucional, la construcción de obras en redes de infraestructura (calles y caminos, agua y alcantarillado) y equipamientos urbanos de gran envergadura (colegios, espacios públicos, parques y áreas de recreación), el desarrollo social y comunitario, la capacitación para la autogestión de las comunidades y el perfeccionamiento de un modelo replicable de MIB.

Este proyecto fue seleccionado en el año 2006 dentro del concurso de Buenas Prácticas, Dubái y catalogado como GOOD. ${ }^{20}$

\footnotetext{
${ }^{18}$ Decreto que posteriormente ha sido modificado por el Decreto 366 de 2006, Decreto 604 de 2007 y Decreto 355 de 2014.

${ }^{19}$ Modificado por el Decreto 469 de 2003 y Decreto 364 de 2013 (Departamento de Planeación Distrital. Bogotá)

${ }^{20}$ En red: http://habitat.aq.upm.es/bpal/onu06/bp1323.html [Consultado Octubre 2015]
} 


\section{PUI Nororiental}

El Proyecto Urbano Integral Nororiental está localizado en un sector periférico de la ciudad de Medellín en las comunas 1 y 2 . Como proyecto nació de la oportunidad para desarrollar, en el área de influencia del metrocable -primer sistema de transporte masivo que se construía para la ciudad-, un plan de intervención que contemplara acciones físicas soportadas por un nuevo modelo de gestión social e institucional. El objetivo era intervenir en las áreas de influencia de las estaciones del mismo para recuperar el espacio público, construir equipamientos y adelantar proceso de regularización, legalización y mejoramiento del entorno y la vivienda ${ }^{21}$.

El proyecto benefició a más de 150.000 habitantes de estratos 1 y 2 de once barrios de las dos comunas. En él se construyeron equipamientos colectivos tales como el parque biblioteca España, depósitos de buses, estaciones de policía, salas de navegación por Internet, un centro de desarrollo empresarial (CEDEZO), la adecuación y mejoramiento de determinados restaurantes escolares, centros de salud, centros educativos y escenarios deportivos. También se adecuaron los espacios públicos con la construcción de plazas y plazoletas (se pasó de $1 \mathrm{~m}^{2} /$ hab. a $1,48 \mathrm{~m}^{2} /$ hab.). Se realizaron acciones en conservación, rehabilitación y prevención ambiental. Y finalmente se promovió la continuidad en la movilidad peatonal a partir de la conexión entre vías y la construcción de puentes peatonales y vehiculares (8 puentes en total).

A nivel normativo el PUI en sí mismo no es una figura que esté regulada ni a nivel nacional ni a nivel local por un marco jurídico especial; no está contemplado en el POT. Es un proyecto estratégico contenido dentro de un Plan de Desarrollo, para el caso del PUI Nororiental el Plan de Desarrollo de 2004-2007. Se ha desarrollado como un instrumento de intervención contundente a corto plazo para un periodo administrativo. Sin embargo su efectividad ha sido tal, que el territorio en donde se ha efectuado la intervención ha sido reconocido posteriormente en la normativa, bajo tratamientos de mejoramiento de barrio o de consolidación. Única manera para garantizar un modelo y una intervención sostenible a mediano y largo plazo.

\section{MIB EI Lucero}

La Unidad de Planeación Zonal (UPZ) El Lucero está localizado en la localidad de Ciudad Bolívar en el sur de la capital. Es un sector periférico de la ciudad con uso residencial predominante de estratos 0,1 y $2(22,6 \%, 61,5 \%$ y $15,9 \%$ respectivamente). Antes de la intervención en la zona se observaban deficiencias en servicios públicos, accesibilidad, equipamientos y espacio público, deterioro de las áreas de la estructura ecológica y precariedad de títulos y de habitabilidad de las viviendas. Además, los hogares existentes presentaban un nivel de pobreza $(41 \%)$ y de miseria $(12,4 \%)$ elevado con problemas relacionados de convivencia y seguridad (violencia, maltrato intrafamiliar, presencia de actores armados y consumo de sustancias psicoactivas entre otras).

\footnotetext{
${ }^{21}$ Como parte de los proyectos de consolidación habitacional, en unos pocos casos fue necesario reasentar a la población en vivienda nueva. Para ello se desarrolló el conjunto habitacional Juan Bobo experiencia seleccionada en el Concurso de Buenas Prácticas patrocinado por Dubai en 2008, y catalogada como AWARD. En red: http://habitat.aq.upm.es/bpal/onu08/bp1982.html [Consultado Octubre 2015]
} 
La vocación del programa MIB se centró entonces en dos variantes la física y la social. En la física se mejoró la accesibilidad con la pavimentación de 31 segmentos viales, se recuperaron parques y zonas verdes, se construyeron equipamientos, se recuperaron las zonas hídricas y rondas de rio y se mejoraron los escenarios de vivienda de algunos hogares. En lo social se fortaleció las condiciones de seguridad y convivencia a través del Programa Sur de Convivencia con las diferentes entidades distritales que actúan en la zona. Dicha experiencia interinstitucional le otorgó en reconocimiento de "Buenas Prácticas en el Mejoramiento del Hábitat” del distrito en el año 2014.

\section{PUI Centroriental}

El proyecto urbano de regularización y legalización de las comunas 8 y 9 , denominado PUI Centroriental está ubicado en la zona oriental parte alta de la ciudad de Medellín. Se enmarca dentro del programa de "Mejoramiento Integral de Barrios" del POT de la ciudad cuya perspectiva de intervención se "orienta a brindar igualdad de oportunidades de desarrollo social y económico a los diversos grupos humanos, mediante la gestión político administrativa y las actuaciones urbanísticas públicas y privadas para elevar la calidad de vida de sus moradores". (Resolución 0065 de 2009)

Las actuaciones físicas, iniciada en el año 2009, han estado dirigidas a la mejora y creación de espacio público, como eje estructurante del territorio, a la edificación de equipamientos, a la construcción de una red vial (que conecte la zona a la única vía de acceso) y a la recuperación de los sistemas orográficos e hidrográficos. Adicionalmente se ha propuesto un conjunto habitacional para delimitar el borde urbano con en 1376 parcelas de vivienda nueva y 1014 nuevos bloques multifamiliares. Actualmente la ejecución del proyecto tan solo va en el $50 \%$.

A continuación, se presenta un cuadro comparativo con los seis estudios de casos seleccionados y los criterios con los que fueron valorados. Cabe especificar que a pesar de la unidad que representan, surgen inevitablemente algunas variantes, originadas en las diferencias entre las dos ciudades en sus condiciones generales, en las prioridades en las políticas de desarrollo adoptadas para cada una de ellas o en su disponibilidad de información. 
Tabla 01 Comparación criterios de selección estudios de caso

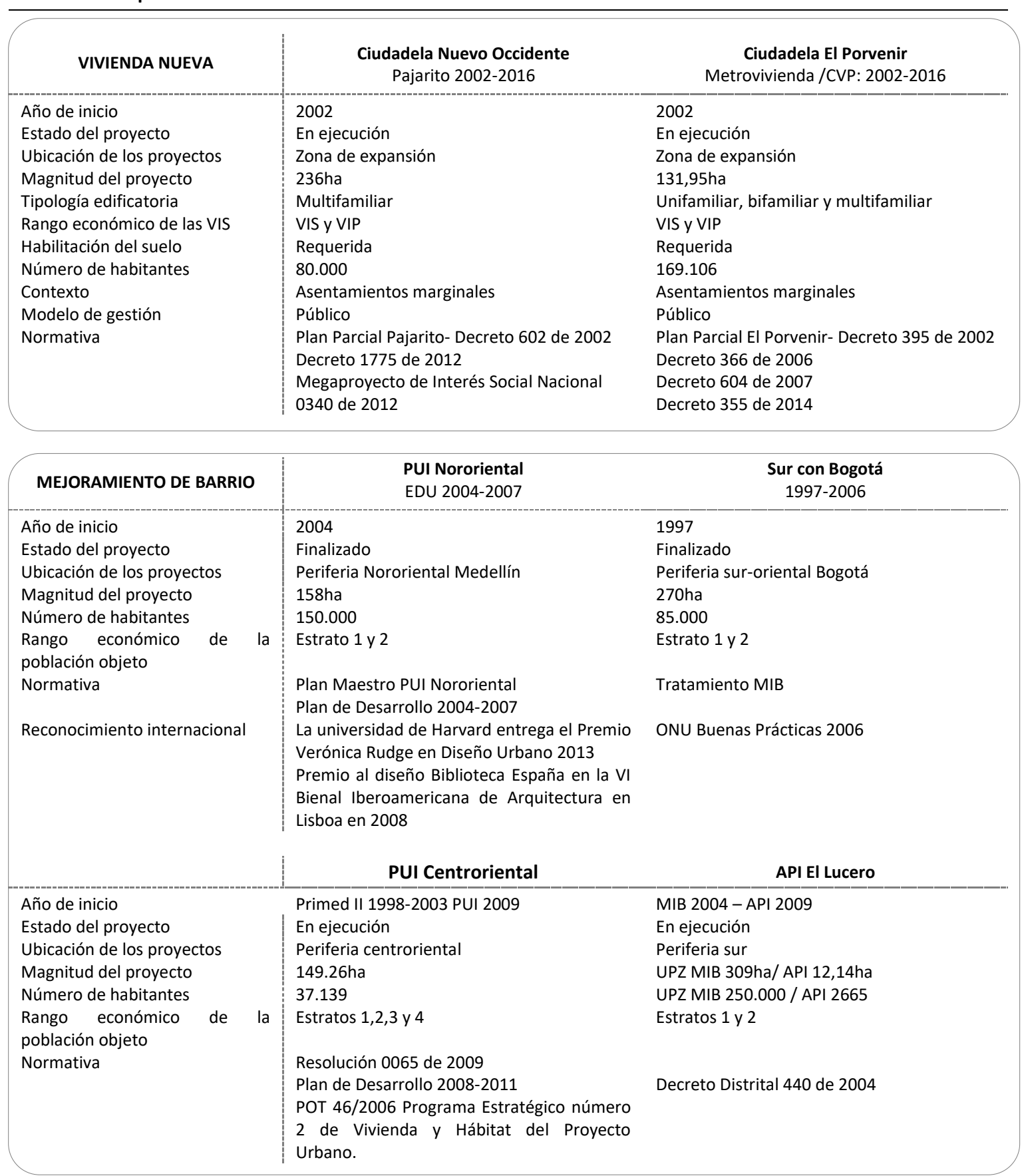




\section{LA VIVIENDA SOCIAL, UN PROBLEMA HISTÓRICO Y CRECIENTE}

Características del espacio residencial, la vivienda Características del espacio público residencial

El problema de la calidad. Conclusiones Parciales 


\section{LA VIVIENDA SOCIAL, UN PROBLEMA HISTÓRICO Y CRECIENTE}

El conflicto de la vivienda social es sin duda uno de los más grandes problemas urbanos de Colombia. "Involucra una multiplicidad de elementos que se conjugan de manera simultánea, tales como las políticas públicas, la economía interna, los asuntos macroeconómicos, las practicas fiscales, las formas de operación del sector financiero y los agentes privados; las prácticas del sector inmobiliario y de la construcción; las condiciones socioculturales de los habitante, los fenómenos derivados de la dificultad interna que genera el desplazamiento forzado de población del campo a la ciudad, el aumento de la pobreza y la miseria y el incremento de los desequilibrios generados por la brecha entre riqueza y pobreza entre otros." (Torres, 2012:50) Todos ellos conforman un conjunto de factores que se asocian inevitablemente a una necesidad insatisfecha de vivienda, que en un momento y en un territorio dado genera diferentes modalidades de producción de ciudad: La producción formal y la producción marginal.

Ambas modalidades de urbanización interactúan simultáneamente en el mismo territorio para toda la población de más bajos ingresos. Sin embargo, la forma en la que ha sido abordada por parte de las instituciones del Estado, en términos de desarrollo de vivienda nueva para la producción formal (políticas de vivienda social) o en términos de legalización y regularización para la producción marginal (políticas de mejoramiento de barrios), se ha dado por separado. Nunca se ha advertido como un proceso único, o integral, que condiciona la calidad de la vivienda social, vivienda y entorno, para dicha población en general.

El presente análisis del contexto del espacio residencial esboza las características de la vivienda con sus formas de producción y tipología edificatoria, su ocupación del suelo y sus densidades y el espacio público colectivo, ese entorno de las viviendas con equipamientos, servicios y espacios de ocio para esos dos procesos de urbanización. Vincula la producción formal y la marginal como una lectura global de la calidad del espacio residencial para la población de bajos ingresos. Se hace además un énfasis en la descripción de los casos de estudios antes de haber sido intervenidos con las propuestas de vivienda nueva o mejoramiento de barrio. Con el examen detallado de estos territorios, se pretende posteriormente reconoce la influencia directa mediada por las decisiones, tomadas u omitidas, y métodos de materialización de las políticas públicas (Planes de Ordenamiento Territorial) que han consolidado los procesos de producción de la vivienda social y sus condiciones de calidad habitacional.

\subsection{CARACTERÍSTICAS DEL ESPACIO RESIDENCIAL, LA VIVIENDA}

\subsubsection{Formas de producción y tipología edificatoria}

La producción del alojamiento social en Colombia, concretamente en Bogotá y Medellín, se puede caracterizar según los procesos urbanos que la configuran y su gestión. Doris Tarchópulos y Olga Lucía Ceballos en su libro "Patrones Urbanísticos y Arquitectónicos en la vivienda dirigida a sectores de bajos ingresos en Bogotá" la clasifica así: producción formal, subdividida en producción de origen normal y producción en la gestión de origen institucional, y producción de origen clandestino o marginal. Al efecto de la revisión interesa dicha distinción 
desde las condiciones en que los habitantes tienen posibilidades para acceder a su alojamiento y desde los procedimientos que los productores ponen en juego para producirlo.

- La producción de origen normal o privada es "una unidad de gestión urbana que cumple las normas correspondientes y obtiene la licencia de urbanismo como condiciones previas a la ejecución del desarrollo por parte del promotor privado. Tanto su construcción como la adquisición de la vivienda son financiadas por la banca privada. El promotor es el directo responsable de su producción siguiendo las normas urbanas." (Tarchópulos y Ceballos, 2005:47) Normas ${ }^{22}$ que solo han regulado la parcela como unidad de gestión junto con el plan vial y las zonas de cesión para equipamientos y zonas verdes pero no han especificado condicionantes de calidad.

Su tipología arquitectónica se caracteriza por ser una unidad de alojamiento mínima desarrollada en una vivienda unifamiliar, bifamiliar o en multifamiliares en altura. Ésta última es representativa tan solo para la clasificación más alta o tope más elevado del valor establecido para éste tipo de viviendas. La forma de producción es realizada por grandes empresas que utilizan alta tecnología, con intervención de numerosos actores (financieros, urbanizadores, agentes de bienes raíces, etc.) en los procesos de construcción y venta en un suelo de alto valor económico. La vivienda se convierte en un producto caro y no asequible para la población de bajos ingresos ${ }^{23}$.

El proceso urbano de este tipo está caracterizado por la construcción sucesiva de la urbanización, parcelación y edificación, típico en los procesos planificados.

- Los desarrollos de gestión estatal son "aquellos que promueven y financian (por medio de subsidio a la demanda ${ }^{24}$ ) las instituciones de vivienda de carácter nacional o local, mediante la realización de programas encaminados a promover alojamiento para la población de más bajos ingresos." (Tarchópulos y Ceballos, 2005:48). Se caracterizan por ser crecimientos planificados con una normativa urbanística y arquitectónica generada por las mismas instituciones que no siempre logra índices de calidad suficientes. Algunos desarrollos tienen problemas con la dotación del espacio público, los equipamientos o su conexión con la ciudad; solo tienen resuelto los servicios públicos y las características geotécnicas del suelo.

En cuanto a la tipología de éstas unidades habitacionales existen dos modalidades, la vivienda en altura marginada según motivaciones políticas y muy poco generalizada hasta principios del

\footnotetext{
${ }^{22}$ Las principales regulaciones que definen las condiciones de la vivienda social para el periodo de investigación $2000-2010$ son: +La ley 3 de 1991 por la cual se crea el Sistema Nacional de Vivienda de Interés Social en Colombia. En ella se establece principalmente el subsidio familiar, el precio tope de las soluciones de vivienda, el ingreso de la población objeto. +La ley 388 de 1997, ley de Desarrollo territorial por medio de la cual se establece

+ Y el decreto 2060 de 2004 en donde el Estado establece Normas Mínimas para la vivienda de interés social urbana con parámetros generales en materia de diseño: área de la parcela mínima, áreas libres, continuidades viales, etc.

Todas ellas definen la vivienda con parámetros relacionados con precios máximos de las viviendas, las posibilidades de acceso a créditos o la suma de fondos por parte del Estado y no con condiciones de habitabilidad, confort, bienestar o satisfacción por parte de sus moradores.

${ }^{23}$ Cabe mencionar que para el año 2009, más del $70 \%$ de la población contaba con ingresos menores a $4 \mathrm{smmlv}$ y más del $47 \%$ con ingreso menores a $2 \mathrm{smmlv}$; de manera que la vivienda tenía un precio que representaba cincuenta o treinta veces el ingreso mensual de una familia. (Fuente DNP Conpes 3583 de 2009). Es decir, existía la necesidad del bien, la vivienda, pero la población de más bajo poder adquisitivo no podía aspirar a ella debido a la inestabilidad ocupacional, por encontrarse desempleados o subempleados, por ser vendedores estacionarios o ambulantes o asalariados con el ingreso mínimo legal.

${ }^{24}$ EL Subsidio a la demanda está definido en Colombia como un "aporte estatal en dinero o en especia entregado por una sola vez a un hogar beneficiario, que no se restituye y que constituye un complemento para facilitar la adquisición de vivienda nueva, construcción en sitio propio o mejoramiento de vivienda. (MINVIVIENDA)
} 
siglo XXI con la entrada en vigencia de los POT, y la vivienda baja de alta densidad desarrollada como vivienda procesos: autoconstrucción dirigida o vivienda básica de desarrollo progresivo y vivienda producto denominada vivienda mínima. ${ }^{25}$ Los dos tipos están determinados por las normas mínimas establecidas, que son las mismas normas que para la producción privada, pero no siempre exigidas o seguidas. El diseño y edificación está a cargo de los promotores inmobiliarios y las empresas constructoras que finalmente, bajo la lógica del mercado, producen y ofertan una mercancía.

Su proceso, como desarrollo planificado, se caracteriza por la realización de la urbanización y parcelación en una primera instancia y posteriormente la edificación, cuya construcción en algunos de los casos es postergada para que sea completada por los propietarios. Su ejecución es realizada por un promotor privado quien desconoce al morador hasta que vende la vivienda.

Estos dos tipos de producción están originalmente dirigidos al desarrollo de vivienda nueva catalogada como vivienda de interés social (VIS) y vivienda de interés prioritario (VIP). Ésta está definida por la normativa mínima de vivienda social ${ }^{26}$ que establece los precios máximos en función de subsidio al cual puede acceder cada familia u hogar. Así la VIS está definida como aquella cuyo valor máximo es de 135 salarios mínimos mensuales -de ahora en adelante smmlv- (tipo 3: $70<100 \mathrm{smmlv}$ y tipo $4100<135 \mathrm{smmlv}$ ) y la VIP como aquella cuyo valor máximo no debe superar los $70 \mathrm{smmlv}$ (tipo 1: $>50 \mathrm{smmlv}$ y tipo $250<70 \mathrm{smmlv}$ )

Finalmente, los asentamientos de origen marginal ${ }^{27}$ son "aquellos que se caracterizan generalmente por la parcelación, venta y ocupación de terrenos no edificables por fuera de los límites administrativos, al margen de las prácticas urbanísticas corrientes. " (TARCHOPULOS 2005:47) Su producción se da por medio de dos situaciones diferentes. La primera, cuando existe una parcelación irregular o clandestina en la que se adquiere una propiedad. Está definida por parcelas y una malla vial indispensable para la venta pero no cumplen siempre con los estándares mínimos establecidos por la legislación normativa urbanística (urbanizaciones piratas). La segunda, cuando las viviendas están construidas en un suelo ocupado, sin ninguna regularidad ni organización en la disposición de las construcciones o en la definición de los espacios públicos o privados (invasión) ${ }^{28}$.

\footnotetext{
${ }^{25}$ La vivienda básica está definida por una parcela urbanizada con un espacio construido de uso múltiple con cocina, unidad sanitaria completa y lavadero. Es completada siguiendo los planos de desarrollo elaborados por las instituciones a cargo o espontáneamente por sus propietarios hasta su consolidación general. La vivienda mínima, producida por el sector privado y subsidiada por el Estado consta de un espacio múltiple, cocina, baño lavadero y una o dos habitaciones (según si es una vivienda mínima completa o incompleta). (TRACHÓPULOS Y CEBALLOS, 2005:49)

${ }^{26}$ Decreto 2190 de 2009, Reglamentario de la Ley 9 de 1989, Ley 3 de 1991, Ley 388 de 1997 y Ley 1151 de 2007 , dentro del acápite de definiciones establece el precio máximo de la vivienda social (VIS y VIP), aun cuando éste puede ser delimitado por los Planes Nacionales de Desarrollo.

Para el año 2010, el salario mínimo legal era de $\$ 515.000$, por lo que los precios máximos para la vivienda subsidiada en cada rango eran entre $\$ 69^{\prime} 525.000$ y $\$ 36^{\prime} 050.000$ respectivamente. (es decir, entre $36.649,7$ y $19.003,6$ USD. tomando la tasa de cambio promedio que establecía el Banco de la República, \$1,897 por dólar, para aquel año).

${ }^{27}$ Alrededor del $50 \%$ de los barrios en las ciudades colombianas son resultado de procesos de ocupación ilegal de suelo, llevadas a cabo por grupos sociales de bajos ingresos. (Fuente: DNP 2005).

28 ."La tolerancia generalizada con respecto a la ilegalidad de la vivienda de bajos ingresos en las ciudades latinoamericanas no es accidental en la sobrevivencia del Estado latinoamericano. A pesar de sus condiciones de pobreza, los asentamientos ilegales actúan como una válvula de escape de las tensiones sociales...pues le proveen a sus habitantes una base para el desarrollo y la mejora... reduciendo las posibilidades de una reacción política en masa“ (A. Gilbert y P. Ward.1989:75 en FIQUE, 2006:66).
} 
Se construyen habitualmente con instalaciones precarias de los servicios de agua y electricidad, desprovistos de infraestructura de servicios públicos, espacios verdes, equipamientos o vías de accesibilidad. La edificación se da por medio de casas de uno o dos niveles con un desarrollo progresivo y espontáneo en el tiempo. Inicia con una construcción precaria, con materiales comprados en el sector manufacturero o a partir de desechos reciclados, que aumenta paulatinamente su área construida y su ocupación en la parcela para finalmente alcanzar hasta cinco niveles promedio. En ella pueden vivir uno o más hogares vinculados o no entre sí.

Los procesos urbanos que los definen se dan en simultaneidad: parcelación, edificación y urbanización, siendo éstas últimas sujetas a procesos de construcción postergados según las posibilidades de los particulares, propias de la ausencia de planificación. Los compradores o poseedores son parte de una población de bajos ingresos que están por fuera del mercado. Su forma de financiación está sustentada en un sistema informal basado en sus posibilidades.

Esta producción de origen marginal es la que está en la mira de los programas de mejoramiento de barrio. El Departamento de Planeación Nacional considera que es virtualmente imposible salir sin la ayuda del Estado o de actores privados de dicha condición o situación.

En consecuencia, son tres modalidades de producción que se caracterizan por estar construidas simultáneamente en el territorio con una importancia semejante - de ahí el interés por su estudio-. Para el caso de Bogotá y Medellín, la modalidad de construcción formal, origen institucional o normal, ha tenido una media de $58 \%$ del total de la actividad edificatoria de la vivienda y las diversas formas de construcción marginal, clandestina o invasión, con frecuencia han superado más de $40 \%$ de dicha producción como se puede ver en la gráfica siguiente. Es importante observar cómo ha aumentado la producción de origen clandestina para el periodo 1990-2000. Uno de los motivos ${ }^{29}$ de su incremento ha sido el desplazamiento de población rural a causa del conflicto armado nacional. Las estimaciones de la Red de Solidaridad Social, ahora Acción Social, señala que desde mediados de los noventa se han desplazado cerca de 25.000 familias al año a las ciudades cabecera. (CONPES 3057 de 1999)

Gráfico 02 Distribución porcentual de las formas de producción en materia de vivienda social

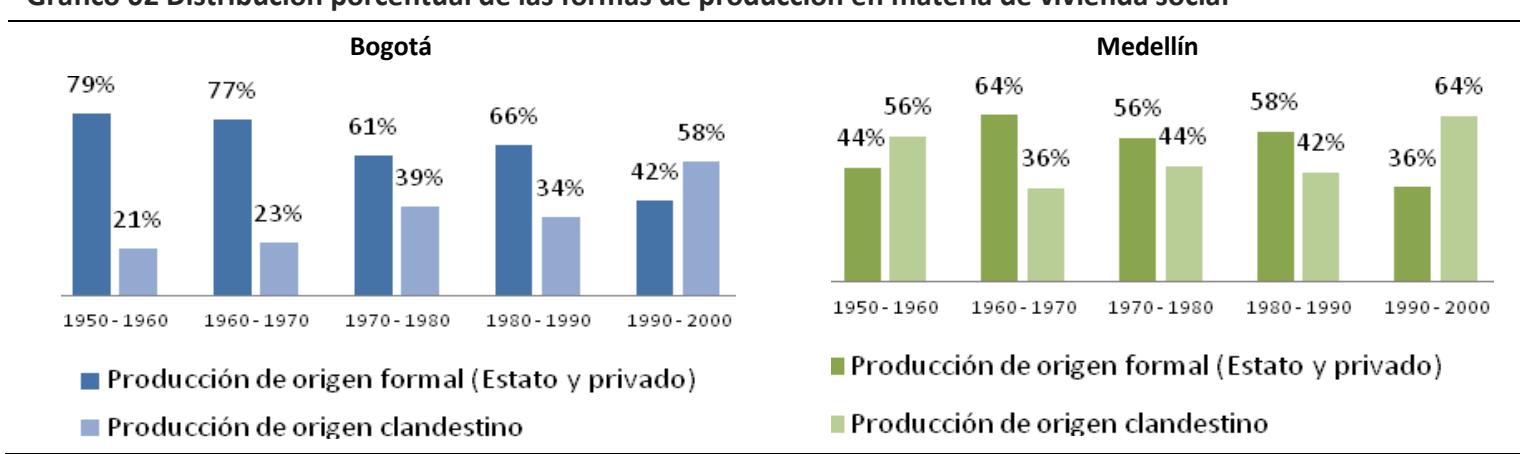

Fuente: Informe final realizado por University College London (2006) Suelo urbano y vivienda para la población de ingresos bajos. Estudios de caso: Bogotá-Soacha-Mosquera; Medellín y Área Metropolitana.

\footnotetext{
${ }^{29}$ Otro motivo, expuesto en el apartado siguiente, es los elevados costos del suelo para desarrollo de vivienda nueva que terminaron repercutiendo en el precio final de la vivienda y que genera que la población de bajos ingresos que no podía acceder a ella, termine en el mercado informal. Dicho fenómeno originó un incremento en la producción de origen marginal pasando de $18 \%$ entre 1985 y 1993 a 44\% de 1993 a 2005 (datos METROVIVIENDA 2011:137)
} 
En Bogotá la producción de la vivienda social, "se ha desarrollado en medio de la inexistencia de una política sostenible de promoción de la VIS, de los insuficientes esfuerzos de la administración distrital al respecto y del acelerado crecimiento de la ciudad" -formal e marginal- (TORRES 2009:104). Una muestra de ello se constata, por ejemplo, en el elevado déficit habitacional, el cual tan solo poco más de veinte años atrás, 1993, era de $44.26 \%$ del total de los hogares en la ciudad ${ }^{30}(32.88 \%$ correspondía a un déficit cuantitativo y $11.38 \%$ a uno cualitativo) y al iniciar el periodo de estudio, año 2000 , de $22.3 \%$ ( $14.4 \%$ correspondía a déficit cuantitativo y $7.9 \%$ a uno cualitativo). Pese al esfuerzo realizado cada año por el Estado, especialmente en la reducción del déficit cuantitativo, no se construían suficientes unidades de vivienda y no se mejoraban las condiciones de las existentes. De acuerdo con el Plan de Ordenamiento Territorial (POT) para congelar ésta cifra y asumir las necesidades de los hogares futuros para el año 2010, la ciudad debía construir anualmente 55.000 nuevas viviendas, lo que nunca hasta la fecha se había construido ${ }^{31}$.

Adicionalmente, teniendo en cuenta el patrón socioeconómico de los demandantes de vivienda se observa que el $82 \%$ de la oferta debería corresponder a vivienda social distribuida en una escala de precios que les permita a familias de estratos socioeconómicos 1,2 y 3 acceder a ella. Sin embargo, el sector de la construcción no está en condiciones de ofrecer vivienda a un costo asequible para ésta población. Entre otros factores porque en Bogotá aproximadamente el $74 \%$ de las familias se ubica en los estratos 2 y 3 y vive con un ingreso mensual promedio de 1 a $5 \mathrm{smmlv}$ ), lo que no les permite adquirir viviendas de más de 50 smmlv (VIP tipo 1).

Tabla 02 Déficit de vivienda por estratos socioeconómicos en Bogotá, año 2000

\begin{tabular}{|c|c|c|c|c|c|c|c|c|c|}
\hline \multirow[t]{2}{*}{ Estrato } & \multicolumn{2}{|c|}{ Población } & \multicolumn{2}{|c|}{ Área ocupada } & \multicolumn{2}{|c|}{ Vivienda } & \multicolumn{2}{|c|}{ Déficit } & \multirow{2}{*}{$\begin{array}{r}\text { Ingreso } \\
\text { No. smmlv }\end{array}$} \\
\hline & miles & $\%$ & $\mathrm{Ha}$ & $\%$ & No. & $\%$ & No. & $\%$ & \\
\hline 1 & 386 & 6.5 & 1,330 & 6.0 & 69,327 & 6.7 & 16,350 & 3.3 & $<1$ \\
\hline 2 & 2,115 & 35.7 & 4,991 & 22.5 & 334,678 & 32.2 & 239,082 & 48.6 & $1-3$ \\
\hline 4 & 44 & 7.5 & 1723 & 7.8 & 117,679 & 11.3 & 10,907 & 2.2 & $5-8$ \\
\hline 5 & 177 & 3.0 & 1,094 & 4.9 & 38,723 & 3.7 & 6,149 & 1.2 & 8-16 \\
\hline \multirow[t]{2}{*}{$*$} & 62 & 1 & 6,188 & 27,9 & 12,711 & 1.2 & 3,731 & 0.8 & \\
\hline & 5,917 & 100 & 22,213 & 100 & $1^{\prime} 040,721$ & 100 & 492,157 & 100 & \\
\hline
\end{tabular}

Fuente: DAPD Subdirección Económica. Ingresos: Cálculos de los autores con base en el DANE 2000.

La consecuencia, una población con necesidad de techo buscando en el mercado informal o construyéndose su propia vivienda. Para el año 2000, la ciudad marginal representaba el $23 \%$ del área urbana, equivalente a 6.906 ha., donde vivía aproximadamente el $22 \%$ de la población total de la ciudad. A ello se sumaba las pésimas condiciones habitacionales de estas áreas, donde se acumulan factores de hacinamiento (35\%); deficiente calidad del tipo de suelo (16\%) problemas estructurales de las viviendas (35\%); inexistente o insuficiente disposición de

\footnotetext{
${ }^{30}$ Déficit que la pasar de los años si bien ha disminuido, sigue siendo aún muy elevado. Para el año 2005 el déficit era del $19.15 \%$ (14.64\% correspondía a un déficit cuantitativo y $4.51 \%$ a uno cualitativo) Fuente: DANE (2016) Déficit de vivienda estimada según metodología propia de la institución.

${ }^{31}$ En el año 2001 se construirían 11.992 unidades y para el año 2010 se duplicaría casi la cifra en 21.287 unidades. (Como media en este periodo de diez años la cantita de unidades construidas sería de 19.320 unidades.) Pese a ello, no se llegaría a la cifra estimada de las 55.000 unidades. El déficit de total de vivienda para el año 2010, si bien segaría menguando, quedaría en una cifra elevada de $11.8 \%$ del total de los hogares bogotanos.
} 
servicios públicos básicos (37,11\%); así como la carencia de infraestructura y equipamiento comunitario (26,3\%). (DAPD, 2005).

Tabla 03 Crecimiento asentamientos marginales por décadas Bogotá

\begin{tabular}{cccc}
\hline Década & Crecimiento Ha/año & Participación relativa de los asentamientos & Tasa de crecimiento de Bogotá \\
\hline 1960 & 464.34 & $18.14 \%(84.23$ ha.) & $6.7 \%$ \\
1970 & 307.83 & & $5.7 \%$ \\
1980 & 126.00 & $33.70 \%(42.46$ ha.) & $3.5 \%$ \\
1990 & 126.00 & & $2.6 \%$ \\
\hline 2000 & 186.00 & $23.00 \%(6.906$ ha.) & $2.3 \%$ \\
\hline
\end{tabular}

Fuente: (DAPD 1990) Y (DAPD 2001) en TORRES 2009: 108

Medellín por su lado cuenta con unas condiciones muy similares, relativas a su escala, a la capital. El déficit habitacional para la ciudad en el año 1993 era de $21.49 \%$ (8.06\% correspondía a déficit cuantitativo y $13.43 \%$ a uno cualitativo) y para el año 2005 de $14 \%$ (6.73\% correspondía a déficit cuantitativo -el cual seguía casi intacto al de 1993- y 7.27\% a uno

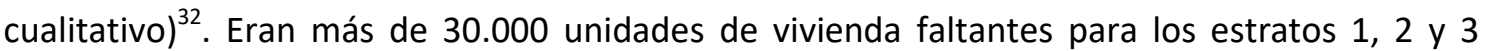
(71.000 familias) que dados sus altos niveles de pobreza (falta de demanda efectiva) ${ }^{33}$ no tienen ninguna posibilidad real acceder a ellas independientemente si reciben o no subsidio.

El crecimiento constante de las áreas deprimidas en zonas de ladera y el paulatino deterioro de las mismas era evidente. La producción de vivienda marginal se intensificaba. Para el año 1992 se contabilizaban 70 barrios de origen marginal con 37.000 viviendas y una población aproximada de 185.000 personas. Solo dos años después, Planeación Municipal registró 87 asentamientos marginales constituidos por 45.000 viviendas, en los que habitaban 202.500 personas (CINEP, 2002). Ya para finales de 2002 estas cifras se habían incrementado a 104 asentamientos marginales con 350.000 habitantes, es decir el 18\% de la población total de la ciudad. De acuerdo con los datos del Sisben de 1999, la población que habitaba en los barrios marginales respondía a dinámicas laborales que por varios motivos no les garantizaba ninguna estabilidad regular para acceder a una vivienda de gestión estatal. Entre esos motivos están que el $59 \%$ de la población percibía un ingreso inferior al salario mínimo, el 59\% estaba desempleada, el $71 \%$ vivía en condiciones de extrema pobreza y el $68 \%$ de los núcleos familiares tenían jefaturas femeninas (Torres, 2009:133).

Este conjunto de datos es relevante en las dos ciudades pues muestra la magnitud de la actividad edificadora para las clases menos favorecidas. La forma en que se está dando de manera sostenida y recurrente una solución de alojamiento para una población tan grande y creciente, (cada vez más personas están siendo excluidas del mercado de la vivienda) hace cuestionarse acerca de los problemas del hábitat que se produce, la calidad, y su sostenibilidad en el tiempo ${ }^{34}$.

\footnotetext{
32 Datos extraídos de los periodos censales realizados por el DANE. Cabe la pena aquí mencionar que en la práctica existen dificultades enormes para determinar el déficit real: las variables e indicadores para calcular el déficit no se encuentran en la mayoría de los casos; los registros estadísticos, cuando se hayan, son incongruentes entre las diferentes agencias o entidades que recopilan la información y adicionalmente para los municipios medianos o pequeños ni siquiera existen datos. (DANE 2005)

${ }^{33}$ La demanda no efectiva estaba entre el $80 \%$ y el $85 \%$ de los estratos socio-económicos 1 y 2. Aun así, en 2004 la oferta de 8.000 viviendas contrasta con una demanda efectiva de 30.000 (Camacol/Universidad de Medellín, 2004).

34 Para un mayor desarrollo sobre la producción de la vivienda informal en Colombia se recomiendo leer a Carlos Torres (2009) Ciudad Informal Colombiana. Barrios construidos por la gente.
} 


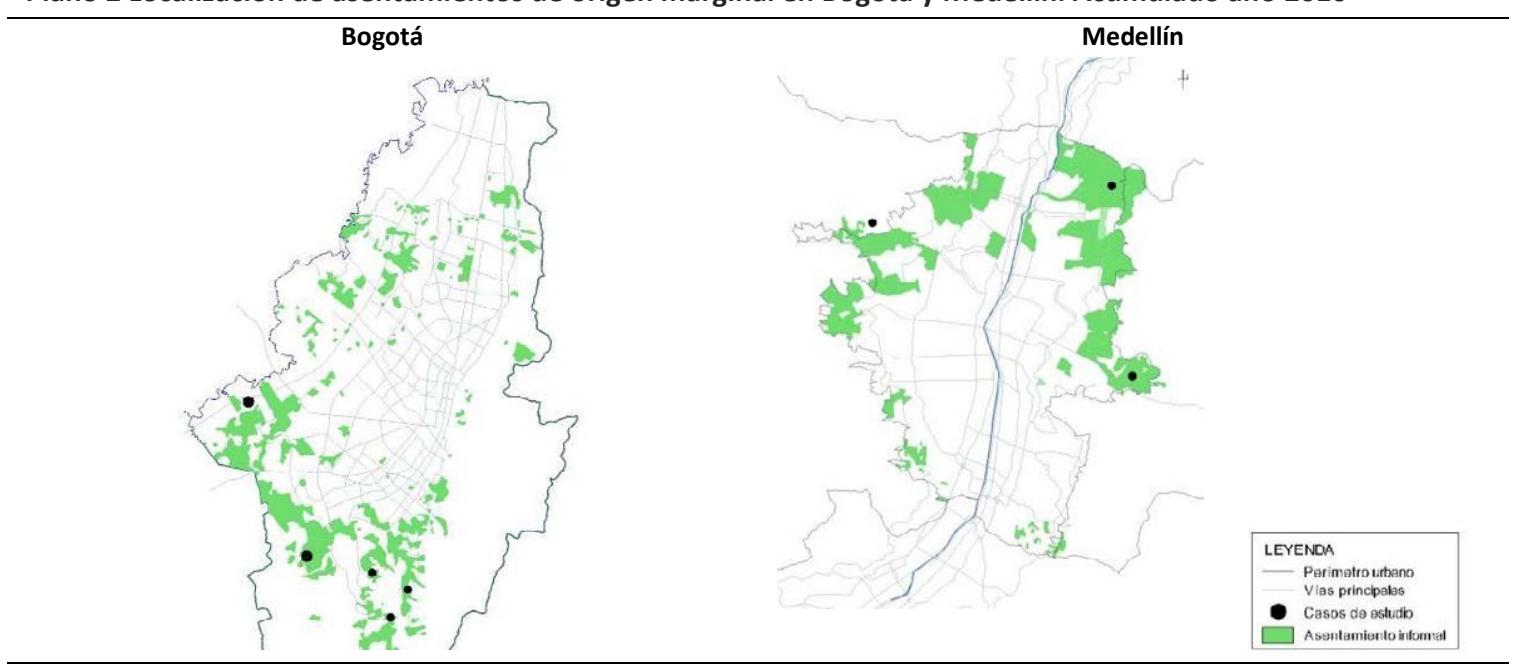

Fuentes: POT de Bogotá. Documento Técnico de Soporte; Informe final realizado por University College London (2006) Suelo urbano y vivienda para la población de ingresos bajos. Estudios de caso: Bogotá-Soacha-Mosquera; Medellín y Área Metropolitana. Elaboración propia.

\section{Tipología de vivienda}

Otra similitud entre los tres tipos de producción antes expuestos es su desarrollo en su gran mayoría con vivienda de baja altura. En Colombia, la vivienda individual de alta densidad o alta densidad en baja altura resultó ser "la fórmula que surge de manera espontánea en todas partes donde es necesario intensificar el uso de la tierra, hacer economías urbanas y a la vez la mejor iniciativa (tanto del sector privado como del Estado) para darle a cada cual un techo propio donde vivir" (Samper, 2003:77). Esto es confirmado por cifras del Departamento de Estadística de Colombia (DANE) en donde se muestra que de 41.468 .384 personas ocupando el territorio colombiano de acuerdo al censo de 2005, 31.504 .022 habitaban en cabeceras municipales y de ellas el $69.7 \%$ lo hacían en casas y tan solo el $24.8 \%$ en edificio en altura. El $5.5 \%$ restante lo hacían en cuartos u otro tipo de alojamientos.

El caso de Bogotá y Medellín no es la excepción (Ver plano 03). En Bogotá, la mayoría del territorio está construido por edificaciones de 1 a 3 niveles. Existen edificaciones de mayor altura para la zona centro y norte de la ciudad esencialmente, zonas que corresponden a los estratos socio económicos medios y altos. En Medellín las edificaciones bajas se ubican principalmente en el norte oriente (comuna 1, 2, 3 y 4) y en los altos de las montañas (comuna 8 y comuna 13). Las edificaciones de más de 5 niveles se encuentran en el centro, área administrativa o en las comunas de más alto nivel socio económico (comuna 11 y 14).

Éste hecho resulta paradójico si se tiene en cuenta que para mediados de los años cincuenta todas las ciudades latinoamericanas fueron influenciadas por los prototipos definidos por el Movimiento Moderno y los CIAM. Países como Venezuela (la gran mayoría en Caracas), México Brasil o Argentina sí adoptaron tipologías de vivienda social en altura, sin embargo Colombia prácticamente no lo hizo ${ }^{35}$.

\footnotetext{
${ }^{35}$ Ver artículo publicado de Doris Tarchópulos (2014) La Unidad Vecinal: Objeto de investigación de Josep Lluís Sert en donde explica la influencia del arquitecto en los Planes de Ciudad para Bogotá, Medellín, Cali o Tumaco y su apuesta por las unidades vecinal de baja altura y alta densidad.
} 


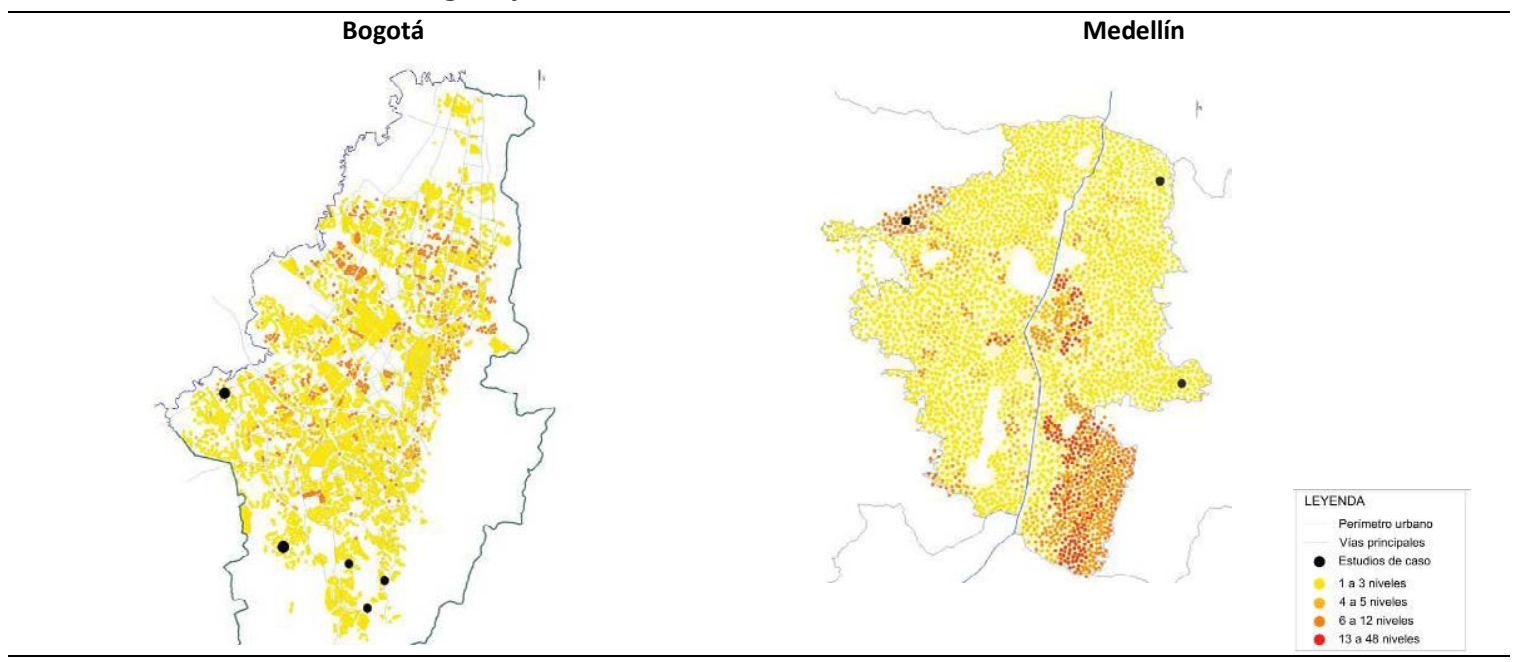

Fuente: Informes de la SDP Estadísticas densidades Bogotá 2010 y la Alcaldía de Medellín: Medellín en cifras 2011. Elaboración propia

Al parecer, los grandes proyectos habitacionales de bloques no llegaron a desarrollarse "por la alternación entre los partidos políticos con diferentes proyectos, la poca acogida hacia éste tipo de construcciones o la no consolidación de unas ciudades con desarrollos económicos importantes." (Ballen, 2009:160) Y podría preguntarse ¿Por falta de condiciones legales? o ¿Por no ser proyectos con lucro lo suficientemente atractivo en un país donde el Estado dejó la promoción y ejecución en manos de privados desde mediados del siglo pasado?

No obstante, con la implementación de los Planes de Ordenamiento Territorial (POT) en las dos ciudades mencionadas la tendencia de oferta de apartamentos o de unidades habitacionales en altura se intensificó. Los multifamiliares se empezaron a consolidar como la forma más "eficiente" ${ }^{.36}$ aun de aprovechar el suelo y ofrecerle una techo "digno" a la población de bajos ingresos. Según Metrovivienda en su Informe sobre modelos de gestión del suelo vivienda y hábitat el conjunto de factores que posibilitaron dicho giro fueron:

"Los cambios en las condiciones del mercado; el margen de maniobra del Estado a través de la gestión de un banco de tierras que llevó a los constructores a competir por la tierra habilitada disponible y a utilizar el suelo de modo intensivo; la actitud de los constructores que, no obstante la presencia de una cierta competencia entre las firmas, asumen una suerte de práctica monopolística frente a márgenes de rentabilidad; y una notoria transformación en los estilos de vida de la comunidad de bajos ingresos en relación con el tipo de vivienda -pasaron de la preferencia por la casa hacia la elección de vivienda tipo apartamento-.(METROVIVIENDA, 2011:268)

Las dos principales ciudades de Colombia empezaron así a ver cambiar su patrón tipológico de vivienda social. (Ver gráfico No.04) En la ciudad de Bogotá, la construcción de nuevos apartamentos, durante el periodo 2004-2011, ascendió con unas 180.000 unidades. El cambio se presentó principalmente en el estrato 1 en donde la proporción en edificios creció de $14 \%$ y en el estrato 2 donde se invirtió dicha proporción. En Medellín el cambio fue aún más importante. Para el año 2004 todos los estratos, salvo el 6, tenían una mayor edificación de

\footnotetext{
${ }^{36}$ El concepto de eficiencia está aquí relacionado con una señal del mercado sobre la viabilidad de construir vivienda de interés social en donde el constructor sigue teniendo grandes beneficios (tasa mínima de ganancia 5\%).
} 
casas, pero para el año 2011 pasaron todos a tener una mayor proporción de apartamentos construidos: el estrato 1 creció en un $20 \%$, el estrato 2 en un $35 \%$ y el estrato 3 en un $40 \%$.

Gráfico 03 Viviendas por tipo según estrato. Comparativa año 2004 y 2011

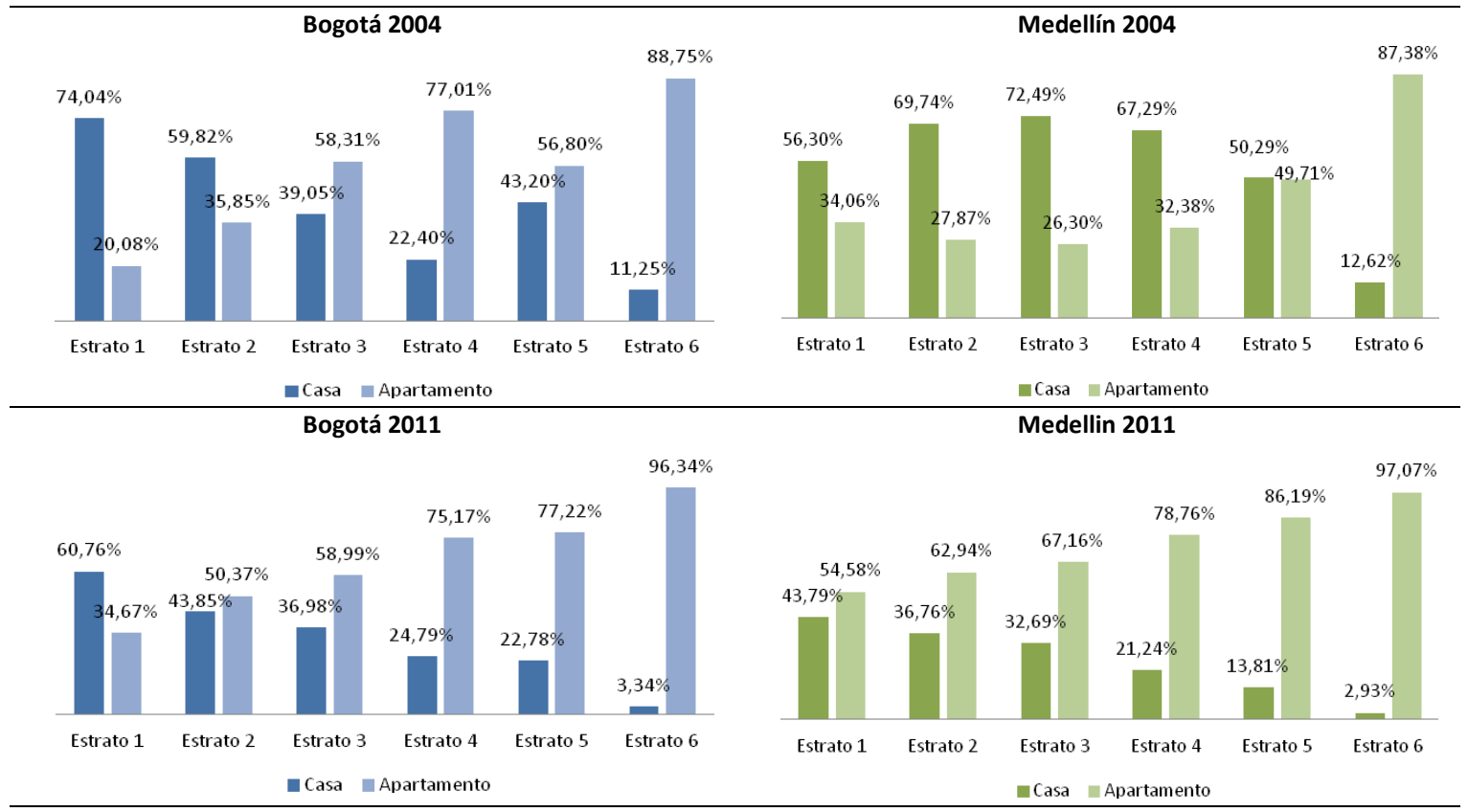

Fuentes: DANE. Encuesta capacidad de pago Bogotá 2004; Encuesta Calidad de Vida Medellín 2004 y 2011 , Encuesta multipropósito Bogotá 2011

Para confirmar esta tendencia se toman algunos datos de los estudios de caso de desarrollo de vivienda nueva de esta investigación. Para el ejemplo de Bogotá, Ciudadela El Porvenir se proyecta construir hasta la fecha 7300 casas unifamiliares y 13.864 apartamentos en altura con bloques de 5 a 6 pisos y un índice de ocupación de 0,40. En el caso de Medellín, en la Ciudadela Nuevo Occidente, no se ha construido ni una sola vivienda de baja altura; todas, absolutamente todas las edificaciones han sido multifamiliares de cinco a ocho niveles sin ascensor aprovechando las fuertes pendientes (índice de ocupación 0,68). De hecho, hasta en el caso de los asentamientos marginales, PUI Nororiental y PUI Centroriental, cuando las familias han sido reubicadas por contar con su vivienda en zona de alto riesgo, éstas han sido ubicadas en edificaciones multifamiliares en altura. (Caso consolidación habitacional en la Quebrada Juan Bobo Comuna 2 -PUI Nororiental- con multifamiliares de seis niveles y con los bloques de redensificación para la comuna 8- PUI Centroriental).

Los datos revisados permiten corroborar la consolidación de dos fenómenos que se superponen. El primero en relación con una producción inmobiliaria en manos del mercado que se constituye como la vía única para la generación formal de vivienda social en donde la población de más bajos ingresos no puede participar. Y el segundo en relación con la tipología edificatoria a elegir según la libre iniciativa privada, es decir según la rentabilidad que ésta le genere. Un tercer fenómeno aparece, difícil de apreciar en el gráfico, con la producción de vivienda marginal y su tipología de vivienda de baja altura en donde se impone cada vez más una forma de subdivisión semejante a apartamentos (o a veces simples cuartos) para alojar mayor número de familias en las construcciones progresivas.

Ahora bien, este no es un tema aislado que se pueda comprender sin tomar en cuenta los aspectos complementarios implícitos en la producción misma de vivienda, como son el precio 
del suelo, los costos de urbanización y construcción, y los tamaños y la localización de la vivienda de bajo costo, aspectos sobre los cuales se presentan a continuación algunas reflexiones generales.

\subsubsection{Mecanismo de ocupación o distribución del suelo}

En Bogotá y Medellín, como en todo Colombia, según April (1992) el modelo de ocupación del suelo combina la lógica del mercado (en función de la capacidad adquisitiva de la demanda según a las cualidades naturales o artificiales del suelo: buenas, mediocres y malas) ${ }^{37}$ en relación a las tres formas de producción de la vivienda social (la marginal, la institucional y la privada). Así, ocurre un reparto en donde i) por lo general, la mayor parte de las tierras con las mejores condiciones llegan a ser construidas por el sector privado. La base de esta situación se da normalmente con una ocupación legal del suelo a través de un contrato que asegura la propiedad o la ocupación a largo plazo; ii) una parte de las tierras mediocres recibe los programas estatales de vivienda, por lo general, con suelos dispersos en el territorio o ubicados en la periferia que están, igualmente, en situación de legalidad; y iii) las peores tierras de la periferia ocupadas por una gran masa de población sin ingresos necesarios para integrarse en los mercados anteriores. La posesión del suelo se da mediante la ocupación deliberada de predios ajenos, por compra de parcelas en desarrollos generalmente ilegales o con una estabilidad de un título de legalidad. (April, 1992:606-611)

De este modo se presentan tres formas de reparto manejada por las lógicas del mercado como actor principal junto con un rol pasivo o activo, según se juzgue, del Estado ${ }^{38}$. Funcionan de manera simultánea y tienen como resultado una calificación y distribución del espacio urbano (segregación socio espacial) y una valorización (formación de precios) diferencial. Aspectos que, como es evidente, condicionan la calidad de la vivienda como se detalla a continuación.

La diferencia espacial se da por medio de la localización de la vivienda y todos los servicios que la complementan como se observa en el plano 04 de estratificación. Es una distribución que acompañada de un proceso de calificación o descalificación ha dependido, entre otras, de "grupos sociales dominantes, que no han tardado en plasmar en reglamentos y normativas, cambiantes de acuerdo a los intereses, una poderosa ideología de localización de dónde deben vivir unos y otros". (Aprile, 1992:612) Para Bogotá la concentración de vivienda social, es decir de los estratos bajos y medio bajos (estratos 1,2 y 3 ) se ubica en el sur y sur occidente de la ciudad, lo estratos 2 y 3 se localizan en el occidente y los estratos altos (estratos 4,5 y 6 ) en el nororiente. Para Medellín, en cambio, la vivienda social se ubica en las zonas de ladera alta tanto en el nororiente como en el occidente, los estratos 2 y 3 se ubican en el norte de la ciudad y los estratos más altos en el sur oriente.

\footnotetext{
${ }^{37}$ Dentro de las condiciones naturales o artificiales calificadas como buenas, malas o peores pueden existir excepcionales, por ejemplo: "Tierras "fronterizas" con pésimas cualidades agrológicas, que no tienen un uso agropecuario altamente rentable, por lo tanto tienen un precio muy bajo. Éstas fácilmente se integran a un mercado urbano destinado a la vivienda llamada "popular",... con un precio urbano relativamente inferior... sin presión para obtener altas densidades. Lo contrario ocurre con zonas "fronterizas" constituidas por tierras de primera categoría agrológica... con alto precio... que podría ser mayor al que experimentaría pasando a ser predio urbano. " (APRILE 1992:610-611).

${ }^{38}$ Con las políticas de aprovisionamiento de servicios, por ejemplo, se determinan qué áreas de una ciudad tendrán la posibilidad de ser servidas o cuáles serán excluidas.
} 
Dicha organización socio-espacial muestra una marcada segregación de la población y la vivienda: los "ricos" y "pobres" no viven en el mismo territorio y no comparten las mismas características de ciudad (exclusión y desigualdad) ${ }^{39}$. La vivienda para la población de bajos ingresos generalmente hace parte de un área periférica de una expansión urbana desarticulada, en zonas de alto riesgo (posiblemente con problemas mecánicos en el suelo o topografías abruptas) y con dificultades o altos costos de acceso a los servicios urbanos y deficiencias en las redes públicas, como se verá en el siguiente apartado. Asimismo, por tratarse de zonas marcadas por su grado de urbanización y consolidación, como es obvio, el margen de precios del suelo y de la vivienda misma varían: entre más lejos se localiza un predio de los centros donde se concentra la mayor interacción social y la mayor dinámica económica -estratos 5 y 6 -, menor es su precio y, por lo tanto, mayor es el interés de los agentes inmobiliarios por impulsar proyectos de vivienda social en esas zonas.

Para los casos de estudio, la mayoría de las viviendas en cuestión están clasificadas en estrato socioeconómico 1 y 2: en la API El Lucero todas las viviendas son estrato 1; en el proyecto Sur con Bogotá en la parte superior del parque Entrenubes son estrato 1 y en la parte baja son estrato 1 y 2 , y en el PUI Nororiental y Centroriental son en su mayoría estrato 2.

Plano 04 Estratificación socioeconómica urbana para Bogotá y Medellín.

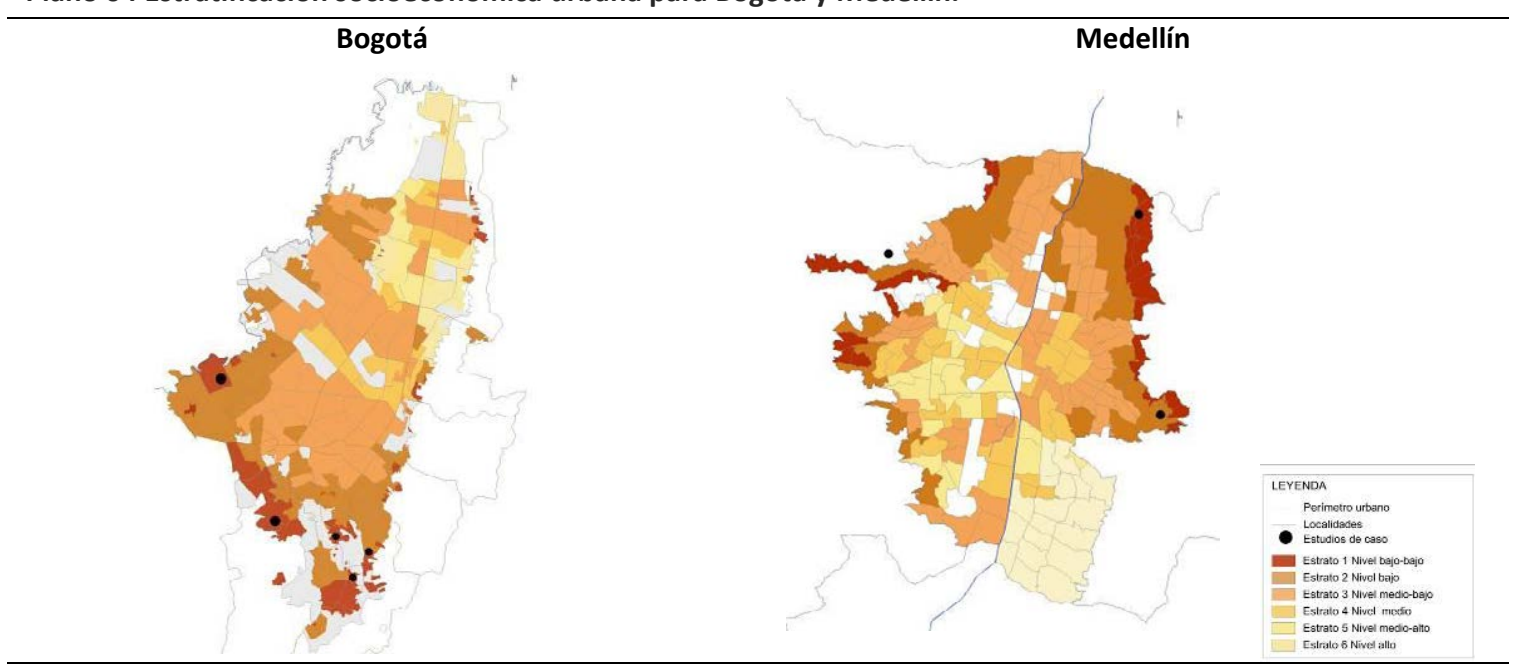

Fuente: Datos del DANE. Bogotá y Medellín 2010. Elaboración propia.

La formación de precios, sin entrar a describir exhaustivamente los mecanismos que los generan, se produce en relación al factor de localización antes descrito y los atributos externos que lo condicionan. Para la producción formal de vivienda, en el marco de la política de los años noventa centrada en la producción privada directa, éstos atributos fundamentales son el precio del suelo, los costos de la habilitación de las áreas útiles que podrán ser urbanizadas, los costos de construcción de las viviendas, el tipo de unidades de vivienda que se produce y los tiempos de entrega efectiva de los derechos de propiedad a cada adjudicatario.

La incidencia del precio del suelo urbanizado o por urbanizar ha sido, dentro de esos atributos, uno de los más significativos. Ha oscilado entre un 10 y 20 por ciento del precio final de la

\footnotetext{
39 Esta tendencia a la segregación espacial urbana se refleja no solo en Bogotá sino en las poblaciones cercanas de la Sabana, de forma que las poblaciones de estratos bajos se localizan en municipios del sur y occidente, como Soacha, Funza, Mosquera, Madrid o Facatativá, y las poblaciones de estratos altos en municipios como Chía, Sopó o La Calera. En Medellín dicha segregación también se da en el área metropolitana. Los municipios al sur son Envigado, Itagüí, Sabaneta, La Estrella, Caldas y al norte Bello, Copacabana, Girardota y Barbosa.
} 
vivienda, dependiendo de la tipología edificatoria que se haya elegido: vivienda unifamiliar o multifamiliar (pesando más en la primera). Para el caso de Ciudadela El Porvenir en Bogotá, el costo de la parcela urbanizada para una vivienda unifamiliar significó un $16,7 \%$ y para una vivienda en un multifamiliar $12,8 \%$ del precio final de la vivienda. Sin embargo, hay excepciones dependiendo del manejo que se haya dado en el momento de adquirir el suelo antes de iniciar el proyecto habitacional. Ese es el caso del complejo multifamiliar Las Flores en Ciudadela Nuevo Occidente en Medellín, en donde el costo del suelo supuso un 5,4\% del total de una unidad habitacional (el costo del urbanismo fue del 11,20\%).

La especulación sobre el valor del suelo, es decir ese manejo sobre la operación comercial, es el elemento central en esa variación de precios. La relativa escasez del mismo o la incorporación de grandes zonas de expansión ha potencializado, dentro de las reglas del mercado, que cada interesado afecte los precios elevando los terrenos más deseables o disminuyendo los de poco interés. Este es un fenómeno del que ni las zonas tradicionalmente ocupadas por asentamientos marginales ni las entidades encargadas de producir vivienda social han podido abstraerse. A la hora de realizar proyectos de vivienda social, cada administración ha pagado un precio por ese terreno ya aumentado.

Plano 05 Valor del suelo Bogotá y Medellín 2010. Miles $\mathrm{m}^{2}$

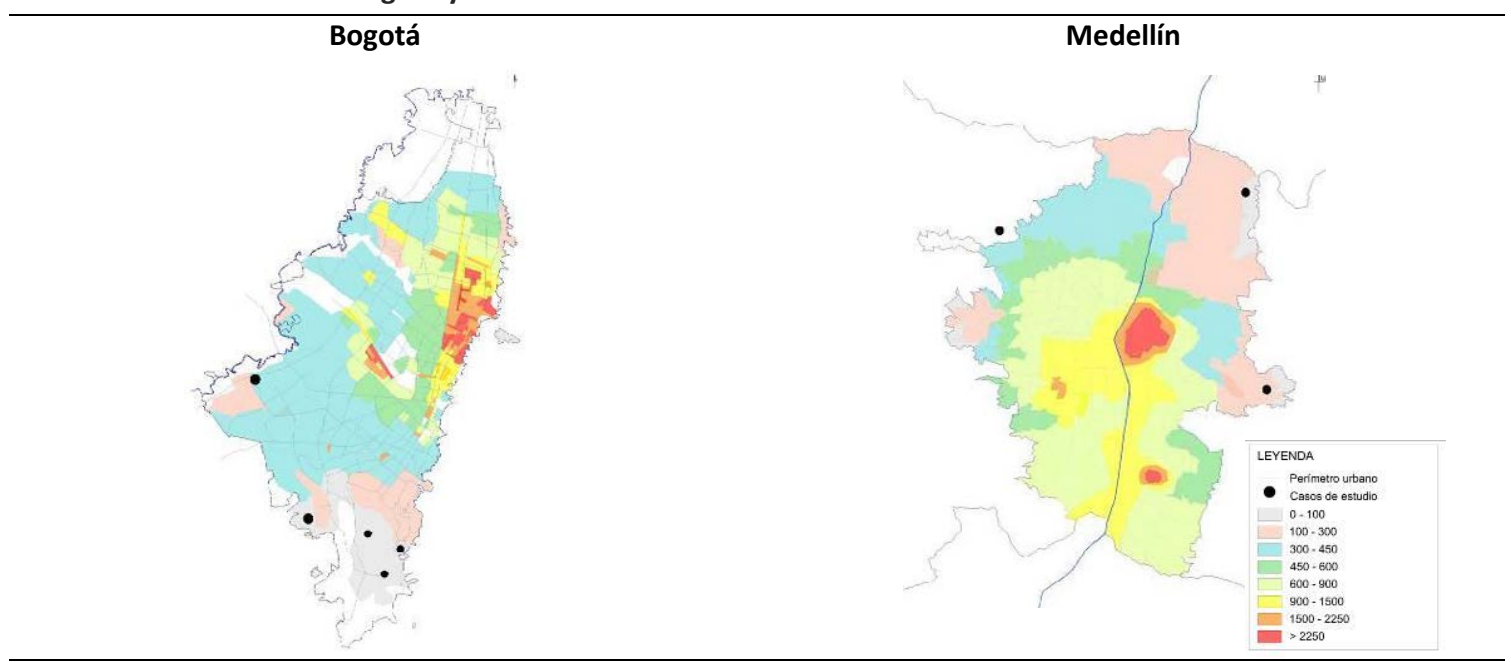

Fuente: SDP Observatorio dinámicas del territorio. Mercado de vivienda. Bogotá - DAP Medellín en Cifras 1.

Para controlar dicha variación de precios del suelo, en especial el requerido para la vivienda social, el Estado colombiano ha diseñado y adoptado un conjunto de políticas desde los años ochenta, Ley de Reforma Urbana (Ley 9 de 1989), que tan solo han empezado a aplicarse recientemente $^{40}$. Con la adopción de la Ley de Ordenamiento Territorial (Ley 388 de 1997) y la creación de cada Plan de Ordenamiento Territorial se ha intentado racionalizar y controlar el suelo $^{41}$ requerido para el desarrollo urbano en general y para la vivienda social en particular.

\footnotetext{
40.. Las aspiraciones de introducir cambios sustanciales en las reglas del juego del desarrollo urbano, particularmente en lo que se refiere a la tierra... a ciertos aspectos de la producción misma de vivienda, han tenido en Colombia una larga trayectoria de fracasos. Las propuestas... han tenido una férrea oposición en grupos muy poderosos ligados fundamentalmente a la construcción y a la propiedad territorial urbana“.(JARAMILLO, 1994:279)

41 ."El Estado, como poseedor de terrenos, con los estímulos a la actividad de la construcción, con los impuestos sobre el suelo urbano y, por otra parte, como inversionista en edificios, servicios e infraestructura y como planificador y controlador de los usos del suelo y de los perímetros y de las áreas de servicios (permitiendo o restringiendo), tiene efectos vitales en sus precios" (GILBERT y WARD 1987:73 en FIQUE, 2005:64).
} 
"Por un lado, se ha adoptado una política general que ha permitido gestionar directamente el suelo en el marco del ordenamiento territorial, que no solo configura el alcance y contenido jurídico y económico del derecho de propiedad, sino que ofrece diversas herramientas a las administraciones municipales para que intervengan el mercado del suelo, guíen su desarrollo urbano y capturen parte de las plusvalías generadas por las actuaciones urbanísticas (banco de tierras); y por otro lado, se ha implementado una política de vivienda que han consistido en otorgar subsidios familiares directos a la demanda por parte del Gobierno nacional o distrital, los cuales para acceder a éstos, es necesario demostrar ingresos regulares y hacer parte del sistema bancario de ahorro y créditos." (METROVIVIENDA, 2011: 146)

Sin embargo, según M. Clara Echeverría (2004) a pesar de los propósitos sociales anunciados en dicha política no ha llegado a existir del todo una regulación de tierras que facilite realmente la asequibilidad a las tierras para la población de bajos ingresos. "El rol del Estado se ha limitado a la planeación de usos del suelo, sin lograr afectar realmente la oferta de tierras para la vivienda social (dadas las diferencias en la rentabilidad lograda mediante otros usos o en vivienda para otros grupos sociales) [...] La Ley 388 ha reactivado el aprovechamiento de la renta del suelo... pues la capacidad de gestión de proyectos de transformación de usos del suelo (con los planes parciales y actuaciones urbanísticas) existe realmente solo entre las empresas asociadas a las organizaciones en las que participan tres actores que resultan ser los beneficiados de la política: propietarios, constructores y financistas; entre quienes el interés social se diluye. (Echeverría, 2004: 28-29).

En Colombia esta tendencia es clara. Al hacer una breve revisión de los precios del suelo para la vivienda social en Bogotá y su incidencia en la producción de inmuebles de bajo precio, se puede inferir que los incrementos injustificados de los precios del suelo incidieron de forma determinante en los incrementos de los precios finales de venta de los inmuebles y, por lo tanto, en las densidades desarrolladas por los urbanizadores y en los tamaños de las unidades habitacionales. La lógica aplicada por los urbanizadores es bastante simple: el mayor precio del suelo se debe reflejar en el precio final de cada unidad inmobiliaria, por lo tanto, si se quiere aprovechar de forma más eficiente el suelo, se debe procurar que haya mayor número de unidades para que estas absorban el incremento ya sea cambiando las tipologías unifamiliares por las multifamiliares -como se comentó anteriormente- o disminuyendo los tamaños bien sea de las viviendas o de las parcelas. (METROVIVIENDA, 2011:163)

La experiencia de con la Ciudadela El Porvenir, gestionada por Metrovivienda así lo demuestra. Los altos costos de la tierra urbanizada (\$39.368 pesos colombianos - 20,75 USD $)^{42}$ y la decisión de desarrollar los proyectos con vivienda individual en algunas de las manzanas condicionaron el tamaño de las parcelas en $30 \mathrm{~m} 2$ de área promedio y exigieron densidades muy altas (225 viviendas por hectárea neta) -una de las menores áreas, con una de las mayores densidades en la historia de la oferta de vivienda social en Colombia-. Con el agravante de que la experiencia se ha tomado como modelo, por gestores privados y públicos, en ciudades y poblados menores en donde, seguramente, las condiciones de precio del suelo y, sin duda, las de la demanda son muy diferentes.

\footnotetext{
${ }^{42}$ A continuación todos los precios serán tomas con la tasa de cambio promedio que establecía el Banco de la República, \$1,897 por dólar, para el año 2010.
} 
Tabla 04 Costo de vivienda (Tipo 1) Ciudadela el Porvenir, Bogotá

\begin{tabular}{lll}
\hline & Vivienda Unifamiliar & Vivienda Multifamiliar \\
Área vivienda & $43,79 \mathrm{~m} 2$. & $36 \mathrm{~m} 2$ \\
Dimensiones parcela/ apto & $2,92 \times 5,25 \mathrm{mts}$ & $5,44 \times 7,09 \mathrm{mts}$. \\
Precio final & $51,8 \mathrm{SMMLV}$. & $47,8 \mathrm{SMMLV}$. \\
Total viviendas construidas por manzana & 256 & 252 \\
Densidades obtenidas & $309.14 \mathrm{viv} / \mathrm{ha}$ útil & $598,26 \mathrm{viv} / \mathrm{ha} \mathrm{útil}$ \\
\hline Parcela urbanizada & $\mathbf{1 6 , 7 0 \%}$ & $\mathbf{1 2 , 8} \%$ \\
\hline Costos directos & $61,90 \%$ & $64 \%$ \\
Costos indirectos & $18,40 \%$ & $18,8 \%$ \\
Costo total (2010) & 25.837 .861 (13.620 USD) & $\mathbf{2 8 . 9 9 5 . 0 0 5}$ (15.284 USD) \\
\hline Utilidades & $3,10 \%$ & $4,5 \%$ \\
\hline Precio venta (2010) & $\mathbf{2 6 . 6 6 2 . 6 2 7 ~ ( 1 3 . 4 1 8 ~ U S D ) ~}$ & $\mathbf{3 0 . 3 5 1 . 7 2 7}$ (15.999 USD) \\
\hline
\end{tabular}

Fuente: METROVIVIENDA (2011)

En Medellín, los precios del suelo han seguido la actividad constructora de Bogotá, salvo por algunos rezagos durante los años noventa. Durante ese periodo los precios reales del suelo urbano tuvieron tasas negativas -mientras que la tasa media anual de interés real de la economía para los años 1983-2004 fue del $13.94 \%$, la tasa de variación geométrica promedio anual de los precios reales fue del 11.4\% (DAP - MEDELLÍN EN CIFRAS 1). Tan solo fue a partir del año 2003 y 2004 que los precios se recuperaron en todos los estratos del mercado exceptuando el estrato medio alto (estrato 5 ).

Esta desvalorización explícita de la tierra puede haber favorecido a los agentes inmobiliarios y de la construcción al permitir la adquisición de suelo urbano a precios favorables. A pesar de los ciclos de auge y recisión que compone la actividad edificatoria, el de la vivienda se mantuvo bastante estable, con un promedio de 76\% entre 1991-2004y una tendencia de crecimiento de esta participación a partir de 2000. (DPU, 2006:164)

En cuanto a la producción de vivienda social en la oferta formal, la lógica de aprovechar el suelo urbano de forma más eficiente cambiando la tipología edificatoria y disminuyendo el área de las unidades habitacionales (antes de $70 \mathrm{~m} 2$ a $60 \mathrm{~m} 2$ o 50m2) también fue aplicada. La estructura de costos del caso de estudio Las Flores así lo muestra. El proyecto por encontrarse en una zona de expansión tiene un costo del suelo relativamente bajo $(5,4 \%)$ pero se compensa a su vez con un costo más elevado de urbanización $(11,2 \%)$.

Tabla 05 Costo de vivienda (Tipo 1) Ciudadela Nuevo Occidente, Medellín

\begin{tabular}{|c|c|c|}
\hline & $\begin{array}{l}\text { Vivienda Multifamiliar: Las Flores } \\
\text { Producción gestión estatal }\end{array}$ & $\begin{array}{l}\text { Vivienda Multifamiliar: Andalucía } \\
\text { Ejemplo Producción formal }\end{array}$ \\
\hline Área vivienda & $44,75 \mathrm{~m} 2$ & \\
\hline Precio final & 50 SMMLV. & \\
\hline Total viviendas construidas & 750 & \\
\hline Suelo & $5,40 \%$ & $18,6 \%$ \\
\hline Urbanización & $11,20 \%$ & $5,43 \%$ \\
\hline Costos Directos & $67,90 \%$ & $49,30 \%$ \\
\hline Costos Indirectos & $15,50 \%$ & $13,10 \%$ \\
\hline Costo total (2010) & 19.075.000 (10.055 USD) & 39.336 .128 (20.735 USD) \\
\hline Utilidades & - & $13,6 \%$ \\
\hline Precio venta (2010) & 19.075 .000 & 45.516.285 (23.993 USD) \\
\hline
\end{tabular}

Fuente: DPU 2006

Dirigiendo la mira ahora a los asentamientos marginales, es sabido que ellos no pagan un precio por el suelo en donde se establecen. La lógica de producción y ocupación de las tierras opera en base a necesidades humanas y a una condición de ilegalidad. Sin embargo, a través del tiempo ese suelo ocupado si llega a tener un valor en sí mismo o un precio de venta en caso de la producción pirata. Toda su edificación, de manera paulatina, parcial e individual, 
termina teniendo unos costos asociados. Según los análisis realizados por el DPU (2006) en "los barrios de invasión, el suelo no tiene costo inicial, aunque representa en promedio el $11 \%$ de los costos familiares totales (oscilando entre el $0 \%$ y el $33 \%$ ), ya que con el paso del tiempo el suelo adquiere un precio de compra-venta, aunque sin soporte jurídico. En los barrios pirata, por su lado, el precio de la tierra es el $3.2 \%$ de los costos familiares totales en el caso de la vivienda en un barrio pirata antiguo y $35 \%$ en donde el proceso de construcción es más reciente. Un mercado del suelo se produce con el paso del tiempo." (DPU, 2006:171) El componente que entra a jugar una cuantía importante en la producción marginal es el costo de urbanización que posteriormente al Estado le toca realizar por medio de los mejoramiento de barrio y que después la familia tiene que asumir en una cierta proporción (conexión a redes de servicios domiciliarios y malla vial). ${ }^{43}$

Es interesante ahora comparar los costos de las unidades habitacionales para cada tipo de producción en las dos ciudades. Si bien, dicho costo no tendría por qué estar directamente relacionado con la calidad espacial de las viviendas, ciertos aspectos, en especial para la producción formal como se ha demostrado, si terminan influyendo en dicha calidad en cuanto al tamaño o las densidades. Cabe señalar que la comparación de costos es bastante compleja, no solo por la falta de datos al respecto, sino porque sus procesos y lógicas de producción son diferentes: El mercado produce valores de cambio y el sector marginal en cambio produce valores de uso; la vivienda formal es un producto "terminado" y la vivienda de los asentamientos marginales, una vivienda en proceso.

Gráfico 04 Comparación costos de vivienda producción formal y marginal periodo de 15 años

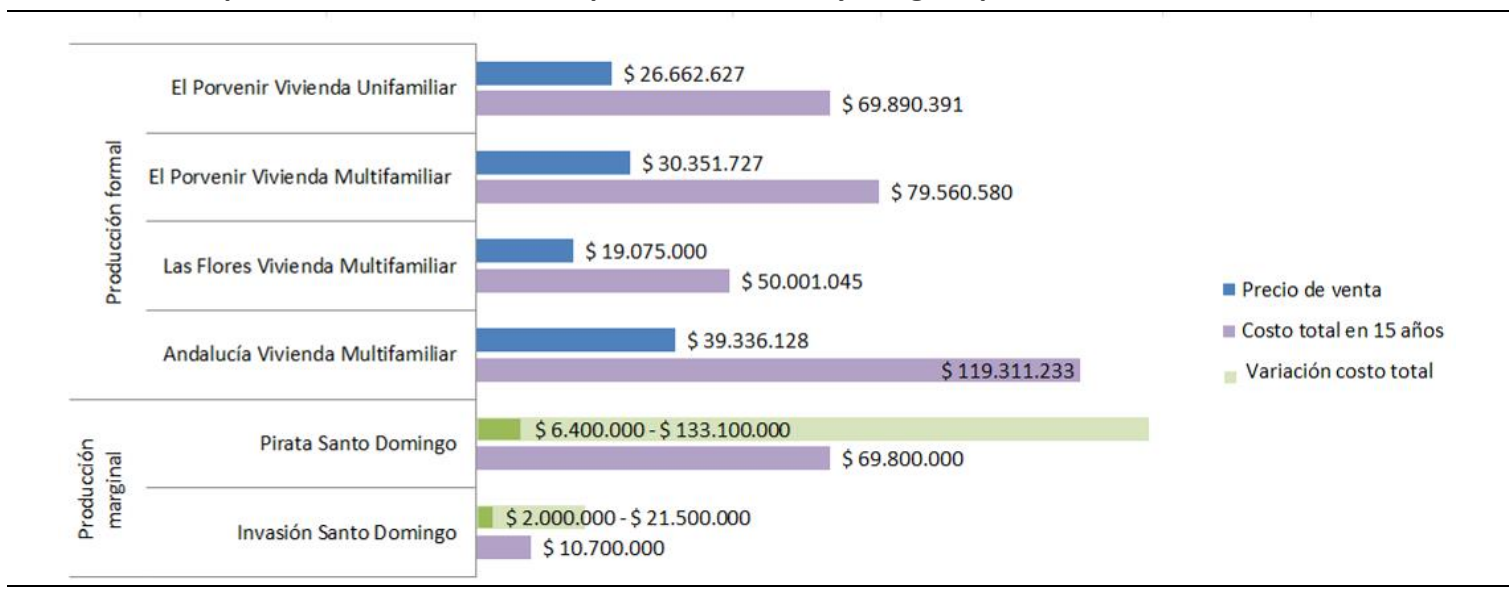

Fuente: DPU 2006

Teniendo en cuenta lo anterior se confrontan , para los estudios de caso de esta investigación, los costos de las dos unidades habitacionales de El Porvenir en Bogotá, los costos de una unidad en el barrio Las Flores, Ciudadela Nuevo Occidente en Medellín y dos viviendas del PUI Nororiental en Santo Domingo. Se suma el ejemplo de una vivienda producida por el sector privado Andalucía en Medellín -anteriormente ya reseñada-. Para el caso de la producción formal se constata que una familia, en el periodo de 15 años en el que se supone finaliza de costear la vivienda, termina pagando 2,32 del valor inicial de la vivienda. Visto de esta manera,

\footnotetext{
${ }^{43}$ El costo unitario total por unidad de vivienda en el programa de mejoramiento de barrio se descompone en infraestructura de acueducto y alcantarillado $12.06 \%$, obras de mitigación de riesgo $3.04 \%$, obras para construcción de vías y pavimentos $18.65 \%$, estimativo del costo por emergencia $6.54 \%$, programa de titulación $3.07 \%$, plan de reubicación por alto riesgo $56.28 \%$, para un total de $\$ 26.425 .120$ en pesos de 2005. El costo equivalente a $69 \mathrm{smmlv}$, es decir al costo de una vivienda VIS tipo 1 . (DPU, 2006:145)
} 
ya no es solo que la población de bajos ingresos no pueda acceder a la vivienda formal por las condiciones de acceso al crédito que impone el sistema bancario, sino que los costos multiplicados en el tiempo superan ampliamente sus posibilidades. Para la producción marginal, los costos estimados varían según cada grupo familiar, por ello se señala un costo promedio y la oscilación que éste puede tener.

\subsubsection{Densidades}

Hay una característica urbana, que responde a factores diferentes para cada forma de producción y que se considera crítica en la configuración de la vivienda social: la densidad. La tipología edificatoria ha estado determinada por los precios de venta del suelo, la cual a su vez ha influenciado en el tamaño de las parcelas y en el trazado del barrio como anteriormente se ha explicado. Relación, que ha producido entonces una máxima ocupación del territorio y una escasa construcción de áreas libres ${ }^{44}$.

En Colombia, la densificación "más efectiva" en términos numéricos de la población ha correspondido a habitantes de bajos ingresos, estratos 1 y 2. (Ver plano 06). Hay más personas viviendo en menor área de territorio. En Bogotá, por ejemplo, en el $40 \%$ del área de la ciudad reside el $57.6 \%$ de la población.

La explicación se debe a los diferentes procesos de densificación que se dan dentro de las formas de producción de vivienda. El primero hace referencia a la alta densificación concebida desde el inicio en los proyectos habitacionales bien sean normales o institucionales y se obtiene por medio de la reducción del área destinada a cada vivienda. Y el segundo, entendido como re-densificación, se consigue por medio del aumento de área útil de la parcela producido por las transformaciones que los habitantes realizan en sus viviendas o como iniciativa pública de renovación urbana en donde se demuele lo existente y se construyen nuevas estructuras con usos más intensivo que el anterior. $Y$ evidentemente un proceso no excluye al otro, por ejemplo una vivienda entregada por el estado y concebida con un área mínima puede a su vez ser re-densificada por sus propietarios si las necesidades así lo exigen.

En términos de calidad ésta característica urbana es la más negativa puesto que se produce un llenado de la mayor cantidad de área, ocupaciones de solares y patios interiores, deteriorando así las condiciones de la vivienda y sus habitantes. Se da en los tres tipos de producción habitacional y varía según el grupo socio económico donde se genere el proceso: los barrios de origen normal de media presentan $146 \mathrm{viv} / \mathrm{ha}$ mientras que los asentamientos de origen clandestino tienen 95 viv/ha y los de origen institucional 45,4 viv/ha. La proporción de área útil sobre área neta urbanizada es de 0.64 para los de origen marginal, 0.48 para los del sector privado y 0.38 para los de gestión institucional. En cuanto al área por vivienda se observan los siguientes datos: $72.31 \mathrm{~m} 2 / \mathrm{viv}$ para los asentamientos de origen marginal, 36.05 para los del sector privado y de 89.8 para los promovidos por el sector público. (Tarchópulos y Ceballos, 2005:57)

\footnotetext{
44 El proceso de urbanización de Bogotá y Medellín las ha llevado a ser una de las ciudades más densas del mundo. Bogotá es la ciudad de todo América más densa con 173 hab./ha sobre áreas brutas y 345hab/ha sobre área útil y Medellín con 154 hab./ha y 307hab/ha respectivamente la sigue relativamente cerca. (Fuente: Demographic World Urban Areas \& Population Projections: 5 th Comprehensive Edition (Revised April 2009)
} 
Pese a lo anterior, estos son escenarios de "densidad baja" en proyectos unifamiliares, análogos con la tendencia general de desarrollo de las zonas urbanas periféricas antes de la introducción de Ley de Ordenamiento Territorial (Ley 388 de 1997). Esta tendencia se ha venido transformando desde inicios del año 2004, cuando se empezó a impulsar proyectos en altura multifamiliares en el desarrollo de vivienda nueva (producción de origen institucional) o en los mejoramientos de barrio en los asentamientos marginales. Ahora las densidades promedio llegan a 280viv/ha para Bogotá y Medellín -obviamente siempre dentro del límite urbano y no en zonas de expansión como es el caso de la Ciudadela Nuevo Occidente con 149viv/ha).

Plano 06 Densidades Bogotá y Medellín en viviendas/hectárea

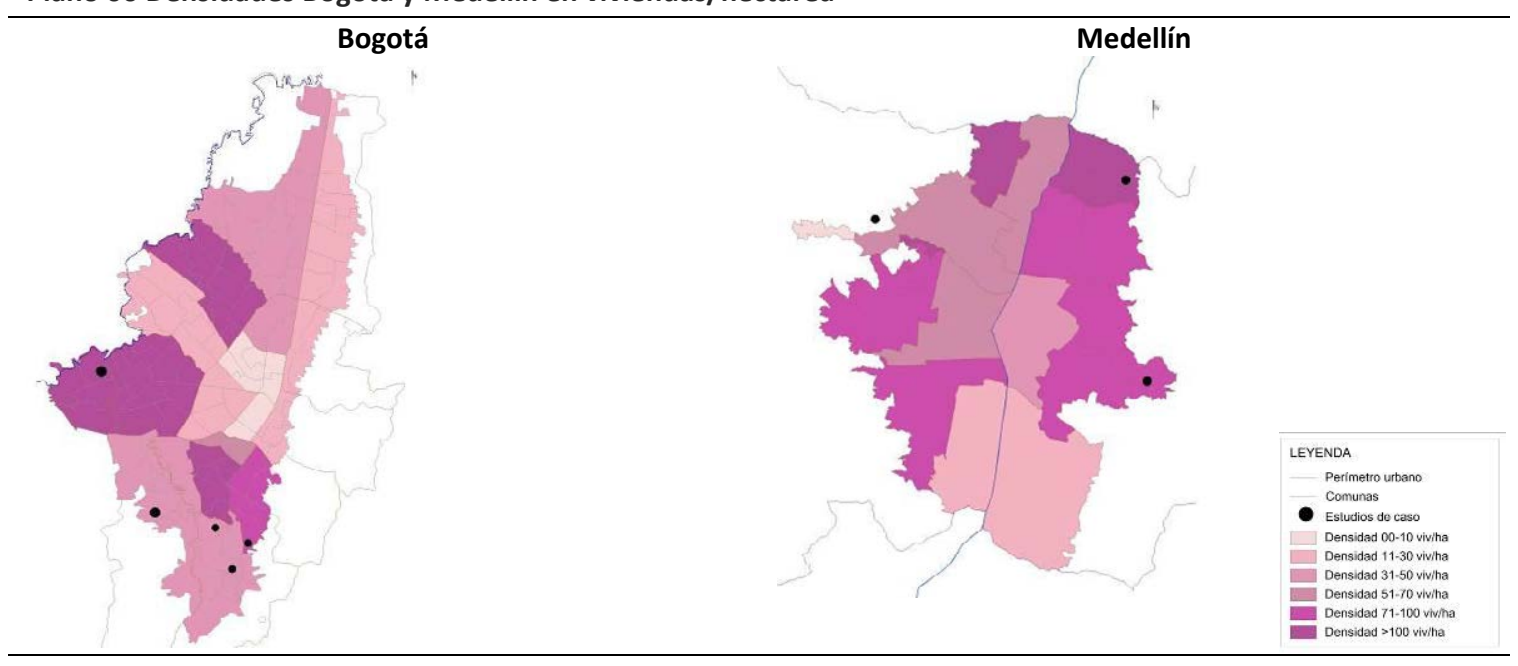

Fuente: DANE Censo 2005

Centrando entonces la mira en las unidades de gestión territorial de los casos de estudio las densidades a seguir han sido en Bogotá a) Para el desarrollo de la vivienda formal en Bosa en donde se ubica la Ciudadela El Porvenir se presentan unas densidades de media de 500viv/ha del área útil en los multifamiliares y $235 \mathrm{viv} / \mathrm{ha}$. del área útil en las viviendas de baja altura. b) Para los desarrollos en los asentamientos marginales en Ciudad Bolívar en la UPZ El Lucero una densidad de 59,11 viv/ha (API EI Lucero 49,24viv/ha. ${ }^{45}$. c) Y en Rafael Uribe Uribe - UPZ Diana Turbay y San Cristóbal - UPZ La Gloria, una densidad de 402,9viv/ha y 303,7viv/ha respectivamente. ${ }^{46}$ Son zonas todas con unos altos niveles de densidad sea cual sea su origen. Para los casos de Medellín las densidades en d) el proyecto de desarrollo de vivienda nueva Ciudadela Nuevo Occidente, como se mencionó, se obtiene una densidad baja entre $100 \mathrm{y}$ 150viv/ha -lo estipulado en el Plan Parcial era de 201 a $240 \mathrm{viv} / \mathrm{ha}-{ }^{47}$ y en e) los asentamientos de origen marginal PUI Nororiental las densidades son zona baja 300viv/ha, zona media 230viv/ha y zona alta 30viv/ha y para el PUI Centroriental zona baja 100viv/ha y zona alta 30viv/ha (promedio de 53 viv/ha).

\footnotetext{
45 La densidad de vivienda por hectárea en este caso delimitada dentro de parámetros de un nivel aceptable no se corresponde con una densidad alta si se mide en habitantes por hectárea. Para la UPZ, este indicador estaría rondando los 395hab/ha y la API estaría por 215hab/ha. Densidades muy por encima de valores adecuados de 120hab/ha.

${ }^{46}$ Fuente. SDP - SIEE - DICE, Boletín No. 18. Población, Viviendas y Hogares a Junio 30 de 2010, en relación con la estratificación socioeconómica vigente en el 2010.

47 Hay que recordar que hasta la fecha de estudio, año 2010, el terreno de ésta Ciudadela seguía considerándose suelo de expansión; no había sido aún anexado y contaba con unas dimensiones importantes 236ha.
} 
De cualquier modo, alcanzar estas densidades conlleva un problema central: aumentar la proporción de redes de infraestructura, de servicios públicos, de vías, de espacio público, de transporte y de equipamientos en un territorio ya deficiente en el tema. Permitir, bajo una regulación estipulada, aumentar la cantidad de unidades habitacionales en un territorio dado debería estar planeado con el aumento de metros cuadrados de zonas verdes y de equipamientos por habitante; tema que evidentemente no está resuelto de forma adecuada por el marco normativo actual que tan solo define los topes de ocupación (índices máximos de ocupación) de las edificaciones destinadas a usos dotacionales y las cesiones a asignar. En términos de calidad no se especifica absolutamente nada.

Ahora bien, abordar este tema con mayor profundidad implica una reflexión más amplia que involucra el contexto urbanístico, normativo, económico y social dentro del cual se construyen soluciones de vivienda y, por lo tanto, lineamientos de política pública que permitan plantear el modelo de ciudad que se desee. El debate entre ciudad compacta de alta densidad o ciudad extensa, en el caso colombiano, de densidad media o de todas formas alta, sigue vigente y demuestra que el tema aún no se ha resuelto ${ }^{48}$. No es objetivo de esta investigación centrarse en dicha discusión, pero sí quiere resaltar su importancia y señalar que éste debe ser ampliamente debatido no solo por parte de las instituciones, sino también por la academia y los propios habitantes.

\subsubsection{Determinantes de la población residente de los seis estudios de caso}

Caracterizar a la población de bajos ingresos objeto de los programas de vivienda nueva o mejoramiento de barrio debería estar estrechamente ligado con la producción de vivienda que se genera. No tienen, por ejemplo, las mismas necesidades una familia rural conformada por seis miembros, desplazada por el conflicto interno, provenientes de alta montaña; que una familia de tres personas reasentada que vivía del reciclaje en el morro de Moravia $^{49}$ en Medellín. Sin embargo se interviene el territorio con una misma tipología edificatoria de vivienda $\left(45 \mathrm{~m}^{2}\right)$, se resuelven los espacios públicos o colectivos de forma semejante y hasta se plantean los mismos procesos "participativos" independientemente del tipo de proyecto.

Se ha mencionado ya en varias ocasiones que el objetivo de una vivienda social con condiciones de calidad adecuada parte de las características de ese espacio residencial, y si

\footnotetext{
48 Desde los años 60, en Colombia, Lauchlin Currie había advertido que los costos que implicaba el modelo de ciudad de baja densidad solo eran soportables por una economía tan poderosa como la de Estados Unidos; tanto por la enorme inversión pública que significa construir la red de autopistas y de servicios públicos en zonas extensas, como por los costos de transportar los habitantes en vehículos privados. Las experiencias internacionales de los últimos 50 años refrendan este postulado (RINCÓN, 2006.49)

49 El proceso de configuración del asentamiento humano en Moravia se inició en forma espontánea a partir de los años 60 del siglo pasado, influenciado principalmente por la localización de la estación El Bosque del Ferrocarril de Antioquia, la actividad de explotación de materiales que se da en la llanura aluvial del río Medellín, el funcionamiento del antiguo basurero de la ciudad, y el desarrollo de la carrera 52, vía arterial principal de acceso al barrio, a la zona nororiental y a los municipios del norte del valle del Aburrá. Hacia 1977 se convirtió en el depósito final de las basuras a cielo abierto de toda la ciudad. Hacia 1987, habitaban ya 14.600 personas en la zona las vuales sobrevivían muchas de ellas gracias al reciclaje y manejo de las basuras. Actualmente en la

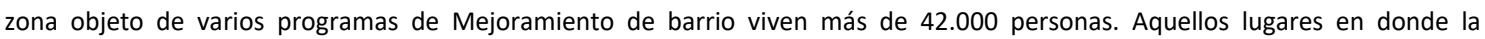
administración consideró no aptas para vivir, la población fue reasentada; muchos de ellos se fueron trasladados a la Ciudadela Nuevo Occidente. (DPA, Documento Técnico del Plan Parcial de Mejoramiento de Moravia 2003)
} 
éste ha de ser modificado por los habitantes para adaptarlo, éste no cumplirá seguramente con dichas condiciones.

Por esta razón interesa estudiar aquí algunas características básicas de la población residente en los seis estudios de caso correspondientes a su relación con el espacio residencial, vivienda y entorno. Para ello, se consideran tres dimensiones fundamentales: las características socioeconómicas, los rasgos demográficos referentes a su lugar de procedencia y finalmente, estrechamente ligado con las dos dimensiones anteriores, su comportamiento o su forma de vivir el espacio. Más delante en este documento se analiza su grado de participación o vinculación con los proyectos realizados en sus áreas de residencia.

Las características socio-económicas de la población residente en los seis estudios de caso como ya se ha mencionado en los apartados anteriores, es primordialmente estrato 1 y 2 , es decir una población con recursos económicos bajos $(\$ 150.569$ pesos colombianos equivalente a 40.31 euros al $\mathrm{mes}^{50}$ ) y poca capacidad de pago. Si bien son beneficiarios de subsidios en los servicios públicos domiciliarios y pueden acceder a subsidios social para la vivienda, para algunas familias esa "ayuda" no es suficiente o no puede acceder a ella. La razón es que este tipo de clasificación por estratos es incapaz de reflejar la disponibilidad real de recursos -lo que muestra un debilitamiento del sistema a la hora de garantizar equidad(Torres, 2009).

Como se observa en la tabla a continuación sobre los estudios de caso, la mitad de la población económicamente activa para laborar está en paro, porcentaje que coincide en muchas ocasiones con el empleo informal. Su vinculación laboral, está en casi todos los casos relacionado con la venta ambulante, la construcción o el comercio. Hay casos específicos, como el de la Ciudadela Nuevo Occidente en donde un porcentaje elevado de su población, aquella proveniente de Moravia, se dedica aún al reciclaje. En todos los casos los ingresos pueden ser variables mes a mes.

Comparando los ingresos medios de la población residente de los proyectos de vivienda nueva frente a los de mejoramiento de barrio no se aprecia una mayor diferencia. Los datos son muy similares. El porcentaje de población viviendo con menos de un salario mínimo, es decir sin los ingresos suficientes para adquirir un conjunto de bienes y servicios destinados a satisfacer sus necesidades elementales es elevado, un cuarto de la población. Lo que lleva a preguntarse cómo logra esta población enfrentar el pago de una vivienda nueva, el cobro de los servicios domiciliarios o el billete para el transporte público. ¿Pueden pagar todo ello o deben conseguir otras soluciones que les permita resolver esas obligaciones o necesidades?

Un recurso para aumentar los ingresos es, como bien se sabe ${ }^{51}$, modificar sus viviendas. Cambiar los usos, dividir el espacio para alquilar, vender, montar un taller o subarrendar son muchas de las opciones que la población improvisa.

\footnotetext{
${ }^{50}$ Según datos obtenidos del SISBEN en junio de 2004 para PUI Nororiental

${ }^{51}$ El censo realizado por la Municipalidad en 2004 a los pobladores de Moravia que iban a ser relocalizados en Ciudadela Nuevo Occidente registraba que el $8 \%$ de los grupos familiares dependía económicamente de la vivienda; es decir, dentro de su casa poseían un negocio de producción, de comercio o de servicios, algunos con permisos de funcionamiento y otros sin este. Situación que no deja de sorprender, una vez más, que no haya sido tenida en cuenta por la administración la construcción de locales comerciales para albergar las actividades comerciales de algunos de los residentes que fueran a habitar el proyecto. Caso similar se presenta en Ciudadela El Porvenir.
} 


\begin{tabular}{|c|c|}
\hline Ciudadela Nuevo Occidente & $\begin{array}{l}\text { +A mayo de } 2010 \text {, cerca del } 15 \% \text { de los apartamentos de La Cascada y de La Montaña } \\
\text { mantenían una unidad productiva dentro de su vivienda. } \\
\text { +Los antiguos pobladores de Moravia que se dedicaban al reciclaje continuaron con su } \\
\text { labor como medio de sustentación. }\end{array}$ \\
\hline Ciudadela El Porvenir & $\begin{array}{l}\text { +Para el año } 2011 \text {, cerca del } \mathbf{4 2 . 0 1 \%} \text { de la población económicamente activa se } \\
\text { encontraba económicamente inactiva o desempleada. } \\
\text { +Cerca del } 25.2 \% \text { de la población trabajaba por menos de } 1 \mathrm{smmlv} \text {, menos de } 4.5 \text { dólares al } \\
\text { día. }\end{array}$ \\
\hline MIB Sur Con Bogotá & $\begin{array}{l}\text { En cuanto al empleo se registra para el año } 2009 \text {, que un (43.1\%) de la población se } \\
\text { encuentra desempleada, en su gran mayoría son personas con mano de obra no calificada } \\
\text { o tecnificada, empleados de oficios generales y obreros de la construcción entre otros, el } \\
\text { ( } 41.8 \%) \text { de la población se encuentran laborando o con trabajos temporales y el (15\%) son } \\
\text { empleados independientes, que en su mayoría son vendedores ambulantes, pequeños } \\
\text { comerciantes y otros dedicados al "rebusque". } \\
\text { +un ( } 28.36 \%) \text { de hogares en condición de pobreza }\end{array}$ \\
\hline $\begin{array}{l}\text { PUI Nororiental en Medellín } \\
\text { (Fuente Sisben junio 2004) }\end{array}$ & 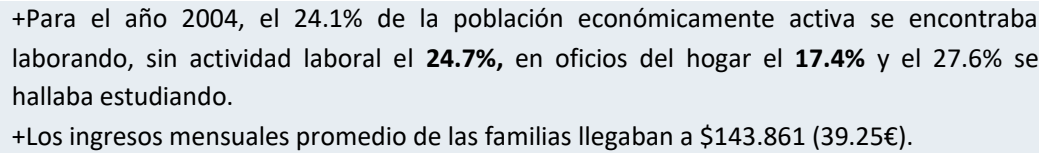 \\
\hline MIB El Lucero en Bogotá & $\begin{array}{l}\text { +Para el año } 2004 \text {, más del } \mathbf{5 0 \%} \text { de la población trabajaba por menos de } 1 \mathrm{smmlv} \text {, menos } \\
\text { de } 4.5 \text { dólares al día. } \\
\text { En el } 7.6 \% \text { de los barrios hay vinculación al empleo formal, en el } 51.9 \% \text { al empleo informal, } \\
\text { en el } 3.8 \% \text { a labores independientes y calculan el porcentaje de desempleo en un } 25 \% \text {. La } \\
\text { vinculación laboral de la población trabajadora se da en distintos campos comerciales e } \\
\text { industriales, algunos caracterizados dentro de la informalidad y otros dentro de la } \\
\text { economía formal o empresarial. }\end{array}$ \\
\hline $\begin{array}{l}\text { PUI Centroriental en Medellín } \\
\text { (Fuente: PRIMED Fase II 1998-2003 }\end{array}$ & $\begin{array}{l}\text { +Para el año } 2005 \text {, el } \mathbf{5 1} \% \text { de la población activa se encontraba laborando (de la cual } \\
11.73 \% \text { corresponde a empleo formal y } 39.27 \% \text { a subempleo). El resto de la población } \\
\text { resolvía sus necesidades a partir de la informalidad, sobresaliendo trabajos como } \\
\text { construcción, venta ambulante, rebusque y venta de productos básicos dentro de los } \\
\text { espacios de la vivienda. } \\
\text { +Los ingresos mensuales promedio de las familias llegaban a (44.21€) }\end{array}$ \\
\hline
\end{tabular}

Fuente: Datos del Sisben y de Dane para la ciudad de Bogotá y Medellín.

Un ejemplo claro es el de la Ciudadela Nuevo Occidente en donde, a mayo de 2010, cerca del $15 \%$ de los pisos habían sido modificados o el de la Ciudadela El Porvenir en donde ésta transformación se había dado en un $8 \%$ de sus viviendas. Dentro de las actividades desarrolladas en esos nuevos espacios modificados se encontraba áreas para materia prima, máquinas de confección, servicio de fotografía, hornos de panadería, peluquería, tienda de misceláneas, tienda de abarrotes, elaboración de productos de limpieza, construcción de rejas, servicios de soldadura, café internet o bares entre otros. En el estudio de caso Ciudadela Nuevo Occidente, por tratarse además de edificios en altura con espacios colectivos de circulación, se encontró que dichos espacios, los corredores servían como espacio para proyectar sus actividades: había venta ambulante anunciando a viva voz sus productos, un estacionamiento de motocicletas a la espera de ser reparadas y un pequeño corral de gallinas.

Otra situación encontrada para hacer frente a los pagos adquiridos era justamente el impago de esas obligaciones. El estudio de Mejía (2012) y de Mena (2012) señalan que un porcentaje de la población dejaba de pagar su cuota mensual de los servicios públicos o de la hipoteca de la vivienda adquirida, subarrendaba y se marchaba a otro lugar de la ciudad o bien se conectaba de forma fraudulenta a los servicios para poder seguir contando con ellos.

Sobre los rasgos de la población residente su procedencia es en parte, base de esa gran complejidad socio-económica brevemente descrita. Tanto para los estudios de caso de los asentamientos marginales como los de vivienda nueva esos desarrollos habitacionales han sido 
el destino de aquellos pobladores que han llegado a la ciudad de Bogotá o Medellín, a causa del conflicto armado de varias regiones del país, por desplazamiento intraurbano o para mejorar su condición de vida ya bastante condicionada. A los proyectos de vivienda nueva se le suma además población reubicada por la construcción de autopistas, parques, centros recreativos o grandes obras públicas de desarrollo urbano y población que con esfuerzo y sacrificios han depositado sus ahorros para la compra de una vivienda de interés social promovida y subsidiada por el Estado.

Tabla 07 Procedencia población residente estudios de caso

\begin{tabular}{|c|c|}
\hline \multirow[t]{4}{*}{ Ciudadela Nuevo Occidente en Medellín } & +Población procedente de Moravia ( antiguo basurero de la ciudad de Medellín) \\
\hline & +Población reubicada dentro de la ciudad. \\
\hline & +Población reubicada de catástrofes naturales del departamento \\
\hline & $\begin{array}{l}\text { +Población con capacidad de ahorro y por lo tanto acceso a un subsidio para } \\
\text { compra de vivienda nueva }\end{array}$ \\
\hline \multirow[t]{3}{*}{ Ciudadela El Porvenir en Bogotá } & +Población reubicada dentro de la ciudad. \\
\hline & +Población reubicada de catástrofes naturales del departamento \\
\hline & $\begin{array}{l}\text { +Población con capacidad de ahorro y por lo tanto acceso a un subsidio para } \\
\text { compra de vivienda nueva }\end{array}$ \\
\hline MIB Sur Con Bogotá & Inmigración no controlada de desplazados por la violencia \\
\hline PUI Nororiental en Medellín & +Primeros asentamientos de población desplazada años 70. Ocupación por invasión \\
\hline \multirow[t]{6}{*}{ MIB El Lucero en Bogotá } & Migración campesina \\
\hline & + Parta baja (1960) Desarrollo de los primeros barrios de la UPZ (Meissen, Lucero \\
\hline & Medio y Bajo) con familias provenientes del Tolima, Boyacá y Cundinamarca. \\
\hline & +Parte alta (1980) surgen los barrios Naciones Unidas, Cordillera, Alpes, Juan Pablo \\
\hline & II, Paraiso y El Mirador. \\
\hline & Barrios de origen ilegal $88.41 \%$ \\
\hline \multirow[t]{6}{*}{$\begin{array}{l}\text { PUI Centroriental en Medellín } \\
\text { (Fuente: PRIMED Fase II 1998-2003) }\end{array}$} & $\begin{array}{l}\text { Barrio Las Estancias (1938 primer asentamiento) Urbanización planificada al } \\
\text { occidente e invasión hacia el oriente }\end{array}$ \\
\hline & Barrio Villa Liliam (1963) Urbanización planificada al sur e invasión hacia el norte \\
\hline & Barrio Villa Turbay (1968) Barrio de Invasión \\
\hline & $\begin{array}{l}\text { Barrio de Jesus (1970) Urbanización planificada al oriente e invasión hacia el } \\
\text { occidente }\end{array}$ \\
\hline & Barrio Juan pablo II (1976) Barrio de Invasión \\
\hline & Barrio Ocho de Marzo (1984) Barrio de Invasión \\
\hline
\end{tabular}

Fuente: Datos del Sisben y de Dane para la ciudad de Bogotá y Medellín.

Esa mezcla indiscriminada de personas provenientes de lugares diversos con una composición económica, cultural y social diferente ha generado problemas en la convivencia y en la correlación entre la morfología del espacio residencial y las prácticas de los pobladores.

Así por ejemplo, para MIB EI Lucero los primeros habitantes provinieron, hace más de treinta años, de los departamentos del Tolima, Pereira, Valle, Gacheta y Pacho Cundinamarca y poblaron de forma precaria los primeros barrios del área de estudio. Su origen era de carácter rural. Utilizaron las parcelas aledañas a su vivienda como zonas de cultivo y tablado de animales. Otros habitantes del Lucero, en un porcentaje muy menor (6\%) fueron habitantes de distintos sectores de Bogotá que por razones económicas se vieron obligados a desplazarse a este sector de la ciudad.

Otro ejemplo en Ciudadela Nuevo Occidente es el caso que expone un habitante de los bloques de La Aurora, la señora Marta.

"Tenemos muchos problemas de convivencia. El manejo de las zonas comunes ha sido un lío. Nos dieron un manual de convivencia cuando nos trasladaron a los apartamentos, pero existe una pequeña dificultad que no se tuvo en cuenta en el proyecto: hay gente que no sabe leer y los que 
saben, simplemente no les gusta" (Agencia de Prensa IPC, Medellín, en red www.ipc.org.co)

Un último ejemplo, es el caso de la población de Moravia que fue reasentada en la urbanización La Aurora, uno de los sectores de Ciudadela Nuevo Occidente. Esa población que vivía junto al morro de basuras, en un sector conocido como El Oasis fue reubicada después que un gran incendio que arrasó con sus viviendas en el año 2007.

Su nueva ubicación les permitiría contar con un nuevo piso "mucho más cómodo, seguro y libre de contaminación ambiental", además de un permanente acompañamiento psicosocial y un plan de capacitaciones para el empleo para que salieran del reciclaje y tuvieran la posibilidad de acceder a créditos para proyectos productivos. Sin embargo, dos años después de su reubicación, varios residentes han perdido el entusiasmo de un "cambio radical en su vida". Los problemas de adaptación al nuevo entorno y el incumplimiento en los proceso de acompañamiento por parte de la administración les ha generado una situación más difícil aún de soportar. Así lo expresa algunos residentes:

"Yo vendo dulces en el centro de Medellín y como Moravia es tan cerca de todo, pues caminaba o hacía otros trabajitos ahí cerca de la casa. Pero aquí, tan lejos de todo, con tantos problemas para moverme, no me estoy ganando ni para comer. No he pagado la cuenta de servicios públicos, estoy casi aguantando hambre",

Su situación es similar a la de su vecina Marta Pérez, también reasentada del sector El Oasis. Ella advierte que los procesos de acompañamiento prometidos a la hora del traslado no han sido suficientes y no han funcionado.

"Las capacitaciones que ofrecieron no surtieron mucho efecto. La gente tenía más fuentes de trabajo en Moravia. Aquí, las posibilidades de acceder a 'capitales semillas' a través del Presupuesto Participativo, para montar negocios, beneficia a un grupo muy pequeño. Aquí falta mucho proyecto para generar empleo", (Mejía, 2012)

Lo anterior, dice la mujer, ha derivado en una situación de pobreza que tiene a decenas de familias en una crisis social bastante delicada: "Hay gente desconectada por montones. Pero eso no es lo más triste: aquí en Pajarito hay varias, pero varias familias que se van caminando hasta Moravia a rebuscarse la comida allá, porque si se quedan aquí, pues aguanta mucha hambre". (Mejía, 2012)

Y por último el comportamiento o la forma de vivir el espacio de los habitantes es la dimensión que determina el uso de los espacios residenciales. Está estrechamente ligada con el lugar de procedencia de los habitantes, es decir con el sentido propio que le da la población a ese territorio que habita. También está relacionada con la dependencia que se genera cuando se vive con otros: integración, satisfacción, filiación o experiencias vividas, y con la percepción sobre las condiciones de calidad de ese espacio cuando interactúa con el otro.

Una de las situaciones encontradas en los esos estudios de caso fue el uso de las zonas verdes para la realización de algunas prácticas culturales, como cocinar con fuego de leña, realización de comidas típicas y comunitarias, ensayo de danzas en las vías públicas con música a alto volumen o huertas.

Dentro de las edificaciones también se observaron algunas particularidades en el uso de esos espacios tales como niños jugando en los pasillos comunitarios, extensión de salón hacia el 
exterior de la vivienda o ampliación, decoración o cerramiento del antejardín cuando tenían. Sin embargo, la problemática no está dada con lo que hacen con el espacio sino también con lo que no pueden hacer con el espacio. Un ejemplo de ello lo relata un habitante de Ciudadela El Porvenir. En su vivienda de 46 metros destinó $16 \mathrm{~m}$ para un negocio de papelería, fotocopiadora, sala de internet y llamadas internacionales. En los 20 metros restantes se acomodó con su madre, sus dos hijas y su hermano. Un día de fiesta que se reunió con sus familiares venidos de otras partes de la ciudad, y según su narración, tuvieron que abstenerse de bailar porque apenas cabían las sillas que distribuyeron en la cocina, las habitaciones, la sala y el comedor.

"En El Porvenir usted puede ver todas las necesidades de la Ciudadela en una misma parte, Hay 8 parqueaderos para 86 apartamentos. Entonces la vía principal está llena de carros parqueados. Como no hay locales comerciales, en el andén de al frente se instalan todos los negocios de chazas que venden legumbres, arreglan zapatos y otras que son cafeterías ambulantes. Para acabar de ajustar, muchas personas sacan la basura al andén aun cuando no sea el día en que pasa el carro recogiéndola, y esto se llena de ratas" (Alcaldía Mayor De Bogotá, 2011)

Sobre ello la administración ha reconocido, en los dos proyectos de vivienda nueva, Ciudadela Nuevo Occidente y El Porvenir, que ha habido cambios en las dinámicas sociales en las familias reubicadas, que sus elementos identitarios se han transformado y con ello su forma de apropiación del espacio. Así los esfuerzos de la población, lejos de ser reconocidos por las autoridades competentes son constantemente destruidos, obligándoles a empezar de nuevo cuando llegan a su nueva residencia.

A estas dificultades descritas se suma adicionalmente la situación de violencia en la que se encuentran varios de los sectores de los estudios de caso. Existe una disputa por parte de los llamados combos delincuenciales. La señora Alba Monsalve cuenta su situación personal en Ciudadela Nuevo Occidente: "Mi hijo de 17 años vivía conmigo pero se metió en problemas al relacionarse con las personas de por acá. Lo tuve que mandar de nuevo para nuestro antiguo barrio. Por allá nos hay combos ${ }^{52}$, ni paras ${ }^{53}$, ni milicias. Aquí ya no puede volver porque se lo tienen prohibido."

El espacio público suele ser el territorio más controlado por dichos combos. Ellos territorializan en esos espacios su poder y controlan quién puede acceder a ellos. Lo que genera evidentemente confrontaciones por parte de la población. Hay subutilización de los parques recreativos, exposición de los menores a venta de drogas o usos de armas y uso de rampas y zonas de parqueo como zonas de juego. Todo ello sumado a la falta de equipamientos, como se verá en el apartado siguiente, ha generado sin duda unas condiciones de calidad urbana deficiente. La manifestación de los conflictos sociales y económicos conduce a su vez a problemas físico-espaciales del espacio.

\footnotetext{
52 La palabra combos, pandillas o bandas hace referencia a un grupo de personas movidas por un mismo fin que por lo general suelen dedicarse a la delincuencia organizada.

${ }^{53}$ Se les llama así a los grupos paramilitares de autodefensa que participan en el conflicto armado de Colombia.
} 


\subsection{CARACTERÍSTICAS DEL ESPACIO PÚBLICO RESIDENCIAL}

Las características del espacio público y colectivo de la vivienda social están relacionadas con la implicación que las densidades, es decir trazada del barrio, tamaña de las parcelas y tipología edificatoria, tienen sobre éste para cada grupo de población según su estrato. Las dificultades anteriormente planteadas sobre la realidad del sector habitacional para la población de bajos ingresos en Bogotá y Medellín no pueden conducir más que a una evidente problemática de calidad, escasez y deficiencia del mismo. La conformación de un entorno con múltiples carencias se reconoce dentro de los dos proceses de urbanización, el formal y el marginal ${ }^{54}$.

Cada uno de ellos, cada forma de producción afecta una cantidad de suelo requerido para disponer de vías internas, de espacio público y de zonas de uso dotacional ${ }^{55}$. Sobre una hectárea bruta urbanizable, las áreas útiles urbanizadas en proyectos que surgen como resultado de gestiones legales son de alrededor el 50\% del área, mientras que, en asentamientos de origen marginal, las áreas que son efectivamente ocupadas son cerca del $70 \%$, con lo cual se sacrifica cualquier tipo de área para equipamientos o zonas verdes. (METROVIVIENDA, 2011:27)

La diferencia radica en que las familias de los barrios marginales deben buscar la totalidad de los servicios sociales que requieren por fuera de los conjuntos desarrollados o bien esperar a que el Estado decida intervenir por medio de sus programas de Mejoramiento de Barrio para contar ellos. Los habitantes de los conjuntos habitacionales formales en cambio, se supone, cuentan desde el inicio con dicha infraestructura. Cabe aquí señalar, que esta condición de "ventaja" para la producción formal es una condición hipotética o incierta, como se quiere demostrar más adelante con el estudio de casos. El terreno (las cesiones) para la construcción de ese espacio público y servicios sociales es efectivamente dejado como un área libre pero la construcción de la infraestructura no se da hasta bien pasado el tiempo. Las decisiones políticas priorizan, por el beneficio económico que éste les aporta a algunos, la construcción de las unidades familiares antes que la urbanización misma.

Para tener una visión más amplia acerca de las deficiencias y problemas de este espacio público conformado para la población de más bajos ingresos, se aporta ahora algunos datos sobre los Índices de Calidad de Vida ${ }^{56}$ en las dos ciudades en cuestión. Se extraen los datos de la población estrato 1 y 2 en las localidades y comunas o de los diagnósticos de las unidades territoriales de gestión de los casos de estudio, en muchos casos, antes de ser desarrollados.

\footnotetext{
${ }^{54}$ Así lo demuestra un estudio reciente sobre los patrones urbanísticos que subyacen en estos procesos urbanos, pues pese a las grandes diferencias que podían esperarse de gestiones por principio antagónicas, al contar con un interés predominante igual máxima rentabilidad del suelo- conducen a un espacio público deficitario tanto en términos cualitativos como cuantitativos (TARCHÓPULOS Y CEBALLOS, 2004)

${ }^{55}$ Entendiendo que los proyectos multifamiliares desarrollados en grandes porciones de suelo tienen implícitas áreas destinadas a usos dotacionales y recreativos en las proporciones que piden las normas urbanas (mínimo el $17 \%$ para parques y $8 \%$ para equipamientos sobre las áreas netas urbanizables). (METROVIVIENDA, 2011:.27)

${ }^{56}$ Fuentes extraídas de la bases de datos locales, diagnósticos institucionales y sectoriales, Censos (DANE 2005 - SDP proyecciones 2005 - 2015), Encuesta de Calidad de vida 2003- 2007 y Sistematización de experiencias de otros sectores e investigaciones. Ver en detalle en Bibliografía.
} 


\subsubsection{Zonas de amenaza ambiental}

Con respecto a las zonas de amenaza ambiental se observa que el $13 \%$ de los hogares de Bogotá y el 10\% de los de Medellín se ubican en lugares con mayores riesgos de inundación, fallas geológicas o problemas de deslizamientos y de ellos la mayoría corresponde a los estratos 1 y 2 (CENSO 2005). Para el caso de la localidad de Bosa, el Fondo para la Prevención y Atención de Emergencias (FOPAE) estableció que la UPZ El Porvenir presenta en todo su territorio una amenaza media por inundación y en su perímetro con el río Bogotá un $5 \%$ de amenaza alta por estar por debajo de la cota del río. La UPZ EI Lucero en Ciudad Bolívar, en cambio, tiene tan solo un 5,34\% de su territorio por amenaza de inundación, pero tiene un $27,87 \%$ de riesgo de deslizamiento (remoción en masa). El proyecto Sur con Bogotá, tiene en sus UPZ colindando en la parte baja del parque Entrenubes alto riesgo por deslizamiento por antiguas zonas de cantera y explotación minera (aproximadamente 9ha) y en la parte alta del parque 8 quebradas que atraviesan la zona de los cerros orientales hacia el río Tunjuelito sin ningún tipo de plan de manejo ambiental (aguas contaminadas, construcciones ilegales en ronda de rio y proliferación de roedores y vectores).

Para los casos de estudio en Medellín, en la Ciudadela Nuevo Occidente el terreno presenta problemas principalmente por corrimiento de tierras y de inundación en rondas de río: 95,11 ha., es decir el $41,26 \%$ de su territorio, corresponden a áreas con restricciones geológicas severas y zonas inestables de manejo especial no aptas para la ubicación de edificaciones, y 32,09 ha. correspondiente al $13,92 \%$ se clasifican como zonas con restricción geológica moderada (con estabilidad condicionada). En las comunas 1 y 2, PUI Nororiental, y las comunas 8 y 9, PUI Centroriental la mayor amenaza se presenta por los deslizamientos de tierra causados, entre otras, por las aguas servidas no conducidas, las fuertes pendientes, el grado de urbanización, de intervención antrópica y las técnicas inadecuadas de modelamiento del terreno. En el PUI Centro oriental de las 126 ha. que conforman el proyecto de mejoramiento, el $58 \%$ corresponden a suelo de alto riesgo no recuperable (con el agravante que el $85 \%$ de las viviendas de las ubicadas en suelo apto, presentan un grado de vulnerabilidad medio, que hace que no estén preparadas para soportar las fuerzas de la naturaleza).

Plano 07 Zonas de amenaza ambiental Bogotá y Medellín

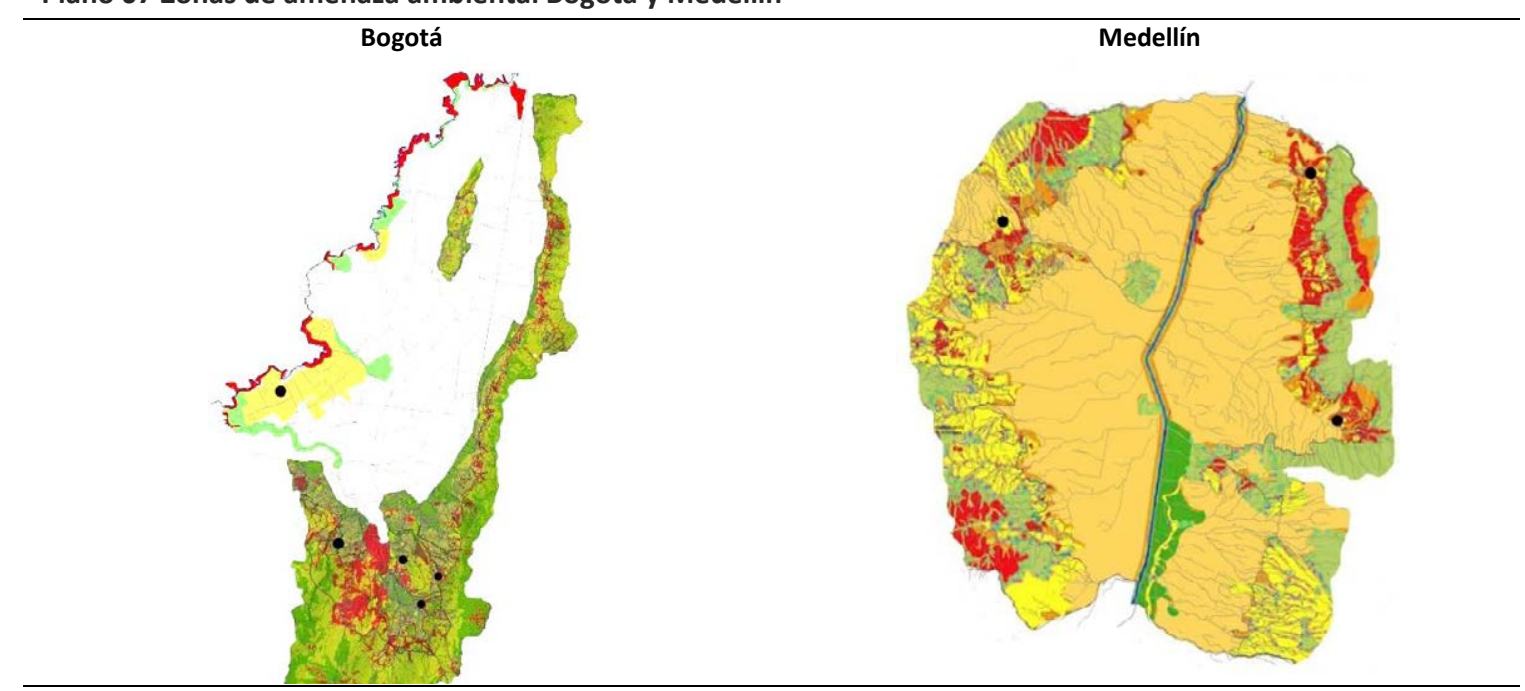

Fuente: Secretaria Distrital de Planeación (SDP) Revisión POT 2013: Zona de inundación por desbordamiento y remoción en masa. Atlas documento de soporte POT 46-2006: Atlas documento de soporte. Medellín 


\subsubsection{Prestación de servicios públicos domiciliarios}

Con relación a los servicios domiciliarios, las dos ciudades cuentan con una cobertura de acueducto, alcantarillado y energía significativa. Según el censo del 2005 Bogotá tiene un servicio de energía 99,4\%; alcantarillado $97,9 \%$ y acueducto $98,6 \%$. Medellín por su lado cuenta con $98,8 \%$ de energía, $95,6 \%$ de alcantarillado y $97,3 \%$ de acueducto. Se presentan algunos problemas de alcantarillado y aguas servidas, especialmente en los asentamientos de origen marginal, por el hecho de compartir sanitarios entre varios hogares ( $10 \%$ de la población de estratos 1 y 2) o por problemas de no conexión o saturación en la red de servicios de alcantarillado. Así mismo se reconocen algunos problemas con uniones fraudulentas a servidores de agua y electricidad. El suministro de gas natural en cambio aún es deficiente, para Bogotá en ese mismo año, 2005, el servicio es suministrado al 79,8\% de la población y para Medellín al 22,2\%.

Una problemática general para todos los servicios domiciliarios es la desarticulación y falta de concertación entre las empresas prestadoras de servicios públicos y los entes de planificación física, social y económica de las dos ciudades. Las distintas predicciones, proyecciones y formulaciones que cada actor formula desconocen las funciones y pretensiones de los otros. Las consecuencias terminan siendo una alta ocupación del espacio público por la infraestructura que requiere cada servicio y una problemática ambiental con coberturas en zonas de alto riesgo o por encima de los límites de ordenamiento territorial de la ciudad.

Para el caso de Medellín, por ejemplo, la provisión de servicios públicos no ha seguido las disposiciones normativas de ordenamiento territorial en la delimitación de las áreas urbanas. El perímetro urbano y el perímetro sanitario difícilmente han coincidido a lo largo de la historia. De facto, según la cartografía de la Empresa Pública de Medellín, dicha empresa consideró el Valle de Aburra, desde Girardota hasta la Estrella, un solo territorio urbano a prestarle cobertura mucho antes que el ordenamiento reconociera ese territorio como el "área metropolitana de Medellín“. En cierto modo, las proyecciones de cobertura de la empresa reforzaban la tendencia de ocupación de las laderas de alta pendiente en la ciudad y su conurbación con las urbes aledañas. Quienes aprovechaban esta circunstancia eran los asentamientos de origen marginal a quienes la cobertura de electricidad era la primera en llegar, seguido del acueducto y el alcantarillado. Unos años después el Estado les haría llegar, aunque no en todos los casos, la conexión al sistema vial y quizás algún equipamiento o espacio público construido.

\subsubsection{Equipamiento y espacio público}

La cobertura de equipamientos y espacios verdes, aun cuando es diferenciada por estrato social en cuanto a los servicios que se ofrecen, es una de las dotaciones del espacio colectivo de la vivienda social más deficitaria. Es diferenciada porque, por ejemplo, en cuanto a equipamientos los estratos de ingresos bajos tienen mayor cobertura de puestos de salud, escuelas, salones comunales y espacio colectivos de bienestar social $\left.\right|^{57}$. Los estratos de ingresos

\footnotetext{
57 Los equipamientos de bienestar social son edificaciones y dotaciones destinadas al desarrollo y a la promoción del bienestar social, a través de actividades de información, orientación y prestaciones de servicios a grupos sociales específicos como la familia, la infancia, la orfandad, la tercera edad, los discapacitados y grupos marginados. Son diseñados para atender a los grupos de
} 
más altos tienen mejores equipamientos de preescolares o jardines infantiles, colegios de secundaria completos, parques con juegos infantiles en buen estado, teléfonos públicos y zonas verdes de uso público. Y es deficitaria porque no llega ni a 4 equipamientos por 1.000 habitantes en ninguna de las dos ciudades. (Censo 2005)

Esto se evidencia en Bogotá en las zonas de estudio en donde como mínimo la mitad de sus equipamientos son de bienestar social: en la UPZ El Lucero de 463 equipamientos casi 300 son de bienestar social, en El Porvenir de 78 equipamientos, 66 son de bienestar social y en Los Libertadores en San Cristóbal de 219, 114 son del mismo servicio. Salvo por algunos centros de salud y algunos centros educativos no existen muchas más construcciones para este fin social. Es debido mencionar que los equipamientos de bienestar social son en muchas veces gestionados, promovidos y constituidos por la propia comunidad a diferencia de los equipamientos de salud y educación que son exigidos dentro de la ley en cada plan sectorial.

Tabla 08 Equipamientos por UPZ Bogotá. Año 2005

\begin{tabular}{|c|c|c|c|c|}
\hline & \multirow{2}{*}{$\begin{array}{l}\text { Vivienda nueva } \\
\text { UPZ EI Porvenir }\end{array}$} & \multirow{2}{*}{$\begin{array}{l}\text { MIB Lucero } \\
\text { UPZ EI Lucero }\end{array}$} & \multicolumn{2}{|c|}{ MIB Sur con Bogotá } \\
\hline & & & $\begin{array}{c}\text { UPZ Los } \\
\text { Libertadores }\end{array}$ & UPZ Diana Turbay \\
\hline Abastecimiento de alimentos & & 3 & 1 & \\
\hline Servicios funerarios & & 2 & & \\
\hline Culto & & & 3 & 3 \\
\hline Recreación y deporte & & 1 & & 1 \\
\hline Salud & & 82 & 56 & 8 \\
\hline Seguridad & 1 & 4 & 3 & 3 \\
\hline $\begin{array}{rr}\text { Total } \\
\end{array}$ & 78 & 463 & 219 & 269 \\
\hline Equipamientos por 1000 habitantes & 1,1 & 2,9 & 3,0 & 3,4 \\
\hline
\end{tabular}

Fuente: SDP - Planes maestros de equipamientos 2005

En Medellín la mayor cantidad de equipamientos para los estratos más bajos, y por lo tanto para las zonas de estudio, son igualmente los servicios de bienestar social (PUI Nororiental: comuna 1 cuenta con 54 edificaciones y la comuna 2 con 39; PUI Centroriental: la comuna 8 tiene 52 construcciones para este fin y la comuna 9, 56). Le siguen, a diferencia de Bogotá, los equipamientos de recreación y deporte (PUI Nororiental: la comuna 1 tiene 47 construcciones de este tipo y la comuna 2, 41; PUI Centroriental: la comuna 8 cuenta con 5 construcciones para este fin y la comuna 9 con 9). Aquí los escenarios que se construyen "son prácticamente todos para la práctica del fútbol en todas sus modalidades y no se proponen o desarrollan nuevos equipamientos para otras disciplinas". (Documento de Soporte POT 2006)

población más vulnerable. Estos equipamientos son de bajo impacto en tanto no generan procesos de transformación urbana. (SDP 2009) 


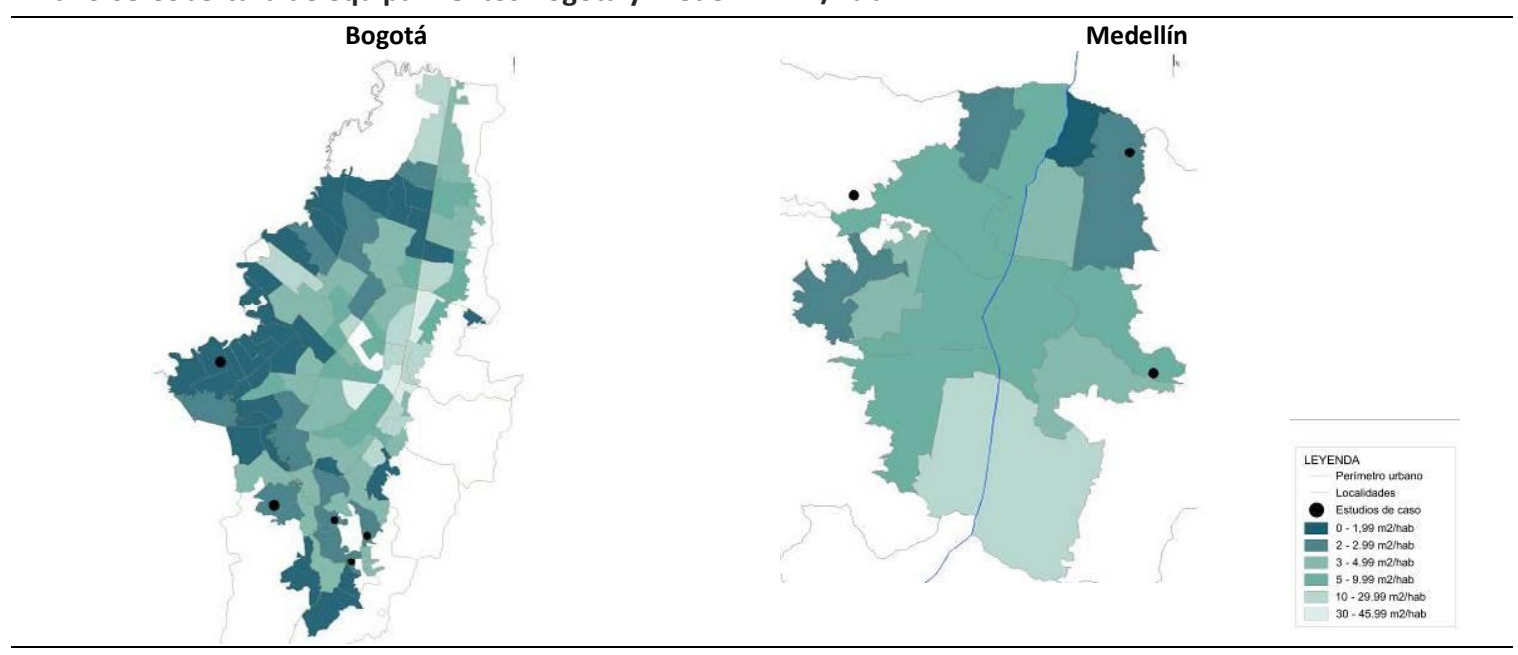

Fuente. SDP, DAP Medellín en Cifras y Departamento Administrativo Nacional de Estadística -DANE-, Censo 2005.

Así mismo, si se detallan los indicadores para los casos de estudio se observa que la meta de $15 \mathrm{~m}^{2} /$ hab. o de $6 \mathrm{~m}^{2} /$ hab. está muy lejana, aun para los proyectos de vivienda nueva. Para la Ciudadela Nuevo Occidente, tomando como referencia el corregimiento San Cristóbal, el índice es de $4,32 \mathrm{~m}^{2} / \mathrm{hab}$. y para la ciudadela EL Porvenir de $1,4 \mathrm{~m}^{2} / \mathrm{hab}$. Para los asentamientos de origen marginal, como es evidente, dicha cifra es aún menor. Para la UPZ EI Lucero el indicador de zonas verdes y parques es de $0,40 \mathrm{~m}^{2} / \mathrm{hab}$., para el PUI Nororiental de $1,9 \mathrm{~m}^{2} /$ hab. para la comuna 1 y 1,1 para la comuna 2 y para el PUI Centroriental de 0,18 $\mathrm{m}^{2} /$ hab. La mayor parte de estas zonas son de carácter residual y presentan algún tipo de conflicto con edificaciones construidas fuera de sus límites parcelarios. Adicionalmente son zonas invadidas con basuras y escombros sin ningún tipo de tratamiento

El espacio público, aquel referido a zonas verdes, libres y de recreación es otro ejemplo claro de las mismas condiciones de insuficiencia. Son espacios por lo general dispersos y sin mayor tratamiento (poco mobiliario, sin arborización, sin alumbrado, etc.) Los indicadores para cada ciudad dan cuenta de ello. (Ver plano 08) Para Bogotá el índice de espacio público efectivo para el año 2000, año de inicio de la investigación, al 2010 no ha variado considerablemente, ha pasado de $2,87 \mathrm{~m}^{2} / \mathrm{hab}$. a $3,2 \mathrm{~m}^{2} / \mathrm{hab}$. En Medellín en cambio el indicador ha bajado, pasando en los mismos años de $3,97 \mathrm{~m}^{2} /$ hab. a $3,55 \mathrm{~m}^{2} /$ hab. Supera el de Bogotá. Ahora bien, si se toma en cuenta como meta el índice mínimo de espacio público efectivo por habitante de $15 \mathrm{~m}^{2}$ definidos por ley ${ }^{58}$, ninguna de las dos ciudades ha alcanzado dicha meta; apenas llegan al $26 \%$ de lo regulado de acuerdo a su población. Eso sí, se mantienen estables a pesar del crecimiento de la población y el desarrollo de los asentamientos marginales desarrollados durante ese periodo.

\footnotetext{
58 Los metros cuadrados de espacio público efectivo han sido modificados en las regulaciones nacionales a través de los años, y quizás después de constatar que ninguna ciudad de Colombia llegaría a dicha cifra propuesta de $15 \mathrm{~m}^{2} / \mathrm{hab}$. La primera normativa, dentro del periodo de estudio de la investigación, fue el Decreto 15 de 1998 por medio del cual se reglamentó el manejo del espacio público en los Planes de Ordenamiento Territorial y se estableció el promedio de $15 \mathrm{~m}^{2} / \mathrm{hab}$. Después se elaboró el documento del Departamento Nacional de Planeación "Visión Colombia 2019" en donde se propuso otra meta diferente, una menos ambiciosa, de $10 \mathrm{~m}^{2}$ por habitante de espacio público efectivo. Y finalmente se redactó el CONPES 3718 de 2012 en donde se estableció una meta de 5 a $6 \mathrm{~m}^{2} /$ hab. Meta que sobra decir aún no se ha cumplido por mucho que se haya disminuido a un tercio de la propuesta inicial.
} 


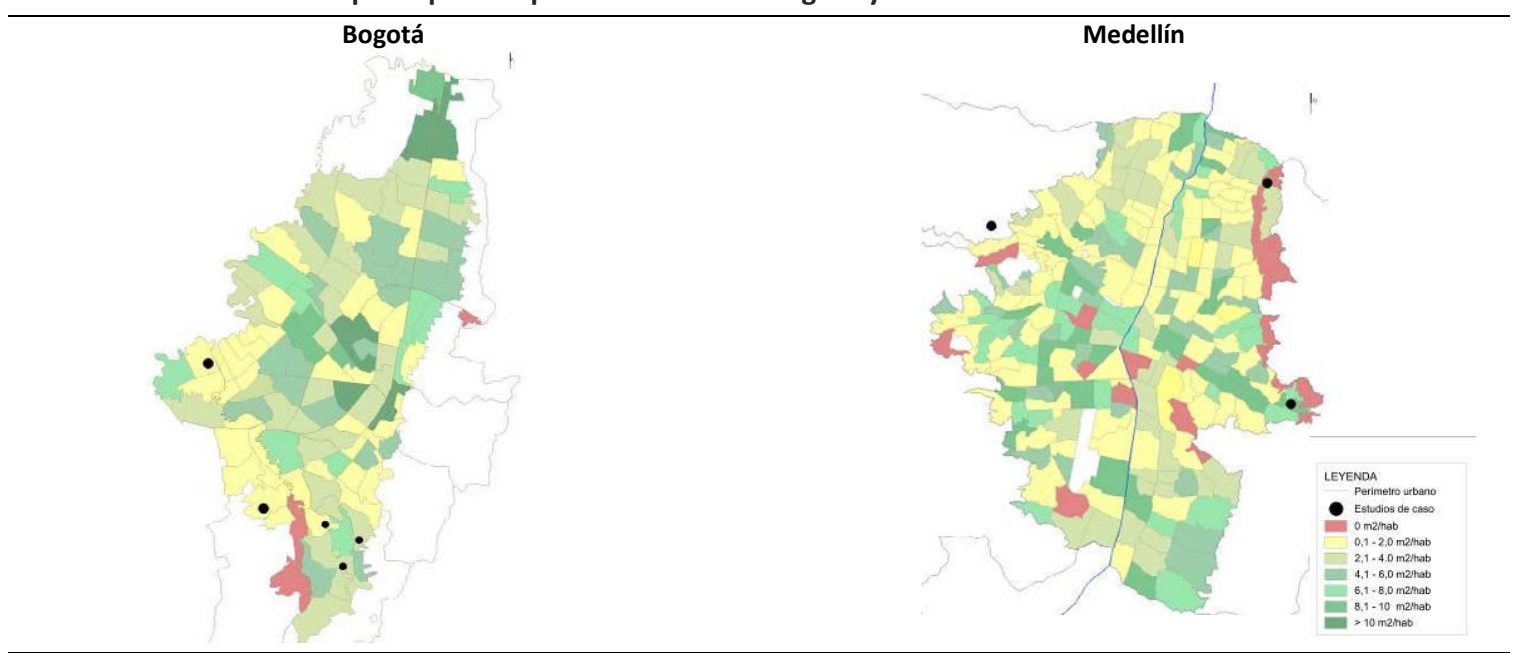

Fuente: Instituto Distrital Recreación y Deporte -IDRD-, base de parques 2005 Bogotá y Departamento Administrativo de Planeación. Documento técnico POT 2006 Medellín.

\subsubsection{Cobertura malla vial}

La cobertura en la malla vial en la ciudad de Bogotá y Medellín alcanza poco más de 90\% de su territorio, sin embargo el estado de las vías arteriales, intermedias o locales están en un $50 \%$ de promedio en mal estado ${ }^{59}$. A ello se le suma la percepción que tiene la población sobre ésta que es entre mala y muy mala. La conexión por medio de vías arteriales en las dos ciudades en cuestión es deficiente y se acrecienta en las periferias. Allí, en los dos tipos de producción, la forma y la marginal, predominan los barrios con conexiones a una sola vía arteria, con una clara tendencia a hacerlo a través de un solo canal de acceso de carácter barrial. [...]No existe ningún tipo de continuidad con la malla urbana colindante, debido a que su trazado, -causado por la topografía o el desarrollo indiscriminado de barrios de diversos tamaños cuyo desarrollo se rige por la iniciativa individual y por una lógica basada en la máxima explotación del suelo, no permite prolongación de ninguna de las vías con los desarrollos aledaños. (Tarchópulos Y Ceballos, 2005:54)

Como consecuencia de ello, los tiempos promedio de desplazamiento son mayores para los estratos de ingresos más bajos. En Bogotá, en promedio para los estratos 1, 2 y 3, la población debe recorrer $20 \mathrm{~km}$ para desplazarse a su zona de trabajo, lo que le toma casi dos horas por trayecto. Para Medellín en cambio, por ser una ciudad de menor tamaño el recorrido medio de viaje es de $8,75 \mathrm{~km}\left(18,5 \mathrm{~km}\right.$ para zonas de periferia) y el tiempo de desplazamiento de $30 \mathrm{~min}^{60}$. Hay que recalcar además que la ciudad de Medellín cuenta con metro. Éste llega por medio de metro cable a dos de los tres estudios de caso, Ciudadela Nuevo Occidente y PUI Nororiental.

\footnotetext{
59 Para Bogotá el estado de las vías es: malo en un 53\%, regular en $19 \%$ y bueno en $28 \%$ según Base de Datos del Inventario y Diagnóstico de la Malla Vial - IDU - Diciembre de 2005.

${ }^{60}$ Fuente: DOCUMENTO TÉCNICO DE SOPORTE POT [ACUERDO 46/2006] Municipio de Medellín. Segunda Parte: Diagnóstico Evaluación y Seguimiento. Movilidad. Pág.337
} 
Tabla 09 Distancia y tiempo de desplazamiento malla vial por estratos. Bogotá 2005

\begin{tabular}{ccc}
\hline & Distancia promedio de viaje & Tiempo de desplazamiento \\
\hline Estrato 1 & $23 \mathrm{~km}$ & $117 \mathrm{~min}$ \\
\hline Estrato 2 & $20 \mathrm{~km}$ & $112 \mathrm{~min}$ \\
\hline Estrato 3 & $17 \mathrm{~km}$ & $103 \mathrm{~min}$ \\
\hline Estrato 4 & $18 \mathrm{~km}$ & $100 \mathrm{~min}$ \\
\hline Estrato 5 & $18 \mathrm{~km}$ & $104 \mathrm{~min}$ \\
\hline Estrato 6 & $16 \mathrm{Km}$ & $92 \mathrm{~min}$ \\
\hline Bogotá & $19 \mathrm{~km}$ & $104 \mathrm{~min}$ \\
\hline
\end{tabular}

Fuente: DANE -GEIH 2005.

Entrando a detallar los estudios de caso, para la Ciudadela Nuevo Occidente la conexión se da, como se mencionó anteriormente, por medio de una sola vía, la Vía al Mar. Al iniciar el proyecto no se observaba una articulación coherente del territorio con el resto de la ciudad y desde el sector de influencia no existía un sistema vial, y mucho menos peatonal, que pudiera responder a las demandas de los nuevos proyectos de vivienda. Lo que se convertía en un problema a solucionar a partir de la implementación del modelo de movilidad que se formulara con ocasión del Plan Parcial. (Plan Parcial Pajarito, 2002). Para los dos PUI en cuestión la situación era similar: una vía estructurante principal por medio de la cual se iban anexando algunas vías de los asentamientos en formas de fragmentos independientes y separados por la estructura geográfica del área, caracterizada por la presencia de un sistema de quebradas que no permitían una fácil integración espacial.

Para los casos de estudio de la ciudad capital, el proyecto Sur con Bogotá, el de más pronta ejecución dentro de los proyectos analizados, es el que menor conexión tenía con el resto de la ciudad. No solo contaba con una sola vía de acceso principal, sino que la mayoría de sus calles, especialmente las que estaban en la parte superior del parque Entrenubes, no estaban pavimentadas y no tenía transporte público "regulado", es decir no contaban con el servicio de Transmilenio ni las rutas alimentadoras. Los desarrollos de los asentamientos se presentaban en forma de unidades sueltas que se autoabastecían, pero que no formaban una red que permitiera el acceso a todo el territorio o hacia la ciudad. Para el estudio de caso El Lucero la cobertura de malla vial era también muy deficiente, lo sigue siendo salvo por la zona en donde se presenta el área prioritaria de intervención (API). Existe un atraso considerable entre la construcción de las vías principales de la zona y la construcción de viviendas que durante las últimas décadas han ocupado los sectores de la ladera suroriental ${ }^{61}$. Adicionalmente las altas pendientes y la presencia de numerosos elementos del sistema hídrico no permiten una ágil respuesta por parte de las instituciones encargadas debido a los altos costos que éste debería asumir para la conexión de estos asentamientos con la ciudad.

Para el caso de ciudadela El Porvenir, aun cuando cuenta con vías arteriales de importancia en su entorno, la accesibilidad al proyecto se da tan solo por una vía intermedia de la localidad. Esto se debe a que los barrios de origen marginal que están en su perímetro cuentan con vías internas en mal estado, incompletas, discontinuas o con un perfil menor al tipificado que dificulta la conexión con la ciudad. Adicionalmente parte de su perímetro colinda con el rio Bogotá o con el canal dela Av. Primero de mayo. Lo que deja aún más aislado el proyecto. Parte de la propuesta del POT para dicha ciudadela es justamente desarrollar dos grandes avenidas: la Alameda Longitudinal y la Alameda El Porvenir para mejorar dicha condición.

\footnotetext{
${ }^{61}$ Las vías principales que ya se encuentran construidas son el 1,52\% del total de las vías que tiene la UPZ y las vías locales son el $1,61 \%$, a diferencia del promedio de la ciudad, que corresponde al 4,6\% para vías principales y al $20 \%$ de vías locales.
} 
En síntesis, del análisis global de las características del espacio público resulta evidente, que más allá de un porcentaje de área libre que se limite a dejar por normativa o por necesidad, es necesaria una intervención eficaz por parte del Estado para construir un espacio público y colectivo de calidad. Como lo expone Ceballos (2005), es notoria la ausencia de reflexión sobre el tema como componente estructurante de la espacialidad urbana. Pues pese a las carencias en prácticamente todos los ámbitos: espacio libre, equipamientos, cobertura de malla vial, etc. no existe un planteamiento que incida en los procesos de urbanización presentes en el momento. Más bien, parecería que el modelo se acoge a lo existente con el ánimo de integrarlo en una propuesta tendiente a aumentar la cobertura de oferta de vivienda de bajo costo sin alterar de manera estructural ni el funcionamiento del mercado ni las deficiencias de la planeación urbana. Deficiencias referidas a la ausencia de parámetros específicos para la regulación de la espacialidad producida en la periferia de la ciudad. (Ceballos, 2005: 20)

De este modo se podría llegar a pensar que las intervenciones en el espacio urbano, e incluso en la vivienda, son más de carácter "paliativo" que intervenciones con capacidad de cambio para el espacio físico y la población misma. Como consecuencia de ello resulta difícil pensar que existe una posibilidad real de superar los problemas deficitarios y de calidad de estas zonas de periferia de la ciudad.

La expedición de la Ley 388 de 1997 y con ella los Planea de Ordenamiento Territorial, vienen a demostrar aparentemente lo contrario. Un nuevo enfoque es introducido con directrices y pautas de diseño más eficiente, según el Estado, para trasformar la estructura urbana. Se define un nuevo modelo de ciudad con diferentes niveles y prioridades de intervención en donde se incorporan renovados conceptos de integralidad, sostenibilidad, interinstitucionalidad o equidad, entre otros. Para verificar sí todo ello es cierto, si realmente la nueva normativa introduce cambios, en el siguiente apartado se exponen a modo de conclusiones parciales los problemas de calidad del espacio residencial, vivienda y entorno y se señala posteriormente lo que el ordenamiento territorial propone modificar.

\subsection{EL PROBLEMA DE LA CALIDAD. Conclusiones parciales}

\subsubsection{Las condiciones de habitabilidad de la vivienda social}

Las condiciones de calidad de la vivienda social están supeditadas, entre otras, como se observó en los dos apartados anteriores, a las características que el territorio, el espacio residencial y su entorno, van configurando. Es por ello que se puede afirmar que las lógicas o mecanismos de formación de una ciudad tienen unas consecuencias directas sobre el conjunto de condiciones físicas y no físicas que permiten la permanencia humana en un lugar, su supervivencia y su grado de satisfacción, es decir sobre su habitabilidad. (Saldarriaga, 1982)

Tres lógicas de formación principales, en síntesis, fueron observadas. En ellas es ahora esencial identificar claramente las implicaciones sobre las condiciones de calidad en la vivienda social: i) las dos formas básicas de producción, entiéndase formal y marginal, que en su configuración tienen condiciones inherentes desfavorables a la obtención de una correcta habitabilidad en la vivienda; ii) las decisiones de intervención del Estado en la producción de la vivienda enmarcadas en un mecanismo para promover más el desarrollo económico que lograr 
condiciones adecuadas de calidad, y finalmente iii) El mercado como mecanismo de ocupación de las tierras que implican una decisión sobre la localización y las características de los terrenos a los cuales puede acceder a una vivienda social, y por ende termina configurando segregación espacial.

Las dos formas básicas de producción del espacio residencial social originan lógicas de configuración urbanas que tienen, en su propio proceso de conformación, condiciones desfavorables o adversas a la calidad misma de la vivienda. Por ejemplo, la vivienda de los asentamientos marginales por sus limitados recursos materiales y constructivos obtiene en su edificación una inadecuada calidad constructiva y estructural, con deficiencias en sus condiciones de iluminación, ventilación, acabados, etc. De ahí que sea una vivienda a postular en planes de mejoramiento. La vivienda formal a su vez, es un objeto de mercado cuyo interés es el de la reproducción del capital invertido más que el de un espacio acondicionado para las necesidades de quien va a habitarla. Como producto se entrega con la menor área posible de metros construidos, sin acabados, con precariedad en la distribución espacial, sin contar el número de personas o actividades que allí se van a alojar o se van a realizar. Se entrega como una solución habitacional completa y terminada, cuando en realidad es una vivienda incompleta y deficitaria. ${ }^{62}$ Las transformaciones que la población puede o debe hacer en ella comprometen, en muchos casos, la adecuación funcional o la estabilidad sísmica. Es así, de manera progresiva en el tiempo, como una solución habitacional entregada como vivienda nueva puede requerir también planes de mejoramiento.

Con respecto al entorno, como se describió, los dos tipos de producción cuentan con un espacio público colectivo de difícil conformación y consolidación. Hay insuficiencia en las vías peatonales y vehiculares para una adecuada accesibilidad y movilidad por los desarrollos habitacionales. Cuando hay vías pavimentadas, estas están en malas condiciones. Las zonas verdes son insuficientes y están dispersas por el territorio. Hay dificultades con el mantenimiento del espacio mismo, el alumbrado, la arborización o el mobiliario. Además, se presenta una carencia en los equipamientos y dotaciones complementarios a la vivienda.

En suma, básicamente las dos formas de producción representan una lógica de necesidad por la que una familia adquiere una vivienda o la otra, pero que en ningún contexto representan una garantía de unas condiciones adecuadas de habitabilidad ${ }^{63}$ y mucho menos de sostenibilidad. Para cualquiera de los dos casos de producción el lapso de tiempo para consolidar la vivienda o pagarla conlleva una responsabilidad superior a 15 años (Torres 2009:135) sin que necesariamente hayan mejorado las condiciones de habitabilidad de los moradores de dichas viviendas.

Las decisiones de intervención del Estado en la producción de la vivienda social constituyen una lógica de actuación que lleva a priorizar el desarrollo de vivienda nueva -en

\footnotetext{
${ }^{62}$ Según Torres, de esto se desprende, como consecuencia, que el déficit real de vivienda -para la ciudad de Medellín o Bogotásea mayor al estimado por las fuentes oficiales ya que contabilizan como viviendas completas, productos inmobiliarios que no son viviendas y que producen una tendencia a la "degradación" de las condiciones de la vivienda social antes que a su mejora. Cada hogar debe terminar de resolver por su cuenta, con escasos medios y al margen de cualquier mecanismo de control, unos mínimos vitales sobre el espacio habitado que repercute a menudo sobre el entorno urbano y que imprimen al espacio construido condiciones propias de los procesos informales. (TORRES, 2012:122)

63 Para mayor detalle sobre las condiciones de calidad en las diferentes formas de producción de la vivienda social se remite al lector al estudio realizado por TARCHÓPULOS, Doris y CEBALLOS, Olga (2003): Calidad de la vivienda dirigida a los sectores de bajos ingresos en Bogotá. Centro Editorial Javeriano (CEJA) Bogotá
} 
propiedad $^{64}$ - con el objetivo imperioso de promover el desarrollo económico, sin asumir responsabilidades en las regulaciones sobre las condiciones adecuadas de calidad.

En Colombia, y por lo tanto en Bogotá y Medellín, la construcción inmobiliaria, especialmente la de vivienda, ha sido el motor del crecimiento económico. Como se puede comprobar en los Planes de Desarrollo de cada gobierno en cuestión, los objetivos o programas en materia de vivienda, vivienda social, han sido relegados a la obtención de objetivos económicos. "Esto puede verse claramente en los diferentes énfasis o la metas que cada uno ha planteado y la distribución de recursos que han hecho. Desde el punto de vista social y político, los problemas específicos del sector habitacional han recibido un tratamiento coyuntural, sin esbozo de una política de largo plazo. En cambio, es en relación con la dimensión económica del sector en donde existe un tratamiento sostenido de gobierno a gobierno, constituyendo, esta sí, en una real política de Estado". (Fique, 2006:59)

Dicho tratamiento coyuntura puede comprobarse fácilmente por la falta de políticas públicas relativas a las condiciones técnicas y habitacionales de la vivienda social. Pocas normativas especifican parámetros concretos en materia de diseño arquitectónico y urbano. Las principales son el Decreto 1259 de $1973^{65}$, el Acuerdo 6 de 1990 para la ciudad de Bogotá, el Acuerdo38 de 1990 para Medellín, el Decreto 2060 de 2004 por el cual se establecen Normas Mínimas para Vivienda de Interés Social Urbana y por supuesto, los POT propuestos para las dos ciudades en cuestión aun con sus aportes o vacíos como se verá enseguida.

Esa falta de medidas concretas sobre cómo han de ser las condiciones de la vivienda social y su entorno, sumado a los cambios en la política de vivienda, cada vez más hacia unas políticas neoliberales ${ }^{66}$ desde los años noventa, "han propiciado la precariedad del producto que entregan los promotores privados. Lo que ha producido una devaluación persistente del espacio edificado para la población de bajos ingresos, que necesariamente ha conducido a la degradación de la vivienda“. (Torres, 2012:116)

Se puede afirmar que la política de vivienda básicamente solo se ha limitado a otorgar ayudas económicas parciales, bien sea al constructor y/o al propietario de la vivienda, a través de subsidios. Dicho aporte, como lo han demostrado diversos autores Torres (2012), Saldarriaga (2009), Fique (2006), Tarchópulos (2003), no ha contribuido a superar el déficit de vivienda, pero sí ha ampliado los beneficios de los agentes privados implicados en el proceso de promoción y construcción cuando se trata de la producción formal.

\footnotetext{
${ }^{64}$ Es muy poco lo que el Estado se ocupa de otro tipo de producción diferente a la de vivienda nueva en propiedad, como vivienda en arriendo, leasing habitacional o inquilinatos entre otros. En Colombia, por lo general se ha promovido el acceso a un techo y mejor aún el acceso al suelo como una mejor o única posibilidad de contar con un patrimonio "seguro" y propio: un bien inmobiliario con el cual participar o negociar en el mercado.

65 En la década de los años setenta, el Estado colombiano se enfrenta al creciente problema del déficit de vivienda para los más pobres, así como el aumento del fenómeno urbano y social de la urbanización clandestina, con mayor impacto en Bogotá. Esta situación exigió explorar alternativas para lograr una acción estatal más eficiente, para lo cual fue contratado el "Estudio de Normas Mínimas de Urbanización, Servicios públicos y Comunitarios" por el ICT, DAPD y el DNP en el año 1972 (CEBALLOS, 2005:19)

${ }^{66}$ El nuevo paradigma caracterizado por la apertura económica y la configuración de un Estado "facilitador", implantado por la Ley3/91, define una forma de actuación en la que el nivel central del Estado asume la formulación de las políticas solo como directrices que flexibilicen la implementación, en lo cual sus instituciones se reducen al mínimo. La implementación queda en manos de los actores regionales y locales, públicos y privados, en el escenario del mercado, dentro de la lógica dominante de que son estos los principales actores del desarrollo. (FIQUE, 2006:58)
} 
Por otro lado, otra decisión del Estado, estrechamente relacionada con la anterior, es la de reconocer, reglamentar y habilitar los asentamientos marginales. Estos, como se ha mencionado, surgen en parte como consecuencia de ofrecer un objeto de mercado, la vivienda formal en propiedad, al cual un margen de la población no puede acceder. Dicho reconocimiento, es decir dicha legalización ${ }^{67}$ cumple una función de "alivio" para el Estado que no posee o no quiere poseer la capacidad de proveer de un techo a cualquier ciudadano colombiano. Como decisión hace parte también de una intervención sobre el territorio que requiere de una inversión de recursos públicos.

Es más, llama la atención cómo a veces dicha intervención, como lo expone Fique despierta el interés local o nacional para dotar dicho territorio de un espacio público, un equipamiento o un sistema de transporte (este ya a nivel más general para la ciudad) con reconocidos niveles de calidad y funcionalidad. La explicación se debe a que su gestión y producción son igualmente acciones que generan actividad económica, pero, además que afectan a más diversas capas de población, incluso a las más influyentes; son acciones esenciales en el logro de la deseada competitividad económica de las ciudades. Esto, a diferencia de lo que sucede con la vivienda, es lo que conduce al Estado a asumir mayores responsabilidades en la obtención de logros en su calidad. (Fique, 2006:70)

Pero esto pasa solo en algunos lugares específicos de Bogotá o Medellín. El resto de territorio legalizado cumple la función básica, por la escasez de recursos que destina el Estado, de mejorar las características urbanas ${ }^{68}$ con la construcción de vías y andenes, equipamientos 0 zonas verdes entre otras. Ésta mejora tampoco cuenta con normas técnicas o de calidad específicas. Se siguen las que se regulan para la construcción de un espacio nuevo formal.

El mercado como mecanismo de ocupación de las tierras implica una lógica sobre la localización y las características de los terrenos a los cuales puede acceder un proyecto de vivienda social y por consecuencia una lógica de distribución, segregación, de la población habitante de dichos proyectos.

Como se ha señalado, los programas de vivienda social generalmente están ubicados en áreas periféricas con un tejido urbano desarticulado. Están en zonas de riesgo, contaminación, deterioro de algún tipo mecánicos del suelo o con topografías espinosas y tienen deficiencias en las redes o dotaciones públicas. Esto se debe, entre otras razones, al tipo del suelo que han logrado ocupar (bien sea para los asentamientos marginales en donde mejor han podido instalarse o para la producción formal en donde han logrado comprar tierra asequible). Las características del espacio urbano, espacio libre o trazado del barrio, pero también el tamaño de las parcelas y tipología edificatoria están condicionadas directamente por el valor del suelo.

\footnotetext{
${ }^{67}$ La legalización no es más que un procedimiento administrativo y técnico por medio del cual se incorpora suelo y procesos de urbanización y edificación, provenientes de una producción informal, a un territorio formal.

${ }^{68}$ Cabe especificar que dicha legalización, si bien trae unas consecuencias positivas para los habitantes del barrio, como las mejoras físicas de la vivienda o el entorno, poder optar a los bienes y servicios de la ciudad o poder contar ahora con un bien negociable en el mercado formal; también existen efectos negativos de dicha legalización. Ahora las familias deben tributar por su vivienda, como cualquier habitante de la ciudad formal, deben pagar íntegramente las tarifas, el valor de conexión y la liquidación de las tasas de los servicios domiciliarios (agua, gas, teléfono, electricidad, etc.).

Una demostración de ello, es como se mencionó en el aparatado de servicios domiciliarios descrito en las características del espacio público (numeral 1.2) es que la cobertura es prácticamente del $100 \%$ en materia de agua potable, electricidad y recolección de basuras, y en alta proporción en materia de alcantarillado, gas natural (para la ciudad de Bogotá y no de Medellín) y de telefonía.
} 
Entre mayor o más agudo sea su precio a pagar menos será el tamaño de las parcelas y de las soluciones habitacionales. Lo que implica por supuesto una reducción de las condiciones de habitabilidad y, para ir más allá, de las condiciones de la calidad de vida misma de la población. Los habitantes de dichos territorios están marginados de los centros productivos, culturales y de servicios de la ciudad. No cuentan con las mismas oportunidades para acceder a ellos.

Con respecto al tamaño de las soluciones habitacionales, tema que hasta el momento solo se había mencionado en la investigación, es sorprendente cómo en las últimas décadas éste ha disminuido gradualmente a nivel mismo de la normativa. Se ha pasado de parcelas de $60 \mathrm{~m}^{2}$ con viviendas de $50 \mathrm{~m}^{2}$ a parcelas de $35 \mathrm{~m}^{2}$ con viviendas de $25 \mathrm{~m}^{2}$. Lo que, por supuesto no ha estado exento de controversia por parte de la academia, diferentes agentes sociales o los propios habitantes.

Adicionalmente, las últimas normativas de ordenación han dado un margen de flexibilidad al no especificar directamente el área de la vivienda en agrupación, tan solo señalan índices de ocupación, lo que no han dejado de ser comprendidos de forma mal intencionada por algunos promotores privados. Así se ha llegado a incrementar las densidades por medio de la reducción del tamaño del área mínima de la vivienda y la disminución del espacio público a un porcentaje calculado en pro de una mayor explotación económica del suelo urbano, y no como soporte de la calidad urbana. Para la vivienda multifamiliar las parcelas se han concebido con área mínimas en donde los apartamentos han tenido un área entre 36 y $46 \mathrm{~m}^{2}$. Para la vivienda unifamiliar, sin antejardín y aislamiento posterior, el área ha sido de $26 \mathrm{~m}^{2}$. Esto se puede evidenciar fácilmente con los estudios de caso. Por ejemplo, para Ciudadela El Porvenir las viviendas unifamiliares han tenido un área de $44 \mathrm{~m}^{2}$ y los multifamiliares tipo I de $36 \mathrm{~m}^{2}$. Para la ciudadela Nuevo Occidente, éstas han sido un poco más holgadas para los multifamiliares con $46 \mathrm{~m}^{2}$ en promedio.

Tabla 10 Comparativo disposiciones normativas sobre tamaño de la vivienda social

\begin{tabular}{|c|c|c|}
\hline Normativa a nivel nacional & Área Parcela & Dimensiones parcela \\
\hline Decreto 1259 de 1973 & 60 a $82 m^{2}$ & \\
\hline Acuerdo 6 de 1990 & & Frente: $5 \mathrm{mt}$ \\
\hline \multirow[t]{2}{*}{ Bogotá } & $60 \mathrm{~m}^{2}$ & Fondo: $12 \mathrm{mts}$ \\
\hline & $33 m^{2}$ & $\begin{array}{l}\text { Frente: } 3 \mathrm{mt} \\
\text { Fondo: } 11 \mathrm{mts}\end{array}$ \\
\hline $\begin{array}{r}\text { Acuerdo } 38 \text { de } 1990 \\
\text { Medellín }\end{array}$ & $54 \mathrm{~m}^{2}$ & $\begin{array}{l}\text { Frente: } 4,5 \mathrm{mt} \\
\text { Fondo: } 12 \mathrm{mts}\end{array}$ \\
\hline \multirow{3}{*}{ Medellín } & $60 \mathrm{~m}^{2}$ & Frente: $6,0 \mathrm{mt}$ \\
\hline & $72 m^{2}$ & $\begin{array}{l}\text { Frente: } 6,0 \mathrm{mt} \\
\text { Fondo: } 12 \mathrm{mts}\end{array}$ \\
\hline & $300-400 m^{2}$ & Frente: $15-20 \mathrm{mt} *$ \\
\hline Decreto 2060 de 2004 & $35 m^{2}$ & $\begin{array}{l}\text { Frente: } 3.5 \mathrm{mt} \\
\text { Fondo: } 10 \mathrm{mts}\end{array}$ \\
\hline $\begin{array}{l}\text { Vivienda bifamiliar } \\
\text { Vivienda multifamiliar }\end{array}$ & $\begin{array}{c}70 m^{2} \\
120 m^{2}\end{array}$ & $\begin{array}{l}\text { Frente: } 7,0 \mathrm{mt} \\
\text { Fondo: } 10 \mathrm{mts} \\
\text { No especifica.* }\end{array}$ \\
\hline \multicolumn{3}{|l|}{ Normativa a nivel local } \\
\hline Decreto 619 de 2000 POT Bogotá & $54 m^{2}$ & $\begin{array}{l}\text { Frente: } 4,5 \mathrm{mt} \\
\text { Fondo: } 12 \mathrm{mts}\end{array}$ \\
\hline Vivienda bifamiliar & $108 m^{2}$ & $\begin{array}{l}\text { Frente: } 9,0 \mathrm{mt} \\
\text { Fondo: } 12 \mathrm{mts}\end{array}$ \\
\hline Vivienda multifamiliar & $216 m^{2}$ & Frente: $9,0 \mathrm{mt}$ \\
\hline $\begin{array}{l}\text { Acuerdo } 62 \text { de } 1999 \text { POT Medellín } \\
\text { Vivienda básica de desarrollo progresivo }\end{array}$ & $24 m^{2}$ & \\
\hline Agrupación de vivienda & No se especifica. & *lo determina el PND \\
\hline
\end{tabular}

Fuente: Ministerio de Ambiente, Vivienda Y Desarrollo Territorial 
En suma, tres lógicas, como las denomina Eduardo Reese ${ }^{69}$ : lógica de la necesidad, lógica del Estado y lógica del mercado, que funcionan en principio contradictoriamente, pero están de manera simultánea en el territorio y producen, como es evidente, deficiencias en la calidad de la vivienda social. Se infiere, por ende, que dichas condiciones de calidad no pueden ser producto únicamente de un procedimiento disciplinar "mal aplicado". Técnicamente se sabe en dónde podría quedar mejor ubicado un proyecto, cómo dotar su entorno en forma más adecuada, cómo se debería acceder a él o con qué tipo de equipamientos debería contar. De ahí que sea factible pensar que estas condiciones son producto también de un modelo territorial impuesto (modelo normativo y finalmente económico).

Es importante reconocer el papel que desarrollan las políticas públicas desde el modelo normativo (perspectiva del Estado) como regulador del mercado y las consecuencias que su aplicación genera en la configuración del espacio residencial.

Las políticas públicas previas al año 2000, fueron fuertemente marcadas por un punto fundamental de inflexión al desarrollarse la Carta Constitucional de 1991. Ésta determinó cambios en la estructura jurídica y política del país e introdujo grandes modificaciones en el modelo de desarrollo hasta entonces estructurado en la búsqueda de un "estado de bienestar". A partir de ese periodo, se hizo migrar rápidamente el modelo hacia la concepción de un "estado facilitador" fundado en las prácticas del libre mercado que determinaron toda forma de actuación en la producción, consumo y transformación del espacio residencial. Los POT no fueron extraños a dichas nuevas formas de proceder. La política de vivienda social estuvo supeditada a las exigencias de los agentes privados inmobiliarios y a convertir a una fracción de la población de bajos ingresos en demanda solvente a través de la asignación de diversos subsidios de vivienda.

Es indispensable entonces reconocer y explicar los objetivos y principios de ese modelo territorial, modelo normativo de orden nacional y local, y constatar qué cambios formula en el modelo de habitabilidad propuesto. Si bien después de lo analizado se puede afirmar que la vivienda social antes del periodo de análisis, antes de la ley 388 de 1997 y la conformación de los POT, no respondía exactamente a una vivienda digna ${ }^{70}$ o una vivienda adaptada para una población de bajos ingresos, ahora hay que verificar las diferencia que esta nueva normativa aporta. Para esto es útil preguntarse: ¿Cuáles requerimientos y temas se desarrollan en las nuevas normativas en materia de vivienda social? ¿Cuáles aspectos se reglamentan y cuáles no? ¿Cuáles se han explorado de cara a resolver problemas específicos de la calidad de la vivienda?

\subsubsection{7 una forma de actuar diferente, supuestamente}

La expedición de la Ley 388 de 1997 constituye el punto de inflexión, teóricamente, en el desarrollo territorial de Colombia. Intenta concertar, en cierta manera, los componentes socioeconómicos de las anteriores normativas junto con las especificaciones técnicas

\footnotetext{
69 Presentación de Eduardo Reese “"Urbanismo, configuración de la ciudad y mercados del suelo: efectos sociales y espaciales” en el Programa de creación de capacidades institucionales locales en gestión del suelo. Medellín (Colombia), 2010.

${ }^{70}$ Referencias sobre vivienda y espacio público mencionados en la Constitución Colombiana de 1991.
} 
necesarias para reorientar el ordenamiento de las ciudades colombianas. Retoma así la función pública del urbanismo ${ }^{71}$ obligando a cada territorio administrativo a determinar las carencias en materia de vivienda, equipamientos y espacio público para proyectar y construir de forma racional en el territorio con unos recursos programados.

El principio fundamental de la ley 388/97 es construir una base de planeación, con una vigencia aproximada de diez años, bajo objetivos ${ }^{72}$ específicos a desarrollar con el fin de ordenar el territorio dando la posibilidad de corregir algunos de los efectos y tendencias negativas generados en los periodos anteriores. Cabe mencionar dos áreas de interés:

Definición de la estructura urbana, una de las principales novedades de la ley, la cual asigna al espacio público un papel protagónico en relación con su infraestructura, espacios libres, sistema vial, equipamientos y servicios domiciliarios. Como se mencionó anteriormente, los municipios tienen la obligación de definir con precisión la demanda de futuras necesidades y de intentar reducir el déficit ya existente. Lo cual no es un tema menor como se demostró. Para ello establece la obligación de incluir en los componentes de los POT, la reglamentación indispensable para la localización y dimensión del espacio público a escala urbana o zonal y el señalamiento de las afectaciones y cesiones urbanísticas.

Como soporte de dicha obligación y para garantizar su correcta inclusión en los POT de cada ciudad, el gobierno nacional expide el Decreto 1504 de 1998 en donde reglamenta el manejo del espacio público, define diferentes niveles constitutivos: elementos naturales, artificiales y complementarios, y concreta cómo debe incorporarse dicha estructura urbana en la regulación. Allí se establece, como novedad, la necesidad de proteger estas zonas por encima de los intereses individuales de los habitantes. Posteriormente se formula, el Decreto 1538 de 2005, por el medio del cual se reglamenta la accesibilidad al espacio público definiendo criterios destinados a evitar y suprimir las barreras urbanísticas.

Por primera vez, -de aquí la novedad-, se monitorea el déficit cuantitativo y cualitativo del espacio público por parte de los municipios y distritos, se establece la categoría de espacio público efectivo y se define una meta de $15 \mathrm{~m}^{2}$ de espacio público efectivo por habitante aplicable a todo el territorio urbano del país. De este modo, el espacio público se convierte en un escenario fundamental, hipotéticamente, para mejorar la calidad de vida de los habitantes y fomentar herramientas de cohesión social y equidad.

\footnotetext{
${ }^{71}$ Artículo 3: Función Pública del Urbanismo. El ordenamiento del territorio constituye en su conjunto una función pública, para el cumplimiento de los siguientes fines:

1. Posibilitar a los habitantes el acceso a las vías públicas, infraestructuras de transporte y demás espacios públicos, y su destinación al uso común, y hacer efectivos los derechos constitucionales de la vivienda y los servicios públicos domiciliarios.

2. Atender los procesos de cambio en el uso del suelo y adecuarlo en aras del interés común, procurando su utilización racional en armonía con la función social de la propiedad a la cual le es inherente una función ecológica, buscando el desarrollo sostenible.

3. Propender por el mejoramiento de la calidad de vida de los habitantes, la distribución equitativa de las oportunidades y los beneficios del desarrollo y la preservación del patrimonio cultural y natural.

4. Mejorar la seguridad de los asentamientos humanos ante los riesgos naturales.

72 Los objetivos principales de la ley $388 / 97$ respecto a espacio público y vivienda social son:

+Garantizar que la utilización del suelo por parte de sus propietarios se ajuste a la función social de la propiedad y permita hacer efectivos los derechos constitucionales a la vivienda y a los servicios públicos domiciliarios, y velar por la creación y la defensa del espacio público, así como por la protección del medio ambiente y la prevención de desastres.

+Promover la armoniosa concurrencia de la Nación, las entidades territoriales, las autoridades ambientales y las instancias y autoridades administrativas y de planificación, en el cumplimiento de las obligaciones constitucionales y legales que prescriben al Estado el ordenamiento del territorio, para lograr el mejoramiento de la calidad de vida de sus habitantes.

$+Y$ facilitar la ejecución de actuaciones urbanas integrales, en las cuales confluyan en forma coordinada la iniciativa, la organización y la gestión municipales con la política urbana nacional, así como con los esfuerzos y recursos de las entidades encargadas del desarrollo de dicha política.
} 
Énfasis en vivienda social y gestión del suelo para la cual se define que cada Plan de Ordenamiento debe ajustarse a qué se entiende por vivienda social, cómo se accede a ella y cómo se resuelven las demandas, formales e informales, de suelo urbano. (Capítulo $X$ de la ley 388/97, art. 91 al 98 y Ley marco de Financiación de vivienda Ley 546 de 1999).

De esa manera, inicia precisando qué es una vivienda social (vivienda de interés social), definida como:

Aquella que se desarrolla para garantizar el derecho a la vivienda de los hogares de menores ingresos. En cada Plan Nacional de Desarrollo el Gobierno Nacional establecerá el tipo y precio máximo de las soluciones destinadas a estos hogares teniendo en cuenta, entre otros aspectos las características de déficit habitacional las posibilidades de acceso al crédito de los hogares, las condiciones de la oferta, el monto de recurso de crédito disponible por parte del sector financiero y la suma de los fondos destinados a los programas de vivienda. (...) (Art. 91)

Posteriormente, sigue con la descripción de cómo se prestan los servicios públicos domiciliarios -según su estratificación- y cómo se otorgan, limitan y transfieren los subsidios familiares de vivienda. (Art. 93 al 98)

Enunciados, definiciones y descripciones, en los que se evidencia cómo la vivienda social es delimitada casi exclusivamente por la variable precio. No se detalla en ningún momento cómo debe ser esa vivienda en términos arquitectónicos o urbanos. En tal sentido, no existe en la legislación colombiana a nivel nacional una especificación sobre el área mínima a construir o sobre estándares de habitabilidad. Esta especificación llegaría tan solo años después con el Decreto 2060 de 2004 en donde se regulan las "Normas Mínimas para la Vivienda de Interés Social Urbana“. ${ }^{73}$

Por último, enuncia la problemática de los asentamientos marginales que son tratados desde los programas y/o tratamientos de mejoramiento integral, y ligados al tema de la titulación de parcelas y la legalización de barrios. Frente la titulación, la ley disminuye el tiempo por el medio del cual un poseedor puede llegar a ser propietario. Con respecto al mejoramiento propone ser desarrollado en cada POT según las necesidades buscando siempre elevar los estándares de accesibilidad vial, zonas verdes y equipamientos.

Paralelo a los objetivos específicos, la ley 388/97 formula una serie de instrumentos de gestión, financiación y ejecución espacial como mecanismo indispensable para la realización de actuaciones urbanas integrales -dentro de las cuales está la vivienda social -. Su desarrollo, el de estos instrumentos, debe quedar consignado y detallado en cada POT adoptado. Allí se debe especificar para cada actuación los beneficios a obtener mediante el establecimiento de los usos, los índices de ocupación y construcción, así como las cargas que debe asumir los propietarios para la obtención de los beneficios: cesión para vías, zonas verdes, infraestructura y equipamientos. Es decir, es en los POT en donde deben quedar determinadas las

\footnotetext{
${ }^{73}$ Con anterioridad, el Ministerio de Desarrollo Económico, aportó en 1998 la Metodología de diseño y evaluación de proyectos de Vivienda de Interés Social que brindaba recomendaciones en cuanto a parámetros mínimos de habitabilidad, que debían ser aplicados a los programas de vivienda de interés social. Sin embargo, el estudio de Saldarriaga (1999) la Nueva política de vivienda social en Colombia, en el que se comparan dichos parámetros frente a las condiciones de veinte proyectos declarados elegibles por el Inurbe en trece ciudades colombianas, demuestran que en su gran mayoría no se cumplen los requisitos mínimos de área y ventilación. (TARCHOPULOS Y CEBALLOS, 2003:30)
} 
características urbanas y arquitectónicas que establecen las condiciones de calidad de la vivienda y su entorno. -Exigencia que no es del todo cumplida, como se analiza a continuación y que, por lo tanto, pone en duda los logros en calidad que la vivienda y su entorno puedan tener ${ }^{74}$.

\section{Rasgos generales de un modelo propuesto de ordenamiento territorial. Bogotá y Medellín.}

Entre los años 1999 y 2000 se inician entonces, los primeros ejercicios de ordenamiento territorial para las principales ciudades de Colombia, entre ellas Bogotá (Decreto 619 de $2000^{75}$ ) y Medellín (Acuerdo 62 de $1999^{76}$ ). Por primera vez todos los agentes que participarían en los programas de planeación se preguntarían ¿Cómo construir en una ciudad con dos producciones de vivienda, formal y marginal, enfrentadas? ¿Cómo crecer o hacia dónde crecer? ¿En dónde se debe ubicar la vivienda social? O ¿Cómo generar espacio público adecuado e incluyente de una sociedad desigual?

La elaboración de cada Plan se definiría como "un instrumento de planificación de desarrollo local, de carácter técnico, normativo y político que sirve para ordenar los territorios municipales y distritales" o bien como "una herramienta básica de acción física y administrativa, que plasma objetivos ambientales, económicos y sociales en el territorio." (Ley 388/97)

Una serie de intervenciones, denominados tratamientos en los POT, guiaría las actuaciones públicas o privadas asignadas a un determinado suelo urbano o de expansión bajo la tutela de planes parciales o planes maestros. Los tratamientos que interesarían, para el desarrollo de la investigación, sobre la vivienda social y el espacio público serían los siguientes:

Tratamiento de Desarrollo definido como aquel que se aplica en parcelas urbanizables, localizadas en suelo urbano o de expansión, que no han adelantado un proceso de urbanización y que pueden ser desarrollados urbanísticamente mediante la construcción de infraestructura y dotaciones necesarias para el desarrollo de nuevos asentamientos de población. (Decreto 619/00 art.350) y (Acuerdo 62/99 Art.159)

Dichos nuevos asentamientos serían preferiblemente desarrollados con programas de vivienda nueva que permitan atender adecuadamente la demanda, tanto cuantitativa como cualitativa de vivienda, de las familias más pobres de cada ciudad. Su desarrollo se realizaría bajo el programa de vivienda de interés social.

Tratamiento de Mejoramiento integral encaminado a mejorar las condiciones de vida de los asentamientos humanos en condición de pobreza y extrema pobreza asentada en barrios de origen marginal mediante el mejoramiento, incluido la regularización y legalización, de su entorno habitacional, con inversiones físicas, sociales, ambientales, económicas y

\footnotetext{
${ }^{74}$ Al parecer, estos instrumentos "se han convertido simplemente en un trámite previo y adicional al ya tradicionalmente utilizado de la obtención de la correspondiente licencia de urbanización y lo que es peor sin tener reglas claras de carácter procedimental para su aplicación" (GIRALDO en MAVDT, 2005:13)

75 EI POT para Bogotá fue formulado en el año 2000 con el Decreto 619/00. Su vigencia estaba prevista para 10 años, sin embargo para el año 2003 fue sometido a un proceso de revisión (Decreto 469 de 2003 y compilado por el Decreto Distrital 190 de 2004) y posteriormente para el año 2010 se inició su segunda revisión que continuo hasta el 2013 con el Decreto Distrital 364/13.

${ }^{76}$ El POT para Medellín, también sufrió de varias modificaciones. El primero fue formulado en el año 1999 bajo el Acuerdo 62/99, posteriormente fue revisado y ajustado bajo el Acuerdo 46 de 2006 y para el año 2014 fue vuelto a ajustar Acuerdo 48 de 2014

Esta investigación, como se mencionó, se centrará esencialmente en la primera formulación de POT para Bogotá y Medellín.
} 
legales que posibiliten su integración a la estructura territorial y funcional de la ciudad. (Decreto 619/00 art.374) y (Acuerdo 62/99 Art.156)

Según las necesidades de cada territorio y sobretodo, de la disponibilidad de recursos, en el tratamiento se podrían llegar a efectuar acciones en el ámbito de i)ordenamiento territorial (legalización, regularización y reasentamiento), ii) infraestructura básica y servicios públicos, iii) obras de protección ambiental, iv) accesibilidad y movilidad, v) mejoramiento de vivienda, vi) espacio público y equipamiento, y finalmente vii) desarrollo social (acompañamiento social, planeación participativa, seguridad y convivencia).

A su vez, cada POT puntualizaría las directrices que dicha vivienda nueva o mejoramiento debería seguir como requisitos (uno lo denomina estrategias o normas, el otro condiciones) a cumplir. Entre ellos vale la pena resaltar los que serían innovadores en su planteamiento:

La ubicación de soluciones habitacionales, la cual es mencionada en los dos documentos normativos como localizaciones equitativa, equilibrada o apropiada ${ }^{77}$ para evitar o revertir problemas de segregación e incentivar la inclusión social. Requisito que, sin entrar a examinar los estudios de caso ya se podría demostrar que si bien es una novedad que se muestra en papel, no es una realidad cumplida. Todos los proyectos seleccionados están ubicados en la periferia, lo que sería contradictorio en sí mismo pues ubicar la vivienda en la periferia no siempre permite "la ubicación óptima" para promover inclusión social. Faltaría analizar cómo logran, si lo logran, revertir entonces los problemas de segregación.

El tamaño de las intervenciones, el cual es solo especificado para el caso de Bogotá como una exigencia para los proyectos de vivienda nueva con un área mínima de (20ha. en suelo urbanizable y $10 \mathrm{ha}$. en suelo urbano). -Anteriormente en este documento fue especificado el tamaño de las soluciones habitacionales el cual no aumenta sino disminuye-.

La habilitación del suelo cuyo propósito es el de eliminar las principales barreras de acceso a la vivienda social por medio de la promoción de un suelo formal, urbano o de expansión, a un precio adecuado. Para ello se crea un banco de tierras que en el caso de Bogotá es manejado por Metrovivienda desde el año 1998 y para la ciudad de Medellín por Insvimed y EDU desde el año 2012.

La distribución espacial de las áreas de cesiones públicas para parques y equipamientos. Para el caso de Bogotá, como en la normativa anterior, del total del área cedida se exige un $50 \%$ agrupada y el resto en área mínimas de $1.000 \mathrm{~m} 2$; la novedad está en su aumento de área a ceder y en su prohibición de localización en zonas inundables, de alto riesgo o de pendientes superiores de $25 \%$. Para el caso de Medellín, se realiza conforme a lo establecido en cada Plan Parcial formulado para cada proyecto.

Con respecto a los equipamientos se determinan jerarquías, escalas e índices de ocupación y construcción, el resto de especificaciones se establece en cada Plan Parcial.

\footnotetext{
77 POT Bogotá, Art. 278: Generar mecanismos que permitan la localización equitativa y equilibrada en la ciudad de los proyectos de Vivienda de Interés Social, evitando las condiciones de segregación socio espacial que los han caracterizado.

POT Medellín Art. 185: Integralidad de los proyectos urbanísticos, gestión ambiental, heterogeneidad o mezcla de población y actividades compatibles con la vivienda, que revierta el fenómeno de la segregación y la especialización en el uso del suelo. - Las condiciones del entorno deben garantizar localización apropiada para el asentamiento humano, valoración del patrimonio cultural y equilibrio entre atributos urbanos y densidades, acorde con la capacidad instalada del respectivo polígono.
} 
Adicionalmente, para la construcción de equipamientos si se detalla que éste debe ser basado según diagnóstico por parte de la municipalidad según las necesidades de los habitantes.

La definición de una malla vial como sistema de varios niveles, con sus disposiciones con respecto a su área y perfil. Para el caso de Medellín se detalla adicionalmente algo sobre las vías férreas por ser una ciudad que cuenta con líneas de metro.

Para el tratamiento de mejoramiento de barrio, dos directrices adicionales serían propuestas; sin con ello decir que las directrices anteriormente citadas no pudieran ser aplicadas en éste tratamiento también:

La participación de la población. Se reconocen el esfuerzo de los pobladores por ocupar y transformar un territorio en busca de mejores condiciones para su desarrollo humano y social, y por lo tanto se les permite pasar a ser sujetos activos en él. Dicha población tiene ahora una mayor capacidad de intervenir en los procesos de toma de decisiones -así sea muy someramente- en relación con la aplicación a la normativa y su condición de control (seguridad y convivencia) en la ciudad.

La intervención "integral" con un componente físico, social e institucional en el territorio procurando mejorar las condiciones de vida de los habitantes de la zona identificada. Se resuelven temas de intervención urbana y social al incorporar acciones mediante obras de infraestructura (construcción y mejoramiento de espacios públicos, vivienda, equipamientos) que cumplan con la participación comunitaria para garantizar su sostenibilidad y la coordinación de las diferentes dependencias institucionales que tengan injerencia en la zona del proyecto. Así "de una visión puramente remedial y casuística, de enfoque asistencialista basado en el logro de metas sectoriales de cada entidad participante, se pasa a una visión más estratégica, dirigida a lograr de manera simultánea y combinada la sostenibilidad social, económica, física y ambiental de los asentamientos auto-producidos”. (TORRES, 2009:156)

Se especifica en la tabla siguiente, los indicadores numéricos de dichos nuevos requisitos enunciados y se comparan con los establecidos en las normativas anteriores para las dos ciudades.

Tabla 11 Normas generales sobre los programas de vivienda social ${ }^{78}$

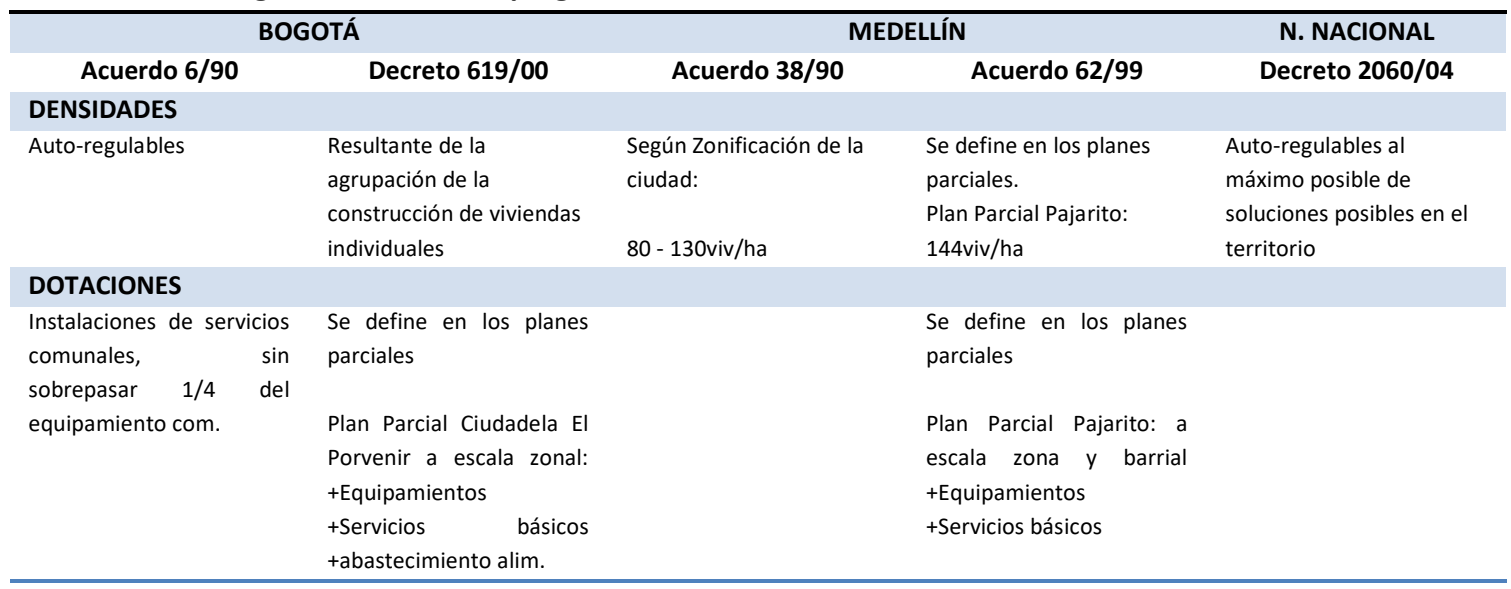

\footnotetext{
78 Para mayor detalle sobre las modificaciones que se han realizado en la normativa distrital a partir de los años 70 se recomienda lectura TARCHÓPULOS, D. y CEBALLOS, O. (2005) Patrones urbanístico y arquitectónicos en la vivienda dirigida a sectores de bajos ingresos en Bogotá. Editorial Pontificia Universidad Javeriana.
} 


\begin{tabular}{|c|c|c|c|c|}
\hline \multicolumn{5}{|c|}{ CESIONES PÚBLICAS Espacio público } \\
\hline $\begin{array}{l}17 \% \text { - } 25 \% \text { del área neta } \\
\text { urbanizable }\end{array}$ & $\begin{array}{l}25 \% \text { del área neta } \\
\text { urbanizable }\end{array}$ & Según zona y tipología. & $\begin{array}{l}\text { Se define en los planes } \\
\text { parciales }\end{array}$ & $\begin{array}{l}\text { entre } 15 \text { y } 20 \% \text { del área } \\
\text { neta urbanizable }\end{array}$ \\
\hline $\begin{array}{l}\text { Distribución: } \\
60 \% \text { en zonas recreativas }\end{array}$ & $\begin{array}{l}\text { Distribución: } \\
17 \% \text { en parques, } \\
\text { plazoletas, paseo y } \\
\text { alamedas }\end{array}$ & $\begin{array}{l}\text { Distribución } \\
\text { Unifamiliar: } 10-13 \% \\
\text { Multifamiliar: } \quad 12-14 \% \\
\text { zonas verdes }\end{array}$ & $\begin{array}{l}\text { Plan Parcial Pajarito } 5,7 \% \\
\text { área neta urbanizable }\end{array}$ & \\
\hline $\begin{array}{l}40 \% \text { en equipamientos } \\
\text { comunales públicos }\end{array}$ & $\begin{array}{l}8 \% \text { en equipamientos } \\
\text { comunales públicos }\end{array}$ & $\begin{array}{l}\text { Unifamiliar: } 5 \% \\
\text { Multifamiliares: } \quad 5-8 \% \\
\text { servicios colectivos }\end{array}$ & $\begin{array}{l}\text { Plan parcial Pajarito } \\
\text { equipamientos } 7,25 \% \\
\text { área neta urbanizable }\end{array}$ & $\begin{array}{l}5 \text { y } 10 \% \text { del área neta } \\
\text { urbanizable }\end{array}$ \\
\hline \multicolumn{5}{|c|}{ CESIONES PÚBLICAS Malla vial } \\
\hline & $\begin{array}{l}7 \% \text { del área bruta } \\
\text { urbanizable }\end{array}$ & & $\begin{array}{l}\text { Plan Parcial Pajarito: } \\
7,63 \% \text { área } \text { bruta } \\
\text { urbanizable }\end{array}$ & $\begin{array}{l}\text { Exigencia de continuidad } \\
\text { sin parámetros creados }\end{array}$ \\
\hline \multicolumn{5}{|l|}{ CESIONES PRIVADAS } \\
\hline $\begin{array}{l}\text { Equipamiento comunal: } \\
15 m^{2}-80 m^{2} \text { área neta } \\
\text { vendible }\end{array}$ & & $\begin{array}{l}\text { Según zona y tipología. } \\
\text { Unifamiliar: } 6 \quad-10 \% \text {. } \\
\text { Multifamiliar, zona } 1: 6-8 \\
\% \text {. Zona } 2: 9-10 \% \\
\text { No incluye aparcamientos } \\
\text { ni acceso vehiculares }\end{array}$ & $\begin{array}{l}\text { Se define en los planes } \\
\text { parciales }\end{array}$ & \\
\hline \multicolumn{5}{|l|}{ ÍNDICES DE OCUPACIÓN } \\
\hline & $\begin{array}{l}\text { IO } 0,25 \\
\text { IC } 1-1,2\end{array}$ & $\begin{array}{l}\text { IO-IC } 60-70 \% \text { del área } \\
\text { neta del lote }\end{array}$ & $\begin{array}{l}\text { IO } 0,14 \\
\text { IC } 0,70\end{array}$ & \\
\hline
\end{tabular}

De lo expuesto, se puede afirmar efectivamente que los POT proponen un nuevo modelo de ciudad y en ese contexto que los desarrollos nuevos de vivienda y los mejoramientos de barrio lo hacen con un modelo diferente a lo planteado en las normativas anteriores. Algunos procedimientos han mejorado las condiciones del entorno o la vivienda pero otros, en cambio, los han reducido. Lo que se ha mantenido es la situación favorable para el mercado de la construcción más que para los habitantes mismos. Por ello se cree que el modelo de intervención para los desarrollos nuevos de vivienda -como mercado rentable- conduce a una condición de calidad espacial inferior que la de los mejoramientos de barrio una vez intervenidos.

\subsubsection{Los proyectos de mejoramiento de barrio a la luz de los desarrollos nuevos} de vivienda. Planteamiento de una hipótesis

El interés del trabajo de investigación se centra en comparar en cuál de los dos tratamientos de intervención en materia de vivienda social se produce, con los cambios de la normativa establecida, una mejor calidad del espacio residencial para la población de bajos ingresos. Son, estos dos tratamientos, dos formas de actuar simultáneas en el territorio pero que configuran un tejido residencial completamente diferente. Se cree, no por su condición legal-marginal o por su condición planeamiento-espontaneidad sino por la lógica de intervención en el territorio por parte del Estado.

Como hasta ahora se ha observado, los proyectos de mejoramiento de barrio pretenden ser proyectos de alta complejidad con un impacto en la calidad de vida y la organización espacial y social de la ciudad significativo. Son proyectos en donde se quiere transformar un territorio físicamente con grandes construcciones de dotaciones, equipamientos, zonas verdes y vivienda, y a su vez en donde se quiere o se piensa que se debe trabajar, sea poco o mucho, con la población objetivo de dichas intervenciones. Aquí por primera vez una población de bajos ingresos parece tener la posibilidad o el derecho de ser parte de la ciudad. Adicionalmente las instituciones son conscientes que deben trabajar todas ellas de la mano 
para producir algún cambio o de lo contrario, las transformaciones del territorio no serán significativas y mucho menos sostenibles. El problema está en que para ello, se requiere de una definición e implementación de un conjunto acciones y programas derivados de una voluntad política y un modelo de ciudad concreto a corto, mediano y largo plazo. No siendo lo anterior siempre realizado. Si bien desde mediados de los años noventa se han realizado ejercicios de mejoramiento de barrio, la normativa como tal y todos los procesos de intervención que lo acompañan son relativamente recientes y por ello, se cree, con un gran vacío en su proceso de formulación y en las garantías de implementación en el tiempo.

Habrá por analizar en los estudios de caso cuáles acciones propias se han terminado definiendo durante su proceso de formulación y qué garantía de permanencia en el tiempo como proyecto de mejoramiento y de ciudad misma se han configurado. Aun así, se piensa que, a pesar de los problemas antes señalados, la implementación de los proyectos es acertada. Hasta el momento parece ser la única vía posible para solucionar el problema de vivienda y su entorno a una cierta parte de la población.

Ahora bien, bajo esas ausencias normativas se podría decir que los desarrollos de vivienda nueva entran a suplir esas falencias al estar estos sí contemplados con una permanencia en el tiempo definida en los POT durante la intervención. Aquí la voluntad política estaría quizás algo más condicionada por unas requisitos establecidas desde el inicio del proyecto -lo que no significa que ésta no pueda ser cambiada o reinterpretada por algunos agentes.- Asimismo, para que se puedan edificar estar soluciones de vivienda nueva, éstas tienen que contar con los permisos pertinentes de licencia urbanística, edificabilidad, densidad, especificaciones técnicas, estudios ambientales y geomorfológicos del suelo, etc. que dotarían al proyecto de una condición técnica "insuperable". No son pocos los cambios que se han realizado en la normativa, como se demostró, para "optimizar" las condiciones de éstos proyectos. Sin embargo, quizás ese marco normativo tan afianzado no permite que la producción de vivienda nueva se realice, sino se puede del todo fuera de las condiciones del mercado, contando con los procesos participativos o la organización física y social de los mejoramientos de barrio. Parecería que en la producción de vivienda nueva se está más preocupado por la construcción del objeto mismo que por la calidad del espacio que se consiga.

En otras palabras, hace falta un análisis sobre las condiciones espaciales que logra cada proyecto de intervención, mejoramiento de barrio o vivienda nueva, más allá de la simple descripción estadística o normativa. No se trata de examinar, en esta investigación, el fenómeno desde una perspectiva jurídica o desde sus objetivos y logros normativos. Tampoco la de evaluar la efectividad real de los procedimientos de legalización o edificación. Pues se piensa que Fique acierta al decir que, "las normas siempre han mostrado su limitación espacial (real aplicación) y temporal (cambio en las circunstancias políticas, económicas, técnicas o sociales) que les ha hecho perder vigencia rápidamente. -Y por lo tanto centrar en ella la mirada no acotaría específicamente los problemas de calidad.- Además, habiéndose planteado siempre como un mínimo aceptable, han terminado estableciéndose en la práctica como el máximo ofrecido por los productores." (Fique, 2006:131). Se trata de comprender o interpretar él vínculo de la normativa con la producción de la vivienda para la población de bajos ingresos y la condición de calidad espacial que se termina configurando. 
Esto se hace mediante el análisis, la comparación y la evaluación de los seis estudios de caso seleccionados bajo las dos modalidades de tratamiento en Bogotá y Medellín. No se puede identificar a priori la vivienda de producción legal y la vivienda de producción marginal con una vivienda "adecuada", ya que no cumplen necesariamente ninguna de las dos con diversas condiciones mínimas aceptadas como la seguridad jurídica de la tenencia, los gastos de la vivienda soportables, la asequibilidad, una localización adecuada y su adecuación cultural. (TORRES 2012:66). Pero si resulta pertinente considerar las condiciones finales -hasta donde se realiza el corte temporal de investigación pues se sabe que una vivienda social nunca termina de transformarse- del espacio residencial para valorar la calidad del espacio resultante. 


\section{LA CALIDAD COMO OBJETIVO}

Aproximaciones a la calidad urbana Iniciativas en la medición de la calidad Modelo de evaluación e indicadores Relación de indicadores 


\section{LA CALIDAD COMO OBJETIVO. Una propuesta metodológica}

Con el fin de definir una propuesta metodológica para la evaluación de la vivienda social y su entorno, trabajos relativamente recientes sobre el tema permiten tener una aproximación a la forma de medición de las condiciones de calidad urbana en este tipo de alojamientos. En ellos es posible encontrar elementos conceptuales y operativos (formulación de metodologías de evaluación y aplicación de indicadores) para identificar las condiciones objetivas -estado de la realidad- de la habitabilidad del espacio residencial.

Se trata de reconocer un proceso de investigación ya adelantado sobre evaluación de proyectos de hábitat o soluciones habitacionales para población de bajos ingresos aplicados a estudios de caso en América Latina como elección de metodología. Se circunscribe para América Latina por la similitud de condiciones en materia de vivienda social y por lo tanto, de posibilidades concretas de aplicación de indicadores acotados para el tema. Ésta, la elección, se hace mediante la descripción, el análisis y la valoración de nueve trabajos de investigación de carácter práctico disponibles sobre la materia. Sobre ellos no se hacen juicios por los estudios de caso examinados ni tampoco se reinterpretan las observaciones, conclusiones o estimaciones, únicamente se tiene en cuenta su enfoque, su metodología de evaluación y sus indicadores.

Ahora bien, considerando que el interés central de la investigación es la comparación acerca de la calidad espacial de las actuaciones y no la evaluación misma, el alcance de este capítulo es, por lo tanto, de describir, analizar y establecer entre los trabajos realizados la metodología de evaluación más adecuada para la aproximación a la calidad del espacio residencial en Bogotá y Medellín. Sin embargo, ésta no es aplicada mecánicamente. El modelo de evaluación desarrollado es detallado y adecuado a las consideraciones del contexto de la investigación y de un marco conceptual sobre qué se entiende por una vivienda y un entorno de calidad.

Para tal propósito se propone entonces definir un modelo sobre la calidad urbana del espacio residencial para la población de bajos ingresos capaz de acotar directrices operativas claves frente a las cuales se comparan las características físicas de la vivienda y su entorno. Para ello en este capítulo se plantean en una primera parte, algunas reflexiones en torno al concepto de calidad urbana o calidad ambiental como lo denomina J. Alguacil. Se precisan las particularidades que se adoptan al referirse a dicho concepto desde el contexto urbano y normativo de Bogotá y Medellín. En la segunda parte se exponen las iniciativas analizadas que ilustran algunas orientaciones metodológicas para llegar a una medida posible de la calidad. En la tercera y última parte, se presentan los lineamientos de una propuesta sobre parámetros de medición de la calidad urbana en la morfología del espacio residencial social y se establecen los indicadores bajos los cuales podrán ser medidos los estudios de caso seleccionados.

\subsection{APROXIMACIONES A LA CALIDAD URBANA}

\subsubsection{La calidad del espacio residencial}

Al inicio del documento se planteó la calidad de la vivienda como el conjunto de las condiciones satisfactorias de habitabilidad del espacio residencial ocupado. Su definición hacía referencia a parámetros óptimos relativos a la forma del medio construido, es decir lo 
edificado y su entorno: área de espacio público, saneamiento básico, servicios domiciliarios, accesibilidad, densidad, tamaño, unidad de viviendas entre otros. Según como sea configurado ese tejido residencial o como estén relacionados entre sí los elementos que lo conforman: la calle, la manzana, la parcela y el edificio ${ }^{79}$, se llega a cumplir o no esa optimización o satisfacción de las condiciones físicas urbanas.

Investigaciones de geógrafos y arquitectos Conzen (1968), Caniggia (1979) han demostrado que las formas fundamentales del tejido urbano están estrechamente relacionadas con las funciones y usos, es decir, con el tipo de ciudad que se construye. Las parcelas, junto con las manzanas, son los elementos más visibles que actúan como marco morfológico en el origen y crecimiento de la ciudad y en este caso del espacio residencial. ${ }^{80}$ Representan el mecanismo esencial para transformar el suelo en lo que se desee: aumentar su valor, cambiar de uso, densificar, etc. y remite, por lo tanto, a unos patrones de manejo económico y social del espacio tales como el comportamientos de renta o la ubicación de la estructura social. Su configuración, el del parcelario y su agrupación en manzanas, es "el reflejo de combinaciones complejas de una evolución histórica, funciones económicas, recursos de los habitantes, tradiciones culturales, etc.". (Capel, 2002:23) que inciden de manera directa en la calidad urbana y una condición de orden mayor, la calidad de vida.

Como es evidente, y como se explicó anteriormente, si bien esta investigación acota el término de calidad urbana a la morfología del espacio residencial, se reconoce que esta está estrechamente ligada con la noción de calidad de vida ${ }^{81}$, es decir con el bienestar y la identidad que dicho espacio genera o produce. Algunos autores Hutchinson (1979), Alguacil (1998), Saldarriaga (2003), Hernández (2009) así lo identifican. Son tres dimensiones, la calidad urbana, el bienestar y la identidad, que forman parte de un conjunto de valores y hechos que no se pueden disociar, pero sí que se pueden estudiar por separado de forma parcial de esa noción general.

Se hace énfasis en ello porque se cree que al indagar por la condición de las formas urbanas no se están desconociendo en absoluto los elementos fundamentales de dicha configuración, los procesos sociales o del concepto general de calidad de vida. Simplemente se está delimitando un área de estudio.

\footnotetext{
${ }^{79}$ Al hacer referencia a los elementos que conforman el tejido urbano y sus formas de configuración es imposible no citar o no relacionar el trabajo realizado por el Laboratorio de Urbanismo de Barcelona con Manuel Solà-Morales a la cabeza. Según dicho autor las diversas maneras de organización de dichos elementos son esencialmente tres: La urbanización, la parcelación y la edificación. Éstas pueden organizarse de forma diferente y de manera total o incompleta dependiendo de las diferentes normas, condicionamientos o ritmos que las configure.

${ }^{80}$ La parcelación estructura también el resto de los elementos del tejido urbano: las calles y las edificaciones. Las construcciones, por ejemplo, que se realiza al interior de una parcela se adaptan a las formas y dimensiones de la misma y si su tamaño no es apropiado conduce a operaciones de reparcelación o de aumento de la edificabilidad. La calle a su vez, delimitado por ese trazado parcelario, es el elemento básico de la vida urbana, uno de los espacios más disputados y al que menos atención se le presta en materia de vivienda social (calles sin pavimentar, sin continuidad, con un perfil más grande o más chico al requerido, ocupado por el espacio privado, adueñado por vendedores ambulantes, etc.).

${ }^{81}$ Ver definición completa de calidad de vida desarrollado en ALGUACIL, Julio (2000) Calidad de vida y praxis urbana: nuevas iniciativas de gestión ciudadana en la periferia social de Madrid. O bien las referencias hechas para este mismo autor en HERNÁNDEZ, Agustín (1997) La ciudad de los ciudadanos o (2011) Calidad de vida y medio ambiente urbano. Indicadores locales de sostenibilidad y calidad de vida urbana.
} 
Tabla 12 Dimensiones del concepto Calidad de Vida

\begin{tabular}{ccc}
\hline CALIDAD AMBIENTAL & BIENESTAR & IDENTIDAD CULTURAL \\
Área territorial & Determina el nivel de vida & Vínculos e interacciones sociales \\
Habitacional - vivienda & Producción - reproducción & Tiempo libre \\
Residencial (local-barrio) & Salud & Participación - apropiación \\
Urbana - territorial & Educación & Relaciones - redes sociales \\
\hline
\end{tabular}

Fuente: Alguacil, Julio (1998)

Centrando la mirada entonces en la calidad ambiental, esa condición del espacio residencial para la población de bajos ingreso, se definen las diferentes escalas que componen ese espacio: el ámbito doméstico, con las características arquitectónicas y técnicas constructivas de la unidad de vivienda; el residencial, como entorno próximo, representativo de lo local con la configuración urbanística del proyecto; y la ciudad, como el espacio de máxima complejidad accesible de lo urbano, la metrópoli o la región. En la medida en que las condiciones habitacionales trascienden la vivienda como tal e incluso, a veces, las particularidades del proyecto en el que ésta se inscribe, es necesario analizar los proyectos desde todas las escalas que lo conforman.

Adicionalmente, lo expone Alguacil, existen una serie de variables que atraviesan la dimensión ambiental (física) antes planteada, de las cuales se mencionan dos de interés: los sujetos, esa estructura socio-demográfica que habita un territorio y el ambiente o las condiciones naturales: aire, agua, suelo, flora y fauna que igualmente ocupa el territorio. Dos variables que expresadas en otros términos enuncian: la sostenibilidad de ese ambiente construido por el hombre (relación de lo urbano con el medio natural del que depende). Así, la calidad urbana lleva implícito la idea de poder mantener unas condiciones habitables por un largo tiempo sin agotar sus recursos o causar daño al medio ambiente y a su vez, de dar soporte al cumplimiento de las necesidades básicas con las que una población debe contar para poder mantener y mantenerse en ese espacio.

Cuando se habla de necesidades básicas se habla de unas condiciones mínimas y universales a cubrir que le otorgan unidad y permanencia a los miembros de una sociedad, especialmente a aquellos que no tiene la capacidad de hacerlo. "Las necesidades humanas son requerimientos o exigencias instituidas, que tienen un valor y reconocimiento general y cuyo cumplimiento expresa fines que se han fijado como esenciales en términos de sus condiciones de existencia ${ }^{82 . *}$ (Fresneda, 1998:7)

En este sentido, así como no es frecuente referirse a una única dimensión (parámetro) cuando se hace alusión a la calidad urbana, tampoco lo es al reseñar las necesidades que en ese espacio residencial se deben gestionar. Aquí diversos autores hacen la advertencia que la condición de calidad de vida y de su sostenibilidad varía con respecto a las modificaciones de las ideas dominantes que conforman lo que se quiere y se desea. Sin embargo, y aunque se cree que es un argumento válido, para este caso de estudios se está hablando de unas condiciones mínimas que independientemente de modos, deseos, capacidades o intereses requieren ser cubiertas. De ahí la necesidad de aclarar los diferentes términos y relaciones que originan o conforman las necesidades.

\footnotetext{
${ }^{82}$ Y sigue así Fresneda: "Desde Aristóteles las necesidades han sido entendidas como factores constitutivos de la sociedad, que le otorgan unidad y permanencia. Las necesidades se expresan en los individuos como impulsos orientados a fines, que son transmitidos a través de las distintas formas de socialización. Hacen referencia a las satisfacciones que el grupo social llámese clase, comunidad o nación ofrece a sus miembros". (FRESNEDA 1998:7)
} 


\subsubsection{Enfoque de necesidades y derechos}

En la perspectiva de la propuesta que se presenta en este trabajo, se toma el papel de las necesidades para dar un referente de valoración colectiva o normativa de lo mínimo a cumplir en la vivienda y su entorno. Las intervenciones en los proyectos no se pueden evaluar y comparar sino en la medida en que ofrezcan un conjunto de requerimientos o de resultados de alcance universal o por lo menos nacional, en torno a las cuales se logran unas condiciones adecuadas -con una perspectiva mínima de igualdad-.

La noción de necesidades conlleva múltiples significados y correspondencias como se ha apuntado anteriormente. Expresa una carencia y, al mismo tiempo, remite al logro de un estado que no está aún realizado o alcanzado. Es decir, no solo está asociada a una falta de algo o una ausencia sino también a la capacidad de alcanzar lo que se considere indispensable. En este sentido, incluye los mínimos deseados con que una sociedad, unas instituciones (y quizás un mercado) fundamentan un proyecto para una población de bajos ingresos.

Es preciso entonces, aclara Fresneda, diferenciar entre lo que son intereses y necesidades. "Los primeros hacen referencia a impulsos individuales o de grupos que no se han generalizado, que no han sido institucionalizados. Los intereses surgen de los individuos pero no corresponden con fines generalizables al grupo social. Las necesidades, por el contrario, constituyen cristalizaciones instituidas en el conjunto de la sociedad, que se encuentran unidas a prescripciones generales." (Fresneda, 1998:8) En ese sentido, se debe entender que las necesidades no se construyen socialmente según el contexto, más bien se satisfacen ${ }^{83}$ socialmente con unos medios o de una forma según los intereses en el uso de los recursos.

Cabría distinguir aquí dos medios por los cuales se pueden satisfacer esas necesidades en el contexto económico y político actual: los del Estado y los del aparato productivo. Si se habla de carencia del medio construido, por ejemplo, es el Estado quien debe asumir el papel o la responsabilidad para satisfacer dicha necesidad por medio de normas -derechos humanossocialmente aceptadas y jurídicamente aprobadas. En cambio, si se habla de una capacidad o de un logro a alcanzar (una aspiración) se demanda de una intervención del aparato productivo en donde se produce una mercantilización de las aspiraciones (deseos). El papel del mercado sería el determinante para la satisfacción de esos deseos. Sin embargo, la desigual accesibilidad al consumo hace de la satisfacción de las aspiraciones una quimera. ${ }^{84}$ (Alguacil, 1998: 55)

\footnotetext{
${ }^{83}$ Las necesidades humanas son objetivas, intemporales, invariables, identificables, dependientes unas de otras, limitadas y universales, todo ello en cuanto que su reconocimiento teórico y empírico puede ser libre de las preferencias individuales condicionadas por la sociedad de consumo. La condición subjetiva en la teoría de las necesidades viene marcada por la satisfacción de las mismas. Lo que varía, en términos perceptivos, diacrónicamente y sincrónicamente, son los medios por los cuales se satisfacen estas necesidades, sus satisfactores. (Max-Neef et al., 1986 en ALGUACIL, 1998:57)

${ }^{84}$ Dos citas hace referencia Alguacil en su texto que complementa la idea de desigual posibilidad de consumo: <<La discriminación radical del sentido que consumir tiene en cada clase social se hace evidente en el marco de la reproducción ideológico-simbólica: las clases dominantes se presentan como el deseo ideal de consumo, pero debido a la innovación, diversificación y renovación permanente de las formas-objeto este modelo se hace constantemente inalcanzable para el resto de la sociedad; en el primer caso consumir es la afirmación, lógica, coherente, completa y positiva de la desigualdad, para todos los demás colectivos consumir es la aspiración, continuada e ilusoria de ganar puestos en una carrera para la apariencia de poder que nunca tendrá fin» (Alonso, 1986: 28). En esa cultura del consumo es concluyente la pérdida del sentido de los límites de las aspiraciones y de las vinculaciones de los sujetos con los sujetos, y de los sujetos con la naturaleza. "Se proclama la soberanía completa del ser humano entendido como individuo que no acepta lazos que limiten la búsqueda sin fronteras de su propia satisfacción (con la consiguiente
} 
Por ello, el cumplimiento de las necesidades para alcanzar una calidad adecuada no puede o no debe estar en permanente tensión entre la acción de uno o del otro, el Estado o el mercado. Las razones son obvias. Por un lado, se desconocería la forma diferente como cada grupo social o estrato resuelve o satisface sus necesidades, cuando puede satisfacerlas (la consideración de la calidad urbana para ciertos grupos sociales pone de relieve en qué aspectos se expresan las desigualdades en dicha calidad). Y por otro lado, se anularía la capacidad de participación de la población en la valoración y gestión de su condición pues los deseos serían ajenos a ellos. ${ }^{85}$

Para que esta condición no se presente, se debe contar por lo tanto con unos derechos de obligatoriedad, apoyados en la ley, que otorguen unos medios concretos para cubrir esas necesidades básicas -y en cierto modo empoderen a la población-. Así, el reconocimiento de la satisfacción de las necesidades lleva a la determinación de tomar medidas que tiendan a reconocerse y aprobarse -a veces sancionarse- como derechos humanos para que esta satisfacción se haga efectiva. ${ }^{86}$ No se trata, sin embargo, de un proceso automático, ni exento de complicaciones. Cada necesidad no tiene correspondencia con un derecho humano, ni cada derecho tiene indispensablemente su correlato en una necesidad (Fresneda, 1998).

Los derechos humanos sociales suponen jurídicamente lo que el Estado y la sociedad deben garantizar individual y colectivamente, y lo que puede ser reclamado por los individuos y la comunidad. En su formulación concreta con frecuencia, señalan metas sociales en la vía de la satisfacción de algunas necesidades 0 , en otras ocasiones, los medios para obtener realizaciones, en el espacio de bienes y servicios. (Fresneda, 1998). La ventaja que se tiene al hablar sobre derechos humanos es la de resaltar la legitimidad de las demandas sociales como requisito de una dignidad o una supervivencia mínima. De ahí que resulte enriquecedor tomar como referencia los derechos humanos, la Constitución Política de Colombia y los POT dirigidos a promover una buena calidad del espacio, el espacio residencial para la población de bajos ingresos en este caso, para señalar capacidades objetivas o reales a cumplir en las intervenciones de vivienda social.

En la pretensión de revisar la condiciones de habitabilidad en los programas de vivienda nueva y mejoramiento de barrio se pone de manifiesto si lo expuesto en ese marco normativo se ha manifestado en cambios reales y si representa realmente las necesidades de los habitantes. Dicha lectura conducirá a definir en términos de parámetros definidos y legitimados, los aspectos a considerar en la calidad del espacio residencial.

entronización de la idea absoluta de propiedad individual). Y se rechaza la legitimidad de los límites que puedan imponerse a la acción humana» (Sempere, 1988: 46).>> (ALGUACIL, 1998. 56)

${ }^{85}$ Según Alguacil "las necesidades son objetivas cuando las objetivan los propios sujetos a través de procesos de participación activa, y son subjetivadas cuando quedan fuera de su control, cuando son normativizadas por élites políticas y administrativas separadas de los individuos y/o inducidas por los mecanismos del mercado'. (ALGUACIL 1998:57)

86 La relación entre necesidades y derechos humanos dentro de la perspectiva de la historia es analizada por Bobbio. Para este autor los "derechos del hombre", son el producto de la civilización, y no están adscritos a un hombre abstracto, a un hombre eterno y substraído del flujo de la historia. Esta universalización de los derechos humanos y su extensión a los derechos sociales expresa que al nivel de los valores se ha ido creando un consenso en la determinación y reconocimiento de ciertas necesidades. Pero, de otra parte, señala que tal consenso no significa que se haya logrado establecer los derechos naturales y permanentes, sino el camino para que la humanidad en su conjunto reconozca valores históricamente generalizables (Bobbio, 1992: 132-133 en FRESNEDA 1998:82) 


\section{Condición de Derechos correspondientes a una vivienda adecuada}

El propósito de este marco normativo es precisar, someramente, los aspectos que se deben valorar en relación con el espacio residencial en donde se construye la vivienda social y su entorno a la luz del Derecho Internacional de los Derechos Humanos y de la Constitución Política de Colombia. Con antelación, en el capítulo 1., ya se definieron los parámetros normativos establecidos como mínimos en los Planes de Ordenamiento Territorial de Bogotá y Medellín. Ahora, se examinan los estándares fijados por el Comité de Derechos Económicos, Sociales y Culturales de las Naciones Unidas (CDESC), seguido del análisis de la Constitución Política de 1991 en donde se establecen los derechos y las obligaciones mínimas a cumplir con respecto al artículo 51 en el que se consagra el derecho a una vivienda digna y adecuada.

El derecho a una vivienda adecuada se encuentra establecido y reconocido como tal en numerosos instrumentos, pactos o declaraciones de carácter internacional de Derechos Humanos. Entre los más notables están la Declaración Universal de Derechos Humanos de 1948, el Pacto Internacional de Derechos Económicos, Sociales y Culturales de 1966, y el Pacto Internacional de Derechos Civiles y Políticos de 1966.

El primero, la Declaración Universal de Derechos Humanos, en el párrafo 1 del artículo 25, establece el derecho que tienen toda persona a un nivel de vida adecuado que le asegure, a sí como a su familia, la salud y el bienestar, y en especial la alimentación, el vestido, la vivienda, la asistencia médica y los servicios sociales necesarios para desarrollarse como ser humano.

El Pacto Internacional de Derechos Económicos, Sociales y Culturales ${ }^{87}$, el más importante de carácter internacional que vincula a Colombia y reconoce el derecho a una vivienda adecuada, en el artículo 11 señala: Los Estados Partes en el presente Pacto reconocen el derecho de toda persona a un nivel de vida adecuado para sí y su familia, incluso alimentación, vestido y vivienda adecuados, y a una mejora continua de las condiciones de existencia. [...].

Y finalmente el Pacto Internacional de Derechos Civiles y Políticos ${ }^{88}$, en donde se protege también ese derecho de vivienda adecuada, siempre que a la persona se le pueda garantizar el disfrute tanto de los derechos civiles y políticos como de los económicos, sociales y culturales. El párrafo 1 del artículo 17, establece que nadie será objeto de injerencias arbitrarias o ilegales en su vida privada, su familia, su domicilio o su correspondencia, ni de ataques ilegales a su honra y reputación.

En paralelo, existen además organismos internacionales que se han preocupado por la condición de los asentamientos humanos en términos de calidad de vida, pobreza, hambre o desequilibrio territorial entre otros. El Centro de las Naciones Unidas para los Asentamientos Humanos $^{89}$ es uno de ellos. La ONU ha realizado trabajos orientados a tomar acciones positivas que garanticen, sin ninguna forma de discriminación y en condiciones de igualdad de toda la población, el pleno disfrute del derecho a una vivienda adecuada. Los esfuerzos de este

\footnotetext{
${ }^{87}$ Ratificado por Colombia mediante la Ley 74 de 1968.

${ }^{88}$ Ratificado por Colombia mediante la Ley 74 de 1968.

${ }^{89}$ Organismo del Sistema de las Naciones Unidas encargado de la coordinación de actividades relativas a los asentamientos humanos.
} 
Organismo se han enmarcado primordialmente en dos objetivos: el primero, en lograr una vivienda adecuada para todos y el segundo, a que se implemente un desarrollo urbano sostenible. Uno de los documentos más relevantes de esta organización ha sido la Declaración de Vancouver sobre los Asentamientos Humanos ${ }^{90}$, conocida como Hábitat I. Esta declaración, se fundamentó en los principios de equidad, justicia social, solidaridad y dignidad humana, con el propósito de concienciar e impulsar a que todos los gobiernos y organizaciones internacionales dediquen todos sus esfuerzos en adoptar medidas apropiadas en esta materia, teniendo en cuenta los niveles extremos de pobreza que se viven a nivel mundial. Veinte años más tarde, en Estambul, Turquía, se celebró la Segunda Conferencia de las Naciones Unidas sobre los Asentamientos Humanos, conocida como Hábitat II. En esta conferencia se reconoció el derecho a una vivienda adecuada como un derecho humano y se aprobó un plan de acción con el propósito de lograr el desarrollo sostenible de todas las ciudades. El programa determinó una serie de compromisos asumidos por los gobiernos en relación directa con el derecho humano a una vivienda adecuada. Específicamente, está el párrafo 8 de la sección III de la mencionada Conferencia, en donde se señala la importancia que tiene la vivienda y los servicios adecuados como un derecho humano básico y confiere a los gobiernos el compromiso de asegurar una vivienda adecuada para todos sin ninguna forma de exclusión, en especial a los grupos poblacionales o sujetos que se encuentran en una situación económica y social más desfavorable. La última conferencia hasta la fecha, Hábitat III, recién se celebró en Quito, Ecuador en el año 2016. En ella, la Nueva Agenda Urbana, se ha establecido un nuevo estándar mundial para el desarrollo urbano sostenible para repensar la forma de planificar, gestionar y vivir en las ciudades. Allí, los gobiernos se han comprometido, entre otros varios, a proporcionar servicios básicos a todos los ciudadanos, entre los cuales se incluye: el acceso a la vivienda, agua potable y saneamiento, alimentos nutritivos, atención de la salud y planificación familiar, educación, cultura y acceso a las tecnologías de comunicación. ${ }^{91}$

Otro organismo internacional de importancia que ha tratado el tema de la vivienda adecuada es la Organización Mundial de la Salud (OMS). En ella se ha proporcionado orientaciones sobre cuestiones y conceptos básicos relacionados con los aspectos sanitarios de la vivienda. Dichas orientaciones han sido recogidas en los Principios de Higiene de la Vivienda publicados en el año 1990 bajo 11 principios y 6 líneas de acción prioritarias ( Ver tabla 13).

El trabajo de la Organización ha consistido en demostrar que la calidad de la vivienda influye en la salud, toda vez que sus condiciones de ubicación, diseño, construcción y equipamiento pueden constituirse en factores de riesgo o, por el contrario, en agentes que permiten mantener condiciones adecuadas para la salud. Para proporcionar un acceso fácil sobre la información, las mediciones y las estadísticas sobre la situación y las tendencias mundiales, nacionales o regionales en materia de salud la OMS ha creado el Observatorio de la Saludo (GHO) dentro de los cuales ha creado un apartado sobre salud urbana (Urban Health). En él se hace el seguimiento de los progresos hacia el logro de los Objetivos de Desarrollo Sostenible.

Cinco medidas son propuestas para incrementar las posibilidades de que los ciudadanos disfruten de mejores condiciones de vida en las ciudades:

\footnotetext{
${ }^{90}$ Adoptada por la Conferencia sobre Asentamientos Humanos de la ONU en Vancouver (Canadá) en 1976.

91 Esta Organización además ha propuesto un sistema de indicador para evaluar las condiciones de calidad de los asentamientos urbanos. Este sistema será examinado en el próximo apartado.
} 
- El fomento de una planificación urbana que favorezca los comportamientos saludables y la seguridad.

- La mejora de las condiciones de vida en las ciudades.

- La participación ciudadana en la acción de gobierno.

- La ordenación urbana que no excluya a ningún grupo y esté adaptada a las necesidades de los ancianos.

- El aumento de la capacidad de recuperación de las ciudades tras los desastres y emergencias.

Con ellas se considera el papel fundamental de la planificación urbana junto con las políticas y medidas coordinadas para la consecución de un espacio saludable.

Tabla 13 Principios de Higiene de la vivienda OMS

\section{Principios Relativos a las necesidades sanitarias}

1. Protección contra las enfermedades transmisibles mediante:

- Abastecimiento de agua salubre en cantidad suficiente

- Eliminación higiénica de excretas

- Eliminación de los desechos sólidos

- Desagüe

- Higiene personal y doméstica

- Preparación higiénica de los alimentos, y

- Salvaguardias estructurales contra la transmisión de enfermedades

2. Protección contra los traumatismos, las intoxicaciones y las enfermedades crónicas

- Características estructurales y ajuar doméstico

- Contaminación del aire interior

- Seguridad química

- El hogar como lugar de trabajo

3. Reducción al mínimo de los factores de estrés psicológicos y sociales, para lo cual las viviendas deberían:

- Contar con suficiente espacio habitable, bien ventilado y alumbrado, decentemente amueblado y equipado, con un grado razonable de privacidad y comodidad

- Dar sensación de seguridad personal y familiar, reforzada por las estructuras comunitarias

- Proporcionar espacio para el juego, los deportes y las actividades recreativas de los niños, con el mínimo de riesgos de traumatismo e infección

- Estar ubicadas de manera que se reduzca la exposición al ruido, haya vegetación en las proximidades y la gente tenga acceso a los servicios comunitarios, y

- Ser fáciles de mantener limpias y ordenadas.

4. Mejora del entorno habitacional, que permita el acceso a lugares de trabajo y a los servicios que promuevan la buena salud como:

- Servicios de seguridad y de urgencia;

- Servicios sanitarios sociales; y

- Servicios de cultura y de otro género

5. Uso adecuado de la vivienda

6. Protección de poblaciones especialmente expuestas, reduciendo al mínimo los riesgos sanitarios para:

Las mujeres y los niños; personas en malas condiciones de alojamiento; poblaciones desplazadas o migrantes; y adultos mayores, enfermos crónicos y personas en condiciones de discapacidad.

Fuente: Organización Mundial de la Salud Ginebra 1990

En red: http://www.bvsde.paho.org/eswww/fulltext/vivienda/principi/principi.htm

\section{Propaganda de la salud}

- Función de las autoridades sanitarias

- Función de grupos conexos

- Mensajes de salud

8. Políticas económicas y sociales

9. Acción intersectorial para la planificación y la gestión del desarrollo

- Planificación y gestión del desarrollo

- Urbanismo y ordenación del suelo

- Legislación y normas en materia de vivienda y su aplicación

- Diseño y construcción de viviendas

- Suministro de servicios comunitarios

-Supervisión y vigilancia

10. Educación para una vivienda salubre

11.Cooperación y autoayuda comunitarias 
En definitiva, existen distintos instrumentos y organizaciones de carácter internacional ${ }^{92}$ que reconocen el derecho a una vivienda adecuada como un componente fundamental para satisfacer las necesidades de una población urbana. Por vivienda adecuada, además como se ha podido constatar, no se hace referencia exclusivamente a la vivienda como ámbito doméstico, sino incluye también su relación con el entorno. En Colombia este derecho ha sido ratificado en su norma Interna, La Constitución Política de Colombia.

\section{Constitución Política de Colombia de 1991}

En esta Carta Política se reconoce el derecho a una vivienda digna para todos los colombianos y se señala de manera general, las políticas en materia de vivienda y hábitat a través de las cuales le corresponde al Estado atender sus obligaciones. Sobre este derecho concreto se desarrolla una serie de artículos sobre la forma como el Estado debe cumplir sus compromisos. Así por ejemplo, el artículo 13 de la Constitución, desarrolla de manera transversal el principio de igualdad, señalando que la población colombiana debe gozar de los mismos derechos, libertades y oportunidades sin ninguna discriminación por razones de sexo, raza, origen nacional o familiar, lengua, religión, opinión política o filosófica. Se garantiza allí las condiciones de igualdad en el derecho a una vivienda adecuada. No obstante, es el artículo 51 es el que precisa de manera más concreta el derecho a una vivienda adecuada y digna, como se denomina así en los siguientes términos: Todos los colombianos tienen derecho a vivienda digna. El Estado fijará las condiciones necesarias para hacer efectivo este derecho y promoverá planes de vivienda de interés social, sistemas adecuados de financiación a largo plazo y formas asociativas de ejecución de estos programas de vivienda. Además de estos dos artículos mencionados, están los artículos 313 y 334 relacionados también con el tema de vivienda adecuada. El primero confiere a los concejos municipales la obligación de reglamentar los usos del suelo y ejercer el control de las actividades de construcción y enajenación de viviendas. El segundo hace referencia a la intervención del Estado en la economía y en los usos del suelo, lo anterior con el propósito, según se explica textualmente, de lograr una mejor calidad de vida de los habitantes, la distribución equitativa de las oportunidades y los beneficios del desarrollo y la preservación de un ambiente sano. Cabe resaltar aquí, como ya se había señalado con anterioridad en el documento, que es sorprendente cómo estas definiciones o determinaciones hacen referencia a formas de producción y asequibilidad de la vivienda sin detallar en ningún grado las condiciones de habitabilidad que la vivienda y su entorno deben contemplar.

Para encontrar alguna determinación sobre dichas condiciones hay que remitirse a los tratados internacionales acatados por el Congreso según lo dispone el artículo 93 de esta Carta Magna. Algunos de ellos son lo que se mencionaron anteriormente. El más importante sin duda, es el Pacto Internacional de Derechos Económicos, Sociales y Culturales del cual se quiere detallar

\footnotetext{
92 -Principios Rectores de los Desplazamientos Internos de 1998; Convención Internacional sobre la Protección de los Derechos de todos los trabajadores y de sus Familiares de 1990; • Convención sobre el Estatuto de los Refugiados, de 1951, art. 21. • Convenio № 117, de 1962, de la Organización Internacional del Trabajo sobre política social (normas y objetivos básicos), art. 5 2). • Convención Internacional sobre la Eliminación de todas las Formas de Discriminación Racial, de 1965, art. 5 e) iii). • Pacto Internacional de Derechos Civiles y Políticos, de 1966, art. 17. - Convención sobre la eliminación de todas las formas de discriminación contra la mujer, de 1979, arts. 14 2) y 15 2). • Convención sobre los Derechos del Niño, de 1989, arts. 16 1) y 273 ). - Convenio № 169, de 1989, de la Organización Internacional del Trabajo sobre pueblos indígenas y tribales, arts. 14,16 y 17 , entre otros
} 
un poco más en relación con su artículo 11:Derecho a una vivienda adecuada. Éste por ser la única fuente que define elementos esenciales que debe contener una vivienda adecuada.

El Comité de Derechos Económicos, Sociales y Culturales, Comité de DESC, en ejercicio de sus funciones de supervisión, emite observaciones generales sobre las disposiciones del Pacto y establecen el contenido de los distintos derechos y alcances de las obligaciones de los Estados en su realización. Entre las Observaciones emitidas por el Comité de DESC, se encuentra la Observación General No. 4, la cual establece y define el contenido esencial del derecho a una vivienda adecuada:

El concepto de adecuación es particularmente significativo en relación con el derecho a la vivienda, puesto que sirve para subrayar una serie de factores que hay que tener en cuenta al determinar si determinadas formas de vivienda se puede considerar que constituyen una "vivienda adecuada" a los efectos del Pacto. Aun cuando la adecuación viene determinada en parte por factores sociales, económicos, culturales, climatológicos, ecológicos y de otra índole, el Comité considera que, aun así, es posible identificar algunos aspectos de ese derecho que deben ser tenidos en cuenta a estos efectos en cualquier contexto determinado. Entre esos aspectos figuran los siguientes:

a) La Seguridad jurídica de la tenencia

La tenencia adopta una variedad de formas como el alquiler (público y privado), la vivienda en cooperativa, el arriendo, la ocupación por el propietario, la vivienda de emergencia y los asentamientos informales, incluida la ocupación de tierra o propiedad. Sea cual fuere el tipo, todas las personas deben gozar de cierto grado de seguridad de tenencia que les garantice una protección legal contra el desahucio, el hostigamiento u otras amenazas. (...)

\section{b) Disponibilidad de servicios, materiales, facilidades e infraestructura}

Una vivienda adecuada debe contener ciertos servicios indispensables para la salud, la seguridad, la comodidad y la nutrición. Todos los beneficiarios del derecho a una vivienda adecuada deberían tener acceso permanente a recursos naturales y comunes, a agua potable, a energía para la cocina, la calefacción y el alumbrado, a instalaciones sanitarias y de aseo, de almacenamiento de alimentos, de eliminación de desechos, de drenaje y a servicios de emergencia.

c) Gastos soportables

Los gastos personales o del hogar que entraña la vivienda deberían ser de un nivel que no impidiera ni comprometiera el logro y la satisfacción de otras necesidades básicas Los Estados Partes deberían adoptar medidas para garantizar que el porcentaje de los gastos de vivienda sean, en general, conmensurados con los niveles de ingreso. (...)

\section{d) Habitabilidad}

Una vivienda adecuada debe ser habitable, en sentido de poder ofrecer espacio adecuado a sus ocupantes y de protegerlos del frío, la humedad, el calor, la lluvia, el viento u otras amenazas para la salud, de riesgos estructurales y de vectores de enfermedad. Debe garantizar también la seguridad física de los ocupantes. El comité exhorta a los Estados Partes a que apliquen ampliamente los Principios de Higiene de la Vivienda preparados por la OMS, que consideran la vivienda como el factor ambiental que con más frecuencia está relacionado con las condiciones que favorecen las enfermedades en los análisis epidemiológicos; dicho de otro modo, que una vivienda y unas condiciones de vida inadecuadas y deficientes se asocian invariablemente a tasas de mortalidad y morbilidad más elevadas.

\section{e) Asequibilidad}

La vivienda adecuada debe ser asequible a los que tengan derecho. Debe concederse a los grupos en situación de desventaja un acceso pleno y sostenible a los recursos adecuados para conseguir una vivienda. Deberá garantizarse cierto grado de consideración prioritaria en la esfera de la vivienda a los grupos desfavorecidos como las personas de edad, los niños, los incapacitados físicos, los 
enfermos terminales, los individuos VIH positivos, las personas con problemas médicos persistentes, los enfermos mentales, las víctimas de desastres naturales, las personas que viven en zonas en que suelen producirse desastres, y otros grupos de personas. (...)

\section{f) Lugar}

La vivienda adecuada debe encontrarse en un lugar que permita el acceso a las opciones de empleo, los servicios de atención de la salud, centros de atención para niños, escuelas y otros servicios sociales. Esto es particularmente cierto en ciudades grandes y zonas rurales donde los costos temporales y financieros para llegar a los lugares de trabajo y volver de ellos puede imponer exigencias excesivas en los presupuestos de las familias pobres. De manera semejante, la vivienda no debe construirse en lugares contaminados ni en la proximidad inmediata de fuentes de contaminación que amenazan el derecho a la salud de los habitantes.

g) Adecuación cultural

La manera en que se construye la vivienda, los materiales de construcción utilizados y las políticas en que se apoyan deben permitir adecuadamente la expresión de la identidad cultural y la diversidad de la vivienda. Las actividades vinculadas al desarrollo o la modernización en la esfera de la vivienda deben velar porque no se sacrifiquen las dimensiones culturales de la vivienda y porque se aseguren, entre otros, los servicios tecnológicos modernos

Estos siete elementos son los que el Comité de Derechos Económicos, Sociales y Culturales ha definido como los básicos que debe contener una vivienda para que las personas que la habitan puedan vivir en un lugar en paz y seguridad. Sin embargo, en relación con lo que en este trabajo de investigación se denomina calidad física de la vivienda y su entorno, se hace alusión a solo tres de ellos: la habitabilidad, la disponibilidad de servicios, materiales, facilidades e infraestructura y la localización de la vivienda. Por su lado, la asequibilidad y los gastos soportables, se cree hacen parte de una denominación genérica de accesibilidad económica la vivienda, que no es objeto de estudio de esta investigación, y la adecuación cultural, como su propio nombre lo insinúa, tiene más relación con las actividades vinculadas con el desarrollo y la identidad cultural que con el espacio físico en sí mismo.

En este caso, los componentes agrupados de interés se refieren, en mayor o menor medida, a la calidad de la construcción de la vivienda para que esta sea habitable. Se habla entonces de los derechos a la seguridad que ésta debe ofrecer a sus ocupantes contra amenazas provenientes de la acción de personas, de la naturaleza, de fuentes de contaminación, a su ubicación adecuada, al completo suministro de servicios públicos, a su relación con el entorno, y en general a lo que se denominan de forma más amplia el derecho a la ciudad. Cuando se abandona el ámbito de la unidad habitacional concreta, como aquí se propone, y se relaciona con las condiciones del entorno, el vecindario y el marco urbano, es inevitable pensar en la ordenación del territorio como única instancia que hace posible el cumplimiento de dichos derechos.

En este sentido, se ha pronunciado la Corte Constitucional Colombiana, institución que, con base en el Derecho Internacional de los Derechos Humanos, ha señalado la importancia de avanzar en la compresión de un derecho a la vivienda integral. Ha definido el concepto de vivienda como unidad habitacional, sobre la cual es necesario asegurar las condiciones físicas para su ocupación segura y adecuada por seres humanos (habitabilidad), y como espacio directamente relacionado con el entorno inmediato y con el medio urbanístico circundante (disponibilidad de servicios, materiales e infraestructura y localización). Y adicionalmente ha 
establecido, por medio de sentencias, los siguientes derechos y obligaciones a cumplir de efecto inmediato o progresivo:

\section{Tabla 14 Derechos y obligaciones sobre la calidad de la vivienda} +Derecho a la a salud en relación a la calidad de la vivienda y su entorno

Los impactos que en la salud generan las condiciones de la vivienda están generalmente vinculados con enfermedades y afecciones relacionadas con la calidad del agua potable y el saneamiento básico. La vivienda saludable y adecuada es aquella que brinda protección contra enfermedades transmisibles y también contra lesiones y factores de otro tipo que contribuyen a generar enfermedades o padecimientos crónicos. En consecuencia, la vivienda adecuada debe proveer acceso a los servicios esenciales de acueducto, alcantarillado y aseo, necesarios para fomentar el buen estado de salud.

Obligaciones de efecto inmediato

Asegurar que las viviendas no se construyan en lugares contaminados ni en la proximidad inmediata de fuentes de contaminación que amenacen el derecho a la salud.
Obligaciones de cumplimiento progresivo

Asegurar que las viviendas protejan a sus habitantes del frío, la humedad, el calor, la lluvia, el viento u otras amenazas para la salud, de riesgos estructurales y de vectores de enfermedades.

\section{+ Derecho a la habitabilidad de las viviendas}

La habitabilidad de la vivienda hace referencia a las condiciones de seguridad y salubridad que hacen adecuado un lugar para que un ser humano desarrolle en él, libre y seguramente, su proyecto de vida. Por el contrario, la ausencia de las condiciones físicas a las que acá se aludirá, impiden que un lugar sea susceptible de ser habitado por las personas de forma digna y adecuada.

Al respecto la Corte Constitucional ha señalado: "Así, se debe aclarar que el derecho a la vivienda digna no comprende únicamente el derecho a adquirir la propiedad o el dominio sobre un bien inmueble, dicho derecho implica también satisfacer la necesidad humana de tener un lugar, sea propio o ajeno, en donde en la mejor forma posible una persona pueda desarrollarse en unas mínimas condiciones de dignidad que lo lleven a encontrar un medio adecuado que le garantice sus condiciones naturales de ser humano". Corte Constitucional. Sentencia T-894 de 2005. M.P. Jaime Araujo Rentería.

Además, la Corte ha precisado el sentido de la habitabilidad como componente del derecho a una vivienda digna y adecuada así. "una vivienda habitable no hace referencia a un simple techo que sea útil para evitar la lluvia y frío o el calor excesivos. La vivienda debe entenderse como un lugar que provea seguridad a la persona frente a inclemencias ambientales y un punto a partir del cual pueda proyectar su vida privada y en sociedad" (Sentencia T-1318/05 Humberto Sierra Porto)

\section{Obligaciones de efecto inmediato}

La entidad o persona que afecte por acción u omisión una vivienda hasta el punto de amenazar la vida e integridad de sus residentes, está obligada a tomar las medidas adecuadas para impedir que el hogar afectado se derrumbe, incluso si su responsabilidad es parcial.

Reubicar a las personas que habiten viviendas ubicadas en zonas de alto riesgo

\section{Obligaciones de cumplimiento progresivo}

Asegurar que las viviendas tengan espacio adecuado para sus habitantes

Asegurar que las viviendas garanticen la seguridad física de sus ocupantes.

\section{+Derecho a la disponibilidad de servicios, materiales, facilidades e infraestructura en las viviendas}

Al respecto, la Corte Constitucional Colombiana, en la sentencia c-936 de 2003, señaló lo siguiente: el derecho a la vivienda digna implica, entonces, una relación estrecha entre las condiciones de vida digna de la persona y la garantía de la realización de derechos sociales y colectivos y el aseguramiento de la prestación eficiente y planificada de los servicios públicos domiciliarios y servicios públicos asistenciales, requeridos para la vida en sociedad de una persona.

Obligaciones de efecto inmediato

Garantizar la prestación eficiente de servicios públicos cuando se expida una licencia para construir una vivienda o un proyecto habitacional

$$
\text { Obligaciones de cumplimiento progresivo }
$$

Garantizar el acceso a condiciones sanitarias básicas Garantizar el acceso a un suministro adecuado de agua limpia potable.

\section{+Derecho a una adecuada localización de la vivienda}

La Corte Constitucional dio cuenta de la importancia de la localización de la vivienda, en particular en cuanto al acceso a opciones de empleo, dentro de la sentencia t-617 de 1995, ante la posible reubicación de los miembros de la comunidad: "Los comuneros", quienes señalaban que el lugar que inicialmente les fue ofrecido por la administración se encontraba muy distante de su principal medio de subsistencia: el reciclaje. En este caso, los habitantes señalaban que la "comunidad estaba dispuesta a una reubicación digna a condición que se respetara su sistema de trabajo que era el reciclaje (sic)". Ante esta situación la Corte advirtió a las autoridades que "cuando una autoridad local se proponga recuperar el espacio público ocupado por los 
administrados que ocuparon tal espacio público, deberá diseñar y ejecutar un adecuado y razonable plan de reubicación de dichos personas de manera que se concilien en la práctica los intereses en pugna".

Asegurar que la vivienda se encuentre en un lugar que permita acceso a opciones de empleo, servicios de atención en salud, centros de atención para niños, escuelas y otros servicios sociales, a costos razonables

Fuente: Defensoría del Pueblo (2009) El derecho a una vivienda digna y adecuada en la Constitución, la jurisprudencia y los instrumentos internacionales de Derechos Humanos. Bogotá

En resumen, el análisis de los diferentes instrumentos internacionales de derechos humanos, la Constitución Política y la jurisprudencia de la Corte Constitucional permiten identificar las obligaciones correlativas del Estado colombiano y los parámetros esenciales referentes a la calidad de la vivienda, y más aún de la calidad de la vivienda social, que se deberían considerar. Ahora bien, se reconoce que no siempre dichas obligaciones institucionalizadas tienen correspondencia con la materialización de lo que se produce en la ciudad.

En este punto surgen, entonces, los siguientes interrogantes: ¿Cómo puede ser mesurable la calidad del espacio urbano producido? ¿Cuáles son los parámetros más adecuados capaces de captar la introducción de obligaciones normativas sobre vivienda y entorno adecuado en proyectos de vivienda nueva o mejoramiento de barrio?

\subsubsection{Posicionamiento de ésta investigación frente a la noción de calidad}

Desde sus orígenes el concepto de calidad urbana o calidad del espacio residencial ha venido acompañado por la necesidad de encontrar la medida de la misma. Sin embargo, para ello es esencial primero posicionar el análisis de investigación frente al concepto de integración urbana.

Como se ha señalado, éste trabajo parte de una propuesta de modelo de ciudad orientado hacia la satisfacción integral de las necesidades de los habitantes, más aun de los habitantes de bajos ingresos. Se considera que el reto es promover un espacio residencial, vivienda y contexto, con unas condiciones dignas de ser habitadas por una gran mayoría. Para ello es necesario "adentrarse", como lo expone Max-Neff (1986), en cómo el sujeto y la comunidad viven, siente, reconocen y valoran su espacio; es decir en cómo reconocen dignamente lo que es un espacio adecuado, en este caso el espacio físico adecuado. No existe dignidad sin reconocimiento.

La calidad es inherente a la integración urbana, es decir a la participación de la población al derecho de la ciudad y de la vivienda. Con una población excluida de dichos derechos es imposible llegar a articular políticas sobre vivienda adecuada. De allí la necesidad de contemplar el espacio residencial como una estructuras articuladas de abajo hacia arriba en donde las relaciones de poder, que parecen perpetuar hasta el momento la pobreza y la desigualdad (Max-Neef, 1986; Harvey 2012; Álvarez 2013) sean revertidas. Para ello es necesario dotar a la población de unas normativas básicas, claras pero muy específicas de cómo debe ser su vivienda y su entorno. Deben existir unas leyes que otorguen equidad social 
y urbana a toda la población y al mismo tiempo los impulse a promover su autonomía económica y su sostenibilidad digna en el territorio.

La integración urbana es el objetivo declarado de un desarrollo adecuado. Sin embargo, su definición, medición y discusión en términos de demanda de políticas públicas, el rol de los agentes privados o del mercado y los espacios formales para la ciudadanía son procesos que todavía están en desarrollo o construcción. Persisten ambigüedades respecto a la multiescalaridad y multidimensional del término integración o calidad, así como sus principales conceptos vinculantes tales como cohesión, equidad o sus contrarios precariedad, exclusión, fragmentación o segregación.

Para encontrar la medida de la misma, el requisito valorado como mínimo a cumplir para una condición adecuada de calidad, de dignidad, se cree preciso analizar referencias de carácter teórico-prácticas al respecto ${ }^{93}$.

\subsection{INICIATIVAS EN LA MEDICIÓN DE LA CALIDAD URBANA}

Diversos enfoques han sido abordados con el fin de contar con una información relevante, desde diferentes orientaciones disciplinares, para medir las condiciones de calidad urbana. Entre ellos se han considerado trabajos analizados desde la arquitectura y el urbanismo con el establecimiento de indicadores para la vivienda y su desarrollo territorial (HIC, 2004; Saldarriaga, 2006), trabajos desde la academia que intentan combinar la observación formal con el observación de satisfacción por parte de la población (Escallón, 2013; Tarchópulos y Ceballos, 2003), trabajos desde el ámbito medioambiental examinando la sostenibilidad de las actuaciones sobre los recursos naturales y los ecosistemas locales (BID 2013; Geo Ciudades 2008, Rueda 2008) o bien trabajos desde los planteamientos normativos que establezcan unas condiciones físicas a seguir con un carácter de obligatoriedad (Alcaldía Mayor de Bogotá, 2005; DAP Medellín 2005; Defensoría del Pueblo,2012; Ministerio de Economía, 1998)

En cambio, trabajos desarrollados desde las ciencias económicas en donde priman los logros por objetivos y el modelo costo-beneficio (Cuenya y Natalicchio 1994; De la Luz Nieto, 1999; Navarro, 2004) no son tenidos en cuenta. Se cree sería un desacierto comparar a través de este modelo la producción de vivienda formal, por ejemplo la vivienda básica, con una producción de origen marginal que puede iniciar con una parcela con servicios ${ }^{94}$. Tampoco son

\footnotetext{
93 Desde sus orígenes el concepto de calidad urbana ha venido acompañado por la necesidad de encontrar una forma de medición específica. "El movimiento científico empeñado en el ejercicio de desarrollar sistemas de indicadores adquiere un auge definitivo en los años sesenta, la institucionalización del concepto de Calidad de Vida no se advierte hasta el inicio de la nueva década. En 1970 la OCDE establece un programa de estudio de la evolución del bienestar o de lo que denomina como «áreas de preocupación social» a través del que se pretenden establecer los criterios políticos a seguir que presten atención a los aspectos cualitativos. En 1972 se organiza la Conferencia Internacional sobre Calidad de Vida por parte del sindicato de los metalúrgicos alemanes IG Metall, En junio de 1974 se crea el Ministerio de la Calidad de Vida en Francia y en 1976 se firma la Charte de la Qualité de la Vie por parte del primer mandatario francés. En España habrá que esperar hasta la Carta Magna de 1978 para que el concepto de Calidad de Vida ocupe un lugar de relevancia institucional" (Alguacil 1998). En Colombia, el concepto de Calidad de vida no aparecerá, como se mencionó hasta la constitución del 91 y la medición de la calidad del espacio urbano o de la calidad de vida se asumirá hasta solo diez años después.

94 La consideración de los costos y de la eficiencia no son, por lo general un tema principal en la evaluación, formulación o implementación de los programas de mejoramiento de barrio. Si bien estos y su replicabilidad podrían llegar a ser temas centrales (dado el contexto de escasez y los imperativos de cambios que se requieren en estos territorios) no se avanza respecto a cómo
} 
tenidos en cuenta los trabajos iniciados desde las ciencias sociales que priorizan únicamente los métodos cualitativos, los indicadores subjetivos y las técnicas de autoevaluación (Cuenya y Natalicchio, 1994; Sepúlveda Ocampo, 1999). Su enfoque estrictamente disciplinar no se ajusta con el objetivo de la investigación.

Ahora bien, en la consulta de esas diferentes iniciativas, más que identificar un consenso de criterios para evaluar la calidad urbana, que de entrada se sabe que no existe, se busca captar los parámetros destacados por los autores y confrontar sus visiones. La finalidad es que sirvan de referencia para orientar el modelo de evaluación a proponer bajo el contexto de los objetivos que se persiguen en este trabajo y las limitaciones de información que se tienen.

\subsubsection{Análisis de nueve metodologías de medición}

Se trata, en este apartado, de comentar algunos aspectos y enfoques básicos de las nueve iniciativas seleccionadas y de explicar el interés que tienen al ser revisados. Se hace énfasis en aquellas iniciativas que se centran especialmente en temas de ordenación urbana, sin embargo se aportan unas más generales vinculadas a la mejora en la calidad de vida en general de la población.

\section{Programa de Indicadores Urbanos de UN-Hábitat (2004)}

UN-Hábitat ha sido una organización precursora en la propuesta de indicadores de vivienda convirtiéndose desde 1991 en un centro de observación y análisis del desarrollo urbano mundial (GUO). Su propuesta de indicadores urbanos ha sido desarrollada a partir de la Agenda Hábitat y de la Comisión de Asentamientos Humanos de Naciones Unidas, como se mencionó en el apartado anterior. El programa está dirigido a evaluar los ámbitos de configuración del territorio, gestión de los recursos naturales, cohesión social y gobernabilidad en la ciudad. Actualmente su monitoreo está orientado principalmente en la meta 11 de los Objetivos de Desarrollo del Milenio: "Mejorar sustancialmente, para el año 2020 las condiciones de vida de por lo menos 100 millones de personas que habitan en asentamientos precarios".

El sistema de indicadores urbanos comprende 20 indicadores principales, 9 listas de verificación y 13 indicadores extensivos que miden los resultados obtenidos y las tendencias de las áreas seleccionadas. En su conjunto constituyen una referencia útil a considerar para la construcción del modelo de evaluación e indicadores de esta investigación pues se considera que proporciona criterios para la delimitación de un área de estudio y a la vez, facilita la posibilidad de comparar entre sí las diferentes áreas urbanas.

Este sistema de monitoreo ha sido puesto en práctica en el programa URB-AL de la Comunidad Europea, por medio del Observatorio del Medio Ambiente Urbano ${ }^{95}$ (OMAU). Nueve ciudades

incorporarlos. La explicación, o parte de ella, puede llegar a ser por la dificultad de "encontrar fondos" por parte del Estado o porque hasta el momento parte importante de ellos proviene de agencias extranjeras.

${ }^{95}$ En diciembre de 2016 se publicó La Agenda Urbana de Málaga, una de las primeras que se desarrollaron en Europa con el nuevo formato que se adoptó por Naciones Unidas en la cumbre Hábitat III de Quito, y la Unión Europea en el Pacto de Ámsterdam. Es una Agenda Urbana de referencia global de la ciudad a medio y largo plazo, donde derivan estrategias integradas y planes sectoriales con 128 indicadores en los ámbitos de cohesión social, gobernabilidad, gestión de los recursos y territorialidad y configuración de la ciudad. La consolidación de la Agenda fue posible gracias al trabajo realizado, desde su creación en el año 
iniciales, entre el año 2000 - 2006 fueron analizadas bajo este sistema: Montevideo (Uruguay), Rosario (Argentina), Belo Horizonte (Brasil), Roma (Italia), Provincia de Treviso (Italia), Málaga (España), Calviá (España), Villa del Mar (Chile) y en la región del Atlántico (Colombia). En ellas se evaluaron temas sobre vivienda y ciudad que incluían el acceso de todas las personas a vivienda y servicios básicos adecuados, seguros y asequibles y la mejora de los asentamientos precarios en aras de una mejora para el año 2030.

De cara a los objetivos de este trabajo, la Agenda Hábitat y sus indicadores aportan, como se dijo, una base útil a considerar. Se valora el esfuerzo de síntesis en el número de indicadores de los temas esenciales a tratar con respecto a la vivienda, el acceso a la tierra, la cobertura de servicios básico, las condiciones ambientales, económicas, de gestión, de género, etc. La crítica, que quizás se le podría hacer, en orden a la utilidad para este trabajo, sería la falta de desarrollo a aspectos de tipo territorial y modelo urbano -aspectos relacionados con la calidad de la vivienda y su entorno-. En cualquier caso, algunos de los indicadores desarrollados por esta iniciativa son integrados en el listado de indicadores de esta investigación. 

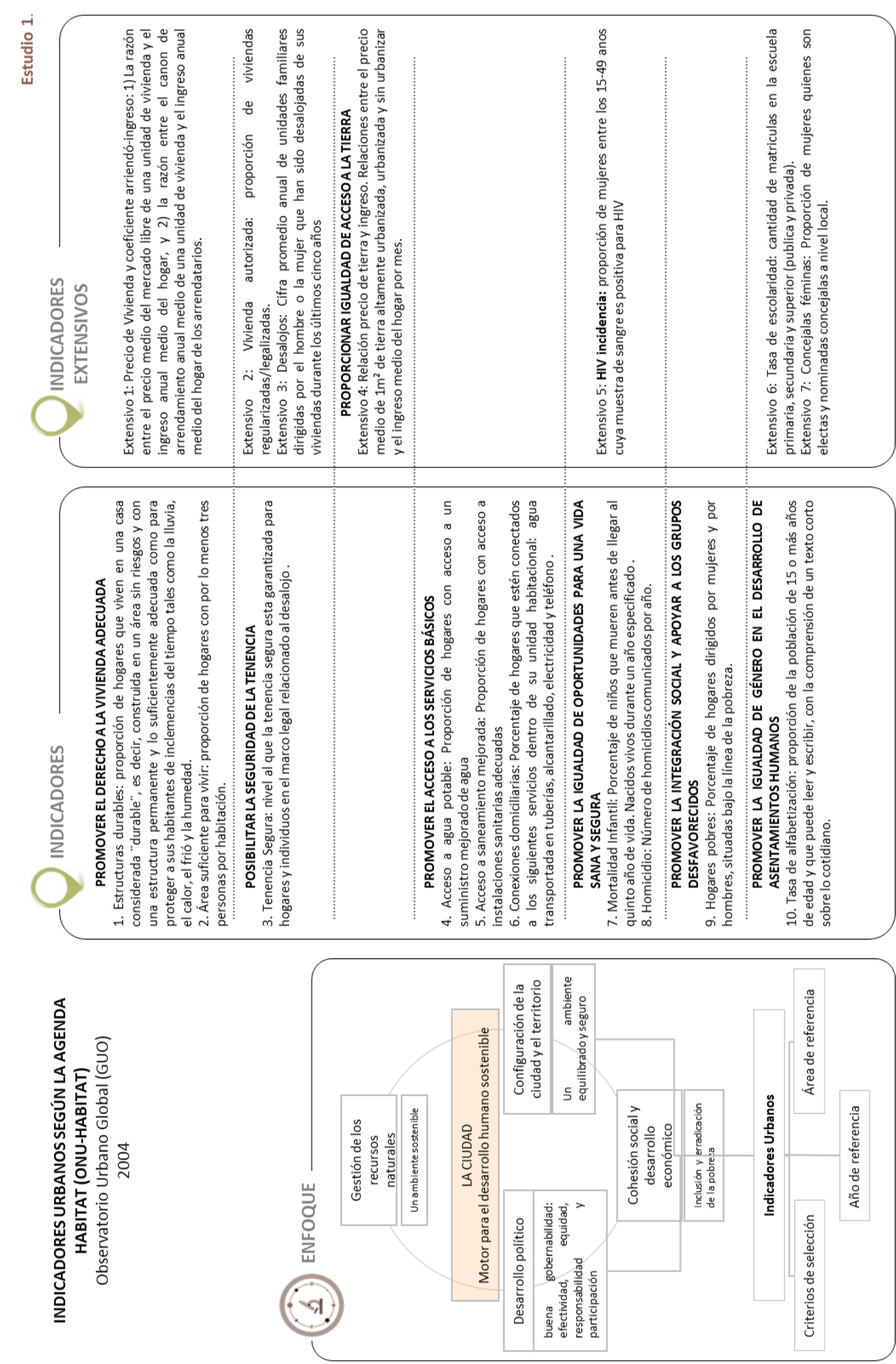


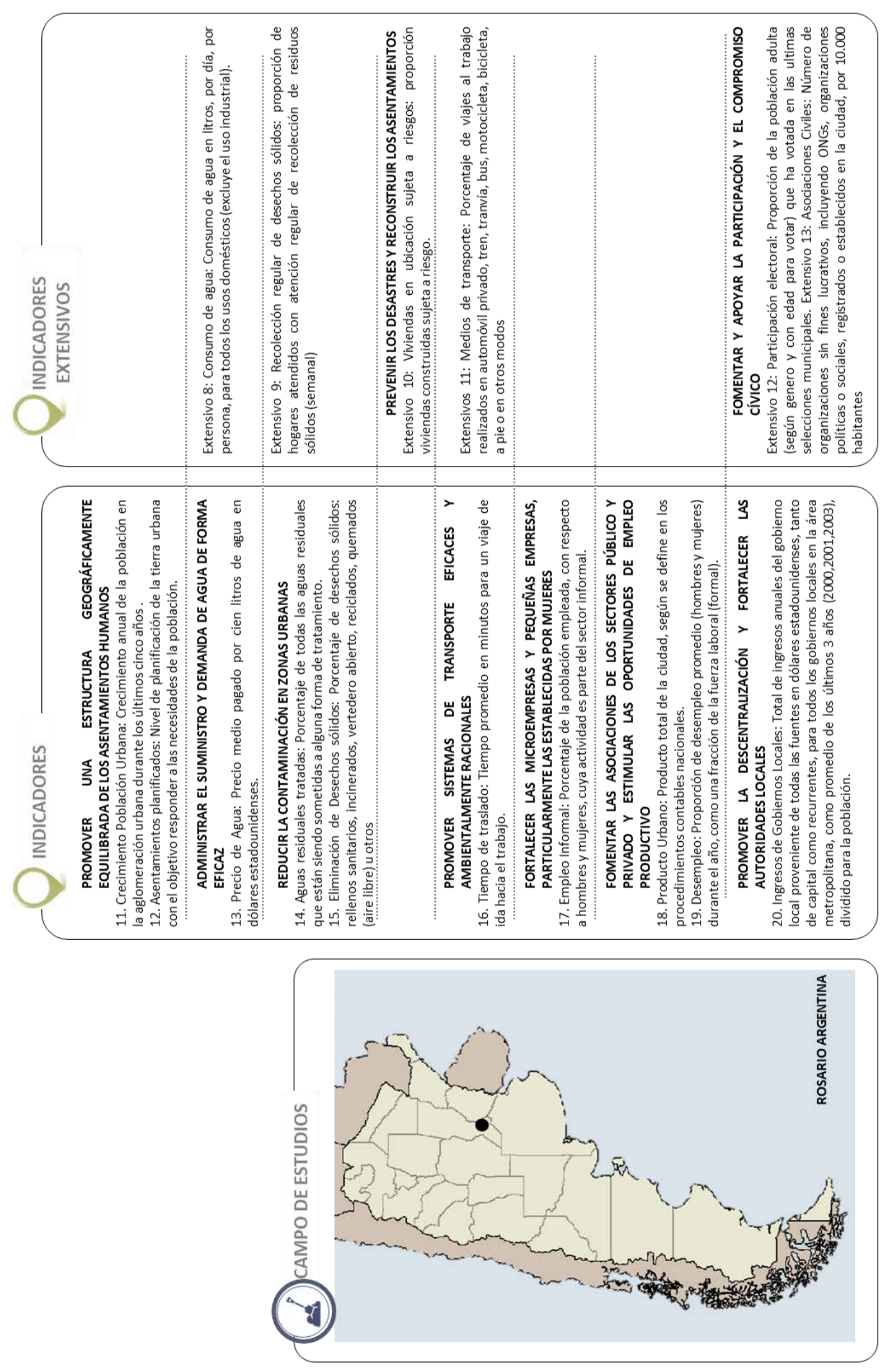


El Banco Interamericano de Desarrollo (BID) creó la Iniciativa de Ciudades Emergentes y Sostenibles en el año $\mathbf{2 0 1 0}$ como respuesta al rápido y poco regulado proceso de urbanización de las ciudades de escala mediana en la región de América Latina y el Caribe (ALC). Su enfoque multisectorial está basado en tres dimensiones: sostenibilidad ambiental, desarrollo urbano sostenible y gobernabilidad. La primera dimensión ambiental desarrolla indicadores sobre la adaptación al cambio climático, la calidad del aire y el agua, la mitigación de las emisiones de los gases de efecto invernadero, la reducción de la vulnerabilidad a los desastres naturales y la cobertura de los servicios públicos domiciliarios. La dimensión del desarrollo urbano considera los aspectos físicos, económicos y sociales del desarrollo urbano. La dimensión de fiscal y de gobernabilidad aborda la transparencia, la participación pública, la gestión orientada a la obtención de resultados y las prácticas fiscales de las ciudades, como la administración de deuda e inversión pública y la recuperación de los costos.

La metodología de la Iniciativa se basa en el diagnóstico de la ciudad a partir de la implementación de los 117 indicadores temáticos (entre uno y nueve indicadores para cada uno de los 23 temas desarrollados) en las tres dimensiones antes descritas. El objetivo es hacer un diagnóstico rápido de los problemas críticos de cada ciudad para priorizar los temas de actuación con una medición, en palabras del BID, precisa, unívoca y fácil de comprender para que cualquier persona o institución pueda verificarlos o replicarlos. -Lo que se reconoce como acierto para valorar en los indicadores a proponer-. Hasta diciembre de 2016, 71 ciudades latinoamericanas (26 ciudades como programas regulares y 45 ciudades como programas adicionales) habían sido diagnosticadas.

Como punto de interés, cabe mencionar la propuesta de indicadores en la dimensión de sostenibilidad urbana centrados en los usos del suelo, la desigualdad urbana y la movilidad. Sin embargo, se echaría en falta para el provecho de este trabajo, tal vez unos indicadores más ajustados hacia la calidad del espacio residencial y su entorno (unidad habitacional, zonas de ocio, recreación, equipamientos comunitarios, etc.). Se cree que si se está teniendo en cuenta un diagnóstico de rápido crecimiento, dicho crecimiento debe estar conformado principalmente por el uso residencial (una de las áreas o usos más problemáticas o deficientes de la ciudad latinoamericana.

Con respecto a las dos iniciativas anteriores, en suma, se puede decir que tienen como ventaja ser producidas por instituciones de alcance mundial y por lo tanto, se benefician de una aplicación regular y sistemática con un alto grado de confiabilidad. Sin embargo, esa misma característica global que le permite cubrir una amplia variedad de situaciones sociales, económicas, ambientales, etc. supera la mirada y la escala de la investigación. Adicionalmente, se consideran metodologías de diagnóstico de ciudad más que de evaluación de proyectos. De hecho, la metodología que utilizan no está desarrollada para identificar las condiciones problemas de la ciudad mismas que se evalúa. ${ }^{96}$

\footnotetext{
96 Evaluaciones sobre el ámbito urbano similares: Indicadores Ambientales del Programa Geo Ciudades de Naciones Unidad para el Medio Ambiente-PNUMA (2008); Indicadores de los Objetivos de Desarrollo del Milenio (2000) e Indicadores de la Meta 11 de los Objetivos de Desarrollo del Milenio desarrollados por UN-Hábitat; Informe de Desarrollo Humano realizado por el PNUD (1990) o Indicadores del Desarrollo Mundial publicados por el Banco Mundial (2014)
} 

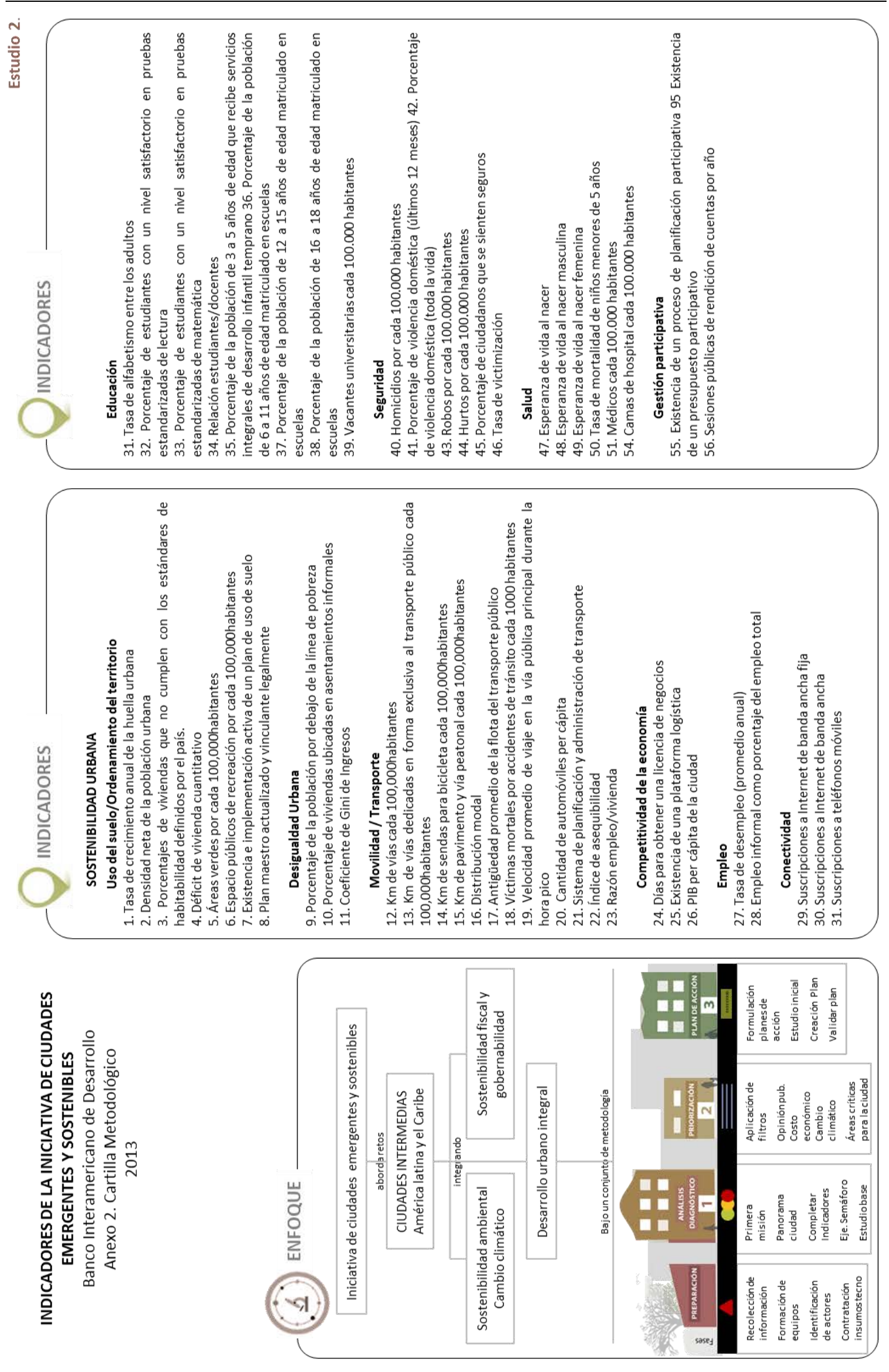

Fuente: BID Ciudades Emergentes y Sostenibles. En red: http://www.iadb.org/es/temas/ciudades-emergentes-ysostenibles/iniciativa-ciudades-emergentes-y-sostenibles,6656.html [Consultado 20/11/14] 
Aplicación de Indicadores de sostenibilidad urbana a la vivienda social - CEPAL (2014)

El trabajo realizado por la CEPAL propone una evaluación de sostenibilidad ambiental, basada en la metodología e indicadores planteados por Salvador Rueda, dentro de la Agencia Ecológica Urbana de Barcelona para la ciudad de Sevilla, aplicada a 12 intervenciones públicas de vivienda social en la ciudad de Concepción del Uruguay, Argentina.

Dentro del marco del "Plan Especial de Indicadores de Sostenibilidad Ambiental de la Actividad Urbanística de Sevilla", en el año 2008, Salvador Rueda formula un modelo conceptual y propositivo de ciudad sostenible basado en cuatro características principales: compacidad, complejidad, eficiencia y, estabilidad social. El documento pone énfasis en "fomentar modelos urbanos más sostenibles con un aprovechamiento más eficiente de los recursos [...] para mantener una coherencia entre todos los componentes que intervienen en el ecosistema urbano con el medio que les sirve de soporte." Así la apuesta para los nuevos crecimientos urbanos, según la Agencia, debe abarcar los siguientes aspectos:

Construir entornos urbanos con una densidad edificatoria y compacidad urbana óptima, que garanticen el equilibrio entre el espacio construido y el espacio libre. Este aspecto relaciona un determinado nivel de ocupación del suelo y la distribución del techo edificado dentro del ámbito de estudio, teniendo en cuenta igualmente, las alturas máximas y la proporción de las secciones de las calles. El grado de compacidad da la pauta para organizar las redes de movilidad y las funciones derivadas del modelo.

Máximo aprovechamiento del potencial de mixticidad de usos que permita dar cabida a una elevada diversidad urbana. Ésta diversidad se relaciona con el tipo de personas jurídicas, la superficie que se destina y la distribución de éstas dentro del ámbito. Incorporación a la nueva era de la información y del conocimiento.

Máxima eficiencia en el uso de los recursos locales con la finalidad de reducir al mínimo los impactos sobre los ciclos de la materia y los flujos de energía que regulan la Biosfera. En este sentido se trata de planificar los futuros edificios como parte de la oferta local de energía a través de su captación en las azoteas, la gestión del ciclo local del agua y la gestión de los residuos.

La creación de entornos que propicien la cohesión social de los futuros habitantes. Esto implica una distribución de los usos del suelo que permita la mezcla de rentas y a su vez, una conformación edificatoria más flexible a medida de los requerimientos espaciales de los diversos grupos sociales: planes de vivienda social, estrategias de accesibilidad y transporte, servicios sociales y diseño de la red de equipamientos y espacios públicos. (RUEDA, 2008:7)

En otras palabras, plantea un modelo que trata de superar las salvedades que hasta el momento se hacían en el urbanismo convencional para analizarlo bajos diferentes ejes de sostenibilidad. Se superan las dos dimensiones de escala establecidos por principio para pasar a tres escalas que redistribuyen las jerarquías propias del urbanismo: la ciudad subterránea vinculada con la funcionalidad, la ciudad en altura relacionada con la eficiencia metabólica y la ciudad en superficie asociada con la habitabilidad. Cada una de estos niveles, además, incorpora un número importante de variables que están asociados a la idea principal. 
Ahora bien, la originalidad del estudio de la CEPAL es aplicar esas variables a proyectos de vivienda social en el contexto latinoamericano. Ello, sin duda, enriquece el análisis con pautas multidimensionales. Sin embargo se considera que una cantidad relativa de indicadores, y más aún de los factores condicionantes de esos indicadores, no se ajusta a la realidad de la vivienda social latinoamericana y colombiana. Una muestra de ello es, por ejemplo, el tema de metabolismo urbano con los indicadores de autogeneración de energía de las viviendas o de autosuficiencia hídrica imposibles de medir. Se cree que esta metodología fue pensada para ciudades con un desarrollo económico y urbano superior. (De los 40 indicadores de Salvador Rueda aplicados por la CEPAL, 21 no se pueden verificar.)

En cuanto al trabajo de la Agencia Ecológica Urbana de Barcelona, sin bien no hace parte de las iniciativas como tal a examinar, se quiere destacar la clara y sintética información aportada en el desarrollo de los indicadores. La combinación de los textos explicativos, junto con las gráficas, los valores de medición y la metodología a seguir son, se piensa, muy acertado. De cara para los indicadores a avanzar en este trabajo, algunos de ellos son retomados de esta iniciativa. 


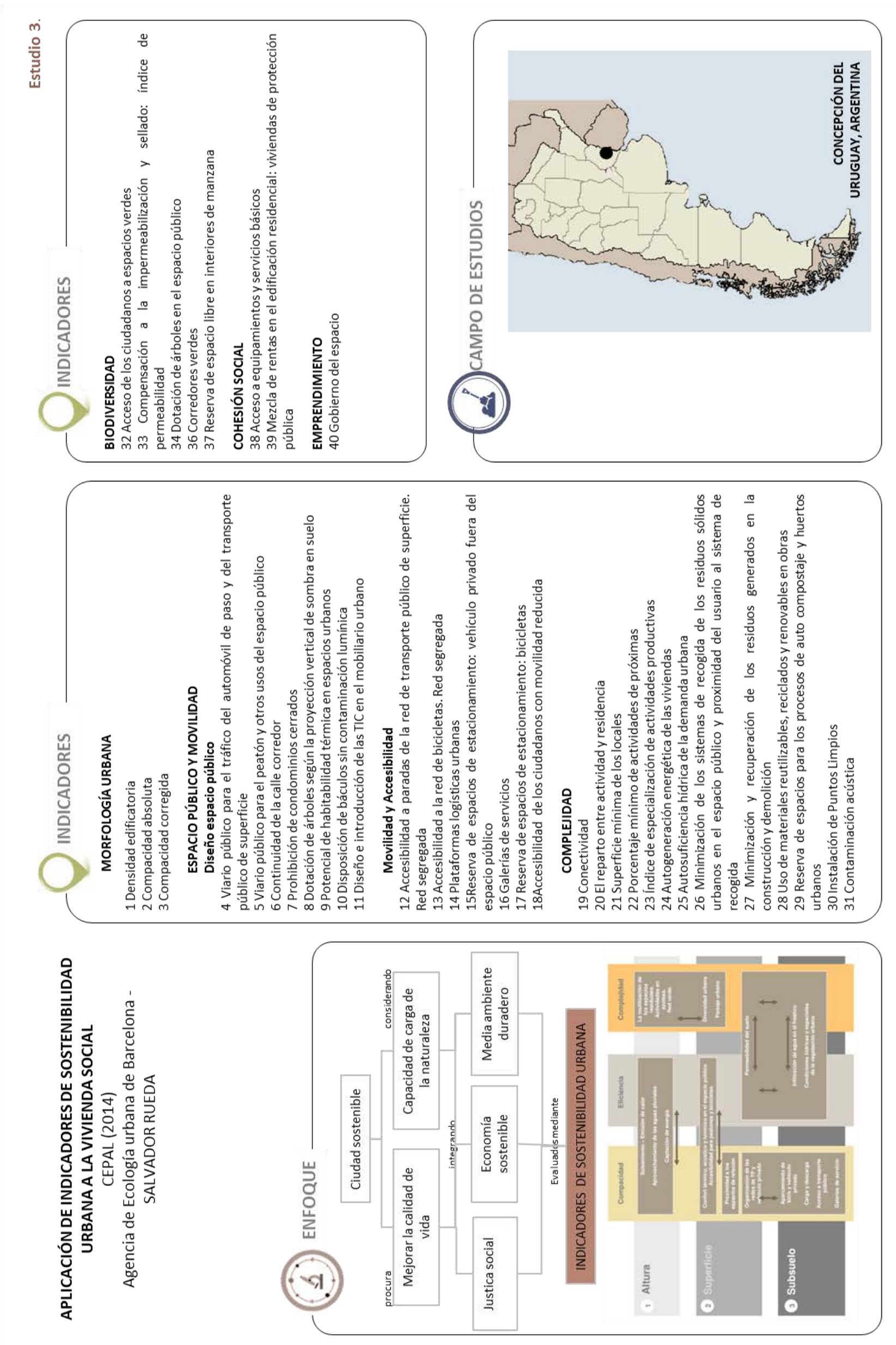


Indicadores de Resultados e Impactos. Metodología de Aplicación en Proyectos Participativos de Hábitat Popular. Coalición Internacional del Hábitat HIC-AL (2004)

Esta publicación de HIC corresponde a la tercera etapa de investigación de la institución cuyo objetivo principal fue la obtención una metodología de evaluación para la identificación, relevamiento y valoración de resultados e impactos en proyectos participativos de hábitat popular. La primera etapa consistió en la realización de una matriz teórica de evaluación de impactos sobre ese tipo de proyectos sociales y la segunda etapa de un estudio exploratorio en dos estudios de caso para validar lo propuesto en la primera etapa. Varios organismos participaron en el total de la investigación: la agencia Alemana para el desarrollo y tres ONG's argentinas de Servicios Habitacional y Acción Social.

La investigación partía, basados en la territorialidad, la temporalidad y la dimensión de análisis no convencional vinculada a la condición social de los habitantes, de tres supuestos preliminares:

Proyectos participativos de hábitat, además de los resultados en el campo físico del hábitat, producen impactos de cambio en otra serie de aspectos del desarrollo de las personas, las familias, los grupos sociales, así como inciden también en la integración social, el desarrollo urbano y las políticas públicas.

Experiencias con resultados de impactos positivos y negativos que se deben tener en cuanta.

Posibilidad de constatar y valorar los resultados e impactos a través de una metodología adecuada según el contexto en el que se aplique.

Los temas desarrollados en la formulación de indicadores cobijaban entonces una amplia gama: psicosocial; equidad de género; salud; educación; empleo; ingreso y economía familiar; desarrollo urbano; situación familiar habitacional; medio ambiente; organización, empoderamiento, inclusión social e incidencia y cambio en políticas. En total 252 indicadores fueron propuestos y fue aplicada en el estudio de caso Villa "Los Cortaderos" en la ciudad de Córdoba, Argentina.

Se valoran los indicadores detallados sobre la caracterización urbanística, de infraestructura y ordenamiento urbano que son, en cierto modo, retomados en el modelo de evaluación e indicadores de esta investigación. Se valoran también las diferentes escalas que son tenidas en cuenta y que van desde la individualidad de la persona, la familia, lo comunitario-barrial, el área urbana y finalmente la ciudad.

Esta iniciativa, así como la siguiente que se va a presentar Sistema Único de Monitoreo de Impacto. PMIB-CVP Bogotá, son dos trabajos realizados con un detalle de análisis extraordinario. Su propuesta de investigación es sumamente compleja pues miden no solo los cambios o variaciones, tanto positivas como negativas, generados por las actuaciones vinculados con los objetivos y las metas del proyecto sino también porque valoran las variaciones sucesivas a los resultados. Utilizan una metodología según los diferentes aspectos, dimensiones y sub-dimensiones de todo el habitar humano. Su ventaja es la posibilidad de observar los efectos de forma pormenorizada. Su dificultad se encuentra en la localización de la información; un requerimiento indispensable de recursos y herramientas para su realización efectiva. 

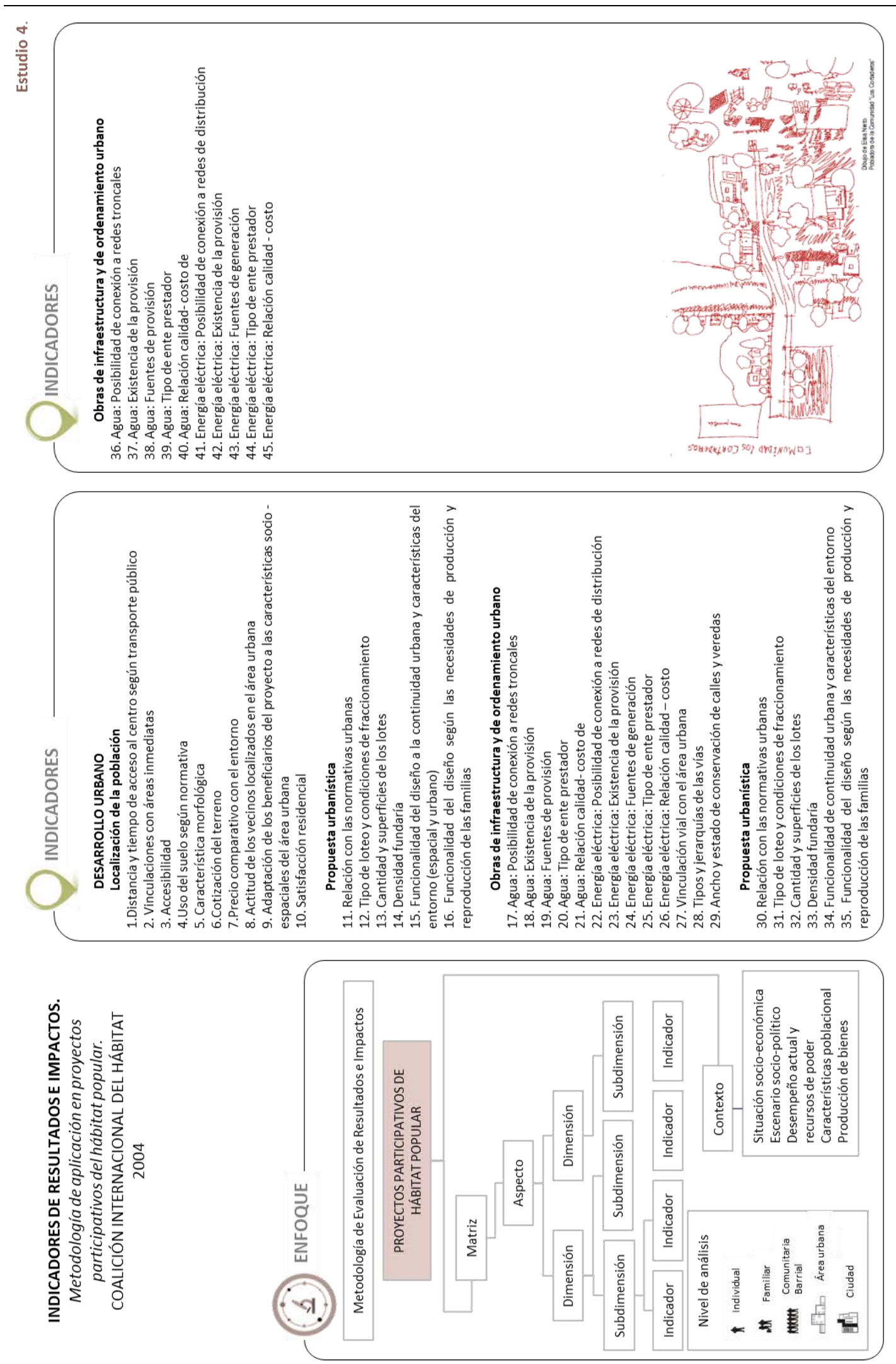

COALICIÓN INTERNACIONAL DEL HÁBITAT (2004) Indicadores de resultados e impactos. Metodología de aplicación en proyectos participativos del hábitat popular. Investigadores Rodríguez, M - Buthet, C - Scavuzzo, J - Taborda, A. En red: www.hic-al.org/documento.cfm?id_documento=1087 [Consultado 20/11/14] 
Sistema Único de Monitoreo de Impacto. PMIB-CVP Bogotá, Colombia (2005) $)^{97}$

Como parte del trabajo de diseño, desarrollo e implementación de un "Sistema de información para el Programa de Mejoramientos Integral de barrios -PMIB-", una empresa consultora, Econometría S.A., desarrolla un sistema de indicadores para obtener, transformar y presentar información acerca de los principales procesos del PMIB. El sistema es creado para hacer un seguimiento a la gestión de manejo de los recursos y cuantificar el cumplimiento de los resultados previstos.

En la práctica, el Sistema sigue como modelo de réplica la intervención y evaluación del Proyecto "Sur con Bogotá" ${ }^{98}$, uno de los estudios de caso de esta investigación, debido a que reconoce en él un valioso aporte metodológico con claros resultados en el mejoramiento de la calidad de vida y la convivencia de los ciudadanos. En el Proyecto se desarrollaban tres temas estratégicos: fortalecimiento institucional, configuración física (urbana, territorial y habitacional) y desarrollo social (participación y corresponsabilidad) que debían ser claramente identificados y valorados al final de la intervención. Medir su impacto y generar una base de indicadores a seguir para futuros tratamientos de MIB era el objetivo del Sistema.

De este modo, se construyó el SUMI una herramienta flexible, adaptable y escalable, en palabras de las propias instituciones de Bogotá, capaz de presentar información sobre los principales procesos del PMIB y de examinar sus resultados a corto y mediano tiempo. Se desarrollaron 95 indicadores basados en los tres temas estratégicos: desarrollo institucional, físico y social en los cuales se expusieron dimensiones como calidad de vida, capital social y convivencia, fortalecimiento técnico y coordinación y seguimiento. Además dos tipos de aproximación fueron propuestas: indicadores de medición e indicadores de percepción.

Cabe destacar aquí los indicadores de la dimensión de calidad de vida, muy similares a los que se busca para este trabajo de investigación bajo el concepto de calidad urbana. En ellos se evalúan la cobertura de servicios, la accesibilidad y movilidad, las condiciones ambientales, los tipos de equipamientos y las condiciones físicas de la vivienda a escala local.

El reparo que se le puede hacer a este Sistema de Monitoreo SUMI, aparte de lo que se expuso en la iniciativa anterior similar hasta cierto punto a este sistema de indicadores, está en que no solo existe una dificultad en encontrar información para poder evaluar el proyecto sino que, hasta el momento, todas las aplicaciones que se han realizado del Sistema han sido de cara al desarrollo social. La medición del espacio físico como tal no se ha dado concretamente y menos aún se ha podido instituir como un modelo de evaluación a seguir.

Gráfico 09 Sistema Único de Monitoreo de Impacto. PMIB-CVP Bogotá (2005)〉> Fuente: ALCALDÍA MAYOR DE BOGOTÁ (2005) Diseño, desarrollo e implementación de un sistema de indicadores para el programa de Mejoramiento Integral de Barrios PMIB, SI-PMIB de la CAJA DE LA VIVIENDA POPULAR. Bogotá

\footnotetext{
97 Para la ciudad de Medellín, existe igualmente dentro del Plan Estratégico Habitacional una matriz de impactos cruzadosmultiplicación aplicada a una clasificación de los métodos de la prospectiva (MIC-MAC) que diagnostican y evalúan las actuaciones en materia de vivienda social.

${ }^{98}$ Como se ha señalado, el Proyecto "Sur con Bogotá" es una experiencia de mejoramiento de barrio impulsada por la Alcaldía Mayor de Bogotá en cooperación con el Gobierno de Alemania desde el año 1999, en 41 barrios de la localidad de San Cristóbal, Usme Y Rafael Uribe Uribe en el sur oriente de la capital.
} 

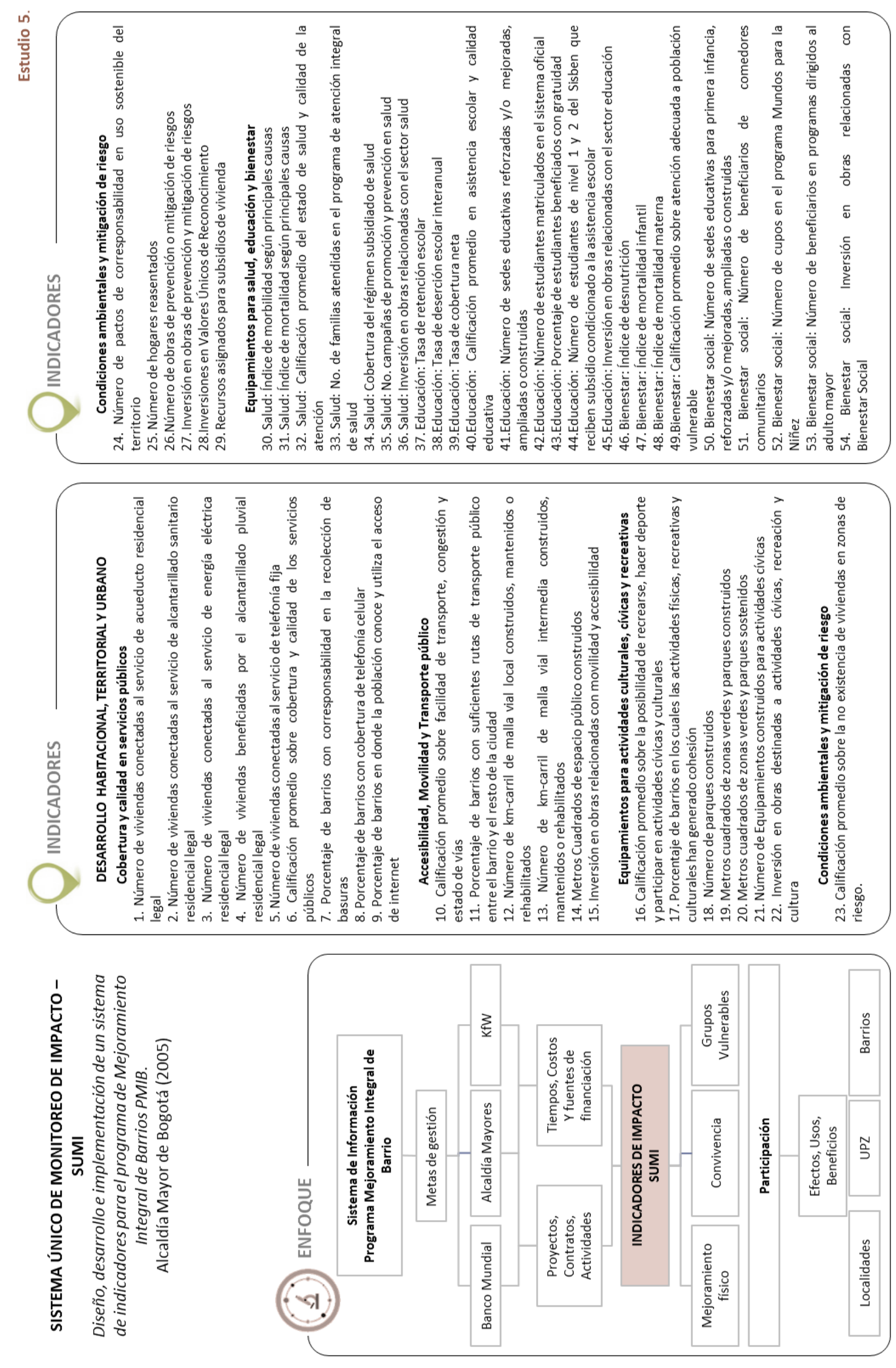


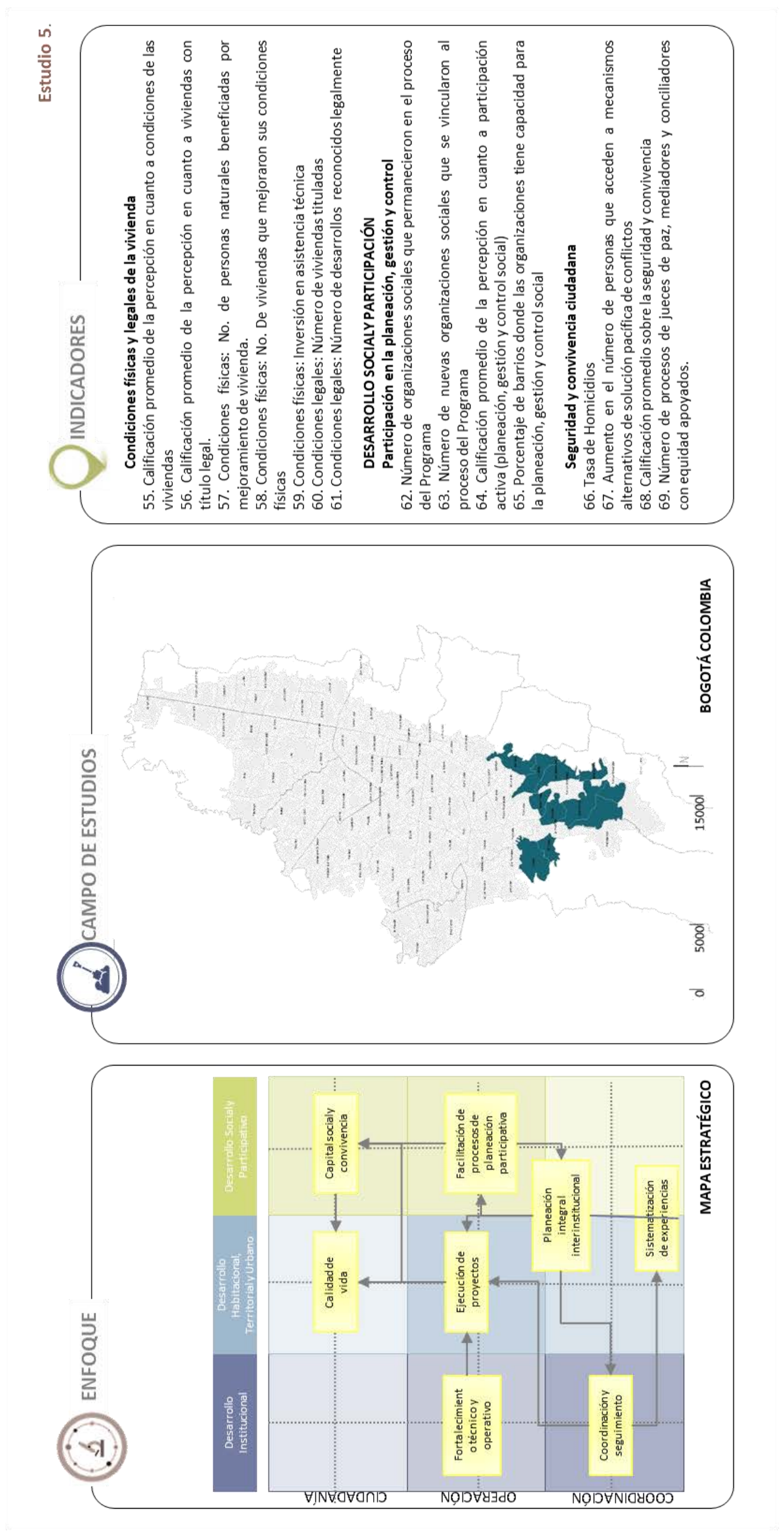


A continuación, se presentan tres iniciativas basadas en la normativa colombiana. Su reseña es importante para verificar cómo se miden y valoran, por medio de indicadores, las condiciones de calidad urbana en las regulaciones. Se recuerda aquí que el interés de analizar estas iniciativas es el de encontrar elementos conceptuales y operativos útiles para la propuesta de una metodología de evaluación y comparación de los estudios de caso de esta investigación. En ningún caso se pretende valorar las iniciativas o comentar sus resultados.

\section{- Sistema de Indicadores. Documento técnico de soporte POT Medellín (2005)}

En el año 2005, El Municipio de Medellín construye un Sistema de Indicadores como base para la revisión y evaluación del Plan de Ordenamiento Territorial (Acuerdo 62 de 1999). Adopta un sistema de Presión-Estado-Respuesta que presupone relaciones de acción y respuesta entre la económica, los aspectos sociales, el territorio y el medio ambiente frente a la normativa nacional y local.

El modelo se basa en elaborar cinco grupos de indicadores. El primero para observar las causas de los problemas (presión sobre los sistemas); el segundo se relaciona con la calidad de las variables de los sistemas; el tercero observa el impacto y efectos de las actividades humanas sobre el ambiente, la sociedad, la economía y la gobernabilidad; el cuarto se refiere a las medidas y respuestas que toma la sociedad, y finalmente el quinto grupo se relaciona con el manejo de los instrumentos legales y económicos generados por la normativa. Adicionalmente, estos cinco grupos de indicadores están delimitados por los lineamientos transversales establecidos por el Departamento Administrativo de Planeación de Política, los cuales son:

Objeto General (con 7 indicadores),

Primero el espacio público (con 32 indicadores);

Medellín de cara a su territorio (con 27 indicadores);

Medellín fortalece sus centralidades y optimiza el uso del suelo (con 51 indicadores); y

El desarrollo de la región como condición del desarrollo local (con 56 indicadores).

Se detallan, en seguida, los indicadores referentes a la configuración del espacio público; cabe resaltar en ellos la referencia pormenoriza que se pretende evaluar.

Lo que quizás se percibe con poca relevancia es el análisis del espacio residencial, la vivienda y su entorno; ni se mide la calidad de sus espacios, ni se evalúa si se siguen los parámetros establecidos como mínimos en las normativas. Medición que sí se hace para el espacio público. La escala que parecería interesar a evaluar para la administración sería la de ciudad más que la de barrio, vecindario o unidad habitacional.

En este sentido, y en aras de los objetivos de esta investigación, se valora la intención de promover la creación de un escenario que sirva de punto de encuentro de técnicos de la administración pública, investigadores y conocedores de la problemática urbana para el análisis de la ciudad por medio de algunos indicadores rigurosos. Se considera, sin embargo, que la metodología del sistema, comparada con las iniciativas anteriores, está aún poco consolidada o sustentada. En ninguna parte del documento de soporte se explica, por ejemplo, cuáles son los valores de referencia a tomar para cada indicador o cómo se presentan como resultado de una evaluación. 

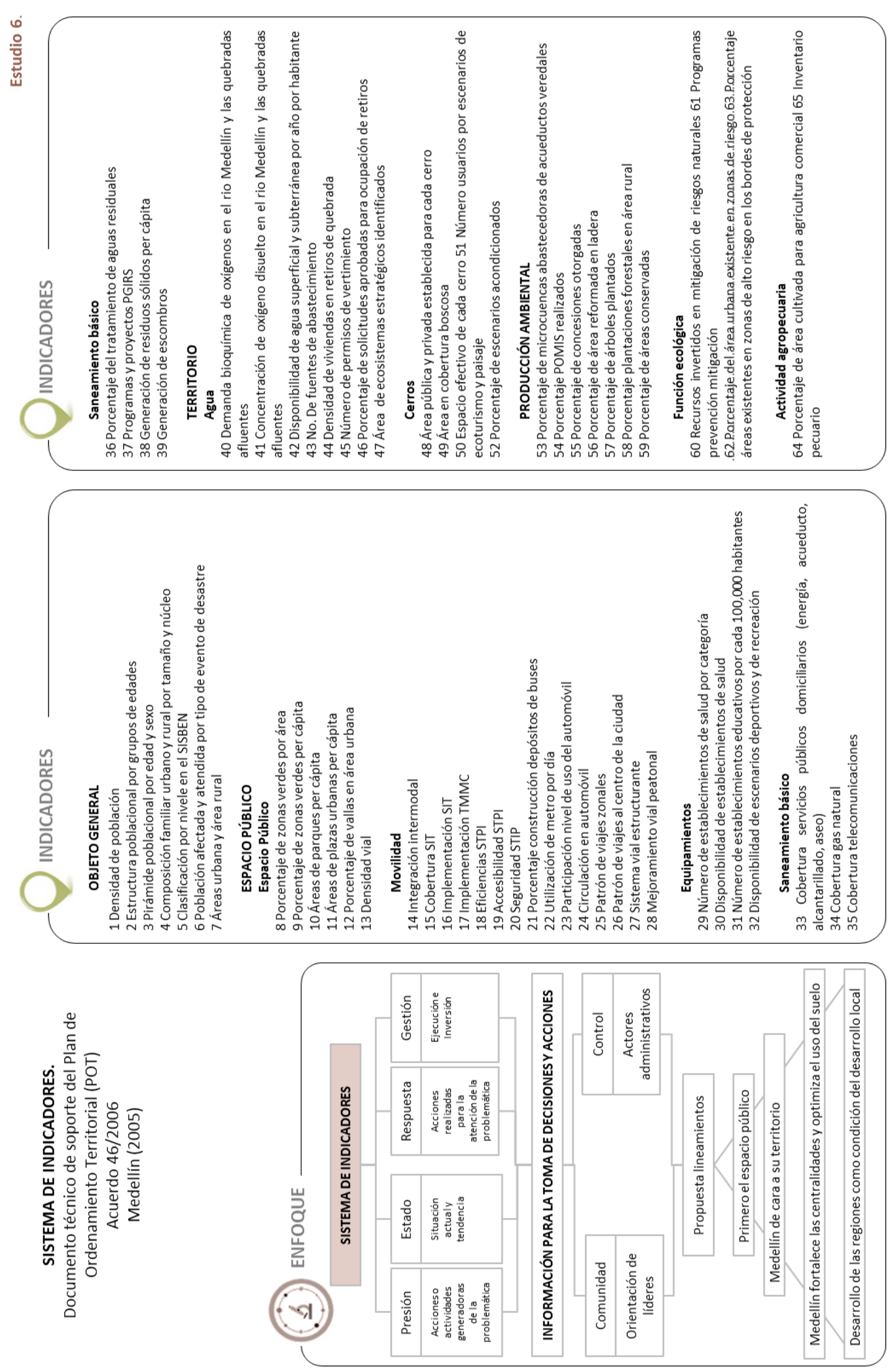

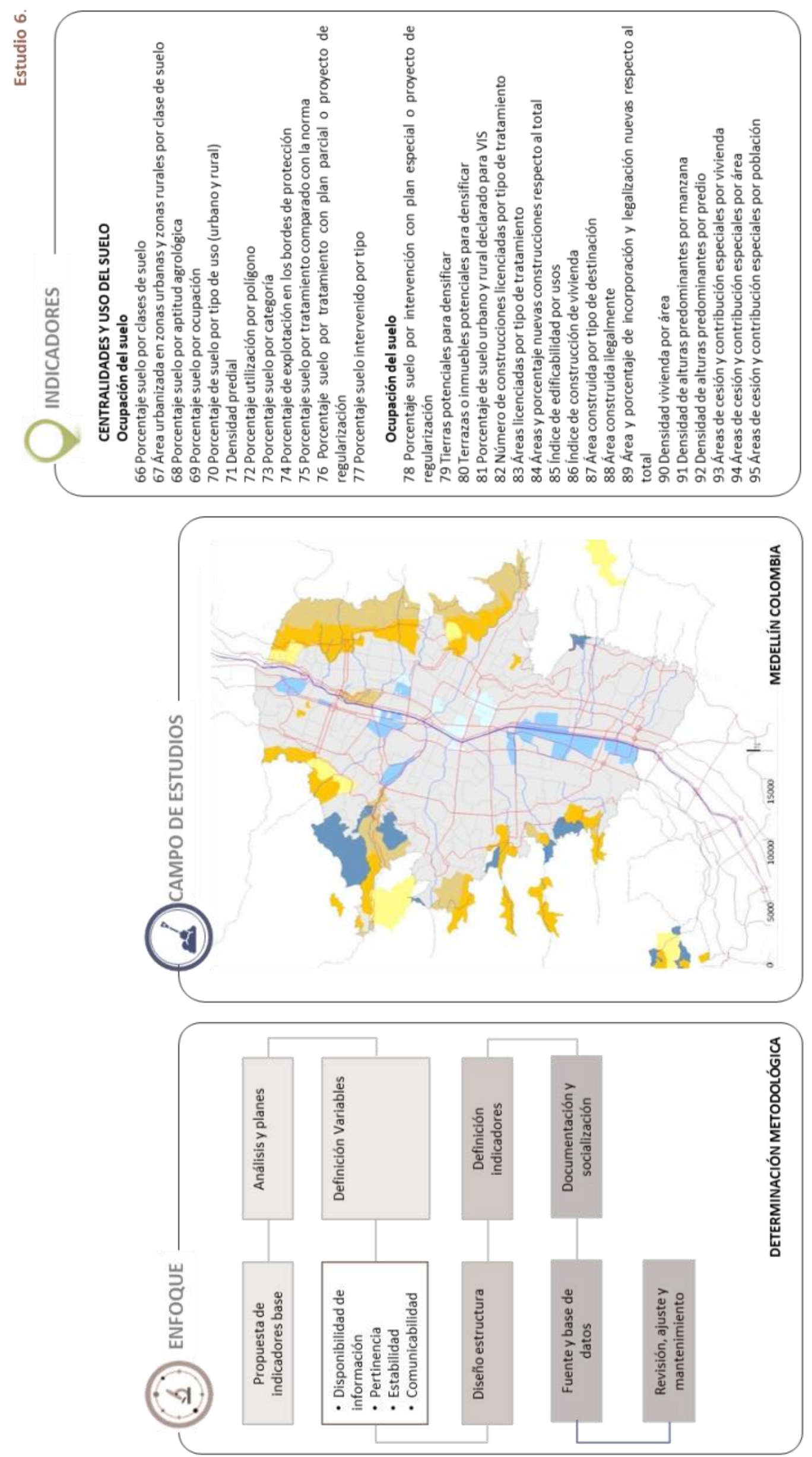
- Metodología de diseño y evaluación de proyectos de vivienda de interés social. MINISTERIO DE DESARROLLO ECONÓMICO (1998)

El Ministerio de Desarrollo Económico a través de la Dirección de Vivienda, Suelo y Construcción presenta una guía metodológica que surge para estudiar, evaluar y calificar los proyectos de vivienda de interés social. Su aplicación es posible tanto en el campo del diseño, es decir para la definición de las principales determinantes y condiciones que el técnico y promotor deben tener como referencia, como para la valoración del proyecto realizado. El trabajo está enmarcado dentro del programa de mejoramiento integral de barrio de la vivienda y su entorno, específicamente para proyectos en áreas urbanas. Involucra condicionantes ambientales, urbanísticas, arquitectónicas, constructivas y financieras.

El tema de evaluación de políticas y programas en materia de vivienda social se ha convertido en las últimas dos décadas en Colombia en un problema central de acción e intervención estatal. Las razones son más que evidentes: la severidad de problemas sociales, la pobreza, la exclusión y la desigualdad no logra ser superada. De ahí que la valoración y medición se estén instalando como necesidad en el sector público y en el privado. Su fin principal es el aprendizaje de las experiencias realizadas para hacerlo "mejor" y para lograr programas más "efectivos y sustentables". Ese es el objetivo de las dos iniciativas anteriores presentadas. Su resultado es una metodología centrada en el modelo de ciudad a desarrollar. Modelo a su vez que si fija más en las en las condiciones macro del territorio que en las especificaciones manzana a manzana, calle a calle o vivienda a vivienda de la ciudad.

Sin embargo, cada sistema de indicadores propuesto, parece desconocer por completo aquellos otros que se han realizado. Por ejemplo, el Sistema Único de Monitoreo de Impacto en Bogotá nada tiene que ver, ni en los indicadores, ni en la metodología, ni el en enfoque sobre qué se debe evaluar en la ciudad, con respecto al sistema de Indicadores del POT de Medellín. A su vez, éstos dos tampoco tienen relación alguna con la propuesta del Ministerio realizada uno años antes.

Como se explicaba anteriormente, la cartilla del Ministerio nace con el fin de ofrecer mejores condiciones generales en los programas de vivienda social. Su énfasis en los condicionantes mencionados se justica, según el Ministerio, en que "la calidad y el mejoramiento de las zonas de carácter público y comunal - a diferencia de las área internas de la vivienda- escapa usualmente del alcance y control de usuario y su aseguramiento desde el inicio del proyecto implica una mejor sustentabilidad para cualquier programa de vivienda y sus condiciones apropiadas de habitabilidad y esparcimiento para los usuarios."

Para lograr esto, esas condiciones apropiadas de habitabilidad, el Ministerio ha recurrido a estándares mínimos nacionales e internaciones considerados adecuados tanto a nivel urbano como arquitectónico. Su inclusión en un sistema de indicadores se convierte entonces en pautas de diseño y evaluación que pueden ser calificadas cuantitativamente por el ente evaluador. Cinco grandes temas con 46 indicadores en total son desarrollados. Dentro de cada uno de ellos se define el tema específico tratado, se exponen los componentes que hacen parte del mismo, se precisa su importancia y se sugiere un valor relativo de medida. Desde esta perspectiva, la metodología se concibe a largo plazo y se somete a revisiones constantemente. Desde la fase de diseño ya se está estableciendo unos indicadores objetivos que van a suponer una referencia para medir los resultados posteriores. 
Lo interesante de esta propuesta es que dadas las innumerables situaciones que afectan a los proyectos de vivienda social, el trabajo selecciona una serie de condiciones comunes o genéricas a evaluar; lo que permite la comparación de los resultados entre diferentes proyectos sin perder la escala local de cada estudio de caso. Esa escala local está dada por principios básicos mínimos muy sólidos que suponen una introducción a los aspectos esenciales de las normas colombianas.

Gráfico 11 Metodología de diseño y evaluación de proyectos de vivienda de interés social. MINISTERIO DE DESARROLLO ECONÓMICO (1998)〉> Fuente: MINISTERIO DE DESARROLLO ECONÓMICO (1998) Metodología de diseño y evaluación de proyectos de vivienda de interés social. Viceministerio de Desarrollo Urbano. Dirección de vivienda, suelos y construcción. Bogotá. 

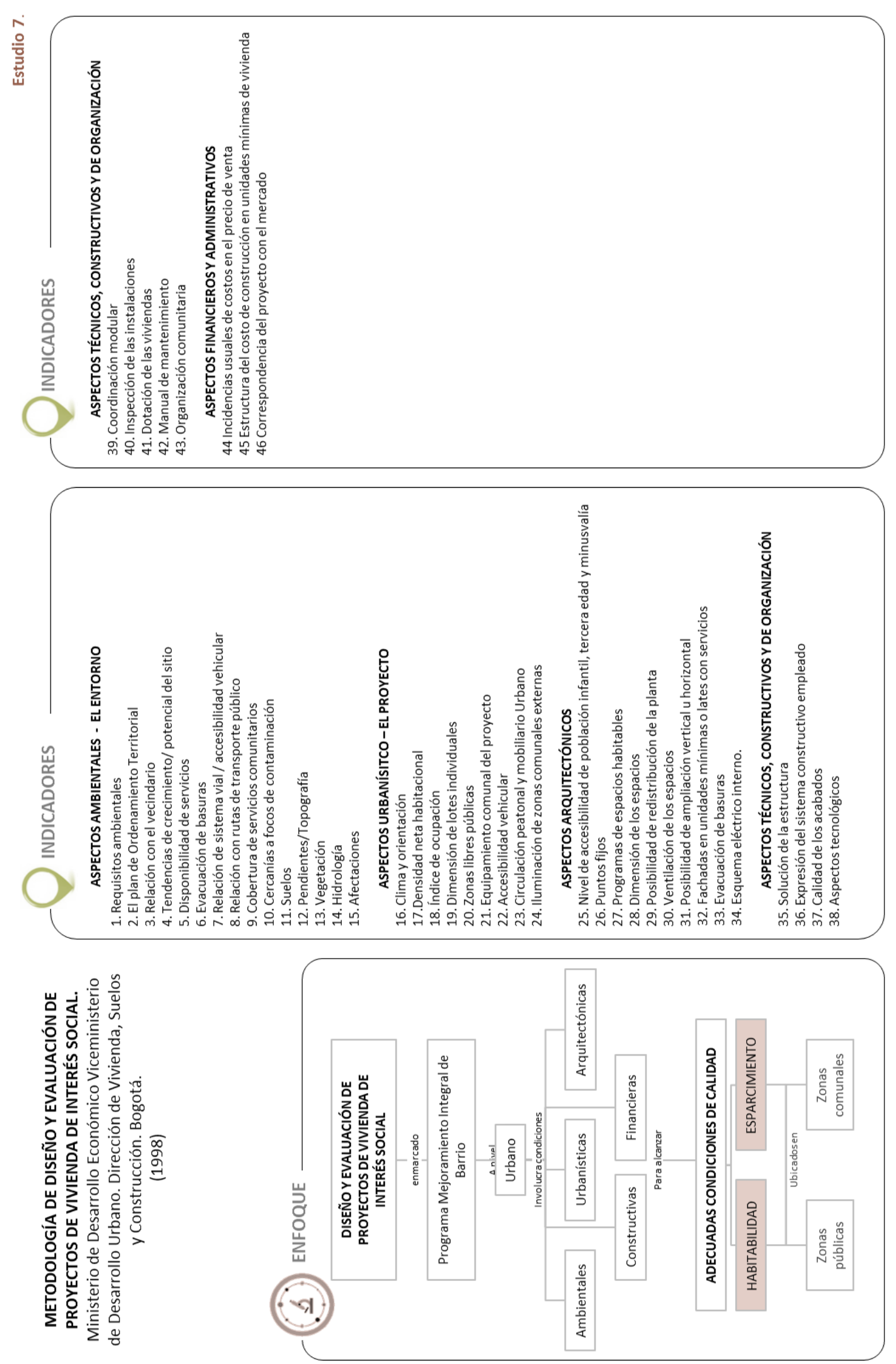
- El derecho a la vivienda digna y adecuada. Evaluación de las condiciones del componente lugar en proyectos de vivienda de interés social (VIS) y viviendas de interés prioritario (VIP), en la ciudad de Bogotá. DEFENSORÍA DEL PUEBLO (2012)

Experiencia realizada por la Defensoría del Pueblo sobre las condiciones del componente de lugar en proyectos de vivienda VIS y VIP en la ciudad de Bogotá. Su fin es verificar el nivel de protección y garantía del derecho de la vivienda digna, como se denomina en la Constitución política de $1991^{99}$, o de derecho a una vivienda adecuada, como se designa internacionalmente. Precisa que para que este fundamento se cumpla, la vivienda debe contar con ciertos elementos esenciales que le permitan a los moradores desarrollar su proyecto de vida y mejorar sus condiciones de existencia. Para ello, incorpora la Observación General No. 4 del Comité de Derechos Económicos, Sociales y Culturales de las Naciones Unidas (CDESC) ${ }^{100}$ que viene a señalar que la vivienda no debe equipararse a "el mero hecho de tener un tejado por encima de la cabeza" (Artículo 7). Por el contrario debe considerarse como una "vivienda adecuada en la cual se garantiza la seguridad jurídica de su tenencia, la disponibilidad de servicios, materiales, facilidades e infraestructura, los gastos soportables, la habitabilidad, la asequibilidad, el lugar y la adecuación cultural independientemente del contexto determinado en el que se encuentre“ (Artículo 8).

El trabajo desarrolla el concepto de lugar como espacio de relación estrecha con garantías constitucionales que permite evaluar las opciones de empleo, los servicios de atención en salud, los focos de contaminación y los centros de atención para niños, escuelas y otros servicios sociales que va más allá de la mera condición tectónica de la vivienda social. Plantea entonces, en desarrollo a lo anterior, un modelo de evaluación bajo los siguientes componentes:

1. Vivienda y opciones de empleo: La vivienda digna y adecuada debe encontrarse en un lugar que permita el acceso a las opciones de empleo de sus habitantes. Lo anterior, de manera que los costos temporales y financieros para llegar a los lugares de trabajo y volver de ellos no implique exigencias excesivas en los presupuestos de las familias pobres.

2. Vivienda y servicios de salud: La vivienda digna y adecuada debe encontrarse en un lugar que permita el acceso a los servicios de atención en salud a los miembros de las familias que viven en su entorno.

3. Vivienda y servicios sociales: La vivienda digna y adecuada debe encontrarse ubicada en un lugar que brinde el acceso a centros de atención para niños, escuelas y otros servicios sociales que permitan la garantía de sus derechos.

4. Vivienda y contaminación: La vivienda digna y adecuada no debe construirse en lugares contaminados, ni en la proximidad inmediata de fuentes de contaminación que amenacen el derecho a la salud de los habitantes.

\footnotetext{
99 Constitución Política de Colombia. Artículo 51: Todos los colombianos tienen derecho a vivienda digna. El Estado fijará las condiciones necesarias para hacer efectivo este derecho y promoverá planes de vivienda de interés social, sistemas adecuados de financiación a largo plazo y formas asociativas de ejecución de estos programas de vivienda.

100 El documento completo Observación general No. 4: El derecho a una vivienda adecuada (párrafo 1 del artículo 11 del Pacto Internacional de Derechos Económicos, Sociales y Culturales) se puede consultar en red: https://treaties.un.org/Pages/ViewDetails.aspx?src=TREATY\&mtdsg_no=IV-3\&chapter=4\&lang=en.
} 
5. Vivienda y discapacidad: La vivienda digna y adecuada debe permitir la accesibilidad física a las personas en condiciones de discapacidad, teniendo en cuenta sus necesidades particulares en términos de localización, ingreso, seguridad y espacio. (DEFENSORÍA DEL PUEBLO 2012:24)

Formula, además, a partir de esos cinco componentes una propuesta sencilla con tan solo trece indicadores. El trabajo puntualiza minuciosamente en cada componente con su indicador correspondiente y la relación con el tema que los encierran más una ficha metodológica de descripción, objetivo y sistema de lectura.

Dentro de los indicadores desarrollados, son de valorar, los referentes a los de equipamientos: salud, centro para niños, escuelas y servicios sociales (de trece indicadores cinco están dedicados a este tema). En ellos se mide el tipo y la ubicación del equipamiento y la accesibilidad en relación al costo-distancia que se emplea para llegar a él calculando el tiempo mínimo de desplazamiento según el estado de las vías, la topografía, la calidad del espacio público, etc.

Este trabajo resulta interesante como metodología de evaluación gracias a su propuesta de analizar la vivienda o el espacio residencial con un valor diferente a los exclusivamente formales o de desarrollo urbano. Si bien centra la mirada en el componente territorial, es a través de éste que evalúa las garantías que toda población debe tener al morar en un proyecto de vivienda social; dichas garantías según el informe son: seguridad jurídica de la tenencia, habitabilidad, asequibilidad o adecuación cultural entre otras. Es una propuesta completa que supone una referencia fundamental de cara al objetivo esencial de esta tesis y del cual se toman algunos indicadores o parámetros de medición.

De todas las iniciativas, se cree que este trabajo de la Defensoría del Pueblo es el único que aporta un enfoque diferente al tradicional de trabajar por separado lo físico y funcional y por otro lado, lo social, participativo o experimental. Su metodología de evaluación es relevante, tienen consistencia analítica, es factible la medición de sus indicadores y es de fácil comprensión. Adicionalmente, y lo más importante, puede emplearse para conocer las tendencias de diferentes fenómenos y al mismo tiempo permite hacer comparaciones entre diversas realidades locales. No sobra recordar que en el contexto colombiano, la política de la vivienda social se enmarca en un problema de cantidades, es decir en un factor económico sobre esas cantidades, en donde la discusión se reduce a unidades producidas o mejoradas, hectáreas destinadas, metrajes mínimos y reparto de subsidios. Se olvidan consideraciones de la vivienda en relación con las cualidades del espacio, es decir con las necesidades de sus moradores. 

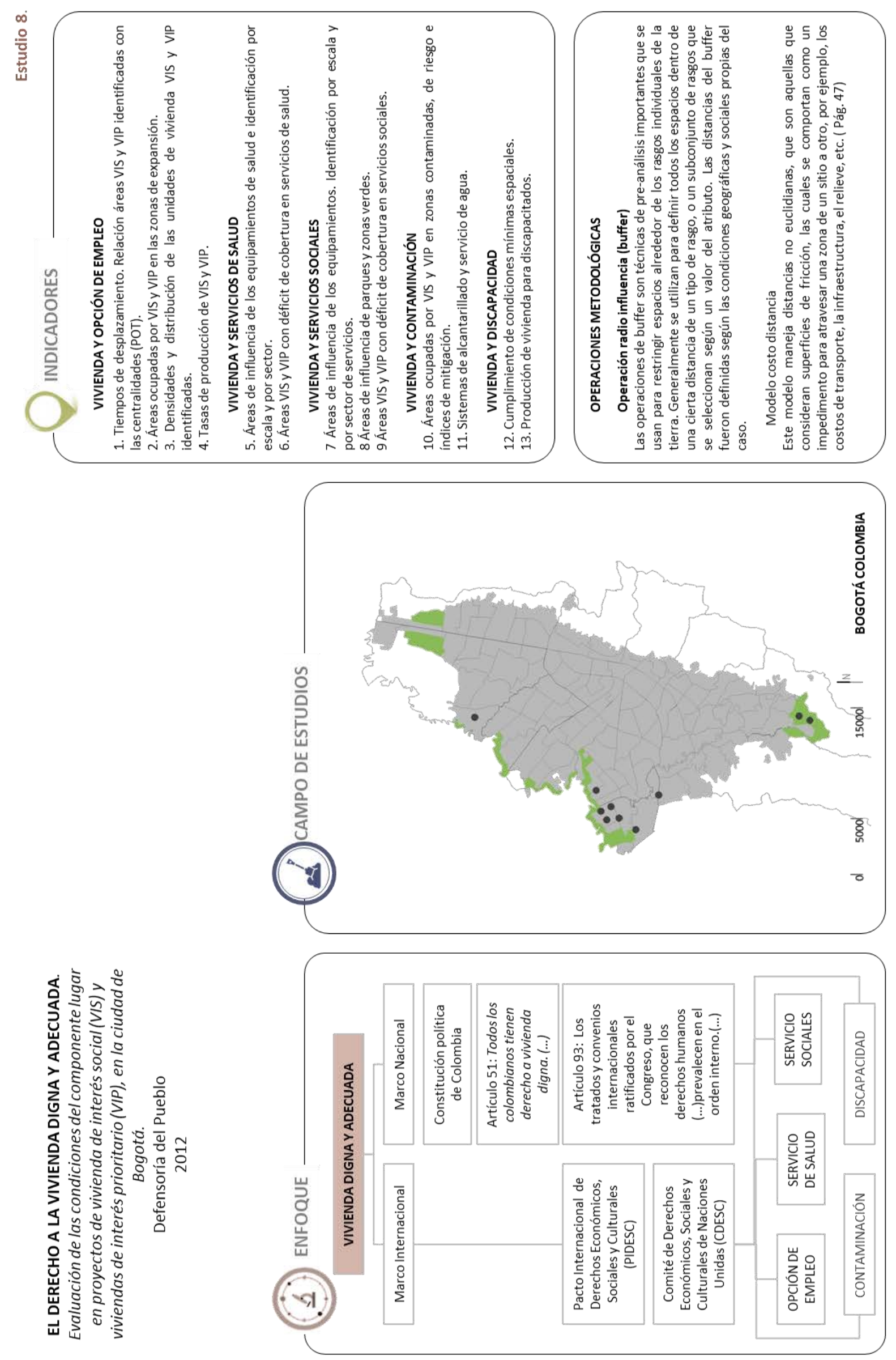


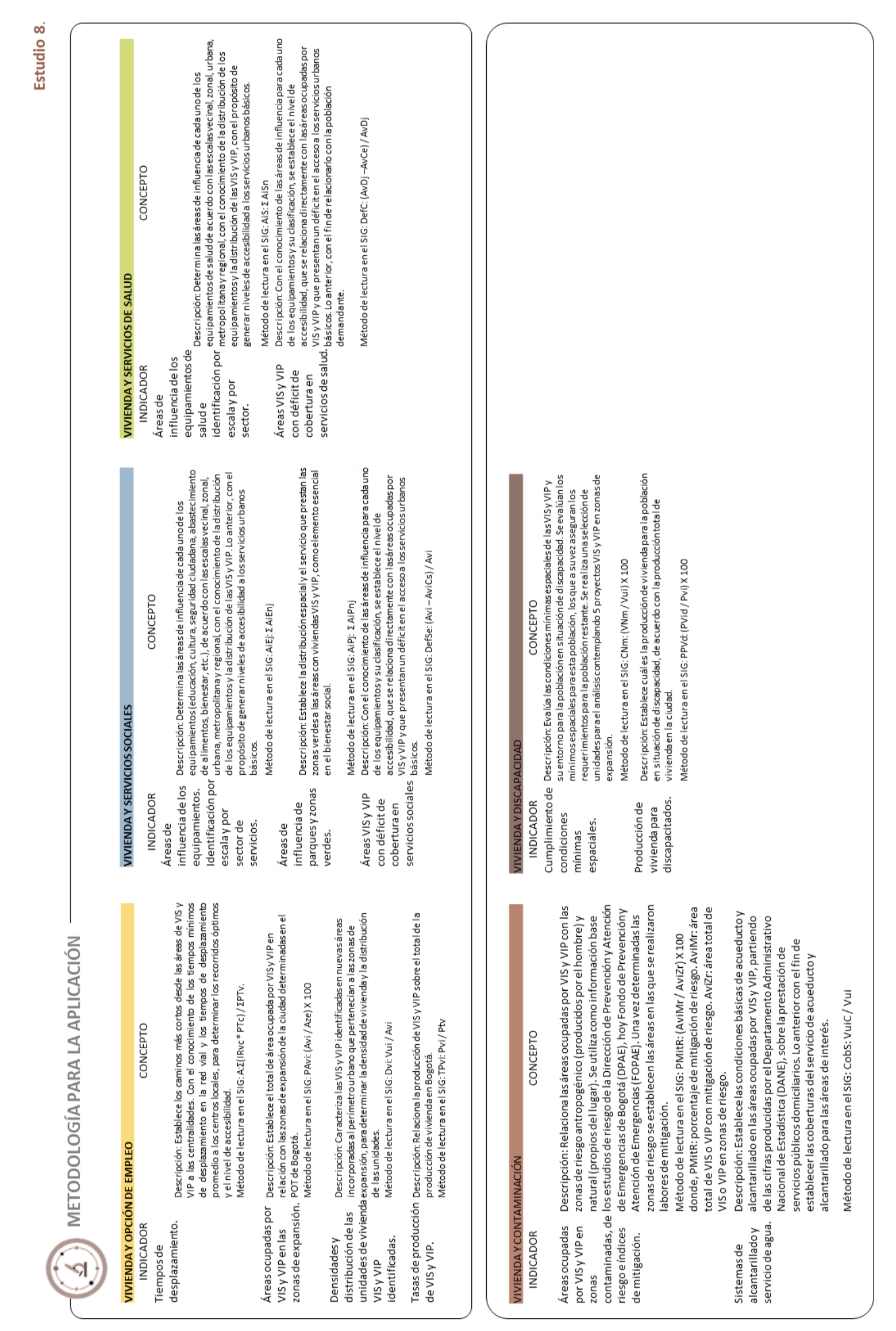


- Calidad de la vivienda dirigida a los sectores de bajos ingresos en Bogotá. TARCHÓPULOS, Doris y CEBALLOS, Olga (2003).

El Instituto de Vivienda y Urbanismo - INJAVIU- de la Pontificia Universidad Javeriana realiza una investigación teórico-práctica para proponer un modelo de evaluación de la habitabilidad de la vivienda social en Bogotá. Centrado en once barrios de origen formal y dos de origen clandestino valora las condiciones objetivas, es decir las características formales, funcionales y constructivas de la vivienda social, y las condiciones subjetivas de satisfacción y expectativas de los residentes de las zonas estudiadas. El aporte del trabajo está en exponer claramente las relaciones complejas entre los dominios, factores y atributos, como lo denominan los autores, que componen la calidad de la vivienda social para una posible orientación de acciones tendientes a su mejoramiento.

El trabajo metodológico inicia con la definición de los términos de vivienda, habitabilidad y calidad de la vivienda. Su descripción, hasta cierto punto, coincide con las nociones desarrolladas, en el primer apartado de este capítulo, sobre el espacio residencial o la calidad de vida de los seres humanos. Estas definiciones son:

El término de vivienda se asume como la construcción socio-física donde simultáneamente es posible la individualización del espacio social y la socialización del espacio individual. Como tal supone unas condiciones físicas, un orden espacial, interior y exterior, y una infraestructura que garantice la continuidad y la cualificación de la existencia humana en las dimensiones públicas y privadas, en su contexto histórico y social. [...] La dimensión privada de la vivienda es la casa o unidad de vivienda; es decir el espacio privado de la familia en el cual se satisface las necesidades elementales y se realizan las actividades cotidianas, características de la vida familiar. La dimensión pública relacionada con el ámbito urbano, es decir, el desarrollo urbano o de barrio en la que se circunscribe la casa.

La habitabilidad es un conjunto de condiciones físicas y no físicas que permiten la permanencia urbana en el lugar, su supervivencia y en un grado u otro la gratificación de la existencia. Entre las condiciones físicas se encuentran todas aquellas referentes al proceso de transformación del territorio y el ordenamiento espacial de las relaciones internas y externas del elemento humano, la construcción del cuerpo físico que alberga las actividades y las personas, y la delimitación física del ámbito individual y colectivo. La trasformación arquitectónica es precisamente la encargada de proporcionar estas condiciones físicas del hábitat cultural del ser humano. (Enunciado a su vez tomado de Saldarriaga 1981)

La calidad de la vivienda en términos de habitabilidad, por consiguiente, es definida como el conjunto de condiciones físicas y no físicas que garantizan la vida humana en condiciones de dignidad.

Continúa el trabajo exponiendo su propuesta de modelo operativo de habitabilidad, el cual desarrolla los parámetros mínimo aceptables a partir de la cual se realiza la medición. Éste está compuesto por los dominios físicos, el cual contiene los factores urbanos y arquitectónicos, y no físico en el que se encuentran los factores sociales.

Con respecto a lo urbano incluye condiciones relacionadas con:

1. Características ambientales y geotécnicas del suelo 
2. Conexión del barrio

3. Movilidad

4. Disponibilidad de espacio público,

5. Equipamientos,

6. Cobertura de servicios domiciliarios.

Con respecto al factor arquitectónico se considera:

1. La higiene

2. La Protección

3. La privacidad

4. La comodidad

Finalmente con el factor social se tiene en cuenta

1. La seguridad en la tenencia

2. Las adecuaciones sociales

La evaluación posteriormente de estos factores se realiza por medio de ámbitos objetivos y subjetivos. Lo objetivo se mide por medio de una observación directa de variables derivadas de parámetros técnico-constructivos (con referencia en lo normativo), y lo subjetivo se mide por medio de entrevistas sobre la satisfacción que expresan los habitantes en relación a la calidad de su vivienda y su entorno.

De este trabajo vale la pena destacar la aproximación al conocimiento de la calidad de la vivienda por medio de un planteamiento teórico que se traduce en un marco metodológico de evaluación. En él se sustenta claramente cada uno de los factores, traducidos posteriormente en indicadores, para medir la habitabilidad. Especialmente aquella que se centra en la parte física de la vivienda y el entorno. No sobra mencionar, por lo demás, que en el ámbito académico colombiano referido a la calidad del hábitat, como lo expresan (Echeverri, 2004), Fique (2007) o Escallón (2013) no existe una definición conceptual sobre-qué es la vivienda social y se reconocen dificultades para la evaluación de la misma.

Como parte de la metodología se identifica también, como de gran utilidad para este trabajo de investigación, los parámetros de medición de algunos indicadores basados en referentes normativos. En cambio, en lo relacionado con las valoraciones de la población hacia su entorno, como se explicó con la iniciativa HIC, no se abarca en este documento pues se considera fuera del alcance cuantitativo que se quiere evaluar.

Gráfico 13 Propuesta de indicadores en Calidad de la vivienda dirigida a los sectores de bajos ingresos en Bogotá. TARCHÓPULOS, Doris y CEBALLOS, Olga (2003)>> Fuente: TARCHÓPULOS, Doris y CEBALLOS, Olga (2003). Calidad de la vivienda dirigida a los sectores de bajos ingresos en Bogotá. En Prensa, Bogotá, Pontificia Universidad Javeriana, Instituto Colombiano para el Desarrollo de la Ciencia y la Tecnología (COLCIENCIAS), Banco Interamericano de Desarrollo, Centro Editorial Javeriano (CEJA). 


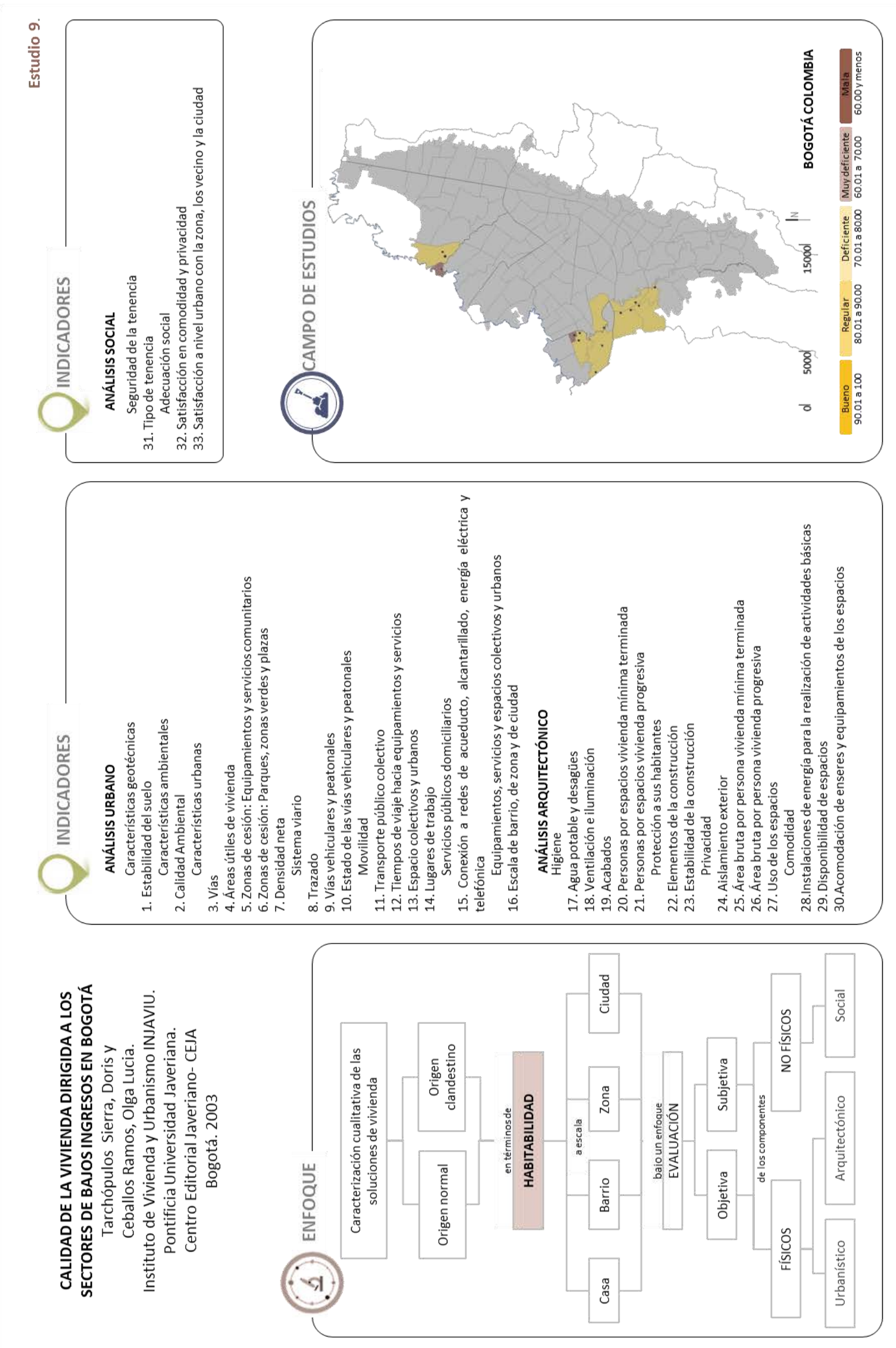




\subsubsection{Herramientas claves sobre la metodología}

La medición sobre los diferentes niveles de calidad del espacio urbano es una labor compleja y difícil de realizar como se observó en las iniciativas examinadas. El principal problema está en la acotación de la noción misma de calidad, que aún está en construcción, y del conjunto amplio y poco homogéneo de lo que se denomina espacio residencial. Cada planteamiento fija una relación propia entre el parámetro analizado y el ámbito o foco de actuación en donde se quiera situar.

Así, la diversidad de perspectivas y prioridades en la evaluación deja en evidencia que la valoración de la calidad no es simplemente un ejercicio técnico. Hay, tras ésta, siempre un marco de referencia previo. Cada trabajo mencionado anteriormente lo tiene según el marco disciplinar del que se origina, por ello se cree conveniente elaborar uno propio centrado en los objetivos de esta investigación. En el gráfico No.14 se refleja el ámbito en el que cada iniciativa se centró. Aquí dicho marco de referencia está acotado por las dimensiones desarrolladas, dentro del ámbito que aborda esta investigación, el urbanismo, consideradas como dimensiones principales que toda propuesta de evaluación y comparación de la calidad deben contemplar: 1) Estructura urbana; 2) Infraestructura y servicios públicos domiciliarios; 3) Equipamientos y Espacio Público; 4) Prevención de riegos, recuperación y protección ambiental; 5) Consolidación (mejoramiento o construcción) habitacional y 6) Provisión de espacios para el desarrollo de actividades productivas que apunten a la inclusión social (generación de empleo, ingresos, participación y tenencia).

Adicionalmente se observa que cada iniciativa considera la escala que cada evaluación debe contemplar. Algunas iniciativas miden la calidad urbana a nivel de ciudad sin puntualizar sobre las condiciones del vecindario o la vivienda. Otras se centran en la configuración y construcción del dominio privado. Para el desarrollo de esta investigación, es evidente que en el caso particular del espacio residencial, éste abarca un conjunto de atributos que se extienden más allá de la unidad de vivienda y conforma un sistema con su entorno, en el barrio y la ciudad. Sin embargo, la evaluación debe estar centrada en la actuación, en la escala de proyecto o agrupación, dado el perfil específico de sus características físicas, funcionales y del grupo social que lo habita.

Bajo estas características, se identifican dos estudios con una aproximación al tema de la calidad urbana, el análisis de la morfología del espacio residencial, de gran utilidad para esta investigación: la experiencia realizada por la Defensoría del Pueblo y el trabajo académico de la UNJAVIU.

Otra consideración posible a realizar sobre las iniciativas comentadas, detectada como tema relevante, es el tipo de indicadores a manejar. Es claro que según la perspectiva en la que se quiera puntualizar en la evaluación se debe distinguir entre indicadores de medición o indicadores de percepción (como los denomina el Sistema Único de Monitoreo de Impacto de la Alcaldía de Bogotá). 
Gráfico 14 Marco comparativo sobre ámbito destacado por cada iniciativa.

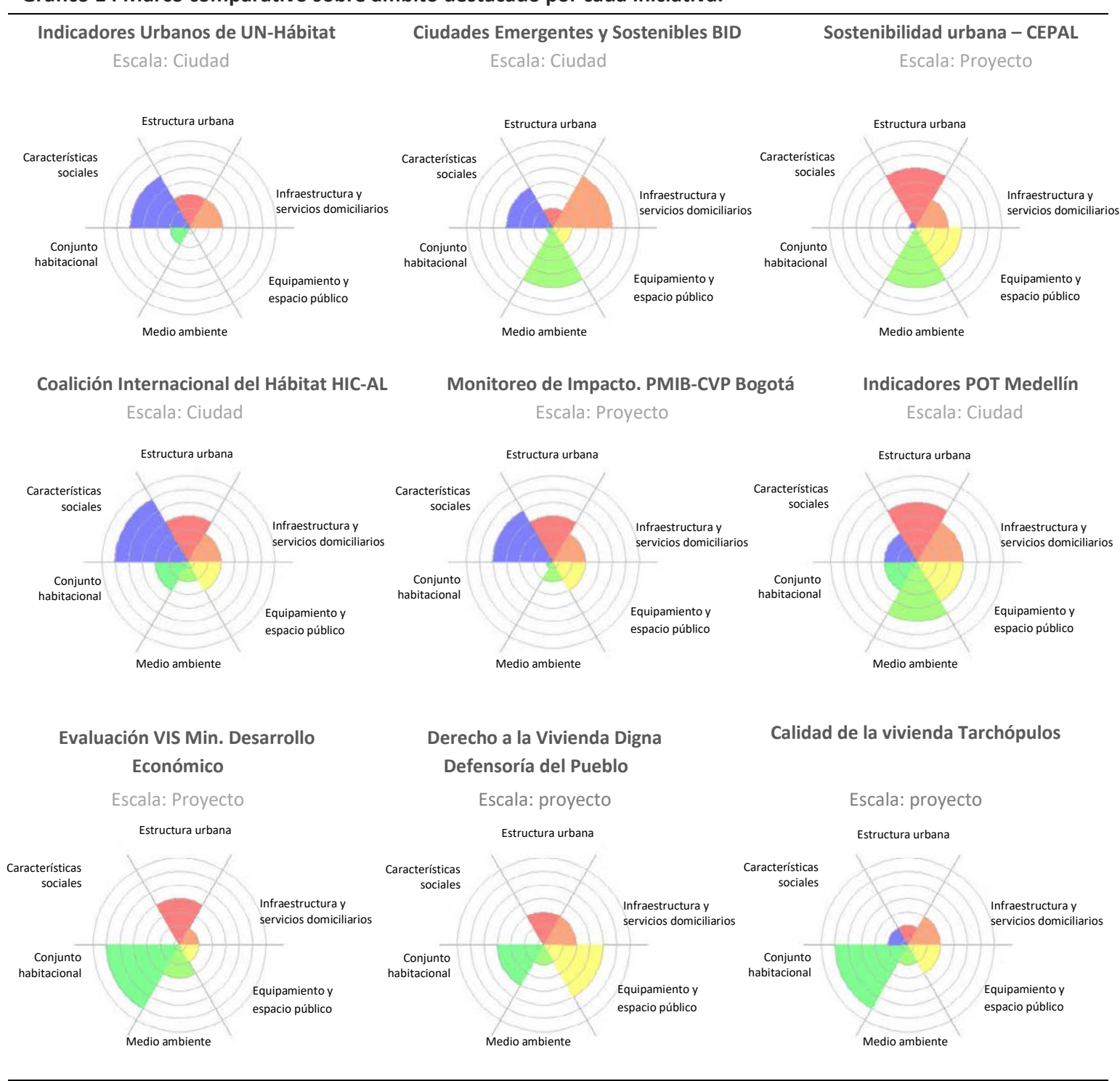

Elaboración propia

El conjunto de indicadores representa las variables o atributos en la que se ha clasificado analíticamente la realidad y hacen posible su descripción. Los indicadores de medición, por los que se opta en esta investigación, son aquellos que permiten ser valorados materialmente y los indicadores de percepción, son aquellos que representan una manifestación simbólica o cultural, los satisfactores.

Se elige la elección de indicadores de medición pues se considera la opción más viable en cuanto a la información que se dispone de los estudios de caso seleccionados y la metodología más reveladora para la posterior comparación de proyectos entre sí.

En este sentido, la opción metodológica de considerar el nivel de satisfacción de los habitantes por medio de la opinión de los participantes como indicador para analizar los proyectos, se intuye, no siempre resuelve el problema de cómo compararlos entre sí. Si bien se cree que en la evaluación de cada proyecto resulta primordial el análisis de la situación de la población, 
desempeño de satisfactores, deseos alcanzados, mejoras sociales obtenidas, capacidad de participación y apropiación, etc., a la hora de verificar la calidad urbana entre un desarrollo y el otro, el peso no puede caer solo sobre estas valoraciones subjetivas. Se cree una persona puede sentir que vive mejor en un espacio o en el otro más allá de la calidad física que aporte su espacio. Si bien muestra indicios y son importantes de valorar, estos no pueden ser la base. Un ejemplo claro de ello se constata en una entrevista realizada a docentes, administrativos y líderes comunitarios residentes de Ciudadela Nuevo Occidente en Medellín en donde se sondea la percepción de las condiciones de calidad de la ciudadela. ${ }^{101}$

Con respecto a las condiciones físicas, el profesor González ${ }^{102}$ menciona problemas relacionados con la falta de espacios verdes construidos y a la ilusoria relación pretendida entre una reducida área de vivienda, media de $45 \mathrm{~m} 2$, y una amplia zona pública como sistema de compensación. Para el: No se puede desconocer que frente al desarrollo habitacional de muchos sectores de Medellín, alli hay mayores porcentajes de áreas verdes o área potenciales de áreas verdes y espacios recreativos, lo que se ha criticado es que han sido creados en procesos posteriores o siguen sin estar creados. Parece que hay que esperar un tiempo para que se consolide el urbanismo con sus diferentes espacios, mientras que ya en lo habitacional se está dando una gran conflictividad. Recordemos que en la Urbanización de las Flores, había simplemente vivienda, no había ninguna espacialidad pública cuando fue habitado. Esta se crea cuando se van desarrollando otros proyectos como los apartamentos de los Juegos Suramericanos.

La pretendida correlación entre áreas de vivienda reducida y amplios espacios públicos, planteada a nivel teórico, es un traslado equívoco de conceptos manejados de otras ciudades como Paris o Tokio. Alli hay muchos elementos que permiten utilizar el espacio público pero eso es una entelequia aquí por una razón muy sencilla, nosotros somos una sociedad muy pobre. Disfrutar de ese espacio público requiere recursos y una capacidad adquisitiva. Tenemos una población que ni siquiera tiene para el transporte cotidiano como para transportar a toda su familia a ese espacio público que han diseñado. ¿Cuánto representa del salario mínimo un desplazamiento hasta el parque Pies Descalzos por ejemplo?

Sobre la falta de equipamientos Claribel Arango, habitante de la comunidad indica: Me incomoda no tener una vivienda adecuada, necesitamos equipamientos, centros de salud, recreación. No soy yo muy creyente pero hace falta una iglesia porque hay personas muy devotas que necesitan una iglesia. No tenemos unidad hospitalaria a la cual asistir en caso de una urgencia. Tenemos mucho que agradecer a la administración que nos ha acompañado pero hacen falta muchas cosas.

\footnotetext{
${ }^{101}$ Con el fin de medir los impactos producidos en términos de mejoramiento de calidad de vida de la población beneficiara del proyecto, se tiene en cuenta en una primera instancia el trabajo realizado por Julio Eduardo Mesa Escobar de la Universidad Nacional de Colombia denominado "Los lugares del hábitat como espacio de realización de lo político y de la política pública a través del habitar: una propuesta teórica para el análisis del hábitat en la Ciudadela Nuevo Occidente". El trabajo, realizado en el año 2012, cuenta con unas interesantes entrevistas realizadas a docentes, administrativos y líderes comunitarios residiendo actualmente en el proyecto en donde se sondea la percepción de las condiciones de calidad de la ciudadela.

102 Luis Fernando González profesor de la Escuela de Hábitat de la Facultad de Arquitectura de Universidad Nacional de Colombia sede Medellín.
} 
Sin embargo, más adelante ante la pregunta ¿Qué ventajas tiene que antes no se tenía en Moravia ${ }^{103}$ ? la misma señora responde: Dignidad, pues no es lo mismo vivir en un espacio así sea chiquito, sin divisiones y sin acabados que en un basurero con enfermedades. Aquí dan ganas de trabajar. Monté un local de peluquería, me va bien. Solo pago servicios, me han dado capacitaciones.

Por su lado, Darío García, otro morador expone: Tengo dos hijas de 13 y 16 años. El apartamento se adecua a nosotros cuatro. En Moravia mi casa era muy pequeña. Hay cosas negativas y cosas positivas. Mis hijas estudian en el colegio de la Huerta. Lo negativo es que "Las dificultades nos han llevado a organizarnos en red para hacer fuerza, por eso nos trajimos a los alcaldes Fajardo y Aníbal. Los comprometimos. Nos reunimos alrededor de 10 personas de la comunidad, generamos unas preguntas para ver a que se podían comprometer si llegaban a ser elegidos ¿A qué se comprometen ustedes con las necesidades de la Ciudadela? ¿Qué pasa con la seguridad o con el tema económico? ¿Qué pasa con los edificios entregados en muy malas condiciones, con un espacio muy limitado, en donde solo hay vivienda, no hay espacios comerciales, no hay canchas y apenas hay dos colegios? Nosotros soñamos con un centro comercial, con un parque biblioteca. Fajardo se comprometió a ello. (MESA: 2012)

Si bien se cree, como se ha mencionado constantemente en este trabajo, que la forma y la calidad del espacio residencial están estrechamente ligadas con todo aquello que abarca el ámbito social y la calidad de vida: bienestar e identidad cultural, satisfactores, actores, agentes, participación, apropiación, etc. y se piensa que la condición, opinión, estado de la población es, por no decir menos, de suma importancia en el territorio, desde una metodología de comparación del espacio no hay posibilidad de relativizar las valoraciones de la población. Todo esto, cuando se tiene dicha información, lo que en esta situación no es posible para todos los estudios de caso. (Por limitaciones en las fuentes de información disponibles no se toman aspectos centrales sobre el control o la intervención en el medio político (participación efectiva, capacidad de decisión, de asociación, etc.)

En consecuencia, las iniciativas que se ajustan al modelo de esta investigación son: la metodología desarrollada por el Ministerio de Desarrollo Económico (1998) y el Trabajo de la Defensoría del Pueblo. Interesan especialmente por los componentes comparativos dirigidos a contrastar un gran número de territorio.

Dentro de la consideración del uso de indicadores, también es importante reseñar que existen matices que no son incorporados en los indicadores mismos y justo por esta razón, se constata necesario acompañarlos con información del contexto de cada estudio de caso. Un mismo dato puede reflejar situaciones muy distintas según condiciones culturales, sociales, territoriales, etc.

Por último, solo hace falta reseñar es esencial definir si se evalúan proyectos a realizar o realidades intervenidas porque, aun cuando el trabajo del Ministerio de Desarrollo Económico

\footnotetext{
103 El barrio de Moravia está ubicado en la zona aluvial del rio Aburrá, en la ciudad de Medellín. En los años 70’s y 80’s fue un territorio que se utilizó como vertedero, donde se disponían más de 100 toneladas de basuras diarias y en donde población desplazada y bajos ingresos encontró una fuente de trabajo. Desde los años 80 se generó allí un asentamiento humano que poco a poco se consolidó como barrio y como comunidad. En el año 2000, se inició la recuperación de la zona y la población habitante fue reasentada en La Ciudadela Nuevo Occidente (Conocida la zona como Pajarito).
} 
establece una misma evaluación para cualquiera de las dos condiciones, la aproximación suele ser diferente.

A modo de conclusión, se presenta de forma concisa las herramientas claves de metodología, que se cree, se deben tener en cuenta en esta investigación:

- En cualquier situación, es primordial contar con un marco de referencia propio, bajo el cual se quiera aplicar un modelo de evaluación. En dicho marco se debe especificar, además, si el fin último es la evaluación en sí o la comparación de estudios de caso (la aproximación suele ser diferente).

- Se debe contemplar la escala en la que se quiere aplicar dicha evaluación.

- En general, los indicadores deben ser ajustados al contexto que se analiza. De ello dependerá, entre otras, el tipo de indicadores a utilizar.

- Es esencial definir si se evalúan proyectos a realizar o realidades intervenidas.

- Es fundamental hacer un esfuerzo de síntesis en el número de indicadores para que la metodología sea operativa.

- Para la valoración de los estudios de caso es significativo un aporte de información gráfica clara y sencilla que muestre claramente lo que se quiere medir.

Teniendo todo ello en cuenta y a la luz de las regulaciones e iniciativas antes mencionadas, se prosigue con la construcción y validación de un modelo de análisis que permita determinar la calidad de la vivienda social en Bogotá y Medellín. Su desarrollo permite vislumbrar el cómo evaluar y comparar las características físicas de las soluciones habitacionales frente a parámetros básicos de calidad.

\subsection{MODELO DE EVALUACIÓN E INDICADORES}

\subsubsection{Modelo de análisis}

En la definición conceptual del modelo de análisis, presentado en la introducción y posteriormente desarrollado en el inicio de este capítulo, se proponía como punto de partida una serie de aproximaciones sobre las características formales del medio urbano y las condiciones de calidad que las originaban. Allí se especificaba que el estudio de la morfología urbana se planteaba como un "análisis desde la dimensión física: el medio urbano, en relaciones con las lógicas de ordenación en el territorio: dimensión normativa y social, capaz de revelar claves sobre la calidad de dicho espacio". El foco del modelo se centraba entonces en el espacio residencial para los proyectos de vivienda nueva y los mejoramientos de barrio. El término "espacio residencial", a su vez, hacía alusión a la vivienda y el entorno, un orden espacial interior y exterior, de carácter público y privado, en donde se garantiza una continuidad y una cualidad de la vida humana.

En seguida se proponía, ligado al análisis de la forma de la ciudad, el análisis de la calidad urbana, definida ésta como "la condición satisfactoria del medio construido y su relación con el entorno". Se proponían diferentes escalas para su análisis: el ámbito doméstico con el bloque, el barrio como representativo de lo local y la ciudad como el espacio de máxima complejidad 
accesible ${ }^{104}$. Y finalmente vinculada con dicha calidad, se hacía referencia a la relación del espacio con el medio del que dependía, es decir con la capacidad de "mantener unas condiciones habitables por un largo tiempo sin agotar sus recursos o causar daño al medio ambiente y a su vez, dar soporte al cumplimiento de las necesidades básicas de la población para mantener y mantenerse en ese espacio".

Ahora bien, soportado por el recorrido realizado en los numerales anteriores, dos acotaciones esenciales surgieron como complemento en el desarrollo de dichas aproximaciones. La primera relacionada con la noción misma de calidad y el logro de derechos humanos en el campo de políticas públicas. De esta manera, sobre la comprensión de un derecho a la vivienda adecuada, la Corte Constitucional Colombiana, definición el concepto de vivienda así: "unidad habitacional, sobre la cual es necesario asegurar las condiciones físicas para su ocupación segura y adecuada por seres humanos, y como espacio directamente relacionado con el entorno inmediato y con el medio urbanístico circundante (disponibilidad de servicios, materiales e infraestructura y localización). Además precisó sobre el sentido de la habitabilidad como: Las condiciones de seguridad y salubridad que hacen adecuado un lugar para que un ser humano desarrolle en él, libre y seguramente, su proyecto de vida. Por el contrario, la ausencia de las condiciones físicas a las que acá se aludirá, impiden que un lugar sea susceptible de ser habitado por las personas de forma digna y adecuada. (Corte Constitucional sentencia t-617 de 1995)

La segunda vinculada con los atributos propiamente urbanos que inciden en la calidad del espacio asociados a las áreas de necesidades básicas a cubrir en el territorio. Un área concerniente con el entorno y que inciden directamente en el bienestar de la población es la de los servicios domiciliarios, el espacio público y los equipamientos, y la otra relacionados con la escala urbana o metropolitana dentro de los cuales se encuentran la movilidad, la accesibilidad y la calidad ambiental general de la ciudad. Aquí aunque la diferencia en determinar las áreas en los enfoques de las iniciativas es notables, hay coincidencia en buena parte de ellos.

Bajo esta perspectiva y buscando dar cuenta de las dimensiones de la calidad de vida en un modelo de análisis propio que corresponda con las condiciones adecuadas definidas para el espacio residencial de la población de bajos ingresos en Bogotá y Medellín, se proponen nueve campos a destacar en la evaluación:

D1. Ocupación del suelo

\footnotetext{
104 Las escalas se definen en base a los parámetros establecido por el POT de Bogotá decreto 619 de 2000.

+Así la escala de ciudad o escala urbana que comprende los equipamientos que por su magnitud, utilización, grado de especialización, preeminencia institucional, alto impacto urbanístico, o requerimientos en materia de servicios y obras de infraestructura, ejercen su influencia urbanística a un amplio territorio de la ciudad y generan alto impacto urbano y social.

+ La escala zonal: Corresponde a los equipamientos que prestan servicios especializados a la población de zonas urbanas generalmente más extensas y complejas que el barrio o grupo reducido y homogéneo de barrios. Debido al tipo de servicios y a la magnitud se consideran de mediano impacto urbano y social, por cuanto se desarrollan en edificaciones especializadas, generan afluencia de usuarios concentrada en ciertos días u horas y durante horarios especiales, requieren zonas de estacionamiento, pueden generar tráfico y congestión y propician la aparición o el desarrollo de usos complementarios en el área de influencia inmediata.

+ Finalmente la escala vecinal: Corresponde a los equipamientos de primera necesidad y cobertura barrial que atienden a la comunidad de residentes y trabajadores de su área de influencia inmediata. Se consideran de bajo impacto urbanístico y alto impacto social por cuanto se desarrollan en establecimientos de magnitud reducida, no generan tráfico ni congestión ni ruidos ni afluentes contaminantes y no propician el desarrollo significativo de usos complementarios.
} 


\section{D2. Accesibilidad \\ D3. Movilidad \\ D4. Equipamientos y dotaciones urbanas \\ D5. Espacio público: recreación y ocio \\ D6. Prestación de servicios domiciliarios \\ D7. Condiciones ambientales \\ D8. Oferta y configuración de la unidad habitacional}

En muchos de estos campos se encuentran coincidencias entre la clasificación presentada y algunas enumeraciones de los derechos humanos (Observación No.4 del Comité de DESC) y de los indicadores de las iniciativas estudiadas. En el apartado final de este capítulo: "Relación de indicadores" se señala, entre otras, los indicadores semejantes propuestos en las iniciativas. El cotejo permite observar que, a pesar de las diferencias en el marco de referencia de los distintos enfoques, hay un campo de coincidencia importante. La propuesta que aquí se acoge expresa de alguna manera los contenidos centrales de esos enfoques, con una forma propia de selección, ordenación y agrupación adecuadas a los objetivos de la investigación.

En definitiva, se propone un modelo de análisis (Gráfico No. 15) capaz de abordar la realidad bajo una visión integral y de diversidad de los elementos presentes (o ausentes) en las condiciones de calidad de la vivienda social. En él, el medio construido -el espacio residenciales destacado como objeto central al que se trata de observar y analizar según el conjunto de componentes que lo configuran, y la calidad urbana como fin último a conseguir por medio de las dimensiones que la originan.

CONDICIONESDE CALIDAD DESDE LA FORMA URBANA Relaciones dinámicasy abiertasy multidireccionales

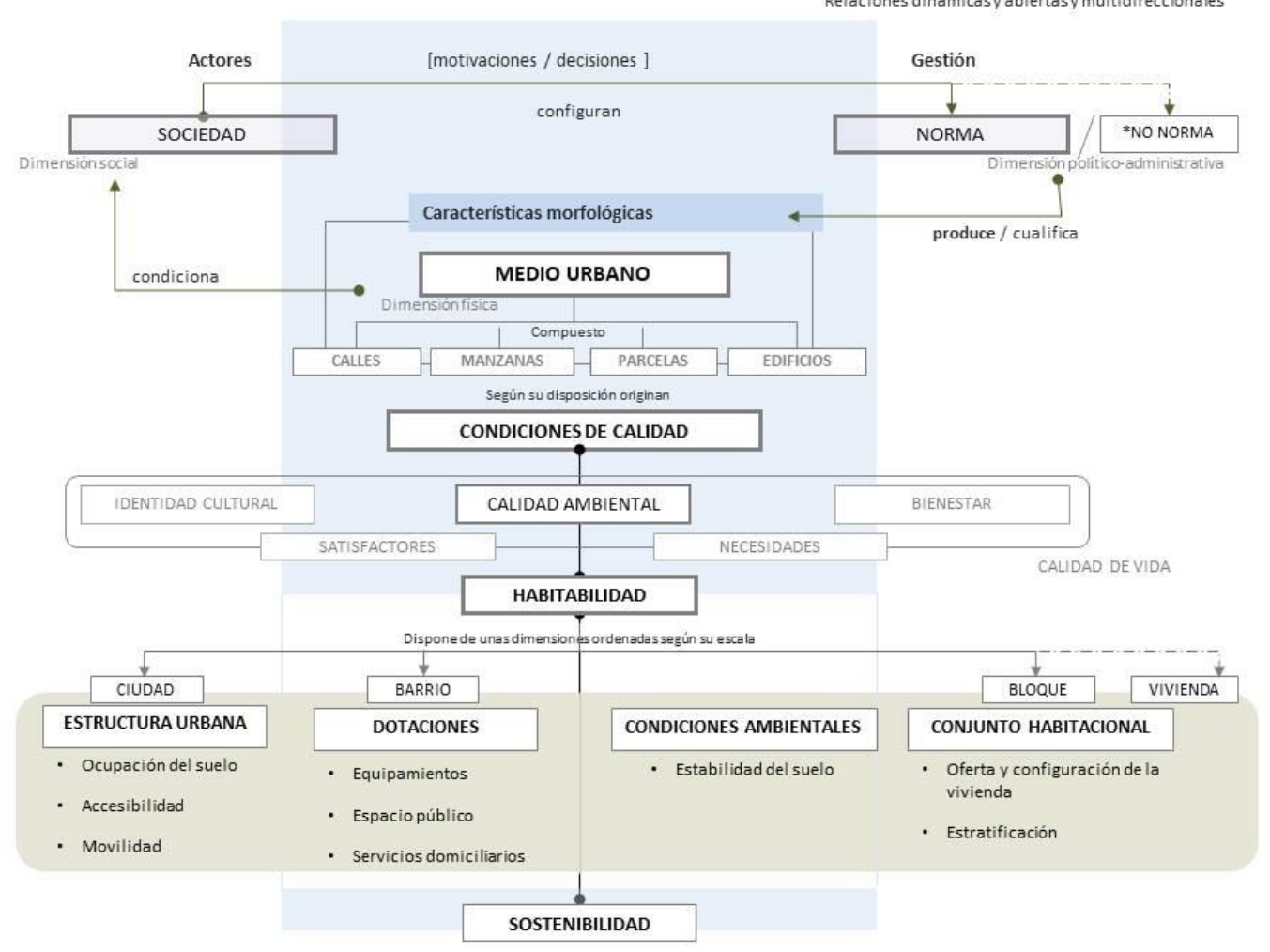




\subsubsection{Parámetros para la medición de la calidad}

La medición de la calidad del espacio residencial necesita, acorde con el desarrollo conceptual presentado, definir de manera operativa parámetros que determinen mínimos aceptables a partir de los cuales se realice la comprobación de su cumplimiento. Dichos parámetros, agrupados en un sistema de indicadores, son semejantes para los desarrollos de vivienda nueva y los mejoramientos de barrio. No se debe olvidar que se indaga por las condiciones de habitabilidad del espacio residencial, de manera integral, para la población de bajos ingresos. El objetivo, como se ha manifestado en varias ocasiones, es comparar las condiciones que se terminan configurando esos espacios residenciales. La forma más acertada de hacerlo, se cree, es por medio de una cuantificación análoga que aporte objetividad en el análisis.

Un tema importante, indicado ya en las herramientas claves de metodología, sobresale con lo expresado anteriormente: tanto los indicadores como los parámetros de medida deben ser ajustados al contexto que se analiza. Así lo ratifican Tarchópulos y Ceballos (2003) al exponer que se debe decidir, a la hora de determinar los parámetros, cuáles aspectos se deben tener en cuenta según su pertinencia y su aplicabilidad frente a las condiciones específicas del contexto donde sean aplicados. (Tarchópulos Y Ceballos, 2003: 45).

En este sentido, el conjunto de indicadores y sus parámetros de medición son tomados de la normativa nacional o municipal (Bogotá y Medellín), de los requerimientos en derechos internacionales o constitucionales establecidos como obligatorios o de la valoración propuesta en algunas de las iniciativas examinadas con posible aplicación para estos territorios. Su pertinencia reviste, de este modo, a la investigación con dos características fundamentales: una referencia territorial y la posibilidad de contrastar los territorios. De ahí el interés de detallar su desarrollo conceptual y técnico.

Por lo anterior, se plantean una propuesta de modelo operativo compuesto por tres niveles de análisis determinados por la escala, las categorías que subyacen y las dimensiones e indicador correspondiente. A continuación, se ilustra el contenido del modelo operativo y posteriormente se describe el alcance de cada una de las dimensiones de dicho modelo para la evaluación de la calidad de vida urbana. Adicionalmente, al final del capítulo se expone el desarrollo de cada indicador con su descripción, el rango de medida, el análisis gráfico asociado y su correspondencia, si la hay, con iniciativas que utilizan el mismo indicador.

\section{ANÁLISIS RELATIVO A LA CIUDAD}

\begin{tabular}{|c|c|c|c|}
\hline Categoría & Dimensión & Indicador & Análisis gráfico asociado \\
\hline \multirow[t]{7}{*}{ Estructura urbana } & \multirow{3}{*}{$\begin{array}{l}\text { D1 Ocupación del } \\
\text { suelo }\end{array}$} & 101 Densidad & Llenos y varios \\
\hline & & & Morfología urbana \\
\hline & & 102 Cesiones & Implantación de espacio público \\
\hline & \multirow[t]{2}{*}{ D2 Accesibilidad } & $\begin{array}{l}\text { I03 Centralidades y tiempos } \\
\text { de desplazamiento }\end{array}$ & Zonificación de usos \\
\hline & & $\begin{array}{l}\text { I04 Acceso a transporte } \\
\text { público }\end{array}$ & Paradas de transporte público \\
\hline & \multirow[t]{2}{*}{ D3 Movilidad } & 105 Trazado de vías & Conexiones viales \\
\hline & & 106 Estado de las vías & Pendientes \\
\hline
\end{tabular}


El análisis relativo a la escala de ciudad caracteriza la producción de la vivienda social en relación con su ubicación dentro del perímetro urbano de Bogotá o Medellín según sea el caso de estudio. Vincula las formas de ocupación de las soluciones habitacionales con las posibilidades de accesibilidad y movilidad por parte de la población en relación al desarrollo de obras de infraestructura y centralidades de cada ciudad. Su estudio se justifica bajo el argumento que una población de bajos ingresos aislada en el territorio tendrá menos probabilidades de llegar a aquellos puntos de la ciudad en donde existan las centralidades.

\section{D1 Ocupación del suelo.}

Para evaluar esta dimensión se establecen dos indicadores relacionados con el modelo de ocupación territorial: las densidades y las cesiones. El objetivo es determinar la ubicación en cada ciudad en donde se está produciendo la vivienda social, con qué principios morfológicos, bajo qué densidades y a qué proporción.

Dos cualidades de ese modelo de ocupación, que no son un calificador directo de la calidad, pero que ofrecen unas condiciones espaciales determinadas según su disposición y están directamente relacionadas con los indicadores a desarrollar en esta categoría, son la forma de implantación de la manzana y la parcela, y la localización de las zonas libres en cada estudio de caso. Por su lado, la forma de implantación de la manzana y parcela indica la presión que ejerce lo construido (volumen edificado en relación al espacio libre o verde urbano) sobre las periferias uniéndola o separándola de la ciudad existente. La localización de las zonas verdes revela el grado de permeabilidad y accesibilidad a estas zonas por parte de la población. Se tiene en cuenta el estado de la malla vial, las pendientes de las vías, el amueblamiento urbano, etc.

\section{D2 Accesibilidad}

Esta dimensión se refiere a la ubicación del proyecto con respecto a las zonas generadoras de empleo y a la oferta de servicios urbanos. En ese sentido, las condiciones de localización y accesibilidad están determinadas por la proximidad y facilidad de comunicación con las centralidades urbanas cercanas. En ella, esta categoría, se miden los tiempos de traslado y la facilidad de acceso al transporte público por parte de la población.

\section{D3 Movilidad.}

La movilidad está asociada con el diseño del trazado y la conformación de la malla vial, preferiblemente jerarquizada, que responda a los diferentes flujos de tránsito al interior del proyecto. Involucra un indicador sobre el trazado de las vías, que permitan una accesibilidad vehicular a las viviendas y la circulación peatonal continua y sin obstáculos especialmente para la población infantil, de tercera edad o discapacitados, y otro indicador sobre el estado de las vías.

Una variable a tener en cuenta, especialmente para la ciudad de Medellín es la pendiente de las vías (topografía del territorio) que condiciona de una manera u otra la movilidad y accesibilidad adecuada a los proyectos y las viviendas mismas. 
ANÁLISIS RELATIVO AL BARRIO - ZONAL

\begin{tabular}{|c|c|c|c|}
\hline Categoría & Dimensión & Indicador & Análisis gráfico \\
\hline \multirow[t]{3}{*}{$\begin{array}{l}\text { Equipamientos y } \\
\text { servicios básicos }\end{array}$} & D4 Equipamientos & $\begin{array}{l}\text { I07 Tipo y porcentaje de } \\
\text { territorio cubierto por } \\
\text { equipamientos }\end{array}$ & $\begin{array}{l}\text { Área de influencia de los } \\
\text { equipamientos según tiempo y } \\
\text { distancia }\end{array}$ \\
\hline & D5 Espacio Público & $\begin{array}{l}\text { I08 Tipo y porcentaje de } \\
\text { espacio público }\end{array}$ & $\begin{array}{l}\text { Área de influencia de parques, } \\
\text { zonas verdes y plazas según } \\
\text { tiempo y distancia }\end{array}$ \\
\hline & $\begin{array}{l}\text { D6 Servicios Públicos } \\
\text { Domiciliario }\end{array}$ & $\begin{array}{l}\text { I09 Conexión a servicios } \\
\text { públicos domiciliarios }\end{array}$ & $\begin{array}{l}\text { Abastecimiento de servicios } \\
\text { públicos (domiciliarios, } \\
\text { recolección de basuras y } \\
\text { alumbrado público) }\end{array}$ \\
\hline Medioambiente & $\begin{array}{l}\text { D7 Condiciones } \\
\text { ambientales }\end{array}$ & I10 Mitigación de riesgo & $\begin{array}{l}\text { Áreas ocupadas por VIS y VIP en } \\
\text { zonas contaminadas, de riesgo e } \\
\text { índices de mitigación }\end{array}$ \\
\hline
\end{tabular}

En el análisis relativo al barrio se establece el acceso local a la red de servicios sociales, equipamientos y espacio público a través del conocimiento de la cobertura de cada uno de ellos y su accesibilidad. En él se determina también, la cobertura de servicios básicos domiciliarios para cada vivienda como parte de la sostenibilidad del proyecto y la calidad ambiental donde se están desarrollando los proyectos a partir de la localización de las viviendas en zonas de riesgo y contaminación, reubicadas o a partir de las obras de prevención o mitigación realizadas con los mismos fines.

\section{D4 Equipamientos}

En esta dimensión se proponen dos indicadores a evaluar: el tipo de equipamientos que disponen los proyectos de vivienda social y la adecuada accesibilidad a ellos. Así se miden, por un lado, la diversidad en los equipamientos que debe dar cobertura a las necesidades de los habitantes en educación, sanidad, cultura, bienestar social o seguridad ciudadana entre otros, y por otro lado, la escala de proximidad correspondiente al radio de servicio de cada equipamiento.

La modelo de ordenación para cada intervención debe vincular el acceso próximo en tiempo, distancia y calidad de los servicios básicos para garantizar el vínculo social de sus habitantes con el resto de la ciudad.

\section{D5 Espacio público de recreación y de ocio}

La evaluación sobre el espacio público de recreación y de ocio, denominad también espacio verde, establece la distribución espacial y el servicio que prestan dichos espacios, como elemento esencial en el bienestar social, para los habitantes de los proyectos. Dichos espacios deben estar localizados próximos a las unidades habitacionales, en terrenos adecuados para su desarrollo y con un acceso fácil y permeable para toda la población, en especial personas de tercera edad, discapacitados y niños. 
Se consideran espacios verdes, los espacios de estancia como parques públicos, jardines, alamedas y plazas y no se consideran como tal, las superficies verdes ligadas al tráfico. Los espacios verdes deben estar clasificados según su escala e preferiblemente interconectados entre sí.

\section{D6 Servicios público domiciliarios}

El objetivo de esta dimensión es medir la cobertura de los servicios domiciliarios básicos: acueducto, alcantarillado, electricidad y recolección de basuras para las áreas de la vivienda social. Sin ellos se considera que la vivienda o el proyecto no cumplen con uno de los mínimos básico para la existencia adecuada del ser humano.

Esta dimensión a su vez puede ser contrastada con los datos del indicador sobre riesgo de las condiciones ambientales, ya que permite identificar si la disponibilidad de conexión al servicio está relacionada con zonas con algún tipo de problemática ambiental. Lo anterior, con el fin de evaluar si las viviendas se encuentran en áreas que puedan poner en riesgo la vida de la población o afectar la salud de los habitantes.

\section{D7 Condiciones ambientales}

La dimensión sobre condiciones ambientales está conformada por la evaluación sobre la cercanía de la vivienda a focos de contaminación, zonas de alto riesgo no mitigable, zonas de inundación o a usos generadores de altos impactos urbanísticos, ambientales o sociales. Abarca por lo tanto las características naturales del suelo: topografía, hidrología en términos de las dificultades o sobrecostos para su urbanización y posterior construcción.

\section{ANÁLISIS RELATIVO AL BLOQUE - VECINDARIO}

\begin{tabular}{llll}
\hline \multicolumn{1}{c}{ Categoría } & \multicolumn{1}{c}{ Dimensión } & \multicolumn{1}{c}{ Indicador } & \multicolumn{1}{c}{ Análisis gráfico } \\
\hline $\begin{array}{l}\text { Conjunto habitacional } \\
\text { y vivienda }\end{array}$ & $\begin{array}{l}\text { D8 Oferta y } \\
\text { configuración de la } \\
\text { vivienda }\end{array}$ & $\begin{array}{l}\mathbf{I 1 1} \text { Morfo-tipología de la } \\
\text { vivienda }\end{array}$ & $\begin{array}{l}\text { Tipología de vivienda } \\
\text { Altura de la vivienda }\end{array}$ \\
& $\mathbf{1 1 2}$ Complejidad Urbana & $\begin{array}{l}\text { Estratificación } \\
\text { Mezcla de usos }\end{array}$ \\
\hline
\end{tabular}

El análisis relativo al bloque evalúa la producción de la vivienda social de acuerdo con su calidad en el conjunto habitacional y en la seguridad que ésta proporciona en relación con el espacio físico (tipología de manzana, parcela y bloque), y la diversidad urbana que se conforma con la mezcla de rentas de la población habitante y los diferentes usos de los proyectos de intervención. Dos indicadores son propuestos: la morfo-tipología del proyecto de intervención con respecto a la localización de los bloques, entorno conformado y las rutas de acceso peatonal o vehicular y la clasificación del suelo conformado por estratos y usos. El primero mide el cumplimiento de condiciones mínimas espaciales requeridas por ley y el segundo, la complejidad del sistema establecido. 


\section{D8. Oferta y configuración de la vivienda}

El estudio de la dimensión y forma predial implica un análisis sobre la correlación entre la parcela y la tipología arquitectónica. Da cuenta de las características de los predios para vivienda unifamiliar o bifamiliar en términos de forma, de área y frente mínimos, de manera que contribuyan a unas mejores condiciones en lo relacionado con las características arquitectónicas planteadas por ley. De igual manera, en el caso de los multifamiliares está referido al área mínima que requiere la vivienda según el programa que contiene (en cuanto a número y tipo de espacios). Aquí también se mide la altura de las edificaciones y el grado de consolidación de las estructuras residenciales y del tejido urbano.

Otro indicador de esta dimensión es la complejidad urbana que orienta sobre los procesos de organización de la población y el tejido urbano. En ella se mide por un lado, el índice de diversidad de la población habitante con sus condiciones sociales: estratificación, niveles de pobreza, capacidad participativa; y por otro lado, la variedad de usos y funciones urbanas que fueron establecidas desde la planeación o creadas posteriormente para cubrir las necesidades de la población.

\subsubsection{Precisiones metodológicas}

En el contexto colombiano, el análisis sobre la vivienda social se enmarca por lo general, en una mirada de cantidades, en donde el problema se reduce a aspectos como las unidades producidas, el porcentaje de área destinadas a dicho uso, metrajes del espacio interno de la vivienda, valor de acceso, gastos, beneficios y reparto de subsidios. "Olvidando que, para una mejor comprensión del panorama, se debe considerar la vivienda -también- en relación con las cualidades del espacio en la ciudad; es decir con proyectos más cercanos a las verdaderas necesidades de la población que a las lógicas ecuaciones de planeación urbana." (DEFENSORÍA DEL PUEBLO, 2012:42)

De esta forma, el modelo de evaluación que se propone desde la calidad del espacio o mejor, desde la morfología del espacio residencial pretende, de forma sencilla, exponer una reflexión y discusión diferente sobre el tema. Se cree de suma importancia la relación existente entre la forma de la ciudad y la calidad que ésta termina adquiriendo.

Con las dimensiones y categoría propuestas en este modelo no se da por cubierto todo el tema. Se reconoce que la noción de espacio residencial y calidad urbana puede ser observada desde diferentes objetivos, puntos de vista o disciplinas. Esta es una propuesta desde el ámbito académico bajo una mirada del urbanismo. Como se ha señalado, el tema de evaluación sobre la habitabilidad de la vivienda social, no ha sido desarrollado con fuerza hasta mediados del año 2000 cuando empiezan a vislumbrase algunas propuestas desde las policías públicas o la academia. De ahí su importancia de seguir desarrollando el tema.

De este modo, en pos de una valoración sobre el estado de cada territorio examinado se expone de forma pormenorizada las consideraciones esenciales tenidas en cuenta en el modelo de análisis: 


\section{El Instrumento}

Los indicadores propuestos fueron desarrollados con base en varios criterios. El primero claramente establecido desde el inicio de la investigación, apuntaba a la necesidad de poder comparar las evaluaciones de los estudios de caso entre sí. El segundo criterio se apoyaba en la posibilidad de obtener la información con las herramientas estadísticas disponibles o de posible implementación. Si bien algunos indicadores no se producen regularmente por parte de las instituciones públicas o de los agentes constructores, son factibles de aplicar y de medir gracias al análisis gráfico correspondiente propuesto para cada indicador. El tercer criterio tenido en cuenta fue tomar aquellos indicadores que contaban con un significado relevante por sí mismos o aquellos que han probado ser discriminantes de las condiciones de la población de menores ingresos como los indicadores de movilidad y accesibilidad. $Y$ finalmente el último criterio considerado, fue captar problemáticas que incidieran significativamente en la calidad urbana como la prestación de los servicios domiciliarios, los equipamientos o el acceso al transporte público.

Con base a las consideraciones expuestas, se definió un enfoque espacial que utiliza indicadores que cuantifican las dinámicas de los fenómenos territoriales y los procesos ligados a sus estructuras. Así, se han manejado conceptos como distancia, proximidad, tiempo de desplazamiento, territorialidad o localización y han sido enmarcados por rangos que permitan una métrica representada en formato gráfica con una puntuación específica. Se han creado tres categorías para clasificar el valor de cada indicador:

Situación que se acerca a una condición de calidad urbana adecuada (sostenible o de buen desempeño). La puntuación que se le da a esta condición es de 0 Puntos

Situación que no cumple con los condicionantes planteados en esta investigación considerados como adecuados pero se acerca a los valores mínimos de referencia de calidad urbana. En muchas ocasiones son situaciones que se adaptan a la normativa vigente en cada POT. Su desempeño es regular o potencialmente problemático.

La puntuación que se le da a esta condición son: 2 Puntos

Situación que no cumple con los condicionantes planteados y representa unas condiciones muy deficientes de calidad urbana. Su situación es no sostenible con un desempeño altamente problemático.

La puntuación que se le da a esta condición son: 4 Puntos.

Con respecto a la puntuación total de los proyectos, su mayor puntuación posible es de 112 puntos. Dicho valor significa que el proyecto cuenta con unas condiciones urbanas muy deficitarias o nada sostenibles. Así mismo, entre más se acerquen el puntaje a esta cifra máxima en cada proyecto se demostrará que éste no cuenta con condiciones adecuadas.

Como se explicó anteriormente, los indicadores cumplen un papel fundamental en la identificación de los temas de menor desarrollo urbano en cada ciudad. Su función primordial, si bien permite brindar un análisis detallado sobre cada territorio, es el de permitir comparar una estudio de caso analizado con el otro. Comparación posible y fácilmente observable por 
medio de la clasificación por colores y por puntajes. Los indicadores y sus criterios de clasificación sirven para señalar cuáles acciones realizadas por el Estado en sus políticas de intervención, mejoramiento de barrio o desarrollo de vivienda nueva, han producido mejores condiciones urbanas. No precisas exactamente la identificación del problema específico del tema que evalúan ni ofrecen soluciones. Este tipo de análisis se lleva a cabo posteriormente en las conclusiones.

\section{Validación del instrumento}

Finalmente cabe mencionar, que para conseguir una validez y confiabilidad del instrumento desarrollado se realiza una prueba piloto del modelo de evaluación en el estudio de caso Mejoramiento de Bario Sur Con Bogotá. Su propósito es optimizar los indicadores seleccionados. Su medición permitió establecer si los resultados obtenidos dan cuenta del fenómeno que se quiere estudiar. Así se logró mostrar la corresponsabilidad de los ítems con los objetivos e hipótesis de la investigación.

\section{Fuente de Información}

A continuación se expone el tipo de información utilizada como base para la obtención de datos numéricos o gráficos de cada caso de estudio, las estrategias utilizadas para su recolección y el método de procesamiento.

El estudio consigue la información necesaria de dos fuentes principales: una información primaria de tipo cualitativa y una información secundaria. La información primaria es obtenida mediante trabajo de campo realizado en las zonas de desarrollo de vivienda social. En tres ocasiones (año 2011, año 2012 y año 2015) se viajó hasta la ciudad de Bogotá y Medellín con el único fin de visitar las zonas de estudio, tomar fotografías y hablar con los habitantes del proyecto. Para cada visita se diseñó un instrumento de medición y se seleccionaron áreas específicas para su aplicación. Cabe señalar que aquellas vivistas de campo resultaban sumamente complejas de realizar apropiadamente ya que en la mayoría de los territorios, por ser zonas dominadas en su mayoría por grupos armados (delincuencia común generalmente), no se puede acceder a la zona sin gente que conozca a los habitantes de allí o sin personal de la administración pública. En el caso de la ciudad de Bogotá para el proyecto MIB EI Lucero no se pudo contactar con el tipo de personas antes mencionado, así que éste proyecto no llegó a visitarse. Las fotografías del proyecto se tomaron de google earth o de imágenes suministradas por la administración.

La información secundaria fue extraída de registros existentes, fuentes de información pública e investigaciones académicas publicadas sobre la materia. Con respecto a la información solicitada a entidades distritales y regionales se tuvo como objetivo pedir información espacial geo-referenciada de las áreas en donde se estaban desarrollando los proyectos de vivienda de interés social (VIS) y los proyectos de mejoramiento de barrio en la ciudad de Bogotá y Medellín, junto con datos estadísticos y de seguimiento a dichos proyectos.

Los criterios utilizados para solicitar la información espacial y evitar modificaciones que pudieran alterar los resultados fueron: 
a) Establecer un formato de solicitud de la información, el cual permitiera comparar datos construidos por diferentes entidades en un modelo y alimentar así una base cartográfica en $\mathrm{dwg}^{105}$.

b) Solicitar información complementaria de diagnósticos elaborados sobre cada proyecto para lograr obtener algún dato numérico o planimétrico de aquella información que no estuviera completa y/o careciera de criterios comunes.

c) Alimentar el modelo con información estadística que se pudiera encontrar en línea. Una de las características de esta investigación es que gran parte de la información fue sumamente compleja de conseguir. Las administraciones, celosas con su información, no estaban muy dispuestas a brindar los datos necesarios a pesar que se demostrara que sería utilizada con un único objetivo académico.

Adicionalmente, gran parte de la investigación se realizó en España, lo que no permitió una visita continua y puntillosa a dichas administraciones.

Con respecto a la solicitud de investigaciones académicas o publicaciones en la materia sobre cada estudio de caso se enfocó la petición en:

a) Resoluciones normativas y documentos de soporte sobre las regulaciones normativas, los planes maestros o los planes de ordenamiento territorial

b) Informe de proyectos habitacionales de carácter académicos o institucionales

c) Archivos públicos e informes estadísticos.

\section{Procesamiento de los datos}

Finalmente, en el procesamiento de la información se procedió a su clasificación de acuerdo con los requerimientos de cada categoría planteada en el modelo de análisis. Cada dimensión se desarrolló con la información del trabajo de campo, los datos numéricos extraídos y los planos gráficos realizados (integrados en un SIG y en planos DWG).

- Sobre los datos extraídos, en ocasiones no fue posible encontrar publicaciones con la información tal cual se requería para esta investigación, pero se pudo llegar a ella empleando variables intermedias teniendo en cuenta la cobertura geográfica y el año de la fuente.

- Sobre los planos gráficos realizados dos metodologías fueron utilizadas: el Sistema de información geográfico y archivos DWG. Sobre el primero si bien se ha constituido en una herramienta importante de trabajo por el ágil manejo de información relacionada con diversos niveles de agregación espacial o territorial, esta no siempre fue utilizada por las instituciones públicas que hasta ahora empiezan a manejar dicha tecnología. Dicha circunstancia condicionó que la mayoría de los planos fueran realizados entonces en archivos dwg. Ahora bien, muchas de las mediciones de los fenómenos espacio-temporales (radios de influencia y modelos de distancia) fueron realizados bajo este sistema de georeferenciación.

\footnotetext{
105 Cada entidad pública maneja un nivel de planos y de detalles diferenciado. No existe un criterio nacional para que todas las instituciones manejes un sistema similar de representación. Esta condición representó un trabajo adicional en la investigación para homologar la información en cada estudio de campo.
} 

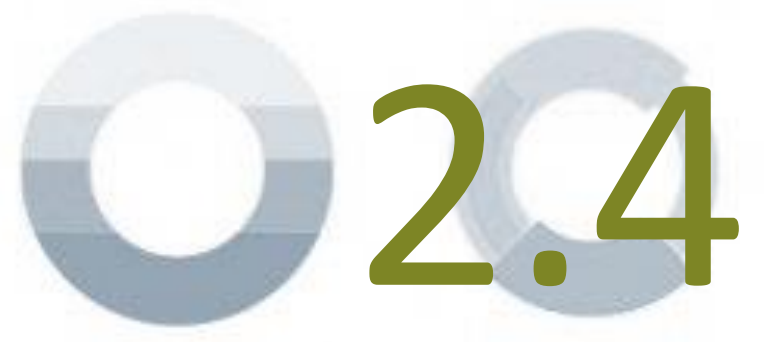

Relación de Indicadores
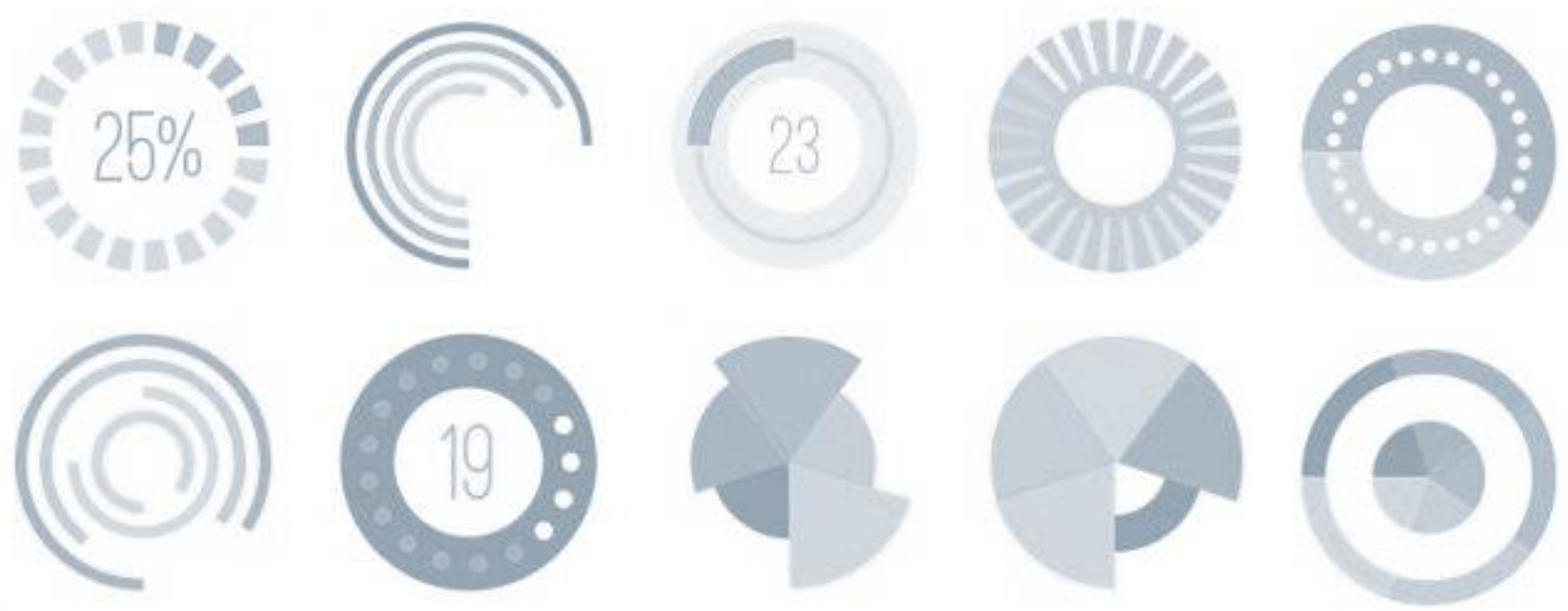


\section{DESCRIPCIÓN}

Este indicador caracteriza las actuaciones de vivienda social seleccionadas por medio del número de viviendas por hectárea bruta desarrollada. Su análisis se realiza en relación con la conformación del espacio urbano y establece la sostenibilidad y funcionamiento del mismo. Se miden las densidades brutas en cuanto se requiere para visualizar el impacto en la superficie total del desarrollo.

\section{RANGO Y VALOR DE MEDIDA}

La densidad de viviendas es clasificada en rangos determinados por la amplitud de los datos en: densidad alta, media y baja. Si el valor máximo de densidad es de 100viv/ha*, este valor determinará los rangos así:

\begin{tabular}{|c|c|c|}
\hline Rango bajo & Rango medio & Rango alto \\
\hline 0-40viv/ha & 41-70viv/ha & 70-100viv/ha \\
\hline 2 puntos & 0 puntos & 4 puntos \\
\hline
\end{tabular}

*Se toma 60viv/ha, como cifra considerada para la densidad ideal en el estándar para la producción de vivienda nueva.

\section{ANÁLISI GRÁFICO ASOCIADO}

Plano de llenos y vacíos

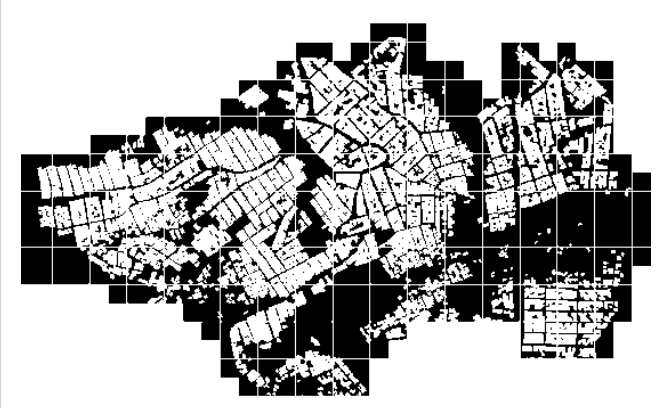

\section{JUSTIFICACIÓN}

La medición de la densidad permite comparar la intensidad de desarrollo en cada actuación frente a programas similares de las mismas características, bien sea de vivienda nueva o de mejoramiento de barrio. Su medición sirve como punto de referencia para determinar cómo se ha configurado el territorio a nivel urbano, espacio público y a nivel habitacional según el tipo de vivienda (unifamiliar, bifamiliar y/o multifamiliar).

Si bien la densidad no es calificador absoluto o directo de la calidad de la actuación, su medición si ofrece una correspondencia entre la intensidad de desarrollo económico con la que se ejecutó el proyecto y las condiciones de calidad que éste finalmente logra. Las densidades medias (60viv/ha), por lo general, ofrecen un equilibrio entre la intensidad de ocupación del territorio y un nivel aceptable de condiciones de vida (actividades de proximidad, accesibilidad a centralidades, etc.). Dependen, por lo tanto, de la tipología edificatoria (número de pisos) y del índice de ocupación.

Una cualidad de esa condición de ocupación del territorio está vinculada con la implementación de la manzana y la parcela en dicho territorio. Según como éstas estén dispuestas o conformadas indican la presión que ejerce lo construido sobre las periferias uniéndola o separándola de la ciudad existente. Muestra el grado de equilibrio a nivel de ciudad.

\section{REFERENCIA SOBRE VALOR Y RANGO DE MEDIDA}

a) La iniciativa de la Defensoría del Pueblo (2012) toma como referencia 100viv/ha considerada como ideal en el estándar de vivienda nueva. Así los rangos quedan determinados:

Densidad baja: 0 - 33,3viv/ha

Densidad media: $33,4-66,6 \mathrm{viv} / \mathrm{ha}$

Densidad alta: $66,7-100$ viv/a

b) El trabajo desarrollado por UN-Hábitat en Urban Planning for City Leaders establece la medida de 35 a 70viv/ha como densidades brutas adecuadas para no elevar el costo de las instalaciones de servicios domiciliarios (agua y alcantarillado), 20\% de más comparados con zonas de bajas u altas densidades.

c) El trabajo del Ministerio de Desarrollo Económico (1998) ofrece los siguientes valores con respecto a la densidad neta. Sus cálculos se basan en la práctica usual de los proyectos de vivienda nueva en Colombia con las siguientes 
constantes: en proyectos multifamiliares 5 niveles, localizados en ciudades grandes e intermedias, las densidades son de alrededor de 180viv/ha neta y para desarrollos bifamiliares de 110viv/ha.

\begin{tabular}{|c|c|c|c|}
\hline No. de Plantas & Densidad Baja & Densidad Media & Densidad Alta \\
\hline 1 & Hasta 63viv/ha & de 64 a 115viv/ha & más de 115 viv/ha \\
\hline 1,5 & de 63 a 79 viv/ha & de 80 a 154 viv/ha & más de 155 viv/ha \\
\hline 2 & de 79 a 90 viv/ha & de 91 a 180 viv/ha & más de 180 viv/ha \\
\hline 2,5 & de 90 a 101 viv/ha & de 101 a 213 viv/ha & más de 213 viv/ha \\
\hline 3 & de 101 a 110 viv/ha & de 111 a 236 viv/ha & más de 236 viv/ha \\
\hline 4 & de 110 a 120 viv/ha & de 121 a 270 viv/ha & más de 270 viv/ha \\
\hline 5 & de 120 a 126 viv/ha & de 127 a 300 viv/ha & más de 300 viv/ha \\
\hline 6 & de 126 a 134 viv/ha & de 135 a 335 viv/ha & más de 335 viv/ha \\
\hline
\end{tabular}

d) En el estudio de la CEPAL (2014), el indicador concerniente al estudio de Salvador Rueda utiliza como densidad adecuada (densidad mínima) 60viv/ha para que el territorio no caiga en una ocupación dispersa y se pueda conseguir una masa crítica de personas y actividades residenciales apropiada para conseguir desarrollar una vida cotidiana con patrones de proximidad.

e) El estudio sobre "Parámetros Dotacionales para la Ciudad de los Ciudadanos" de Agustín Hernández -Aja fija los rangos de densidad neta según el tipo de tejido urbano al que se haga referencia. Los define así: Tejido residencial entre 40 - 50viv/ha, Tejido medio entre 65 - 75 viv/ha y Tejido Central entre 90 - 100viv/ha.

De las diferentes referencias citadas se aprecian un rango de valores promedio como densidad bruta deseable, a pesar de los diversos rangos establecidos, de 60viviendas/ha en promedio. En cualquier caso, como se resalta en la iniciativa del Ministerio de Desarrollo económico ésta depende de la tipología edificatoria desarrollada y del contexto específico o tipo de tejido urbano del que se haga referencia.

Ahora bien, la densidad habitacional o urbana (viviendas/ha) debe ser contrastada a su vez con la densidad población. Se puede presentar el caso de valores similares en densidades urbanas pero con una mayor cantidad de personas u hogares habitando cada vivienda.

A continuación, se presenta el ranking de las diez ciudades de Latinoamérica con mayores densidades habitacionales como datos de comparación:

Densidades Urbanas de 10 ciudades de Latinoamérica con más de 500.000habitantes

\begin{tabular}{|c|c|c|c|c|c|c|}
\hline Ranking & País & Ciudad & Población & Tamaño (ha) & $\begin{array}{c}\text { Densidad sobre } \\
\text { área bruta }\end{array}$ & $\begin{array}{c}\text { Densidad sobre } \\
\text { área neta }\end{array}$ \\
\hline 32 & Colombia & Bogotá & 7.150 .000 & 41.400 & 173 & 345 \\
\hline 45 & Colombia & Medellín & 2.905 .000 & 18.900 & 154 & 307 \\
\hline 65 & Colombia & Bucaramanga & 850.000 & 6.000 & 142 & 283 \\
\hline 77 & Colombia & Cali & 2.100 .000 & 15.500 & 135 & 271 \\
\hline 104 & Colombia & Barranquilla & 1.650 .000 & 14.200 & 116 & 232 \\
\hline 104 & Perú & Lima & 7.500 .000 & 64.800 & 116 & 231 \\
\hline 143 & Ecuador & Guayaquil & 2.300 .000 & 22.000 & 105 & 209 \\
\hline 148 & Colombia & Cartagena & 850.000 & 8.300 & 102 & 205 \\
\hline 214 & México & Ciudad de México & 18.100 .000 & 213.700 & 85 & 169 \\
\hline 218 & El Salvador & San Salvador & 1.300 .000 & 15.500 & 84 & 168 \\
\hline
\end{tabular}

Fuente: Fuente: Demographia World Urban Areas \& Population Proyections: 5th Comprehensive Edition (Revised April 2009) */ Estimación de densidad sobre el área útil asumiendo un aprovechamiento del 50\% del área bruta

\section{ANÁLISIS GRÁFICO ASOCIADO}

El plano asociado a este indicador es el plano de llenos y vacíos. Esta forma gráfica se considera las más idónea para contrastar la forma de ocupación del territorio.

\section{OTRAS INICIATIVAS QUE UTILIZAN ESTE INDICADOR}

- DEFENSORÍA DEL PUEBLO (2012) El derecho a la vivienda digna y adecuada. Indicador: Densidad y distribución de las unidades de VIS y VIP identificadas 
- BID (2013) Iniciativa de Ciudades Emergentes y Sostenibles. Ind.42 Densidad de la población

- CEPAL (2014) Aplicación de Indicadores de sostenibilidad urbana a la vivienda social. Ind. 1: Densidad Edificatoria

- Coalición Internacional del Hábitat HIC-AL (2004) Indicadores de Resultados e Impactos. Indicador Densidad Fundaria.

- MINISTERIO DE DESARROLLO ECONÓMICO (1998) Metodología de diseño y evaluación de proyectos de vivienda de interés social. Indicador Densidad neta habitacional

- TARCHÓPULOS, Doris y CEBALLOS, Olga (2003) Calidad de la vivienda dirigida a los sectores de bajos ingresos en Bogotá. Indicador Densidad neta. 


\section{DESCRIPCIÓN}

El indicador de cesiones urbanas indica la intensidad de aprovechamiento del espacio público desarrollados dentro de las actuaciones, determinada por el área cedida a vías, parques y equipamientos. La forma como se resuelvan dichas área: superficie destinada, ubicación y accesibilidad dota de ciertas calidades, negativas o positivas, al espacio residencial.

\section{RANGO Y VALOR DE MEDIDA}

Las cesiones están clasificadas en rangos determinados por la amplitud de los datos en área deficiente, normal (referente a lo que establece la normativa) y buena. Para establecer los valores pertenecientes a cada rango se toma lo establecido en la normativa (POT)

Malla Vial:

\begin{tabular}{|c|c|c|}
\hline Rango bueno & Rango normal & Rango deficiente \\
\hline$>$ al $30 \%$ del área neta & 20-30\% del área neta & $<$ al $20 \%$ del área neta \\
\hline 0 puntos & 2 puntos & 4 puntos \\
\hline \multicolumn{3}{|c|}{ Espacio Público (zonas recreativas y equipamientos comunales públicos): } \\
\hline Rango bueno & Rango normal & Rango deficiente \\
\hline > al $25 \%$ del área neta & 15-25\% del área neta & $<$ al 15\% del área neta \\
\hline \multicolumn{3}{|c|}{ Equipamiento y servicios } \\
\hline > al 8\% del área neta & 5-8\% del área neta & $<5 \%$ del área neta \\
\hline 0 puntos & 2 puntos & 4 puntos \\
\hline \multicolumn{3}{|c|}{ Parques, zonas verdes y plazas: mínimo $50 \%$ concentrados en un globo con acceso vehicular } \\
\hline$>$ al $8 \%$ del área neta & 5-8\% del área neta & $<5 \%$ del área neta \\
\hline 0 puntos & 2 puntos & 4 puntos \\
\hline
\end{tabular}

\section{JUSTIFICACIÓN}

La observación de la ubicación, ocupación y permeabilidad de las zonas cesión permite reconocer la relación de áreas entre lo público y lo privado. El indicador mide la proporción destinada a vías, zonas verdes y comunales obligatorias para albergar los servicios comunitarios como guarderías, salones comunales, dotaciones deportivas o carriles bici en una proporción adecuada al número de viviendas construidas. Según normativa las cesiones públicas deben ser entre $15 \%-30 \%$ del área neta distribuida en 5\%-10\% para servicios comunitarios y entre $10 \%-20 \%$ para parques y zonas verdes. Su carácter es obligatorio y son legalmente vinculantes al modelo de ordenamiento territorial.

Así la distribución y disposición de áreas libres se refiere a estacionamientos, zonas verdes y comunales, vías peatonales y vías vehiculares en términos de su localización con respecto al conjunto de las viviendas, la ejecución completa del amoblamiento urbano como iluminación de zonas verdes o dotación de bancas y canecas, las condiciones de accesibilidad a estas zonas por parte de población infantil, tercera edad y discapacitados.

En los desarrollos de vivienda social las cesiones han sido, por lo general, ignoradas como patrimonio urbano vital para resolver estándares de vida de los habitantes de la ciudad.

\section{REFERENCIA SOBRE LA UBICACIÓN DE LAS CESIONES}

Con respecto a la ubicación de las cesiones, zonas verdes y equipamientos, la normativa establece para los desarrollos de vivienda nueva parámetros de configuración determinados. Prohíbe la localización de cesiones en zonas inundables o de pendientes mayores de $25 \%$, exigiendo que en los de mayor escala (metropolitanos, urbanos y zonales) y especifica que un $50 \%$ del área con dicho fin este agrupada en un solo globo de terreno y el restante conformando otras zonas menores con un mínimo de $1000 \mathrm{~m} 2$ de área. 
Por lo general tres características de ubicación se suelen presentar en los barrios de origen institucional: cesiones localizadas en el centro del proyecto, en la periferia o de forma combinada (mixta):

Ubicación céntrica

Ubicación periférica

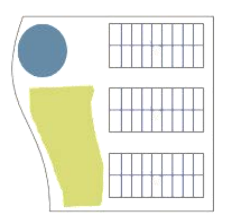

Ubicación mixta

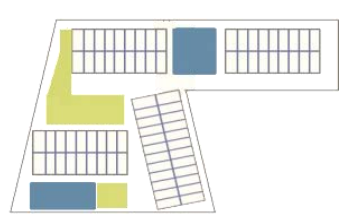

Cesiones públicas

Malla vial $24 \%$

Reserva ambiental 10\%

Parques $17 \%$

Equipamiento: $8 \%$

Con respecto a los barrios de origen marginal, las cesiones no son contempladas en un principio como tal, sino como zonas periféricas relacionadas con los bordes irregulares de las parcelas o como parcelas que no hayan sido edificadas con uso residencial y se consagren a eset fin. Sin embargo, cuando se entra a intervenir estos territorios, si se crean zonas de cesión específica bien para las zonas libres, bien para los proyectos de vivienda nueva que se construyen como parte del mejoramiento. Este tipo de intervención, a su vez, se debe someter a las obligaciones normativas.

\section{OTRAS INICIATIVAS QUE UTILIZAN ESTE INDICADOR}

- TARCHÓPULOS, Doris y CEBALLOS, Olga (2005) Patrones urbanísticos y arquitectónicos en la vivienda dirigida a sectores de bajos ingresos en Bogotá. Pag.57

- TARCHÓPULOS, Doris y CEBALLOS, Olga (2003) Calidad de la vivienda dirigida a los sectores de bajos ingresos en Bogotá. Ind.5-6 Zonas de cesión

- CEPAL (2014) Aplicación de Indicadores de sostenibilidad urbana a la vivienda social. Ind. 8: Reserva de espacio libre de manzana 


\section{DESCRIPCIÓN}

El indicador de zonificación y tiempos de desplazamiento establece los caminos más cortos desde las unidades habitacionales a la centralidades, equipamientos o servicios colectivos de los proyectos o de la ciudad de Bogotá y Medellín (estos definidos por el POT o creados por la propia población) según el recorrido óptimo y el nivel de accesibilidad (pendiente y calidad de las vías).

Se ubican adicionalmente los usos comerciales y centralidades adecuados por parte de la población dentro de los proyectos de vivienda social como soluciones próximas a sus necesidades.

\section{RANGO Y VALOR DE MEDIDA}

Los tiempos de desplazamiento y la accesibilidad a las centralidades se clasifican en: altas, medias y bajas de acuerdo con el tiempo de los recorridos. Los rangos se han establecido conforme a la escala de las centralidades de tipo barrial o zonal. Para calcular el tiempo de desplazamiento se ha tomado como referencia las viviendas más lejanas de las centralidades como el máximo de tiempo de desplazamiento posible de la población y la red de carreteras óptimas para llegar a la centralidad.

Escala de vecindario a pie:

\begin{tabular}{ccc} 
Accesibilidad alta & Accesibilidad media & Accesibilidad baja \\
0:001-10:00min & $10: 01-20: 00 \mathrm{~min}$ & 20:01-30:00min \\
\hline 0 puntos & 2 puntos & 4 puntos
\end{tabular}

*Se considera una velocidad de $4 \mathrm{~km} / \mathrm{h}$ de recorrido a pie para desplazarse $300 \mathrm{mts}$.

Escala zonal en transporte público

\begin{tabular}{|c|c|c|}
\hline Accesibilidad alta & Accesibilidad media & Accesibilidad baja \\
\hline $0: 001-20: 00 \mathrm{~min}$ & 20:01 - 40:00min & $40: 01-60: 00 \mathrm{~min}$ \\
\hline 0 puntos & 2 puntos & 4 puntos \\
\hline
\end{tabular}

Los rangos definidos para cada centralidad a nivel local son de máximo 31 minutos a pie y a nivel ciudad con automotor un máximo 60 minutos según Tarchópulos y Ceballos (2003)

\section{ANÁLISIS GRÁFICO ASOCIADO}

Plano de centralidades y comercio primera planta

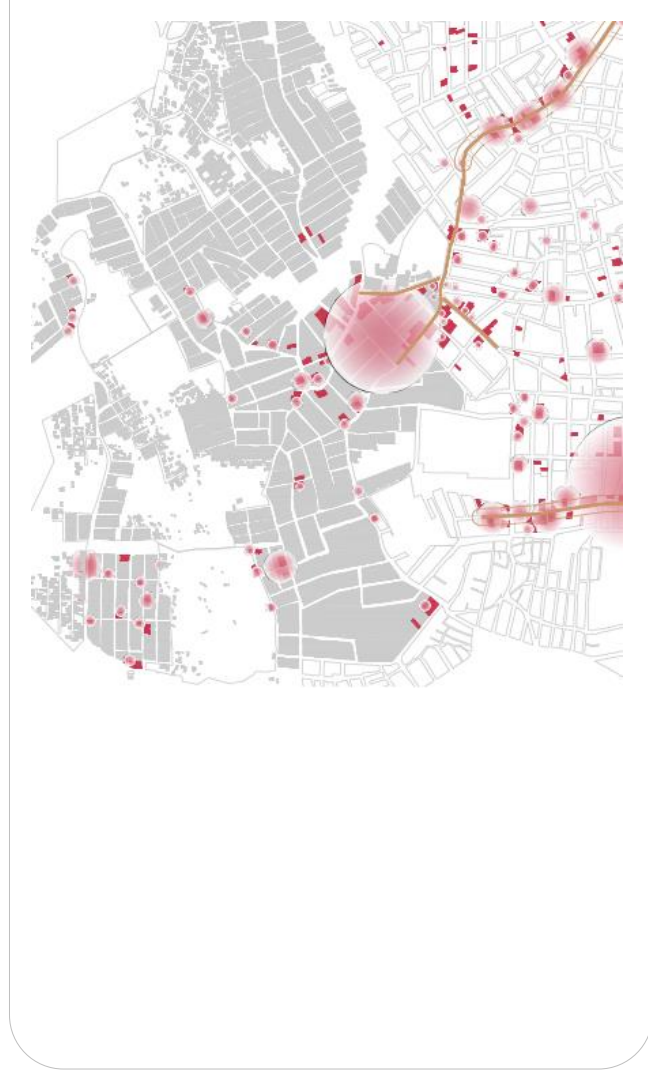

\section{JUSTIFICACIÓN}

El análisis espacial de usos y zonificación de los proyectos permite una rápida comprensión de la relación distanciaaccesibilidad de la población a puntos de importancia en la ciudad. Las centralidades por lo general se generan alrededor de un espacio público en función de una serie de equipamientos colectivos en sus diferentes usos: educación, recreación, cultural, salud, bienestar social y seguridad, además del patrimonio y la mezcla de usos. Su consolidación ayuda a disminuir los desequilibrios urbanos instituidos en la ciudad colombiana.

Una red de centralidades con los diferentes elementos que la conforman debe procurar un conjunto de oportunidades favorables para toda la población, especialmente la de bajos ingresos.

\section{REFERENCIA SOBRE VALOR Y RANGO DE MEDIDA}

a) La iniciativa de la Defensoría del Pueblo (2012) toma como referencia el tiempo mínimo de desplazamiento de 5 minutos y el tiempo óptimo de 31minutos de recorrido de una población promedio de manzana de 179 habitantes (promedio de habitantes por manzana según DANE 2005 en la ciudad de Bogotá) y 7000empleos (determinados por cada sector censal como mínimos). Así los rangos que establece de accesibilidad a las centralidades son: 


\begin{tabular}{lcc}
\multicolumn{1}{c}{ Valor de índice de accesibilidad } & Rango & Tiempos de recorrido \\
\hline $0-303,07$ & Accesibilidad alta & $0,01-7,54 \mathrm{~min}$ \\
$303,08-606,14$ & Accesibilidad media & $7,75-15,49 \min$ \\
$606,15-909,21$ & Accesibilidad regular & $15,5-23,24 \mathrm{~min}$ \\
$909,22-1212,3$ & Accesibilidad baja & $23,25-31 \mathrm{~min}$
\end{tabular}

Para determinar el Método de lectura, propone la siguiente ecuación IA $=\Sigma$ (IRvc x PTc) / $\Sigma$ PTV en donde IA es el índice de accesibilidad; IRvc es el tiempo mínimo de desplazamiento entre las unidades habitacionales y las centralidades; PTc es la población central de las centralidades; y finalmente PTv es la población total de la actuación. Los tiempos son calculados despejando en la ecuación del indicador el tiempo mínimo de recorrido para cada caso.

b) El trabajo realizado por Tarchópulos y Ceballos sobre Calidad de la vivienda dirigida a los sectores de bajos ingresos en Bogotá propone como rangos de medida:

Tiempos de viaje hacia equipamientos y servicios de escala zonal: máximo 30 minutos a pie

Tiempos de viaje hacia espacio colectivos y urbanos de escala ciudad: máximo 1 hora en transporte público

Tiempos de viaje hacia el lugar de trabajo: máximo $45 \mathrm{~min}$ en transporte público

c) La propuesta realizada por Caminos y Goethert en Elementos de Urbanización define los desplazamientos a equipamientos básicos, centros de empleo u zonas de altas actividades con recorridos máximos:

A nivel peatonal de $2.000 \mathrm{mts}$ ( $30 \mathrm{~min}$ caminando a $4 \mathrm{~km} / \mathrm{h}$ )

En bicicleta de $8.000 \mathrm{mts}$ ( $30 \mathrm{~min}$ desplazándose a $16 \mathrm{~km} / \mathrm{h}$ )

Motorizado de $15.000 \mathrm{mts}$ (30min recorridos a $30 \mathrm{~km} / \mathrm{h}$ )

d) Los indicadores desarrollados por Salvador Rueda para el Plan de Sevilla proponen como tiempos de desplazamiento para las zonas comerciales o de abastecimiento de alimentos según la escala a:

\begin{tabular}{|c|c|c|}
\hline Escala barrial, & $\begin{array}{l}\text { mercado de abastos } \\
\text { centro de salud } \\
\text { entro comunitario } \\
\text { logar de mayores } \\
\text { iblioteca/centro cultural } \\
\text { entro de educación secundaria } \\
\text { espacio deportivo }\end{array}$ & en un tiempo menor a $10 \mathrm{~min}$ \\
\hline Escala de vecindario, & $\begin{array}{l}\text { acceso a comercio de productos cotidianos } \\
\text { acceso a centro cívico } \\
\text { acceso a escuela infantil y educación primaria } \\
\text { paradas transporte público }\end{array}$ & en un tiempo inferior a $5 \mathrm{~min}$ \\
\hline
\end{tabular}

Este indicador debe contemplarse junto con otros indicadores como acceso a transporte público o cobertura de equipamientos y zonas verdes y de recreación para medir de forma completa la compacidad urbana.

\section{OTRAS INICIATIVAS QUE UTILIZAN ESTE INDICADOR}

DEFENSORÍA DEL PUEBLO (2012) El derecho a la vivienda digna y adecuada. Ind. Tiempos de Desplazamiento.

Coalición Internacional del Hábitat HIC-AL (2004) Indicadores de Resultados e Impactos. Ind. Distancia y tiempo de acceso al centro según transporte público.

- TARCHÓPULOS, Doris y CEBALLOS, Olga (2003) Calidad de la vivienda dirigida a los sectores de bajos ingresos en Bogotá. Ind. Tiempos de viaje hacia equipamientos y servicios

· UN-Hábitat (2004) Programa de Indicadores Urbano. Ind. Tiempos de traslado 


\section{DESCRIPCIÓN}

La accesibilidad a rutas y paradas de la red de transporte público de superficie o aéreo en caso de la ciudad de Medellín, mide la proximidad de desplazamiento a pie de los habitantes desde sus unidades de vivienda hasta los puntos de generación o retorno de viajes en la ciudad. El indicador proporciona información sobre la potencialidad de uso y la funcionalidad real de un determinado sistema de transporte público.

\section{RANGO Y VALOR DE MEDIDA}

La accesibilidad se clasifica en rangos determinados por la amplitud de los datos: distancia deficiente, media y óptima. Para determinar los valores pertenecientes a cada rango se toma como máximo 300mts de distancia del paradero a cualquier punto del proyecto. El resultado se da en porcentaje de área cubierta según los radios de accesibilidad.

Accesibilidad óptima Accesibilidad media

\begin{tabular}{|c|c|c|}
\hline$<100 \mathrm{mts}$ & $101-300 \mathrm{mts}$ & $>300 \mathrm{mts}$ \\
\hline 0 puntos & 2 puntos & 4 puntos \\
\hline
\end{tabular}

*Se toma 300mts como referencia máxima según Rueda, Salvador.

\section{ANÁLISIS GRÁFICO ASOCIADO}

Plano de accesibilidad de transporte público

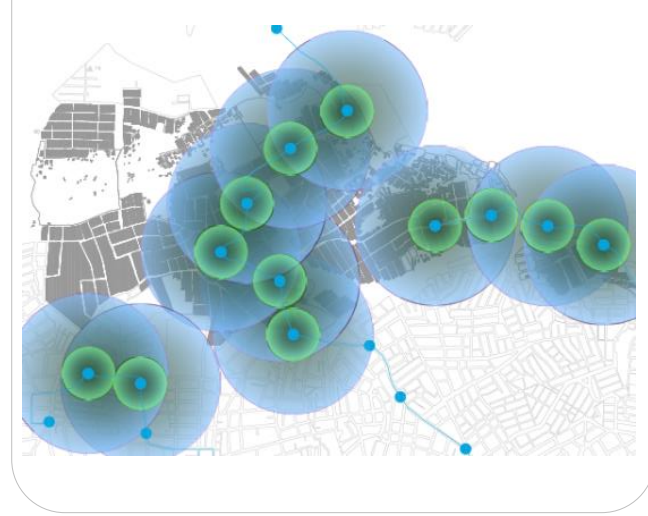

\section{JUSTIFICACIÓN}

Los medios de transporte público tienen un papel importante en el modelo de ciudad adecuado a construir. El vínculo entre la vivienda social, los equipamientos y las centralidades debe estar relacionado con la proximidad de un desplazamiento a pie o en un medio de transporte público con unas distancias acotadas. Se considera que existe una buena accesibilidad cuando desde cualquier parte del viario público puede accederse en 5 minutos (300 m) a una parada de transporte público, (el recorrido se tiene en cuenta en relación a la topografía y al estado de las vías).

Con ello se quiere profundizar en que no solo es importante para una adecuada calidad urbana, la existencia de una red de transporte público que llegue hasta los proyectos de vivienda social sino también que ofrezca una cobertura de paraderos próximos que no requiera desplazarse en una distancia muy larga.

\section{REFERENCIA SOBRE VALOR Y RANGO DE MEDIDA}

a) Salvador Rueda dentro de su plan de indicadores para el Plan de Sevilla considera que existe una buena accesibilidad cuando desde cualquier parte del viario público se puede accederse en 5 minutos (300 m) a una parada de transporte público, lo que equivale a dar cobertura al total de la población.

Para dicho autor, los medios de transporte público tienen un papel clave en el modelo de movilidad sostenible para reducir la dependencia respecto al automóvil y así vincular la urbanización y los equipamientos al desplazamiento preferente en transporte público, a pie o en bicicleta.

b) Para el Sistema de Transporte Público de Bogotá (SITP) una buena calidad en el servicio de transporte público, con buena frecuencia y cercano al lugar de residencia de los habitantes se debe establecer con paradas de autobuses cada $700 \mathrm{mts}$ de distancia o con una proximidad de 10 minutos caminando.

c) El sistema de indicadores propuesto por el Observatorio de Calidad para la Vivienda Nueva de la Universidad de los Andes \& Prodesa S.A. propone una proximidad de las diferentes rutas de transporte público:

Óptimo a una distancia inferior o igual a $500 \mathrm{mts}$

Normal a una distancia entre $501 \mathrm{mts}$ y $2 \mathrm{~km}$

Deficiente a una distancia superior a $2 \mathrm{~km}$

\section{OTRAS INICIATIVAS QUE UTILIZAN ESTE INDICADOR}


- TARCHÓPULOS, Doris y CEBALLOS, Olga (2003) Calidad de la vivienda dirigida a los sectores de bajos ingresos en Bogotá. Ind. Transporte público colectivo

UN-Hábitat (2004) Programa de Indicadores Urbano. Ind. Medio de transporte

- CEPAL (2014) Aplicación de Indicadores de sostenibilidad urbana a la vivienda social. Ind. Accesibilidad de paradas de transporte público. 


\section{DESCRIPCIÓN}

Este indicador determinar las relaciones de conexión de las actuaciones con la ciudad por medio de la lectura de la disposición y disponibilidad de los canales de comunicación con los desarrollos circundantes y su enlace con las centralidades. Dicha conexión tiene implícita también el análisis sobre las pendientes de las vías.

\section{RANGO Y VALOR DE MEDIDA}

La conexión está dada según el tipo de acceso y de perfil vial con el que se accede al proyecto. Su medición es definida como buena, suficiente o deficiente. La conexión buena será la de menor puntuación y la conexión deficiente obtendrá 4 .

Conexión buena Acceso barrial continuo 0 puntos
Conexión suficiente Acceso barrial discontinuo 2 puntos
Conexión deficiente Acceso barrial aislado 4 puntos

*Fuente de clasificación Tarchópulos y Ceballos (2005)

Las pendientes de las vías están consideradas según el porcentaje de inclinación, con un rango que varía de 0 a $40 \%$ y su clasificación es de plana o semi-plana, moderada y media. Entre menor sea la inclinación mayor es el grado de confort en su uso y menor la barrera espacial que éstas generan. Las inclinaciones superiores a $60 \%$ son consideradas como suelos no urbanizables y por ello no son contempladas dentro de la evaluación.

Cabe especificar que dicha clasificación es solo válida para las vías vehiculares ya que toda pendiente superior de $6 \%$ es insuperable para peatones con movilidad reducida.
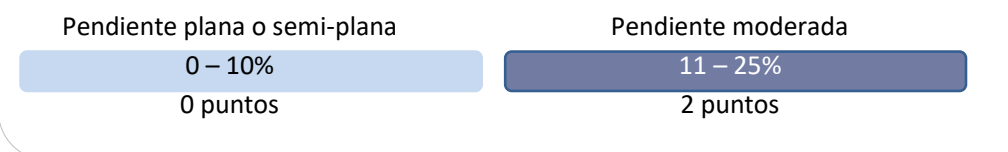

\begin{tabular}{|c|} 
Pendiente media \\
\hline $26-40 \%$ \\
4 puntos
\end{tabular}

\section{JUSTIFICACIÓN}

Medir la movilidad en los proyectos habitacionales permite verificar la calidad del espacio público como eje de la ciudad capaz de generar inclusión, convivencia e intercambio con otras zonas de la ciudad. Un proyecto con un tipo de acceso adecuado y con un perfil de vías siguiendo las normas establecidas permite la fácil comunicación del proyecto con la ciudad. Las vías urbanas constituyen una infraestructura con características que discurren fuera y dentro del proyecto. De ahí su complejidad. Deben satisfacer las necesidades de tráfico locales y al mismo tiempo acomodarse a las necesidades urbanas y del medio natural.

A pesar de lo anteriormente explicado, se cree que el tipo de conexión, especialmente aquel de escala barrial y la pendiente no están directamente relacionados con la calidad urbana en sí mismo pero su configuración espacial si determina la forma de desplazamiento de la población por el espacio público y por lo tanto se considera necesario contemplarlo.

\section{REFERENCIA SOBRE VALOR Y RANGO DE MEDIDA}

a) Se toman en cuenta algunas recomendaciones dadas por el Ministerio de Obras Públicas y Transporte de España en su libro Carreteras Urbanas.

Criterios a considerar en el momento de medir el tipo de conexión dada el trazado vial:

Criterios funcionales

+Jerarquías viarias y al tipo de tráfico que discurre por ella

+Eficacia de la carretera como parte de un sistema global de transporte, incluidos otros modos.

+Mejora de la seguridad de los usuarios de las vías y los peatones.

Criterios ambientales:

+niveles admisibles de ruido y contaminación atmosférica

+Afección al medio natural

+Afección al paisaje

Criterios urbanísticos: 
+Ocupación del suelo

+Mejora de accesibilidad y capacidad estructurante sobre el suelo urbano

+Pérdida de accesibilidad transversal y efectos de barrera

b) En el trabajo de Patrones urbanísticos y arquitectónicos en la vivienda dirigida a sectores de bajos ingresos en Bogotá Tarchópulos y Ceballos para comprender las relaciones de conexión de los barrios con la ciudad identifica dos tipos de conexiones según la escala: la conexión de ciudad y la conexión barrial.

La conexión a escala de ciudad

+Acceso ramal el cual consiste en una vía de penetración que se desprende de una vía de arteria y que sirve de vía de comunicación. Puede variar según el número de canales de comunicación y la distancia a la vía principal.

+ Acceso tangencial el cual se configura por medio de una comunicación directa con la vía directa debido a que colinda con ésta.
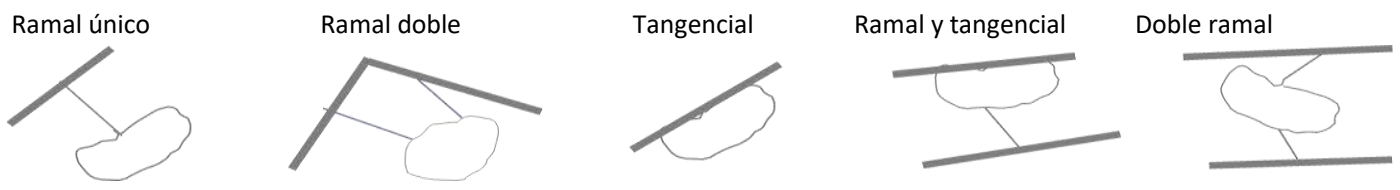

La conexión a escala barrial

Depende de las características de los puntos de intersección vial, el número de accesos y la continuidad de las vías. Se clasifica como continuo, discontinuo, combinado y aislado
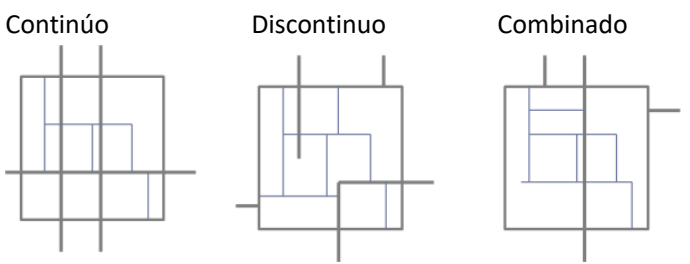

Aislado

Respecto al trazado vial, plantean tres tipos de trazados: los orgánicos, los composicional y los reticulares. Éste último presenta variaciones según el sentido que predomina en la orientación de las retículas., distinguiéndolas entre bidireccionales y multidireccionales.

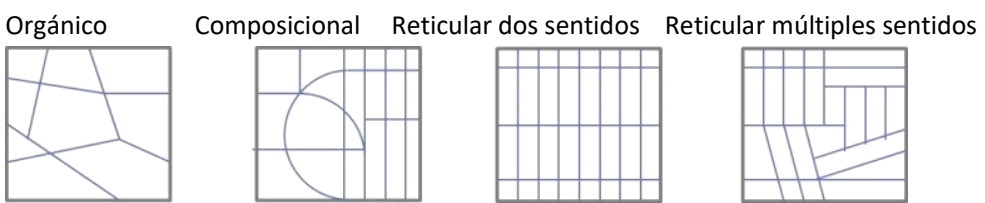

c) El trabajo de Salvador Rueda para la Red de Redes de Desarrollo Sostenible pondera la accesibilidad vial en función del ancho de las aceras y de la pendiente del trazado, para posibilitar los desplazamientos de personas con movilidad reducida.

Los requerimientos mínimos son para las aceras con un ancho mínimo de $90 \mathrm{~cm}$ y con una pendiente máxima de $5 \%$ En función de las dimensiones de las aceras y de la pendiente de los tramos, se establecen las siguientes categorías:

+Accesibilidad excelente (pendiente $<5 \%$ y aceras de más de $2,5 \mathrm{~m}$ de anchura)

+ Accesibilidad buena (pendiente $<5 \%$ y una acera de más de 2,5 metros de ancho)

+Accesibilidad suficiente (pendiente $<5 \%$ y una acera de más de 0,9 metros de ancho)

+Accesibilidad insuficiente (pendiente entre 5 y $8 \%$ y/o aceras de menos de 0,9 metros)

+Accesibilidad muy insuficiente (pendiente $>8 \%$ y/o aceras de menos de 0,9 metros).

\section{OTRAS INICIATIVAS QUE UTILIZAN ESTE INDICADOR}

Coalición Internacional del Hábitat HIC-AL (2004) Indicadores de Resultados e Impactos. Ind.72 Accesibilidad MINISTERIO DE DESARROLLO ECONÓMICO (1998) Metodología de diseño y evaluación de proyectos de vivienda de interés social. Ind.22 Accesibilidad vehicular 
- TARCHÓPULOS, Doris y CEBALLOS, Olga (2005) Patrones urbanísticos y arquitectónicos en la vivienda dirigida a sectores de bajos ingresos en Bogotá. Pag.55-56

TARCHÓPULOS, Doris y CEBALLOS, Olga (2003) Calidad de la vivienda dirigida a los sectores de bajos ingresos en Bogotá. Ind.8 Trazado 


\section{DESCRIPCIÓN}

Determinar el porcentaje de km-carril construidos, mantenidos o rehabilitados de superficie de viario peatonal y vehicular considerando su estado (pavimentado o no en adoquín, concreto o asfalto), mobiliario (postes de iluminación, bancas y papeleras) y perfil según especificaciones del POT.

\section{RANGO Y VALOR DE MEDIDA}

La superficie de viario construido, mantenido o rehabilitado para el tráfico vehicular, peatonal o de otros usos es medido porcentaje y calificado como bueno si la totalidad de sus vías están pavimentadas ( 0 puntos) y mala si menos del 75\% no lo están.

Superficie buena

$100 \%$
0 puntos

Superficie moderada

$75-99 \%$
2 2puntos

Superficie mala

\section{$<75 \%$} 4 puntos

Entra aquí en consideración también el ancho mínimo establecido para las vías de acceso de $18 \mathrm{mts}$ y de 16 mts para las vías locales. En esta valoración simplemente se especifica si cumple o no cumple. Para los proyectos de vivienda nueva se especifica adicionalmente si éstos, los perfiles, cumple o no con lo establecido en la normativa.

\section{JUSTIFICACIÓN}

La definición del grado de accesibilidad de la superficie de viario construido en función de las variables a medir, según su diseño, puede limitar o facilitar el desplazamiento de las personas con movilidad reducida. Su consideración pone de manifiesto condiciones de habitabilidad en el espacio urbano.

De acuerdo con lo propuesto por Caminos y Goethert en Elementos de Urbanización "el sistema de circulación es una de los componentes más importantes del trazado viario, no solo canaliza el movimiento de los vehículos y peatones, sino que debido a su suelo público, también determina el tipo de utilización del suelo, subdivisión y el trazado de las infraestructuras de servicios". De ahí la importancia de su estado ya no solo para la población de los barrios de estudio sino también para la ciudad misma y su mantenimiento.

\section{OTRAS INICIATIVAS QUE UTILIZAN ESTE INDICADOR}

CEPAL (2014) Aplicación de Indicadores de sostenibilidad urbana a la vivienda social. Ind. Viario público para el tráfico del automóvil y del transporte público e Ind. Viario público para el peatón y otros usos.

MINISTERIO DE DESARROLLO ECONÓMICO (1998) Metodología de diseño y evaluación de proyectos de vivienda de interés social. Ind.22 Circulación peatonal y mobiliario Urbano

PMIB-CVP (2005) Sistema Único de Monitoreo de Impacto. Ind. No. km-carril de malla vial local construidos.

TARCHÓPULOS, Doris y CEBALLOS, Olga (2003) Calidad de la vivienda dirigida a los sectores de bajos ingresos en Bogotá. Ind.9 Vías vehiculares y peatonales Ind. Estado de las vías vehiculares y peatonales 


\section{DESCRIPCIÓN}

Este indicador especifica el tipo de equipamiento con el que cuenta cada proyecto y limita la superficie territorial de cobertura de cada uno de estos, los equipamientos, de acuerdo con la escala vecinal y zonal en relación con el nivel de accesibilidad física. Mide el porcentaje de área con acceso a usos básicos requeridos para la actividad cotidiana.

\section{RANGO Y VALOR DE MEDIDA}

Para determinar las áreas de influencia de los equipamientos se establecen radios de proximidad de 5 minutos de recorrido a pie con una velocidad de $4 \mathrm{~km} / \mathrm{h}$. Para dicho cálculo se tiene en cuenta la localización de los equipamientos, su escala de cobertura y los niveles de accesibilidad.

i) Escala bloque - vecindario.

$\begin{array}{ccc}\text { Área influencia alta } & \text { Área influencia media } & \text { Área influencia baja } \\ \text { 0-300mts } & 301-600 \mathrm{mts} & >600 \mathrm{mts}\end{array}$ Con respecto al área de influencia alta, tomada como la óptima, la puntuación varía según el porcentaje de cobertura:
$100-80 \%$
$79-75 \%$
0 puntos
2 puntos
$<75 \%$
4 puntos

ii) Escala barrio - zona

Área influencia alta

Área influencia media

Área influencia baja

0-600mts

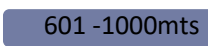

2 puntos

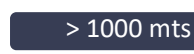

4 puntos

* Ios rangos se toman de acuerdo a estándares por la Defensoría del Pueblo

Adicionalmente se establece el grado de accesibilidad con respecto a la cantidad de equipamientos a los que una vivienda puede acceder. Así el nivel de accesibilidad será 1 cuando el área seleccionada tenga acceso a solo un equipamiento; 2 si las áreas están servidas por dos equipamientos ( $\sin$ discriminar el tipo); y el nivel será 3 cuando se cuente con el acceso a 3 equipamientos, etc.

\section{ANÁLISIS GRÁFICO ASOCIADO}

Plano de proximidad de equipamientos

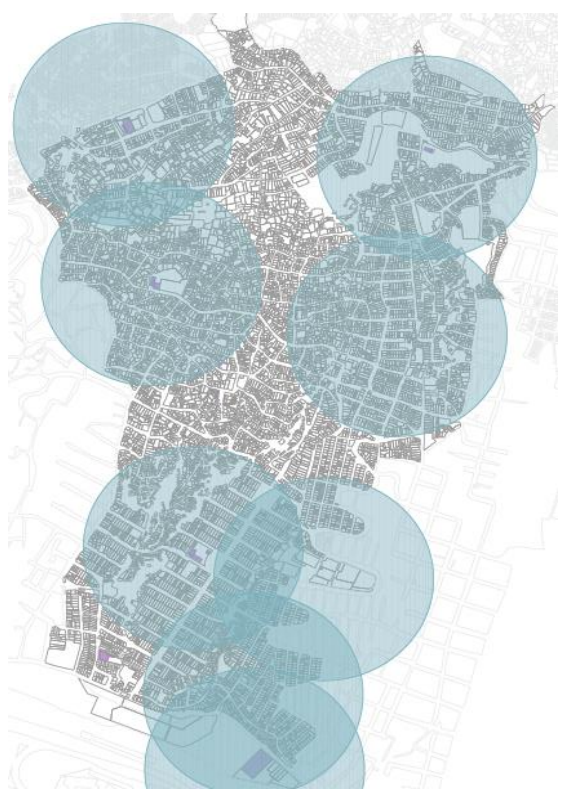

\section{TIPO DE EQUIPAMIENTO SEGÚN ESCALA A CONSIDERAR}

Escala de bloque-vecindario:

+Bienestar social (centros comunitarios, guarderías infantiles, salón comunal)

+ Centro de culto

+ Comercio local u ordinario

+Educación infantil y primaria

Escala barrio-local:

+Educación secundaria y bachillerato

+ Centros culturales y bibliotecas

+Centro de abastecimiento o comercio especializado

+ Centros de salud de primer nivel 


\section{JUSTIFICACIÓN}

La identificación de la accesibilidad diferencial a los equipamientos, tanto públicos como privados, permite reconocer el sentido y la naturaleza de los servicios colectivos requeridos para la satisfacción de las necesidades básicas de la población. Son como lo expresa Hernández-Ajá (1997) el eje que recompone o recrea una sociedad articulada que sean germen y sostén de una cultura propia, de un proyectos de vida urbano compartido por la mayoría de los habitantes en un territorio determinado.

Los equipamientos son soporte para la articulación urbana, elementos de integración social y vínculos de unión de la comunidad. Sin una distribución, localización, número y tipo de equipamientos adecuados se provoca un desequilibrio territorial y finalmente unas condiciones urbanas inadecuadas.

\section{REFERENCIA SOBRE VALOR Y RANGO DE MEDIDA}

a) Siguiendo el trabajo de Caminos-Goethert en Elementos de Urbanización los recorridos máximos de conexión con los equipamientos básicos a escala de vecindario y zonal son:

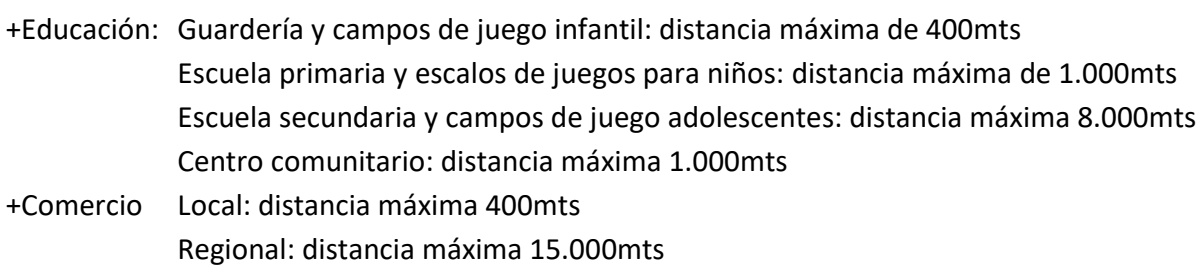

b) El trabajo de Coalición Internacional del Hábitat HIC-AL (2004) Indicadores de Resultados e Impactos especifica como rango general para acceder a los equipamientos una distancia no mayor a 400mts. Determina además unos factores a valorar:

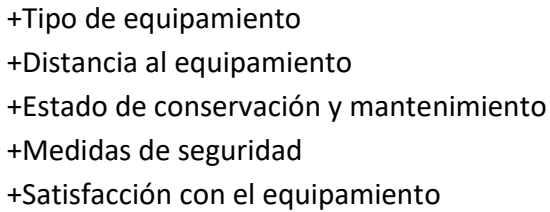

c) El sistema de indicadores propuesto por el Observatorio de Calidad para la Vivienda Nueva de la Universidad de los Andes \& Prodesa S.A. propone una proximidad óptima para los siguientes equipamientos:

+ Comercio de alto impacto inferior o igual a $2 \mathrm{~km}$

+Comercio de bajo impacto inferior o igual a $500 \mathrm{~m}$, medio de $500 \mathrm{~m}$ a $2 \mathrm{~km}$ y bajo superior a $2 \mathrm{~km}$

+Equipamientos de salud inferior o igual a $2 \mathrm{~km}$

+Equipamientos de seguridad inferior o igual a $2 \mathrm{~km}$

+Equipamientos educativos inferior o igual a $500 \mathrm{~m}$, medio de $500 \mathrm{~m}$ a $2 \mathrm{~km}$ y bajo superior a $2 \mathrm{~km}$

+Equipamientos culturales inferior o igual a $2 \mathrm{~km}$

+ Centros de recreación inferior o igual a $2 \mathrm{~km}$

+Servicios de culto inferior o igual a $2 \mathrm{~km}$

\section{OTRAS INICIATIVAS QUE UTILIZAN ESTE INDICADOR}

Coalición Internacional del Hábitat HIC-AL (2004) Indicadores de Resultados e Impactos. Ind.115-136 Tipo, distancia, estado, conservación, satisfacción y accesibilidad geográfica del equipamiento a medir. PMIB-CVP (2005) Sistema Único de Monitoreo de Impacto. Ind. 48-52 metros cuadrados y número de equipamientos construidos.

TARCHÓPULOS, Doris y CEBALLOS, Olga (2003) Calidad de la vivienda dirigida a los sectores de bajos ingresos en Bogotá. Ind.9 Vías vehiculares y peatonales e Ind. 16 Equipamientos, servicios y espacios colectivos y urbanos a escala de barrio, de zona y de ciudad.

CEPAL (2014) Aplicación de Indicadores de sostenibilidad urbana a la vivienda social. Ind. Proximidad a equipamientos y servicios básicos públicos

DEFENSORÍA DEL PUEBLO (2012) El derecho a la vivienda digna y adecuada. Ind. Área de influencia de Equipamientos 


\section{DESCRIPCIÓN}

Establece la distribución espacial y el servicio que prestan las zonas verdes, incluyendo plazas, parques, zonas de juegos infantiles, campos de juego y alamedas, a las unidades habitacionales de la actuación a medir según los requerimientos de desplazamiento y de estancia de los habitantes.

\section{RANGO Y VALOR DE MEDIDA}

Este indicador de zonas verdes útiles mide la densidad del sector determinada por el área de influencia mínima y máxima de cada uno de los espacios según su escala en un radio de $300 \mathrm{mts}$ a $700 \mathrm{mts}$ y la proporción de metros cuadrados por número de habitante.

i) Área de influencia para zonas verdes a escala de bloquevecindario.

\begin{tabular}{ccc} 
Accesibilidad alta & Accesibilidad media & Accesibilidad baja \\
0-300mts & $301-700 \mathrm{mts}$ & $>700 \mathrm{mts}$ \\
\hline
\end{tabular}

Con respecto a la accesibilidad alta, la puntuación varía según el porcentaje de cobertura:

$\begin{array}{lcc}100-80 \% & 79-60 \% & <60 \% \\ 0 \text { puntos } & 2 \text { puntos } & 4 \text { puntos }\end{array}$

ii)Proporción de área por habitante

\begin{tabular}{ccc} 
Cobertura óptima & Cobertura regulada & Cobertura deficiente \\
\hline $10-15 \mathrm{~m} 2 / \mathrm{hab}$. & $9-6 \mathrm{~m} 2 / \mathrm{hab}$. & $<6 \mathrm{~m} 2 / \mathrm{hab}$. \\
\hline 0 puntos & 2 puntos & 4 puntos \\
\hline
\end{tabular}

\section{ANÁLISIS GRÁFICO ASOCIADO}

Plano de cobertura de zonas verdes

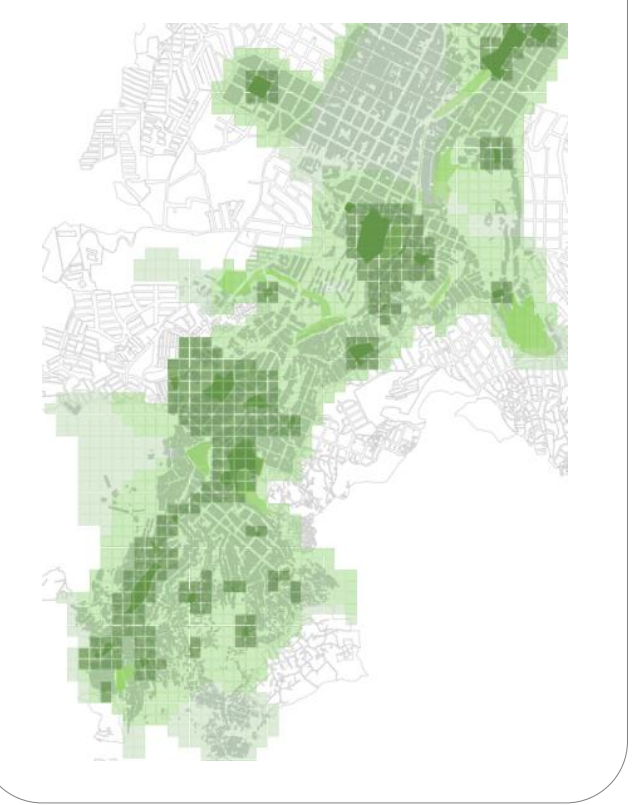

\section{JUSTIFICACIÓN}

Las zonas verdes son un elemento esencial de bienestar social vinculado a la calidad del espacio residencial y a la posibilidad de acceder a zonas de ocio y esparcimiento. Como conjunto de espacio libres debe funcionar como red, desde su concepción como soporte del tejido residencial fundamental de la ciudad, que relaciones los diferentes elementos de su sistema según las distintas escalas que lo conforman.

\section{REFERENCIA SOBRE VALOR Y RANGO DE MEDIDA}

a) La Organización Mundial de la Salud (OMS) en UN-Hábitat Urban Planning for City Leaders recomienda que la mínima área de zona verde por habitante sea de $9 \mathrm{~m}^{2}$ (lo óptimo sería $15 \mathrm{~m} 2$ ) y a menos de 15 minutos a pie.

b) Con respecto a la normativa en Colombia, los metros cuadrados de espacio público efectivo han sido modificados a través de los años. La primera normativa, dentro del periodo de estudio de la investigación, fue el Decreto 15 de 1998 por medio del cual se reglamentó el manejo del espacio público en los Planes de Ordenamiento Territorial y se estableció el promedio de $15 \mathrm{~m} 2 /$ hab. Después se elaboró el documento del Departamento Nacional de Planeación "Visión Colombia 2019" en donde se propuso otra meta diferente, una menos ambiciosa, de $10 \mathrm{~m}^{2}$ por habitante de espacio público efectivo. Y finalmente se redactó el CONPES 3718 de 2012 en donde se estableció una meta de 5 a $6 \mathrm{~m} 2 /$ hab.

c) El trabajo de la Defensoría del Pueblo establece como rangos en las áreas de influencia de parques y zonas verdes a escala de barrio como

+accesibilidad alta valores entre $0-300 \mathrm{mts}$

+accesibilidad media valores entre $301-700 \mathrm{mts}$ 
Las áreas fuera de esos rangos no las clasifica, pues se determinarían como accesibilidad baja frente a los equipamientos evaluados a escala zonal o local. Dichas áreas medirían, de otra forma, la cobertura de los parque a escala de ciudad y metropolitana.

d) La propuesta de Salvador Rueda para el Plan de Sevilla, establece la proximidad a espacio verdes según su superficie y distancia así:

+ Desplazamiento a pie de carácter cotidiano: superficie superior a $1.000 \mathrm{~m} 2$ en una distancia inferior a $200 \mathrm{~m}$

+ Desplazamiento a pie de carácter no cotidiano: superficie superior a 5.000m2 en una distancia inferior a $750 \mathrm{~m}$

+ Desplazamiento en bicicleta: superficie superior a 1.0 ha en una distancia inferior a $2.0 \mathrm{~km}$

+ Desplazamiento en trasporte público: superficie superior a 10ha en una distancia inferior a $4.0 \mathrm{~km}$

\section{OTRAS INICIATIVAS QUE UTILIZAN ESTE INDICADOR}

BID (2013) Iniciativa de Ciudades Emergentes y Sostenibles. Ind.45 áreas verdes por cada 100.000 habitantes CEPAL (2014) Aplicación de Indicadores de sostenibilidad urbana a la vivienda social. Ind. 33 Acceso de los ciudadanos a espacios verdes

Coalición Internacional del Hábitat HIC-AL (2004) Indicadores de Resultados e Impactos. Ind.113 Superficie de área verde y proximidad a espacios verdes

PMIB-CVP (2005) Sistema Único de Monitoreo de Impacto. Ind.50 Metros cuadrados de zonas verdes y parques sostenidos.

DEFENSORÍA DEL PUEBLO (2012) El derecho a la vivienda digna y adecuada. Ind. Área de influencia de equipamientos 


\section{DESCRIPCIÓN}

Caracteriza las condiciones básicas de acueducto, alcantarillado, gas y energía eléctrica en las áreas ocupadas por la actuación, partiendo de las cifras producidas por el Departamento Nacional de Estadística (DANE) sobre servicios públicos domiciliarios.

\section{(3)}

\section{RANGO Y VALOR DE MEDIDA}

La cobertura de servicios básicos domiciliarios se debe realizar superponiendo las áreas de cobertura de servicios sobre el área de actuación a analizar. Su evaluación se mide en tres rangos: cobertura buena, media y baja. Se considera que para servicios básicos como el agua, el alcantarillado y la energía la cobertura debe ser del $100 \%$ y por lo tanto será aquella que tenga 0 puntos.

Agua, Alcantarillado y Energía:

Cobertura buena

$100 \%$

0 Puntos

\begin{tabular}{c} 
Cobertura media \\
\hline $99-85 \%$ \\
\hline 2 puntos \\
\hline
\end{tabular}

\begin{tabular}{c} 
Cobertura baja \\
$>85 \%$ \\
\hline 4 puntos
\end{tabular}

La cobertura de gas natural en cambio, se calcula con unos porcentajes diferentes (basados en los estándares establecidos por La Defensoría del Pueblo) pues se considera un suministro que aún no es esencial si se cuenta con electricidad.

\begin{tabular}{|c|c|c|}
\hline Cobertura buena & Cobertura media & Cobertura baja \\
\hline $100 \%$ & $99-70 \%$ & $>70 \%$ \\
\hline 0 Puntos & 2 puntos & 4 puntos \\
\hline
\end{tabular}

+No se mide la gestión de residuos sólidos por la dificultad que representa conseguir daros estadísticos al respecto, sin embargo éste subíndice es considerado y evaluado cualitativamente según las vivistas a las zonas de estudio y a la valoración de los habitantes.

\section{JUSTIFICACIÓN}

El suministro de servicios básico es absolutamente necesario para una condición de vida adecuada, sin embargo en muchas zonas de la ciudad de Bogotá y Medellín no hay acceso a este suministro, se obtiene con cortes del servicio o con una mala calidad (interrupciones, contaminación del agua). De ahí la necesidad que todas las unidades habitacionales cuenten con él de forma regular y a un precio adecuado que la población de bajos ingresos pueda soportar.

En contexto de desarrollos marginales, el BID (Banco Interamericano de Desarrollo) ha estimado que el coste, en los programas de mejoramiento de barrio, de prever la infraestructura a cada vivienda para que se le puedan suministrar los servicios es en 2,6 el coste de un desarrollo de vivienda nueva. Incluso a zonas en donde es imposible acometer dichas obras.

\section{REFERENCIA SOBRE VALOR Y RANGO DE MEDIDA}

a) El trabajo realizado por el BID sobre Iniciativas de Ciudades Emergentes y Sostenibles propone como valores de referencia con respecto al porcentaje de hogares con conexiones domiciliarias así:

+ Agua: Cobertura óptima 90 - 100\%; Cobertura media 75 - 90\% y Cobertura baja inferior a $75 \%$

+Alcantarillado: Cobertura óptima superior a 75\%; Cobertura media $60-75 \%$ y Cobertura baja inferior a $60 \%$

+Gestión de residuos sólidos: Cobertura óptima 90 - 100\%; Cobertura media 80 - 90\% y Cobertura baja inferior a $80 \%$

+Energía: Cobertura óptima 90 - 100\%; Cobertura media 70 - 90\% y Cobertura baja inferior a $70 \%$

+Gas natural: Cobertura óptima superior a 25\%; Cobertura media 15 - 25\% y Cobertura baja inferior a 15\%

b) En los indicadores para el seguimiento de los Objetivos del Milenio se calcula el porcentaje de la población con acceso sostenible a un suministro adecuado de agua potable en su vivienda o a una distancia aceptable de la 
misma. En la Evaluación Mundial del Abastecimiento de Agua y Saneamiento del año 2000, el acceso sostenible se definió como "disponibilidad de 20 litros per cápita por día a una distancia no superior a 1.000 metros". No obstante, es difícil medir el acceso y el volumen de agua disponible, por lo que se utilizan como indicador aproximado las fuentes de abastecimiento de agua que se consideran que permiten disponer de agua potable. Pasa algo similar con el resto de servicios domiciliarios en donde se deben hacer estimados para poder obtener un dato comparable.

Ahora bien, si se tiene en cuenta el último informe realizado en el año 2015 sobre el porcentaje de población en Colombia con acceso a algunos servicios domiciliarios, se encuentran los siguientes porcentajes:

+ La proporción de la población con acceso a métodos de abastecimiento de agua adecuados (conexión a Acueducto) en la zona urbana en 2014 se encuentra una cifra cercana al 97\% en todo el país.

+la proporción de población con acceso mejorado es del $95 \%$

\section{OTRAS INICIATIVAS QUE UTILIZAN ESTE INDICADOR}

BID (2013) Iniciativa de Ciudades Emergentes y Sostenibles.

MINISTERIO DE DESARROLLO ECONÓMICO (1998) Metodología de diseño y evaluación de proyectos de vivienda de interés social. Ind.5 Disponibilidad de servicios

OBJETIVOS DE DESARROLLO DEL MILENIO

TARCHÓPULOS, Doris y CEBALLOS, Olga (2003) Calidad de la vivienda dirigida a los sectores de bajos ingresos en Bogotá. Ind.15 Conexión a redes de acueducto, alcantarillado, energía eléctrica y telefónica

UN-Hábitat (2004) Programa de Indicadores Urbano. Ind. 6 Conexiones domiciliarias 


\section{DESCRIPCIÓN}

Este indicador sobre áreas con obras de prevención o mitigación de riesgo relaciona las áreas ocupadas por las actuaciones con las zonas de riesgo antropogénico (producidas por el hombre) y naturales (propias del lugar) según las siguientes características: deslizamiento de tierras e inundaciones.

\section{RANGO Y VALOR MEDIDA}

Para su medición se localizan las zonas determinadas de riesgo por la Dirección de Prevención y Atención de Emergencias tanto de la ciudad de Bogotá como de Medellín para, posteriormente, superponerla con la zona de actuación. Así se determinan aquellas unidades habitacionales localizadas según la zona y el riesgo al que se encuentran expuestas. Dos tipos de riesgos son tenidos en cuenta en esta investigación: corrimiento de tierras e inundación.

Los rangos con los que se evalúa el porcentaje de áreas de vivienda social con mitigación de riesgo u ocupación son: alta, media y baja. Los valores pertenecientes a cada rango son:

\begin{tabular}{|c|c|c|}
\hline Ocupación/mitigación baja & Ocupación/mitigación media & Ocupación/mitigación alta \\
\hline $0-4 \%$ & $5-8 \%$ & $>9 \%$ \\
\hline 0 puntos & 2 puntos & 4 puntos \\
\hline
\end{tabular}

\section{JUSIFICACIÓN}

La construcción sobre áreas vulnerables es una de las condiciones críticas de los asentamientos de origen marginal, pero no exclusivamente de ellos. Se encuentran también proyectos desarrollados con vivienda nueva sobre este tipo de terrenos. Los riesgos de edificar sobre estas zonas comprometen las condiciones físicas y de vida de los propios pobladores. De allí su importancia de reconocer y delimitar estos espacios para que no sean ocupados o sean desalojados por la población que allí habita.

\section{REFERENCIA SOBRE VALOR Y RANGO DE MEDIDA}

Por su consideración trascendental, los valores de este apartado, deberían ser sin matices para unos rangos deseables igual al $0 \%$ del territorio ocupado. Sin embargo, considerando que existen rangos dentro de los riesgos a determinar se toman como referencia los porcentajes asumidos por la iniciativa realizada por la Defensoría del Pueblo.

a) La iniciativa de indicadores del BID en su ámbito de Sostenibilidad ambiental y cambio climático mide por un lado, la existencia de planes de mitigación, planes de respuesta y mapas de riesgo a escala adecuada para los principales peligros que amenazan la ciudad, y por otro lado, la vulnerabilidad en porcentaje de hogares en riesgo debido a los materiales de su vivienda o a su ubicación en área con riesgo no mitigable. Para este último ámbito, los valores que utiliza son:

+Porcentaje de hogares en riesgo alto. Superior al $20 \%$

+Porcentaje de hogares en riesgo medio. 10 - $20 \%$

+Porcentaje de hogares en riesgo bajo. Inferior a $10 \%$

\section{OTRAS INICIATIVAS QUE UTILIZAN ESTE INDICADOR}

BID (2013) Iniciativa de Ciudades Emergentes y Sostenibles. Ind.40 Porcentaje de hogares en riesgo debido a construcción inadecuada o ubicación en áreas con riesgo no mitigable

PMIB-CVP (2005) Sistema Único de Monitoreo de Impacto. Ind.54 Número de hogares reasentados e Ind.55 Número de obras de prevención o mitigación de riesgos

UN-Hábitat (2004) Programa de Indicadores Urbano. Chek-list 5 Prevención de Desastres e instrumentos de mitigación

DEFENSORÍA DEL PUEBLO (2012) El derecho a la vivienda digna y adecuada. Ind. Áreas ocupadas por VIS o VIP en zonas de riesgo e índice de mitigación 


\section{DESCRIPCIÓN}

El indicador sobre tipología edificatoria y cumplimiento de condiciones mínimas espaciales determina la tipología y las condiciones básicas espaciales de las viviendas y su entorno para la población, según el POT, con respecto a:

i) área y frente de las parcelas en cualquier tipo de tratamiento, y área y frente de la solución habitacional según normativa para el tratamiento de desarrollo de vivienda nueva.

ii) forma y disposición de lo construido

\section{RANGO Y VALOR DE MEDIDA}

i) El área y frente de las parcelas se mide según las condiciones mínimas establecidas por la ley para los desarrollos de vivienda nueva. Para los desarrollos marginales, aun cuando se sabe que no deben seguir dichas especificaciones, se toman los mismos tangos para obtener unos datos semejantes.

Lo establecido por ley es vivienda unifamiliar $54 \mathrm{~m}^{2}=$ frente de $4.5 \mathrm{mts} x$ fondo $12 \mathrm{mts}$ de

$$
\text { Vivienda multifamiliar } 216 \mathrm{~m}^{2}=\text { fondo de } 8 \mathrm{mts}
$$

De este modo, para establecer los valores de cada rango se toma el valor establecido por ley, como el valor medio (2puntos). Todas las parcelas con un área superior tendrán 0 puntos y las parcelas con área inferior a la norma tendrán 4 puntos, así:

Cumplimiento alto

$>60 \mathrm{mts}$

Cumplimiento normativo

0 puntos

\begin{tabular}{ccc}
$>60 \mathrm{mts}$ & $50-60 \mathrm{mts}$ & $<50 \mathrm{mts}$ \\
\hline 0 puntos & 2 puntos & 4 puntos \\
\hline
\end{tabular}

Cumplimiento bajo

\section{RANGO Y VALOR DE MEDIDA}

ii) Forma y disposición de lo construido

Dado la dificultad por determinar el grado de adecuación de los procesos morfológicos o tipológicos, éste subindicador evalúa el grado de ocupación de la manzana bajo el rango de bueno, medio y bajo dependiendo de la concentración o dispersión de las manzanas y la continuidad interna del trazado viario.

\begin{tabular}{|c|c|c|}
\hline bueno & medio & bajo \\
\hline 0 puntos & 2 puntos & 4 puntos \\
\hline
\end{tabular}

Así mismo, dentro de este sub-indicador se tiene en cuenta las condiciones de las rutas de circulación públicas:

+Andenes continuos y a nivel de mínimo 0.90mts sin obstáculos con los predios colindantes y tratados con materiales duros y antideslizante.

+Rampas para superar los cambios de nivel con un ancho mínimo de $0.90 \mathrm{mts}$ (1.20mts recomendado) con una pendiente máx. de 1.12

+Islas o pasos peatonales con dimensiones $1.50 \mathrm{mts} x$ $1.50 \mathrm{mts}$

\section{ANÁLISIS GRÁFICO ASOCIADO}

Plano de morfología urbana

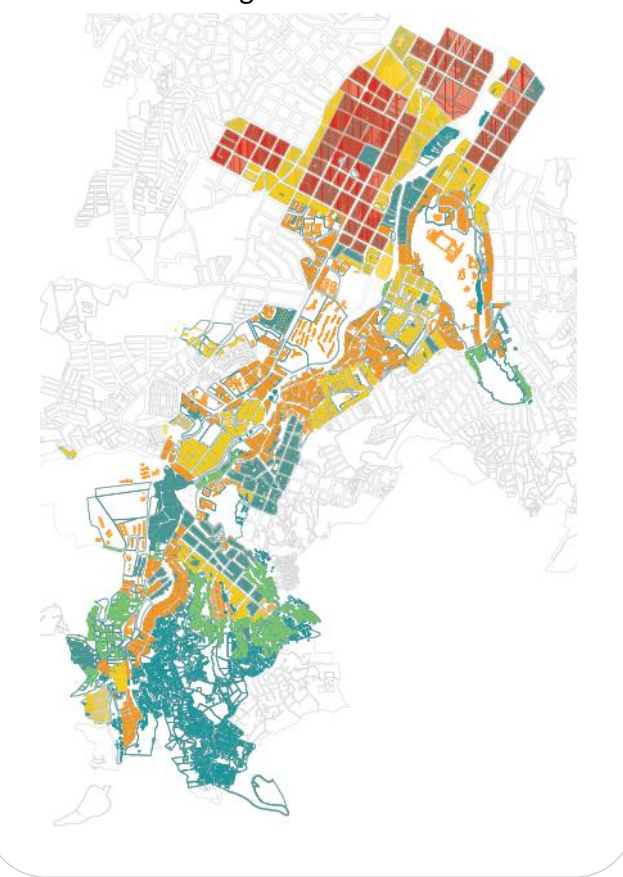

\section{CONSIDERACIONES}

Para apoyar la valoración de la forma y la disposición de lo construido se tienen en cuenta los datos sobre

+ Densidades. Analizados en el indicador número 101

+ Las alturas de las construcciones (datos extraídos de las visitas de campo y los diagnósticos institucionales sobre los estudios de caso

+ La tipología edificatoria construida

+ Las condiciones ambientales y topográficas evaluadas en el indicador número 109 
+ La conexión y trazado de vías medido en el indicador número 105

+la morfología urbana determinada por el tejido residencial según su producción, normal o marginal, y su condición de orgánica, reticular o mixta.

\section{JUSTIFICACIÓN}

En los modelos de crecimiento urbano en necesarios identificar la funcionalidad de la propuesta con respecto a la continuidad urbana determinada por la configuración de las manzanas, las parcelas y los bloques. De su configuración dependerá en gran medida, que el desarrollo de los tejidos urbanos sea más o menos favorable o adecuado para una articulación a nivel local o de ciudad con el resto del territorio.

\section{REFERENCIA Y RANGO DE MEDIDA}

a) En el trabajo de Patrones urbanísticos y arquitectónicos en la vivienda dirigida a sectores de bajos ingresos en Bogotá Tarchópulos y Ceballos especifican la disposición de lo construido, distribución y ocupación de la manzana y la parcela, respecto al territorio ocupado. La clasificación, de acuerdo a la concentración o la dispersión de las manzanas y la continuidad interna del trazado viario, que proponen es:

Continua

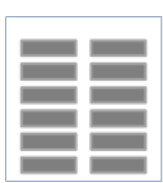

Discontinua

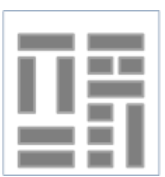

Irregular

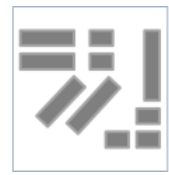

Dispersa

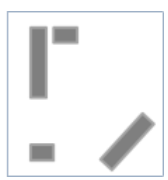

\section{OTRAS INICIATIVAS QUE UTILIZAN ESTE INDICADOR}

MINISTERIO DE DESARROLLO ECONÓMICO (1998) Metodología de diseño y evaluación de proyectos de vivienda de interés social. Ind.25 Nivel de accesibilidad de población infantil, tercera edad y minusvalía e Ind. 35 Solución de la estructura

UN-Hábitat (2004) Programa de Indicadores Urbano. Ind. 2 Área suficiente para vivir y Check-list 1 Derecho a una vivienda adecuada MINISTERIO DE DESARROLLO ECONÓMICO (1998) Metodología de diseño y evaluación de proyectos de vivienda de interés social. Ind.19 Dimensión de lotes individuales

- TARCHÓPULOS, Doris y CEBALLOS, Olga (2005) Patrones urbanísticos y arquitectónicos en la vivienda dirigida a sectores de bajos ingresos en Bogotá. Pag.57 


\section{DESCRIPCIÓN}

En este indicador de complejidad urbana establece la diversidad de usos y rentas conformadas en las intervenciones de vivienda social. Dos variables son tenidas en cuenta, los usos mixtos para identificar los diferentes lugares de mayor concentración de actividades de la población y la mezcla de rentas de la población para medir el grado de cohesión social.

\section{RANGO Y VALOR DE MEDIDA}

i)Mezcla de rentas

Según el Departamento Nacional de Estadística -DANE- "La estratificación socioeconómica es el mecanismo que permite clasificar la población en distintos estratos o grupos de personas que tienen características sociales y económicas similares, a través del examen de las características físicas de sus viviendas, el entorno inmediato y el contexto urbanístico de las mismas". Como indicador permite medir el grado de integración o segregación de la población del proyecto a analizar.

Para medirlo se establecen tres rangos de medida: presencia alta, media y baja de porcentaje de cada estrato social.

\begin{tabular}{ccc} 
Presencia alta & Presencia media & Presencia baja \\
\hline$>25 \%$ & $13-24 \%$ & $0-12 \%$ \\
\hline 0 puntos & 2 puntos & 4 puntos \\
*Los rangos se toman de acuerdo a estándares establecidos por la defensoría del Pueblo & \\
\hline
\end{tabular}

\section{RANGO Y VALOR DE MEDIDA}

ii) Mezcla de usos

La reserva mínima de usos no residenciales permite garantizar valores mínimos de complejidad urbana que doten el espacio de mayor funcionalidad. Interesa medir aquí, dado que ya se evaluaron en otros indicadores las áreas de los otros usos referidos al espacio residencial, el reparto entre las actividades económicas y residenciales. Como medida idónea se establece que debe existir un $80 \%$ de área residencial y un $20 \%$ de área comercial.

\begin{tabular}{|c|c|c|}
\hline $\begin{array}{l}\text { Presencia alta de } \\
\text { comercio }\end{array}$ & $\begin{array}{c}\text { Presencia media } \\
\text { de comercio }\end{array}$ & $\begin{array}{c}\text { Presencia baja } \\
\text { de comercio }\end{array}$ \\
\hline$>23 \%$ & $17-23 \%$ & $0-12 \%$ \\
\hline
\end{tabular}

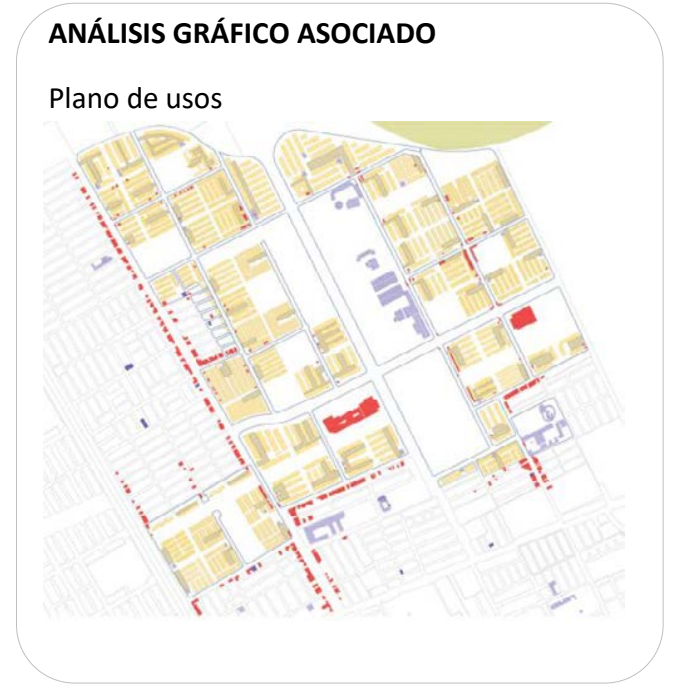

\section{JUSTIFICACIÓN}

La evaluación de las condiciones de la población habitante y sus necesidades en cuanto a actividades a realizar en el tejido urbano permite garantizar la mayor probabilidad de intercambio de funciones del espacio residencial y por lo tanto de la calidad que éste ofrezca. La convivencia entre diversos grupos de personas complementado por diferentes tipos de espacio dentro del tejido urbano se cree enriquece el espacio residencial y el espacio público con el fomento de múltiples ritmos, actividades o trayectorias, entre otros, entre lo público y lo privado.

Como lo expone Salvador Rueda la complejidad, que atiende el grado de mixticidad de usos y funciones, está ligada a una cierta mezcla de orden y desorden, mezcla íntima que en los sistemas urbanos puede analizarse, en parte, haciendo uso del concepto de diversidad. La estrategia urbana para analizarlo es aquella que busca el equilibrio entre usos y funciones urbanas a partir de la definición de los condicionantes urbanísticos.

La utilidad de generar esta diversidad en el territorio es, entre otros muchos, de aproximar a las personas a sus lugares de trabajo, los servicios, y los centros de interés. Como dimensión por lo tanto está estrechamente ligada a otros indicadores como lo son, los de proximidad de equipamientos, centralidades o tiempos de desplazamiento. 


\section{REFERENCIA Y RANGO DE MEDIDA}

a) Luis Moya en el capítulo "Optimización de las Promociones. Tamaño y Características" del libro Vivienda Reducida (Ed. Mairea, Madrid. 2007), insiste en la idea de la complejidad a partir de un escenario urbano diverso y continuo que acoja, sin distinción, a todo ciudadano. Considera que deberían existir pequeñas actuaciones que se vayan insertando en la trama y vayan proporcionando unos espacios y ambientes ricos, heterogéneos y armoniosos a la ciudad.

\section{OTRAS INICIATIVAS QUE UTILIZAN ESTE INDICADOR}

CEPAL (2014) Aplicación de Indicadores de sostenibilidad urbana a la vivienda social. Ind. 18 Reparto entre actividad y residencia 


\section{EL ANÁLISIS MORFOLÓGICO DEL ESPACIO RESIDENCIAL}

Estructura urbana y ordenación

Dotaciones y servicios públicos

Condiciones ambientales

Oferta y configuración del conjunto habitacional

Síntesis transversal y conclusiones parciales 


\section{EL ANÁLISIS MORFOLÓGICO DEL ESPACIO RESIDENCIAL}

En este capítulo se presentan las características particulares que determinan la calidad del espacio residencial para la población de bajos ingresos en los seis estudios de caso analizados en la ciudad de Bogotá y Medellín, bajo el modelo de análisis conceptual y operativo antes desarrollado. Supone la puesta en práctica de los indicadores establecidos para verificar su utilidad en la proporción de información sobre los proyectos evaluados.

Hay que recordar que la intención es comparar la configuración del espacio producido en los desarrollo de vivienda nueva frente a los de mejoramientos de barrio. El objetivo se centra en analizar la configuración habitacional de cada uno de ellos, de cada tipo de producción, y no en la confrontación sobre la gestión, planeación o desarrollo institucional promovido por cada ciudad (aun cuando ésta posteriormente sea inevitable de mencionar). No se trata de hacer competir a las dos ciudades principales en Colombia sobre sus actuaciones en la vivienda social. Se trata de comparar el modelo de ciudad que se configuran en cada uno de los dos tipos de producciones de vivienda ${ }^{106}$. Su puesta en práctica supone una buena información de cada ciudad para una posible toma de decisiones sobre sus estrategias urbanas, sobre su evolución y sobre sus problemas a solucionar.

Es preciso mencionar también que la aplicación del modelo de evaluación, si bien se basa en elementos cuantitativos para homogenizar y relativizar las diferentes dimensiones a medir, éstos van acompañados de comentarios adicionales, datos básicos o elementos cualitativos que se consideran aportan una aproximación más detallada, y quizás acertada, sobre el análisis. Con ello se evidencia que, en ocasiones, la complejidad de obtener ciertos datos o de desagregar varios de ellos al nivel deseado para una posible comparación resulta una tarea espinosa. (Más aun cuando se habla de proyectos planificados enfrentados a proyectos no planificados.)

A continuación, se presentan según lo planteado los resultados obtenidos bajo las tres escalas analizadas: ciudad, barrio y bloque. Ello, recordando de nuevo, que los desarrollos de vivienda se asumen como componentes de un conjunto urbano del cual dependen y se relacionan, y por lo tanto que su examen por escalas es simplemente operativo.

Por último, cabe resaltar que la aplicación del modelo supone un diagnóstico en sí mismo para cada proyecto que es fácilmente visible en la cartilla con los seis estudios de caso analizados. EI documento se convierte así en un instrumento válido para la puesta en realidad de las condiciones de la vivienda social en Colombia. Instrumento, que como siempre se ha reiterado, no se da por concluido y menos aún exento de posibilidades de mejora o de seguir construyéndose en futuras investigaciones.

\footnotetext{
${ }^{106}$ Es necesaria la acotación, pues en las dos principales ciudades de Colombia ha existido desde hace tiempo ya una rivalidad de carácter económico, político, social, cultural por establecer qué ciudad "lo hace mejor". Esta disputa no interesa en este trabajo de investigación; interesa centrarse en cómo desde diferentes formas de actuar en materia de vivienda social, es decir en materia de políticas habitacionales, ordenamiento territorial, economía urbana, se está produciendo el espacio residencial para la población con menos ingresos y posibilidades.
} 


\subsection{ESTRUCTURA URBANA Y ORDENACIÓN}

Para comprender la configuracion del alojamieto social en relacion con su estructura urbana, se examinaron los tres primeros ámbitos del modelo de análisis sobre ocupación del suelo, accesibilidad y movilidad. Así con la aplicación de cada uno de los indicadores se logró analizar el desarrollo de dichos proyectos a nivel de ciudad.

\subsubsection{Ocupación del suelo}

En el primer indicador analizado sobre la ocupación del suelo, las densidades, se constató que los proyectos de origen normal presentan unas densidades mas altas que los de origen marginal, con una media para los primeros de 166viviendas por hectares y para los segundos de 85 viviendas/hectárea. Siendo para los dos casos de produccion de vivienda una densidad considerablemente alta ( la media se estableció en 60viviedas/hectárea). La diferencia radica en que para los proyectos de origen formal la densidad era la misma en todo su territorio mientras que las densidades en los barrios de oirgen marginal dependian de la consolidación de su tejido. Así entre menos consolidado estuviera menos viviendas se encontraban por hectárea. Tal fue el caso de PUI Centroriental, PUI Nororiental o MIB Sur Con Bogota, en donde se hallaron 30viviendas/hectárea.

Se demuestra así lo planteado en el primer capítulo, sobre las dos modalidades de densidad constatadas en el territorio colombiano. La primera modalidad dada por la edificaciones de mayor altura, cambio de norma y presión del mercado inmobiliario, ejemplificada en los proyectos de desarrollo de vivienda nueva. Y la segunda, dada por la ocupación total de la parcela mediante un desarrollo progresivo en los barrios de origen marginal.

Grafico 16101 Densidades urbanas. Comparativa estudios de caso

\begin{tabular}{l}
\hline DESARROLLO VIVIENDA NUEVA \\
\hline CIUDADELA NUEVO OCCIDENTE
\end{tabular}

Elaboración propia

Ahora bien, en contextos de vivienda para la poblacion de bajos ingresos es necesario plantearse la evolución en el tiempo de las unidades habitacionales para los dos tipos de gestión. Tanto en la producción formal como en la marginal, las viviendas terminan albergando varios uso, subdividiendose, aumentando el número de hogares por vivienda y por lo tanto, terminan colmatando su estructura y su capacidad de soporte en relacion con la infraestructura pública o los servicios básicos domiciliarios. Lo que tiene, como es evidente, implicaciones a nivel urbano y en la calidad de la vivienda misma. Es por ello, que las decisiones sobre le modelo tipológico y la configuracion de manzana es crítica en relacion a los 
desarrollos de vivienda nueva, especialmente en le caso de Bogotá. La supuesta búsqueda de la utilización eficiente del suelo público disponible para impulsar proyectos de vivienda de bajo costo ha permitido la construcción de barrios en los que las densidades sobre las áreas brutas son mucho mayores que la media de las dos ciudades ya altamente densificadas (Bogotá al año 2010, 67.4viviendas/hectárea y Medellín 62,2viviendas/hectárea)

Por otro lado, al hacer una revision de las densidades que se han consolidado en los casos de estudio, se percibió que es esencial mirar en paralelo las densidades de poblacion en el mismo territorio. La valoracion de la densidad esta estrechamente ligada con el tamaño familiar y la cantidad de hogares que habitan una misma vivienda. No son iguales las necesidades de un territorio de 40viviendas/hectárea con 100 habitantes que un territorio de 40viviendas/hectárea con 50 habitantes. Esto se manifiesta, por ejemplo, en dos desarrollos que tienen una densidad similar, MIB Sur Con Bogota con 55,89vivviendas/ hectárea y PUI Centroriental con 53viviendas/hectárea pero con casi 100 habitantes de diferencia por hectárea.

Tabla 15 Densidades de población. Comparativa estudios de caso

\begin{tabular}{lclc}
\hline \multicolumn{2}{c}{$\begin{array}{c}\text { DENSIDADES DESARROLLO DE VIVIENDA NUEVA } \\
\text { (hab/área bruta) }\end{array}$} & \multicolumn{2}{c}{$\begin{array}{c}\text { DENSIDADES MEJORAMIENTO DE BARRIO } \\
\text { (hab/área bruta) }\end{array}$} \\
\hline Ciudadela El Porvenir & 407hab/ha unifamiliares & MIB Sur con Bogotá & $312,78 \mathrm{hab} / \mathrm{ha}$ \\
& $872,47 \mathrm{hab} /$ ha multifamiliares & MIB EI Lucero & $229,37 \mathrm{hab} / \mathrm{ha}$ \\
& & (API El Lucero) & $215 \mathrm{hab} / \mathrm{ha}$ \\
Ciudadela Nuevo Occidente & $524,99 \mathrm{hab} /$ ha multifamiliar & PUI Nororiental & $543 \mathrm{hab} / \mathrm{ha}$ \\
& & PUI Centroriental & $235 \mathrm{hab} / \mathrm{ha}$ \\
\hline
\end{tabular}

Con respecto, entonces a la cantidad de habitantes, existen tambien diferencias comparado los dos tipos de gestión. La vivienda formal sigue siendo la que cuenta con una densidad mas alta (mas de 400habitantes/hectárea en todos los casos. El doble frente a la gestion de origen marginal). Aquí, si se sigue lo planteado por Caminos y Goether (1985) que consideran que para contexto de bajos y medianos niveles de renta, aparecen conflicto o condiciones físicas inadecuadas si se llegan a densidades de 200habitantes/hectárea y a una saturación cuando hay mas de 600habitantes/hectárea, es evidente que por lo menos unas condiciones físicas inadecuadas estan aseguradas en todos los casos de estudio.

Sin embargo, hay otra consideración a tener en cuenta en relacion a la densidad, es el hacinamiento. Aun cuando la densidad urbana hace referencia al número de personas que residen en una parte del territorio o área específica de la ciudad y que el hacinamiento crítico está conceptualizado como el número de personas por habitaciones para dormir, las necesidades o los requerimientos a nivel físico y de ciudad (vías, parques, andenes, coliseos, colegios, administración pública, etc.) para una determinada cantidad de habitantes será la misma. Asi con respecto a los estudios de caso, ésta resulta mas alta para los asentamientos de origen marginal aparentemente según los datos refrentes a su localidad -límite administrativo( no se tiene datos con respecto a cada estudio de caso). La localidad de San cristobal (MIB Sur Con Bogota) tiene por ejemplo 5,9\% de hacinamiento miestras que El Porvenir tiene 3,7\% De este modo, según se observa en el indicador 111 el número de personas habitando una vivienda de origen marginal suele ser mayor ( 6 miembros por vivienda) que una vivienda de origen formal ( 4.5 personas por vivienda). 
Tabla 16 Número de personas por vivienda. Comparación estudios de casos

\begin{tabular}{|c|c|c|c|}
\hline \multicolumn{2}{|c|}{ DESARROLLO DE VIVIENDA NUEVA } & \multicolumn{2}{|c|}{ MEJORAMIENTO DE BARRIO } \\
\hline Ciudadela El Porvenir & 4.75 personas por vivienda & MIB EI Lucero & 6.26 personas por vivienda \\
\hline & & PUI Nororiental & 4.6 personas por vivienda \\
\hline Ciudadela Nuevo & 1 personas: $3 \%$ & PUI Centroriental & 1 personas: $5 \%$ \\
\hline \multirow[t]{4}{*}{ Occidente } & 2 a 4 personas: $53 \%$ & & 2 a 4 personas: $38 \%$ \\
\hline & 5 a 7 personas: $33 \%$ & & 5 a 7 personas: $30 \%$ \\
\hline & 8 a 10 personas: $7 \%$ & & 8 a 10 personas: $25 \%$ \\
\hline & >11 personas: $4 \%$ & & $>11$ personas: $2 \%$ \\
\hline
\end{tabular}

Fuente: DAP (2009) Documento de Soporte COR; Velásquez (2011) y DANE (2007) Encuesta de calidad de vida - Bogotá 2007. Bogotá

En este sentido, la densidad urbana refleja de mejor manera el componente macro de las políticas urbanas y el hacinamiento, por su parte, el componente micro. De ahí que sea importante reconocer los procesos de urbanización de cada ciudad y las condiciones de esos procesos que las determinan.

Tabla 17 Porcentaje de la población en hacinamiento crítico. Comparación estudios de casos

\begin{tabular}{|c|c|c|c|c|c|}
\hline \multicolumn{2}{|c|}{ HACINAMIENTO DESARROLLO DE VIVIENDA NUEVA } & \multicolumn{4}{|c|}{ HACINAMIENTO MEJORAMIENTO DE BARRIO } \\
\hline \multirow[t]{2}{*}{ Ciudadela El Porvenir } & \multirow[t]{2}{*}{ Localidad de Bosa 3,7\% } & MIB Sur con Bogotá & \multicolumn{3}{|c|}{ Localidad San Cristobal $\quad 5,9 \%$} \\
\hline & & MIB EI Lucero & \multicolumn{3}{|c|}{ Localidad Ciudad Bolivar 5,1\% } \\
\hline Ciudadela Nuevo & Corregimiento San Cristobal & PUI Nororiental & Comuna 1 & $3,63 \%$ & \\
\hline \multirow[t]{3}{*}{ Occidente } & $3,99 \%$ & & Comuna 2 & $3,91 \%$ & \\
\hline & & PUI Centroriental & Comuna 8 & $4,16 \%$ & \\
\hline & & & Comuna 9 & $4,63 \%$ & \\
\hline
\end{tabular}

Fuente: Indicador de Calidad de Vida para Medellín 2013 y Encuesta Multipropósito para Bogotá 2011

En conclusion, con respecto a este indicador, para el caso de las dos ciudades colombianas parecería poco deseable promover densidades altas desde el inicio de los proyectos, en este caso en aquellos que se puede manejar, es decir en los de desarrollo de vivienda nueva o vivienda nueva en los mejoramientos de barrio. En el alojamiento social se ha demostrado que el modelo habitual o las practicas de ocupacion de la población seran, por diversos motivos, de densificar o colmatar aun mas el espacio. Por ello es importante comprender la incidencia que tiene la densidad sobre el funcionamiento y la sostenibilidad del territorio; en definitiva sobre la calidad del espacio. Habría entonces por garantizar, desde la normativa, unos máximos urbanizables.

- En el segundo indicador examinado sobre la estructura urbana, las cesiones, se percibió que en los barrios de origen marginal se presentaron proporciones significativamente menores de cesiones públicas, especialmente en equipamientos y zonas verdes, que en los barrios de origen institucional. Los dos casos extremos son Ciudadela Nuevo Occidente con $47,48 \%$ de su territorio destinado para este fin y PUI Centrorientak con $25,9 \%$. No obstante, debido a las altas densidades alcanzadas por los barrios formales y a la falta o postergada construcción de sus equipamientos y áreas verdes, la relacion de área de cesión publica por vivienda se invierte (para el caso de El Porvenir que pasa a ser la de menor proporción con $6,59 \%)$ o practicamente se iguala para el caso de Ciudadela Nuevo Occidente $(34,23 \%)$ y el proyecto Sur con Bogotá $(29,87 \%)$.

Con respecto a la normativa, los dos proyectos formales rozaron lo permitido. Para la Ciudadela El Porvenir, por ejemplo, lo establecido por ley eran $17 \%$ del área neta en zonas 
verdes ( $15,99 \%$ del área bruta) y el $8 \%$ (7,53\% del área bruta) en equipamientos y el proyecto matematicamente siguió esos porcentajes. Allí no se construyó, cuando se realizó, ni un metro cuadrado mas de parques, plazas o colegios. Lo que lleva con seguridad a pensar que el proyecto respondió mas a unas demanas concretas relacionadas con el tema de la rentabilidad de la construccion de la vivienda que de las necesidades de los habitantes.

De lo anterior, se puede señalar entonces que el modelo de ciudad establecido por los POT para la producción formal con la exclusion o incremento de las densidades y el uso de la agrupación o cambio tipológico de edificación y el aumento, mínimo, en las cesiones, no estuvo ligado a un componente de tipo técnico sino a uno de tipo económico. No se buscó en ningun caso, relamente encontrar un equilibrio entre el espacio privado (cada vez mas reducido y colmatado) y el público. No se presentó una compensación como se pretendía. Simplemente resultaron espacio deficientes tanto en el ámbito urbano como en el arquitectónico.

Grafico No. 17102 Cesiones en porcentaje. Comparativa estudios de caso

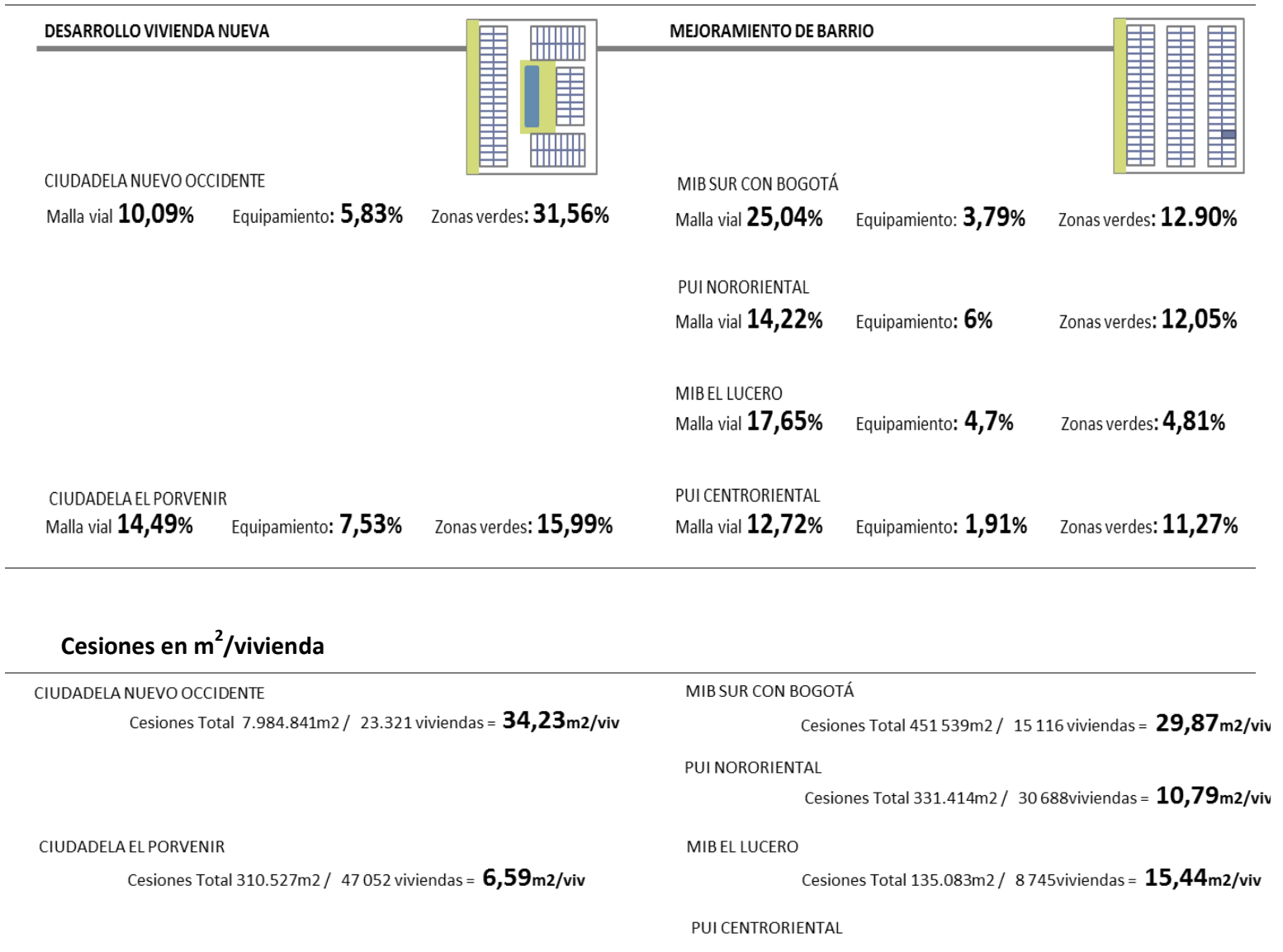

Cesiones Total $196.959 \mathrm{~m} 2 / 13.597$ viviendas $=\mathbf{1 4 , 4 8} \mathbf{m} / \mathbf{v i v}$

De lo anterior, se puede señalar entonces que el modelo de ciudad establecido por los POT para la producción formal con la exclusion o incremento de las densidades y el uso de la agrupación o cambio tipológico de edificación y el aumento, mínimo, en las cesiones, no estuvo ligado a un componente de tipo técnico sino a uno de tipo económico. No se buscó en ningun caso, relamente encontrar un equilibrio entre el espacio privado (cada vez mas reducido y colmatado) y el público. No se presentó una compensación como se pretendía. 
Simplemente resultaron espacio deficientes tanto en el ámbito urbano como en el arquitectónico.

En cuanto a la ubicación, delimitación e implantacion de dichas cesiones, en general se observó que en los proyetos de origen formal las áreas de zonas verdes y equipamientos estan, como lo establece la ley, agrupadas en torno a las viviendas. Éstas se han propuesto como pequeñas centralidades que reúnen el comercio, los equipamientos educativos, culturales o de transporte y los espacios públicos de ocio y circulación. En cambio, en los asentamientos de origen marginal, como es obvio por su proceso de configuración, estas zonas se dan de forma dispersa en el territorio, en espacios residuales u ocupandos en una parcela cualquiera sin relacion alguna de red o articulación con el espacio privado. Condición que intenta ser modificada con la intervención de mejoramiento pero que no siempre es lograda. El espacio público se construye allí donde se logra abrir camino. Su permeabilidad, por ende, al igual que para los desarrollos de vivienda nueva, es lograda por medio de vias vehiculares de acceso salvo en aquellos caso extremos en donde la malla vial es desarticulada y precaria.

Con respecto a las cesiones privadas dentro de manzana para los barrios de origen normal se presentan dos tipos de configuración o uso de estas áreas: Unas son empleadas como zonas de aparcamiento al lado de la vía pública, como es el caso de Ciudadela Nuevo occidente, o dentro de la manzana misma contigua a dichas vías vehiculares como es el caso de Ciudadela El Porvenir. Y otras, son resultantes de la distribución de la manzana o de la parcela después de ubicar las edificaciones. Estas cesiones son por lo general sin definición o formal alguna. Son consecuencias de lo que sobra. Lo que demuestra claramente un desdeño por un patrimonio urbano vital que podría fácilmente resolver algunos estándares sobre la calidad de vida urbana de los habitantes de la ciudad.

\subsubsection{Accesibilidad}

En el tercer indicador, éste ya relacionado con la accesibilidad de la población a las centralidades de la ciudad, se calcularon los tiempos de desplazamiento en transporte público y a pie para llegar a dichos centros. La primera constatación que se observó es que los únicos proyectos que cuentan con una centralidad a escala zonal, relativamente consolidada, dentro de su territorio son la Ciudadela Nuevo Occidente y PUI Nororiental. Los otros cuatro proyectos no cuentan con una zona de estas características o bien por que no se ha construido aun la infraestructura o dotaciones del caso o porque no existe un interes por parte de la administración de desarrollar dicha zona. En estos últimos casos, se han creado unas centralidades a escala de barrio configurada por la propia población que ha modificado sus viviendas con la implantación de nuevos usos: guarderias, farmacias o comercio cotidiano entre otros.

Cotejando ahora el tiempo de desplazamiento de la población hasta la centralidad a escala zonal más próxima, se evidenció que dicha condicion de tener o no en su territorio una zona de estas caracteríticas, no garantiza del todo a la población una adecuada accesibilidad. El recorrido que los habitantes del Ciudadela Nuevo Occidente o del PUI Centroriental deben realizar supera los 40 minutos a pie y los 20 minutos en transporte público para el caso del PUI; la ciudadela no cuenta con un sistema de transporte público dentro de su territorio mas que 
una parada del metrocable. Los dos proyectos mas alejados de las centralidades son el proyecto MIB Sur Con Bogotá y MIB EI Lucero; en ellos los habitantes se tiene que desplazar a pie de $1 \mathrm{~h}: 40 \mathrm{~min}$.

La consecuencia de esta accesibilidad regular y deficiente demuestra, como es evidente, una ciudad descompensada, en la que los costos mas altos de desplazamiento estan a cargo de la población que mas dificultades tiene para pagarlo. Son estos habitantes, los de la vivienda social en la periferia, lejos de cualquier centro laboral, los que deben invertir más recursos para llegar a su trabajo, limitando su capacidad de producción y sus posibilidades de movilidad social. Cómo es posible que los proyectos de vivienda nueva, con mas de 100.000 habitantes cada uno no cuenten o no se haya construido aun una centralidad, no de escala zonal, sino de ciudad. Qué calidad urbana se le puede ofrecer a un morador que deba desplazarse $45 \mathrm{~min}$ a pie para poder llegar a único centro de actividad.

\section{Grafico No 18. 103 Centralidades y tiempos de desplazamiento. Comparativa estudios de caso}

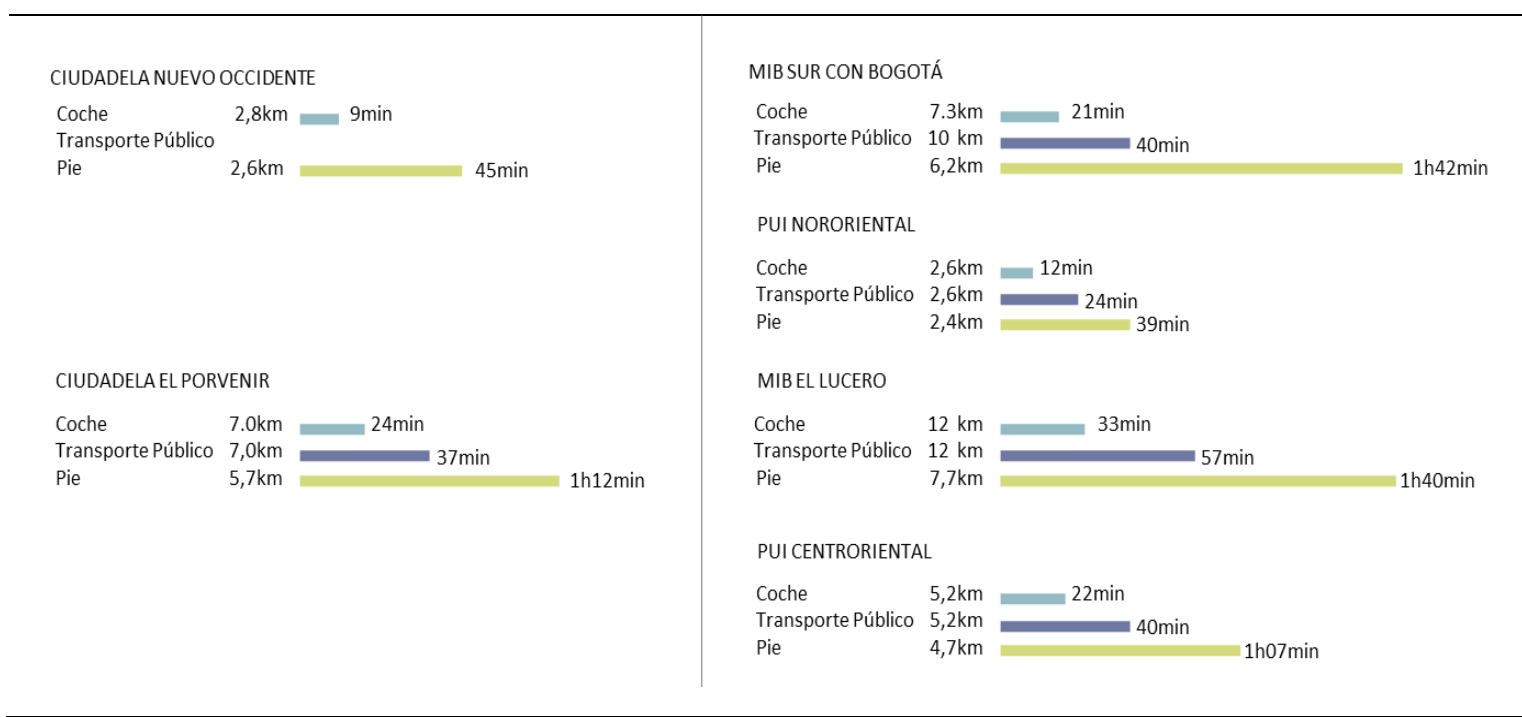

La consecuencia de esta accesibilidad regular y deficiente demuestra, como es evidente, una ciudad descompensada, en la que los costos mas altos de desplazamiento estan a cargo de la población que mas dificultades tiene para pagarlo. Son estos habitantes, los de la vivienda social en la periferia, lejos de cualquier centro laboral, los que deben invertir más recursos para llegar a su trabajo, limitando su capacidad de producción y sus posibilidades de movilidad social. Cómo es posible que los proyectos de vivienda nueva, con mas de 100.000 habitantes cada uno no cuenten o no se haya construido aun una centralidad, no de escala zonal, sino de ciudad. Qué calidad urbana se le puede ofrecer a un morador que deba desplazarse $45 \mathrm{~min}$ a pie para poder llegar a único centro de actividad.

Recordando así a Salvador Rueda (2012) "La habitabilidad debe exceder el estricto ámbito de las condiciones físicas de la vivienda, para extenderse hacia la consideración de que la calidad de vida urbana depende del acceso próximo a servicios básicos y equipamientos. La propuesta de ordenación debe vincular la edificación al acceso en tiempo, distancia y calidad de los servicios esenciales. " -y se añadiría- a los centros laborales. 
- Relacionado con el tema de centralidades y tiempos de desplazamiento, en el cuarto indicador sobre proximidad de paradas de transporte público se observó que prácticamente los seis proyectos tienen una mala accesibilidad.

Para llegar a esta conclusión se tuvo en cuenta el tiempo óptimo que debe emplear la población en el desplazamiento de su vivienda hasta la parada de transporte pública más cercana. Así las cosas, se encontró que en zonas como El Porvenir o MIB el Lucero la mitad de su territorio cuenta con una accesibilidad normal y alta (inferior a 300mts). Allí la oferta de rutas de transporte público es relativamente amplia, el problema está, como se mencionó anteriormente, en que sus habitantes deben tomar más de una ruta para desplazarse en el mínimo tiempo posible a su lugar destino. Lo cual significa un gasto en tiempo y espacio significativo. Los otros proyectos, los tres de mejoramiento de barrio, cuentan con un $40 \%$ de su territorio accesible para su habitante en términos de transporte público. La novedad la trae el PUI Centroriental con el desarrollo del tranvía que conecta parte del proyecto con el centro de la ciudad y con el sistema de metro.

El proyecto más crítico, también en Medellín, es la Ciudadela Nuevo Occidente en donde el $87,93 \%$ de su territorio no cuenta con un paradero de transporte público a menos de $300 \mathrm{mts}$. Cómo se señalaba, este desarrollo urbano cuenta solo con una parada de metrocable en la centralidad de pajarito y toda la población debe acercarse hasta allí.

Tabla 18104 Proximidad de paradas de transporte público. Comparativa estudios de caso

\begin{tabular}{lccc}
\hline & Accesibilidad inferior a & Accesibilidad entre & Accesibilidad superior a \\
Ciudadela El Porvenir & $100 \mathrm{mts}$ & $100-300 \mathrm{mts}$ & $300 \mathrm{mts}$ \\
Ciudadela Nuevo Occidente & $18.03 \%$ & $\mathbf{5 5 , 0 7 \%}$ & $\mathbf{2 6 , 9 0 \%}$ \\
& $1,34 \%$ & $10,73 \%$ & $\mathbf{8 7 , 9 3 \%}$ \\
Mib Sur con Bogotá & & & $\mathbf{6 1 , 1 6 \%}$ \\
PUI NOR & $7,39 \%$ & $31,44 \%$ & $\mathbf{6 1 . 9 4 \%}$ \\
Mib EI Lucero & $4,98 \%$ & $33,36 \%$ & $\mathbf{2 8 , 7 1 \%}$ \\
PUI COR & $19,42 \%$ & $\mathbf{5 1 , 8 7 \%}$ & $\mathbf{6 3 , 8 1 \%}$ \\
\hline
\end{tabular}

En suma, este indicador viene a demostrar que existe una necesidad urgente de integrar el sistema de transporte público a toda la periferia de Bogotá y Medellín si se quiere tener un nivel aceptable de accesibilidad real a las zonas de alojamiento social. No basta con ubicar una sola parada de transporte público, sea tranvía, metrocable o alimentador de transmilenio, para considerar solucionado el problema de movilidad de la población de bajos recursos.

\subsubsection{Movilidad}

En el quinto indicador sobre la estructura urbana en relación con el sistema viario, conexión y trazado vial, se identificaron tres tipos de conexión a nivel de ciudad: mediante acceso tangencial, acceso central y acceso ramal. El primero y segundo presenta una conexión directa con la vía arterial que confina o atraviesa el proyecto. Su condición le permite integrarse, de cierta manera, más fácilmente al resto de vías de la ciudad. Los proyectos que presentan esta conexión son Ciudadela Nuevo occidente, con la vía al mar en la parte sur de su territorio, PUI Nororiental con una vía tangencial en las orillas del rio y PUI Nororiental con una vía central paralela a la quebrada Santa Helena que cruza el territorio. Para este último caso de estudio, vale la pena mencionar que hasta la intervención de mejoramiento de barrio, la zona 
era considerada como dos territorios separados por la quebrada. No existían prácticamente pasos vehiculares que unieran las dos comunas, lo que había era una frontera imaginaria intrasitable. El Proyecto de Mejoramiento ha intentado revertir esta situación.

El tercer tipo de conexión, el ramal, consiste en una vía o varias de penetración que se desprenden de una vía arterial y que funciona como canal único de comunicación hacia y desde los proyectos. Por su condición de canal único, por lo general, señala que el proyecto se encuentra en una ubicación aislada en el territorio. Este es el caso de Ciudadela Porvenir, MIB El Lucero o MIB Sur Con Bogotá.

Grafico No. 19105 Conexión y trazado de vías. Comparativa estudios de caso

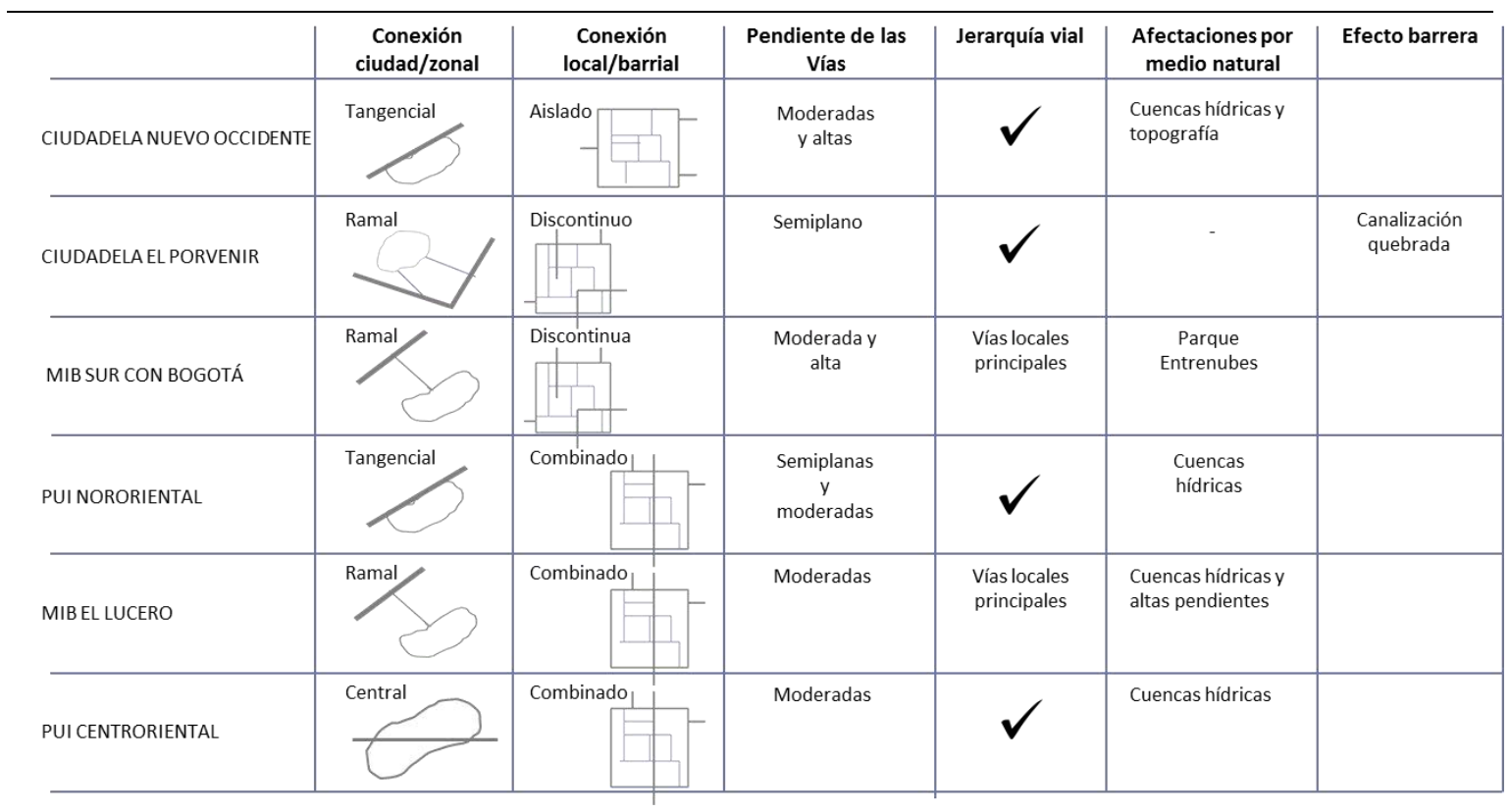

En relación con la conexión local, determinada por la continuidad e integración vial de los proyectos con las vías con su contexto inmediato son, similares a la conexión de ciudad, desarticuladas, sin jerarquías y con perfiles diferentes. Tres tipos de conexión se identificaron a esta escala: una conexión aislada, en donde las vías interiores no se prolongan por fuera de los límites del proyecto, como es el caso de Ciudadela Nuevo Occidente; una conexión discontinua, en donde solo algunas vías de carácter principal se articulan con las del contexto y finalmente la conexión de tipo combinado en donde las vías principales y algunas secundarias se articulan con el contexto. Esta última conexión es la más reproducida en los proyectos de mejoramiento de barrio.

Los dos casos más paradójicos, sin embargo, sobre el tipo de vías construidas y su conexión son los de vivienda nueva. En ellos se desarrollan vías arteriales, con las especificaciones normativas, con el perfil adecuado -o quizás a veces sobredimensionado -, con mobiliario urbano y con señalización. No obstante cuando llegan justo al límite del proyecto, sea territorio urbano o rural, la calle se acaba, se corta. No se construye ningún tipo de remate. Simplemente se deja ahí donde el plano mostraba una línea de demarcación.

Otra consideración importante dentro de este indicador son las pendientes de las vías; tema nada despreciable en la mayoría de los proyectos por encontrarse en zonas de montaña con pendientes muy elevadas. Las zonas de los estudios de caso se caracterizan, en general, por 
presentar un buen alineamiento horizontal (semiplano), bastante homogéneas en casi toda su extensión, con inclinaciones suaves y medias pero con pendientes bastante pronunciadas a nivel vertical que por lo general oscilan entre un $15 \%$ y un $27 \%$.

Esta condición topográfica, conlleva a que la construcción de las vías requiera una gran cantidad de áreas de taludes, tanto en corte como en lleno, que si no son mantenidos por parte de la administración adecuadamente pueden generar problemas de erosión y sedimentación de las corrientes de agua. Su lado positivo, en cambio, son las amplias visuales hacia la ciudad que constituyen uno de los mayores atractivos de los cinco estudios de caso, restando a Ciudadela El Porvenir que se encuentra en un territorio semiplano.

- Finalmente en el último indicador de la estructura urbana, el estado de las vías peatonales y vehiculares en los proyectos, se señala el porcentaje de vías pavimentadas en cada estudio de caso. La movilidad, como hasta ahora se ha señalado, es uno de los temas más sensibles en este tipo de proyectos de alojamiento social. Las dificultades de acceso a algunos barrios ubicados en zonas de riesgo, la ausencia de vías peatonales y vehiculares o el mal estado de algunas de ellas junto con el riesgo por la velocidad de los vehículos circulando en la misma calzada que los peatones, genera permanente tensión e inseguridad para los habitantes.

La inexistencia de la diferenciación entre vehicular y peatonal, es especial en los proyectos de mejoramiento de barrio antes de la intervención o allí donde no se llega a ejecutar el componente físico, genera una movilidad laberíntica y poco articulada que viene a ser reforzada por la falta de pavimento en sus calles. Así los proyectos de vivienda nueva, en este caso superan a los proyectos de mejoramiento de barrio con todas sus calles pavimentadas. El caso en peor estado de sus vías es indudablemente MIB El Lucero con tan solo el $56 \%$ de sus vías pavimentadas.

Tabla 19106 Estado de las vías. Comparativa estudios de caso

\begin{tabular}{lcccc}
\hline & $\begin{array}{c}\text { Peatonal } \\
\text { pavimentada }\end{array}$ & $\begin{array}{c}\text { Peatonal sin } \\
\text { pavimentar }\end{array}$ & $\begin{array}{c}\text { Vehicular } \\
\text { pavimentada }\end{array}$ & $\mathbf{1 0 0 \%}$ \\
Ciudadela El Porvenir & $\mathbf{1 0 0 \%}$ & & $\mathbf{1 0 0 \%}$ & \\
Ciudadela Nuevo Occidente & $\mathbf{1 0 0 \%}$ & & $\mathbf{6 7 , 7 7 \%}$ & $\mathbf{3 2 , 2 3 \%}$ \\
& & $\mathbf{3 7 , 3 5 \%}$ & $\mathbf{9 7 , 6 7 \%}$ & $\mathbf{2 , 3 3 \%}$ \\
Mib Sur con Bogotá & $\mathbf{6 2 , 6 5 \%}$ & $\mathbf{8 1 , 2 0 \%}$ & $\mathbf{5 6 \%}$ & $\mathbf{4 4 \%}$ \\
PUI NOR & $18,80 \%$ & $\mathbf{7 4 \%}$ & $\mathbf{8 3 , 8 4 \%}$ & $16,16 \%$ \\
Mib EI Lucero & $26 \%$ & - & & \\
PUI COR & - & &
\end{tabular}

En conclusión sobre las tres dimensiones que condicionan la estructura urbana: ocupación del suelo, accesibilidad y movilidad, los seis estudios de caso presentan una situación crítica en su relación con la ciudad. Todos, sin excepción, cuentan con escenarios deficitarios o escasamente reglamentarios - lo que, como en muchas ocasiones ya se ha pronunciado, no es seguridad de condiciones óptimas de calidad habitacional-.

Una de las circunstancias que genera dicha situación crítica es la localización con respecto a la ciudad de los seis proyectos estudiados. En todos los casos se cumplió lo analizado en el texto de April (1992) del capítulo 1, en donde el reparto de tierras con las peores condiciones, la periferia pobre de cada ciudad, es asignada a una gran masa de población sin ingresos 
necesarios para integrarse a las lógicas de mercado con la que se construye la ciudad. De este modo, las estrategias puntualizadas por cada POT, el de Bogotá y de Medellín, como condiciones o normas a seguir con respecto a una ubicación de la vivienda social más equitativa, equilibrada y apropiada para evitar o revertir problemas de segregación $e$ incentivar la inclusión social no se han cumplido. No solo los proyectos de vivienda nueva se siguen construyendo en la periferia, sino siguen teniendo, los seis estudios de caso, las peores conexiones, estados de vía, escaso acceso al transporte público y baja accesibilidad con los centros de servicios, empleos y equipamientos.

\subsection{DOTACIONES Y SERVICIOS PÚBLICOS}

La segunda escala analizada en la comprensión de la configuración del espacio residencial para la población de bajos ingresos estuvo centrada, a nivel barrial, en los indicadores que evaluaban la cobertura o accesibilidad espacial de los equipamientos, las zonas verdes y los servicios domiciliarios. Cabe especificar que la medición colocaba la mirada específicamente en el ámbito físico o territorial; no determinaba la accesibilidad de acuerdo a los cupos que dispone un centro educativo o uno de salud, aun cuando ello fuera una información esencial a considerar.

\subsubsection{Equipamientos}

Sobre la cobertura física de los equipamientos se analizaron aquellos de escala local y zonal que tuvieran mayor impacto en el territorio. Estos fueron: centros educativos, centros de bienestar social, centros de salud, centros de culto, centros culturales, bibliotecas y comercio especializado u ordinario. El rango establecido para ser considerados en un área de influencia alta o adecuada fue $300 \mathrm{mts}$. o 600mts según la escala. En la tabla a continuación se observan los porcentajes alcanzados en cada uno de los seis estudios de caso:

Tabla 20107 Cobertura territorial de equipamientos. Comparativa estudios de caso

\begin{tabular}{|c|c|c|c|c|c|c|}
\hline & $\begin{array}{l}\text { Ciudadela } \\
\text { Nuevo } \\
\text { Occidente }\end{array}$ & $\begin{array}{l}\text { Ciudadela } \\
\text { El Porvenir }\end{array}$ & $\begin{array}{l}\text { MIB Sur Con } \\
\text { Bogotá }\end{array}$ & $\begin{array}{c}\text { PUI } \\
\text { Nororiental }\end{array}$ & MIB EL Lucero & $\begin{array}{c}\text { PUI } \\
\text { Centroriental }\end{array}$ \\
\hline Educación primaria & $49,42 \%$ & $35,99 \%$ & $58,19 \%$ & $82 \%$ & $78,63 \%$ & $68.24 \%$ \\
\hline $\begin{array}{l}\text { Educación } \\
\text { secundaria }\end{array}$ & $94,32 \%$ & $99 \%$ & $78,42 \%$ & $100 \%$ & $99 \%$ & $90.90 \%$ \\
\hline Bienestar social & $33,25 \%$ & $13,55 \%$ & $68,22 \%$ & $74,02 \%$ & $81,82 \%$ & $65.98 \%$ \\
\hline Salud & $34,18 \%$ & $9,44 \%$ & $35,56 \%$ & $28,87 \%$ & $53,83 \%$ & $40.46 \%$ \\
\hline Culto & $0 \%$ & $14,25 \%$ & $54,09 \%$ & $92,22 \%$ & $63,34 \%$ & $75.24 \%$ \\
\hline Cultura & $23,78 \%$ & $57,22 \%$ & $5,45 \%$ & $58,08 \%$ & $28,82 \%$ & $53.75 \%$ \\
\hline Comercio diario & $11,53 \%$ & $88,21 \%$ & $98,50 \%$ & $97,31 \%$ & $85,63 \%$ & $65.70 \%$ \\
\hline
\end{tabular}

\section{+Centros educativos:}

En cuanto a la educación ${ }^{107}$ se pudo establecer que los habitantes de los estudios de caso tienen una accesibilidad espacial alta a este tipo de equipamientos, especialmente en aquellos de educación secundaria. No son necesarios los desplazamientos a través de los sistemas de

\footnotetext{
107 Corresponde a los equipamientos destinados a la formación intelectual, la capacitación y la preparación de los individuos para su integración en la sociedad. Agrupa, entre otros a las instituciones educativas de preescolar, primaria, secundaria básica y media, centros de educación para adultos, centros de educación especial, centros de investigación, centros de capacitación ocupacional, centros de formación artística, centros de capacitación técnica, instituciones de educación superior. (DAPD, Plan de Ordenamiento Territorial, Decreto No. 619 del 2.000, Titulo II, Subtítulo III, Capitulo 9, artículo 220, Bogotá D.C)
} 
transporte público para tener acceso a este servicio; la mayoría de los jóvenes y niños pueden acceder a pie fácilmente.

Sin embargo, en regla general la actual demanda del servicio educativo no se logra atender en la zona misma, ya que no se cuentan con los cupos necesarios. Un ejemplo claro se tiene en MIB El Lucero. En esta zona de la ciudad, la oferta de cupos disponibles en equipamientos de educacion en colegios oficiales y no oficiales (coloquialmente llamados de garaje) cuenta con un déficit del 43,13\%; es decir que la mitad de la población en edad de estudiar no puede hacerlo en su propia zona. Dicho porcentaje se acentúa para la educación infantil (bienestar social/ guarderías) en donde el déficit asciende al 95\% de la demanda. En la actualidad solo se está supliendo un $5 \%$ de la demanda requerida y estos pocos jardines infantiles existentes no cuentan con los requerimientos básicos de área construida y espacio libre por niño.

Con lo anterior y teniendo un indicador promedio de $7.75 \mathrm{~m} 2$ de construcción para equipamientos educativo y de jardines infantiles (Subdirección Desarrollo Social), se necesitarían $964.663 \mathrm{~m}^{2}$ nuevos de construcción para nivelar el déficit actual, lo que equivaldría a más o menos 48 ha de terreno. (Más que lo que existe actualmente en el total de las cesiones logradas $-38,57$ ha).

Tabla 21 I07 Oferta educativa MIB El Lucero

\begin{tabular}{ll}
\hline Equipamiento educativo & Indicador \\
\hline Oferta de cupos educativos colegios oficiales & 20.943 \\
\hline Oferta de cupos educativos colegios no oficiales: & 8.351 \\
\hline Oferta de cupos Educación Infantil Oficial: & 789 \\
\hline Oferta de cupos educación infantil No Oficial: & 200 \\
\hline Demanda cupos educativos & 51.516 \\
\hline Demanda cupos educación Infantil: & 18.454 \\
\hline Déficit en educación primaria y secundaria & $22.222(43,13 \%)$ \\
\hline Déficit en educación infantil & $17.465(94,64 \%)$ \\
\hline
\end{tabular}

Fuente: SDHT (2009) Caracterización Unidades de Planeamiento Zonal Prioritarias del Programa de Mejoramiento Integral de Barrios Localidad de Ciudad Bolívar - UPZ 67 Lucero

El hecho que no exista edificaciones o aulas suficientes responde, se intuye, a varios motivos:

Con respecto a los desarrollo de vivienda nueva: a)El desarrollo urbanístico de los proyecto ha sido adelantado mediante inmobiliarias, que si bien han cumplido con las obligaciones urbanísticas exigidas, éstas no se han orientado a atender el desarrollo de los equipamientos de educación requeridos. Se justifican diciendo que éste no les corresponde a ellos. b)El área a ceder para equipamientos no llega a ser suficiente para el desarrollo de un establecimiento educativo, y por lo tanto es permitido ser remplazado este equipamiento por una sede comunal, una placa polideportiva, un parque infantil o una piscina.

En los seis estudios de casos en general: c)Los equipamientos educativos en su mayoría han sido desarrollados por el Estado, a partir de la demanda; y con la participación del sector privado, pero nunca se ha logrado completar la cobertura por falta de capacida o de previsión.

Asi, aunque existe una cobertura territorial en los estudios de caso, como se señaló, esta se explica por la existencia de oferta de aulas en las zonas contiguas al proyecto (lo que obligan a un desplazamiento de la población escolar mayor del adecuado). Teniendo en cuenta que la población en edad escolar es toda menor de edad, lo ideal sería que éstos pudieran estudiar en su barrio. 
Existe una situación contraria en el PUI Centroriental. Allí el cupo de la población en edad de estudiar está cubierta pero las condiciones de las edificaciones, según diagnóstico realizado por la administración misma (Documento técnico de soporte - resolución nº 0065 de 2009) no cumplen con las áreas mínimas de aulas (normativa $56 \mathrm{~m} 2$; aulas encontradas de $35 \mathrm{~m} 2$ ), hay ausencia de ambientes escolares tipo B y tipo C a los que se refiere el Decreto 409 de 2007 y existe un déficit de espacio para la recreación de los alumnos (normativa $30 \mathrm{mts} \times 18 \mathrm{mts}$ ).

Tabla 22107 Oferta educativa PUI Centroriental

\begin{tabular}{ll}
\hline Equipamiento educativo & Indicador \\
Oferta de cupos educativos colegios & 5.306 \\
Demanda cupos educativos & 4860 \\
Excedente cupos en educación primaria y secundaria & 446 \\
\hline
\end{tabular}

Fuente: Documento técnico de soporte - resolución $n^{\circ} 0065$ de 2009 proyecto urbano cor- alta de regularización y legalización urbanística para los barrios: La Sierra, Villa Liliam, Villa Turbay, Las Estancias, Juan Pabloll, Ocho de Marzo y Barrios De Jesús. Pág. 181

Es claro que el proceso de ocupación de los asentamientos de origen marginal, debido a la forma en que surgieron, no permiten una comparación equitativa con los estándares que se manejan a nivel normativo ${ }^{108}$ en la ciudad de Bogotá o Medellín, sin embargo para efectos del análisis y poder evidenciar así las condiciones de los equipamientos educativos a continuación se presenta un cuadro del estado de estas instituciones. De las ocho educaciones existentes en la zona ninguna cuenta con el área de parcela ideal, el área construida en primera planta o el área de espacio recreativo ideal.

Tabla 23107 Comparación de indicadores (POT) en Instituciones educativas PUI Centroriental

\begin{tabular}{|c|c|c|c|c|c|c|}
\hline Institución educativa & $\begin{array}{c}\text { Área parcela } \\
\text { ideal }\end{array}$ & Actual $\left(\mathrm{m}^{2}\right)$ & $\begin{array}{l}\text { Área construida } \\
\text { 1piso ideal }\end{array}$ & Actual $\left(\mathrm{m}^{2}\right)$ & $\begin{array}{l}\text { Área espacio } \\
\text { recreativo ideal }\end{array}$ & Actual $\left(\mathrm{m}^{2}\right)$ \\
\hline Villa Turbay & 8.500 & 1.215 & 1.750 & 510 & 540 & 0 \\
\hline $\begin{array}{l}\text { Arzobispo Tulio Botero } \\
\text { Salazar }\end{array}$ & 8.500 & 4.982 & 1.750 & 639 & 540 & 250 \\
\hline Arzobispo Escuela & 8.500 & 372 & 1.750 & 400 & 540 & 0 \\
\hline Escuela 8 de Marzo & 8.500 & 120 & 1.750 & 219 & 540 & 42 \\
\hline
\end{tabular}

Fuente: Documento técnico de soporte - resolución $n^{\circ} 0065$ de 2009 proyecto urbano Cor- alta de regularización y legalización urbanística para los barrios: La Sierra, Villa Liliam, Villa Turbay, Las Estancias, Juan Pabloll, Ocho de Marzo y Barrios De Jesús. Pág. 183

\section{+Centros de bienestar social}

En términos generales se encontró que los salones comunales son el equipamiento que tiene una mayor cobertura sobre el alojamiento social. En los proyectos de vivienda nueva, por ejemplo, las constructoras procuran destinar un espacio específico para ellos. En los barrios de origen marginal en cambio, es la población que adecúa un espacio para este fin.

Estos equipamientos son importantes pues son los que satisfacen las necesidades de los grupos más vulnerables y los que permiten además la consolidación de procesos comunitarios o de agrupación, manifestaciones individuales y colectivas tanto sociales como culturales. Son

\footnotetext{
${ }^{108}$ Los indicadores que se toman como referentes son los que inicialmente había determinado el Departamento de usos y normas, en el documento de Los Espacios Públicos y los Equipamientos, los cuales fueron ajustados a la norma básica para Medellín o Decreto 409 de 2007.
} 
básicamente los que atienden a los niños, ancianos, jóvenes, mujeres, discapacitados, minorías étnicas y los destinados al culto, manifestaciones culturales, etc. Estos cuando no son construidos por el Estado, la propia población se encarga de levantarlos en transformado alguna vivienda o construyendo en una parcela desocupado un salón para tales fines.

\section{+Centros de salud}

Este tipo de equipamientos muestra un déficit importante de cobertura, principalmente para el segundo y tercer nivel atención a nivel general para los seis estudios de caso ${ }^{109}$. Los proyectos, en general, presentan una cobertura mínima de servicios de salud de escala zonal, que atienden las necesidades generales y primordiales de la población. No es así para los equipamientos de escala urbana, es decir, aquellos hospitales de la red pública de segundo y tercer nivel de atención, que se encuentran a más de 15 minutos de las unidades habitacionales.

En el caso de Medellín, en el PUI Nororiental por ejemplo, se observó que ésta es el área de la ciudad con mayores requerimientos de este tipo de equipamientos, (especialmente los de ámbito barrial -nivel I). Si se miran los datos absolutos de la ciudad, se constata que como tal ésta posee una media urbana de 1 equipamiento del nivel 1 por cada 10.000 habitantes, un muy buen indicador en términos absolutos, pero bastante cuestionado si se analiza a nivel territorial. La zona Nororiental cuenta con solo 2 equipamientos de salud tipo I, es decir una por cada 235.465 habitantes, la zona centroriental cuenta con 20 equipamientos, 1 por cada 14.888habitantes y La Ciudadela tiene tan solo un equipamiento de salud tipo II, que da de promedio 1 equipamiento por cada 50.000 habitantes. Estándares todos por debajo de la media de la ciudad y de las necesidades de los habitantes.

\section{+Centros de culto}

Los centros de culto, no suelen ser un equipamiento de importancia a referenciar en los estudios morfológicos. Sin embargo, reconociendo la importancia que tienen para la población de bajos ingresos y el deseo explícito, expresado en los diagnósticos de satisfacción, porque sean construidos en sus proyectos, éste sub-indicador es tenido en cuenta. En el análisis se ha constatado, que aquellos lugares en donde no existía una centro de culto cerca, a menos e $600 \mathrm{mts}$, la población construía uno.

\section{+Centros culturales}

Los equipamientos colectivos de cultura, como se ha mencionado, corresponden a los espacios o edificaciones destinados a las actividades culturales, custodia, transmisión y conservación del conocimiento, fomento y difusión de la cultura y fortalecimiento y desarrollo de las relaciones y las creencias y los fundamentos de la vida en sociedad. Agrupa entre otros, los teatros,

\footnotetext{
109 Integran los equipamientos de salud el conjunto de instituciones públicas, privadas y mixtas de la seguridad social en salud, destinadas a la administración y prestación de servicios de salud del tercero, segundo y primer nivel de atención. Las instituciones prestadoras de salud del primer nivel de atención prestan servicios básicos de salud a los usuarios del sistema, a través de las unidades primarias de atención (UPA), las unidades básicas de atención (UBA), centros de atención médica inmediata (CAMI) y los hospitales de nivel I. Para la proyección de las unidades de primer nivel de salud, se toma un estándar de una unidad por cada 20.000 habitantes. (DAPD, Plan de Ordenamiento Territorial, Decreto No. 619 del 2.000, Titulo II, Subtítulo III, Capitulo 9, artículo 220, Bogotá D.C)
} 
auditorios, centros cívicos, bibliotecas, archivos, centros culturales y museos ${ }^{110}$. Son indispensables en cuanto preservan y fomentan la memoria colectiva, las tradiciones, la expresión artística y el encuentro para una posible cohesión social; sin embargo son el equipamiento que más carece en los seis estudios de caso.

Las bibliotecas populares son lo más representativo en este subindicador y lo que más se ha construido con un supuesto valor arquitectónico añadido. Los tres ejemplos de Medellín y Ciudadela Porvenir en Bogotá cuentan con una edificación de este tipo. También se han construido centros de vida, un centro cultural y una casa de música, todos como único ícono en el territorio. Lo que por supuesto es insuficiente para cubrir las demandas culturales de toda la población de estos proyectos con alrededor de 100.000 habitantes.

\section{+Comercio especializado u ordinario}

Finalmente, se evaluó la accesibilidad espacial a los abastecimientos de alimentos, tomando como referente a las plazas de mercado, los centros comerciales o los comercios ordinarios. Al respecto, se determinó que los equipamientos de abastecimiento de alimentos de gran escala no tienen influencia directa sobre las áreas los proyectos. Lo que significa que el acceso a los alimentos se realiza a través de las dinámicas económicas locales que se obtienen en el comercio de pequeña escala.

En términos generales se puede constatar que los tiempos de ejecucion de los equipamientos en los desarrollos de vivienda nueva son similares a los tiempos en los mejoramientos de vivienda. Todos se construyeron posteriormente y una vez existía una cierta consolidación. Como se señala en la cartilla para el estudio de caso ciudadela Nuevo Ociidente, por ejemplo, algunos equipamientos fueron construidos ocho años despues de la construccion de las unidades habitacionales. Asi en los primeros cuatro años, los 15.000 habitantes de las primeras unidades habitacionales no contaron con ningún equipamiento nuevo construido dentro de la Ciudadela. Tan solo existía en este territorio un área cívica y dos institutos académicos. No había ningún tipo de dotación o de infraestructura para llegar hasta este lugar apartado y en lo mas alto de las laderas de Medellín. Tan solo fue en el año 2008 cuando la estación de metrocable Aurora. Algunos de los equipamientos principales de educación o servicios social no llegaron hasta el año 2011-2012. La única unidad hospitalaria en su primera fase fue entregada en el año 2015 y la segunda fase en el año 2017. Varias instituciones educativas, jardines infantiles, y muchas zonas recreativa quedan aun por ser construidas.

\subsubsection{Zonas verdes}

Centrando ahora la mira en los espacios verdes se registra una escasez de espacios libres, plazas, plazoletas, parques juegos infantiles o campos de juego adecuados para la recreación de población en general y particularmente para los ancianos y mujeres. Predominan las canchas y placas polideportivas en casi todos los espacio públicos recuperados o construidos en las proyectos de vivienda nueva.

\footnotetext{
${ }^{110}$ SDP, POT decreto 190 de 2004, Titulo II, subtótlo III, Capítulo 9 Página 197-198. Bogotá. D.C.
} 
Tomando como referencia la normativa de Colomiba con respecto a la proporción de metros cuadrados por habitante, la situacion optima de $15 \mathrm{~m} 2 / \mathrm{hab}$ o la deseada (regulada) $6 \mathrm{~m}^{2} / \mathrm{hab}$, ningun proyecto de los seis estudios de caso cumple con lo requerido por ley. Los dos proyectos que mayor proporción tienen alrededor de $4 \mathrm{~m}^{2} /$ hab y son MIB Sur Con Bogotá y PUI Centroriental, su razon se debe a la gran cantidad de área verde recuperada al lado de las zonas ambientales (presencia de un gran porcentaje de suelos de protección, asociadas a los retiros de corrientes de agua (quebradas y canales) y zonas de alta pendiente). En cambio, los dos proyectos con peor proporcion son, los dos de desarrollo de vivienda nueva. Éstos aun cuando cumplen con las cesiones de espacio público establecido por ley, debido a la gran cantidad de habitantes que tienen su condicion empeora.

Grafico No. 24108 Proporción $\mathrm{m}^{2} /$ habitante de zonas verdes. Comparativa estudios de caso

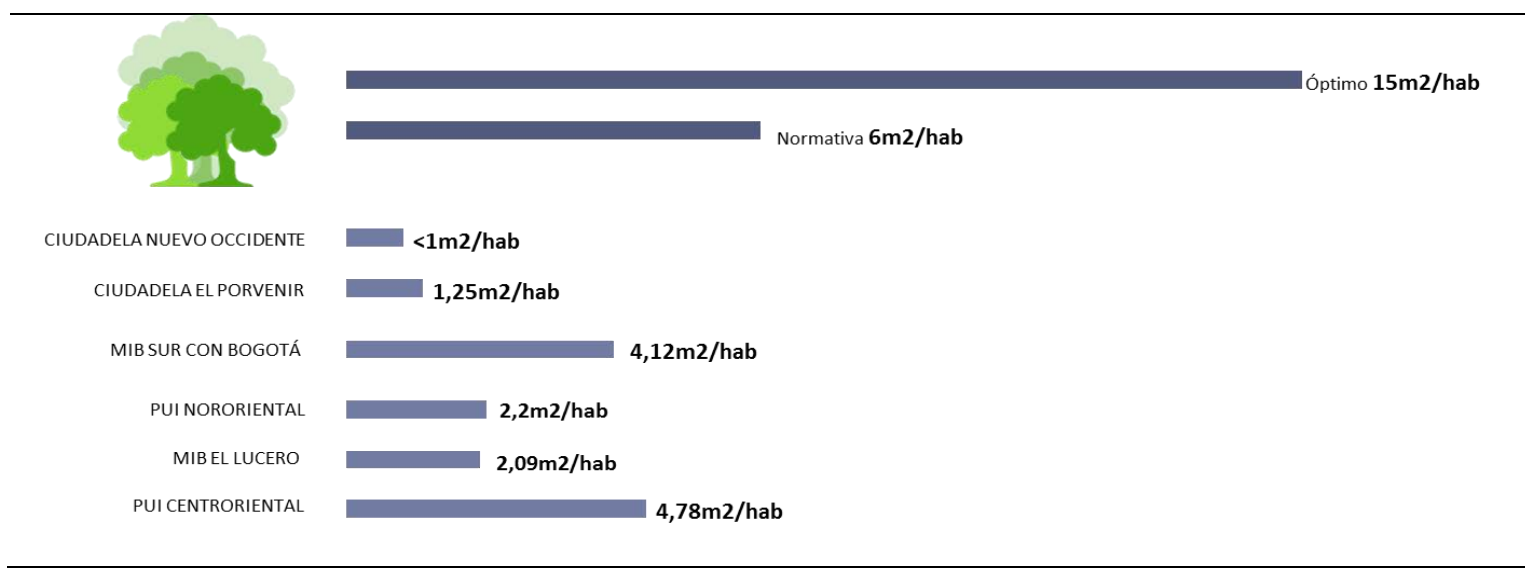

Conceptualmente la formulación del sistema de espacio público para los proyectos analizados, se fundamenta en el principio de calidad, cantidad y diversidad según lo especifica cada Plan de Ordenamiento Territorial. El de Medellín, por ejemplo, dice lo siguiente:

En razón de que la calidad de una ciudad se mide por la calidad de su espacio público urbano y rural, el sistema de espacio público constituye el estructurante principal de la construcción de ciudad y de ciudadanía.

Este principio fundamenta el conjunto de las formulaciones del Plan de Ordenamiento en cuanto se orientan a proteger el espacio público existente, a procurar incrementar la cantidad, la variedad y calidad de su oferta global a la vida ciudadana y a convertirlo efectivamente en el articulador principal del desarrollo urbano y municipal, tanto en lo urbano como en lo rural." (Acuerdo 46 de 2006, por el cual se ajusta el Plan De Ordenamiento Territorial - Artículo $\left.8^{\circ}\right)$

No obstante, dichos principios se quedan solo en plano teórico insipiente. En los dos proyectos de vivienda nueva, habría toda la posibilidad de generar espacio público adecuado en cantidad, calidad y variedad, pero la necesidad o ansias de vender todo el suelo en el mercado para generar mayores ganancias no lo consienten. Es sorprendente que exista mayor espacio público efectivo en los barrios de origen marginal después de su intervención.

Analizando ahora, la accesibilidad de este equipamiento a una distancia inferior de $300 \mathrm{mts}$ de radio a las unidades habitacionales, se estableció que la proximidad de las zonas verdes a las áreas de los proyectos tiene una cobertura media o alta. Este es el caso de MIB el lucero con 
un $88,02 \%$ de su territorio cercano a un parque o una plaza o el caso del Porvenir o el PUI Centroriental.

Tabla 24108 Zonas verdes. Comparativa estudios de caso

\begin{tabular}{|c|c|c|c|}
\hline CIUDADELA NUEVO & Accesibilidad alta 63,54\% & MIb SCB & Accesibilidad alta $43,78 \%$ \\
\hline \multirow[t]{5}{*}{ OCCIDENTE } & Accesibilidad media $36,46 \%$ & & Accesibilidad media $45,07 \%$ \\
\hline & Accesibilidad baja $0 \%$ & & Accesibilidad baja $11,15 \%$ \\
\hline & & PUI NOR & Accesibilidad alta $\mathbf{6 7 , 3 7 \%}$ \\
\hline & & & Accesibilidad media $32,63 \%$ \\
\hline & & & Accesibilidad baja $0 \%$ \\
\hline \multirow[t]{6}{*}{ EL PORVENIR } & Accesibilidad alta 79,14\% & Mib El Lucero & Accesibilidad alta $\mathbf{8 8 , 0 2 \%}$ \\
\hline & Accesibilidad media $20,86 \%$ & & Accesibilidad media $11,98 \%$ \\
\hline & Accesibilidad baja 0\% & & Accesibilidad baja 0\% \\
\hline & & PUICOR & Accesibilidad alta $\mathbf{7 3 , 1 4 \%}$ \\
\hline & & & Accesibilidad media $26,86 \%$ \\
\hline & & & Accesibilidad baja $0 \%$ \\
\hline
\end{tabular}

Esto indica que a pesar que la evaluación general de las zonas verdes no cumplen con la cantidad de área necesaria para la demanda de la población habitante, si cumple con respecto a la ubicación en el proyecto equidistante a casi todas las viviendas. Esto se explica gracias a la necesidad, que ha comprendido la administración, de generar un espacio público, sea mucho o poco, que sirva de costura entre tramas y sectores que articulen lo público con el tejido residencial construido.

Un problema que vale mencionar, particular de los seis estudios de caso, es el estado y ocupación de ese espacio público. La definición de un sistema de espacio público parte de la identificación de las relaciones que establece la comunidad con el entorno; cómo lo viven, cómo se apropian de ese espacio y qué función le dan a los elementos artificiales como espacios deportivos, parques y zonas verdes. En general, uno de los principios más importantes del espacio público es que exista físicamente y posteriormente que cumplen una función determinada para que tengan sentido en las actividades sociales. Pues en estos casos, las actividades sociales que se dan en estos espacios son de robo, de actos violentos o sitio de estancia para vender o consumir drogas. Las bandas de delincuencia se han apropiado de estos espacios y no permiten que la población disfrute de ellos.

\subsubsection{Servicios públicos domiciliarios}

Con relación a los servicios domiciliarios, es los seis estudios de caso se observó que todos cuentan con una cobertura de acueducto, alcantarillado y energía significativamente alta. Los proyectos de vivienda nueva tiene el $100 \%$ cubierto y los asentamientos de origen marginal, en promedio tiene el $98 \%$ resuelto. Esto se debe, como se mencionaba en el diagnóstico, a que las empresas de servicios domiciliarios, como empresa dedicadas a prestar una asistencia con ánimo de lucro ${ }^{111}$, prestan el servicio en cualquier territorio (sea marginal o no) siempre y cuando la población pague sus obligaciones al respecto. Éstas no tienen problema en sobrepasar las regulaciones de ordenamiento territorial con respecto a límites o legalizaciones. Son por lo general, organizaciones eficientes que alcanzan una buena cobertura. Sin embargo, vale la pena mencionar algunos problemas que se detectaron

\footnotetext{
111 Tanto la Empresa de Acueducto, Alcantarillado de Bogotá (EAAB) y la Empresa Pública de Medellín (EPM) son organizaciones pública-privadas prestadora de los servicios de acueducto y alcantarillado sanitario y pluvial.
} 
especialmente en los asentamientos de origen marginal, pero no exclusivamente. Es necesario señalar aquí que el término cobertura, es decir "disponibilidad de servicios básicos" no arroja datos sobre la calidad del servicio prestado, de ahí los problemas a mencionar:

- La cobertura de alcantarillado en áreas que no alcanzan a estar por encima del nivel de los colectores principales, como son las que se ubican en los causes de las quebradas o en los bajos de las vías, no cuentan con una red colectora. Las aguas sucias que generan esas viviendas se siguen aún vertiendo directamente en las quebradas. Solución poco adecuada que genera sorpresa de cómo hasta el momento no se ha podido pensar en una solución técnica para subsanar dicha situación.

Dicha circunstancia de los niveles, no es sin embargo exclusiva de los asentamientos marginales. El proyecto Ciudadela El Porvenir, como se señala más adelante sobre los riesgos de inundación presenta problemas en su alcantarillado por taponamiento o el revertir de sus aguas por encontrarse por debajo de la cota del Rio Bogotá.

- Otro problema encontrado, no directamente relacionado con la prestación o cobertura del servicio pero si con una realidad que atañe la vivienda social, es el hecho de compartir sanitarios o cocina entre varios hogares que termina generando saturación en las redes de servicios de alcantarillado.

- Problemas de no conexión o corte del servicio. Hay zonas donde definitivamente no puede llegar la cobertura dada por las condiciones topográficas de las dos ciudades y hay población incapaz de pagar el servicio de forma sostenida. Las tarifas son considerablemente altas. En Ciudadela Nuevo Occidente por ejemplo, se encontró que habían grupos familiares que a los seis meses de su ocupación ya había presentado problemas para la realización de los pagos pues no tenían el dinero para hacerlo. En palabras de un residente: "no es que no quiera pagar; yo quiero pagar, pero no tengo con qué y no nos ayudan a pagar de otra forma, y entonces nos cortan los servicios."

En algunos de los pisos donde sus ocupantes decían tener dificultades para pagar estas nuevas obligaciones y tenían el servicio cortado, se observó que la vivienda gozaba de energía eléctrica (conexión fraudulenta), cocinaba con bombonas de gas propano o bien, en casos particulares, con cocinas de leña en los corredores comunes o zonas verdes. (Mejía 2012, 212)

Tabla 25109 Cobertura servicios domiciliarios. Comparativa estudios de caso

\begin{tabular}{|c|c|c|c|c|c|}
\hline & Acueducto & Alcantarillado & Energía & Gas natural & Basuras \\
\hline CIUDADELA NUEVO OCCIDENTE & $100 \%$ & $100 \%$ & $100 \%$ & $100 \%$ & $100 \%$ \\
\hline CIUDADELA EL PORVENIR & $100 \%$ & $100 \%$ & $100 \%$ & $100 \%$ & $100 \%$ \\
\hline MIB SUR CON BOGOTÁ & $99,03 \%$ & $99,16 \%$ & $99,2 \%$ & $89,6 \%$ & - \\
\hline PUI NORORIENTAL & $98,72 \%$ & $93,97 \%$ & $100 \%$ & $50,96 \%$ & $94,22 \%$ \\
\hline MIB EL LUCERO & $99,4 \%$ & $91,3 \%$ & $100 \%$ & $73,91 \%$ & $60,86 \%$ \\
\hline PUI CENTRORIENTAL & $99,9 \%$ & $99 \%$ & $100 \%$ & $40,71 \%$ & $78,53 \%$ \\
\hline
\end{tabular}


Con respecto al suministro de gas natural en cambio, éste es aun para los estudios de caso de Bogotá deficiente en los asentamientos de origen marginal y muy deficiente para los mismos tipos de asentamientos en Medellín. La razón está dada, nuevamente, por las condiciones topográficas difíciles de acceder y porque aún le empresa que presta el servicio Gas Natural Fenosa no ha extendido todas las redes guías.

El mayor problema que se presenta, en los seis proyectos, es la recolección de basuras. No hay para todas las viviendas una recolección domiciliaria ni una prestación de servicios de limpieza de calles, zonas verdes o separadores. Hay, como solución, puntos de acopio en donde un camión pasa cada dos o tres días de la semana a recoger lo depositado. Frecuencia para estas zonas tan densificadas, es muy baja pues genera un manejo inadecuado de los residuos sólidos, los cuales se dispersan en los puntos de recolección o son finalmente arrojados a los cauces de las quebradas.

\subsection{CONDICIONES AMBIENTALES}

Como parte del análisis a nivel barrial sobre la morfología del espacio residencial, se tuvieron en cuenta las áreas con obras de prevención o mitigación de riesgo según las dos características presentadas en los estudios caso: deslizamiento de tierras e inundaciones. Se tuvo especial atención en estas dos constantes no solo porque representan un riesgo en la vida de los habitantes sino además por su cercanía con las fuentes hídricas pueden generar problemas de contaminación o saturación en el ambiente.

De este modo se identificó que las viviendas del proyecto El Porvenir se encuentran ubicadas en zonas de riesgo de inundación medio en el $100 \%$ de su territorio y que las viviendas de la Ciudadela Nuevo Occidente presentan problemas de inundación y deslizamiento en un $41,26 \%$ de su territorio con restricciones severas y el 13,92\% con restricción media. Sobre ello, las entidades institucionales encargadas de la promoción de los proyectos manifestaron en su momento que para la construcción de viviendas, se habían realizado labores de mitigación. No se tienen datos exactos si dicho trabajo fue realizado para el caso de Medellín. Para el caso de la Ciudadela El Porvenir, la administración, en cambio ha reconocido que los trabajos de mitigación no fueron suficientes. En el año 2011, la población presentó la denuncia sobre aguas negras que se devuelven por las cañerías presentando inundaciones. El canal Cundinamarca, borde occidental de la ciudadela, que desemboca en el Rio Bogotá se encontraba taponado y no permitía un desagüe correcto de las instalaciones de alcantarillado. ${ }^{112}$

Para los casos de estudio de los asentamientos de origen marginal, el mayor riego que condicionaba el terreno y que debió ser contemplado a la hora de las mejoras urbanas, fue el de deslizamiento de tierras. La inestabilidad de estas tierras había estado asociada al estado del recurso agua, las fuertes pendientes, el grado de urbanización, de intervención antrópica y las técnicas inadecuadas de modelamiento del terreno. En el PUI Centroriental, por ejemplo, de las 126 ha. que conforman el proyecto de mejoramiento, el 58\% correspondían a suelo de

\footnotetext{
112 Ver nota de prensa: http://caracol.com.co/radio/2011/09/09/bogota/1315544700 544663.html [Consultada en febrero 2017].
} 
alto riesgo no recuperable (con el agravante que el $85 \%$ de las viviendas ubicadas en suelo apto, presentaban un grado de vulnerabilidad medio). El total del proyecto en riego de deslizamiento era de $27,80 \%$. La administración inició y continúa aún en los trabajos de mitigación con la recuperación de las rondas de rio, el desalojo de viviendas en zonas no recuperables o con la reforestación sobre las pendientes entre otras labores.

Otro ejemplo de trabajos realizado es el caso estudio MIB Sur Con Bogotá, el proyecto con menor riesgo de todos. Sus porcentajes eran bastantes bajos con respecto a los otros cinco casos analizados. En éste, su mayor riesgo era por inundación. En época invernal las quebradas de la zona presentaban desbordamiento y los desarrollos ubicados en la ronda se veían afectados. La causa era, y sigue siendo por el mal manejo de residuos sólidos y vertimientos, que ocasionan daños en la capa vegetal, contribuyendo al taponamiento y desbordamiento del cauce de los ríos.

Gráfica No. 21 I10 Zonas de riego. Comparativa de los seis estudios de caso

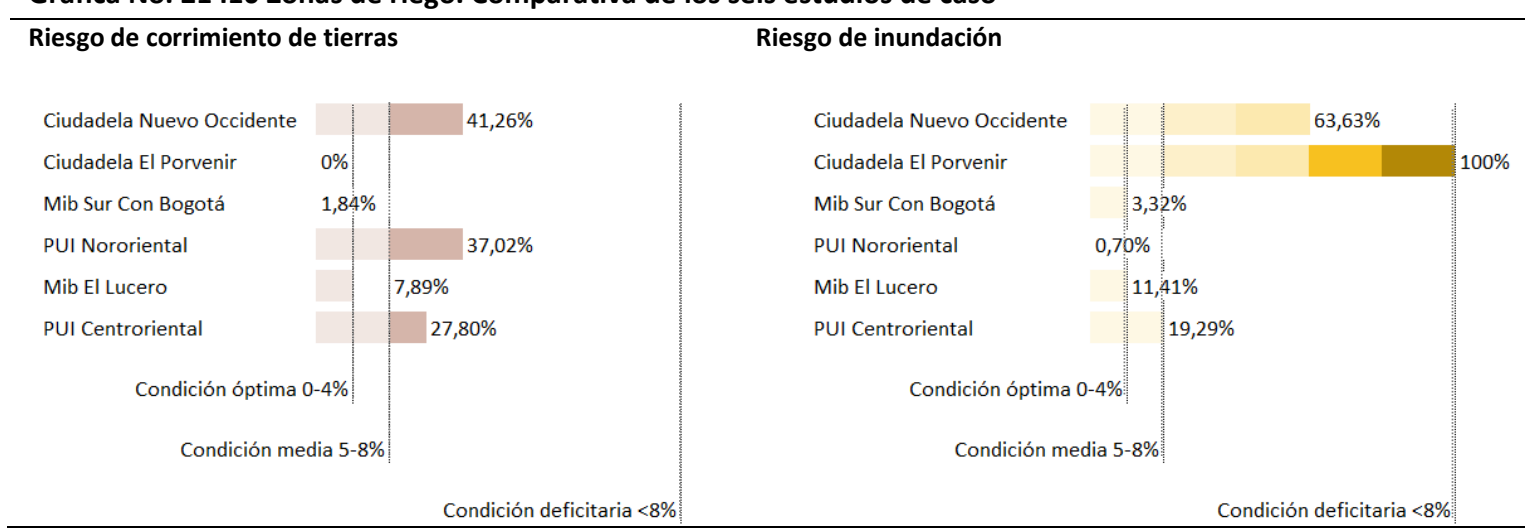

En conclusión, por su consideración trascendental, los valores de este apartado, deberían ser sin matices de unos rangos igual a $0 \%$ del territorio ocupado. Sin embargo, por muchos trabajos realizados de mitigación, los seis estudios de caso presentan dificultades al respecto. El problema está dado por la ubicación y las condiciones de montaña de las ciudades colombianas en donde se decide construir vivienda social $y$, por otro lado no menos importante, por los riesgos antropogénicos, es decir por las condiciones producidos por el hombre. El no tirar basura, usar adecuadamente los recursos hídricos o no talar árboles viene dado por una condición cultural que puede ser enseñada, si la administración decide enfocar sus esfuerzos hacia ello.

\subsection{CONJUNTO HABITACIONAL}

El análisis relativo al bloque, oferta y configuración del conjunto habitacional, fue la menor escala a examinar dentro del modelo de evaluación. En él se aplicaron los indicadores sobre morfo-tipología, es decir sobre las características de las parcelas y las tipologías arquitectónicas en relación con su tamaño, composición y consolidación, y los indicadores sobre la complejidad lograda con los procesos de organización de la población y la diversidad de actividades o funciones establecidas a nivel urbano. Allí se pudo observar que la calidad en la configuración de las unidades habitacionales en relación con su entorno y la diversidad urbana dada por los usos que la población establecía en dicho territorio era uno de los 
componentes esenciales para contar con unas condiciones de habitabilidad apropiadas 0 inadecuadas. A continuación, se detallan dichas observaciones.

\subsubsection{Morfo-tipología}

Para comprender los factores que condicionaban la forma y el tipo construido en los seis estudios de caso se definieron, dentro de la aplicación del indicador, tres variables de análisis: a) los tipos de producción, entendidos como los proceso de formación y morfología del tejido urbano, b) la relación espacial entre la parcela y el espacio público (analizada ya con el indicador de cesiones) y c) finalmente, la dimensión de la manzana, la parcela y el bloque.

- Sobre los procesos de formación se constató, como era evidente, que los desarrollos de vivienda nueva estaban construidos con la secuencia Urbanización, Parcelación y Edificación ${ }^{113}$, típicos de este tipo de producción de vivienda realizada completamente por el promotor inmobiliario. En cambio, en los asentamientos de origen marginal el orden de estos procesos de formación se daban según cada territorio o cada barrio. Así, por ejemplo, en el PUI Nororiental o en MIB Sur con Bogotá, los barrios con una parcelación irregular o clandestina ${ }^{114}$ (de origen ilegal en la compraventa de tierras) se producía una secuencia de Parcelación y posteriormente de Edificación (vivienda de autoconstrucción levantada durante años) y en los barrios de invasión ${ }^{115}$ solo se daba el proceso de Edificación (esta también de autoconstrucción). Curiosamente, para el caso de Medellín, el primer caso de formación coincidía con la localización de los barrios más próximos al rio y a la parte llana, y el segundo, a los barrios localizados sobre pendiente en las laderas medias y altas. Para el caso de Bogotá, la localización de los barrios clandestinos o de invasión se daban indistintamente de su localización (teniendo en cuenta que se habla de la periferia sur oriental, ubicada a una distancia considerable del centro de la ciudad y sobe los cerros de la capital). Aun así, en cualquier de las dos situaciones resultaba ausente, en una primera instancia, el proceso de Urbanización. Éste era realizado posteriormente por el Estado cuando decidía proponer las mejoras urbanas en estos territorios.

\footnotetext{
113 Procesos definidos y ampliamente desarrollados por el Laboratorio de Urbanismo de Barcelona con Manuel Solà-Morales a la cabeza como se mencionó y cito en el capítulo 1. Según dicho autor en su texto Las Formas del Crecimiento Urbano, las diversas maneras de organización en los proceso de formaciones son esencialmente tres:

+La urbanización: entiende la conexión de un territorio edificable a los ramos principales de las instalaciones de infraestructura física como alcantarillado, acueducto, energía, vías y demás infraestructura básica.

+La parcelación: Fase de descomposición física del territorio en polígonos con geometrías y dimensiones dictadas por la lógica de intervención, y caracterizados cada uno por derechos de propiedad particulares.

+La edificación: entiende todo proceso de construcción física de edificios y obras civiles al interior de cada parcela, con la finalidad de completar y volver operativa la nueva área urbana.

Son tres procesos que pueden organizarse de forma diferente y de manera total o incompleta dependiendo de las diferentes normas, condicionamientos o ritmos que las configure.

114

La producción de vivienda de características clandestinas se define así cuando se realiza bajo un proceso de parcelación en un suelo irregular en su propiedad por parte de un urbanizador "pirata", como se denomina en Colombia, una venta de dichas parcelas y posteriormente una edificación a lo largo de los años por parte de los moradores.

Hacen parte de esta categoría los barrios de Andalucía, La Francia y Santa Cruz para el caso del PUI Nororiental.

115 Los barrios de invasión son, por lo general, el resultado de una ocupación igualmente ilegal del suelo como los asentamientos clandestinos pero esta vez son ocupados por un grupo de pobladores sin los recursos para acceder a una vivienda o a una parcela. En ellos resulta postergado en el tiempo no solo el proceso de urbanización sino también el de parcelación. Este último, en ocasiones, se hace de manera sumaria para definir de inmediato límites o linderos del nuevo suelo ocupado.
}

En el caso del PUI Nororiental, hacen parte de esta categoría los barrios Popular 1 y 2, Santo Domingo 1 y 2 y Granizal. 
Ahora bien, paralelo a esos primeros procesos de formación, una constante como se mencionaba de esta vivienda social, fuera cual fuera su forma de producción, era, y sigue siendo, la transformación, ocupación o división de su unidad habitacional. El proceso de Edificación realmente nunca ha sido un proceso terminado. Siempre ha estado en permanente desarrollo. Circunstancia a tener en cuenta a la hora de proponer una tipología de construcción en los proyectos de desarrollo de vivienda nueva; de lo contrario las condiciones de habitabilidad de esas unidades de vivienda construidas pueden verse afectadas.

Tabla 26 I11 Morfo-tipología: Etapas del proceso de formación

\begin{tabular}{|c|c|c|c|c|c|c|c|}
\hline \multirow[b]{2}{*}{ Tipo de desarrollo } & \multicolumn{3}{|c|}{ Primera etapa } & \multicolumn{2}{|c|}{ Segunda Etapa } & & \\
\hline & $\mathbf{U}$ & $\mathbf{P}$ & $E^{*}$ & $\mathbf{P}$ & $\mathbf{U}$ & & \\
\hline Desarrollo formal & $x$ & $-x$ & $-x$ & & & $\begin{array}{l}\text { *vivienda mínima que se } \\
\text { va transformado } \\
\text { *barrio consolidado }\end{array}$ & $\begin{array}{l}\text { Ciudadela Nuevo Occidente } \\
\text { Ciudadela El Porvenir }\end{array}$ \\
\hline $\begin{array}{l}\text { Desarrollo marginal } \\
\text { clandestino }\end{array}$ & & $x$ & $>\mathrm{X}^{* *}$ & & $x$ & $\begin{array}{c}\text { **vivienda que se va } \\
\text { edificando y barrio } \\
\text { consolidando con el } \\
\text { tiempo }\end{array}$ & $\begin{array}{l}\text { MIB Sur con Bogotá } \\
\text { PUI Nororiental } \\
\text { MIB El Lucero } \\
\text { PUI Centroriental }\end{array}$ \\
\hline $\begin{array}{l}\text { Desarrollo marginal } \\
\text { Invasiones }\end{array}$ & & & $x$ & $x$ & $>X$ & $\begin{array}{l}\text { ** módulo de vivienda } \\
\text { que se edifica al tomar } \\
\text { posesión y se va } \\
\text { desarrollando con el } \\
\text { tiempo. }\end{array}$ & $\begin{array}{l}\text { MIB Sur con Bogotá } \\
\text { PUI Nororiental } \\
\text { MIB El Lucero } \\
\text { PUI Centroriental }\end{array}$ \\
\hline
\end{tabular}

- Otra condición estrechamente relacionada con los proceso de producción son las características morfológicas que adquiere los tejidos urbanos de cada territorio. Estos, para los estudios de caso, fueron definidos según su proceso de formación: planeados o marginales y según su tipo de configuración: reticular ${ }^{116}$, orgánico ${ }^{117}$ o mixto ${ }^{118}$. Para los desarrollos de vivienda nueva, producción planificada, el tipo de configuración del tejido dependía de las condiciones topográficas del terreno. En el estudio de caso de la Ciudadela Nuevo Occidente, por ejemplo, su tipo de morfología es orgánica pues se desarrolla según las pendientes del territorio o los cauces de ríos y quebradas. Para el caso de la Ciudadela El Porvenir, el tejido es

\footnotetext{
116 Este tipo de configuración, la reticular, se caracteriza por la existencia de un trazado regular, de tipo ortogonal, que permite obtener el máximo número de parcelas de tamaño uniforme. El resultado es un tejido uniforme que se repite a lo largo del barrio (con pequeñas variaciones en algunos casos por causa de la topografía del terreno. La forma de la manzana en donde se agrupan las parcelas es igualmente rectangular. Los desarrollos de tipo planeado se diferencian de los marginales por tener unas manzanas más alargadas, y una estructura vial más definida: senderos peatonales o jerarquía vial.

117 El tejido orgánico organiza las parcelas adecuándose al máximo a las características topográficas casi de forma espontánea. Como consecuencia, la configuración de la manzana y la parcela resultan de tamaños y formas distintas y son dispuestas de forma irregular. En principio, el acceso a las parcelas es garantizado por senderos discontinuos a lo largo del todo el barrio o todo el desarrollo. Estos caminos de acceso actúan como senderos peatonales en las fases iniciales de formación del barrio, para luego ser absorbidos por las parcelas o convertirse y consolidarse en vías estructurantes.

Aquí los desarrollos de tipo marginal se establecen sin ningún orden en el posicionamiento de las parcelas y se presentan, con mayor frecuencia pero no exclusivamente, en las zonas de borde entre los diferentes barrios, las cuencas de quebradas o altas pendientes. Esta tipología se destaca por ser compuesta de agrupaciones difusas sobre el territorio, sin definición de ninguna manzana.

118 Una configuración mixta prefigura una forma de parcelación que integra los dos casos descritos anteriormente. Este tipo de parcelación se presenta bajo el aspecto de una agrupación de manzanas compactas y regulares que van desfigurándose a medida que las condiciones topográficas se vuelven más abruptas. La parcela puede resultar regular o irregular. El origen de este tipo de configuración procede de unos primeros trazados regulares que dan origen al barrio, que van posteriormente integrándose a parcelas de origen espontáneas y trazados irregulares que finalmente van consolidándose como trazado definitivo. El resultado formal produce parcelas y manzanas de diferentes formas y dimensiones que se vuelven más irregulares a medida que se alejan de los corredores principales.
} 
una retícula ortogonal casi perfecta, que se establece de esa forma por un capricho arquitectónico y urbano, más que por unas condiciones ambientales. El área es prácticamente plana y no tiene ninguna condicionante geotécnica.

En el caso de los barrios de origen marginal, el tipo de configuración del tejido dependía, en circunstancias generales, del proceso de formación y no de las características topográficas del terreno como los barrios de origen planificado. Los barrios de origen clandestino, por ejemplo, por su propio proceso de formación que consta de una parcelación primero y de una edificación posterior, el tejido suele ser de carácter reticular. Es eficiente con respecto al uso del suelo. Los barrios de invasión son de carácter orgánico. Las edificaciones se ubican allí en donde mejor pueden instalarse.

No obstante, dicha característica morfológica para los barrios de origen marginal dependía del grado de consolidación. Los barrios de invasión una vez han llegado a un grado elevado de desarrollo pueden llegar a tener un tipo morfológico reticular o en todo caso mixto (semi reticular - semi orgánico).

Para los barrios de origen marginal, otro componente que da pautas sobre su grado de consolidación es el número de niveles construidos por unidad habitacional y el tipo de materiales de las viviendas utilizados (dos condiciones ligadas con el año de legalización de los barrios a nivel de ciudad). La mayoría de las viviendas, en todos los estudios de caso de producción marginal, son con materiales estables (ladrillos, hormigón, piedra, bahareque, tapia o adobe) en casi un $90 \%$. Las viviendas con materiales perecederos (latas, plásticos, maderas entre otros) son por lo general viviendas que llevan muy poco tiempo de ser instaladas en la zona o viviendas abandonadas.

Gráfica No. 22111 Configuración del tejido urbano. Comparación estudios de caso

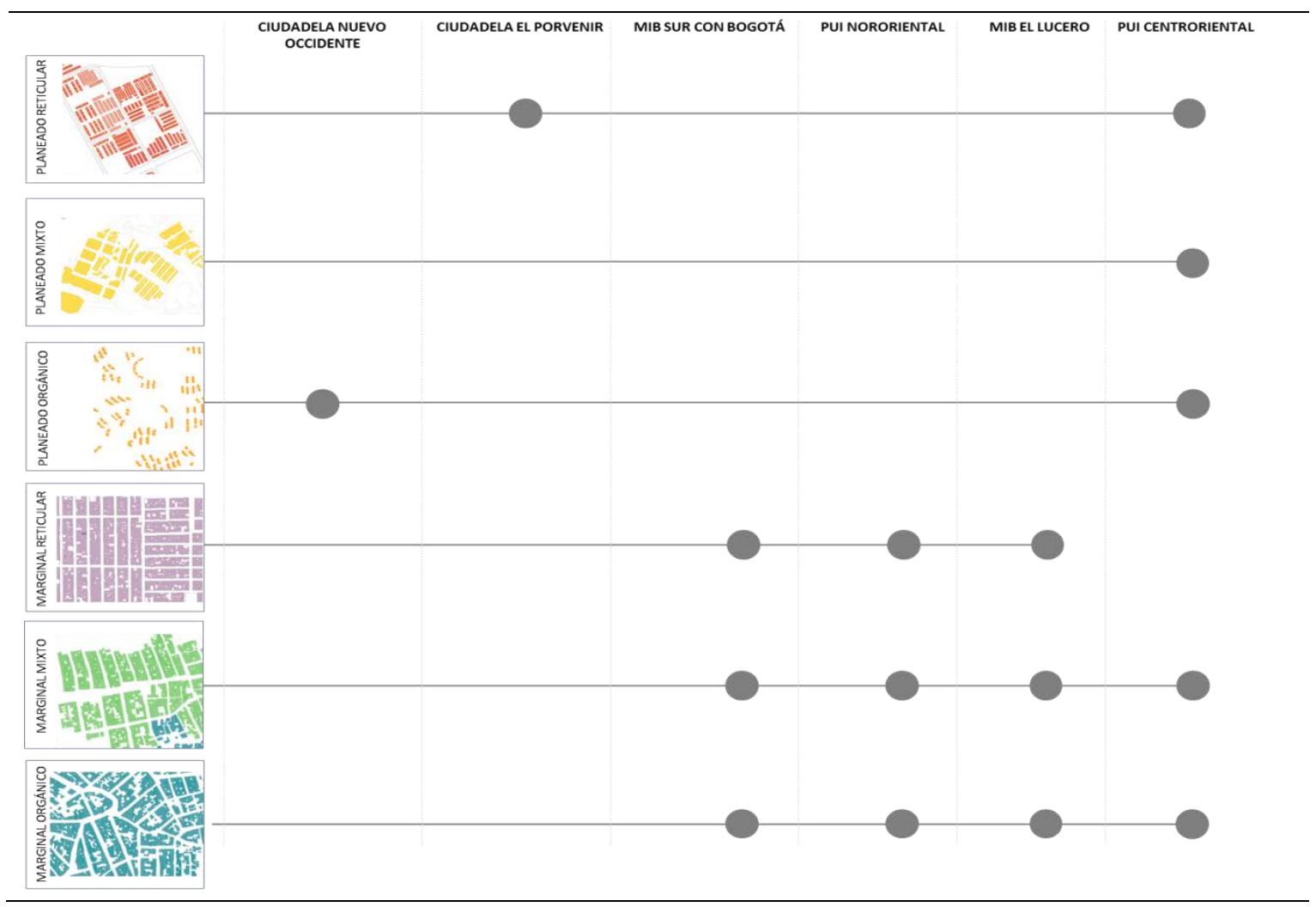


En este caso, sobre los materiales utilizados en las viviendas de producción formal podrían considerarse de mejor calidad o en todo caso de mejor condición estructural y arquitectónica que en la vivienda de origen marginal. En ésta última como es sabido, en muchos casos, se omitan las regulaciones sobre construcciones sismo resistentes o sobre las leyes básicas de continuidad de cargas o de reforzamiento estructural. Con ello, no se excluye que los materiales utilizados en las viviendas formales sean de óptimas calidad o estén siempre bien utilizados. En varias de las encuestas de satisfacción de los dos proyectos analizados, existen quejas de la población sobre grietas, filtraciones, estado deficiente de las tuberías ${ }^{119}$.

Tabla 27 I11 Grado de consolidación, materiales y alturas de las viviendas de los barrios de origen marginal

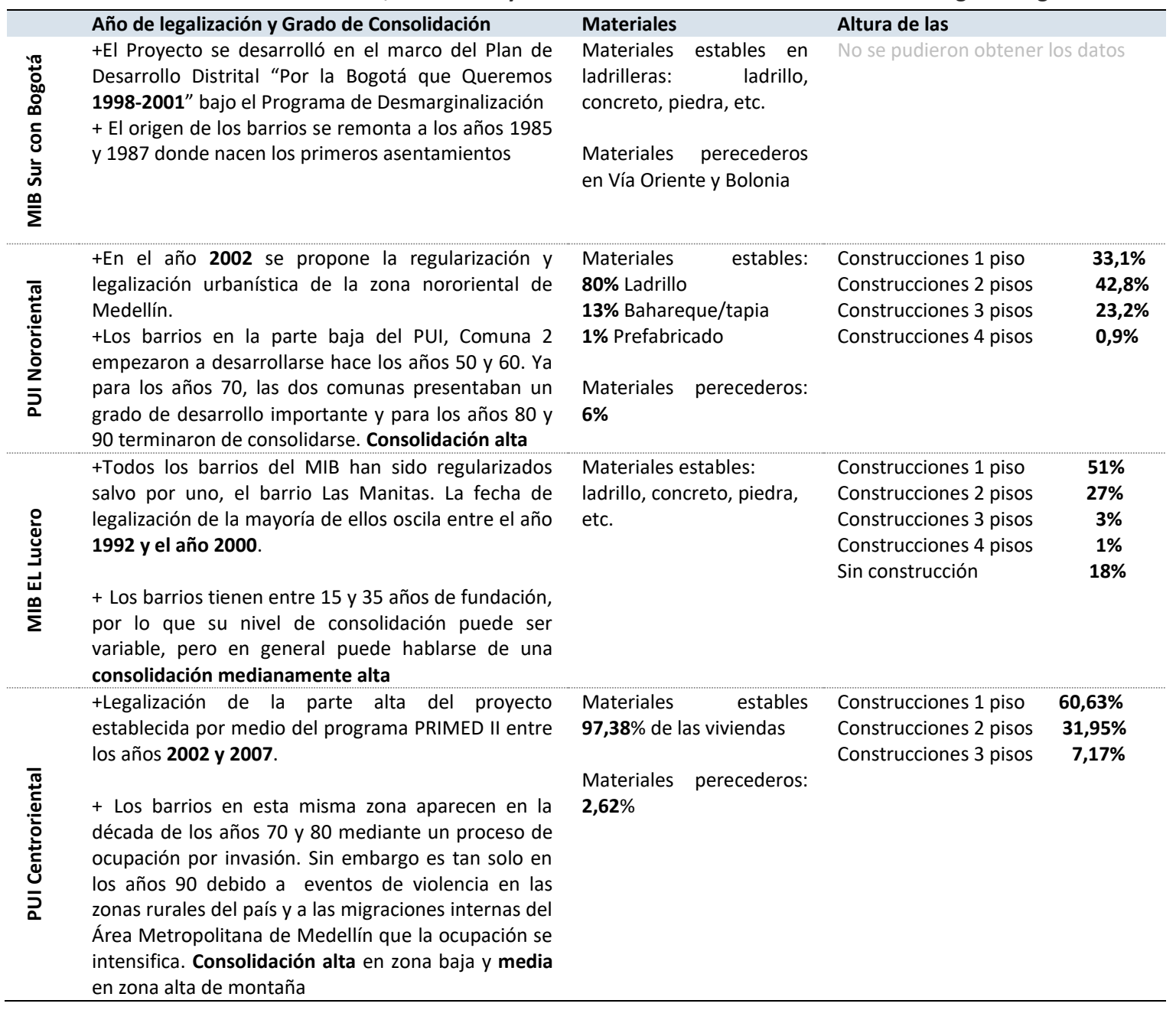

${ }^{119}$ El artículo de Mejía, Mónica titulado Habitabilidad en la vivienda social en edificios para población reasentada. El caso de Medellín, Colombia recoge algunas características sobre el estado de la vivienda entregada en el estudio de caso Ciudadela Nuevo Occidente. Su descripción es el siguiente. " Los proyectos de Álamos I y La Cascada se construyeron con el Sistema Outinord, lo que en términos locales es el "sistema constructivo de cajón". Son edificación levantada en panel prefabricado de concreto con muro estructural, por lo que las paredes no pueden ser modificadas. Este sistema responde a las exigencias de la Norma Técnica Colombiana sobre Sismorresistencia, la NSR-98. Sus características ofrecen, por lo tanto, seguridad física a sus habitantes y los protegen de las inclemencias del tiempo, ventajas respecto a lo que padecían con sus viviendas en Moravia, de material desechable o de baja confiabilidad tecnológica. [...] En cuanto al estado de la vivienda de destino, las edificaciones evidencian vicios y patologías de construcción, e inclusive lo hicieron al momento de la entrega de los apartamentos a los nuevos propietarios, generándose así un proceso de ruina física del edificio que redunda en afectación a la calidad de vida y al patrimonio familiar. El morador que acaba de llegar a su nuevo hábitat destino recibe del Isvimed - por obligación a "entera satisfacción"su unidad de vivienda, y no tiene otra opción, pues su anterior casa ya ha sido demolida o un desastre lo ha dejado sin hogar. Respecto a esta situación, los habitantes dicen haber llenado formatos de quejas entregados a la Empresa de Desarrollo Urbano (EDU) y al Isvimed sobre: marcos de ventanearía sueltos, atascados o con cerramientos malos; puertas metálicas torcida; instalaciones eléctricas quemadas o que se saltan los plomos; taponamiento de tuberías o lavamanos o sanitario roto; y techo o suelos con humedades, grietas o desniveles. (Mejía, 2012: 216) 
Con respecto al número de niveles edificados, predomina en todos los casos las viviendas de una y dos plantas (acorde a sus posibilidades de construcción y materiales a utilizar). Alturas que contrastan con los desarrollos de vivienda nueva que promueven torres de hasta nueve plantas en Nuevo Occidente y de seis en El Porvenir o en las nuevas edificaciones construidas en los mejoramientos de barrio, especialmente en el caso de Medellín en donde se sigue esa dinámica de alturas (caso Consolidación Juan Bobo en el PUI Nororiental con edificaciones de 6 plantas).

Sobre estas nuevas soluciones en altura, se cree, quizás no parten de una lectura de tradiciones o de aspectos culturales de la población que allí se aloja. Si bien los edificios en altura pueden llegar a ser una solución razonable ante el argumento de la escasez de suelo en la ciudad, Medellín o Bogotá, éste cambio implica una transformación de las prácticas culturales de la población a las que no siempre están preparadas. Como se menciona más adelante, la población a la que va dirigida esta vivienda es por lo general de procedencia rural o por la reubicación de asentamientos marginales acostumbrada a vivir en casa de una o dos plantas.

- La segunda variable analizada sobre el indicador de morfo-tipología fue la comparación entre la dimensión de la parcela y el bloque o unidad habitacional entre los diferentes estudios de caso. Así las cosas, se observó que las viviendas de los barrios de origen marginal son, por lo general, de mayor tamaño que los de las proyectos de vivienda nueva. Las unidades habitacionales de los proyectos planeados tienen como promedio un área de $45 \mathrm{~m}^{2}$ mientras que las unidades habitacionales de los asentamientos de origen marginal pueden alcanzar los $100 \mathrm{~m} 2$ o incluso más si colmatan su parcela (de dimensiones entre $100 \mathrm{~m}^{2}$ y $150 \mathrm{~m}^{2}$ en promedio). Cabe aclara que las dimensiones para los asentamientos de origen marginal son medidas promedio, tanto las dimensiones de las manzanas las parcelas o las edificaciones mismas varían de los $30 \mathrm{~m}^{2}$ a los $300 \mathrm{~m}^{2}$.

Existe una relación, aquí también, entre el proceso de formación, el tipo de configuración del tejido urbano y el tamaño de las parcelas. Dicha relación se vio principalmente establecida en los asentamientos de origen marginal como se ha venido mencionado a lo largo del análisis de este indicador. Las parcelas de los asentamientos de invasión suelen ser de mayor tamaño que las parcelas de los desarrollos clandestinos. La explicación se debe al rendimiento que quieren sacarle al suelo. La cuestión o la pregunta estaría en cuestionarse: ¿Por qué, si la meta de cualquier urbanizador es sacarle el mayor beneficio a su venta del suelo, los urbanizadores piratas pueden permitirse dimensiones más holgadas que los urbanizadores "legales"? ¿Qué beneficios le trae a un particular acceder a una vivienda o parcela más pequeña (a parte del hecho de contar desde el inicio con un proceso regulado)? 
Gráfica No. 23 I11 Comparativa entre las dimensiones de las parcelas o unidades habitacionales de los seis estudios de caso

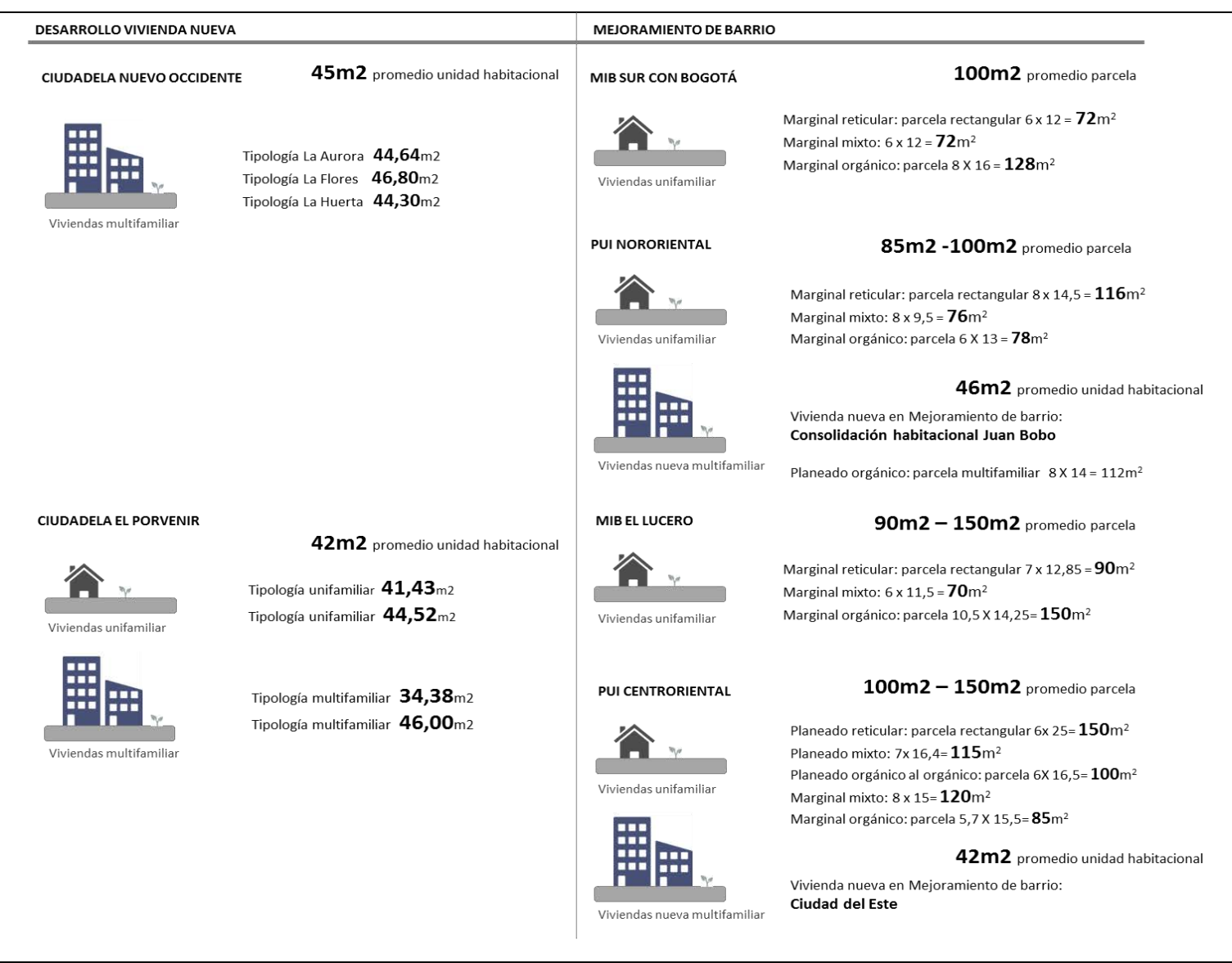

Sobre estas circunstancias resulta sorprendente que la normativa (cada POT) especifique teóricamente unas condiciones de diseño, ya inferiores a las de los asentamientos de origen marginal, y que aparte de ello permita que dichas disposiciones sean flexibles o mal interpretadas, es decir con dimensiones aún más reducidos. Ese es el caso, por ejemplo de la Ciudadela El Porvenir, en donde los constructores se inventaron para la vivienda unifamiliar y bifamiliar, un diseño coloquialmente denominado "multifamiliar acostado" que consiste en la subdivisión de una parcela en copropiedad con parcelas muy pequeñas que por obvias razones no cuentan con antejardín o patio, puesto que son multifamiliares. Logrando de este modo menor dimensiones a las establecidas por norma $\left(54 \mathrm{~m}^{2}\right)$ y con unas pésimas consecuencias en la calidad.

Una situación inversa hasta la ahora señalada de "área más grandes para las viviendas de origen marginal", está dada en la relación parcela-edificación; es decir en el índice de ocupación. Si se analiza la proporción del área del suelo ocupada por la edificación en primera planta de cada estudio de caso, los datos señalan con holgura que el porcentaje es mucho menor en los desarrollos de vivienda nueva. Menos del $20 \%$ de la parcela es ocupada en las edificaciones de altura recién construidas frente a un promedio del $80 \%$ construido en una vivienda de auto-construcción. 
Gráfica No. 24 I11 Comparativa entre las dimensiones de las parcelas o unidades habitacionales de los seis estudios de caso

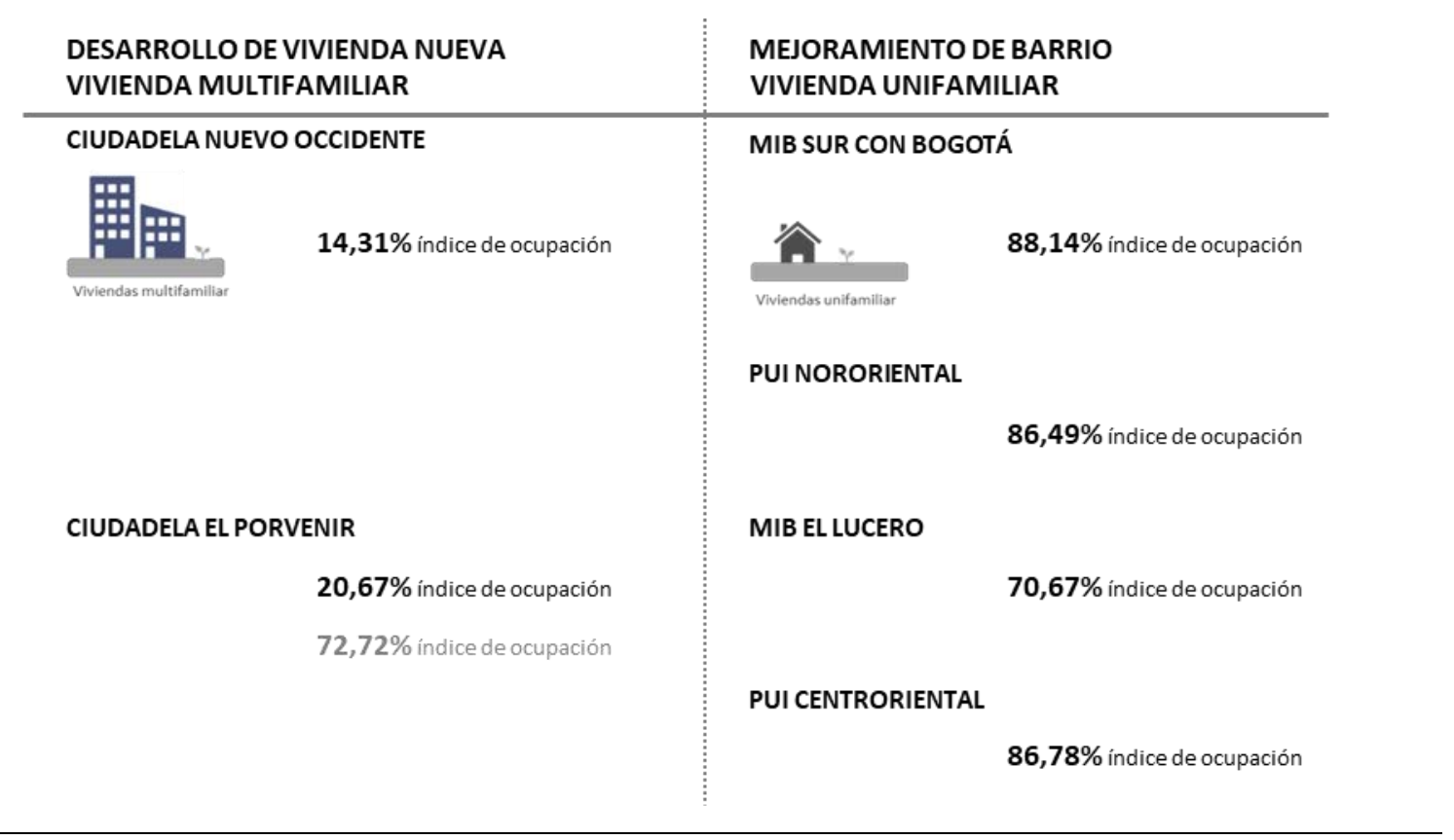

Existe sin embargo otro matiz, para el caso de la Ciudadela El Porvenir, si bien para sus edificios en altura su índice de ocupación es de $20.67 \%$ para sus viviendas unifamiliares o bifamiliares su índice de ocupación es del $72.72 \%$. Porcentaje muy cercano a los alcanzados en los asentamientos marginales y superior por ejemplo a la media encontrada el MIB EI Lucero.

Esta diferencia de área libre entre los edificios en altura y las viviendas unifamiliares es relativamente obvia. Está en estrecha relación con los espacios comunes, la circulación o el acceso para un hogar o para varios. A pesar de ser la vivienda nueva un lugar en donde sacarle la mayor rentabilidad al metro cuadrado, esta decisión de dejar un espacio colectivo puede llegar a considerarse criterio social de la economía; un giño de los agentes privados para con los residentes. Para los asentamientos marginales en cambio el mayor provecho del área total de la parcela es inevitable.

\subsubsection{Complejidad urbana}

En el segundo indicador a evaluar relativo al bloque, la complejidad urbana, también se contemplaron dos variables: el índice de diversidad de la población con sus condiciones sociales y la variedad de usos y funciones urbanas que se establecían o se fueron estableciendo gracias a los moradores en el proyecto.

- Con respecto a la primera variable, la mezcla de habitantes, según lo observado, no hubo tal en ninguno de los proyectos. Toda la población que en este tipo de desarrollos fue alojándose fue de un estrato socioeconómico bajo (estrato 1, 2 y 3). Tan solo en los proyectos de vivienda nueva, producción formal o en mejoramiento de barrio, los pisos de mayor valor en el mercado fueron adquiridos por algunas familias de estrato medio, estrato 4 . 
Sobre ello, por mucho que se promovieron conceptos en cada tratamiento (cada POT) como: cohesión social, integración, equilibrio o superación de desigualdad, éstos no lograron cambiar la realidad colombiana (como se ha demostrado, las instituciones tampoco han hecho mucho para ello). Los "ricos" y "pobres" no viven en el mismo territorio y no comparten las mismas características de ciudad. El alojamiento social en Colombia solo es considera para la población "pobre". Ninguna familia estrato medio alto o alto iría a vivir allí.

Por otro lado, el que no exista una mezcla de rentas no significa que no se presente en estos proyectos una diversidad de población bastante heterogénea. En los seis estudios de caso, la población alojada en estos territorios viene por reubicación de otras zonas de la ciudad (zonas por lo general deprimidas), por desplazamiento de zonas rurales, otras ciudades de Colombia o la misma ciudad debido al conflicto armado ( causado por bandas, guerrilla o paramilitares en la mayoría de los casos), por calamidad natural (inundaciones, sismos, deslizamientos de tierras, etc.), por necesidad en caso de invasión o por tener la capacidad de pago para acceder a una vivienda del mercado. Lo que trae, como se ha demostrado en diversos contextos habitacionales a nivel nacional e internacional, un conflicto social entre los habitantes por el dominio y uso del espacio, la convivencia o la seguridad ${ }^{120}$.

Gráfica No. 25 I12 Comparativa entre estrato socioeconómico de la población de los seis estudios de caso

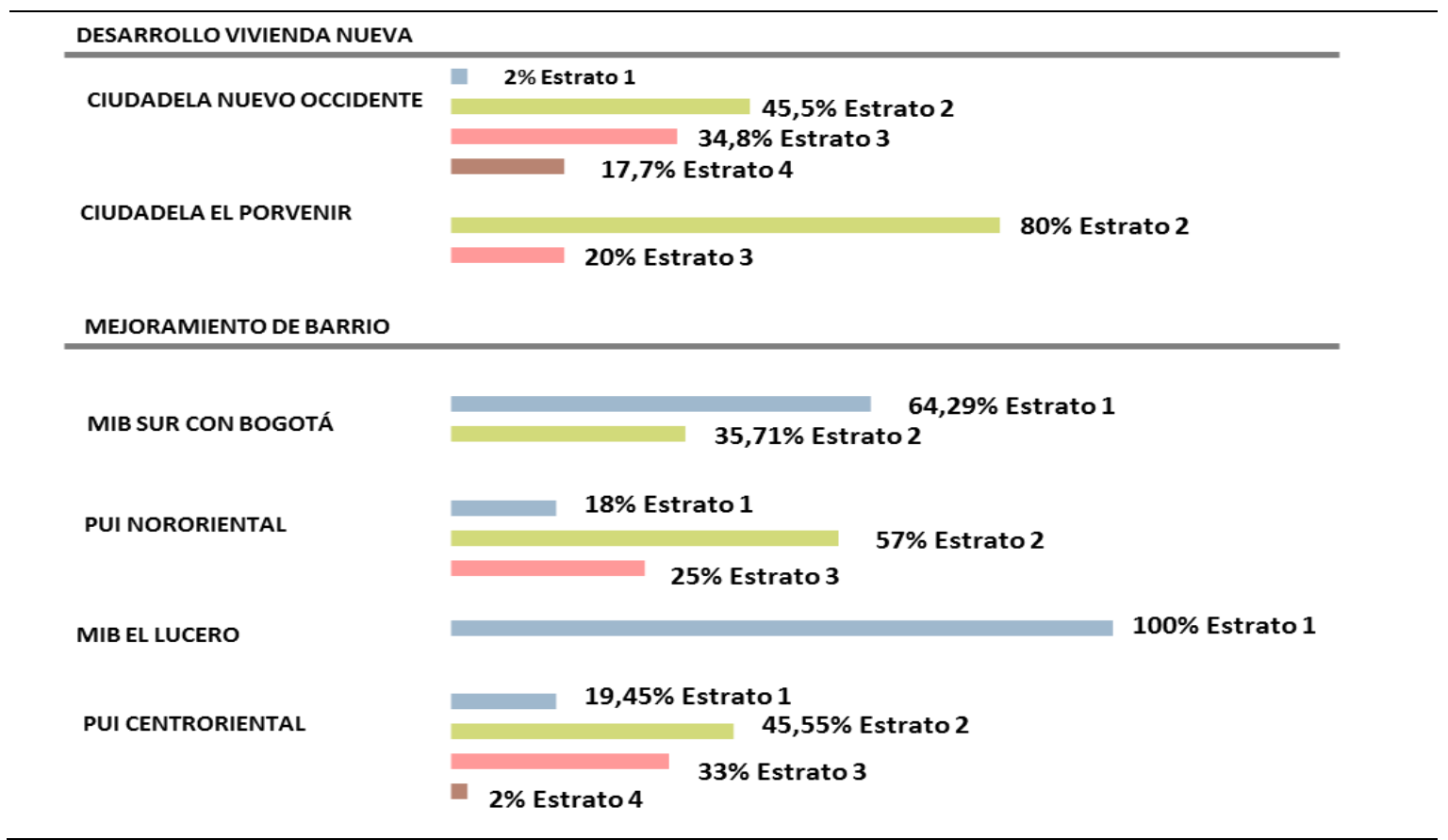

En definitiva, ninguno de los dos tratamientos presenta entornos que propicien una cohesión social entre los moradores. No existe en Colombia un plan de vivienda social adecuado que

\footnotetext{
120 Algunas notas de prensa señalan el tipo de conflictos presentados en estos proyectos: +El Diario.com publica un artículo en el año 2011 titulado: Damnificados de Altos de la Virgen se niegan a vivir en Nuevo Occidente. No todos quieren vivir en Pajarito. Según se explica en el texto las familias acusan problemas de seguridad por ir a vivir en esa zona y las viviendas les parecen muy pequeñas. En Red: http://www.elmundo.com/portal/pagina.general.impresion.php?idx=170311 [Consultado en diciembre de 2016]

+La revista Semana publica otro artículo en el año 2015 llamado: la urbanización en Medellín que se convirtió en zona de guerra. En este explica como algunas bandas criminales se hacen con los pisos aun no entregados para convertirlos en zonas de prostitución, acopio y venta de droga, lugares de extorsión. Los moradores y comerciantes de la zona son amedrentados y deben pagar una cuota por su "seguridad"- "estancia'. En red: http://www.semana.com/nacion/articulo/medellin-urbanizacion-de-casasgratis-en-manos-de-grupo-armado/453291-3 [Consultado en diciembre de 2016]
} 
logre superar la severidad de los problemas sociales, la pobreza, la exclusión o la desigualdad. Con ello, se reconoce que la situación supera la escala territorial, arquitectónica o urbana, e incluso la económica bajo la cual se suele regular la vivienda social; abarca cada dimensión que pueda relacionar la sociedad y la ciudad. Sin embargo, más allá de su complejidad y de sus múltiples correspondencias, algo se debe hacer. No se puede construir sin tener en cuenta a la población. $Y$ por supuesto no se puede repetir las experiencias de los grandes conjuntos habitacionales construidos en los años 50 en los Estados Unidos o en Francia por poner dos ejemplos con los problemas sociales y urbanísticos ya reconocidos ${ }^{121}$.

Acerca de la variedad de usos, el otro componente básico para establecer una diversidad adecuada en el territorio, se observó que los proyectos de vivienda nueva si bien planteaban unas centralidades dentro de su territorio, éstas solo contemplaban en un porcentaje estándar (según normativa) de equipamientos educativos, de salud o recreativos y muy poco comercios. Tan baja era la oferta y tan demorada en su construcción por parte de la administración que los habitantes, vieron la posibilidad de transformar sus viviendas en comercio de alimentos con productos diarios, servicios de peluquería o sastrería, pequeños talleres mecánicos o lugar para guardar la chatarrería. Para el estudio de caso en Medellín, incluso se alcanzó a ver viviendas con otro uso diferente al residencial hasta en la novena planta, el último nivel sin ascensor.

- En el caso de la Ciudadela el Porvenir, muchas viviendas de tipo unifamiliar fueron transformadas, casi en su totalidad, para albergar comercio. En este último caso además, la población se ha organizado desde hace varios años ya para realizar un mercadillo de frutas y verduras, dos veces a la semana, que es instalado de forma provisional en uno de los parques de la zona y desmontado el mismo día.

Existe también en el caso de El Porvenir, dos nuevos centros comerciales recientemente construidos. Estos si bien habían sido planeados desde el inicio, no se habían construido. Al parecer, y no se tiene información exacta al respecto, este comercio formal, no compite con el comercio "informal" establecido en las unidades habitacionales. Cada uno representa un nicho de mercado y suple unas necesidades diferentes. De todos los estudios de caso, este es el desarrollo con mayor uso comercial.

En el caso de los proyectos de origen marginal la variedad de usos se fue configurando, igualmente, según las necesidades y posibilidades de la población en el territorio. La diferencia radicaba en que allí la transformación de un espacio para una actividad o la otra se realiza de forma mucho más ágil o simultánea a la construcción del alojamiento. Al estar dentro de una práctica no planeada la población contaba, y cuenta aún, con la posibilidad de construir y

\footnotetext{
${ }^{121}$ Capel, en su texto ya citado: La morfología de las ciudades. Tomo I: Sociedad, cultura y paisaje urbano sobre dichos grandes conjuntos habitacionales en USA dice: "Los problemas aparecieron ya en Estados Unidos desde la década de los sesenta. Algunos de los polígonos de vivienda pública construidos en los años cincuenta se habían deteriorado rápidamente. Se había realizado granes inversiones en su construcción, pero no se había previsto adecuadamente el mantenimiento, que recaía sobre los residentes. Como muchos de ellos eran familias de muy bajos recursos, no estaba en condiciones de atender a dicho mantenimiento. Además los residentes tenían a veces familias numerosas y los pisos, de dimensiones estándar, resultaban inapropiados. Finalmente, los equipamientos tardaban en llegar. El resultado fue la rápida deterioración. El caso más significativo fue el del barrio Pruit-Igoe, en Saint Louis, un polígono de bloques construido en 1951 convertido muy rápidamente en un gueto negro con graves problemas sociales y urbanísticos; tras un amplio debate público los bloques tuvieron que ser demolidos en 1972. (CAPEL 2002: 427)
} 
transformar los espacios de forma mucho más flexible. Ese es el caso del PUI Nororiental, por ejemplo, en donde se percibe un gran dinamismo comercial con diversidad de servicios y productos ofrecidos (panaderías, carnicerías, papelerías, graneros, talleres, misceláneas, licoreras entre otros). Su desarrollo está dado en gran medida por la construcción y utilización del sistema de transporte masivo Metro.

Tabla 28 I12 Comparativa diversidad de usos entre los seis estudios de caso

\begin{tabular}{lccc}
\hline Desarrollo vivienda nueva & Residencial & Dotación & Comercio \\
\hline Ciudadela Nuevo Occidente & & & $2 \%$ \\
Ciudadela El Porvenir & $93,40 \%$ & $4,6 \%$ & $7,06 \%$ \\
Mejoramiento de barrio & $91,46 \%$ & $1,48 \%$ & \\
MIB Sur Con Bogotá & & $1,86 \%$ & $4,24 \%$ \\
PUI Nororiental & $93,90 \%$ & $2,21 \%$ & $4,36 \%$ \\
MIB El Lucero & $93,41 \%$ & $2,13 \%$ & $2,14 \%$ \\
PUI Centroriental & $95,73 \%$ & $1,45 \%$ & $2,54 \%$ \\
\hline
\end{tabular}

En todo caso, como se puede observar fácilmente en la tabla anterior, ningún proyecto cuenta con una mezcla de usos diferenciada. Sea un desarrollo planeado o un espontáneo se terminan, prácticamente, configurando las mismos inercias. Mismo tipo de población, mismas características de funciones y usos.

De nuevo la normativa sobre este tema poco viene a transformar o a mejorar frente a las condiciones anteriores de la ciudad. Si bien la regulación en cada POT especifica la diversidad de usos a contemplar en un proyecto de alojamiento social, ésta no da porcentajes o pautas en sus dimensiones claramente definidos. Tan solo especifica las áreas sobre cesiones públicas y privadas a dejar. Así, la creación de entornos que propicien una diversidad urbana tan aclamada en todos los postulados de urbanismo con una distribución del suelo proporcionada, una mezcla de rentas adecuada y una conformación edificatoria más flexible capaz de adecuarse a las necesidades o medidas de la población habitante, será difícilmente lograda.

\subsection{SÍNTESIS TRANSVERSAL Y CONCLUSIONES PARCIALES DE LOS RESULTADOS}

A continuación se discuten los resultados obtenidos sobre las condiciones de calidad habitacional logradas en los seis estudios de caso analizados en la ciudad de Bogotá y Medellín durante los años 2000-2010. Las tablas (29, 30 y 31$)$ que se presentan en cada apartado recogen la síntesis de los resultados obtenidos respecto al marco de evaluación por indicadores y su sistema de puntuación propuesto. El análisis se realiza bajo las tres escalas definidas: ciudad, barrio-local y bloque-vecindario.

Cabe insistir de nuevo, que la intención es comparar la configuración del espacio producido en los desarrollo de vivienda nueva frente a los asentamientos marginales luego de la intervención de mejoramiento de barrio. Interesa identificar los parámetros esenciales aplicados bajo normativa en cada tratamiento y reconocer sus diferencias. Solo de esta manera se puede posteriormente comprobar si la hipótesis de partida ha sido alterada por los resultados obtenidos.

Para entender los resultados numéricos se explica de nuevo que la condición predominante media (puntuación media) representa la condición exigida por la normativa y su puntuación es dos o cero según los casos. Cuando el subindicador medido mejora lo establecido por la 
normativa la calificación es cero y si no cumple con lo especificado la puntuación es cuatro. Entre mayor sea la puntuación de un indicador en un estudio de caso peor será su condición de habitabilidad.

Como complemento de ese análisis transversal en el último apartado se considera someramente el margen de cambio social de la población residente a través de unos estudios de percepción y su grado de participación o vinculación con los proyectos realizados en sus áreas de residencia.

\subsubsection{Análisis relativo a la escala de ciudad}

Con respecto a la escala de ciudad los resultados obtenidos muestran una condición predominantemente deficitaria frente a la media establecida. Los seis proyectos tienen un puntaje superior al puntaje establecido como medio, es decir como la condición mínima establecida por la norma (20 puntos). Condición que por supuesto se ha traducido en viviendas con condiciones inadecuadas frente a su ubicación, su accesibilidad, su cercanía a centralidades, su nivel de ocupación y sus densidades.

Tabla 29 Análisis relativo a la escala de ciudad

\begin{tabular}{|c|c|c|c|c|c|c|c|c|c|}
\hline \multirow[b]{2}{*}{ Categoría } & \multirow[b]{2}{*}{ Dimensión } & \multirow[b]{2}{*}{ Indicador } & \multirow[b]{2}{*}{ Subindicador } & \multirow[t]{2}{*}{$\begin{array}{l}\text { Ciudadela } \\
\text { Nuevo } \\
\text { Occidente }\end{array}$} & \multirow[t]{2}{*}{$\begin{array}{l}\text { Ciudadela EI } \\
\text { Porvenir }\end{array}$} & \multirow[t]{2}{*}{$\begin{array}{l}\text { Mib Sur Con } \\
\text { Bogotá }\end{array}$} & \multirow[t]{2}{*}{$\begin{array}{c}\text { PUI } \\
\text { Nororiental }\end{array}$} & \multirow[t]{2}{*}{ Mib EI Lucero } & \multirow[t]{2}{*}{$\begin{array}{c}\text { PUI } \\
\text { Centroriental }\end{array}$} \\
\hline & & & & & & & & & \\
\hline \multirow[t]{11}{*}{$\begin{array}{l}\text { Estructura } \\
\text { urbana }\end{array}$} & $\begin{array}{l}\text { D1 Ocupación } \\
\text { del suelo }\end{array}$ & 101 Densidad & & 4 & 4 & 0 & 4 & 0 & 0 \\
\hline & & 102 Cesiones & Malla vial & 4 & 4 & 2 & 4 & 4 & 4 \\
\hline & & & Equipamiento & 2 & 2 & 4 & 2 & 4 & 4 \\
\hline & & & Zonas verdes & 0 & 2 & 2 & 2 & 4 & 2 \\
\hline & D2 Accesibilidad & 103 Centralidades y & A pie & 4 & 4 & 4 & 4 & 4 & 4 \\
\hline & & $\begin{array}{l}\text { tiempos de } \\
\text { desplazamiento }\end{array}$ & $\begin{array}{l}\text { Transporte } \\
\text { público }\end{array}$ & 4 & 2 & 2 & 2 & 2. & 2 \\
\hline & & $\begin{array}{l}104 \text { Acceso a } \\
\text { transporte público }\end{array}$ & $\begin{array}{l}\text { Paradas de } \\
\text { transporte público }\end{array}$ & 4 & 2 & 4 & 4 & 2 & 4 \\
\hline & D3 Movilidad & 105 Trazado de vías & Conexiones viales & 4 & 2 & 2 & 2 & 2 & 2 \\
\hline & & & Pendientes & 4 & 0 & 4 & 2 & 2 & 2 \\
\hline & & 106 Estado de las vías & & 2 & 2 & 4 & 2 & 4 & 2 \\
\hline & & Condición predominante & $\begin{array}{r}\text { media } 20 \\
\text { deficiente }>20\end{array}$ & 32 & 24 & 28 & 28 & 28 & 26 \\
\hline
\end{tabular}

Elaboración propia

Así el proyecto con la peor valoración a escala de ciudad es La Ciudadela Nuevo Occidente (32 puntos/20 de media). En los indicadores de densidad, tiempos de desplazamiento, acceso a transporte público, trazado de las vías obtiene la peor puntuación posible. Solo cumple con la normativa en cuanto a cesiones de equipamientos (aunque estos para la fecha de corte del análisis 2010 no estaban construidas las edificaciones) y en estado de las vías. Se recuerda que este es un proyecto de vivienda nueva, es decir un proyecto que para ser construido debía contar con la aprobación normativa. Solo supera las pautas mínimas en cesiones de zonas verdes.

El resultado obtenido en la Ciudadela de Medellín vendría a apoyar entonces la hipótesis de partida: se produce una mejor calidad del espacio residencial en los asentamientos marginales después de la intervención de mejoramiento de barrio que en los proyectos de construcción 
nueva. Aun cuando estos últimos, los proyectos de vivienda nueva, por "iniciar de cero", deberían contar con condiciones arquitectónicas y urbanas mejores. Sin embargo, la mejor puntuación a esta escala de ciudad, la calificación más cercana a la media es la de Ciudadela EI Porvenir (24 puntos/20 de media), el otro proyecto de vivienda nueva. Este sigue los reglamentos normativos en prácticamente todos los indicadores.

Los proyectos de mejoramiento de barrio tuvieron casi todos, una puntuación similar (28 puntos/20 de media). Cumplen hasta cierto punto con lo establecido en la normativa con relación al acceso del transporte público (es allí donde la administración ha puesto mayor interés en construir cable-metro, metro o estaciones de Transmilenio) y a las conexiones viales, necesarias como infraestructura para llegar con el transporte público.

En concreto, ningún estudio de caso obtuvo con la calificación absoluta lo mínimo establecido por la normativa o supuso una condición mejor que lo regulado. Lo que demuestra una vez más que las condiciones de calidad especificadas en el POT son entendidas maliciosamente como lo máximo obligado por ley y que no hay control alguno por parte de las administraciones a revisar que se cumple esa ley.

\subsubsection{Análisis relativo a la escala de barrio-zonal}

Siguiendo ahora con el análisis a escala intermedia, la escala barrio-zona, los resultados muestran de nuevo que los proyectos están por encima de la puntuación establecida como mínima por la norma (media de 14 puntos). Aquí la peor puntuación la tiene el PUI Centroriental (38 puntos) y la más cercana a la media Ciudadela El Porvenir ( 26 puntos). No obstante, vale la pena analizar por dimensión cada estudio de caso ya que la valoración varía considerablemente.

Tabla 30 Análisis relativo a la escala de barrio-zona

\begin{tabular}{|c|c|c|c|c|c|c|c|c|c|}
\hline & & & & $\begin{array}{l}\text { Ciudadela Nuevo } \\
\text { Occidente }\end{array}$ & $\begin{array}{c}\text { Ciudadela El } \\
\text { Porvenir }\end{array}$ & Mib Sur Con Bogotá & PUI Nororiental & Mib El Lucero & PUICentroriental \\
\hline \multirow{19}{*}{$\begin{array}{l}\text { Equipamientosy } \\
\text { servicios básicos }\end{array}$} & Dimensión & Indicador & Subindicador & & & & & & \\
\hline & D4 Equipamientos & $\begin{array}{l}107 \% \text { territorio cubierto } \\
\text { por equipamientos }\end{array}$ & Educación & 2 & 2 & 2 & & 2 & 2 \\
\hline & & & Sanidad & 4 & 4 & 4 & 4 & 4 & 4 \\
\hline & & & Bienestar social & 4 & 4 & 2 & 2 & & 4 \\
\hline & & & Cultural & 4 & 4 & 4 & 4 & 4 & 4 \\
\hline & & & Comercio local & 4 & & & & & 2 \\
\hline & & & Culto & 4 & 4 & 4 & & 4 & 2 \\
\hline & & Condición predominante & media 12 & 22 & 18 & 16 & 10 & 14 & 18 \\
\hline & D5 Espacio Público & 108 \%espacio público & Zonas verdes & 4 & 2 & 4 & 4 & 2 & 2 \\
\hline & $\begin{array}{l}\text { D6 Servicios Públicos } \\
\text { Domiciliario }\end{array}$ & $\begin{array}{l}\text { s } 109 \text { Conexión servicios } \\
\text { públicos domiciliarios }\end{array}$ & Авиа & & & 2 & 2 & 2 & \\
\hline & & & Alcantarillado & & & 2 & 2 & 2 & 2 \\
\hline & & & Electricidad & & & 2 & & & \\
\hline & & & Gas & & & 2 & 4 & 4 & 4 \\
\hline & & & Basuras & 2 & 2 & 4 & 2 & 4 & 4 \\
\hline & & Condición predorminante & media 0 & 2 & 2 & 12 & 10 & 12 & 10 \\
\hline & & $\begin{array}{l}110 \text { Condiciones } \\
\text { ambientales }\end{array}$ & Corrimiento de tierras & 4 & & & 4 & 2. & 4 \\
\hline & & & Inundación & 4 & 4 & & & 4 & 4 \\
\hline & & Condición predorminante & media 0 & 8 & 4 & 0 & 4 & 6 & 8 \\
\hline & & ndición predominante total & 14 & 36 & 26 & 32 & 28 & 34 & 38 \\
\hline
\end{tabular}

Elaboración propia

Con respecto a la dimensión de equipamientos, la media son 12 puntos y solo PUI Nororiental obtiene una calificación menor a esa media (10 Puntos); es decir que el porcentaje de 
territorio cubierto por esta dimensión es mayor al mínimo reglamentado. Una calificación similar, aunque no tan óptima, se da en los dos proyectos de mejoramiento de barrio de Bogotá. La explicación se debe al desarrollo de dichas edificaciones de manera informal por la población. Un ejemplo claro son los espacios destinados al comercio local. Dichos espacios, como se ha reseñado son impulsados por la población.

Sobre la cobertura de zonas verdes, una de las principales deudas a priori de los desarrollos marginales, es obtenida gracias a la generación de suelo antes inexistente a través de la integración de predios y la eliminación de áreas residuales. Así los dos proyectos de mejoramiento de barrio, MIB EI Lucero y PUI Centroriental cumplen con la normativa y los otros dos no. Similar situación sucede con los proyectos de vivienda nueva, Ciudadela El Porvenir cumple y Nuevo Occidente no.

La disposición de servicios públicos de acueducto, alcantarillado y saneamiento básico como no podía ser diferente es óptima en los proyectos de vivienda nueva y deficiente en los proyectos de mejoramiento de barrio. Aunque en los dos tipos de proyectos existan problemas ya mencionados de frecuencias del servicio, desconexión, cortes o impagos.

$Y$ finalmente en cuanto a las condiciones ambientales la peor situación se de en los proyectos de vivienda nueva; condición que sobra decir debería estar resuelta por la misma condición de los proyectos: ejecutados desde el inicio, con los estudios geotécnicos del caso y la aprobación por parte de las administraciones.

En definitiva, con respecto a la escala de barrio-zona los estudios de caso de mejoramiento de barrio y los de vivienda nueva tienen unas igualitarias condiciones deficientes. Ninguno tiene una puntuación cercana a la solicitada por la normativa. Lo que lleva una vez más a matizar la hipótesis plateada. No parecería del todo cierto que existan mejores condiciones en los asentamientos marginales después de su intervención de mejoramiento de barrio.

\subsubsection{Análisis relativo a la escala de bloque-vecindario}

El examen a escala de bloque-vecindario ratifica una vez más que los cumplimientos básicos no se han traducido en viviendas con condiciones adecuadas de calidad habitacional. La calificación media es de 8 puntos y esos puntos solo lo obtiene el PUI Centroriental. El resto de proyectos tienen un puntaje superior, puntaje que por lo tanto no cumple con la normativa y da señales de baja calidad. La peor valoración, duplicando la media, es el de Ciudadela El Porvenir. Resultados que esta vez comprobarían parcialmente la hipótesis en donde se asegura: se produce una mejor calidad del espacio residencial en los asentamientos marginales después de la intervención de mejoramiento de barrio. 


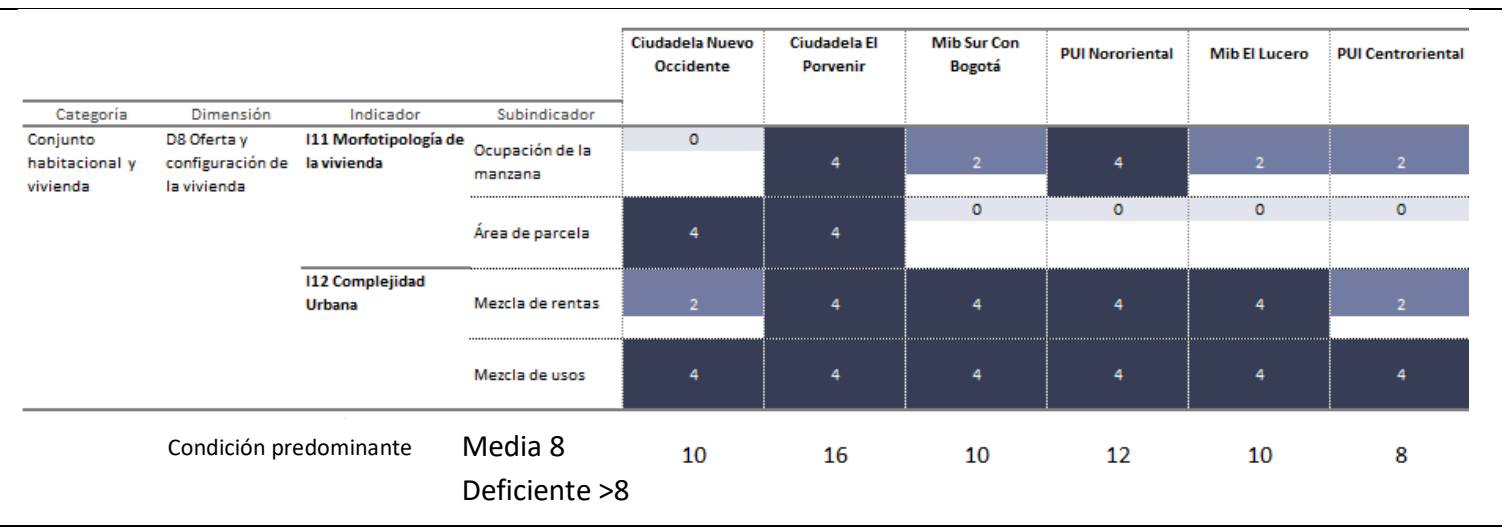

Elaboración propia para

Sin embargo, como se expone cada estudio de caso con su puntuación, esa aseveración de hipótesis no es del todo cierta. El PUI Nororiental (12 puntos) tiene perores condiciones habitacionales que la Ciudadela Nuevo Occidente (10puntos). De ahí la importancia de escudriñar una vez más esta calificación en esta escala concreta de bloque-vecindario.

Se infiere, como se mencionó, que los proyectos de vivienda nueva, por "iniciar de cero", deberían contar con condiciones arquitectónicas y urbanas mejores. Para demostrar éste punto sería consecuente analizar indicadores tales como seguridad y salubridad de las construcciones, espacios interiores (dimensiones, iluminación y ventilación), calidad y dimensiones de los espacios de acceso, circulación y evacuación, presencia de espacios colectivos o índice de ocupación del suelo entre otros. Indicadores todos que supondrían una deficiencia mayor respecto a la calidad en los asentamientos marginales. Suposición que se cree cuestionable pero que queda para futuras investigaciones dado el grado de dificultad y la insuficiencia de medios para llegar al análisis vivienda (el interior de la misma) en los seis estudios de caso $^{122}$.

No obstante si se puede llegar a señalar ciertos puntos críticos que demostrarían que los proyectos de vivienda nueva no cuenta tampoco con condiciones de calidad adecuados:

- Con respecto a la seguridad y salubridad de las construcciones se demostró que la mayoría de las viviendas (90\%) en todos los estudios de caso son construidos con materiales estables (ladrillos, hormigón, piedra, bahareque, tapia o adobe). Las viviendas con materiales perecederos (latas, plásticos, maderas entre otros) son, por lo general, viviendas autoproducidas que llevan muy poco tiempo de ser instaladas en la zona o viviendas abandonadas.

Sobre los materiales estables utilizados en las viviendas nuevas se reconocen vicios y patologías incluso en el momento mismo de la entrega a los nuevos propietarios. Por ejemplo en Ciudadela Nuevo Occidente, los habitantes dicen haber llenado formatos de quejas entregados a la Empresa de Desarrollo Urbano (EDU) y al Isvimed sobre: marcos de ventanearía sueltos, atascados o con cerramientos malos; puertas metálicas torcida; instalaciones eléctricas quemadas o que se saltan los plomos; taponamiento de tuberías o lavamanos o sanitario roto; y techo o suelos con humedades, grietas o desniveles. (Mejía, 2012: 216)

\footnotetext{
${ }^{122}$ Cabe señalar aquí las dificultades para acceder a estas zonas de estudio, especialmente las zonas de desarrollo auto-producido. Éstas son zonas deprimidas de la ciudad en donde se presentan altos grados de violencia, control de bandas, robos, etc.
} 
- Acerca del sistema constructivo, los proyectos en altura de los desarrollo de vivienda nueva se construyeron con el Sistema Outinord ${ }^{123}$, lo que en términos locales colombianos es el "sistema constructivo de cajón". Su construcción se levanta con paneles prefabricados de hormigón que son a la vez muros estructurales y cerramientos o muros divisorios de la vivienda, por lo que no pueden ser modificados. El sistema como tal responde a las exigencias de la Norma Técnica Colombiana sobre Sismorresistencia, la NSR-98. Sus características ofrecen seguridad física a sus habitantes y los protegen de las condiciones ambientales. Sin embargo, el estudio de Mejía (2012), señala como algunos pisos han sido modificados con la eliminación de algunos muros para generar espacios más amplios según las necesidades de los residentes. Situación que pone en grave riesgo el sistema constructivo de toda la edificación.

Sobre la calidad de los espacio interiores por ejemplo, se observó tanto en Ciudadela Nuevo occidente como en El Porvenir que algunas familias residentes subdividieron sus espacios de tal forma que generaron nuevas habitaciones sin ventilación o iluminación natural. Con ello la "superioridad" espacial que tendrían las viviendas nuevas sobre las viviendas de los asentamientos marginales se vería revocada.

Así que ya no solo se habla de espacio subdivididos sino, como ya se había mencionado de menor área que los espacios de las viviendas de barrios marginales. Según demuestra Escobar en su trabajo en Ciudadela Nuevo Occidente el espacio mínimo de cada vivienda se redujo al espacio mínimo vital, habitaciones de 2.20 o $2.30 \mathrm{mts}$ en donde "ni siquiera cabe una cama', según sus palabras. Además según él "se disolvieron conceptos como los espacios compartidos y los semiprivado. Ahora son un solo espacio que hace de manera virtual prácticamente la integración de cocina, sala, comedor y estudio. Es un solo espacio con muebles llevados a su mínima expresión." A esto se le suma otros problemas como las condiciones técnicas y constructivas que "rebajan las dimensiones no solo bidimensioneles sino tridimensionales. Para ahorrar costos ya no hay alturas de 3 metros sino alturas de 2.20 metros."

\subsubsection{Margen de cambio social}

Con el fin de medir los impactos producidos en términos de mejoramiento de calidad de vida de la población beneficiara de los estudios de caso se consideraron algunos sondeos de percepción o encuestas realizadas a esa población. Desafortunadamente solo se obtuvieron informes o trabajos sobre Ciudadela Nuevo Occidente, MIB Sur Con Bogotá y PUI Centroriental. Sus resultados no son extrapolables al resto de estudios de caso, pero se cree sí dan un panorama sobre el tema. Así la reseña no pretende dar una visión exhaustiva de los procesos sociales o del grado de vinculación de la población residente pero sí de exponer su relación con el espacio edificado.

\footnotetext{
123 El sistema Outinord, es el resultado de la evolución de los encofrados hasta lograr un vaciado total de muros y placas. Esencialmente consiste en la fundida monolítica de muros y placas de hormigón, de poco espesor. Se utiliza un molde con dos elementos verticales y uno horizontal, fácil de armar y con sistemas adecuados de tornillería, cuñas y rodachines para el descimbre.

Con este sistema se trata de lograr que todas las actividades se realicen entre las 8 de la mañana y las 6 de la tarde de cada día, dejando un tiempo de 14 horas para el fraguado del concreto, suficiente para que este tenga una resistencia adecuada para retirar los encofrados y repetir el ciclo. Es decir, el objetivo principal es el de emplear un sistema industrializado de construcción que permita ejecutar proyectos repetitivos con gran rapidez y calidad.
} 
Los documentos estudiados fueron:

- Los lugares del hábitat como espacio de realización de lo político y de la política pública a través del habitar: una propuesta teórica para el análisis del hábitat en la Ciudadela Nuevo Occidente" realizado por Julio Eduardo Mesa Escobar de la Universidad Nacional de Colombia. El trabajo fue realizado en el año 2012 y cuenta con unas interesantes entrevistas realizadas a docentes, administrativos y líderes comunitarios sobre las condiciones de calidad habitacional en la Ciudadela Nuevo Occidente.

. Habitabilidad en la vivienda social en edificios para población reasentada. El caso de Medellín, Colombia“ realizado por Mónica Mejía Escalante y publicado en la revista EURE Vol. 38 en el año 2012.

- Encuesta de opinión sobre los resultados del Proyecto Sur con Bogotá. BoloniaLadrilleras-Vía oriente realizado en el año 2004 por la Alcaldía Mayor de Bogotá con el apoyo del Observatorio de Cultura Urbana. La encuesta es un sondeo de percepción con una muestra de los residentes de la zona que indagaba sobre el grado de conocimiento del proyecto en la población, las formas prioritarias de participación, las acciones sobresalientes realizadas, el tipo de beneficios aportados y las apreciaciones con relación a seguridad y convivencia en las zonas del proyecto.

- Diagnóstico comunitario del barrio Villa Turbay. Comuna 8 de Medellín realizado en el año 2011 por Carlos Velásquez con la colaboración de Mesa Interbarrial de desconectados y Corporación Paz y Futuro en Medellín.

Tabla 32 Entrevista realizada a residente de Ciudadela Nuevo Occidente

\begin{tabular}{|l|l|}
\hline \multicolumn{2}{|l|}{ Entrevista realizada a Claribel Arango. Persona residente de Ciudadela y referencia dentro de la comunidad } \\
\hline ¿Dónde vivía antes? & $\begin{array}{l}\text { ¿Cómo llegó al barrio? } \\
\text { Por ser zona de alto riesgo y por obstaculizar vías de } \\
\text { transporte que se iban a construir. La Alcaldía nos propuso el } \\
\text { traslado a Pajarito. }\end{array}$ \\
\hline $\begin{array}{l}\text { ¿Cómo empezó a trabajar en la parte organizativa? } \\
\text { una, organizamos una asociación de mujeres cabeza de hogar } \\
\text { para conseguir el sustento y viendo las oportunidades que el } \\
\text { gobierno tiene con nosotras, pues me empoderé de eso. }\end{array}$ & $\begin{array}{l}\text { ¿Qué desearía del nuevo lugar que habita? } \\
\text { Faltan espacios para la comercialización, faltan espacios para } \\
\text { la recreación pasiva de los adultos, no tenemos donde } \\
\text { sentarnos. Me gustaría y he luchado mucho por un parque, un } \\
\text { espacio para nosotros. Queremos adornar muy bien este lugar, } \\
\text { hacer un parque. }\end{array}$ \\
\hline $\begin{array}{l}\text { ¿Qué experiencias agradables le han marcado su existencia? } \\
\text { Pertenecer a un grupo de mujeres. No sabía que era eso. No } \\
\text { sabía qué era la economía solidaria, ni que era una juta de } \\
\text { acción comunal. Hoy participo en todo ello. }\end{array}$ & $\begin{array}{l}\text { ¿Qué ventajas tiene que antes no tenía? } \\
\text { Dignidad, pues no es lo mismo vivir en un espacio, así sea } \\
\text { chiquito, sin divisiones y sin acabados que en un basurero con } \\
\text { enfermedades. } \\
\text { Monte un local de peluquería. Me va muy bien. Solo pago } \\
\text { servicios. Me han dado capacitación. }\end{array}$ \\
$\begin{array}{l}\text { Me incomoda eso si no tener una vivienda adecuada. } \\
\text { Necesitamos equipamientos, centros de salud y recreación. No } \\
\text { soy muy creyente pero hace una iglesia porque hay personas } \\
\text { muy devotas que necesitan una iglesia. No tenemos unidad } \\
\text { hospitalaria a la cual asistir en caso de urgencia. } \\
\text { La administración y su labor han sido regular. Nos han dejado } \\
\text { tirados. Por eso tenemos que luchar y caminar nosotros. } \\
\text { Tenemos mucho que agradecerle pero hacen falta muchas } \\
\text { cosas. }\end{array}$ \\
\hline Fus
\end{tabular}

Fuente: Encuestas realizadas a docentes, administrativos y líderes comunitarios en Ciudadela Nuevo Occidente en el trabajo de Trabajo fin de master de MESA ESCOBAR, Julio (2012) 
Tabla 33 Entrevista realizada a docentes sobre Ciudadela Nuevo Occidente

\begin{abstract}
Entrevista a Luis Fernando González
¿Una característica que han tenido los últimos gobiernos ha

sido el presupuesto participativo ¿Se contó con la

participación de la gente para el proyecto Pajarito? ¿Se tuvo

en cuenta el contexto cultural de la gente para ser asentada en este nuevo espacio?

"Yo creo que hay una gran confusión entre que es una agenda de participación y qué es el desarrollo de presupuestos participativos. Obviamente desde hace muchos años en los proyectos urbanos, los proyectos urbanísticos y los proyectos arquitectónicos, se habla de participación de la comunidad pero yo creo que es una manera equivocada de hablar de ciertas consultas. Hablar de consultas no es hablar de procesos participativos ni de considerar algunos talleres sobre imaginar cuál es el sueño del futuro".
\end{abstract}

Profesor de la Escuela del Hábitat de la Faculta de Arquitectura de Universidad Nacional de Colombia sede Medellín

\section{¿Se puede considerar que los espacios físicos pueden generar} o posibilitan organización social y tejido social en ese sector? Sobre los espacios públicos, no se puede desconocer que frente al desarrollo habitacional de muchos sectores de Medellín, allí hay mayor porcentaje de áreas verdes o áreas potenciales para áreas verdes y espacios recreativos. Lo que se ha criticado es que esos son procesos posteriores, no van de la mano en forma mancomunada con el desarrollo habitacional.

\section{¿Qué dificultades ve usted en el interior de las viviendas?}

Se construyeron muros de $7 \mathrm{~cm}$ de espesor que no garantizan aislamiento acústico, que generan expansión del sonido casi como una caja de resonancia. Esto dispara el nivel de contaminación auditiva, lo que genera otro elemento de conflicto diferente al de concentrar poblaciones de diversas procedencias, con diferentes condiciones sociales, con diferentes antecedentes culturales e históricos y de conflictividad.

Están también los problemas estructurales, cuando a una persona se le entrega un piso con esas características constructivas, este no se puede prácticamente remodelar porque son muros estructurales, definitivos, entonces es muy compleja la intervención. Habitar esos espacios todavía es muchos más complejo porque hay problemas hasta clavando un clavo en la pared.

¿Conoce de qué manera la gente se ha apropiado de ciertos lugares de la ciudadela?

Hay personas que encontraron en la ciudadela el gran logro de su vida. Conozco muy bien la historia de una señora que el mejor momento de su vida ha sido recibir su apartamento. Le hizo una intervención, lo remodelo todo con sus ahorros. Pero eso es a título individual, el problema está en juntar todas esas historias en una comunidad, en una sociedad e insertar eso en el plano de la ciudad. Ahí es donde empieza a fallar y ahí es donde se encuentran las grandes carencias, ahí es donde hay que pensar cómo actuar en este tipo de intervenciones para lograr pasar el éxito del plano individual al colectivo. Pajarito se accedía por una carretera veredal...
Frente a la realizado en ese espacio habitacional de la ciudadela ¿qué era necesario y no se tuvo en cuenta o qué se pudo haber hecho mejor?

"Hay cosas de sentido común que no se hicieron. Se urbaniza sobre vías públicas preexistentes cuyas secciones viales están hechas y pensadas para comunidades rurales. Para acceder a

"Otro ejemplo fue el gran rechazo de la comunidad rural por el metrocable. Hubo un fuerte arrasamiento de sus formas habitacionales rurales con esa acción invasiva, agresiva y contundente de crecimiento urbano que se llevó allí."

\section{¿Qué ventajas o desventajas a mediano y largo plazo se} pueden observar en la Ciudadela?

La política y el discurso oficial se concentran, en que por primera vez en menos de una administración se ha logrado construir y triplicar el número de soluciones habitacionales de la administración anterior. Construir más de 15.000 viviendas es considerado un éxito. Los indicadores están generalmente por el orden de lo cuantitativo.

¿Se puede plantear que existe una correlación entre espacios reducidos de la vivienda y gran adecuación de espacios públicos?

Ese es el traslado equivoco de conceptos manejados en otras ciudades como Paris y Tokio, donde hay estándares de vivienda mínimos y grandes espacios públicos. Pero eso es una entelequia por una razón muy sencilla, nosotros somos una sociedad muy pobre.

Usufructuar ese espacio público requiere de recursos, una capacidad adquisitiva, una capacidad de ingresos que permita usar la calle y el espacio público, eso no lo podemos hacer nosotros aquí. Tenemos a una población que ni siquiera tiene para el transporte cotidiano.

¿Cómo observa el tejido social que se ha generado en la ciudadela y que ha estado tranzando con la administración y otras organizaciones?

Lo que se ha generado son organizaciones clientelares. Lo que pasa es que se ha institucionalizado la participación como un mecanismo clientelar. Una cosa es la decantación en el tiempo de organizaciones comunitarias de orden vecinal, de orden comunitario que tiene otro sentido a estas organizaciones clientelares que tienen intereses políticos, económicos y territoriales. Incluso uno puede preguntarse hasta qué punto proyectos como presupuestos participativos y esas instrumentalizaciones de la participación comunitaria han ayudado a atomizar la búsqueda de prebendas y maximización de objetivos particulares.

Fuente: Encuestas realizadas a docentes, administrativos y líderes comunitarios en Ciudadela Nuevo Occidente en el trabajo de Trabajo fin de master de MESA ESCOBAR, Julio (2012) 
Tabla 34 Encuesta de opinión a los residentes del Proyecto MIB Sur con Bogotá

\begin{tabular}{l}
\hline Sondeo de Percepción proyecto "Sur con Bogotá". \\
¿Conoce el Proyecto Sur con Bogotá? \\
Si, $19 \%$ frente a lo esperado de $60 \%$ \\
*El bajo nivel de conocimiento del Proyecto en términos \\
generales se puede atribuir a que muchas personas no lo \\
reconocen por su nombre, sino más bien por las intervenciones \\
específicas realizadas. \\
¿Qué hace el Proyecto? \\
Arreglo de vía y andenes, ayuda a la comunidad, planeación \\
zonal y construcción de parques. \\
*Dentro de las acciones que han tenido más reconocimiento \\
por la comunidad se destacan las realizadas en acueducto y \\
alcantarillado (51\% de quienes dicen conocer el proyecto), \\
seguida por la pavimentación de las vías (reconocida por el \\
$44 \%$ ), la construcción de zonas verdes (con un $32,2 \%$.) y \\
finalmente la edificación de colegios (con $26,4 \%$ ). \\
\hline ¿Cómo conoció el Proyecto? \\
La mayoría (63\%) de quienes conocen el proyecto se enteraron \\
de su existencia en reuniones comunitarias. El resto lo hizo por \\
medio de divulgación entre vecinos, radio o volantes.
\end{tabular}

\section{¿Cómo ha participado?}

Quienes dicen haber participado lo han hecho bajo Asamblea (69\%), Talleres de capacitación (36\%), Comisiones (21\%) o Comités (20\%).

\section{¿Qué beneficios le ha aportado a su comunidad el Proyecto?}

El $73 \%$ de los encuestados piensa que el proyecto le ha mejorado la calidad de vida en cuanto a oportunidades de ingresos y empleo, optimización del servicio de transporte y el aumento del sentido de pertenencia. El $26 \%$ considera que el segundo aporte fue la integración de los jóvenes.

¿Cómo se ha manifestado el aumento de la oportunidad de ingresos y empleo?

Las oportunidades de ingreso y empleo aumentaron según la mayoría de quienes conocen el Proyecto por medio de la vinculación de mano de obra durante la intervención. Una tercera parte en el sector piensa que con la apertura de tiendas y negocios.

¿Qué tan de acuerdo está usted con la afirmación: "las instituciones del estado promueven bienestar de la comunidad"?

La mayoría de los encuestados (58\%) está de acuerdo con el hecho de que las instituciones promueven el bienestar de la comunidad. Para un $18 \%$ le es indiferente y un $23 \%$ no está de acuerdo.

¿EL grado de satisfacción de vivir en este barrio y su entorno ha aumentado en los últimos años?

El $85 \%$ de quienes conocen el proyecto SUR con Bogotá reconoce que en los últimos dos años se han sentido satisfecho de vivir en el sector. En el sector de Bolonia es donde existe mayor satisfacción.

Fuente: Encuesta de opinión sobre los resultados del Proyecto Sur con Bogotá. Bolonia-Ladrilleras-Vía Oriente. Alcaldía de Bogotá 2004
¿Usted cree que en los últimos años los conflictos sociales en esta zona han...?

En general, un $45 \%$ de los habitantes de las zonas intervenidas creen que los conflictos sociales han disminuido; para la tercera parte este problema sigue igual y para un $17 \%$ ha aumentado.

¿Qué acciones cree usted que han contribuido a que esto suceda?

En las acciones que han contribuido a que los conflictos sociales disminuyan se destacan la unión y convivencia de la comunidad y la presencia de la policía. En las acciones que la comunidad reconoce como igual o peor se encuentran el desempleo, la falta de oportunidades, la inseguridad, la desunión de la comunidad y la presencia de pandillas.

\section{¿Cuáles conflictos sociales cree usted que se presentan con} mayor frecuencia?

Los conflictos sociales que se presentan con mayor frecuencia son las riñas callejeras, los altercados y las agresiones entre vecinos, en menor proporción se percibe la violencia intrafamiliar y el abuso a menores.

¿Qué grupo de la comunidad cree usted que genera más conflictos sociales en la zona?

Las pandillas son quienes tienen peor imagen dentro de la comunidad (77\%). Un $7 \%$ cree que son los habitantes de la calle.

¿Qué tan a menudo cree usted que se presentan actos violentos en esta zona?

Según el $31 \%$ de los habitantes encuestados, las acciones violentas (como atracos) se presentan con mucha frecuencia en el sector, contrario a lo que se piensa de los conflictos sociales.

\section{¿Con qué frecuencia utiliza usted los parques de este barrio?}

Los parques son muy poco utilizados por los ciudadanos del sector: la tercera parte nunca los frecuenta, una parte va algunos fines de semana y un $20 \%$ va sólo una vez al mes. Solo el 3,5\% los utiliza todos los días.

* Las principales razones por las que no se frecuentan los parques son la existencia de delincuencia e inseguridad como robos y atracos, el consumo de drogas, la presencia de pandillas y una consideración de una infraestructura no adecuada porque sencillamente es peligrosa para los niños

Considera que las oportunidades de transporte del barrio al centro de la ciudad en los últimos tres años...?

Las oportunidades de transporte aumentaron según el 86,2\% de quienes conocen el proyecto en el sector Vía Oriente, el $79,4 \%$ en Ladrilleras y el $45 \%$ en Bolonia. En este último sector existe un gran porcentaje $(43,3 \%)$ que no perciben cambio alguno en materia de transporte. 


¿Qué haría ante una eventual intervención urbanística en el
barrio?

Los resultados fueron muy parejos, el $55 \%$ manifestó que se iría para otro barrio y el $45 \%$ dijo que le gustaría quedarse.

" $Y$ es que la decisión no es nada fácil, hay que sentarse a analizar con la familia que es lo que más le convendría y con la comunidad cuales son los pros y los contras de tomar esa decisión".

"Si queremos quedarnos primero que todo necesitamos muros de contención, senderos pavimentados con cunetas y construcción de alcantarillados para aguas negras y lluvias, segundo mejoramientos de vivienda subsidiados por el Estado, y tercero, si necesitan desalojar algunas familias porque están en zonas de alto riesgo, que las puedan reubicar en el mismo barrio, no construyendo edificios sino haciendo casas de 2 pisos (bifamiliares), en un piso una familia y en el otro la otra, y que podamos decidir con quién nos vamos a vivir en la casa".

"Y ya si la última opción es irse, tener unas condiciones, plantear nosotros cómo nos vamos, por ejemplo conjuntamente las familias que somos las más conocidas ya que queremos seguir viviendo juntos, que no nos vayan a dispersar la idea de vecino y comunidad; nos vamos con la gente que quiera construir conjuntamente, con los amigos, uno para qué se va a vivir con los enemigos".

¿Sabe usted cuáles son las implicaciones y que tareas se deben asumir como familia y como comunidad?

"La casa tiene que ser con pieza individual para cada persona, un baño donde no se oiga, no que todo el mundo sepa que uno está en el baño. Eso no es digno para uno. Tiene que tener su salita, y su cocina".

"Nosotros que vivimos en estrato 1, nos queda muy duro la reubicación, ya que tendremos que tener mínimo dos salarios mínimos en la familia para poder sobrevivir. Porque al cambiar de estrato tenemos que cambiar también de ingresos. Acá en el barrio sobrevivimos con lo que ganamos, pero ¿llegando a otro barrio de mayor estrato?, entonces lo pone a uno a pensar tanto, ¿me quedaría o me iría? Cómo decía mi mamá, yo prefiero quedarme, si voy a morir tapada por tierra, tocara quedarme aquí y será que me tape esta tierra, porque yo con qué me voy a vivir en otro barrio".

\section{¿Qué pasa con las organizaciones comunitarias?}

"Una de las estrategias del Estado es ver como desarticula el tejido social. Porque si ven una niña que está siendo capaz de orientar un grupo de jóvenes y la ven muy animadita y aprendiendo mucho sobre sus derechos e inyectando ese conocimiento, entonces dicen, llevémonosla mejor para Las Flores, para La Huerta en Robledo, donde ya le quede muy distante el grupo con que se integraba, con el que compartía y construían sociedad".
Algunos dicen: "si nos ofrecen vivienda propia me iría, pero así de arriendo temporal no". Para otros el hecho de quedarse es casi por obligación, por no tener a donde irse, porque salir del barrio implica salir a pagar arriendo. Sin embargo muchos plantean que depende de las condiciones y de las propuestas toma la decisión. Además de los compromisos que ellos deban asumir, cómo el pago de ahorro programático por la vivienda nueva.

Dentro de los que se quedan dicen: "A mí me gusta mucho mi rancho", "Me quedo siempre y cuando no exista ningún riesgo para mi familia", "Yo me quedo, pero me voy si me dan una casa donde vivir". Y de los que se van dicen: "si las condiciones son buenas", "con la certeza de la reubicación", "si no hay otra alternativa", "me voy pero con garantías" o "si es una vivienda mejor".

Otros argumentan: "Depende, si a uno le dan casa propia sí, pero para uno irse a pagar arriendo o cuotas por una nueva vivienda teniendo su casa propia no", eso sin saber si va a conseguir empleo para poder pagar las cuotas, si va a tener con que comer, con que mantener los hijos, con que tener todo lo de la casa al día y pagar servicios más costosos pues subiría de estrato, "Cómo se va a ir uno de sus casa, que puede que no esté muy bien, pero para uno irse de Guatemala a Guatepeor no aguanta".

"Hay personas que no se quieren ir, pero en el proyecto de la Administración no han puesto una encuesta a ver qué es lo que quiere la gente. Hay gente que ni sabe, a otros que les dicen les damos 8 millones y se van o si no lo mandamos a desocupar, no les preguntan si se quieren quedar, la opción es irse". Por ejemplo ¿a la comunidad le preguntaron si quería el metrocable? No, el plan de la comuna 8 frente a la movilidad se había definido la ampliación de la carretera a La Sierra y llegan estos proyectos y no tuvieron en cuenta lo que habíamos priorizado como comunidades.

"No se nos está tomando en cuenta, para mí cualquier proyecto debe de hacerse con la comunidad, muchas personas no saben si les van a tumbar la casa o se la van a comprar, realmente no sabemos qué va a pasar en el barrio. Entonces eso es lo que nosotros queremos es que nos tengan en cuenta, así sea para construir un andén".

Y ellos no lo dicen, precisamente por el miedo de que la comunidad se organice, porque si la gente sabe que la van a sacar en dos años, empieza a organizarse, ellos avisan un mes antes, para que la comunidad en el desespero haga cualquier cosa. Por eso hay que prepararnos y mirar que es lo que va a pasar en el barrio.

"Y cómo así que nosotros estamos en zona de alto riesgo, y si van a poner el metrocable, que necesita de unas vigas gigantes. Riesgo pero para nosotros, para ellos es ganancia." Con lo que valió el metrocable, la comunidad hubiera preferido mejoramientos de vivienda. "Por ejemplo en el sector La Acequia, no sabemos si arreglar los ranchos, pues nos dicen que por ahí va a quedar un camino y un parque $y$ supuestamente nos van a sacar, pero no sabemos nada en concreto"

Fuente: Resultados de la encuesta realizada a 173 familias (15\% del total de las viviendas de la zona alta del PUI Centroriental en el Diagnóstico comunitario del barrio Villa Turbay. Comuna 8 de Medellín realizado en el año 2011 por Carlos Velásquez con la colaboración de Mesa Interbarrial de desconectados y Corporación Paz y Futuro en Medellín. 
Los resultados de los sondeos evidencian la existencia de varios problemas sociales presentes en los estudios de caso desarrollados a partir del modelo urbano implantado. Su reconocimiento permite exponer los logros o erros en la calidad de ese espacio habitacional creado.

Al parecer el fenómeno de la violencia, que ha afectado considerablemente a cada sector, es el principal. Si bien la administración pública ha hecho ocasionalmente algunos acompañamientos en capacitación, la situación señalada por lo docentes, los líderes comunitarios o los residentes requiere medidas contundentes. Los estudios de caso son territorios altamente castigados por la presencia de bandas, robos o drogas y si estos problemas no se manejan de forma adecuada no tiene mucha utilidad construir un parque nuevo o hacer una alameda pues la población no podrá utilizarlos.

Otro problema social señalado son los cambios en las prácticas culturales. El iniciar un nuevo modo de vida en pisos de edificios en altura, tener espacios reducidos privados que no permitan realizar sus costumbres o el compartir espacios comunitarios muestra una fractura de su identidad. No existe una correlación entre la tipología edificatoria y los contextos de los residentes.

Otro es la vulnerabilidad de los residentes asociada a las nuevas responsabilidades económicas de la formalidad. El tener casa propia, pagar comunidad, los servicios domiciliarios o un abono de transporte son nuevos costos que las familias no siempre están en condiciones de asumir o de pagar. Aparecen entonces así nuevas amenazas por expropiación de la vivienda o cortes de servicio o bien nuevas actividades informales o ilegales que se realizan dentro o fuera de la vivienda.

Dicha condición de vulnerabilidad hace además sentir a la población además excluida o segregada. Un ejemplo de ello se vió reflejado en la "Feria de vivienda" de 2009, programada por el Instituto Social de Vivienda y Hábitat de Medellín (Isvimed), donde se promocionaban proyectos de VIP y VIS, las conversaciones entre los participantes giraban en torno a una frase determinada: "Es que a los pobres nos quieren mandar a vivir lejos, ya no nos quieren cerquita al centro ni al trabajo, nos quieren por allá donde no hay nada". (Velázquez, 2011)

Un tema que aparece recurrentemente en las entrevistas es la capacidad de participación. Existe un relato contradictorio entre lo que la administración dice haber aportado en el tema y lo que la población siente que fue la participación. La administración habla de talleres de imaginarios, de presupuestos participativos, de empoderamiento de los líderes comunitarios por medio de cursos de capacitación pero la población habla de consultas, de no tener en cuenta la comunidad, de hacer lo que la administración quiere.

Un ejemplo claro de ello se constata en los documentos sobre PUI Nororiental. La EDU en su informe "Modelo de transformación urbana. Proyecto urbano integral en la zona nororiental y consolidación habitacional en la quebrada de Juan Bobo" expone lo siguiente:

Desde la fase de diagnóstico y planificación, hasta la fase de ejecución, se invitó a la comunidad a participar activamente en el proceso, acompañando los equipos técnicos, a los trabajadores sociales y a los comunicadores en la realización de sus tareas. Debido a la amplitud del territorio se conformaron comités de escala barrial agrupados en las áreas de influencia de cada estación del Metrocable: Andalucía, Popular y Santo Domingo. Estos adicionalmente, no estaban necesariamente ligados a las Juntas de Acción Comunitaria (JAC) para prevenir así posibles influencias políticas y ampliar el nivel de participación. El resultado fue, por ejemplo, la conformación de los Talleres de Imaginarios, donde la comunidad participaba 
directamente en la definición y en el diseño de los proyectos. Los talleres tuvieron el mérito de fomentar el liderazgo, elevando el espíritu de pertenencia y el nivel de compromiso de la comunidad hacia el barrio. (EDU, 2011)

Sin embargo la población frente a ese mismo desarrollo de metrocable y los mismo "proceso participativos" establecidos por la EDU en el PUI Centroriental dicen:

Es importante tener una propuesta del barrio que queremos y soñamos, porque incluso con esa propuesta se puede hacer una denuncia internacional, donde demostremos que el gobierno local no nos está parando bolas y sólo realizan lo que ellos planean, sin tener en cuenta las comunidades. (Velázquez 2011)

Como respuesta a esa falta de participación las organizaciones comunitarias parecen haber cogido fuerza. Daria Garcia, residente de Ciudadela Nuevo Occidente lo relata así:

"Las dificultades nos han llevado a organizarnos en red para hacer fuerza, por eso nos trajimos a los alcaldes Fajardo y Anibal. Los comprometimos. Nos reunimos alrededor de 10 personas de la comunidad, generamos unas preguntas para ver a que se podían comprometer si llegaban a ser elegidos ¿A qué se comprometen ustedes con las necesidades de la Ciudadela? ¿Qué pasa con la seguridad o con el tema económico? ¿Qué pasa con los edificios entregados en muy malas condiciones, con un espacio muy limitado, en donde solo hay vivienda, no hay espacio comerciales, no hay canchas y apenas hay dos colegios. Nosotros soñamos con un centro comercial, con un parque biblioteca. Fajardo se comprometió a ellos". .". (Mesa 2012)

Sin embargo dichas organizaciones o dichas conformaciones de grupos sociales no siempre son bien catalogadas por parte de los expertos. El profesor González en su entrevista las denomina como organizaciones clientelares.

\footnotetext{
"Se ha institucionalizado la participación como un mecanismo clientelar. Una cosa es la decantación en el tiempo de organizaciones comunitarias de orden vecinal, comunitario y otras organizaciones clientelares que tienen intereses políticos, económicos y territoriales. Se han generado profesionales de la participación comunitaria y esos profesionales de la participación saben dónde están los recursos, cómo obtenerlos y cómo capitalizarlos. Es muy importante la participación comunitaria y sobre todo una participación que se configure como verdadera sociedad civil, pero sociedad civil no es la cooptada, ni la institucionalizada, ni la informal. Hay que tener mucho cuidado con esto. Ni romantizar ni catalogarla como mala". (Mesa 2012)
}

Con todo, en aras de reconocer un trabajo positivo de la administración se concede un cierto esfuerzo por preguntar e informarle a la población lo planteado en las intervenciones. No cabe duda además que una de las mayores dificultades de un proceso participativo es pasar del discurso retórico a un proceso efectivo en la realidad. Sin embargo se cree que el fallo está en que no se entiende, o no se quiere entender, la participación como un medio único para iniciar los planteamientos urbanos de un territorio ya habitado en el que se va a intervenir. El diseño y la ejecución óptima de las políticas públicas de vivienda social se deberían fundamentar en el conocimiento de las relaciones entre las necesidades de la población y el espacio requerido.

La participación es un medio para defender los derechos de una población existente. El incumplimiento de esos derechos, como es evidente, trae consigo una condición de desigualdad o de exclusión. Vidal (2009) sostiene que la exclusión social es "una institución de explotación, dominación o alteración que desempodera a los sujetos y sus comunidades de modo que se anula socialmente su presencia, impidiendo satisfacer sus necesidades libremente (Vidal, 2009:48)

La Administración ahora está hablando de Medellín imparable, pero ¿Imparable en qué?, en la pobreza será, y tienen hasta razón, no nos hemos podido parar de esta miseria". (Relato de residente de PUI Centroriental en Velázquez Carlos (2011) 


\section{CONCLUSIONES SOBRE EL AMPLIO E IRRESOLUTO SENTIDO DE LA CALIDAD}

Conclusiones sobre el modelo de análisis y sus posibles contribuciones a la disciplina Conclusiones sobre los resultados Conclusiones sobre la hipótesis planteada Búsqueda de condiciones de calidad adecuadas 
Me animaría a decir que si hasta ahora hemos sido incapaces de erradicar la pobreza, es porque sabemos demasiado de ella pero no comprendemos su esencia. (Max-Neef 1986)

Las conclusiones y recomendaciones presentadas en este apartado son el resultado del análisis morfológico del espacio residencial para la población de bajos ingresos en la ciudad de Medellín y Bogotá en el marco de los Planes de Ordenamiento Territorial durante el período de estudio 2000-2010. A partir de la aplicación de un modelo de análisis comparativo entre los proyectos de mejoramiento de barrio y los proyectos de vivienda nueva gestionados por el Estado, se evaluó la calidad urbana obtenida en seis estudios de caso en las dos ciudades en cuestión.

La motivación sobre este tema surgió al observar la forma indiscriminada en la que se impone un modelo de ciudad, producida con una normativa nacional o municipal bajo un esquema de mercado que poco específica sobre las condiciones de calidad que este alojamiento social debería contemplar. Garantizar el acceso efectivo a una vivienda digna y adecuada debería ser una de las obligaciones primordiales del Estado colombiano. Pero como se deduce de los resultados obtenidos, dichas obligaciones no se han correspondido con la materialización de lo que se produce en la ciudad o con la satisfacción efectiva de las necesidades de los habitantes.

El análisis de los diferentes instrumentos internacionales de derechos humanos, la Constitución Política colombiana y la jurisprudencia de la Corte Constitucional junto con las ordenanzas en materia de vivienda social han confirmado los diferentes compromisos. La consideración de la Carta Magna, por un lado, permitió vincular el derecho a la vivienda como un principio de dignidad y, a su vez, la Corte Constitucional brindó un concepto completo de vivienda adecuada proclamada en el Pacto Internacional del Comité DESC. Al mismo tiempo, el análisis de la normativa (POT) permitió reconocer los parámetros mínimos establecidos por ley referentes a la calidad de la vivienda social. Sin embargo, tales derechos o parámetros han quedado en muchos casos tan solo plasmados de forma sesgada en la normativa sin generar avances en la calidad de la vivienda que se produce.

Los hallazgos obtenidos tras la comparación entre los dos modelos de intervención, mejoramiento de barrio y desarrollo de vivienda nueva, han sido numerosos y de manera general distan de contribuir a la mejora de calidad del alojamiento social. Con respecto al primer objetivo propuesto en la investigación, la caracterización de la morfología residencial, se comprobó que a pesar de algunos cambios positivos propuestos por la nueva normativa de ordenamiento, las condiciones de calidad del alojamiento social siguieron siendo muy deficientes. Todos los estudios de caso presentaron carencias en sus espacios urbanos y arquitectónicos. Con respecto al segundo objetivo, la construcción y aplicación de un modelo de análisis para comparar la calidad urbana en los dos tipos de tratamiento, se alcanzó un aporte válido y operativo que facilitó la lectura de dichas condiciones determinadas como críticas. La definición de cada indicador, establecida gracias el examen de nueve iniciativas similares de reconocimiento internacional aplicadas en América Latina, permitió dotar la evaluación de condiciones objetivas -estado de la realidad- de la habitabilidad del espacio residencial. 
Así pues, se pudo llegar a comprobar la hipótesis planteada sobre la presunta mejor calidad del alojamiento social en los mejoramientos de barrio que en los proyectos de vivienda nueva, siendo en los dos muy deficitarios. La propuesta de regularización y mejora del espacio urbano en los asentamientos de origen marginal presentó pequeñas condiciones de adelanto en materia de equipamientos e infraestructura que no fueron observados en los desarrollos de vivienda nueva.

En suma, se pudo determinar que a pesar de los esfuerzos realizados por las administraciones de Bogotá y Medellín en materia de ordenamiento urbano, la calidad urbana sigue siendo un concepto amplio y en muchos casos irresoluto. Los resultados mostraron cómo la vivienda social es una necesidad aún desatendida. Para revertir todo ello, se propone entonces cambiar el modelo de ciudad impuesto, apoyado en "prácticas de mercado que determinan todas las formas de actuación y del quehacer de la sociedad colombiana, incluidas la producción, consumo y transformación del espacio residencial y urbano" (Torres, 2012:35) para centrarlo, de una buena vez, en las posibilidades de la población más necesitada.

A continuación, se amplían los aspectos recién señalados y se sintetizan algunas de las reflexiones observadas en los principales temas de estudio. Se presenta en una primera instancia las conclusiones sobre el modelo de evaluación como principal contribución de este trabajo de investigación. Posteriormente se exponen los resultados sobre las condiciones de calidad observadas en los seis estudios de caso. Se comprueba la hipótesis sostenida a lo largo de la investigación. Y finalmente se presentan, a manera de propuesta, posibles principios básicos para conseguir una condición de habitabilidad adecuada.

\section{CONCLUSIONES SOBRE EL MODELO DE EVALUACIÓN Y SUS POSIBLES CONTRIBUCIONES A LA DISCIPLINA.}

El desarrollo de este trabajo de investigación ha permitido constituir y validar un modelo de evaluación y comparación cuantitativa de la habitabilidad de la vivienda social a escala de bloque, barrio y ciudad para la población de bajos ingresos en las dos principales ciudades de Colombia. Su planteamiento inició con la caracterización del espacio residencial, la vivienda y su entorno, para los dos tratamientos objeto de estudio, programa de vivienda nueva y mejoramiento de barrio. Para ello se indagó sobre las formas de producción y tipología edificatoria según el modelo de gestión, los mecanismos de ocupación del suelo, las densidades y las características del espacio público residencial. Adicionalmente, se analizaron los rasgos generales que la nueva ordenación de planeamiento urbano (POT) pretendía modificar con respecto a la habitabilidad del alojamiento social.

Posteriormente, se realizó una aproximación conceptual y operativa sobre la morfología del espacio, su condición física de calidad urbana y de vivienda adecuada. Se determinaron los parámetros mínimos, algunos de carácter normativo nacional e internacional, que regulaban y exigían el cumplimiento imperioso de dichas condiciones. Como soporte referencial, además, se abordaron nueve iniciativas sobre la medición de la calidad urbana en ciudades con contextos similares a las de los seis casos de estudio.

Acto seguido, se continuó con la construcción del modelo de análisis, la formulación y aplicación de sus instrumentos y el levantamiento de la información estadística, planimetría y de trabajo de campo. 
Una vez obtenidos los resultados, se logró consecuentemente reconocer los factores objetivos asociados a las condiciones urbanas que incidían de manera significativa en la vivienda de origen normal y marginal. De este modo, se pudo comparar los dos tipos de producción y conocer las similitudes o diferencias entre los productos de ambas gestiones. Así se han encontrado algunos patrones comunes, a pesar de partir de un esquema de configuración urbana diferente (urbanización, parcelación y edificación) originada, entre otras razones, por un único modelo de ciudad impuesto.

Como estrategia metodológica se utilizó, como se mencionó, la comparación entre los dos modos de gestión y lo que la normativa había establecido para ellos. El proceso de verificación de cada indicador precisó tener que profundizar en el conocimiento de la realidad local de cada estudio de caso. La tarea de síntesis y de reflexión sobre los resultados no fue inmediata. Requirió una importante valoración de fuentes primarias (censos, informes institucionales, decretos normativos, sentencias judiciales, documentación bibliográfica, trabajo de campo, visores cartográficos, entre otros) para obtener una información con un cierto grado de detalle. Gracias a ello, los indicadores han proporcionado una lectura de varias escalas útil para comprender de forma crítica los elementos condicionantes sobre la habitabilidad.

Ahora bien, para tener claridad sobre las conclusiones e interpretaciones de esta investigación, se deben exponer también algunas limitaciones que surgieron en la aplicación del modelo de análisis propuesto:

La primera, relacionada con la metodología misma para determinar el número de variables a utilizar para la medición de la calidad en términos físicos. Si bien, como se había establecido en el capítulo dos, era necesario contar con un número suficiente pero reducido de indicadores para hacer posible una aplicación real, en la medición de la calidad se consideró necesario contemplar unos pocos indicadores adicionales frente a los que se habían establecido inicialmente.

Un ejemplo de ello, se constató al medir la densidad urbana en términos de viviendas por hectárea. Los valores establecidos daban tan solo parcialmente cuenta de las condiciones territoriales y se conjeturó necesario verificar también la densidad de población (habitantes por hectárea). O bien, otra muestra, los datos de proximidad de los equipamientos educativos que no incluían su cobertura en cupos escolares o los costes para llegar hasta la edificación. Es decir, no solo es necesario que los niños puedan estar próximos a instituciones educativas, es también esencial que puedan inscribirse y acceder al edificio. Este caso se presentó en el MIB El Lucero en Bogotá.

Las mediciones vinieron entonces a demostrar que las variables reflejan el comportamiento de otras variables a la vez y que la información proporcionada se encuentra constantemente con matices. Sin embargo, al considerar los resultados de las variables en su conjunto y acotando el análisis al plano territorial, se cree que el modelo proporciona una varianza relativamente alta de certeza en la medición de la calidad.

- La segunda objeción surge al considerar la representatividad de los estudios de caso tomados durante un determinado período de tiempo. Lo anterior si se tiene en cuenta que la vivienda para la población de bajos ingresos, especialmente aquella producida de forma marginal, aunque no exclusivamente, es una construcción, a nivel de unidad y de barrio, en constante proceso de transformación y consolidación en el tiempo. Evaluar las condiciones de 
calidad de un territorio con estas circunstancias puede llegar a dar una visión realista pero estática de la situación.

Otro ejemplo que viene a demostrar esta limitación del modelo es el estado actual de algunos de los equipamientos culturales de gran envergadura que se construyeron en algunos de los estudios de caso. En su momento fueron grandes obras arquitectónicas, premiadas por su diseño, por su capacidad de transformación del territorio o por dotar a la población de unos servicios de los cuales carecían pero unos años después, debido al costo del mantenimiento que no fue contemplado o al uso de materiales mal instalados, se encontraron en mal estado, cerrados o en proceso de reconstrucción. Ese es el caso de la Biblioteca España en PUI Nororiental en Medellín

- La tercera limitación se plantea con respecto al establecimiento de los rangos estipulados para los indicadores. Éstos pueden tender a rigidizar la realidad según cada estudio de caso. Es cierto que la ciudad no se construye en base de datos y que la complejidad del territorio urbano supera y trasciende la reducción de las cifras. Sin embargo se cree, los rangos aportan unos datos que permiten el reconocimiento de un territorio con referencias objetivas y válidas; éstos, son base además para el análisis comparativo.

Para sopesar dichos valores de los rangos seleccionados como los más adecuados para el análisis de los territorios en cuestión, se analizaron los valores propuestos en las nueve iniciativas de medición de la calidad en contextos de Latinoamérica. Su razón, como se explicó, es que fueran valores acotados a un contexto similar al que se iba a investigar. Era claro que imponer valores de medidas de ciudades europeas o norteamericanas en espacios residenciales marginales de Colombia debía evitarse.

Por último, sobre las conclusiones del modelo de análisis queda por resaltar la representación gráfica de los indicadores aplicados en cada estudio de caso. La visualización en planos y esquemas, complementado en este caso en la cartilla con fotografías sobre las dimensiones a medir, resulta un segmento esencial para la interpretación de la información. En materia de urbanismo, los datos numéricos por sí solos en muchos casos no son suficientes para demostrar la complejidad de cada ámbito; como tampoco lo son los planos en sí. Se precisa para ello de un documento que contemple las dos formas de medición y observación.

En suma, el objetivo esencial de elaborar un perfil de las condiciones de calidad urbana de los proyectos de alojamiento social en el contexto de las dos ciudades colombianas encuentra su resolución en el análisis propuesto. El modelo de habitabilidad ha permitido identificar los aspectos formales de la vivienda y su entorno asociados a la calidad de la misma, comparar los diferentes estudios de caso entre sí y valorar el modelo de ciudad con los que fueron construidos. A continuación, se presentan los resultados esperados sobre éste tema.

\section{CONCLUSIONES SOBRE LOS RESULTADOS DE LOS ESTUDIOS DE CASO}

En términos generales, se pude afirmar que el modelo de ciudad propuesto por el primer aliento de ordenamiento territorial no ha logrado aún resolver los problemas estructurales sobre la calidad de la vivienda social en las ciudades de Bogotá y Medellín. Siguen coexistiendo las dos formas básicas de producción del espacio social, la formal y la marginal, con unos resultados sobre habitabilidad desfavorables. El análisis morfológico de los dos modelos de 
gestión demostró que existe una condición deficitaria que se ha configurado como un plano roto, como lo denomina Tarchópulos y Ceballos (2005), por fragmentos incompletos, inconexos, deficitarios de espacio público y de equipamientos típicos de las periferias de las ciudades colombianas.

Viviescas en su escrito La calidad espacial urbana de los barrios para sectores de bajos ingresos en Medellín, señalaba en el año 1985 que en Colombia "no resulta exagerado sostener que hay más familias sin casa que cuando se inició el programa de vivienda nueva o mejoramiento de barrio y el problema del alojamiento es cada vez más agudo; con el agravante de que en este transcurso, la calidad no solo del espacio individual de la vivienda sino sobre todo del espacio colectivo, visible en muchos de los desarrollos hasta ahora realizados se ha degradado. Paradójicamente, los resultados cuantitativos de las acciones de tantos mecanismos, modelos, ensayos, políticas, etc., que responden a estas inquietudes, no pueden ser más desalentadores: parece que entre más se hace menos se alcanza". Argumento que parecería, casi veinte años después, aun válido y ajustado a la realidad.

En este sentido, se podría avanzar en una conclusión inicial afirmando que mientras no cambie el marco estructural vigente sobre la formulación de qué es una vivienda social de calidad, la forma espacial urbana de estos territorios, no tendrá alternativa alguna más que la precariedad. El análisis de los diferentes instrumentos internacionales de derechos humanos, la Constitución Política colombiana y la jurisprudencia de la Corte Constitucional han permitido identificar las obligaciones del Estado y los parámetros esenciales referentes a la calidad de la vivienda social. La consideración de la Carta Magna, por su lado, ha permitido vincular el derecho a la vivienda como un principio de dignidad y a su vez la Corte Constitucional ha brindado un concepto más completo de vivienda digna y adecuada proclamada en el pacto internacional del Comité DESC. Sin embargo, dichas proclamaciones o derechos no han tenido correspondencia con la materialización de lo que se produce en la ciudad o con la satisfacción efectiva de las necesidades de los habitantes. Existe una brecha importante entre lo que se formula como derecho, se plasma como normativa y se construye como vivienda.

Con todo, de lo expuesto sobre la caracterización de la calidad habitacional, se ha demostrado, que aún a pesar de contar con condiciones desfavorables, en términos generales, los planes de ordenamiento territorial sí han aportado nuevos elementos para avanzar en ciertos aspectos físicos de las periferias de Bogotá y Medellín. Algunos de los que se han observado en el análisis son:

- El aumento efectivo de los tamaños de las intervenciones en ambas gestiones (los seis estudios de caso superan las 130 hectáreas).

- La ampliación en el porcentaje de distribución de las cesiones para el espacio público y la condición de obligatoriedad en su localización por fuera de zona de riesgo o de pendiente alta superior a $40 \%$.

- En cuanto a los equipamientos, estos se han definido según la demanda precisada en los diagnósticos sectoriales realizados.

- Finalmente, el establecimiento de parámetros en el sistema vial en jerarquías y su definición de perfiles. 
Sin embargo, se ha advertido que existen también aspectos en los que poco se ha avanzado y las condiciones habitacionales han quedo iguales o peores. Allí, la norma se ha convertido en un postulado de intenciones dado por lo que se dice y no se cumple o bien, por lo que se omite decir. Varios de estos aspectos son:

- La persistencia por ubicar la vivienda social como única posibilidad en la periferia del límite urbano o incluso ya en los municipios aledaños a pesar de las múltiples menciones sobre la necesidad de localizar a la población menos favorecida en los centros urbanos y de servicios.

- El manejo deliberado sobre las densidades deseadas o permitidas, que se ha traducido en la reducción del tamaño de la vivienda y el cambio de tipología edificatoria para obtener una rentabilidad más elevada.

- La inserción de la parcela y el bloque en el territorio sin importar especialmente la relación con el contexto que lo rodea ${ }^{124}$, es decir entre lo público y lo privado y las condiciones naturales o topográficas existentes.

- La flexibilidad en la definición de la volumetría que ha permitido perfiles discontinuos entre viviendas unifamiliares y multifamiliares.

- Y por último, la alteración de las especificaciones sobre las dimensiones de áreas construidas y libres en cada tipología de vivienda con la formulación de edificaciones coloquialmente llamados multifamiliares acostados que no son más que viviendas unifamiliares en copropiedad sin seguir las normativas de aislamiento y antejardín establecidos en parcelas unifamiliares.

En otras palabras, lo enunciado viene a señalar que efectivamente la normativa ha ido proponiendo pequeños atributos cualitativos, esencialmente en el espacio público, pero a cambio, ha ido perdiendo grandes ventajas a nivel arquitectónico. De esta manera, frente a una de las preguntas iniciales de la investigación ¿Trae cada tratamiento una nueva forma de actuar en el territorio? Se puede afirmar que los POT sí proponen una nueva forma de actuar, distinta a los planteamientos normativos anteriores, específica para los desarrollos de vivienda nueva y los mejoramientos de barrio. La diferencia entre los dos tratamientos radica en que para la vivienda nueva todo el esfuerzo va dirigido hacia la vivienda como unidad habitacional mientras que para el mejoramiento de barrio todo el trabajo va encaminado hacia el espacio público. Lo que, según los resultados analizados en los estudios de caso, esto conlleva condiciones desfavorables, o aún más desfavorables para un tratamiento, el de vivienda nueva, que para el otro.

La explicación de ello podría estar relacionada por el interés continuado, a pesar de las modificaciones o de las nuevas actuaciones propuestas, de mantener una situación favorable para el mercado en la construcción de vivienda nueva. Así toda la flexibilización con respecto a las densidades, las tipologías o la configuración del bloque, la parcela o la manzana, por mencionar algunas, parecerían estar formuladas alrededor de unos beneficios de rentabilidad y maximización de ganancias (reproducción del capital invertido), por encima de las

\footnotetext{
124 Hacen referencia sobre ello Tarchópulos y Ceballos (2005) así: En ambos sistemas -el de parcela individual o de agrupación- es evidente que no ha existido interés por explorar opciones diferentes, ni desde las disposiciones normativas ni de los promotores de vivienda. Aun cuando el POT retoma estos sistemas para la definición de las pautas generales para el tratamiento de desarrollo- de vivienda nueva- no presenta ninguna reflexión sobre la elección tipológico ni en el diagnostico ni en la propuesta. (TARCHÓPULOS y CEBALLOS, 2005:99)
} 
condiciones de habitabilidad de los espacios residenciales y de las necesidades de los habitantes. La producción de vivienda nueva estaría enmarcada entonces bajo " una visión de ciudad mercado", como la denomina Torres (2012) basada en la iniciativa individual, la búsqueda de suelo barato y su máxima explotación posible. (Tarchópulos y Ceballos, 2005:118) Visión que considera a los ciudadanos exclusivamente como consumidores de mercancías y que por ende, solo pueden permanecer en ella, ésta ciudad mercado, aquellos que estén en condiciones de pagar estos valores, los demás deben abandonarla. (Torres, 2012) Enfoque éste por lo demás nada novedoso y basado en la relación clientes- productos financieros y no en la relación derechos-habitantes. Así lo advertía Castells ya en los años ochenta: "El Estado concentra sus inversiones en aquellas necesidades urbanas para el funcionamiento del polo dominante, o sea el capital. Mientras se dejan de lado las necesidades de la vivienda, transporte y equipamientos sociales de la población". (Castells, 1979:15)

Lo contrario, se podría llegar a pensar para los tratamientos de barrio. Allí cada POT ha propuesto que se inicien procesos de regularización urbana (mejora del componente físico) independientemente del estado de legalización. En las normativas precedentes, para que el Estado pudiera intervenir en estos barrios marginales debía realizarse primero una causa judicial, con los tiempos que ésta conlleva. Sobre ello se podría apuntar entonces que estas mejoras físicas, sí estarían encaminadas en una búsqueda de una mejora en la habitabilidad del espacio residencial y, en cierta forma, dirigida a los habitantes. Se puede argumentar que con estas intervenciones existe, en aquellos barrios olvidados, una nueva presencia institucional y por ende nuevas posibilidades de acceder a diversos programas municipales o estatales. De igual forma, se puede suponer que obtener un título de propiedad, cuando se obtiene, amplía el patrimonio de las familias y da la posibilidad de adquirir a créditos.

No obstante como se ha señalado durante la investigación, existen también, en la habilitación de los asentamientos marginales actividades económicas que generan interés. Una de ellas es la regularización fiscal. Ahora las familias deben tributar por su vivienda como cualquier habitante de la ciudad formal (impuesto predial y el impuesto por valorización), y deben pagar también las tarifas, el valor de conexión y la liquidación de las tasas de los servicios domiciliarios. ${ }^{125}$ Otra de ellas es la generación de acciones dirigidas hacia la deseada competitividad económica (marketing urbano) como estrategia. Para ello se construyen grandes equipamientos e infraestructura que permitan visibilizar los logros de calidad y de gestión asumidos por el Estado.

En síntesis, la revisión de las disposiciones normativas a nivel nacional y en las dos principales ciudades de Colombia muestra claramente como en estos territorios no se ha logrado afianzar aún políticas claras, coherentes y durables en el tema de la reglamentación e

\footnotetext{
${ }^{125}$ Sobre ello, Torres (2012) explica:

La legalización implica la incorporación inmediata al sistema de tributación de la ciudad y por lo tanto, el pago del impuesto predial, así como ser incluidos para el pago de los impuestos de valorización por beneficio general y valorización por beneficio local. [...]

También supone el aumento en las tarifas de servicios público, así como el pago asociado al suministro de redes técnicamente instaladas y el suministro de medidores para cada una de las viviendas. También los costos asociados a la legalización de la tenencia jurídica de la parcela y la edificación, costos relacionados con los gastos notariales los costos de los servicios jurídicos. Finalmente están los costos correspondientes a las mejoras o ampliaciones de la vivienda, es decir el pago de las tasas para obtener una licencia de construcción, los pagos de honorarios profesionales, impuestos de delineación urbana, impuestos sobre los metros cuadrados aprobados, a lo que hay que sumar los costos administrativos de la curaduría urbana. (TORRES, 2012:162)
} 
intervención del espacio residencial con condiciones de habitabilidad adecuadas. Los grandes vacíos han permanecido. Las pequeñas mejoras sobre las condiciones de calidad mínimas a aplicar, especialmente a nivel urbano, han puesto de manifiesto el abandono por parte del Estado en el reconocimiento de las necesidades de los habitantes en términos de habitabilidad. En este contexto, el tratamiento de desarrollo de vivienda nueva y el de mejoramiento de barrio no han sido asumidos del todo como soportes de la configuración espacial de la vivienda y su entorno, ni de la calidad urbana para sus habitantes, sino como parte del componente de un desarrollo urbano subordinado a los intereses de los promotores y el mercado inmobiliario.

\section{Modelo a (no) replicar}

Cada práctica institucional realizada en cada uno de los estudios de caso, por algunas mejoras que ha logrado consolidar sobre el territorio, no ha adquirido un impacto a nivel nacional representativo que logre formular un modelo replicable en otras ciudades colombianas ni a nivel físico ni a nivel social. Cada intervención, a su manera ha sido fuerte a nivel local, y tan solo ha llegado a ser retomado como proyecto estratégico en el siguiente Plan de Desarrollo de la ciudad donde se ha realizado el proyecto.

Dicha condición puntual ha acarreado un ejercicio de corto plazo que va en dirección contraria a lo que se considera debería ser una labor de planificación con resultados de largo aliento. Lo que demuestra la vulnerabilidad de las intervenciones antes procesos sostenibles. La diferencia en el tiempo entre los proyectos de vivienda nueva y los barrios marginales ha sido que para los segundos, para los que han tenido un tratamiento de mejoramiento, la intervención parece nunca poder ser finalizada. En el caso de MIB Sur con Bogotá, por ejemplo el proyecto ha continuado con los programas "Sur de Convivencia" y "Proyecto de Servicios Urbano". Programas que también han ampararodo a MIB EI Lucero. Los dos PUI de Medellín iniciaron su transformación con el proyecto PRIMED y aún siguen en construcción. Para los proyectos de vivienda nueva, el Estado solo intervino en una primera instancia para la gestión del suelo y relegó la construcción de las viviendas a los promotores privados. Posteriormente para la construcción y acceso a los servicios sociales, de educación, salud, bienestar social, recreación y cultura, por no ser competencia directa de los programas de vivienda y estar segmentados en instituciones separadas cada sector ha manejado según su lógica, presupuesto y mantenimiento ${ }^{126}$.

Con todo vale la pena destacar algunas consideraciones positivas a nivel institucional tales como la concurrencia de recursos de diversas fuentes como La Nación, el Departamento y el Municipio y entes internacionales o la interacción directa de las entidades distritales con las comunidades, evitando así el clientelismo. Con ello no solo se logró establecer dinámicas favorables para la acción estatal sino también que la población no se desgastará en procesos que no correspondía.

\footnotetext{
${ }^{126}$ Lo que según Torres dicha separación es incomprensible pues "la ciudad es un solo territorios que está bajo una única administración, no una superposición de territorios y administraciones distintas que comparten recursos". Por lo tanto para él no es concebible que se sigan presentando dificultades de coordinación o acción interinstitucional y debe superarse con la reconfiguración de las prioridades de la ciudad frente a sus ámbitos de actuación. (Torres 2009:27)
} 


\section{COMPROBACIÓN DE LA HIPÓTESIS}

En coherencia con los resultados obtenidos y con la formulación del modelo de habitabilidad para comparar la calidad del espacio residencial en los dos tratamientos dirigidos a la vivienda social no se llega a evidenciar de manera tajante lo supuesto en la hipótesis: Se producen mejores condiciones en los asentamientos marginales una vez intervenidos que en los desarrollos de vivienda nueva. La diferencia numérica entre ambas gestiones no es de gran amplitud (68 a 78 puntos frente a 40 de media). De hecho la peor y la mejor valoración numérica la obtienen los dos proyectos de vivienda nueva. Como resultado global, se puede apreciar una incipiente valoración positiva en las condiciones morfológicas de los asentamientos marginales intervenidos.

En términos generales, los territorios analizados en esta investigación que han sido intervenidos con el programa de mejoramiento de barrio son:

- Menos densos (de media 85,9viv/ha frente a 166viv/ha. de la vivienda normal),

- Con menor área de cesión a nivel global (de media 10,53\% frente a $14,17 \%$ de la vivienda normal) pero con un número similar de metros cuadrados por habitante $\left(19 \mathrm{~m}^{2} / \mathrm{hab}\right.$. para los dos tipos de gestión)

- Con una cobertura de equipamientos a nivel local y zonal superior a la de los barrios normales. La diferencia radica que en el momento de intervenir los barrios marginales una de las primeras actuaciones por parte del Estado es la construcción de los equipamientos faltantes en la zona, mientras que en los barrios de origen normal estas edificaciones, cuando se realizan, son construidas con posterioridad a la construcción de las viviendas. Adicionalmente, los habitantes de los barrios de origen marginal cuentan con más flexibilidad a nivel arquitectónico para transformar un espacio en el uso que deseen o requieran; generando así todo lo que el Estado no les ha suministrado aún. Esta razón es la que conduce a explicar por qué se observan tantos equipamientos de culto o de bienestar social: salones comunales y de guarderías.

- De mayor área a nivel de parcela: Las unidades habitacionales de los proyectos de vivienda nueva tienen como promedio un área de $45 \mathrm{~m}^{2}$ mientras que las unidades habitacionales de los asentamientos de origen marginal pueden alcanzar los $100 \mathrm{~m} 2 \mathrm{o}$ incluso más si colmatan su parcela.

- Con una mezcla de usos mayor dado por la posibilidad de transformar los espacios residenciales con mayor flexibilidad.

A su vez, son similares a los desarrollos de vivienda nueva con respecto a:

- La conexión y trazado vial pero con un estado de las vías en peores condiciones. Entre un $20 \%$ y un $30 \%$ de las vías siguen aún sin pavimentar en los asentamientos de origen marginal.

Los tiempos de desplazamiento hacia las centralidades debido a la ubicación periférica en ambas gestiones. En general, los trayectos a pie para llegar a dichas centralidades superan los 40 min (la media es 1 h20 min) y los desplazamientos en transporte público los $25 \mathrm{~min}$ (la media es $40 \mathrm{~min}$ ). Todos estos desplazamientos cuentan además con las complicaciones por el estado de las vías, pendientes o cambios en el sistema de transporte descritos en la caracterización de cada estudio de caso. 
- La cobertura de servicios públicos domiciliarios es equivalente y prácticamente del $100 \%$ en relación al alcantarillado, al suministro de agua potable y al servicio de energía. El servicio de recogida de basuras, en cambio, es bajo frente al de los barrios de origen normal. Dadas las condiciones de las vías de los barrios marginales, la recogida de basuras no se hace siempre puerta a puerta. Se establecen centros de acopio pero no se recoge todos los días, lo que termina generando basura diseminada, malos olores, contaminación en el espacio público, etc.

- Los riesgos medioambientales por estar construidas las viviendas en zonas de desplazamiento de tierras o inundación por obstrucción de rondas de ríos.

$Y$ con menores condiciones tan solo referentes a:

- El área de zonas verdes y por lo tanto, de cobertura (alta accesibilidad de los barrios de gestión normal, $80 \%$ de media, frente a $65 \%$ de los barrios marginales)

- Las condiciones técnicas de construcción y materiales de las viviendas como unidad habitacional.

En suma, son todas transformaciones, aun incipientes como se señaló, e insuficientes para configurar un cambio importante en las condiciones de calidad del espacio residencial pero que han de ser reconocidas como positivas. Así pues, se viene a demostrar que las normas urbanísticas desarrolladas para los proyectos de vivienda nueva no han logrado constituir un nivel de estándares de calidad aceptable (o suficiente para superar las deficiencias de los barrios marginales intervenidos). Lo que resulta, por lo menos, sorprendente. Parece insólito que existan carencias en los temas expuestos como la falta de equipamientos por construir o las densidades exorbitantes en ciudades ya altamente pobladas con casi ocho millones de habitantes para la capital y tres para Medellín. Es inesperadamente insuficiente que solo estén resueltos los suministros de servicios domiciliarios y las vías al interior de los proyectos. Lo que llevaría a cuestionarse sobre qué beneficio puede traerle a un habitante de escasos recursos el acceder a una vivienda nueva frente a una marginal, si una vez legalizada y mejorada a nivel urbano podría contar con mejores calidades.

Otras condiciones que vendrían a apoyar la hipótesis y que han sido mencionadas a lo largo de este trabajo pero que no estarían soportadas exactamente en las condiciones urbanas son: Por un lado, el sesgo económico bajo el cual se construye la vivienda social de origen formal como lo es el valor del suelo, las ganancias a obtener por lo construido, la condición de ahorro para obtener un subsidio familiar de vivienda o el costo, o sobrecosto, al comprar con un crédito hipotecario que aumenta el valor a pagar en 2,5 veces el valor de la vivienda. Y por otro lado, el papel desempeñado por los habitantes frente a su vivienda y su entorno. En el caso de la vivienda formal el habitante no tiene relación alguna con el producto obtenido hasta la realización de la compra, mientras que en el caso de los mejoramientos de barrio, tal como son ahora planteados en los POT, la participación y el control de los habitantes por su territorio es tenido en cuenta en menor o mayor medida. Esto permite, como decía Alguacil (2000) en su desarrollo sobre la noción de calidad de $v^{1} a^{127}$, dar soporte al cumplimiento de sus

\footnotetext{
127 La Calidad de Vida refiere un completo espectro de las dimensiones de la experiencia humana que se corresponde totalmente con la satisfacción de las necesidades humanas, tanto las denominadas básicas como las no básicas, las materiales como las inmateriales, las primarias como las secundarias, las vitales como las radicales... de tal forma que no se pueden disociar unas de otras. La satisfacción óptima de las necesidades y por ende la consecución de altas cotas de Calidad de Vida es preciso ir a buscarlos donde lo subjetivo se objetiviza (o si se prefiere cuando se pone en disposición de operativizarse), donde lo objetivo se
} 
necesidades según su forma de resolverlas o satisfacerlas. ${ }^{128}$ Ahora bien, este proceso participativo, tan positivo y del que se cree genera una de las diferencias con el tratamiento de vivienda nueva, tiene dos caras. Una de ellas es que efectivamente se han generado espacios de intercambio donde la población expone sus deseos o sus necesidades. Sin embargo, habría que preguntarle a esa población qué tanto se tuvieron en cuenta sus propuestas (Información prácticamente imposible de obtener ya que en pocas ocasiones la administración se ha preocupado por generarla, y si lo han hecho no son de libre consulta). Y la otra cara de ese enfoque participativo es que puede ser visto como un proceso que se utiliza para expandir las relaciones de poder desigual (Álvarez 2013) ya que limita la participación a una mera consulta que ha servido para justificar las reformas que se consideran necesarias para seguir fortaleciendo los mercados.

En definitiva, las diferencias positivas en las condiciones de habitabilidad de los mejoramientos de barrio frente a los desarrollo de vivienda nueva son casi inexistentes. La realidad de la vivienda social en Bogotá y Medellín es que su intervención como proyecto nuevo o mejoramiento de barrio no ha alcanzado a cualificar el espacio urbano. Los instrumentos de planeamiento, si han existido, en la práctica no se han operado eficazmente. El resultado ha sido, y por el momento seguirá siendo, el de una periferia desarticulada, marginada y deficitaria en términos de calidad de la forma urbana.

En este punto surgen, entonces, los siguientes desafíos: ¿Cómo generar unas condiciones urbanas de calidad en un contexto en donde se presentan unas fuerzas de poder desigual? Y en consecuencia, ¿Qué procesos sociales genera cada proyecto: equidad, seguridad, bienestar, desarticulación, exclusión, etc.? Y por lo tanto, ¿Cuán sostenibles son?

\section{LA BÚSQUEDA DE CONDICIONES DE HABITABILIDAD ADECUADAS}

Mediante el desarrollo de este trabajo, con la propuesta de evaluación y comparación de los seis casos representativos de las soluciones de vivienda de origen normal y marginal, se han podido establecer algunos principios de calidad urbana con los cuales poder especificar, y ojalá garantizar, tanto en procesos de planeamiento urbano como en la valoración de lo construido, unas condiciones posibles a seguir. La caracterización de las condiciones de habitabilidad que se han estado configurando hoy con las intervenciones del Estado, pueden dar pautas a seguir para en el futuro, corregir las tendencias negativas antes descritas.

La propuesta de unos principios básicos en búsqueda de una habitabilidad adecuada tiene como fin último de la investigación enriquecer la reflexión disciplinar y académica sobre nuevas pautas para construir las soluciones habitacionales para la población menos favorecida. Las inquietudes que en este sentido resultan, son una búsqueda de coherencia entre las directrices para la implementación del modelo de ciudad y la proyección de las formas

\footnotetext{
relativiza, donde lo subjetivo y lo objetivo se funden. Así cualquier mejora, económica o social, que implique un coste o pérdida de cualidad, significa un perjuicio en otro lugar o en otro tiempo, en otra dimensión humana; mientras que cualquier mejora que implique favorecimientos simultáneos en otros lugares, tiempos o dimensiones humanas tiene efectos multiplicadores que llevan a mayores cotas de satisfacción vital. (ALGUACIL, 2000:66)

128 Para futuras investigaciones podría desarrollarse el tema de cuánto es el grado de participación real de la población en los mejoramientos de barrio y qué tanto influyen ésta en las condiciones físicas alcanzadas
} 
urbanas. Se establecen, con ese objetivo, dos escalas de principios básicos, unos de carácter conceptual, orientados a aportar estrategias para el planeamiento urbano, y unos principios legales o técnicos que den soporte al marco normativo.

- Configuración urbana sostenible

Un tema central respecto al planeamiento del alojamiento social, y del urbanismo en general, es el logro de una configuración urbana sostenible. Se entiende sostenible como lo describe Tarchópulos y Ceballos (2005) como propósito de lograr un territorio con forma urbana equitativa, eficiente, socialmente incluyente, dotada de los servicios básicos que minimicen condiciones de riesgo a sus habitantes y mantenga el uso responsable de los recursos naturales. Así la equidad territorial vendrá a dar igualdad de oportunidades para alcanzar el desarrollo de un territorio en función de la calidad de vida de su población a través de condiciones de accesibilidad similares en materia de espacio público, servicios públicos, equipamientos e infraestructura y la inclusión social asegurará los recursos necesarios para que la población pueda participar plenamente en la esfera económica, social y cultural.

Sin embargo, para que ello sea posible se defiende aquí la necesidad de mantener un modelo de ciudad compacta como sistema sostenible, habitable y funcional. Dicho modelo debe asegurar, por ende, un equilibrio en la densidad de vivienda y habitantes por hectárea, en el porcentaje de espacio público para vías, zonas verdes y equipamientos, una constitución de un sistema eficiente de transporte público, el uso mixto de actividades y la reutilización de suelo ya construido en el interior de la ciudad. También se deben manejar con sumo cuidado las tipologías edificatorias, las implantaciones de los volúmenes construidos y los parámetros arquitectónicos de las viviendas.

Ahora bien, para cumplir este propósito deben existir unos principios legales e instrumentales que lo generen $y$, en el caso colombiano, prácticamente que lo impongan. Dadas las características espaciales de las periferias analizadas, no caben posibilidades, como las que hasta ahora se están dando, de flexibilización, omisión de la norma o retribución monetaria. Es necesario retomar principios normativos básicos a nivel espacial, hacerlos vinculantes y restrictivos para alcanzar mínimos habitables.

\section{- Gestión del suelo}

La gestión del suelo está estrechamente relacionada con el modelo de ciudad compacta. Es de necesaria atención para que el modelo no redunde en un simple proceso de densificación sin el acompañamiento de una mayor provisión de espacio verde y equipamientos que requiere la población. Para guiar su proceso, hace falta la definición de estándares de calidad en la relación de los espacios públicos con los privados.

Este enfoque, el de la gestión del suelo dentro de los límites administrativos, implica también garantizar la oferta de suelos urbanizados y el valor del mismo al ser adquirido para la construcción de vivienda social a bajo precio. Con respecto a la oferta del suelo ya que va dirigido a la población de bajos recursos, este debe ser preferiblemente situado en los puntos más cercanos posibles a las centralidades. La ley sobre ello debería ser clara. Lo que se observó es que, si bien el tema es mencionado a lo largo de los dos documentos de 
planeamiento urbano, en ninguno de los dos casos se aplica en realidad. La excusa es la falta de mercado de un suelo barato. Con respecto al valor del suelo, es obvio que debe ser necesario garantizar un precio bajo que no aumente los costos finales de las construcciones y no permita, como consecuencia, se realicen cambios tipológicos, áreas mínimas en las viviendas o escuetas zonas de cesión solo por una cuestión económica. Para ello, el Estado debe programar recursos necesarios para garantizar la adquisición de dichos suelos. Así como también debe, hasta que no se supere la condición de marginalidad, garantizar recursos para el manejo del "suelo público" en los mejoramientos de barrio.

Un instrumento técnico a utilizar para esta gestión del suelo es la creación o la puesta en marcha de un banco de tierras que hasta cierta medida regule el mercado del suelo para el desarrollo de la vivienda social. El objetivo es contar con suelo público para, siguiendo las pautas actuales, ser vendido posteriormente a las inmobiliarias a bajo precio o bien para desarrollar otro modelo de vivienda que no sea el de propiedad. Esta última opción ha sido muy poco desarrollada en Colombia, y se cree puede tener grandes opciones.

\section{Vivienda como elemento de orden}

El tejido residencial debe ser considerado como el elemento estructurante del territorio que constituya o articule el resto de las piezas urbanas. Su formación es la base, en extensión y uso, del crecimiento de las ciudades. Para el caso de las dos principales ciudades de Colombia éste crecimiento, dado por dos tipos de producción, la formal y la marginal, es esencial a considerar.

Actualmente, los desarrollos producidos por la gestión de origen normal han sido construidos como una sumatoria de viviendas, una al lado de la otra, sin mayor condición morfológica que logre cualificar la ciudad construida. Se han conformado así como una isla dentro de la periferia (o quizás ciudad dentro de la ciudad) sin conexión alguna con el resto del tejido urbano, desprovistas de equipamientos, con zonas verdes poco animadas y usos comerciales agrupados en grandes centros comerciales, como es el caso de Ciudadela El Porvenir en Bogotá.

Los asentamientos de origen marginal, por su naturaleza, han sido igualmente construidos parcela a parcela y desprovistos de dotaciones e infraestructura. Su regularización, aun cuando intenta integrarlos al tejido urbano y constituirlos como una pieza de la ciudad, tampoco logra llegar al objetivo de equipararlos al resto de la ciudad o de lograr su desaparición o disminución.

Se originan así dos formas de producción diferente pero con una configuración similar que vienen a señalar el vacío normativo del Planeamiento urbano de Bogotá y Medellín. La ausencia de una política de alojamiento por definir correctamente, revela dos cuestiones principales a contemplar, la reflexión sobre la conformación de la tipología, la parcela y la manzana a consolidar en este tejido urbano, y la escala dada por las tres dimensiones antes mencionadas, el bloque, el barrio y la ciudad.

Otra consideración a tener en cuenta es la modificación como norma de dicha vivienda. La trasformación del espacio ha sido considerada siempre como un proceso exclusivo de la autoconstrucción de los barrio marginales. Se ha visto como una irregularidad cometida por los 
pobres en sus viviendas progresivas, sin embargo el análisis hasta ahora hecho invita a reflexionar sobre esa condición. No solo la gente en viviendas de autoconstrucción transforma sus viviendas a lo largo de su vida, también lo hacen aquellos habitantes que adquieren una vivienda formal con muchos o pocos ingresos. Así lo expone Armelle Choplin (2017) en el libro Repenser les quartiers précaires "Si bien la informalidad siempre ha sido considerada como una excepción, se recuerda que en los distritos legales, la mayoría de los propietarios de viviendas construyen pisos sin respetar las reglas. [...] Diciéndolo de otra forma, la excepción de la informalidad como modo de gestión de la ciudad se convierta más bien en la regla" (CHOPLIN 2017:268).

Esa condición de transformación o de informalidad se cree se da en paralelo a los ciclos de vida de los habitantes y por ende son inherentes la una del otra. De ahí la necesidad de tener en cuenta a la hora de proponer una tipología de construcción en los proyectos de vivienda nueva que sea flexible. De lo contrario, como se observó, las condiciones de habitabilidad de esas unidades de vivienda siempre podrán verse afectadas.

\section{Espacio público como soporte:}

El espacio público, destinado al uso y el disfrute colectivo, se constituye como el soporte que permite la existencia de manifestaciones culturales, sociales y políticas en donde se cualifica la vida cotidiana. En su materialización física permite que en él se produzcan los encuentros y desencuentros de las comunidades, se localicen las actividades de ocio, de comercio y de desarrollo social. Es el complemento de la vivienda, el espacio privado, que hace posible el habitar.

Así la consecución de un adecuado ambiente urbano descansa, sin duda, [...] en una acertada proporción y disposición del espacio público. (Ezquiaga,1997:9) Supone entonces la construcción de redes de movilidad, por medio de calles peatonales, vehiculares, carriles de bicicleta, andenes o rampas que permitan la conexión de la ciudad. Suponen también la infraestructura necesaria para llevar las redes de servicios domiciliarios. Constituye el espacio para el desarrollo de los equipamientos, plazas, parques y alamedas necesarios para una vitalidad urbana de los desarrollos residenciales. Y por último, es integradora de las actividades comerciales en sus diversas formas organizativas y previsión de usos complementarios según las diferentes horas del día.

Por lo anterior, su localización, su tamaño, sus proporciones, la variedad de tipo y cantidad de usos y actividades que en el espacio público, se desarrollen son esenciales para superar las deficiencias sobre la calidad urbana. Las condiciones sobre el espacio público encontradas en los estudios de caso analizados muestran justamente dicha situación de precariedad.

Habitantes y comunidades como agentes activos y participativos

Existe un reconocimiento creciente de que los habitantes son actores protagonistas de su propio desarrollo (Max-Neff 1986) y que por lo tanto no son agentes pasivos sino son los que más han hecho por la construcción de sus viviendas y barrios. Moser (1998) sostiene que es necesario apoyar las soluciones que generan los habitantes en lugar de anularlos o de sustituirles y esto solo es posible si el Estado se centra en las necesidades de los habitantes y 
se sienta a trabajar con ellos. De ahí la necesidad de promover la participación democrática con estructuras de red articuladas de abajo hacia arriba.

En definitiva, la utilidad práctica de los principios conceptuales y técnicos, que aquí se aportan, radica en su consideración a la hora de crear mecanismos que garanticen la calidad habitacional en el nuevo esquema de producción de vivienda social. La formulación de un manual que por un lado, articule las dos formas de producción para lograr el acceso a un alojamiento social sostenible y de calidad, y, por otro lado, regule los patrones productivos con estándares esenciales no negociables, ni retribuibles en dinero y con principios como las anteriormente expuestas, permitiría asegurar el gran deseo de la población colombiana en la obtención de una vivienda adecuada. Se cree que unas condiciones de habitabilidad ajustadas a unos requerimientos específicos de calidad les aseguraría un patrimonio importante en términos físicos, económicos y simbólicos. 


\section{CARTILLA DE ESTUDIOS DE CASO}

Ciudadela Nuevo Occidente en Medellín

Ciudadela El Porvenir en Bogotá.

MIB Sur Con Bogotá

PUI Nororiental en Medellín

MIB El Lucero en Bogotá

PUI Centroriental en Medellín 


\section{APLICACIÓN DEL MODELO DE ANÁLISIS EN LO SEIS ESTUDIOS DE CASO}

La cartilla desarrollada con los seis estudios de caso, que se presenta a continuación, tiene como objetivo exponer el análisis pormenorizado, la elaboración gráfica y cuantitativa, de cada uno de los proyectos seleccionados. Su valor es el de permitir observar de manera sencilla la aplicación del modelo de análisis con cada uno de los indicadores establecidos. Como estudio morfológico se centra en las condiciones físicas más significativas de cada territorio y como estudio comparativo intenta encontrar regularidades o patrones.

De este modo, se pretende así, como se señaló al inicio de la investigación, que los estudios de caso seleccionados brinden un panorama diverso, amplio y representativo de las condiciones del alojamiento social en las ciudades de Bogotá y Medellín bajo el contexto de las primeras propuestas de los POT. La información así expuesta, se cree, lo facilita.

La cartilla contiene una serie de datos numéricos, planos esquemáticos, algunos gráficos y pequeños comentarios descriptivos sobre cada proyecto que han servido de base para la elaboración del tercer capítulo de esta investigación: La morfología del espacio residencial. Caracterización de la calidad. Su estructura clasifica y presenta los proyectos según su modelo de intervención: tratamiento de vivienda nueva y tratamiento de mejoramiento de barrio, bajo el siguiente orden:

01. Ciudadela Nuevo Occidente en Medellín

02. Ciudadela El Porvenir en Bogotá.

03: MIB Sur Con Bogotá

04. PUI Nororiental en Medellín

05. MIB El Lucero en Bogotá

06. PUI Centroriental en Medellín

Bogotá

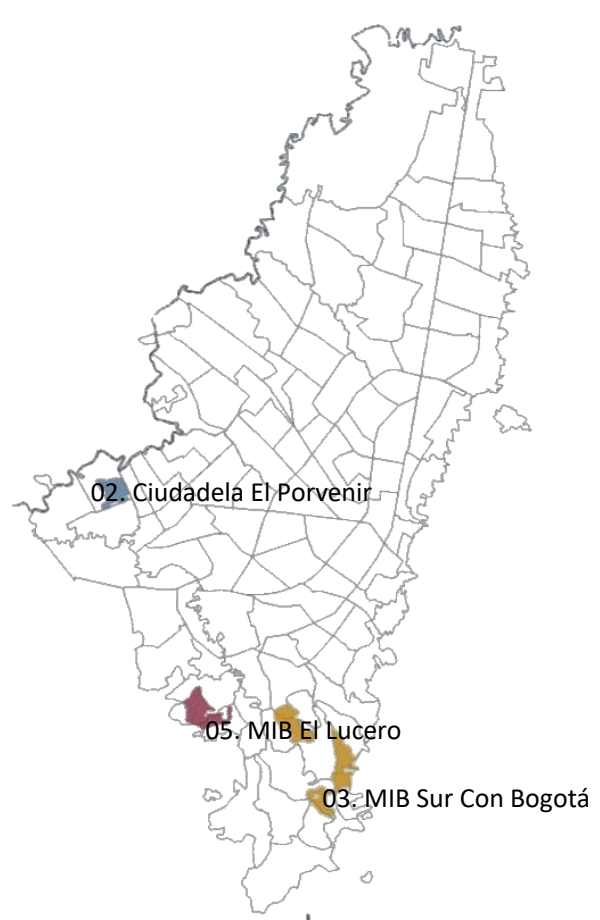

Medellín

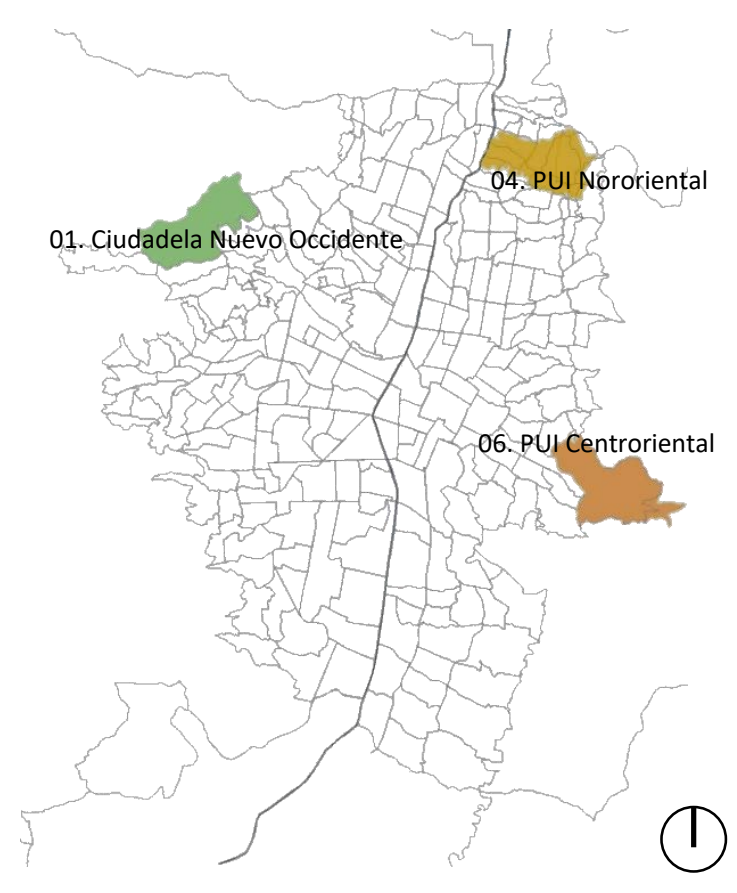


Cabe señalar previamente que se considera que todos los estudios de caso seleccionados son, sin duda, una apuesta por parte del Estado que ha transformado el territorio de una menara excepcional o innovadora. Sin embargo, se presume son un proyectos que no ha terminado por mejorar las condiciones de calidad de vida de sus habitantes de la forma deseada o propuesta en su formulación de ordenamiento territorial. Las intervenciones, aun cuando han mejorado las condiciones físicas y ambientales de una $u$ otra manera, se cree, no han repercutido considerablemente en el aumento de capital social, ingresos o empleo de la población. Ni siquiera han llegado a consolidar un modelo físico realmente satisfactorio. Comparado, además unos proyectos con los otros y siguiendo la hipótesis de la investigación, los proyectos de vivienda nueva no presentan unas condiciones de calidad urbana superiores a los de los mejoramientos de barrio.

Para evidenciarlo, se propone aplicar el modelo de análisis y exponer la información que cada indicador revela. Interesa centrara la mirada especialmente en las condiciones urbanas, entendidas como espacio colectivo, que van más allá de las unidades residenciales y son escenario de encuentros, actividades y lugar de la vida cotidiana.

Dicha análisis va además acompañado de algunas preguntas, que se consideran esenciales y pertinentes para plantearse en cada indicador. Estas preguntas son:

+ ¿En qué consiste el tratamiento de desarrollo de vivienda nueva y de mejoramiento de barrios? ¿Cuáles son las variables que se han trabajado en las diferentes intervenciones?

+ ¿Cuál ha sido la eficacia de los programas de mejoramiento de barrios o desarrollo de vivienda nueva? ¿Han mejorado la calidad de vida de los habitantes?

+ ¿A qué motivaciones o intereses responde cada tratamiento? ¿Para quién va realmente dirigido? ¿Qué procesos sociales genera cada proyecto: equidad, seguridad, bienestar, desarticulación, exclusión, etc?

+¿Cuál es el margen de transformación que aceptan los asentamientos marginales y qué avances en sus condiciones de habitabilidad se han alcanzado si se tiene en cuenta el reto de una sostenibilidad económica ligada a dichas condiciones?

+ ¿Qué tan sostenibles son los proyectos que se realizan por parte de las instituciones del Estado? ¿Qué acciones públicas se han encaminado a mejorar las condiciones económicas de las familias, teniendo en cuenta que éstas darán soporte a los procesos sociales y territoriales impulsados? ¿Qué tanto tienen en cuenta que una intervención debe trabajar en paralelo el tema de participación, cohesión social, empleo, educación, etc.? 



\section{CIUDADELA Nuevo Occidente - Medellín}

La Ciudadela Nuevo Occidente está ubicada en la ladera occidental de Medellín en una zona de expansión urbana propiedad de la administración (dueña de hasta un $65 \%$ del terreno). Nació como un proyecto habitacional impulsado por las instituciones locales para proporcionar vivienda masivamente a la población de bajos ingresos de esa ciudad. Su desarrollo se realizó bajo la modalidad de un Plan Parcial Pajarito (2002) siguiendo las directrices establecidas en el POT de "generar dinámicas urbanas en la zona que obedecieran a criterios de sostenibilidad y calidad de vida, ofreciendo a sus futuros moradores las condiciones óptimas de habitabilidad con las mejores características del entorno y el contorno de su hábitat." (DAP 2012:11)

Así bajo un crecimiento fundamentado en la insuficiencia del suelo (de las 500 ha de suelo de expansión que poseía la ciudad, 236ha se concentrarían en lo que sería la Ciudadela), se propuso allí la implementación de vivienda en altura con torres entre cinco y nueve niveles y apartamentos entre 45 y $47 \mathrm{~m}^{2}$ con dotación de espacio público, zonas de aprovisionamiento de bienes y servicios, actividades complementarias y equipamientos. La intervención contempló la construcción de centros culturales, jardines infantiles, colegios y un hospital.

Antes de la intervención, el terreno estaba ocupado con viviendas campestres, fincas de producción agrícola, parcelas sin uso y dos asentamientos informales, Pedregal bajo y Pajarito Central. Su población aproximada era de 2000 personas de las cuales 1845 se concentraban en los dos asentamientos. Actualmente cuenta con más de 100.000 personas algunas provenientes de procesos de reasentamiento de Moravia o de la comuna 1 y 2 de la ciudad de Medellín, por calamidad ambiental o por desplazamiento generado por el conflicto armado.

La intervención que inició en el año 2002 se encuentra aún en ejecución (año 2019), lleva ya más de 20 urbanizaciones edificadas y cuenta con centros culturales, un jardín infantil, institutos académicos, un hospital y un centro de vida. Estos equipamientos, vale la pena mencionar, fueron construidos en muchas de los casos posteriormente a las unidades habitacionales.

Como parte de los conjuntos habitacionales se destaca la Villa Suramericaca ${ }^{129}$. El proyecto fue concebido y desarrollado en una primera instancia como villa olímpica para 3.500 atletas y delegados que participaban en los IX Juegos Suramericanos Medellín 2010 y en una segunda instancia como unidad habitacional para 621 familias que pudieran adquirir la propiedad.

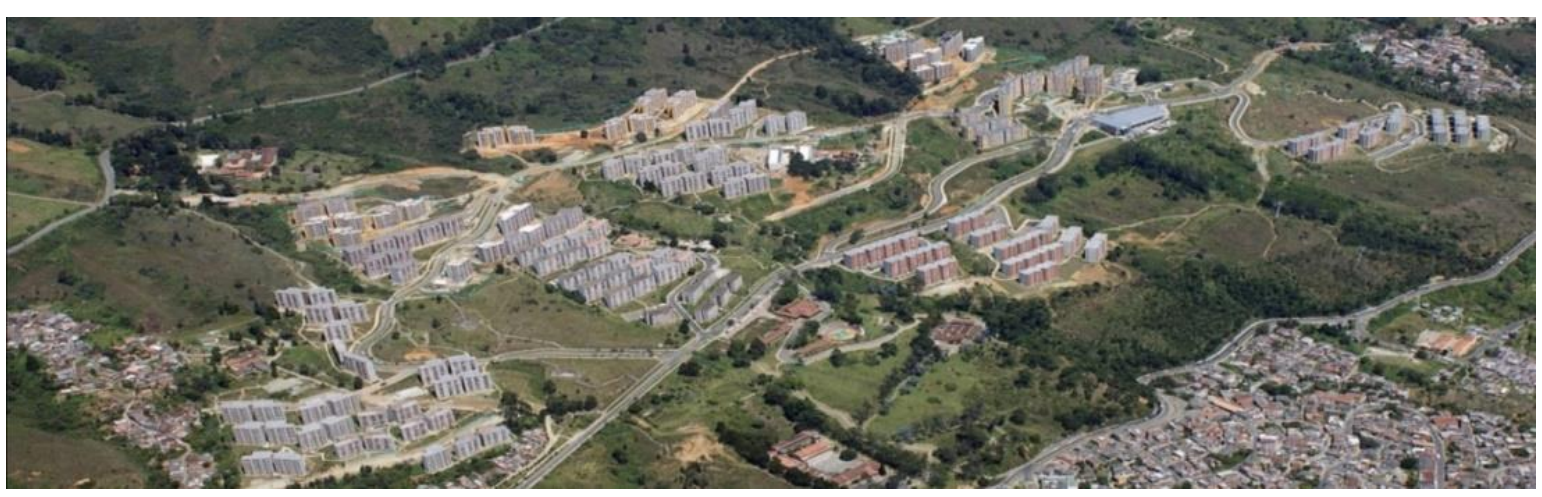

129 http://habitat.aq.upm.es/dubai/12/bp4439.html 


\section{Determinantes}

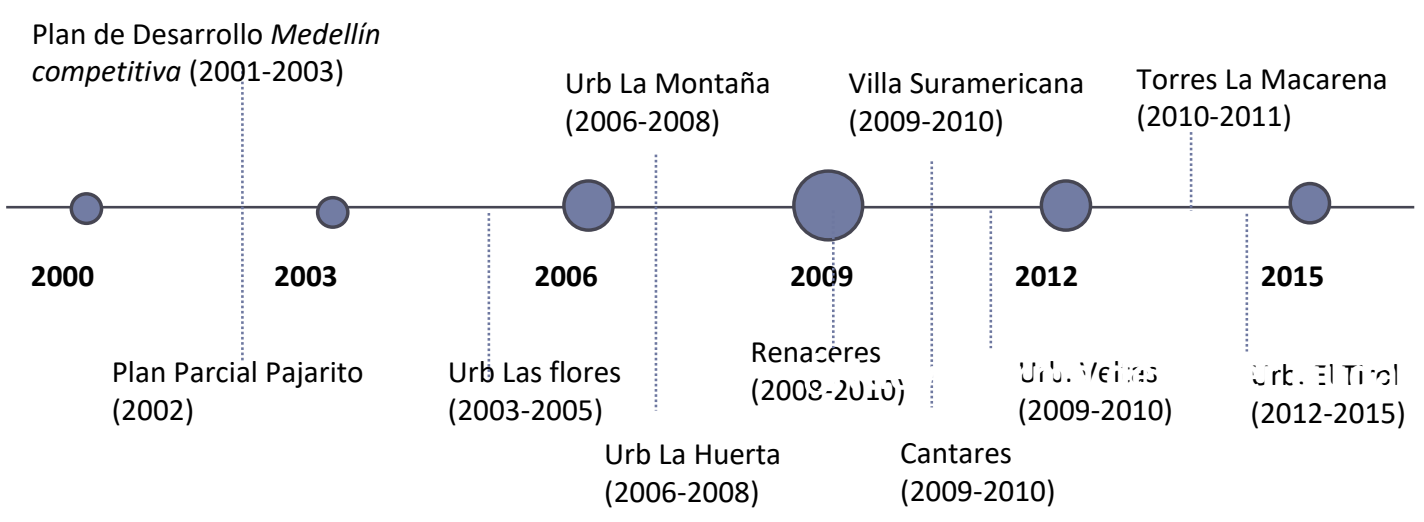

Desde principios del año 2000, la administración municipal de Medellín, de la mano del sector privado, ha intentado implementar un modelo de intervención urbano inclusive e integral, como lo denominaban ellos, enfocado a reducir las profundad deudas sociales acumuladas por décadas en la ciudad. La estrategia, encabezada inicialmente por el alcalde Luis Pérez con el Plan de Desarrollo 2001-2003 Medellín competitiva, nació con el objetivo de crear una ciudad justa, participativa y con equidad en lo social y en el uso del espacio público. Dicho plan, en lo que correspondía con el tema específico de vivienda y hábitat (art.26), en coherencia con el POT, proponía la puesta en marcha del Sistema Municipal de Vivienda de Interés Social CORVIDE (hoy liquidado y remplazado por ISVIMED) como mecanismo de gestión mixta, bajo el cual se desarrollarían los programas de vivienda nueva y mejoramiento de barrio. Como objetivo del Plan se había programado construir 20.000unidades de vivienda social y gran parte de ellas tan solo se podían realizar en Pajarito.

El sector Pajarito, a pesar de haber sido incorporado como parte del suelo urbano, a partir del acuerdo 01 de 1994, no se había urbanizado debido a la carencia de infraestructura de servicios públicos y conexiones viales. El terreno era un suelo libre de edificaciones y la administración era su dueño hasta un 65\% (EDU 2002).

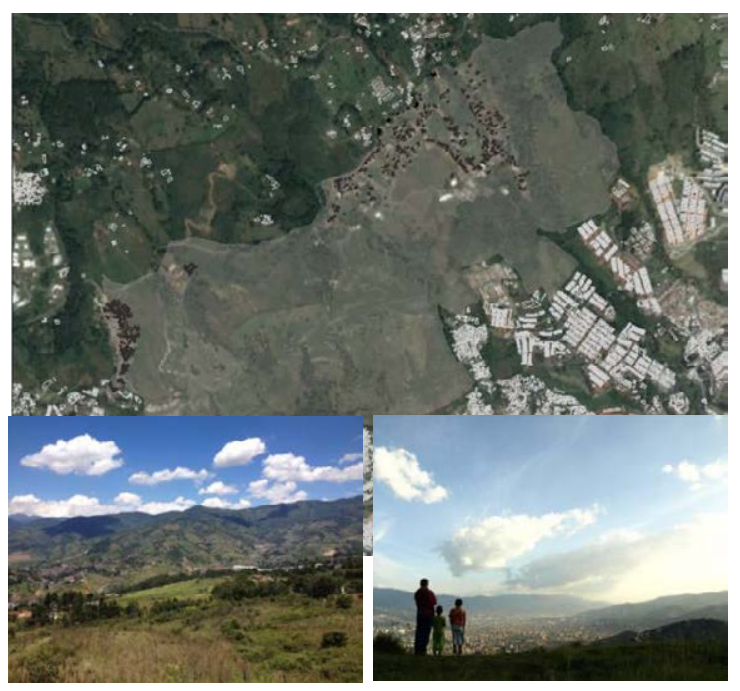

El sector de Pajarito está ubicado en el costado occidental de la ciudad, en cercanías del área urbana del Corregimiento San Cristóbal. Según relatos de la comunidad, toda esta ladera era asiento de casas de veraneo, en donde los habitantes de Medellín acudían en épocas de vacaciones a descansar y disfrutar del paisaje cuya panorámica domina buena parte del extremo sur del valle de Aburrá. (DAP 2012)

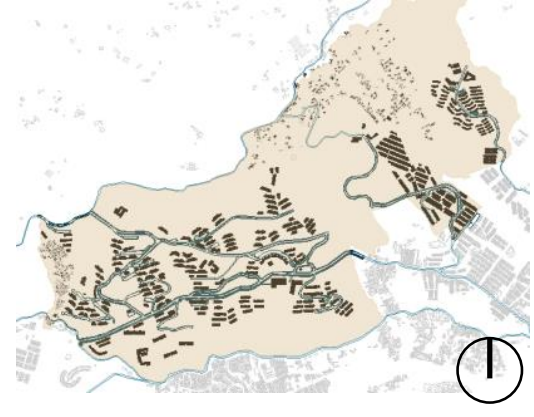




\section{Modelo de ciudad propuesto y construido}

El proyecto Ciudadela Nuevo Occidente es una de las primeras experiencias de vivienda social a gran escala desarrollado en Colombia. Como proyecto estratégico pretende constituirse en un referente espacial en la construcción de nueva ciudad, bajo las directrices de un Plan Parcial, con excelentes infraestructuras urbanas, con calidad urbanistica y valoración ambiental para la comunidad que lo habite. (DAP 2012:6)
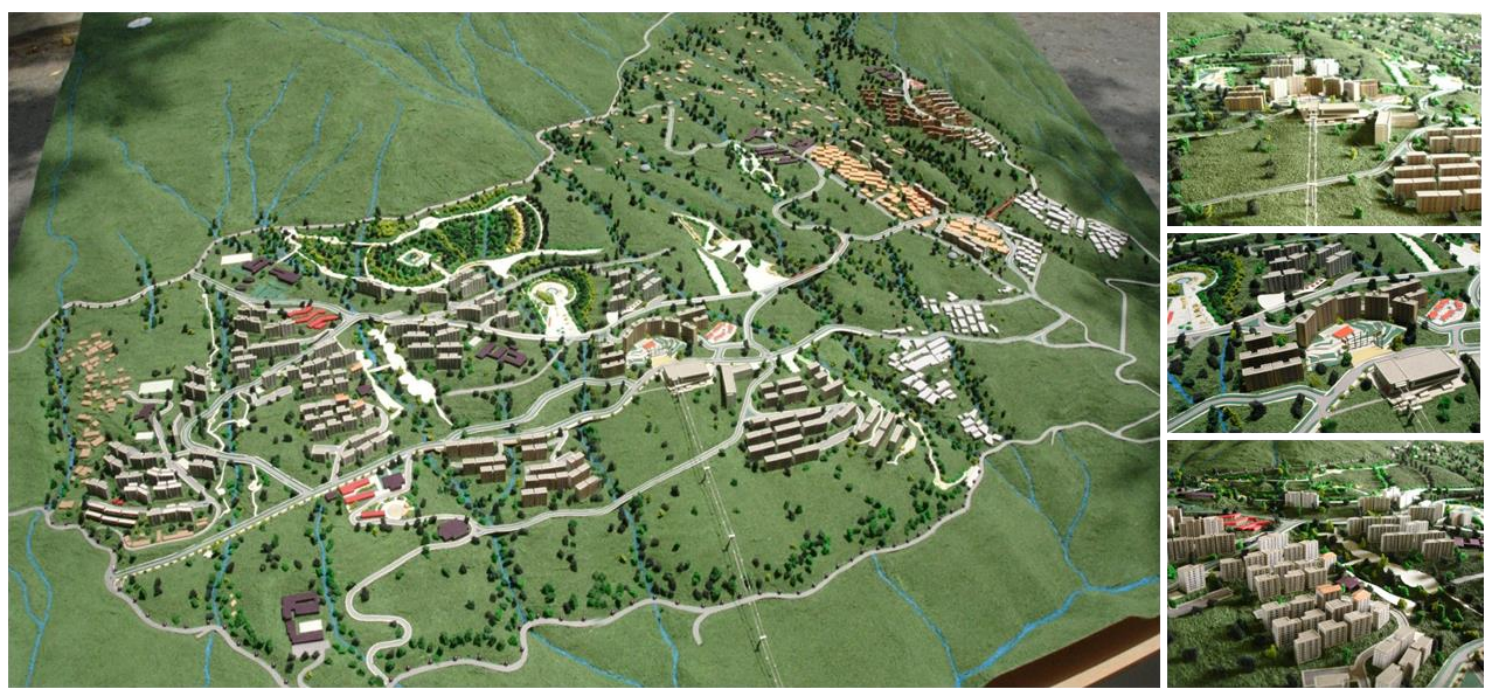

Para ello abarca seis componentes principales:

+ Un desarrollo urbanístico que se inserte en un medio natural con alta oferta ambiental como una alternativa para la protección del medio natural y para la generación de espacio público.

+Un desarrollo sobre media ladera que posibilite visuales desde y hacia la ciudad.

+Una conformación de cinco centralidades, una a escala zonal y cuatro barriales, destinadas principalmente a conformar equipamientos educativos, recreativos, deportivos, áreas cívicas y representativas como expresión de comunidad, civilidad, intercambio cultural e identidad.

+Un corredor de transporte complementario al Metro como fundamento de movilidad

+Un desarrollo urbanístico con una baja ocupación y un alto aprovechamiento de los terrenos aptos.

+Una sana mezcla de usos que permita disponer de actividades productivas comerciales y de servicios, equipamientos comunitarios y vivienda que requiere la población.

A continuación, se analiza por medio de la aplicación del modelo de análisis cómo estos seis componentes no fueron del todo desarrollados y se convirtieron más en un postulado de intenciones determinando unas condiciones de calidad urbana poco adecuadas.
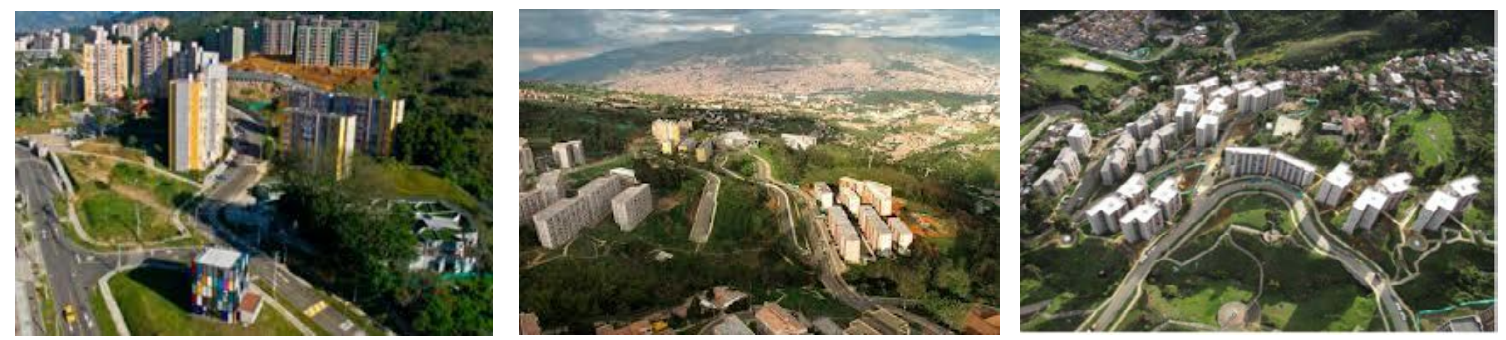


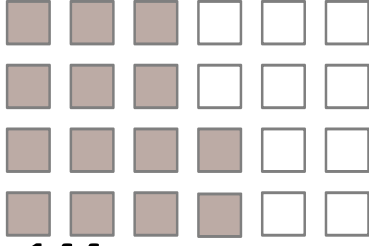

144viv/ha multifamiliar

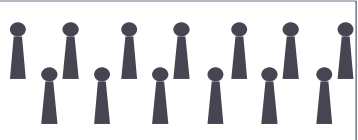

525hab/ha multifamiliar

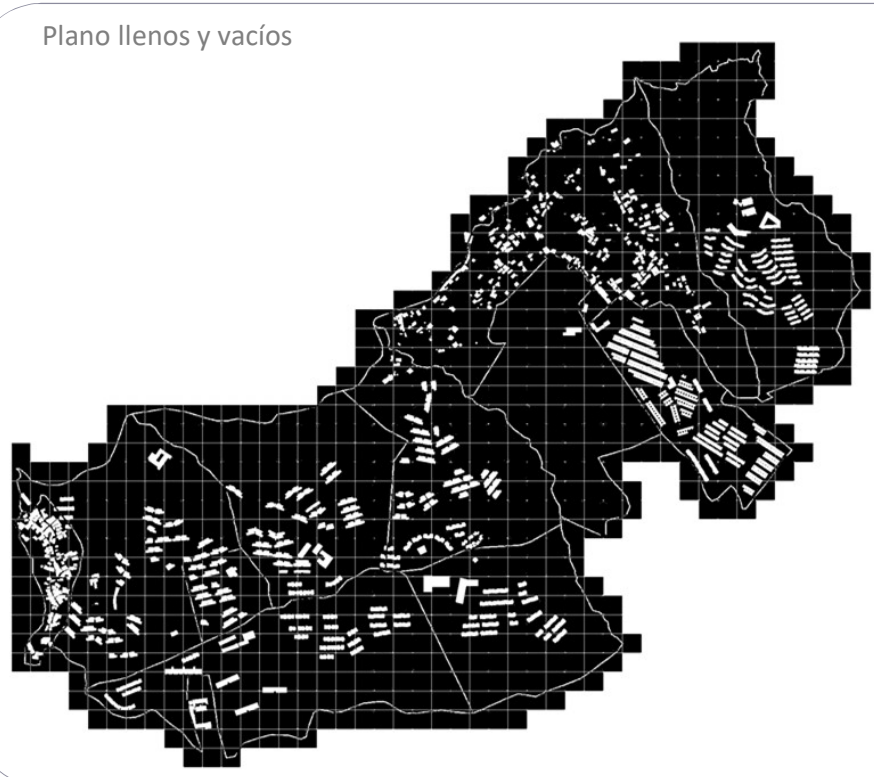

102 Cesiones

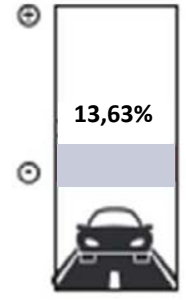

Malla vial

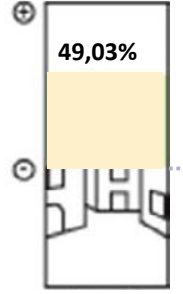

Espacio público

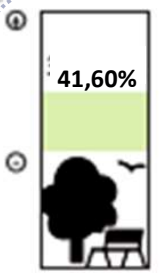

Zonas verdes

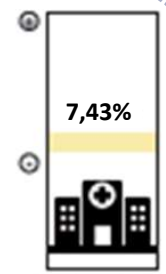

Equipamientos
La novedad que propone el proyecto Nuevo Occidente con respecto a sus cesiones es estimular el desarrollo urbanístico de tipología abierta en las soluciones habitacionales para integrar así las cesiones de carácter privado al sistema general de espacio público conformado en centralidades.
Cesiones de espacio público
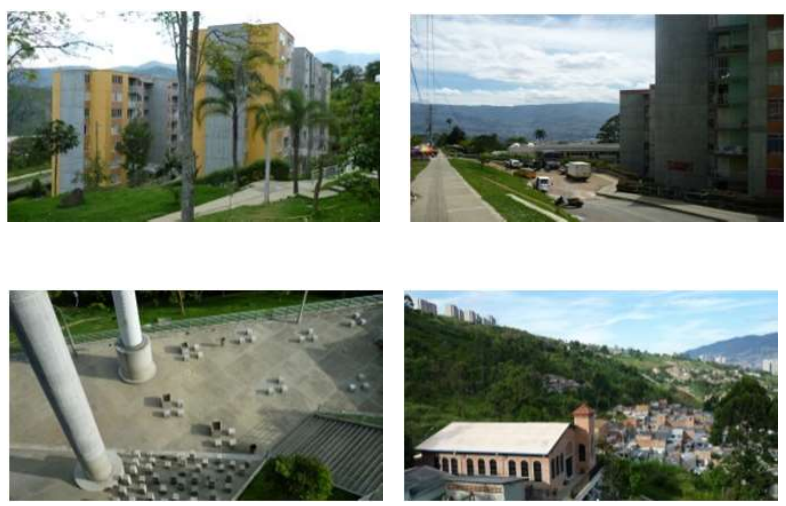

Áreas
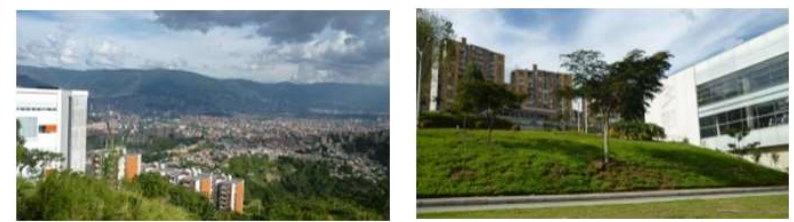

Cesiones públicas

\begin{tabular}{cc}
\hline Cesiones públicas & ... 102,0297ha \\
Malla via & $\ldots . . . .22,1813 \mathrm{ha}$ \\
Equipamientos & $\ldots . . .12,1652 \mathrm{ha}$ \\
Zonas verdes & $\ldots . . . .67,6832 \mathrm{ha}$
\end{tabular}




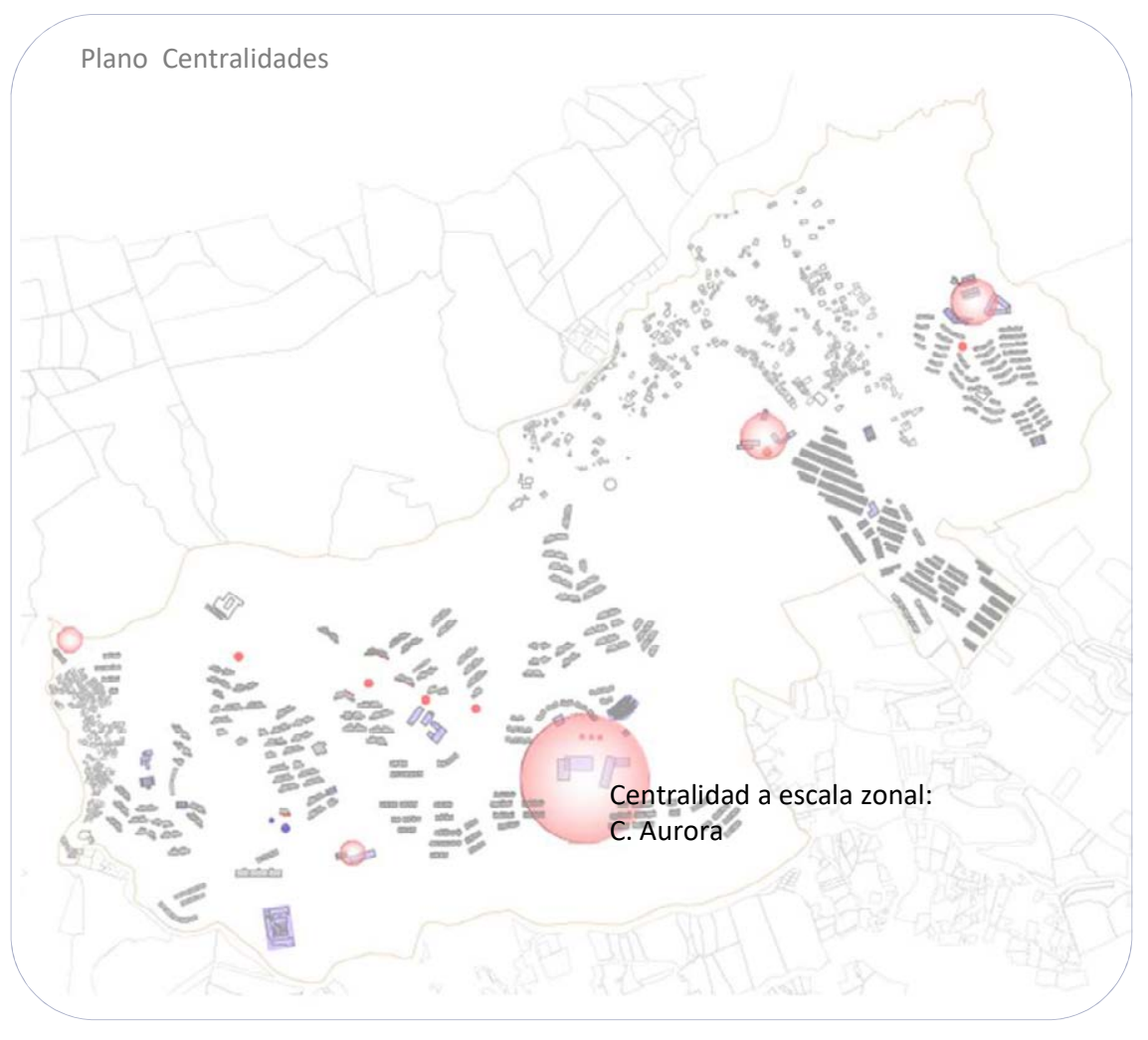

En el proyecto se propone una conformación de cinco centralidad, una a escala zonal y cuatro a escala barrial, destinadas principalmente a conformar equipamientos educativos, recreativos, deportivos, áreas cívicas. Su suelo está conformado principalmente por las cesiones urbanísticas de carácter público y privado que han sido agrupados en un solo globo de terreno. Actualmente no todas las centralidades se encuentran edificadas; dos de ellas se encuentran paralizadas.

Tiempos de desplazamiento a la centralidad más cercana

Escala Ciudad: Corregimiento San Cristóbal

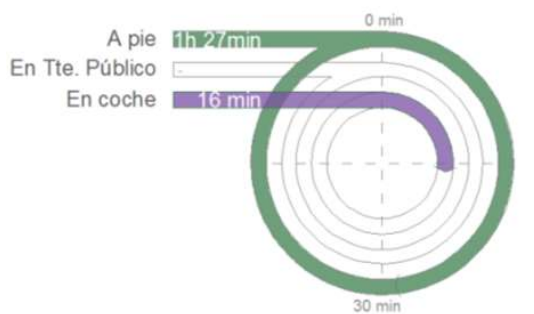

Escala Zonal: Robledo

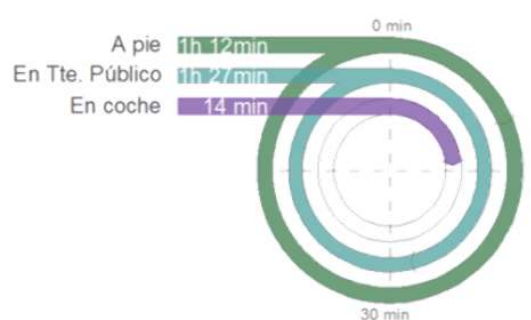

Escala Local: Centralidad Aurora

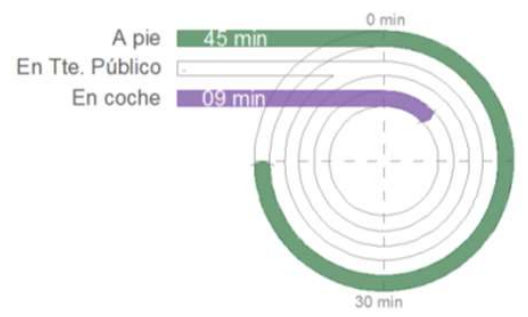

Según los criterios establecidos sobre los tiempos de desplazamiento a pie y en transporte público, se hace evidente que las centralidades cuentan con una accesibilidad muy, muy baja en cualquier escala valorada. Cabe resaltar, además, que a dos de las centralidades ni siquiera hay posibilidad de tomar el transporte público pues no existen rutas que conecten dichos puntos.

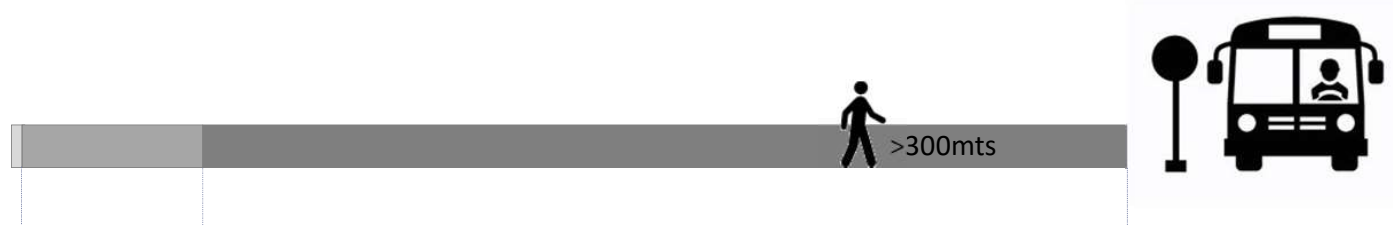

$1,34 \% \quad 10,73 \%$

$87,93 \%$

Como se señalaba en la valoración del indicador anterior, al accesibilidad al transporte público en la Ciudadela es muy deficiente, tan solo cuenta con una estación de Metrocable para mas de 80.000habitantes. La unidad habitacional mas lejana tarda a pie para llegar a la estación mas de $45 \mathrm{~min}$ a pie y recorre mas de $2,8 \mathrm{~km}$ (muy distante de los $300 \mathrm{mts}$ considerados como máximos recorridos). La población soluciona dichas distancias tomando un sistema de autobuses, paralelo al sistema público. 


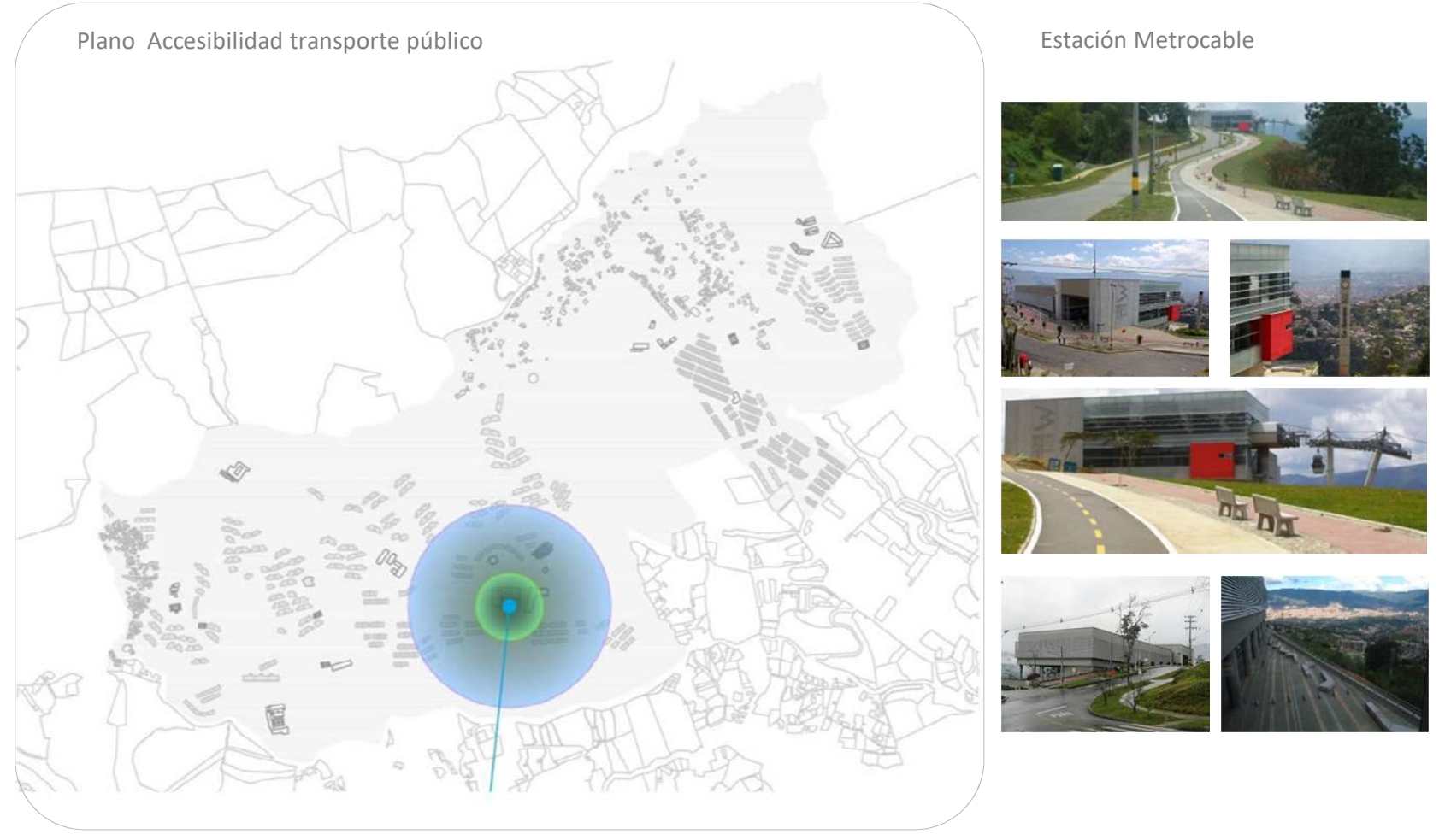

Pendiente

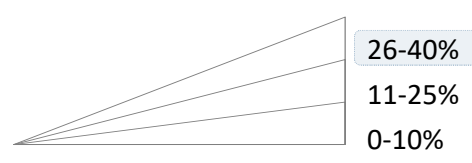

Acceso a escala de ciudad
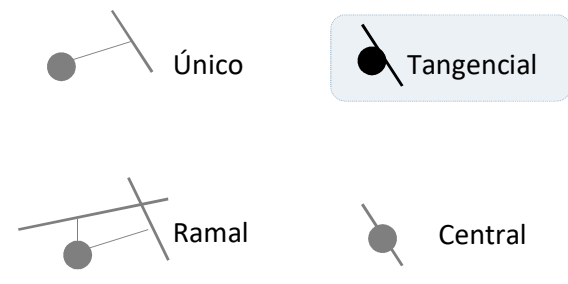

Conexión a escala de barrio

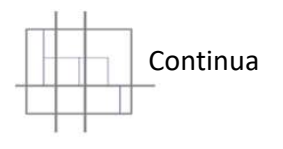

Combinada
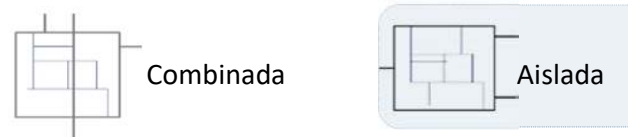

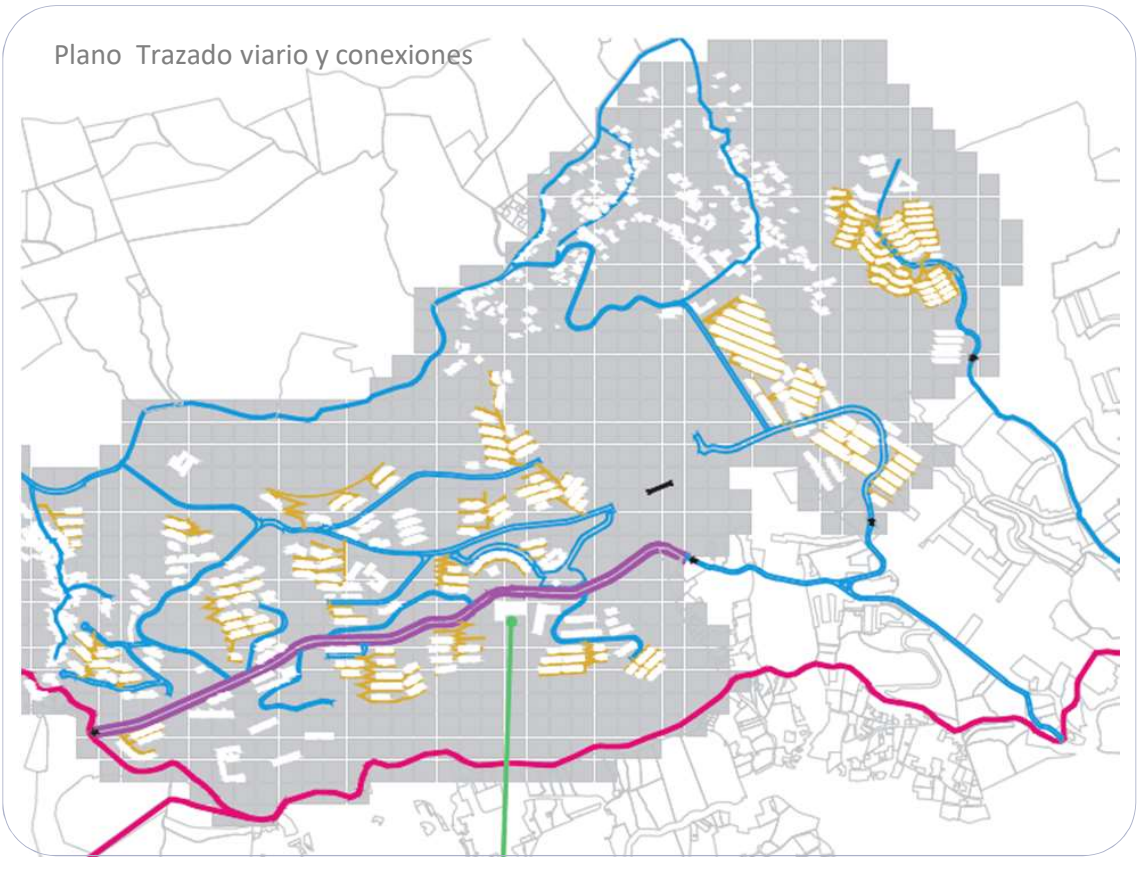

Unos de los mayores problemas de la ciudadela es su conexión con la ciudad. Así lo ha sido desde 1994 cuando el área se incorporó al perímetro urbano y así lo sigue siendo aún hoy. El único acceso vehicular es bastante tortuoso dadas las condiciones técnicas de las vías aledañas existentes, las barreras geotécnicas y urbanísticas, las pendientes topográficas y las condiciones hidrográficas que lo atraviesan literalmente. 


\section{VÍA VEHICULAR}

Pavimentada

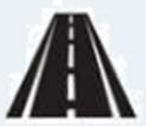

$100 \%$
VÍA PEATONAL

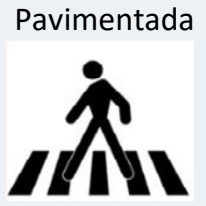

$100 \%$
No Pavimentada

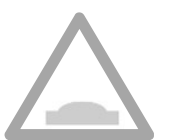

El proyecto cuenta, hasta el periodo de análisis, con todas sus vías construidas pavimentadas. Lo que se valora cono una superficie vial construida óptima. Sin embargo, no todas las vías que han sido planificadas han sido realizadas. El motivo, según la administración, es que la ejecución supera la escala zonal y se convierte en un proyecto de movilidad para la ciudad, y por lo tanto no son realizadas bajo el presupuesto del proyecto de la Ciudadela.

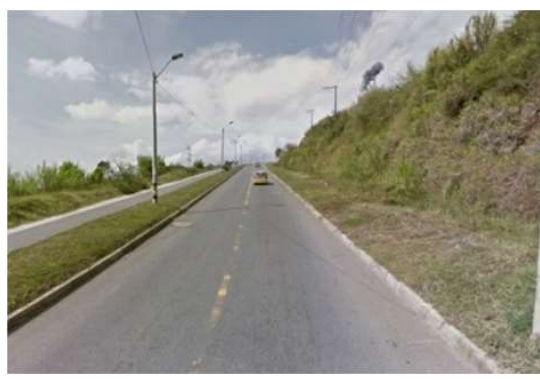

Acceso al proyecto

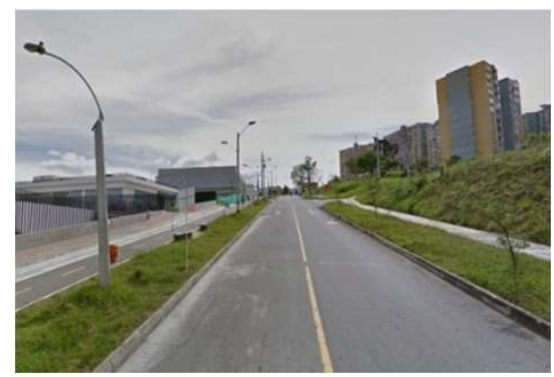

Acceso a la Centralidad Aurora

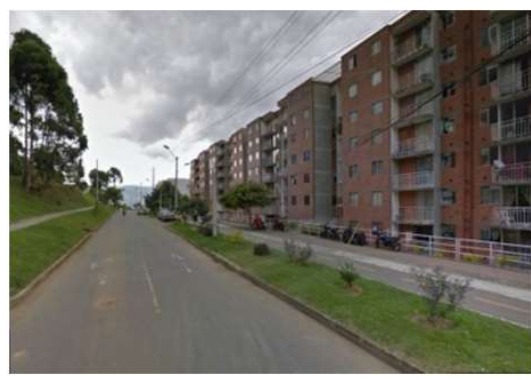

Vía entre urbanizaciones

\section{Equipamientos}

\section{EQUIPAMIENTOS ESCALA BLOQUE-VECINDARIO}
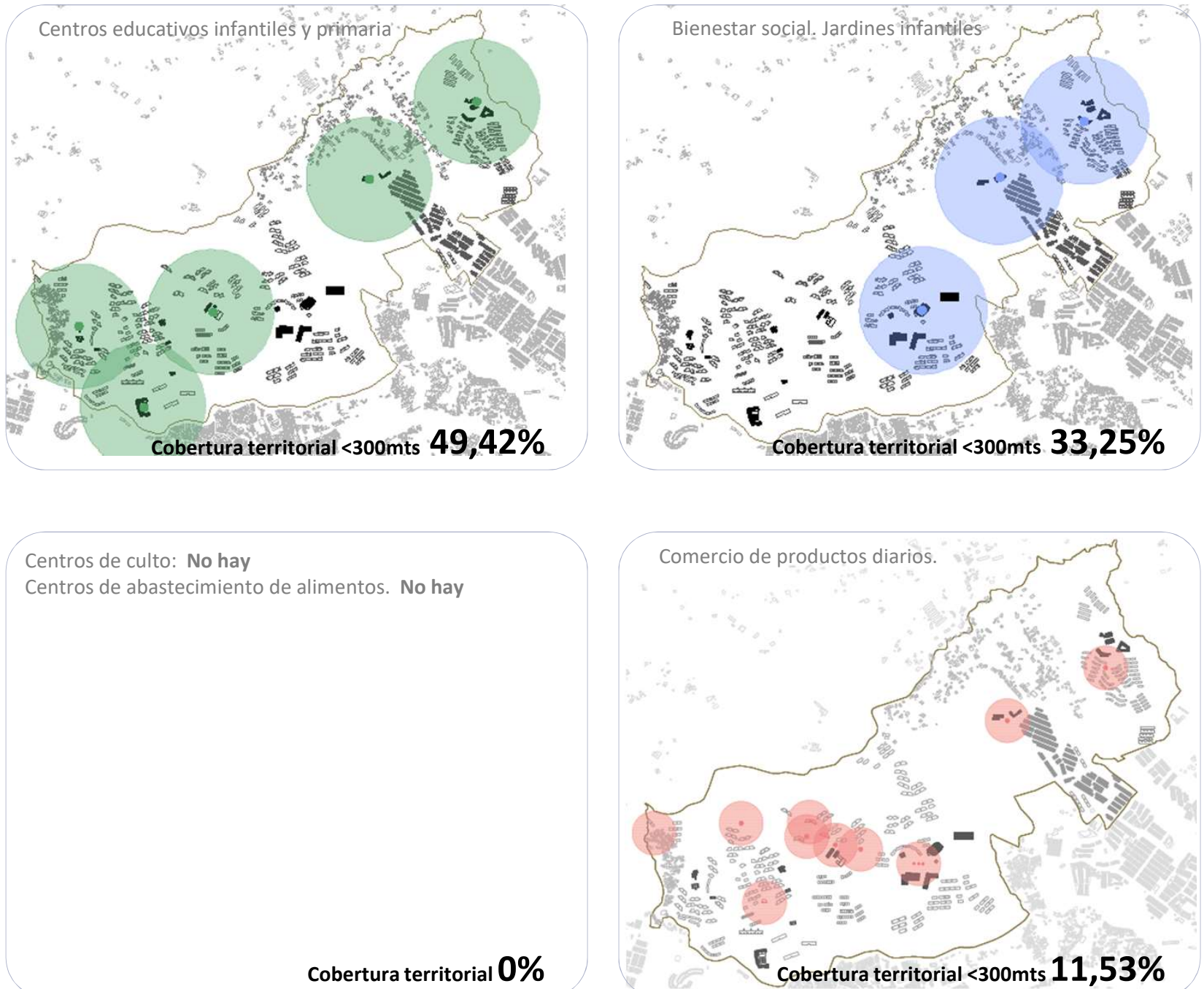


\section{Centros educativos}

La cobertura actual de los centros educativos a nivel territorial es relativamente buena en educación secundaria, cubre casi el $100 \%$ del territorio, y deficiente en educación primaria, cobertura de tan solo el $50 \%$ del territorio. Sin embargo, ésta cobertura empeora, al tener en cuenta la demanda de niños en edad de ser escolarizados. No hay ni suficientes infraestructura para soportar la población de esta Ciudadela.

Hay que destacar, no obstante, el intento por hacer de los pocos centros educativos construidos, una 'arquitectura de diseño'.

\section{Centros de bienestar social}

Una situación similar sucede con los centros de bienestar social. Tan solo hay tres guarderías y una Unidad de Vida Articulada (centro múltiple), de una cierta calidad arquitectónica, pero escasa cobertura a nivel territorial o de demanda para las más de 100.000 personas que habitan la zona.

Todos estos equipamientos, adicionalmente han sido ejecutados unos pocos a partir de los años 2005-2006 y otros a partir de los años 2010 y finalizados hasta el año 2017. Llegaron primero, año 2002, más de 50.000 habitantes a la zona y aun no había construida ninguna dotación.

\section{Centro de salud}

Se terminó de construir para el año 2015, la Unidad Hospitalaria Nuevo Occidente, un centro de salud de nivel II con capacidad de atender mas de 150.000habitantes.
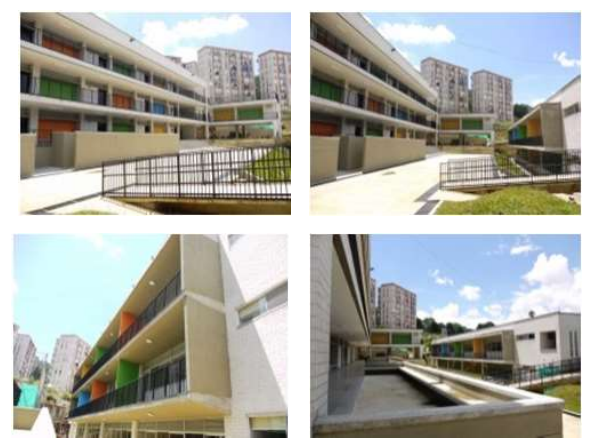

Centro educativo Las Flores
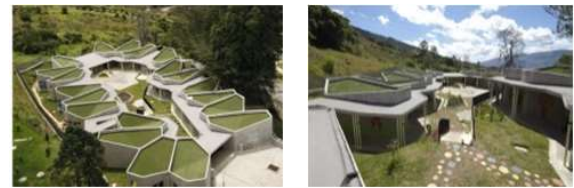

Jardín infantil Buen Comienzo Aurora
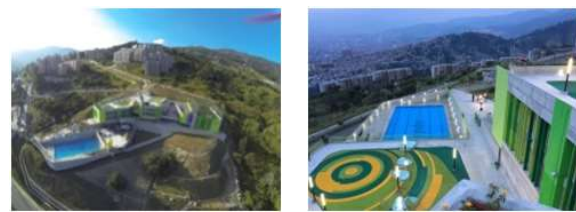

Unidad de Vida articulada

\section{EQUIPAMIENTOS ESCALA BARRIO-ZONAL}
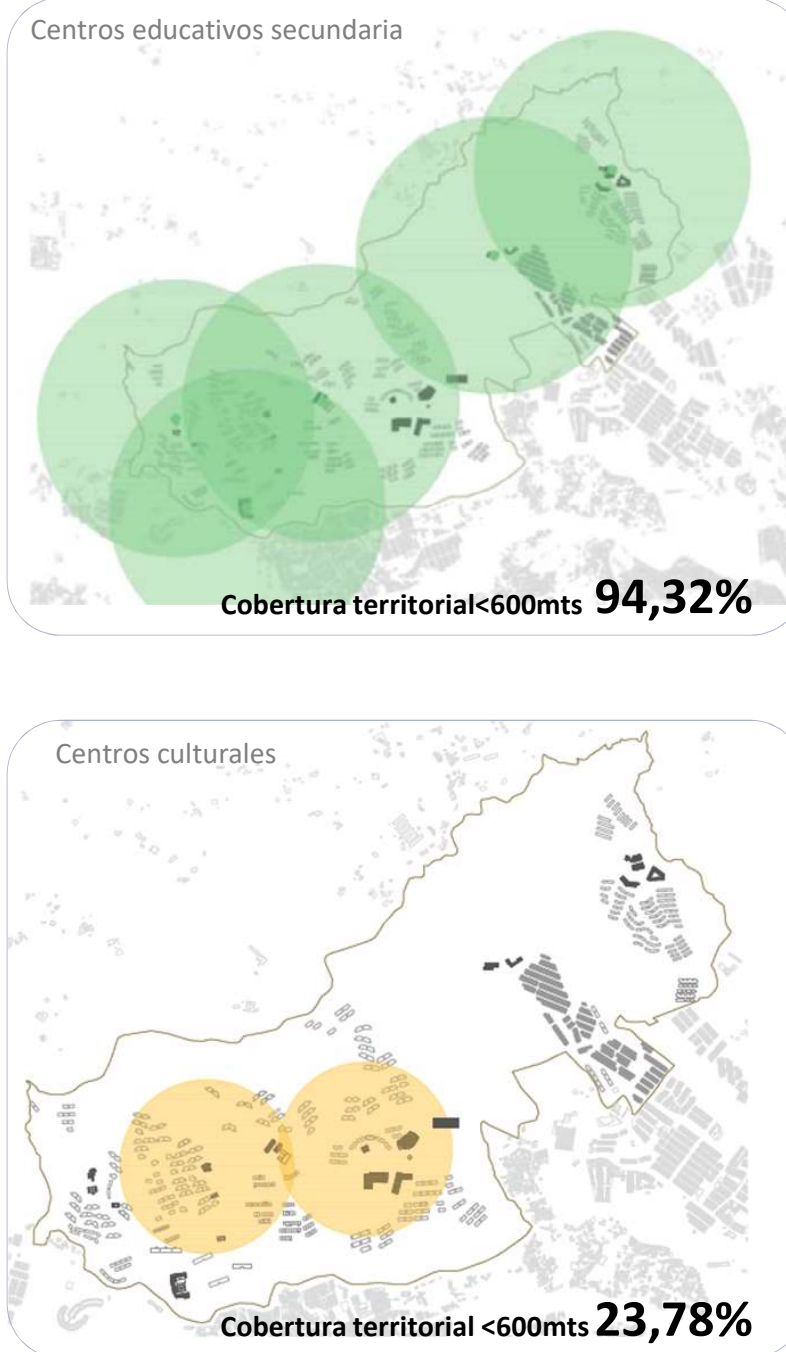

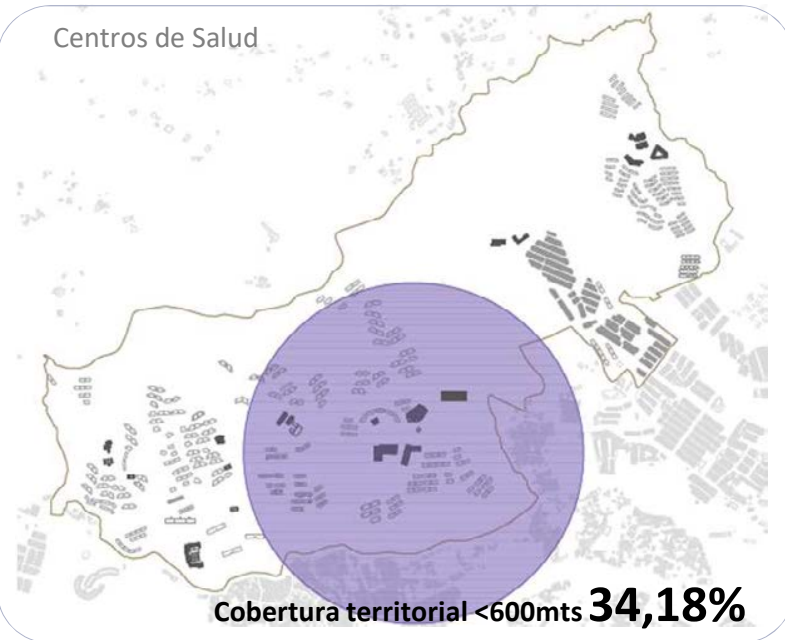


Cuadro comparativo entre la fecha de construcción de las unidades habitacionales y los equipamientos

\begin{tabular}{|c|c|c|c|c|}
\hline Urbanizaciones construidas & & No. de habitantes & Equipamientos construidas & \\
\hline Las Flores & 2005 & & & \\
\hline Puertas del Sol & 2005 & & & \\
\hline La Huerta & 2006-2009 & & & \\
\hline Aurora & 2006-2009 & 15.500 & & 2008 \\
\hline La Cascada & 2008 & & Estación de Metrocable & 2008 \\
\hline Mirador del valle & 2008 & & & \\
\hline La Montaña & $2008-2014$ & & & \\
\hline Cantares & $2009-2013$ & & & \\
\hline Chagualón & 2009 & & Área Cívica & 2010 \\
\hline Nazareth & 2009 & & I.E. La Huerta & 2010 \\
\hline El Tirol & $2009-2015$ & & I.E. Ciudadela Nuevo Occidente & 2011 \\
\hline Renaceres & 2009 & & Jardín infantil Buen Comienzo La Aurora & 2011 \\
\hline Atardeceres & 2009 & & Sede Social Puertas del Sol & 2011 \\
\hline Veletas & 2010 & & Hogar Buen Comienzo Puertas del Sol & 2011 \\
\hline Villa Suramericana & 2010 & 45.000 & & 2012 \\
\hline \multirow{10}{*}{$\begin{array}{l}\text { Pedregal Alto } \\
\text { Mirador de la Cascada } \\
\text { Colinas de Occidente } \\
\text { Torres de la Macarena } \\
\text { Altos de la Macarena } \\
\text { Portón de Occidente } \\
\text { Bosques de la Macarena } \\
\text { Casa San martín } \\
\text { Ángeles de la Aurora }\end{array}$} & 2013-2014 & & & \\
\hline & $2013-2015$ & & Hospital & 2015 \\
\hline & & & I.E. Lusitania & 2015 \\
\hline & & & & \\
\hline & & & & \\
\hline & & & & \\
\hline & & & Unidad de vida articulada & 2017 \\
\hline & & & & \\
\hline & & & \multirow{2}{*}{\multicolumn{2}{|c|}{ Por construir }} \\
\hline & & 56.000 & & \\
\hline Lusitiana & & & Hogar Buen Comienzo La Huerta & \\
\hline Mirador de Pajarito & & & Buen Comienzo Lusitania & \\
\hline Balcones de Pajarito & & & Centro de acopio residuos sólidos & \\
\hline Urbanización Todelar & & & & \\
\hline Urbanización Corcovado & & & & \\
\hline ICBF & & 80.000 & & \\
\hline
\end{tabular}

Fuente: Cantidad de habitantes estimados (4 por vivienda) según cantidad de unidades construidas y proyectada. INSVIMED

En términos generales, según se demuestra en el cuadro anterior, los equipamientos han sido construidos de forma muy posterior a las unidades habitacionales. En los primeros cuatro años de haber sido entregadas las primeras unidades habitacionales con mas de15.000 habitantes residiendo en la zona, éstos no contaron con ningún equipamiento nuevo construido especialmente para la Ciudadela. Tan solo existía en este territorio un área cívica y dos institutos académicos. No había ningún tipo de dotación o de infraestructura para llegar hasta este lugar apartado y en lo mas alto de las laderas de Medellín.

La estación de metrocable Aurora no se inauguró hasta el año 2008 y algunos de los equipamientos principales de educación o servicios social no llegaron hasta el año 2011-2012. La única unidad hospitalaria en su primera fase fue entregada en el año 2015 y la segunda fase en el año 2017. varias instituciones educativas, jardines infantiles, y muchas zonas recreativa quedan aun por ser construidas.

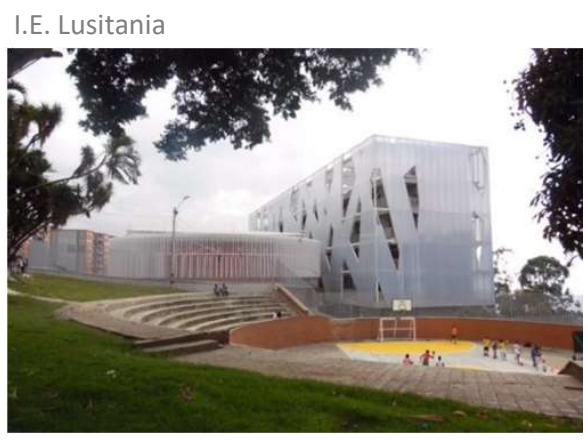

Hogar Buen Comienzo Puerta del Sol

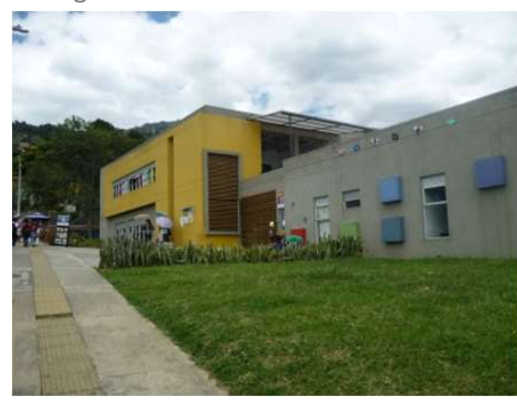

Centro cívico

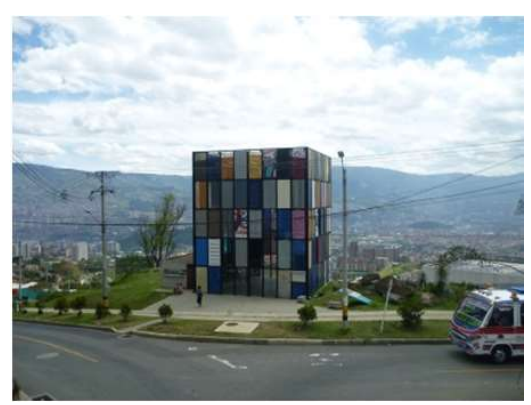




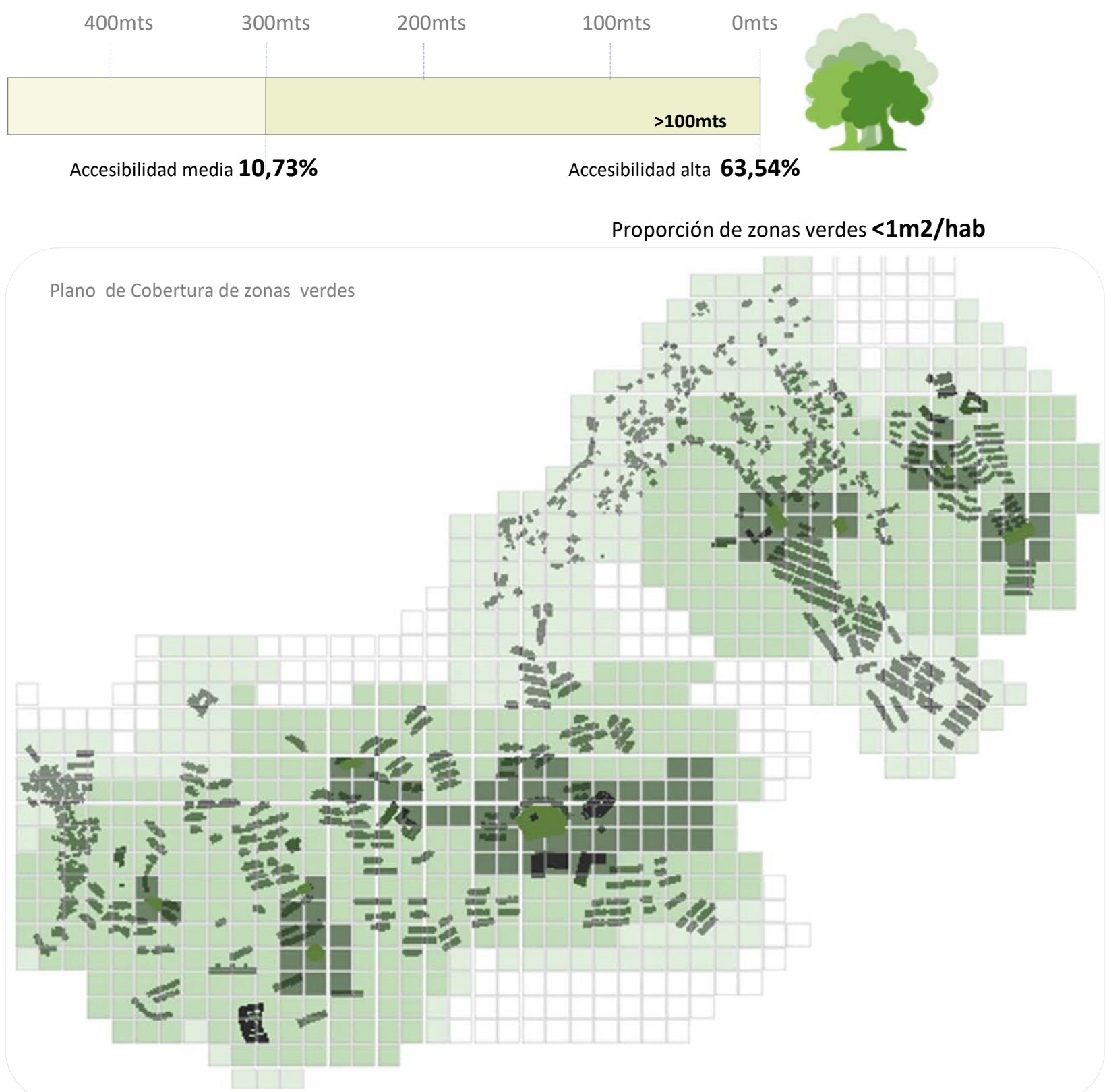

El espacio público del proyecto tiene como fundamento en su planeación insertarse en el medio natural como alternativa para proteger y conservar las cuencas hidrográficas, fomentar la reforestación e impulsar obras que garanticen la estabilidad de los diferentes procesos geológicos activos en la zona. Dicha inserción, sin embargo aun no se ha dado pues no han sido creados dichos espacios. Tan solo se cuenta con los espacios colectivos abiertos entre las diferentes edificaciones como se observa en las fotografías.
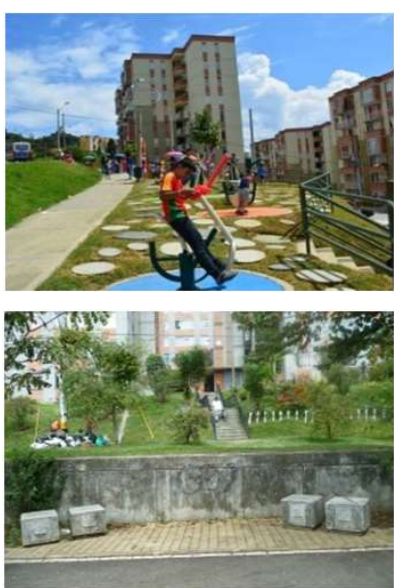
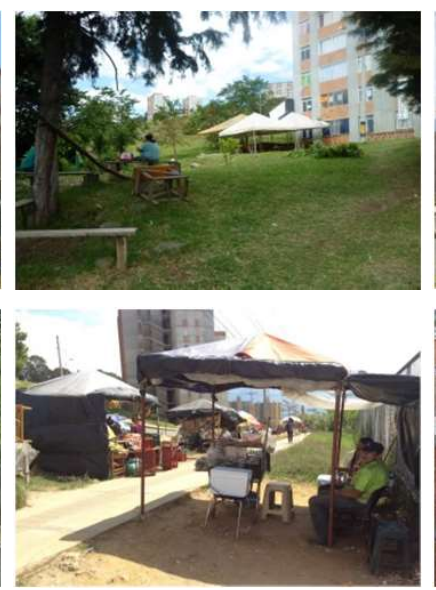
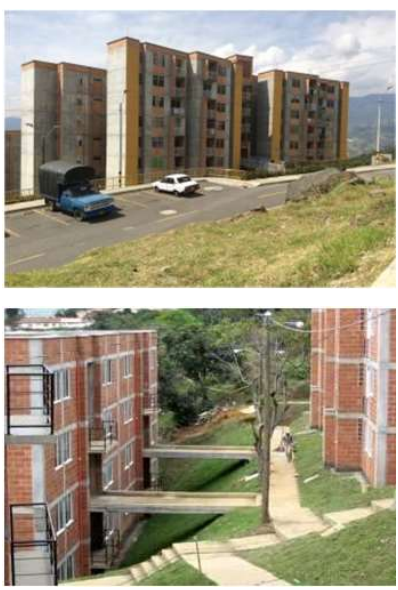

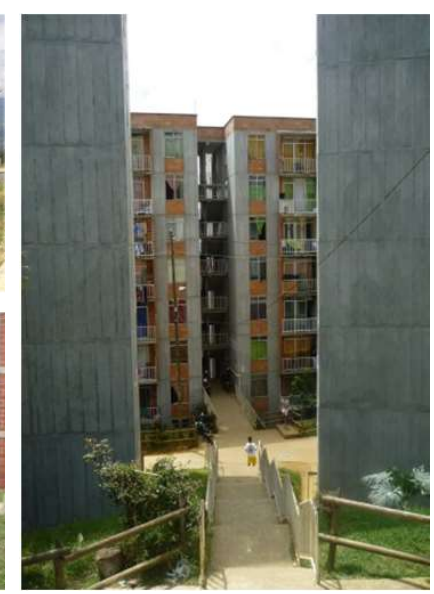




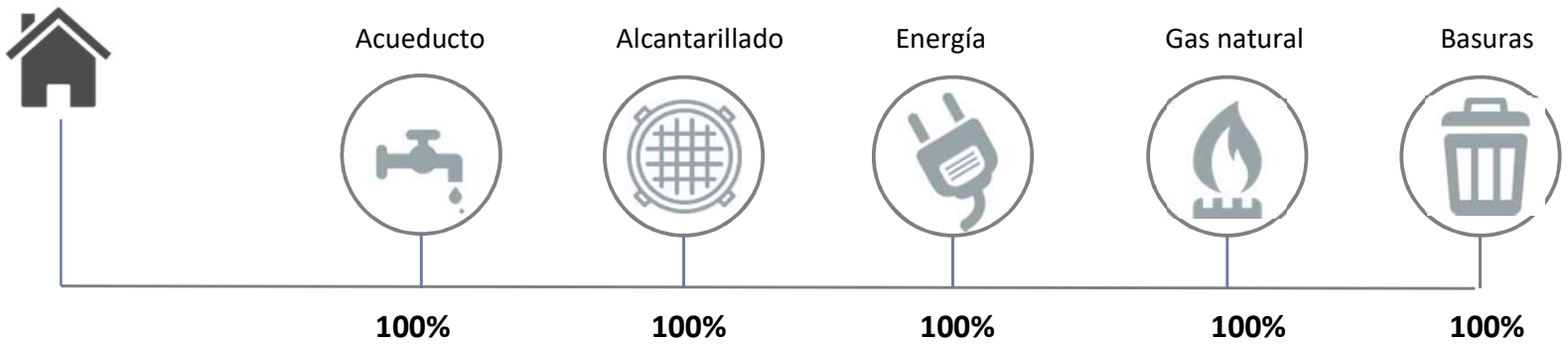

En la Ciudadela se propone un sistema completo de redes de servicios públicos domiciliarios que de una cobertura total a las nuevas edificaciones construidas. Sin embargo, no presta la misma infraestructura para los dos asentamientos informales existentes en la zona. Éstos no cuentan aun con alcantarillado, gas natural o recogida de basuras.

Con respecto a este último servicios, el de la recolección de basuras, cabe resaltar que dentro de las urbanizaciones si bien se presta el servicio, su frecuencia no es diaria y en muchas ocasiones se acumula basura en las calles a la espera de ser recogida.

I10 Condiciones geotécnicas. Riesgos Condiciones ambientales

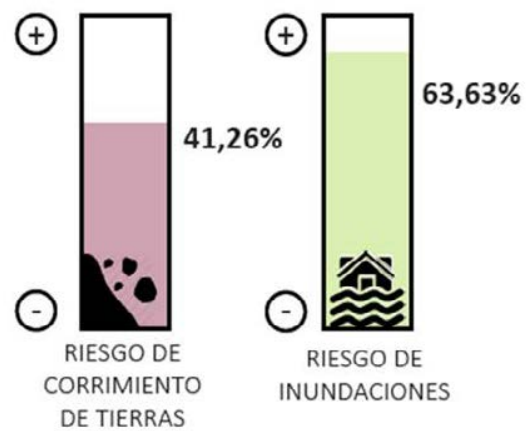

Prácticamente la mitad del territorio de la Ciudadela se encuentra con restricciones de tipo geomorfológicas, geológicas, geotécnicas e hidrológicas.

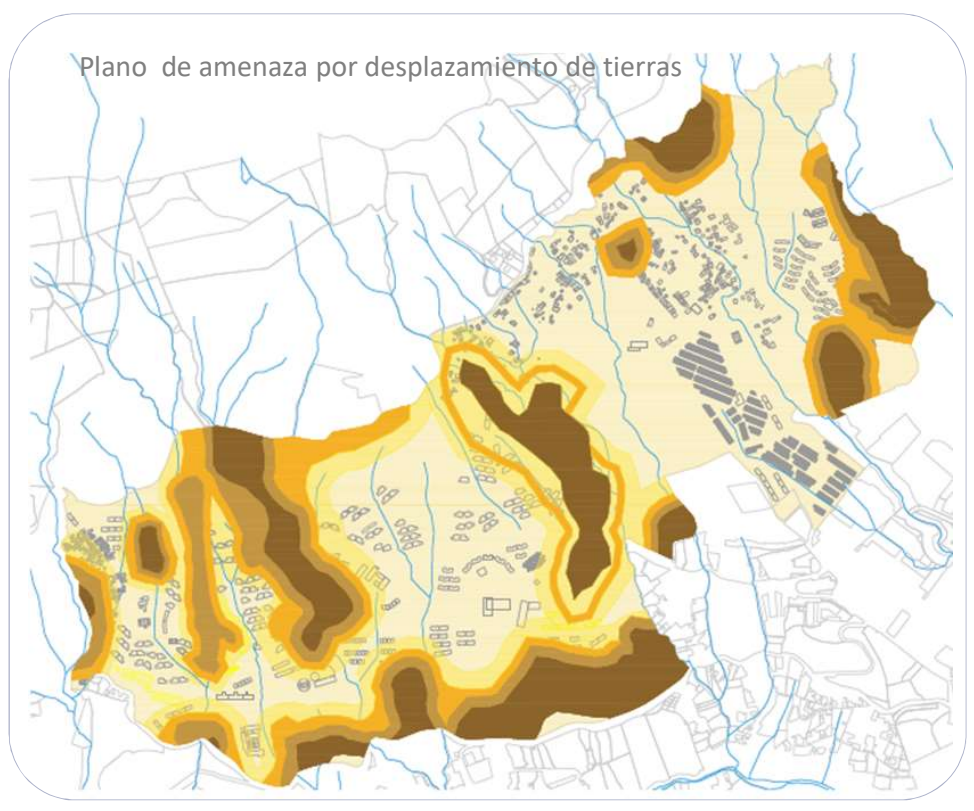

Unidades habitacionales construidas

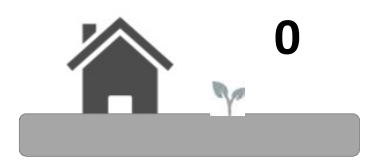

Viviendas unifamiliar

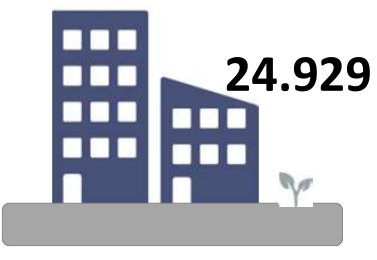

Viviendas multifamiliar
Ocupación de la manzana y tipología de la vivienda

La ocupación planteada en la Ciudadela se basa en un sistema de barras o edificaciones pareadas que busca el mayor provecho del suelo. Su composición es orgánica y depende, en todos los casos, de la topografía (quebradas y pendientes).

Todas las edificaciones son multifamiliares en altura de cinco a nueve plantas con acceso en la planta media del edificio y sin ascensor. En promedio, el índices de ocupación en vivienda es de 0.68 y de otros usos de 0.3 .

Hasta la fecha hay construidas poco mas de 25.000 unidades de vivienda y según censo de 2012, allí habitan 100.000personas (3,8personas por vivienda). Para el año 2020, se estima que habrá mas de 30.000 unidades (31.855) de vivienda y más de 120.000 habitantes.

Total $=\mathbf{2 4 , 9 2 9}$ viviendas

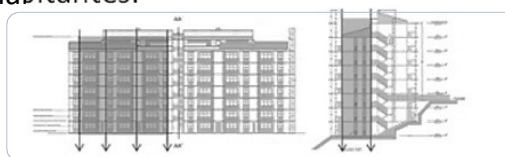




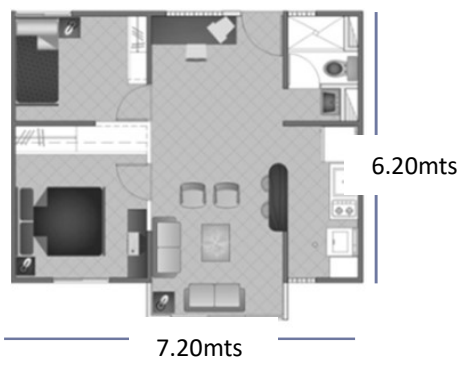

Tipología La Aurora 44,64m2

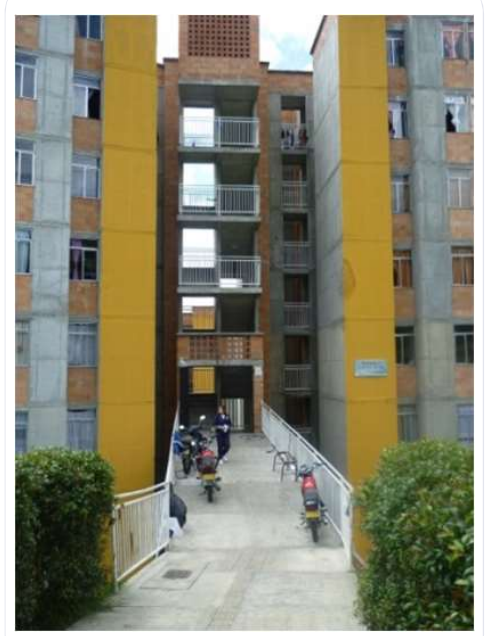

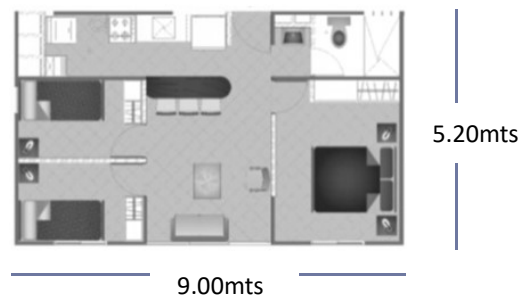

Tipología La Flores $46,80 \mathrm{~m} 2$
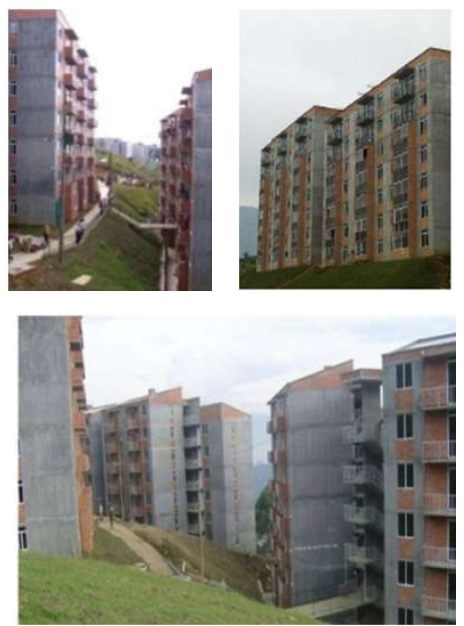

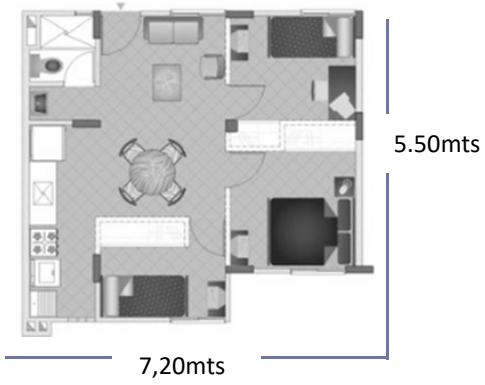

Tipología La Huerta $44,30 \mathrm{~m} 2$
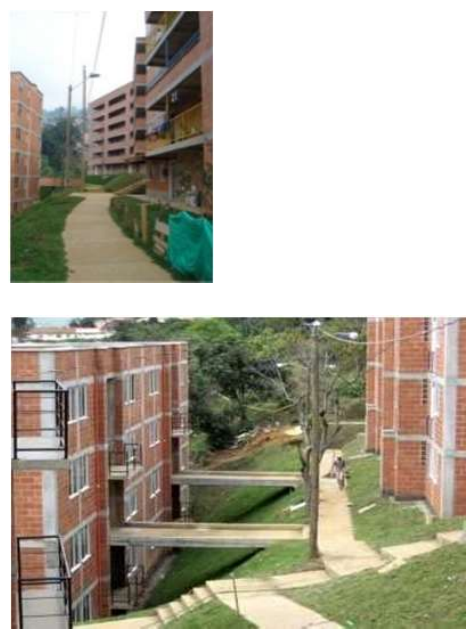

\section{Complejidad}

Uso Múltiple $\mathbf{5 , 6 \%}$ Uso Vivienda $\mathbf{9 4 , 4 0 \%}$

El Proyecto, en su Plan Parcial, propone como uno de sus objetivos base: Una sana mezcla de usos que permita disponer de actividades productivas comerciales $y$ de servicios, equipamientos comunitarios $y$ vivienda que requiere la población que allí va a habitar, sin embargo dicha mezcla no se da mas allá de las centralidades construidas. En todo el proyecto no se construye un centro de abastecimiento de alimentación o construcciones con uso comerciales. Es la población quien modifica sus viviendas para convertirla en peluquerías, carnicerías, ferreterias, etc...

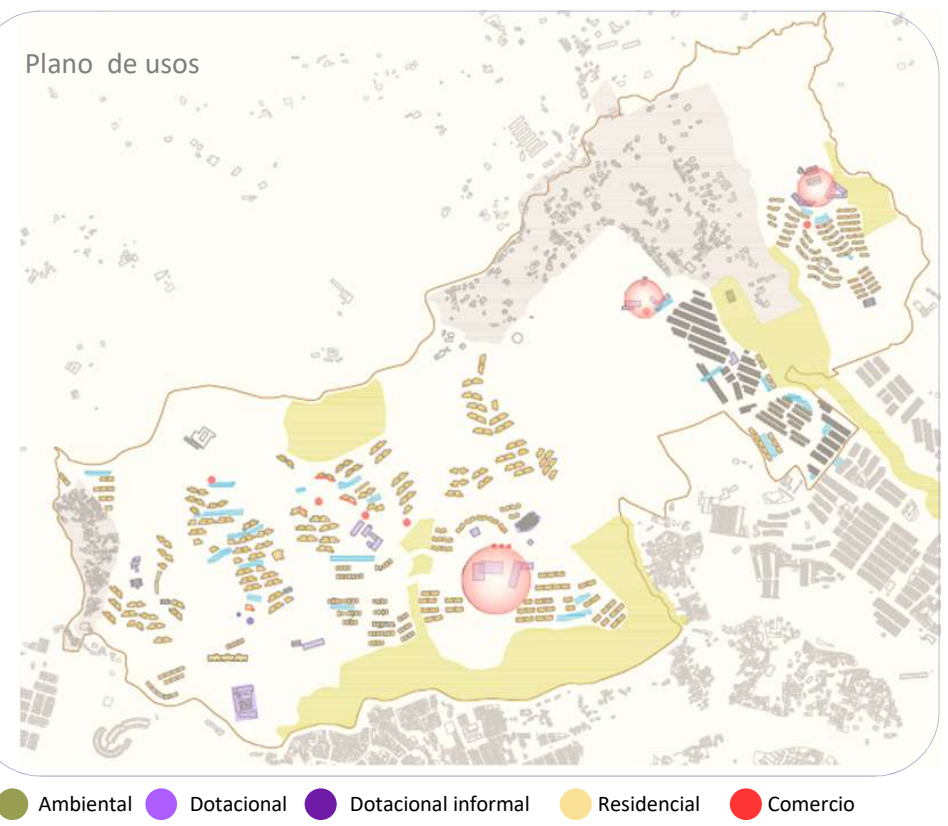



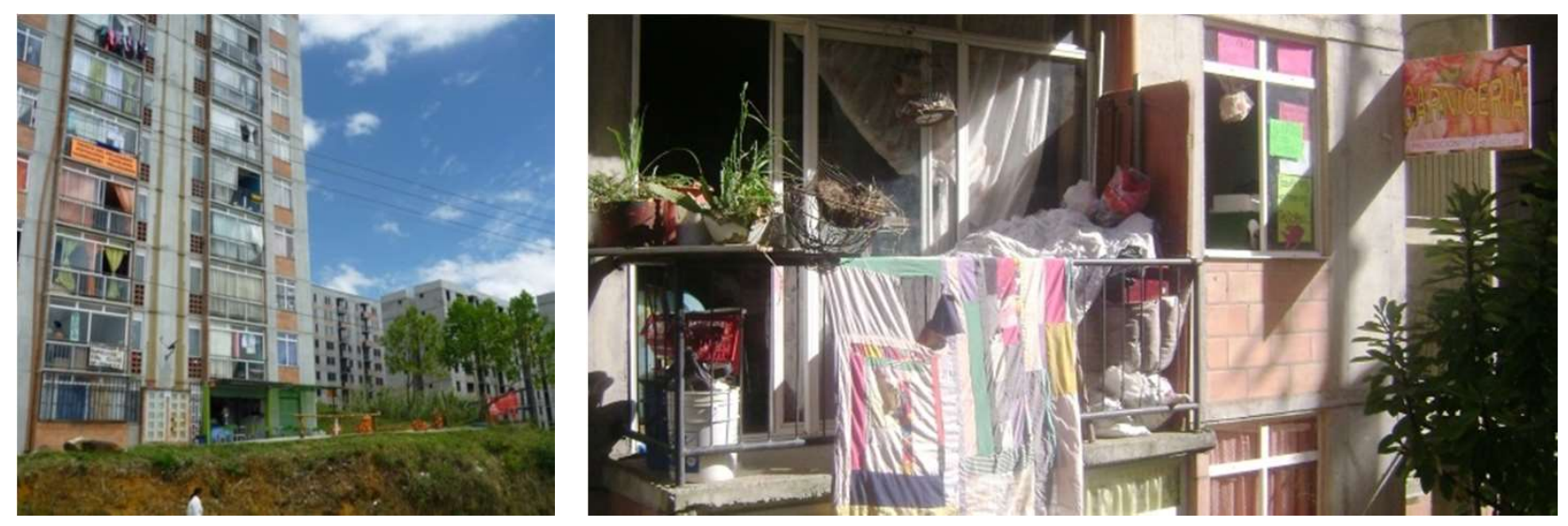

Los moradores de la Ciudadela son grupos familiares reasentados de toda la ciudad (a este proyecto llega gente especialmente de Moravia y Santo Domingo), población damnificada por calamidades naturales, desplazados por el conflicto armado y habitantes con capacidad de ahorro de estratos uno, dos y tres. Una mezcla de población con culturas, desarrollos históricos y condiciones económicas bastante diferentes entre sí que traen grandísimas dificultades a la hora de la convivencia.

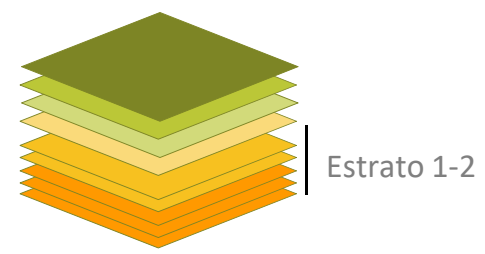

\section{Información de prensa}

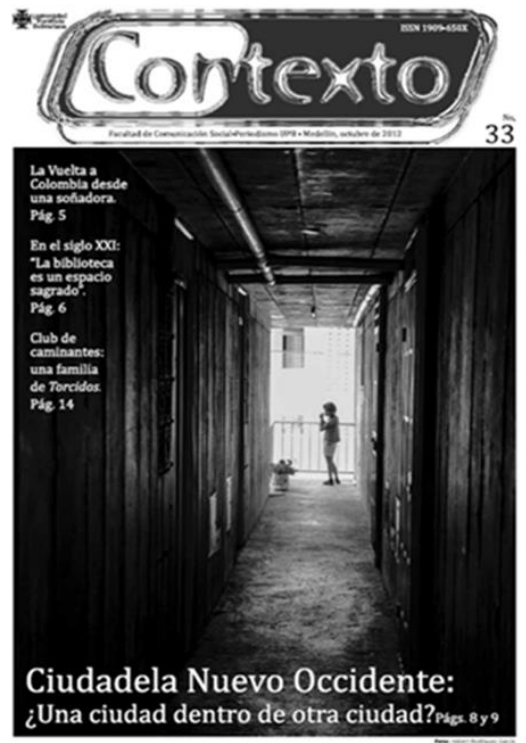

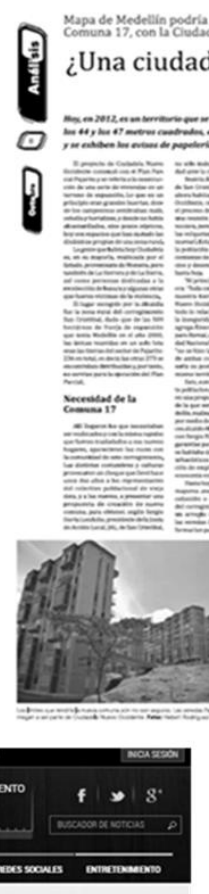

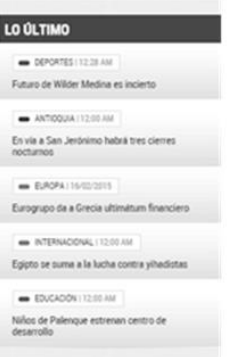

San Cristóbal y Ciudadela se sienten "sobrepoblados"

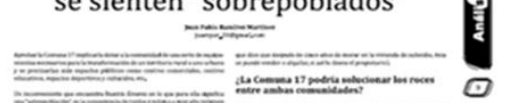$$
=
$$

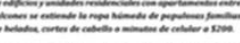
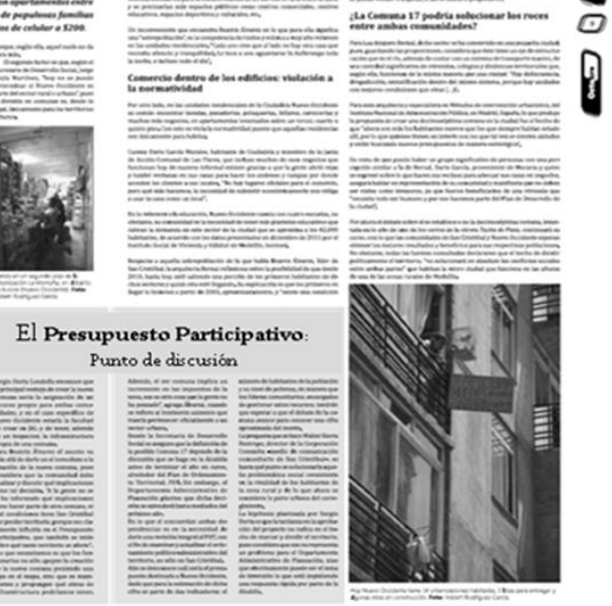
to de discusión
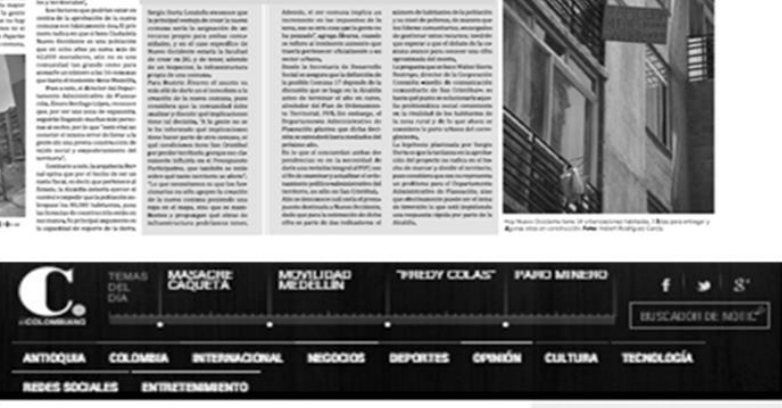

Histurico

Pajarito crece en gente, pero no en infraestructura

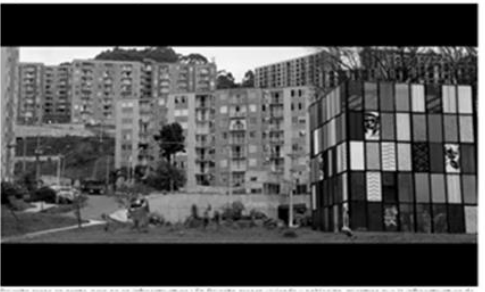

Temor a balas confina y desplaza en Las Flores

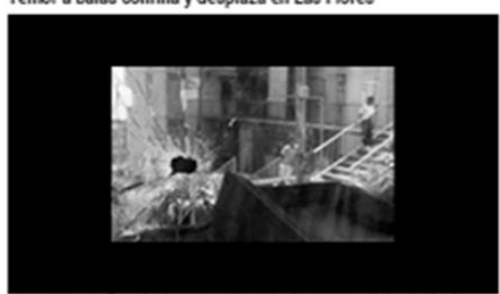

\section{wotra}

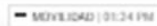

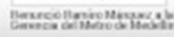

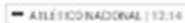

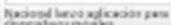

-

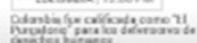

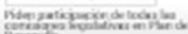

Noticias en prensa sobre la situación en la Ciudadela. Fuente. Revista Contexto 2012 y Periódico El Colombiano 


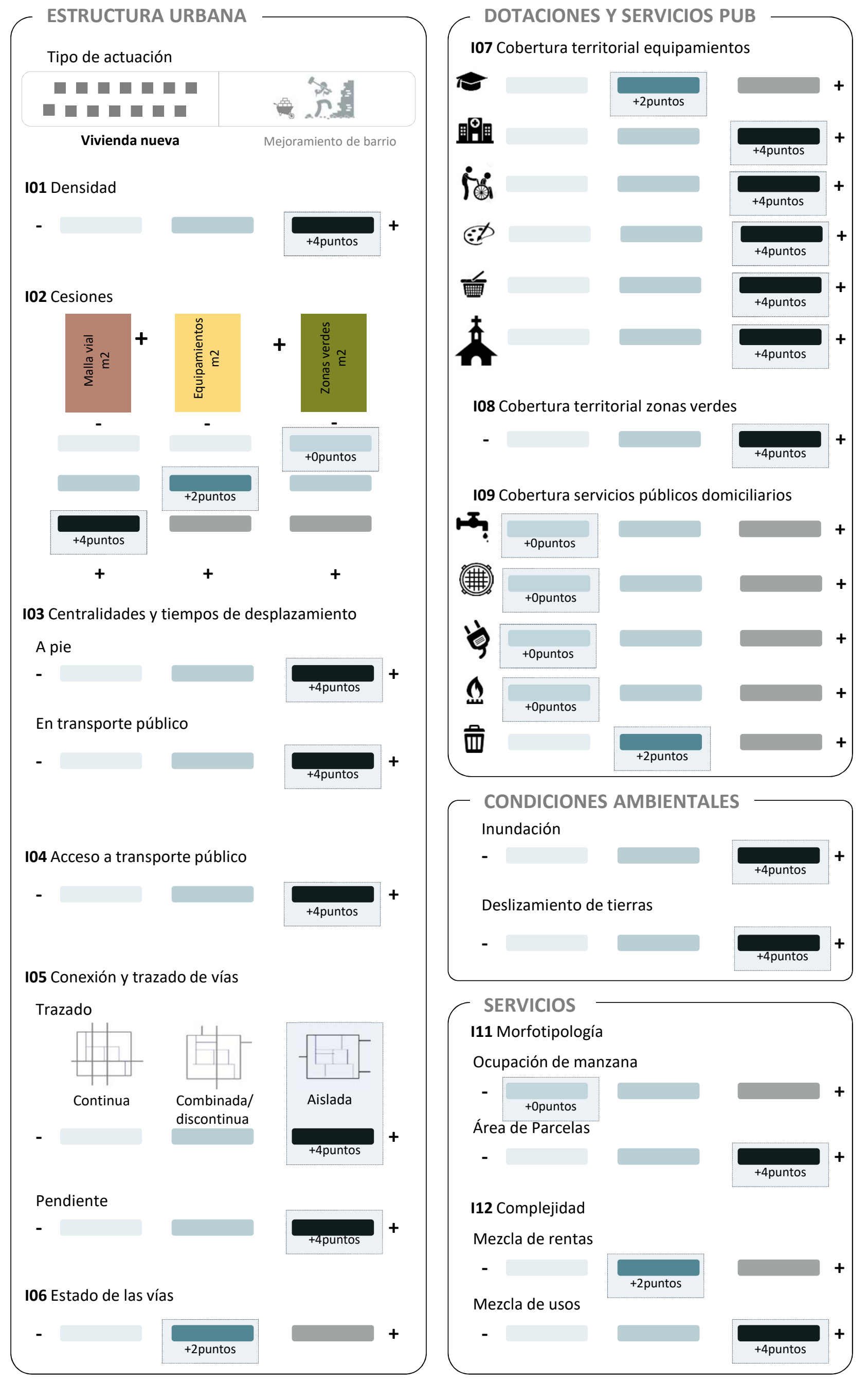




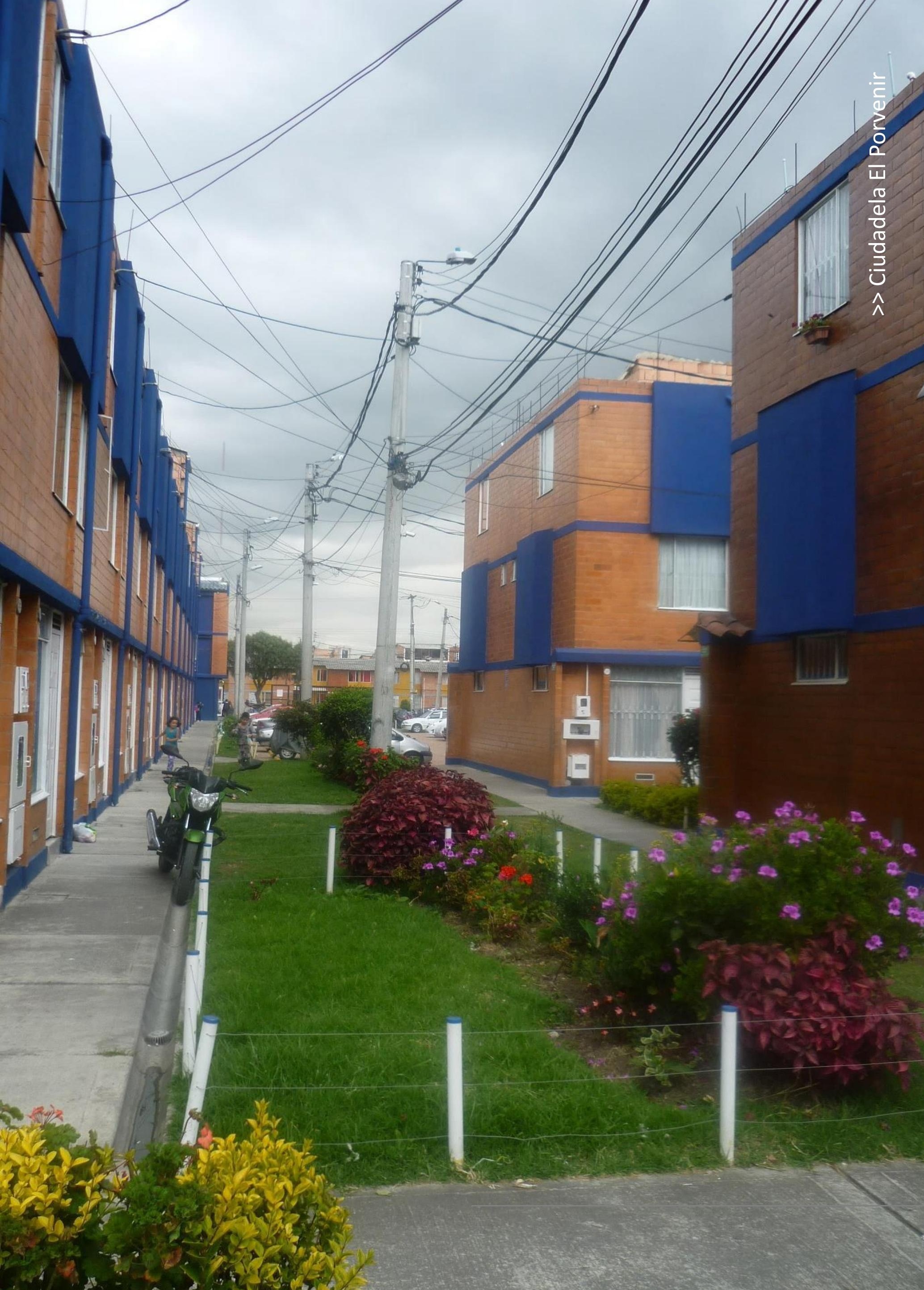




\section{CIUDADELA El Porvenir - Bogotá}

Ciudadela El Porvenir está ubicada en la localidad de Bosa, a las orillas del Rio Bogotá. Su extensión bruta es de 131,95 hectáreas, de las cuales la mitad corresponden a suelo útil $(67,84$ hectáreas). Su ocupación está dada en su mayoría por uso residencial, $45 \%$ para viviendas unifamiliares y $46 \%$ para viviendas multifamiliares, y por un uso, en el $9 \%$ restante, dotacional y comercial. Como proyecto es un complejo urbanístico de grandes dimensiones planeado para más de 85.000 moradores (en más de 21.000 unidades de vivienda) con una dotación completa en servicios públicos domiciliarios, malla vial vehicular y peatonal y una red de carriles bici (que cuando sea construida en su totalidad comunicará la ciudadela con la Biblioteca Tintal). Cuenta además con zonas verdes compuestas por un parque lineal, la Alameda el Porvenir que atraviesa el proyecto de norte a sur, y cuatro parques de una manzana completa cada una, repartidos por toda la ciudadela. En un futuro el proyecto colindará en su costado norte con el Parque Metropolitano El Porvenir que tendrá una extensión superior a 80 hectáreas. Igualmente en un futuro, la ciudadela se supone deberá contar con una instituciones de educación universitaria y un centro de salud que beneficiarán a sus habitantes y a los de las zonas circundantes. Actualmente cuenta con dos centros educativos, un centro cultural, dos centros comerciales y un jardín infantil (equipamientos insuficientes como se verá en el análisis a continuación para todos los moradores allí habitando).

La ciudadela inicio cómo proyecto en el año 1999, se formuló bajo decreto en el año 2002 (Plan Parcial El Porvenir- Decreto 395 de 2002) y hasta la fecha se encuentra aún en ejecución (2019). Su gestión, habilitación y construcción ha sido realizada por etapas en cada uno de sus procesos. Sobre la adquisición del suelo, por ejemplo, ésta inició en diciembre de 1999 y se extendió hasta mediados del año 2010 dada la alta complejidad en la compra de tierras en los barrios de origen informal (la administración utilizó la enajenación voluntaria (83\%) o la expropiación por vía judicial (17\%) para conformar el suelo necesario para la construcción de la Ciudadela). Similar situación se encontró en la habilitación y comercialización del suelo. La primera habilitación inició en el año 2004 y aún no ha sido completada. Hasta el año 2011, se habían urbanizado 102,14ha brutas (el 77\% del total del área bruta), estaban en proceso de urbanización 14,11ha (11\% del área bruta) y faltaba la urbanización de 15,70ha (15\% del área bruta). De ese porcentaje sin habilitar, MetroVivienda vio la posibilidad de vender una parte (3,46 ha) directamente a los constructores para que fueran ellos quienes desarrollaran todas las obras de urbanismo y habilitaran las manzanas para urbanizar.

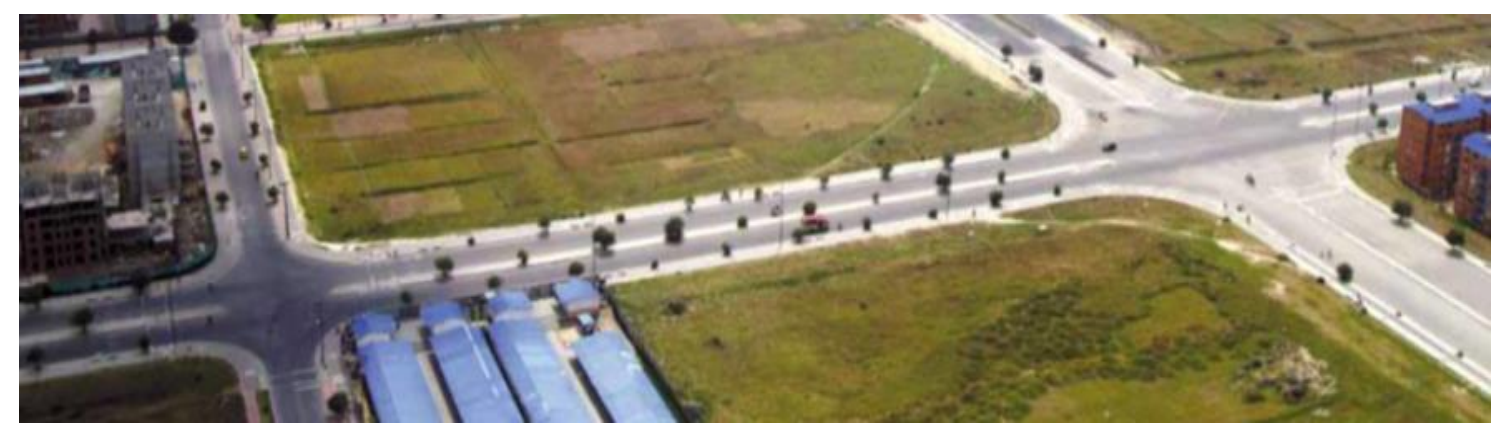


Ciudadela El Porvenir se ubica en la localidad de Bosa, en el borde sur-occidental de la ciudad, sobre el margen del Río Bogotá. Su suelo, predominantemente clasificado como de expansión urbana, limita con importantes avenidas como la avenida Longitudinal de Occidente, la avenida El Tintal, la calle 48 sur o la calle 55A sur, posibilitando así un gran potencial de desarrollo urbanístico ( si este algún día llega a desarrollarse). Su contexto es principalmente residencial, de origen marginal, con problemas de infraestructura, movilidad y déficit de espacio público y equipamientos urbanos.
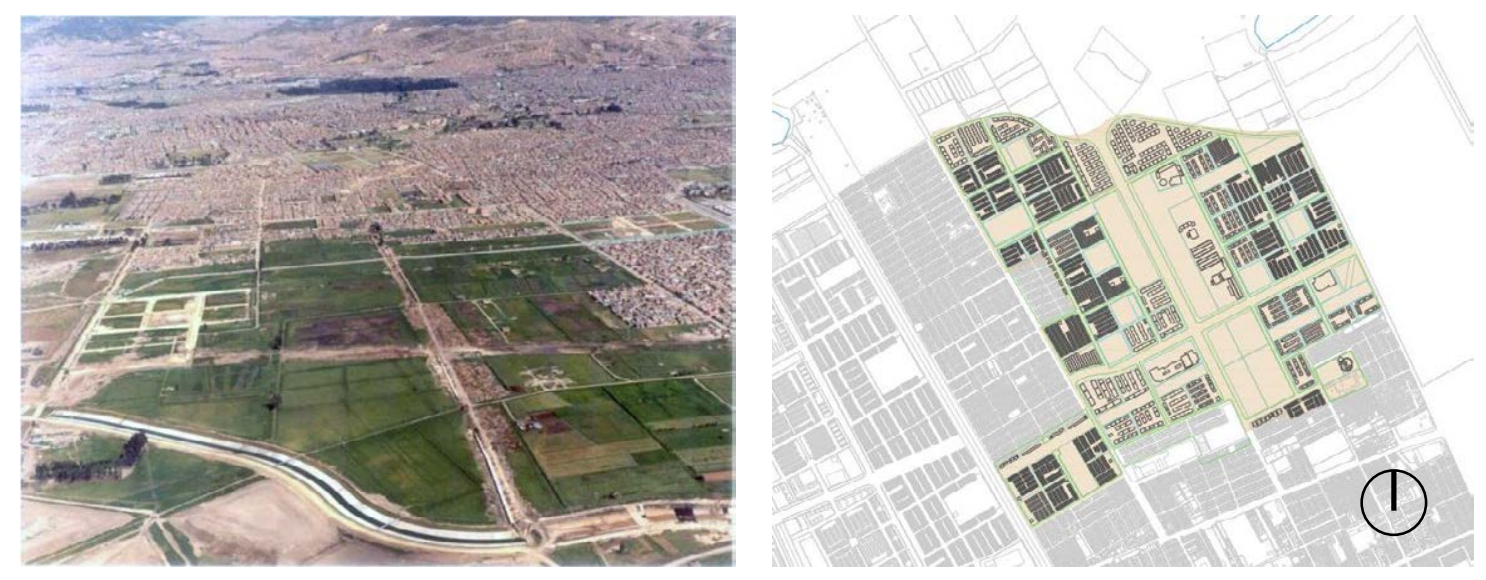

\section{Estructura urbana}

La estructura y morfología del proyecto están determinadas por el sistema vial y el canal del rio Bogotá que circunscriben la zona. Bajo una retícula ortogonal rigurosa siguiendo la geometría de las vías, el proyecto articula los dos ejes viales principales: la Av. Primero de Mayo y la Av. Santafé, con la unidad básica de composición morfológica: la manzana, de una hectárea útil aproximadamente rodeada de vías vehiculares y fragmentada por dos vías peatonales.

Las manzanas desarrolladas a lo largo de las dos vías principales son concedidas para los equipamientos principales, tales como los educativos, culturales, recreativos (eje cívico cultural) y comerciales (eje cívico comercial). Las manzanas subsiguientes son utilizadas para la vivienda. Dicha organización está concebida, supuestamente, de ésta forma para cualificar lo público y permitir así una relación directa con la ciudad. (Una condición presentada en dicha configuración, una vez edificada las unidades habitacionales, se dio en la transformación para usos comerciales o dotacionales en las viviendas que estaban ubicadas relativamente distantes a esos dos ejes principales.)
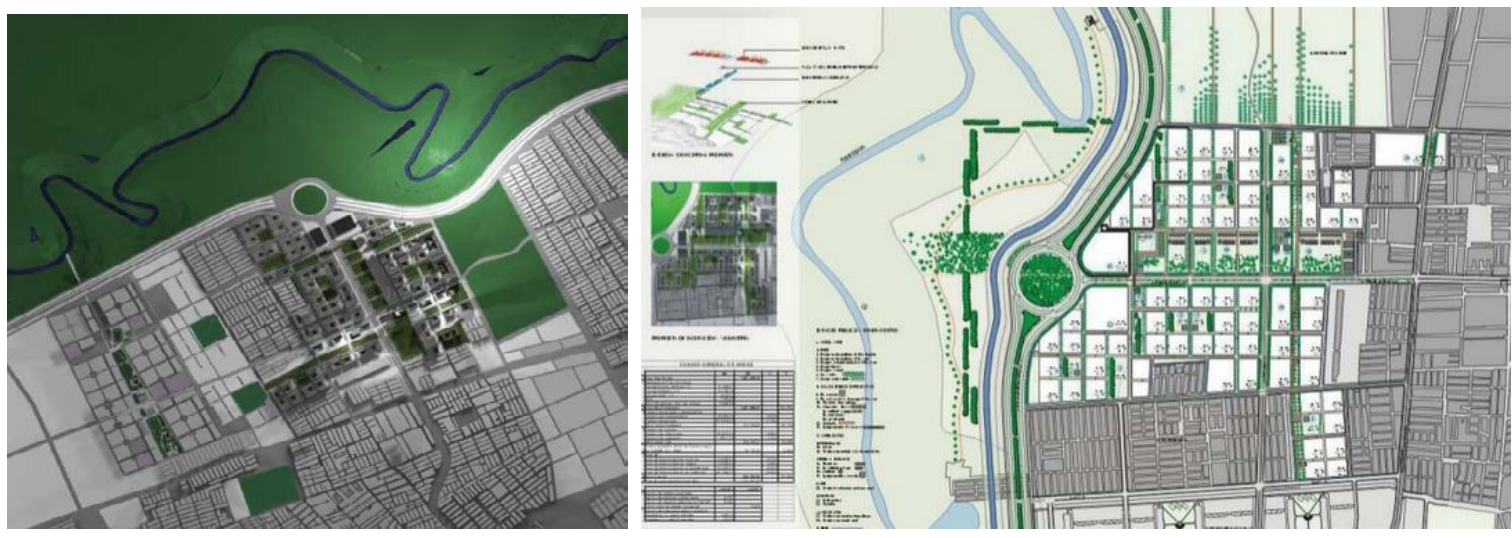


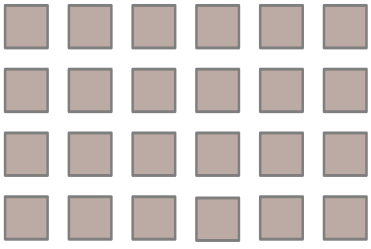

120 viv/ha unifamiliar

236,76 viv/ha multifamiliar

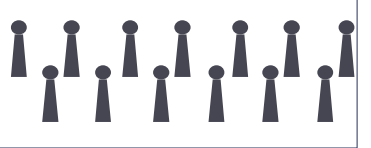

407 hab/ha unifamiliar

872 hab/ha multifamiliar

\section{Plano llenos y vacíos}

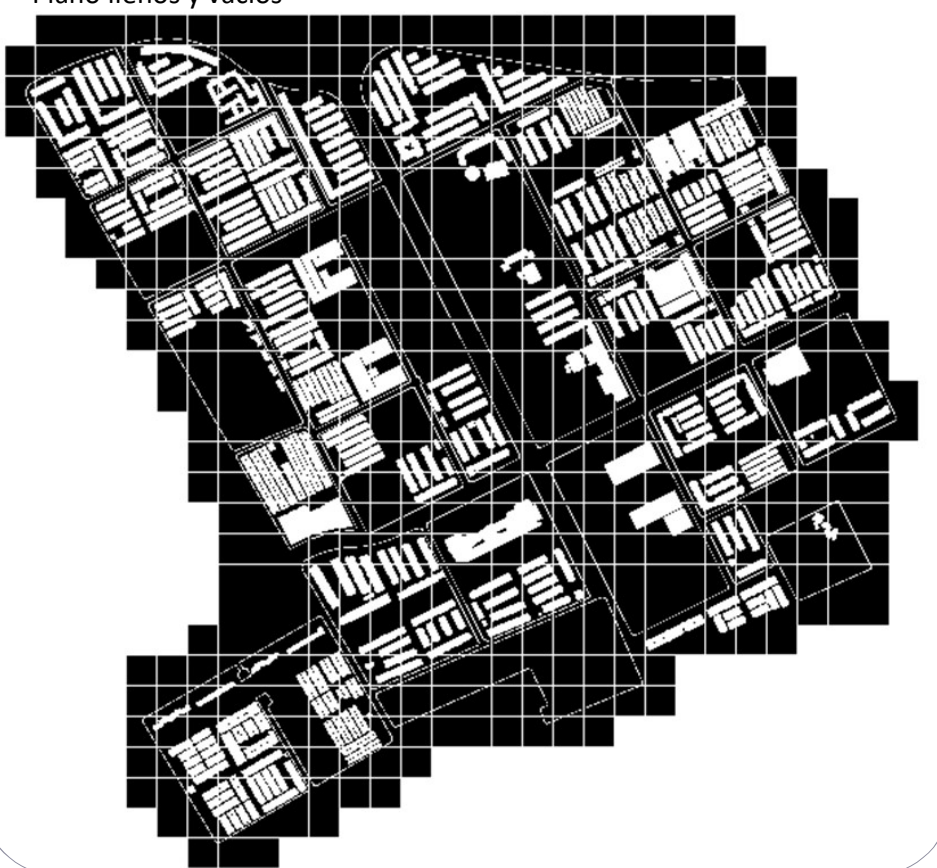

102 Cesiones

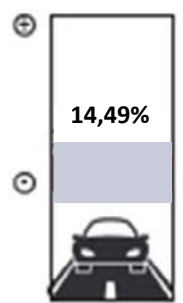

Malla vial

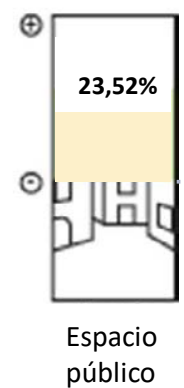
público

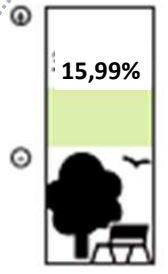

Zonas verdes

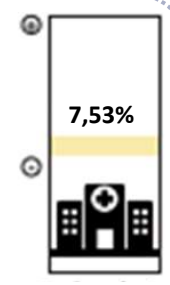

Equipamientos
Las cesiones públicas en Ciudadela El Porvenir se localizan, por lo general, en zonas céntricas del proyecto fácilmente accesibles por todas las unidades de vivienda.

Las cesiones privadas, en cambio, se ubican de forma mixta. Las zonas verdes y espacios libres se sitúan en los centros de manzana mientras que los equipamientos se hallan en la periferia.

En los dos casos, las áreas destinadas a estos espacios llegan justo a lo determinado por la normativa. No cuentan con un solo metro de más.

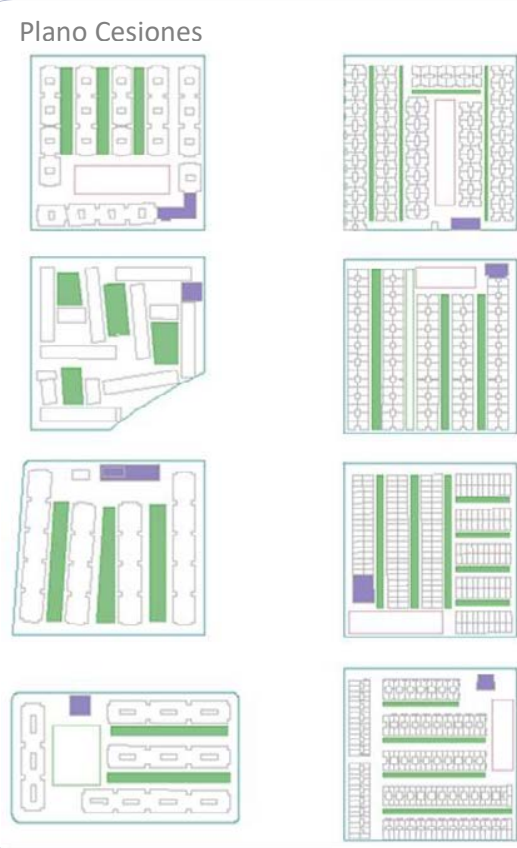

Áreas

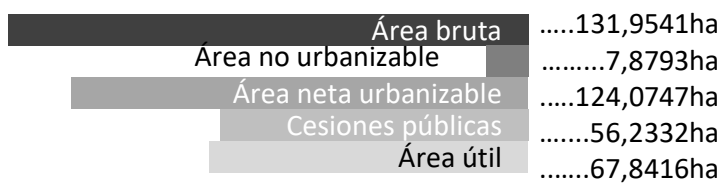

Cesiones públicas

\begin{tabular}{cc}
\hline Cesiones públicas & ...... 56,2332ha \\
\hline Malla vial & ......19,7526ha \\
Equipamientos & .......9,9442ha \\
Zonas verdes & ..... 21.1085ha
\end{tabular}




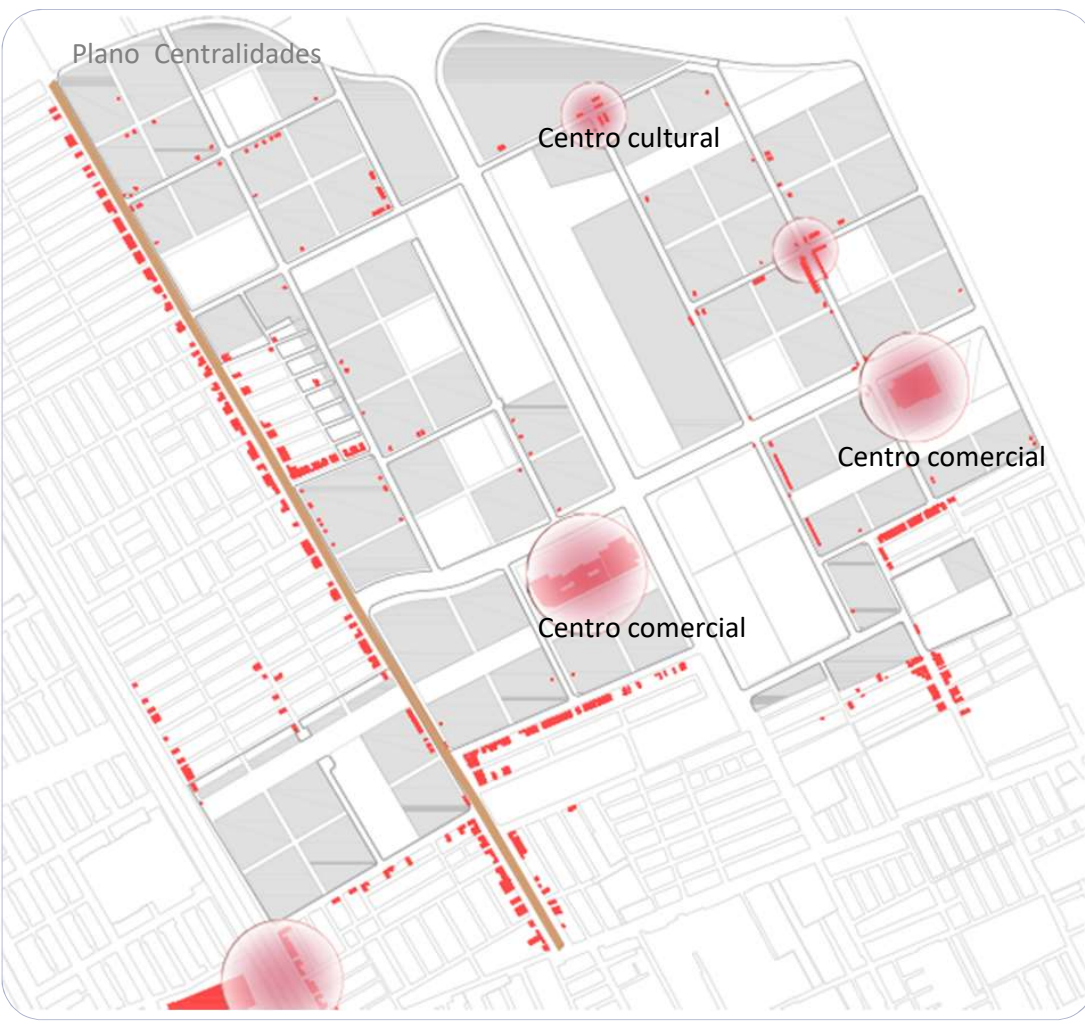

En la Ciudadela existen dos tipos de centralidades a escala de barrio, aquellas establecidas desde el proyecto: dos grandes centros comerciales y un centro cultural; y aquellas que la población ha ido creado con la modificación de sus viviendas para suplir sus necesidades básicas, con comercio diario o pequeños equipamientos como guarderías o academias deportivas. La accesibilidad de estos dos tipos de centralidades no superan los $25 \mathrm{~min}$ a pie.

La centralidad a nivel de localidad, aquella establecida por el POT, se encuentra fuera del proyecto a un a distancia considerablemente alta: $1 \mathrm{~h}: 12 \mathrm{~min}$ a pie o $37 \mathrm{~min}$ en transporte público.

\section{Tiempos de desplazamiento a la centralidad más cercana}

Escala Ciudad: Corabastos

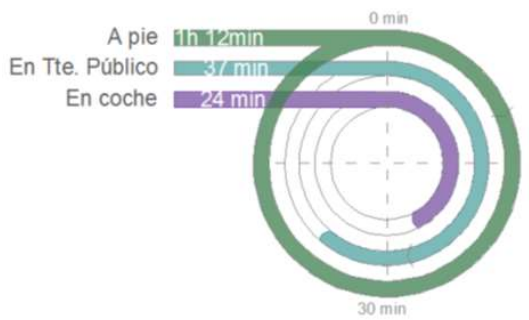

Escala Zonal: Centro Comercial

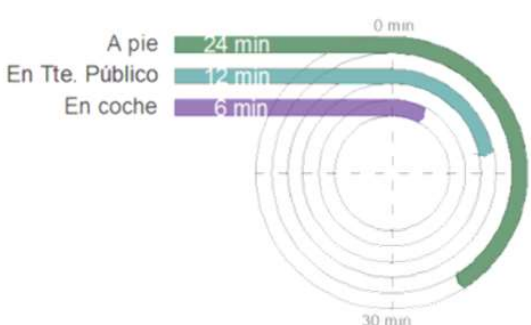

Escala Local: Desarrollo comunitario

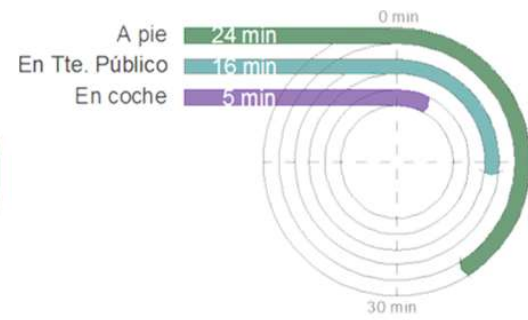

En el caso de la El Porvenir, aun cuando la accesibilidad desde la vivienda mas lejana a las centralidades de escala zonales y locales es de rango bajo por superar los 20 minutas a pie, éstas se encuentran ubicadas dentro del proyecto mismo, lo que dota al espacio de una mezcla de usos y de una permeabilidad adecuada. Como se observa en las fotografías, la mayoría del comercio de productos diarios ha sido creado por la población habitante.
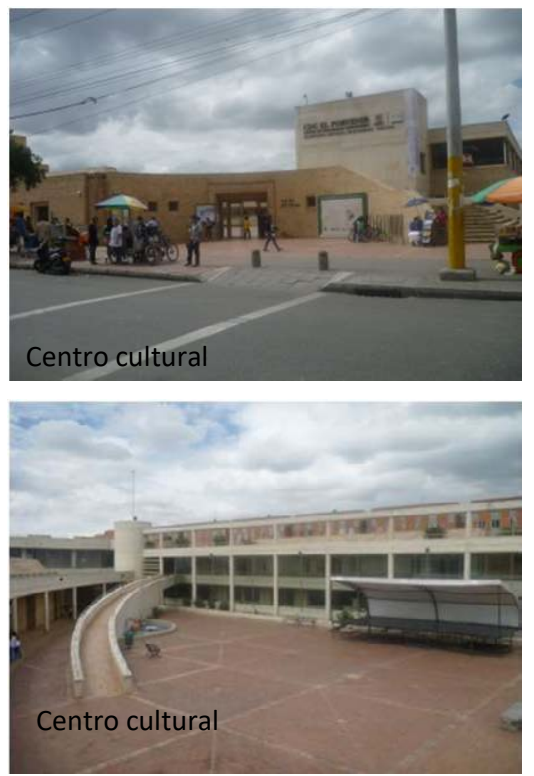
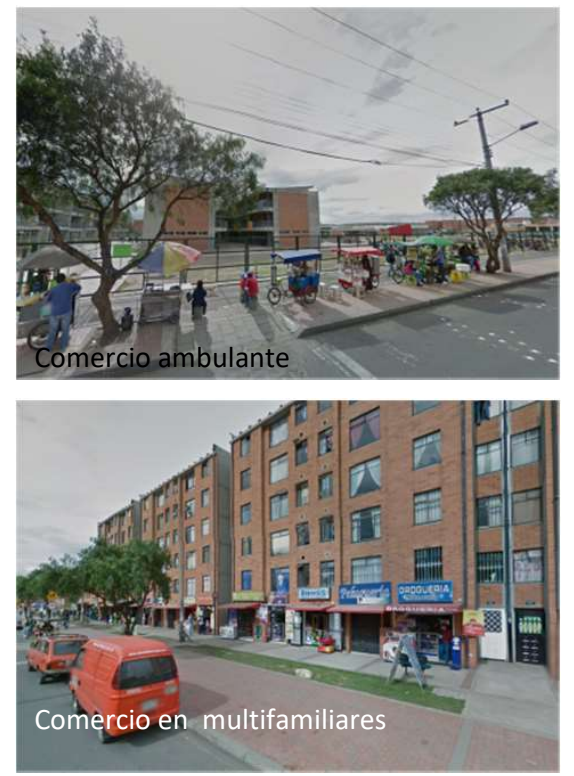
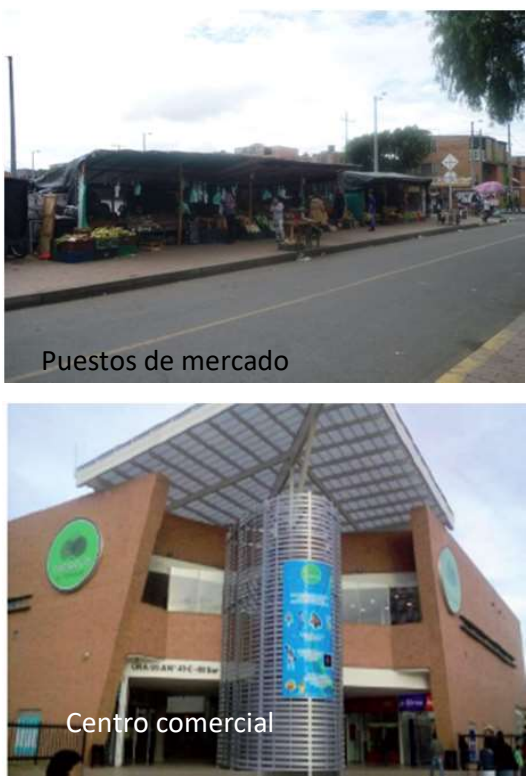


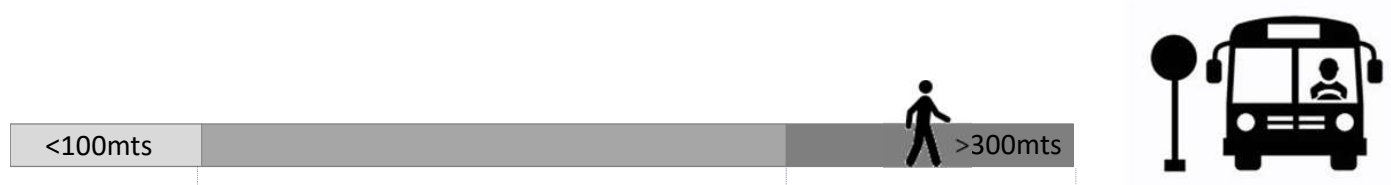

$18,03 \%$

\section{$55,07 \% \quad 26,90 \%$}

El acceso al transporte público en este proyecto es relativamente bueno. La infraestructura de paraderos a un máximo de 300mts de la vivienda más lejana supera el $70 \%$ y la cobertura de líneas de transporte público abarca prácticamente todo el territorio. El problema allí detectado es que el servicio es prestado por medio de alimentadores de Transmilenio, lo que requiere un tiempo de transbordo significativo hasta llegar al sistema nodal mismo.

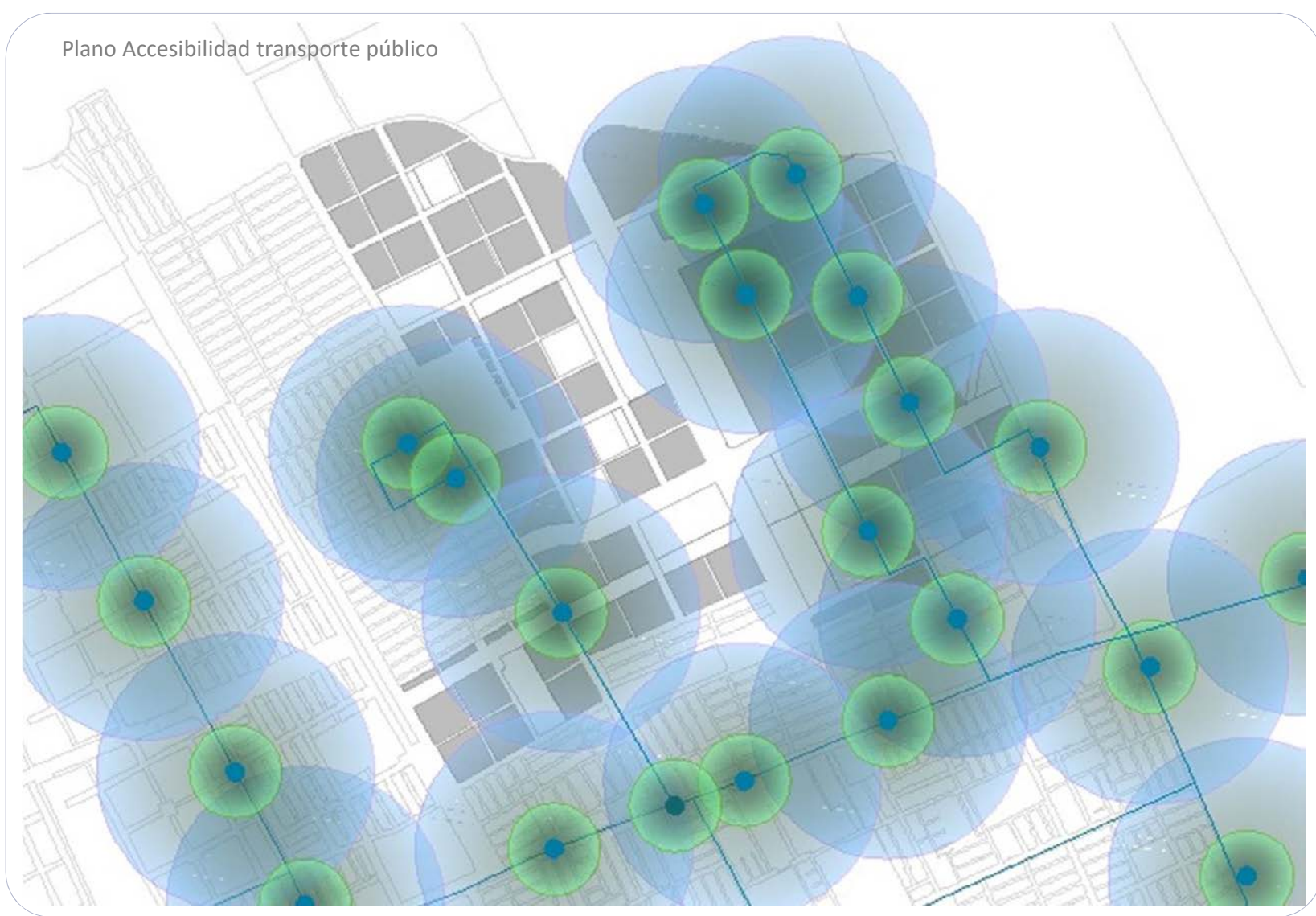

Pendiente

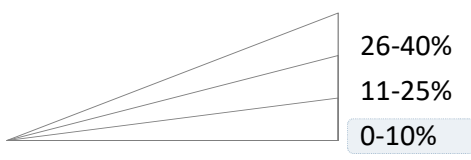

Acceso a escala de ciudad<smiles>CC(C)C(C)O</smiles>

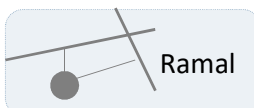

Tangencial

Central
Conexión a escala de barrio
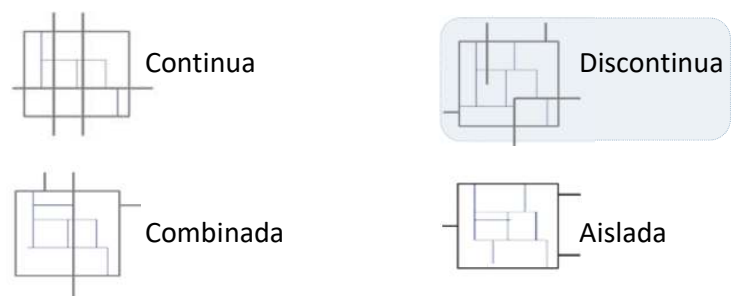


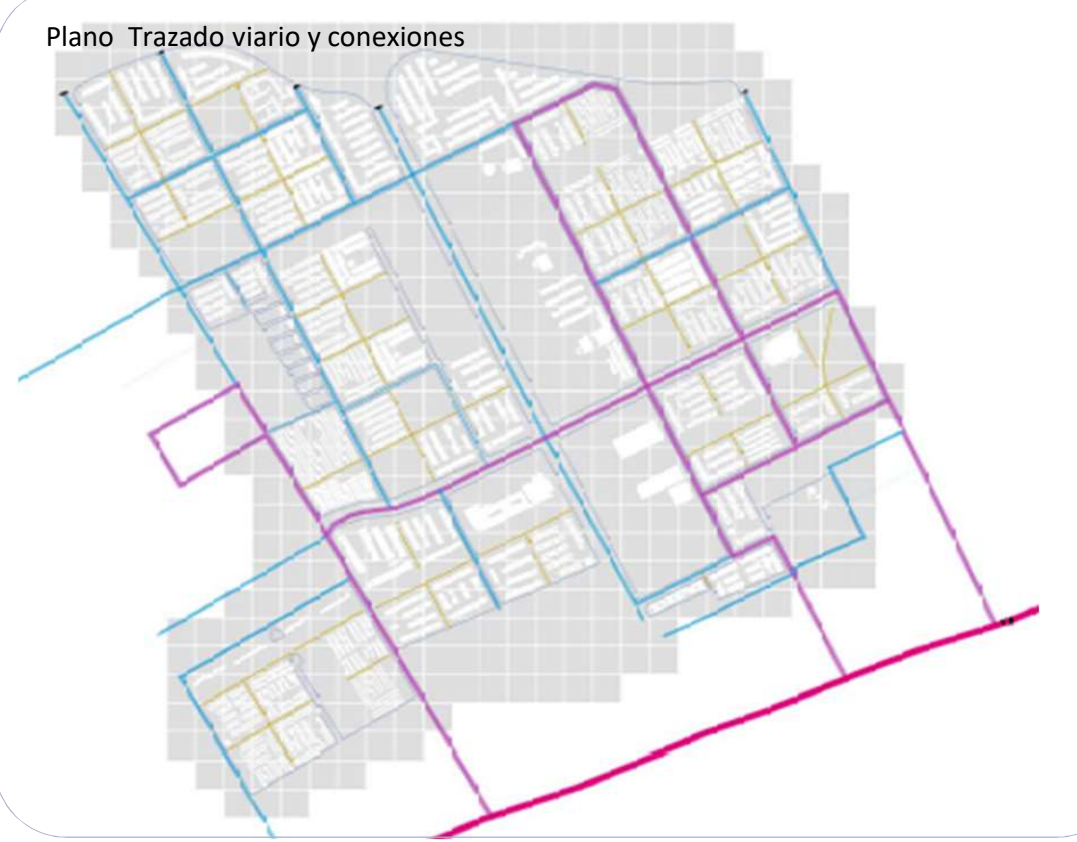

El sistema vial del proyecto esta determinado por la composición morfológica de manzana rectangular que articula el tejido urbano por medio de vías vehiculares y vías peatonales.

Un eje vial principal atraviesa la Ciudadela, calle 54sur. Sus dimensiones son quizás, sobredimensionadas ( 3 carriles en cada sentido) y su conexión con la ciudad existente o su pieza como remate de la ciudad es inexistente.
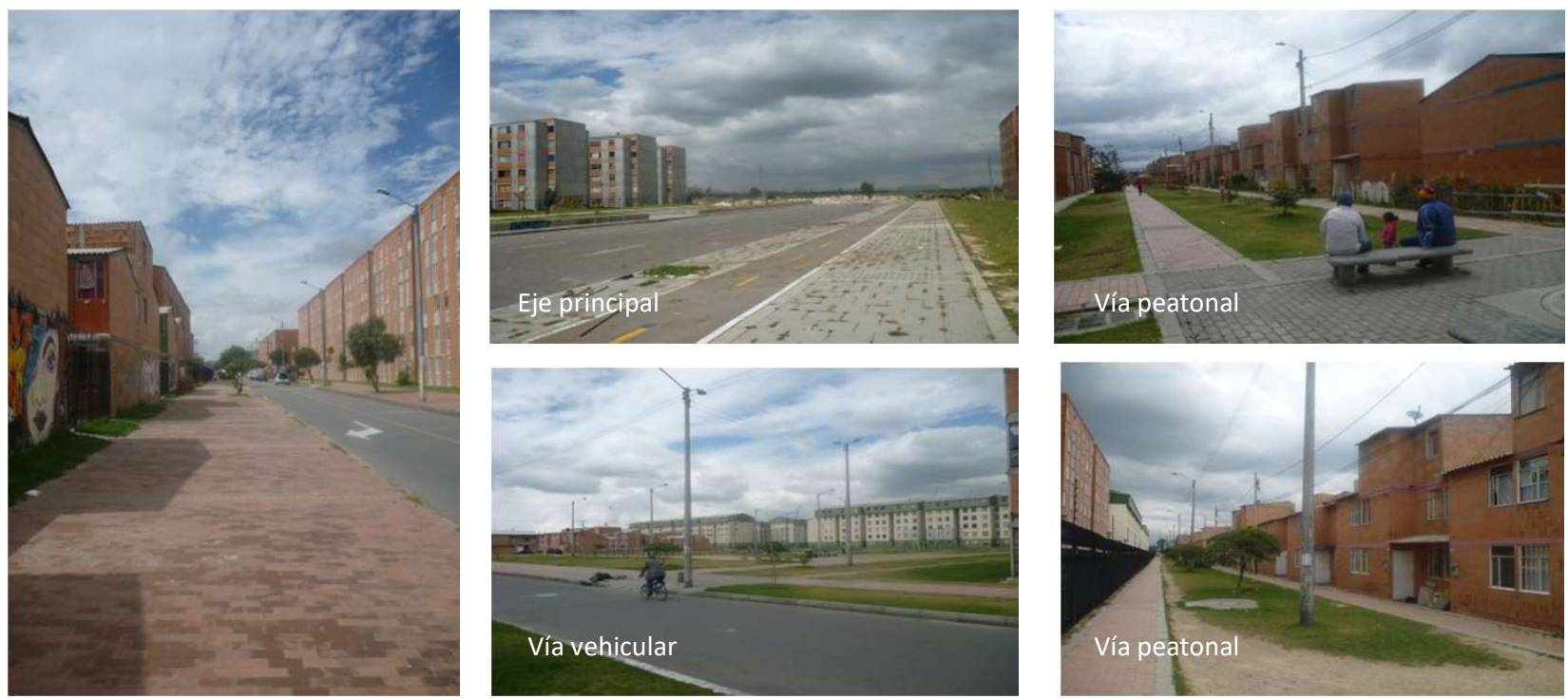

\section{Estado de las vías}

\section{VÍA VEHICULAR}

Pavimentada

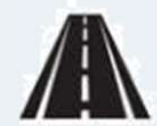

No Pavimentada

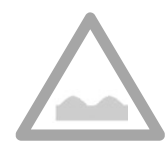

\section{VÍA PEATONAL}

Pavimentada

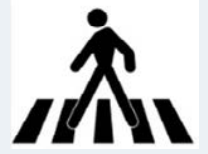

No Pavimentada

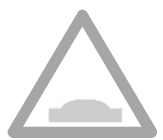

La Ciudadela cuenta con un sistema de movilidad muy deficiente en su conexión con la ciudad y con los barrios aledaños. Si bien el proyecto mismo cuenta una jerarquía de vías desarrolladas en su interior en buenas condiciones, pavimentadas, con iluminación y señalización, éstas terminan abruptamente al llegar al perímetro del proyecto y no continúan con las vías existentes. El barrio marginal de su perímetro no cuenta con las calles o andenes perimetrales y esto se observa tan solo con cruzar la calle.
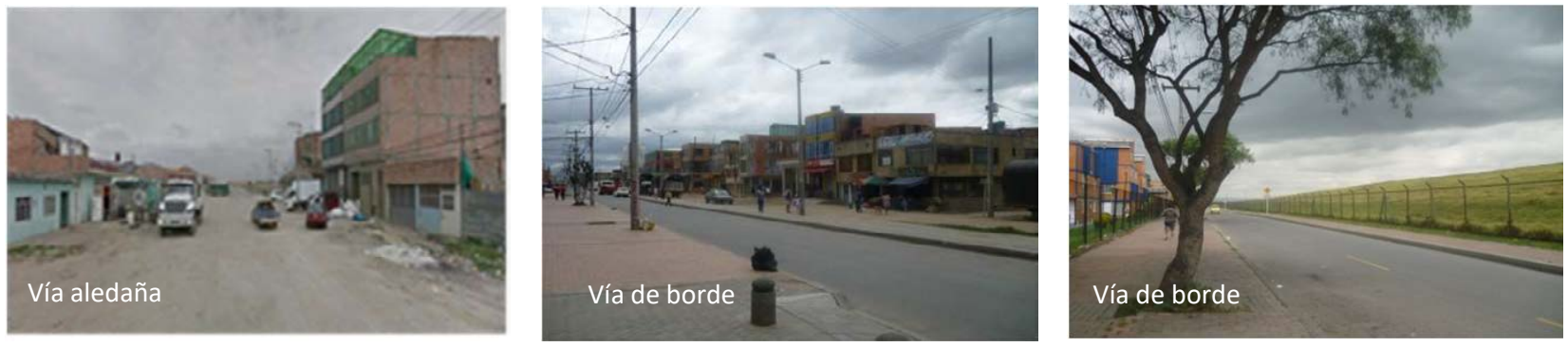


\section{EQUIPAMIENTOS ESCALA BLOQUE-VECINDARIO}
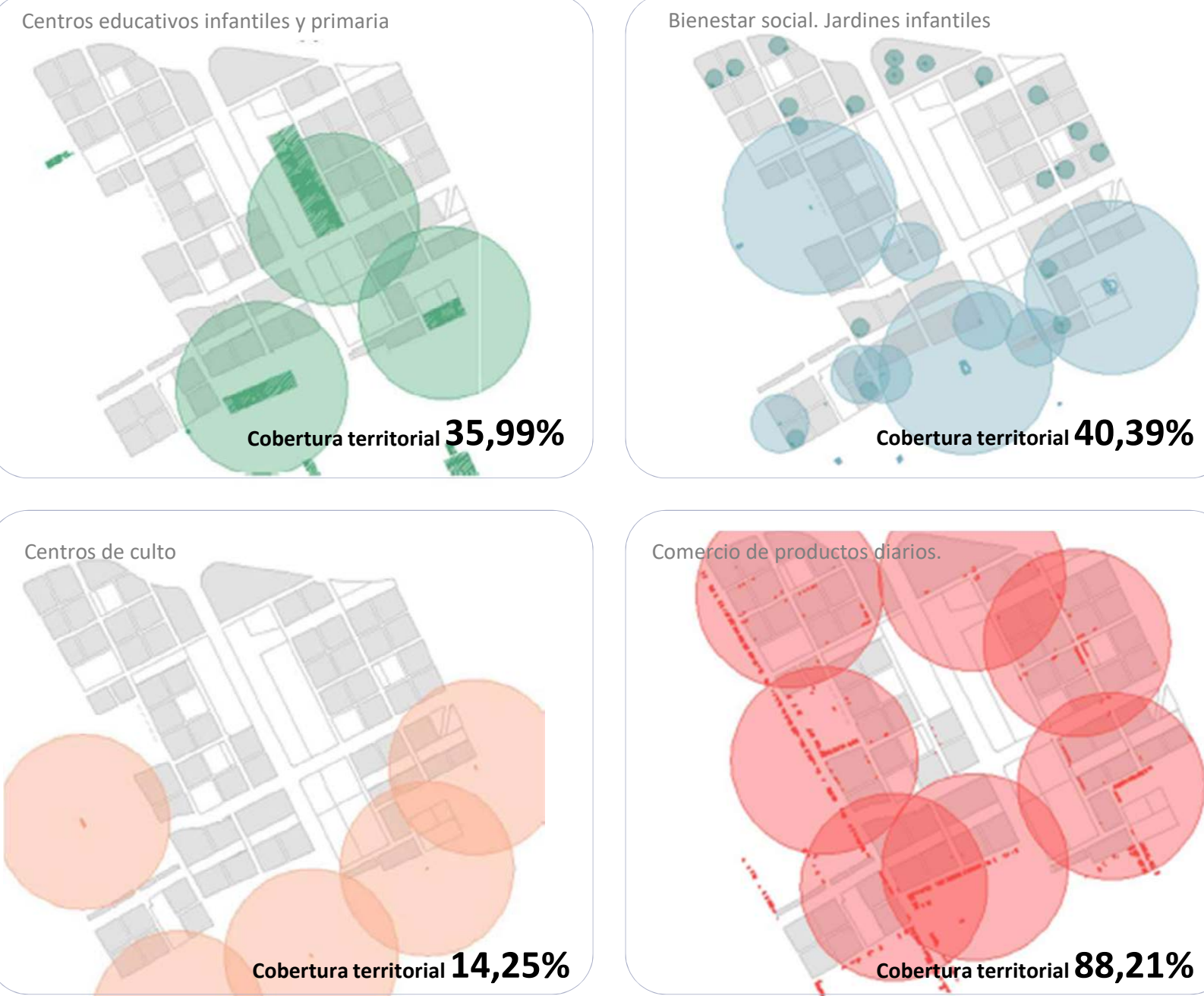

La mayoría de equipamientos existentes en El Porvenir son los destinados a educación secundaria, bienestar social: salones comunales y guarderías. Su área de influencia es relativamente correcta pero su cobertura muy insuficiente (menos de $2 \mathrm{~m}^{2} / \mathrm{hab}$.) salvo por el comercio de productos diarios. Adicionalmente, existe una zona denominada eje cultural y educativo, que en la actualidad 15 años después de haberse iniciado la construcción de las primeras unidades de vivienda, no ha sido aun edificado.

Como énfasis positivo se valora el esfuerzo por haber implantado equipamientos educativos con un cierto diseño arquitectónico ( en dichos diseños participaron arquitectos como Rogelio Salmona o Giancarlo Mazzanti)
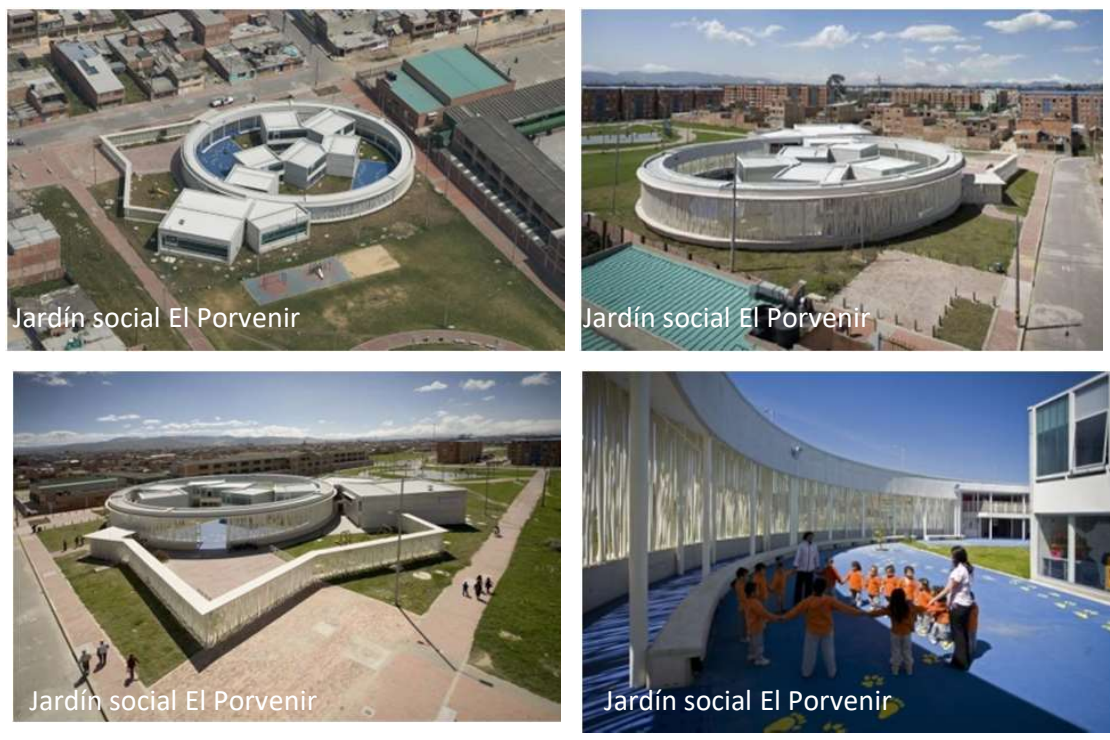
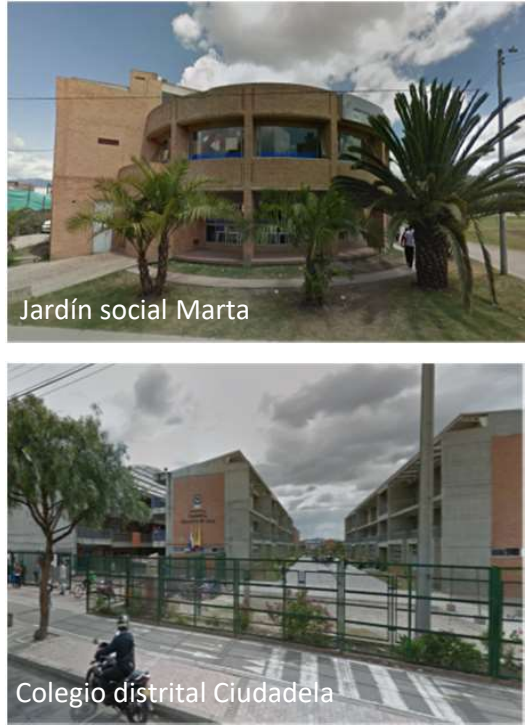


\section{Centros de culto}

Si bien los centros de culto no hacen parte de la batería de equipamientos esenciales a plantear por parte de la administración o el Estado, éstos son de suma importancia para la población en este tipo de territorios (como se señala en las encuestas de satisfacción que se les han realizado). En el caso de la Ciudadela, la población ve como positivo que se hayan creado lugares de culto (dentro de las mismas viviendas) en donde se pueda poner en práctica los rituales concernientes a su religión.

\section{Centro de salud}

Es de señalar la carencia en infraestructuras de salud en toda la ciudadela. Es insólito que en un proyecto de mas de 80.000habitantes no se cuente con ningún un centro de asistencia primaria. La población en caso de necesidad debe desplazarse mas de $40 \mathrm{~min}$ a pie para poder llegar al centro de salud mas cercano o acceder, en los barrio colindantes, a los dos centros básicos existentes.

\section{Equipamientos de carácter privado}

Como parte de la obligaciones urbanas, cada urbanización en cada manzana, debe construir un centro de bienestar social, por lo general ocupado por un salón múltiple de no mas e $40 \mathrm{~m} 2$, y un espacio con un uso diferente a la vivienda, como puede ser comercio, un jardín infantil, una veterinaria o centro deportivo. Estas construcciones han sido respetadas en todos los casos, sin embargo, por su carácter privado no son accesibles para toda la población del proyecto ni para la población de los barrios aledaños.

\section{EQUIPAMIENTOS ESCALA BARRIO-ZONAL}
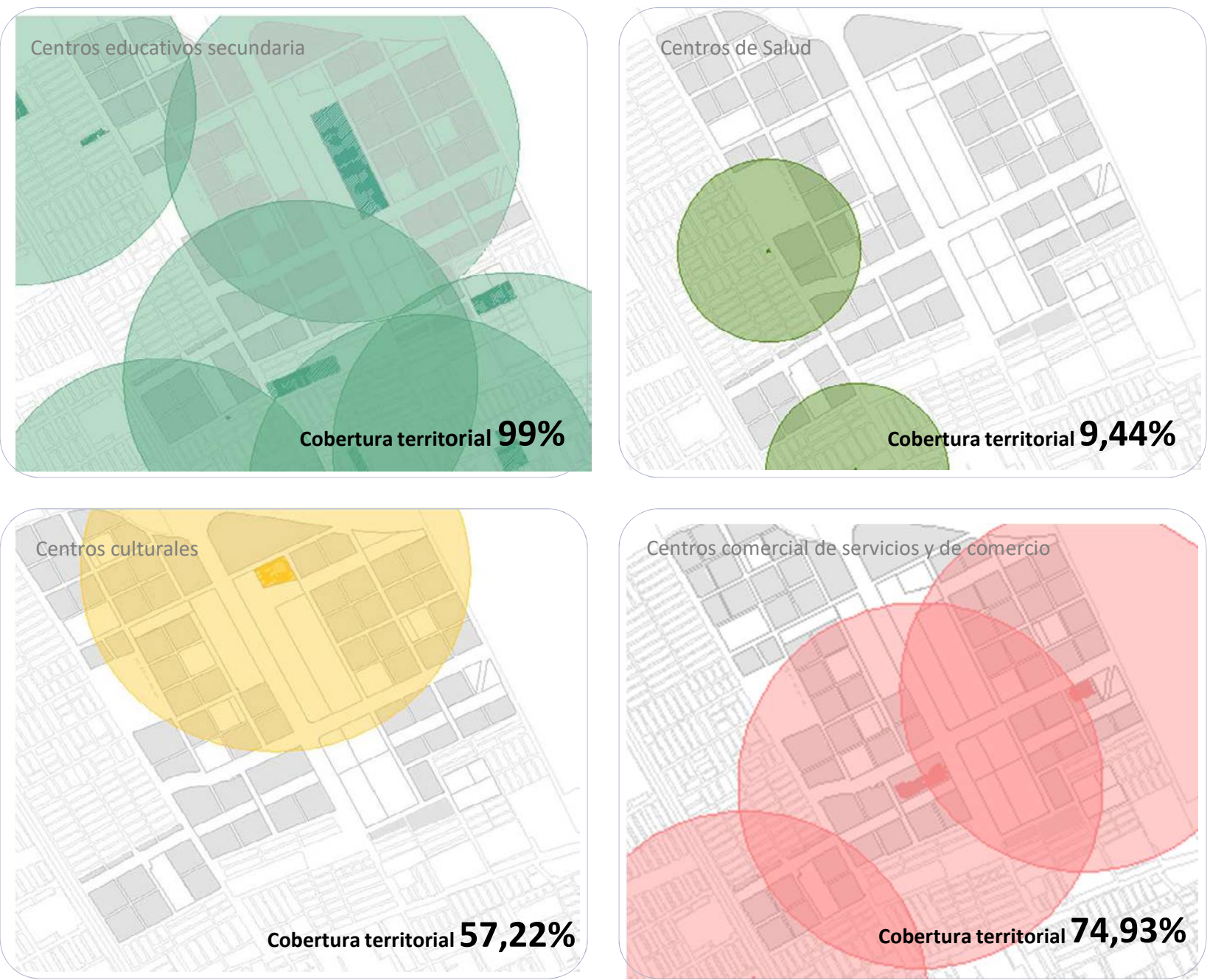


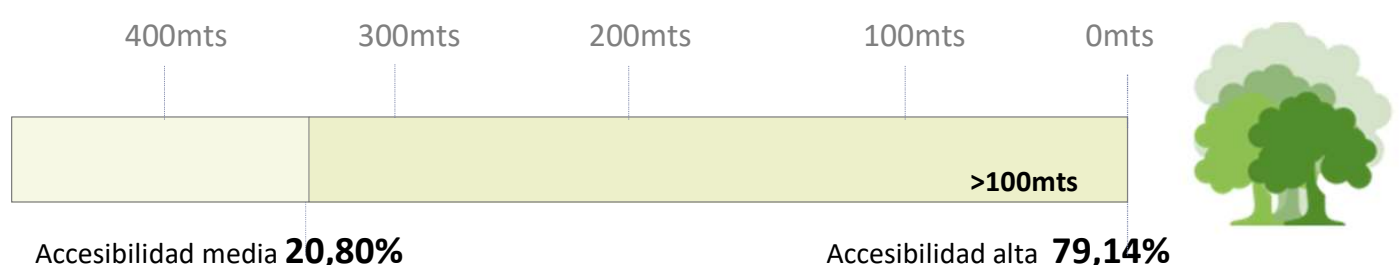

Proporción de zonas verdes 1,25m2/hab

Plano de Cobertura de zonas verdes

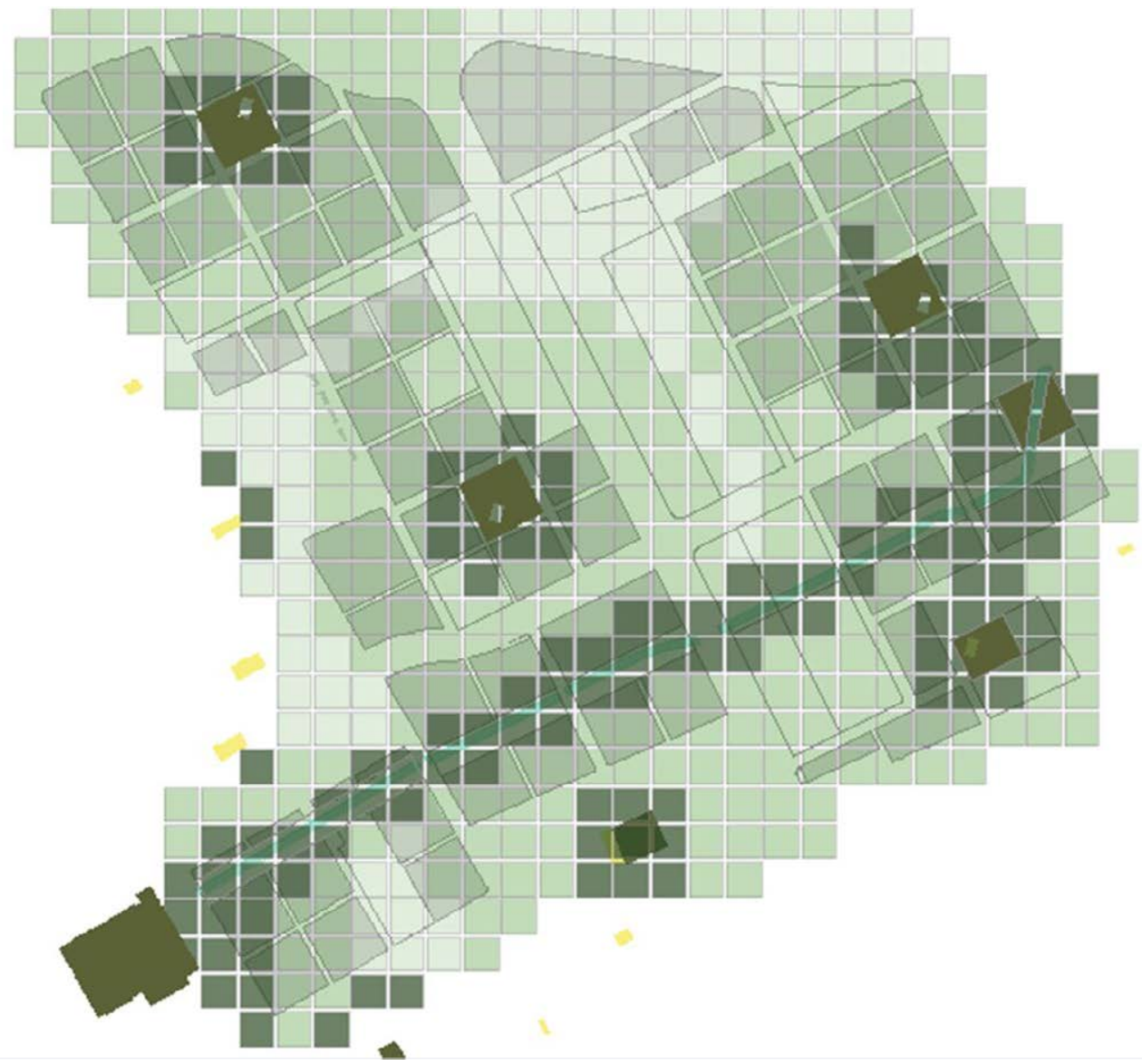

Las zonas verdes, de recreación y de ocio en la ciudadela El Porvenir se categorizan en dos tipos de zonas: unas manzanas libres ( parques de bolsillo) que han sido usadas para este fin y en las cuales,en algunos casos, se encuentran con alguna placa deportiva o juegos infantiles; y una alameda o sendero peatonal de este a oeste del proyecto, con zonas de estancia, un carril bici, iluminación y arborización en los tramos en la que esta construida, en los tramos en la que no esta construida es una parcela desocupada. En general, la proporción de este espacio público cumple con los estándares normativos en áreas y accesibilidad, sin embargo, su proporción por habitantes es muy baja: $1,25 \mathrm{~m}^{2} /$ hab.
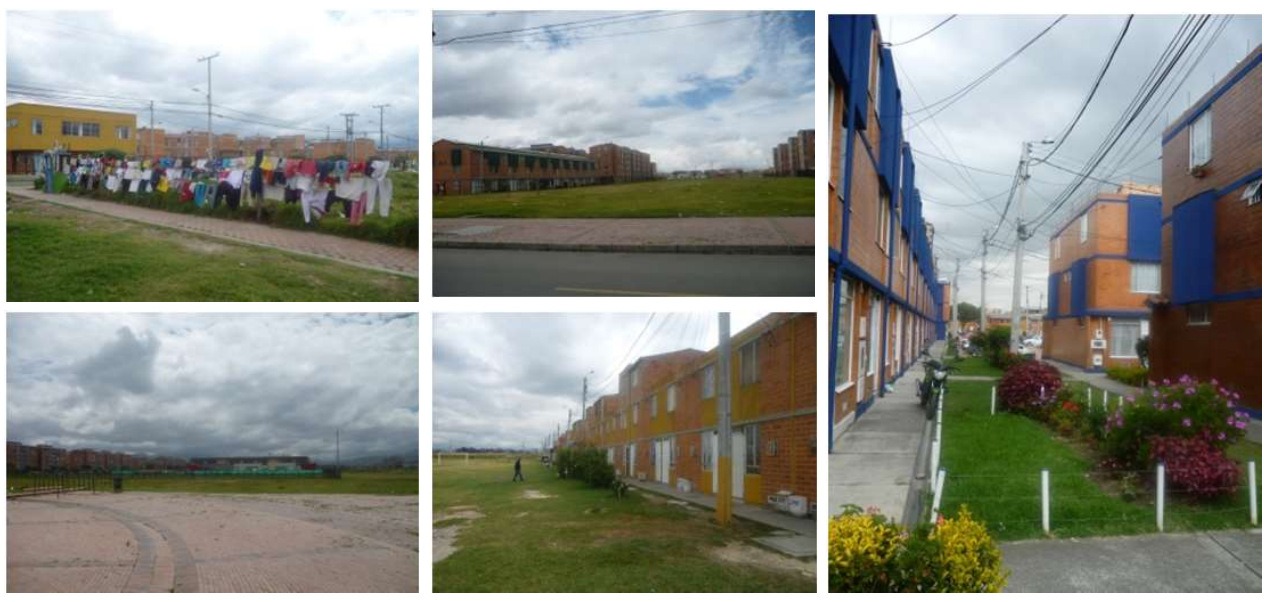
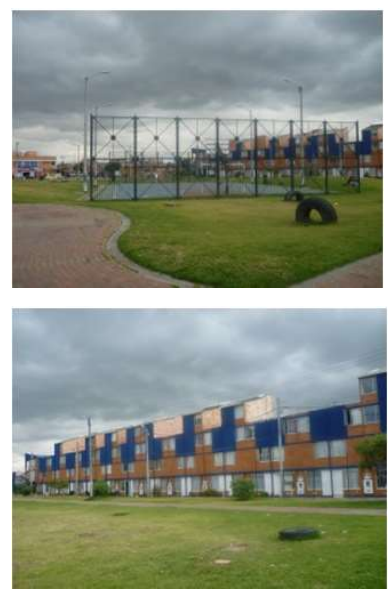


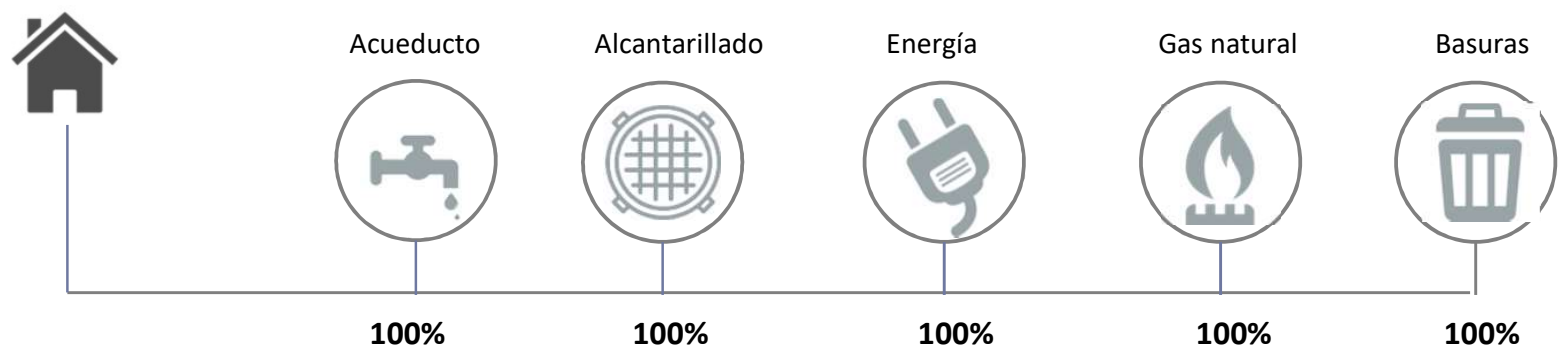

La cobertura de servicios domiciliarios es buena en todo el proyecto, ésta incluyendo el servicio de recolección de basuras. Solo se encuentran algunos problemas de desechos y desperdicios en las parcelas baldías causadas por la propia población que los bota allí.

Con respecto a este último servicios, el de la recolección de basuras, cabe resaltar que dentro de las urbanizaciones si bien se presta el servicio, su frecuencia no es diaria y en muchas ocasiones se acumula basura en las calles a la espera de ser recogida.

\section{I10 Condiciones geotécnicas. Riesgos} Condiciones ambientales

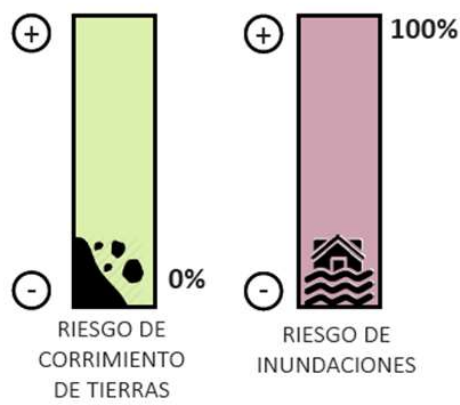

El $100 \%$ del área total de la Ciudadela El Porvenir presenta un nivel medio de amenaza por inundación debido a su ubicación en la cuenca media del Rio Bogotá. En épocas de lluvia el ineficiente sistema de alcantarillado, canales, interceptores y colectores se satura al no poder verter sus aguas en el rio y genera reflujos y encharcamientos en todo el territorio.

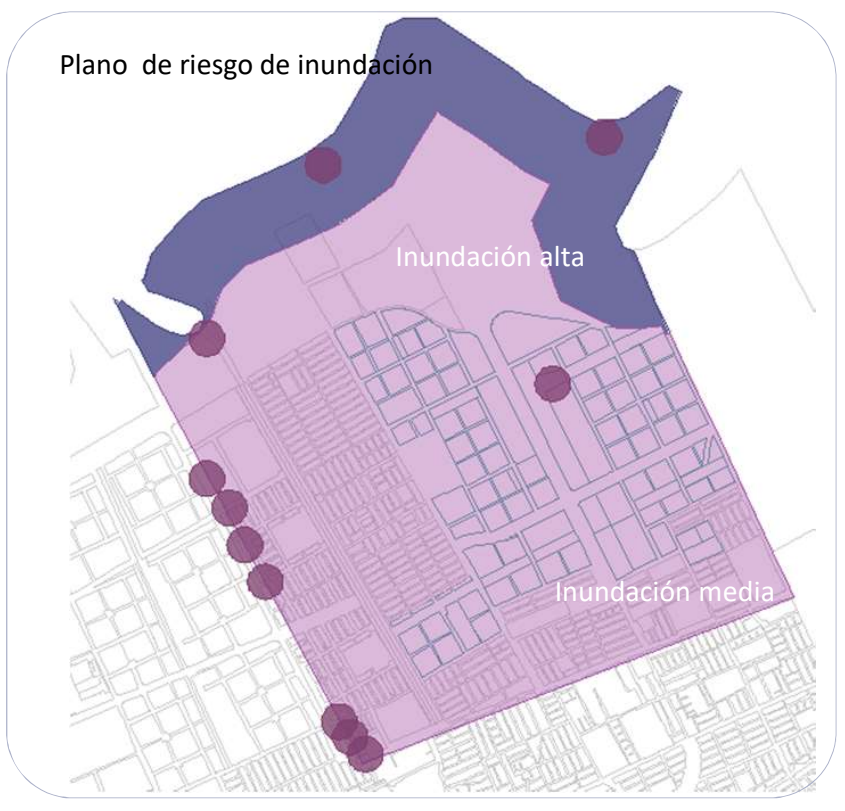

\section{I11 Morfo-tipología}

Unidades habitacionales construidas

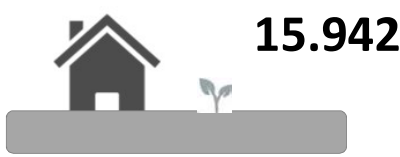

Viviendas unifamiliar

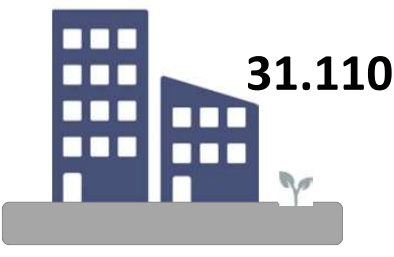

Viviendas multifamiliar
Ocupación de la manzana y tipología de la vivienda

La ocupación recurrente que plantean las constructoras en la Ciudadela se basa en un sistema de barras paralelas que buscan el mayor aprovechamiento del suelo. En el caso de los multifamiliares, estas barras constituyen bloques de 5 y 6 pisos, logrando una menor ocupación en área construida en primer piso que en el caso de los unifamiliares.

En promedio, los índices de ocupación en vivienda de estas manzanas son de 0.40 para los multifamiliares y 0.46 para los unifamiliares, mientras el de áreas verdes representa un índice promedio de ocupación de 0.32 en multifamiliar y 0.25 en unifamiliar.

Hasta la fecha hay construidas poco menos de 50.000 unidades de vivienda y habitan 170.000personas (3,59personas por vivienda).

Total $=\mathbf{4 7 . 0 5 2}$ viviendas 


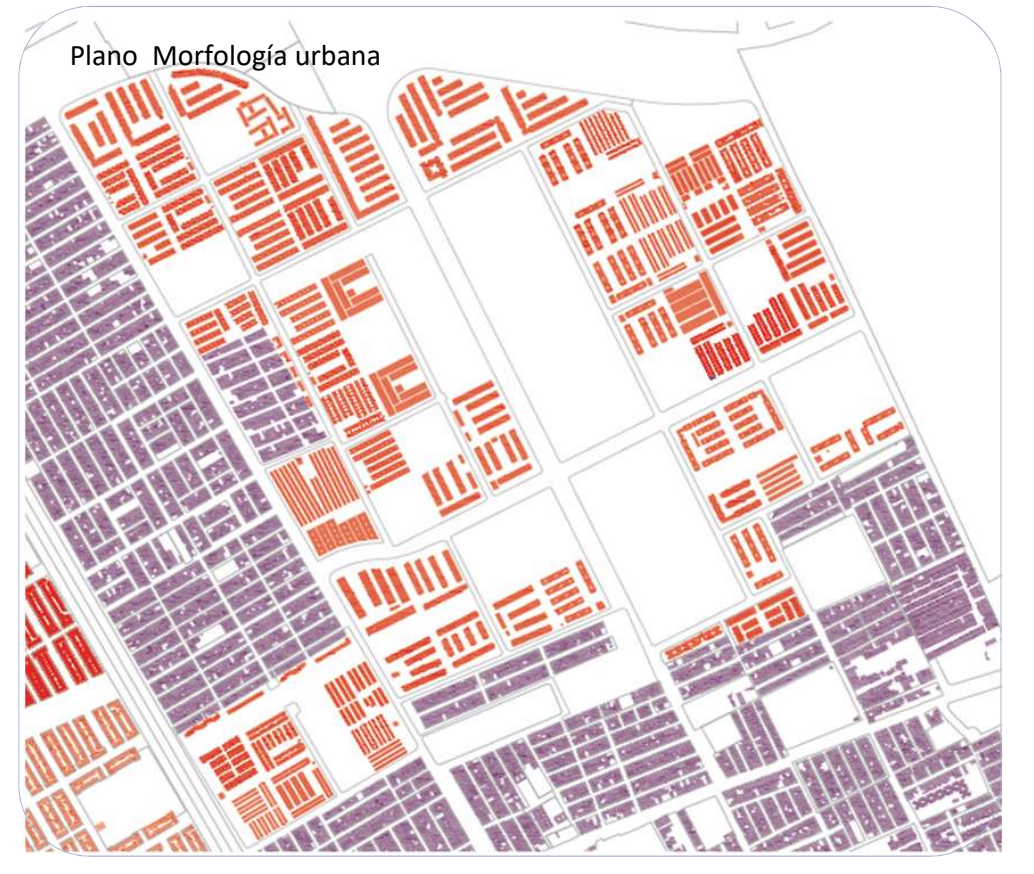

La configuración morfológica de El Porvenir es reticular planeada. El esquema de configuración es de megamanzanas ortogonales de 180mts x 180mts subdivididas en cuatro manzanas de $80 \mathrm{mts} x$ $80 \mathrm{mts}$ rodeadas de vías locales y peatonales.

El área de las parcelas y de las unidades de vivienda, inferiores a los $45 \mathrm{~m} 2$ no cumplen con las dimensiones establecidas en la normativa.

Unidades habitacionales construidas

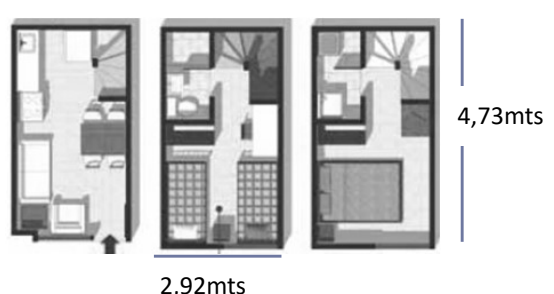

Tipología unifamiliar $\mathbf{4 1 , 4 3 m 2 ~}$

Este tipo de viviendas, construidas en el año 2008, es uno de los ejemplos de "multifamiliar acostado" resuelto como una barra de vivienda horizontal con dimensiones mínimas de área en primera planta y sin patio o antejardín.
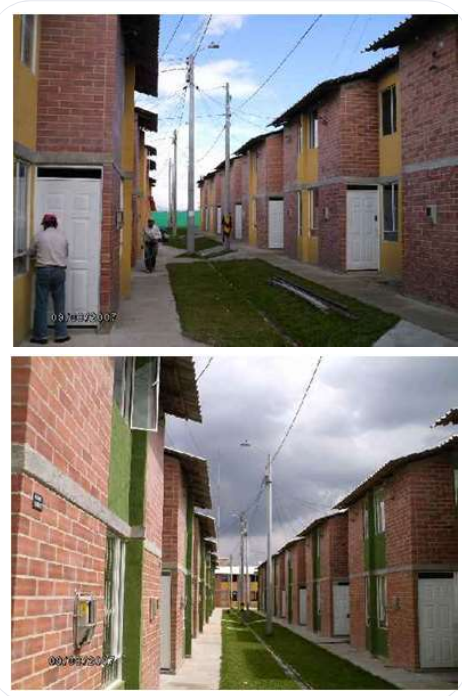
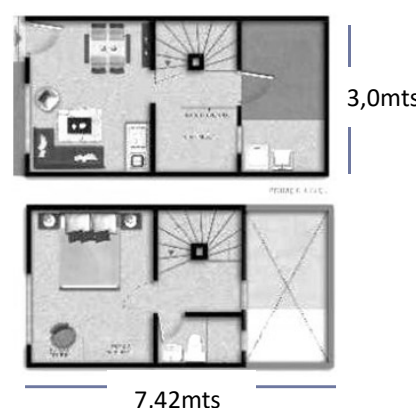

Tipología unifamiliar 44,52 $\mathrm{m} 2$

Esta es una tipología de vivienda unifamiliar con posibilidad de desarrollar una tercera planta.

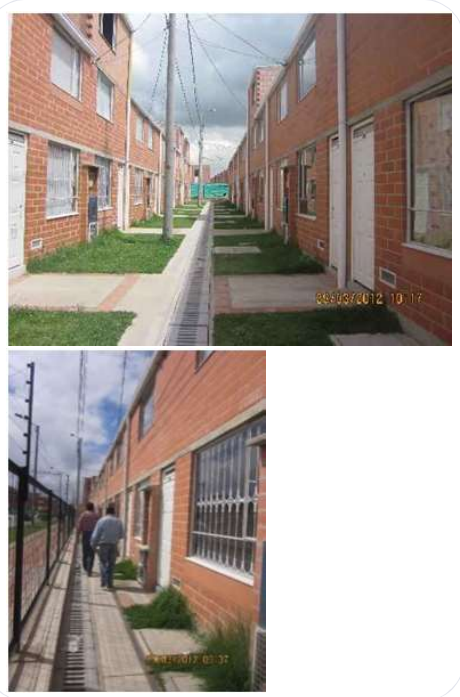

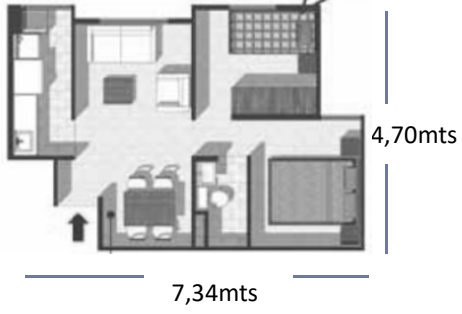

Tipología multifamiliar $\mathbf{3 4 , 3 8} \mathrm{m} 2$

Los proyectos realizados bajo esta tipología son los que presenta mayor densidad de toda la Ciudadela y la menor área por unidad habitacional.

Las viviendas se conforman en bloques de 5 y 6 niveles que ocupan el $43 \%$ del área de la manzana en primera planta.

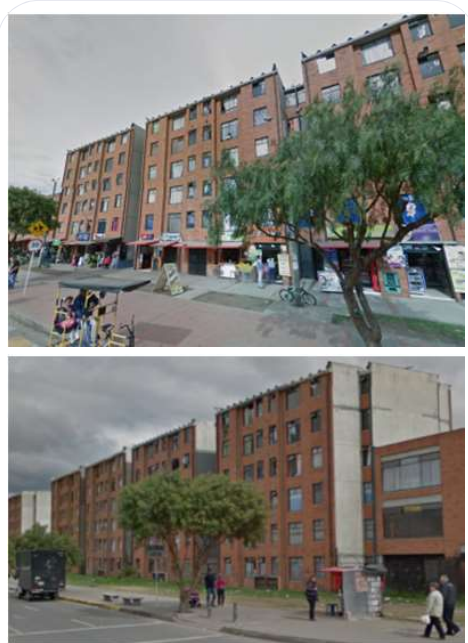




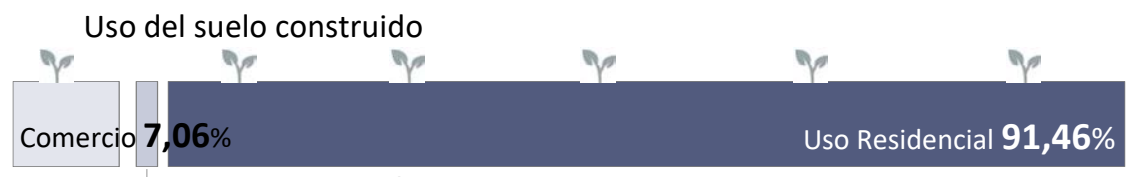

L Dotacional $\mathbf{1 , 4 8} \%$

El proyecto cuenta con 85 manzanas de una hectárea útil aproximadamente de las cuales 80 manzanas se destinan al desarrollo de vivienda: 40 de tipo unifamiliar, 38 de tipo multifamiliar y 2 para el uso múltiple en las cuales hay construidos dos centros comerciales.

Adicionalmente dos grandes parcelas en la zona central están destinadas a equipamientos educativos, los cuales aun no están construidos en su totalidad.
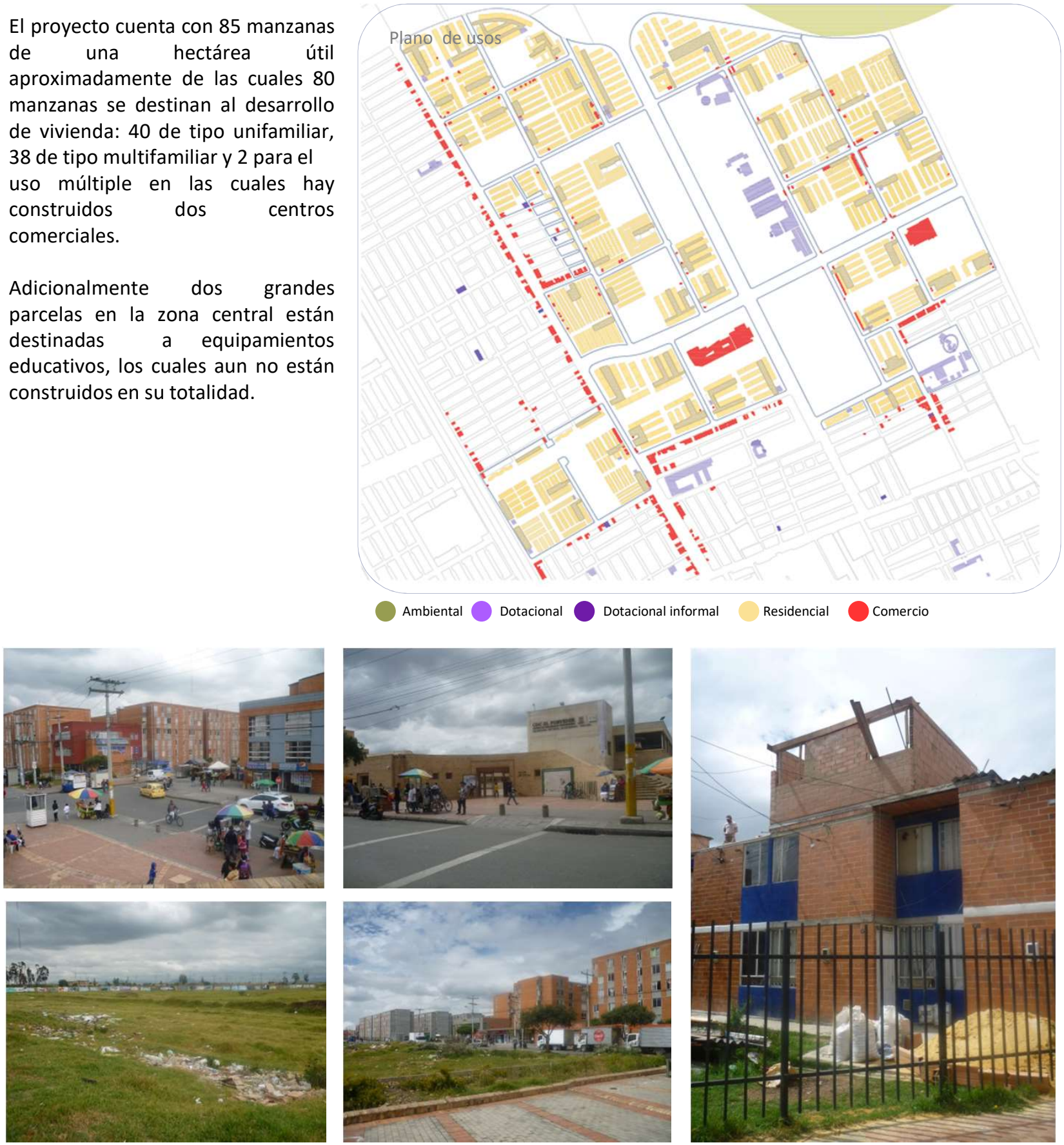

Por ser un proyecto de vivienda nueva, toda la población que allí habita ha logrado de una forma u otra poder acceder a un crédito bancario y al subsidio ofrecido por el Estado. Su condición la clasifica como una población con un estrato socioeconómico medio bajo (estrato 2 predominantemente).

Estrato socioeconómico de la población

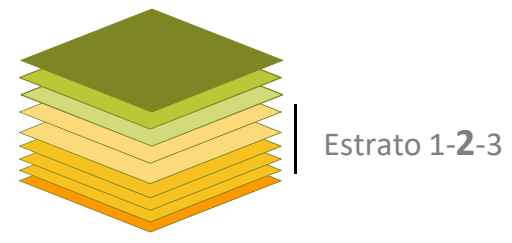




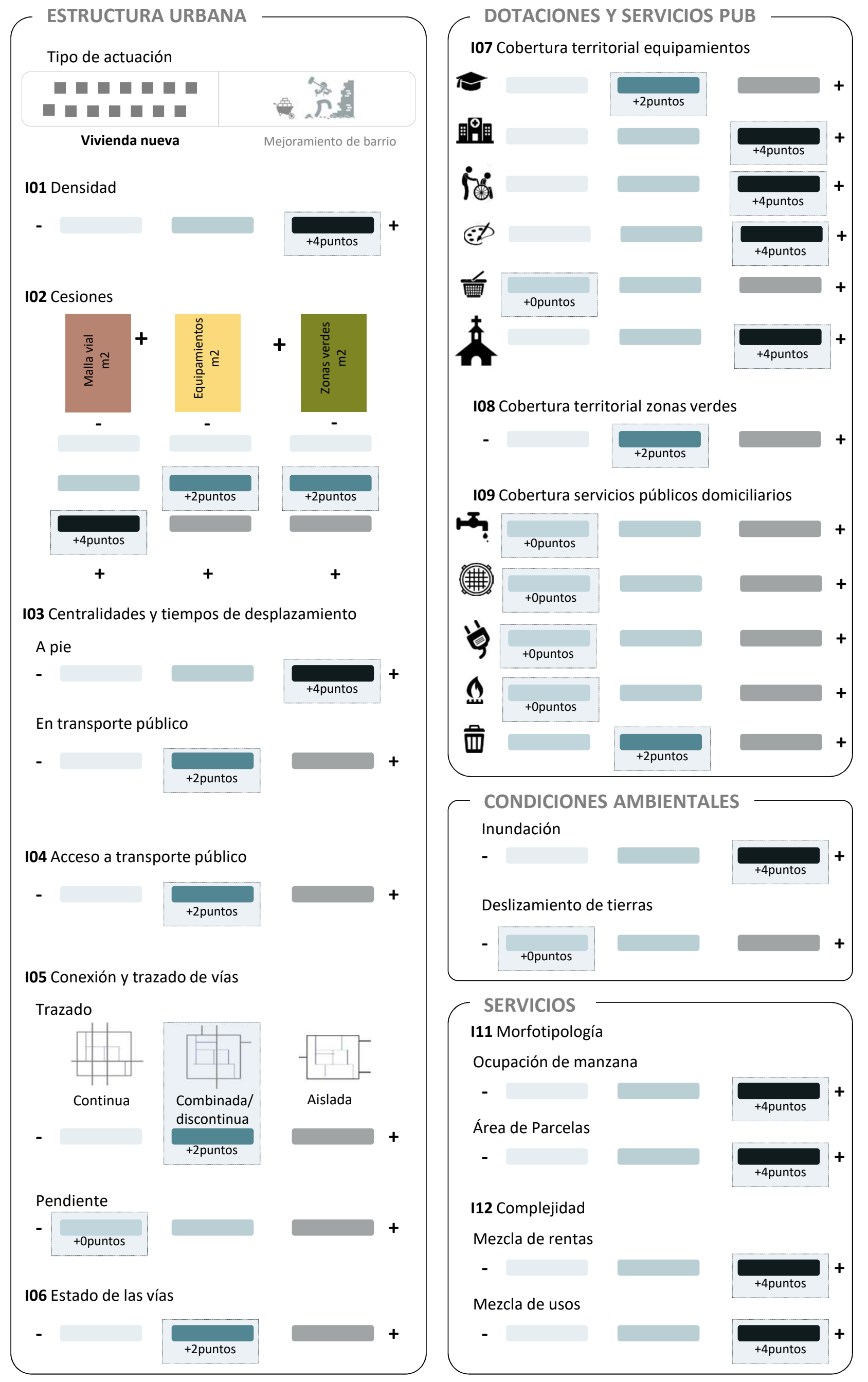




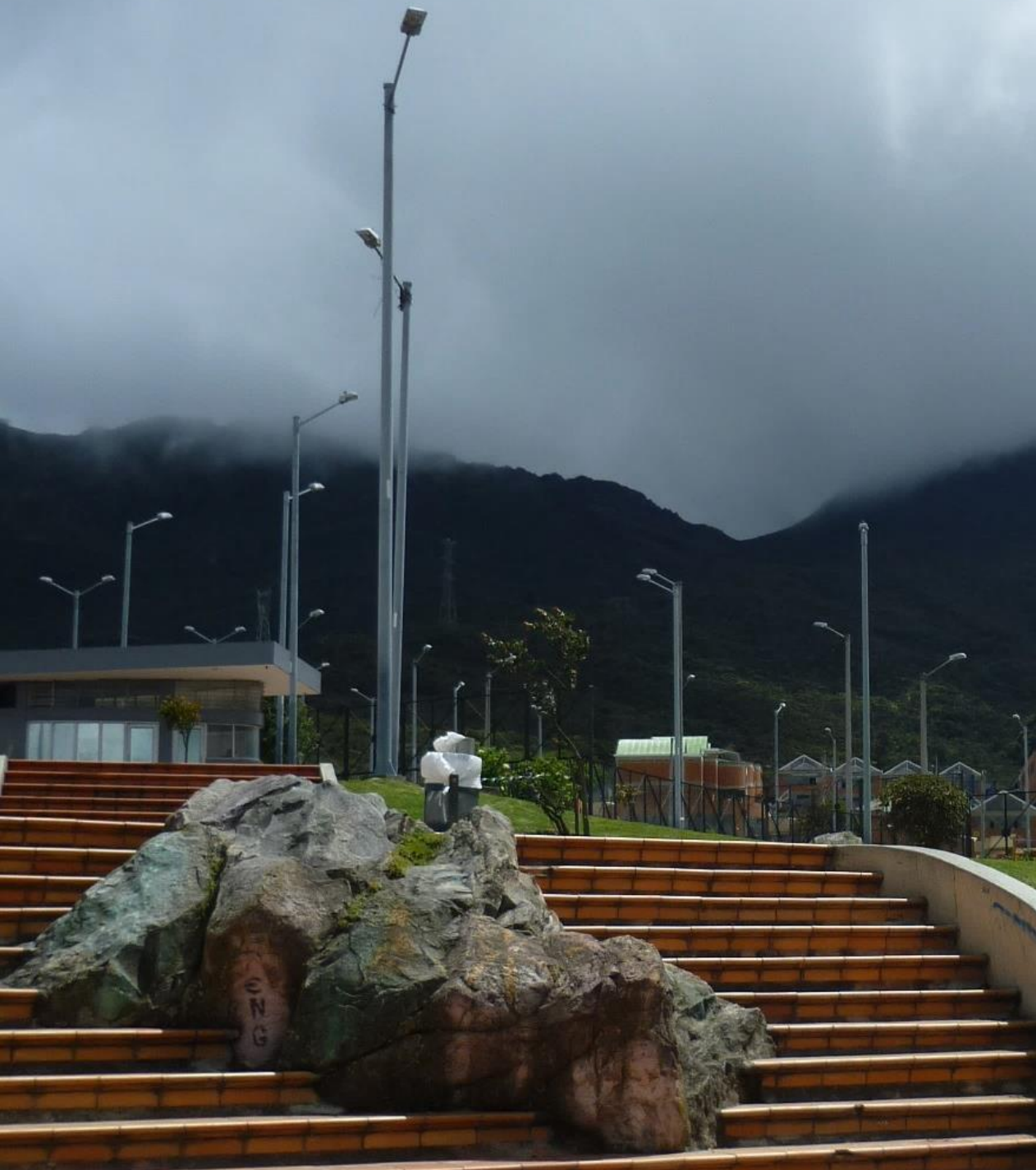




\section{MIB Sur con Bogotá - Bogotá}

El proyecto MIB "Sur con Bogotá" fue una de las primeras experiencias innovadoras de mejoramiento integral de barrios de gran escala ejecutadas entre los años 1997 y 2005 . Fue impulsada por el Departamento Administrativo de Planeación Distrital (DAPD) y la Empresa de Acueducto y Alcantarillado de Bogotá (EAAB) en cooperación con el Gobierno Alemán, a través del Kreditanstaltfiir Wiederaufbau (KfW) para optar por la legalización de barrios. Su implantación buscaba contribuir al mejoramiento sostenible de la calidad de vida de una población ( 85.000 habitantes) en altas condiciones de pobreza en 41 barrios próximos al Parque Entrenubes en las localidades de San Cristóbal, Usme y Rafael Uribe Uribe. En el proyecto se proponía, con una visión de áreas estratégicas de intervención en obras físicas, el desarrollo social y fortalecimiento institucional, la construcción de una infraestructura de servicios sociales y comunitarios, la capacitación para la autogestión de las comunidades y el desarrollo de un modelo replicable de MIB. Así el proyecto no solo contemplaba la recuperación física de una gran zona en el sur oriente de la capital sino también la generación, a través de la práctica, de elementos teóricos, metodológicos e instrumentales reproducibles en el marco de una política distrital de hábitat.

Entre los logros alcanzados a nivel físico en el proyecto se destacó la cobertura del $98 \%$ de rede de acueducto y alcantarillado mejorando las condiciones de salubridad. Se mejoró la accesibilidad vehicular y peatonal a través de circuitos viales y pavimentos locales ( $75 \%$ de los barrios conectados a sistemas de trasporte público y reducción de tiempos de viaje en 30 minutos). Se aumentó el aforo en educación básica y media de un $43 \%$ gracias a la construcción de 3 grandes jardines sociales, 3 escuelas de educación básica y media y 4 ampliaciones de colegios existentes. Adicionalmente, se aumentó de $92 \%$ las zonas recreativas con 22 parques de barrio nuevos con canchas múltiples y equipamiento de ocio. En total fueron 22 barrios legalizados con una mejora elevada en sus estándares de calidad.

A nivel social, los avances se consolidaron con procesos participativos en los que se logró congregar organizaciones comunitarias, sectoriales y generacionales para la elaboración de planes zonales en nuevos salones comunitarios construidos. Se amplió la cobertura de salud y nutrición por medio a la afiliación del SISBEN y la postulación en comedores infantiles. Se diseñaron 23 proyectos ligados a programas de convivencia con el Fondo de Desarrollo Comunitario y la cooperación internacional. Adicionalmente, se capacitó a la población objeto en economía solidaria y se prestó formación en la gestión para consolidar empresas solidarias (8 empresas fueron formadas). Como agregado, durante el proyecto se crearon 670 puestos de trabajo temporal en las obras de construcción.

Los logros ofrecieron sin duda una posibilidad de cambio inigualable en el territorio. Sin embargo, quedan dudas sobre cuál es el margen de transformación que aceptan los desarrollos marginales y qué avances en sus condiciones de habitabilidad se han alcanzado si se tiene en cuenta el reto de una sostenibilidad basada en una población con altos niveles de desempleo, bajo nivel académico y escasas oportunidades laborales entre otras muchas condiciones de dicha población. 


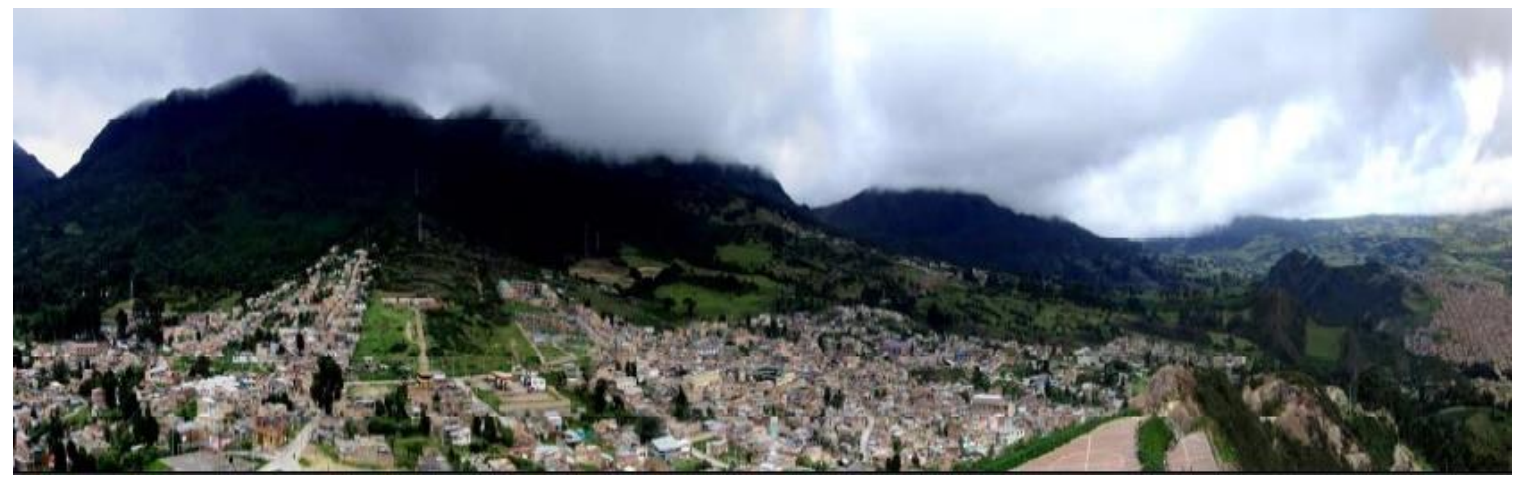

\section{Localización y determinantes}

El proyecto de mejoramiento de barrio, como se mencionó está ubicado en el suroriente de Bogotá, en todo el perímetro el Parque Entrenubes en las localidades de San Cristobal, Usme y Rafael Uribe Uribe. Esta área de intervención fue seleccionada con dos propósitos esenciales para su recuperación. El primero, fortalecer la legalización de barrios de la periferia limitando el crecimiento espontáneo. El segundo, contemplar la mejora ambiental de las rondas hídricas del parque Entrenubes. Área reconocida como una de las reservas ecológicas hídrica más importante para la ciudad que ha sido objeto de explotación ilegal de canteras para agregados y ha sufrido un progreso sucesivo de deterioro.

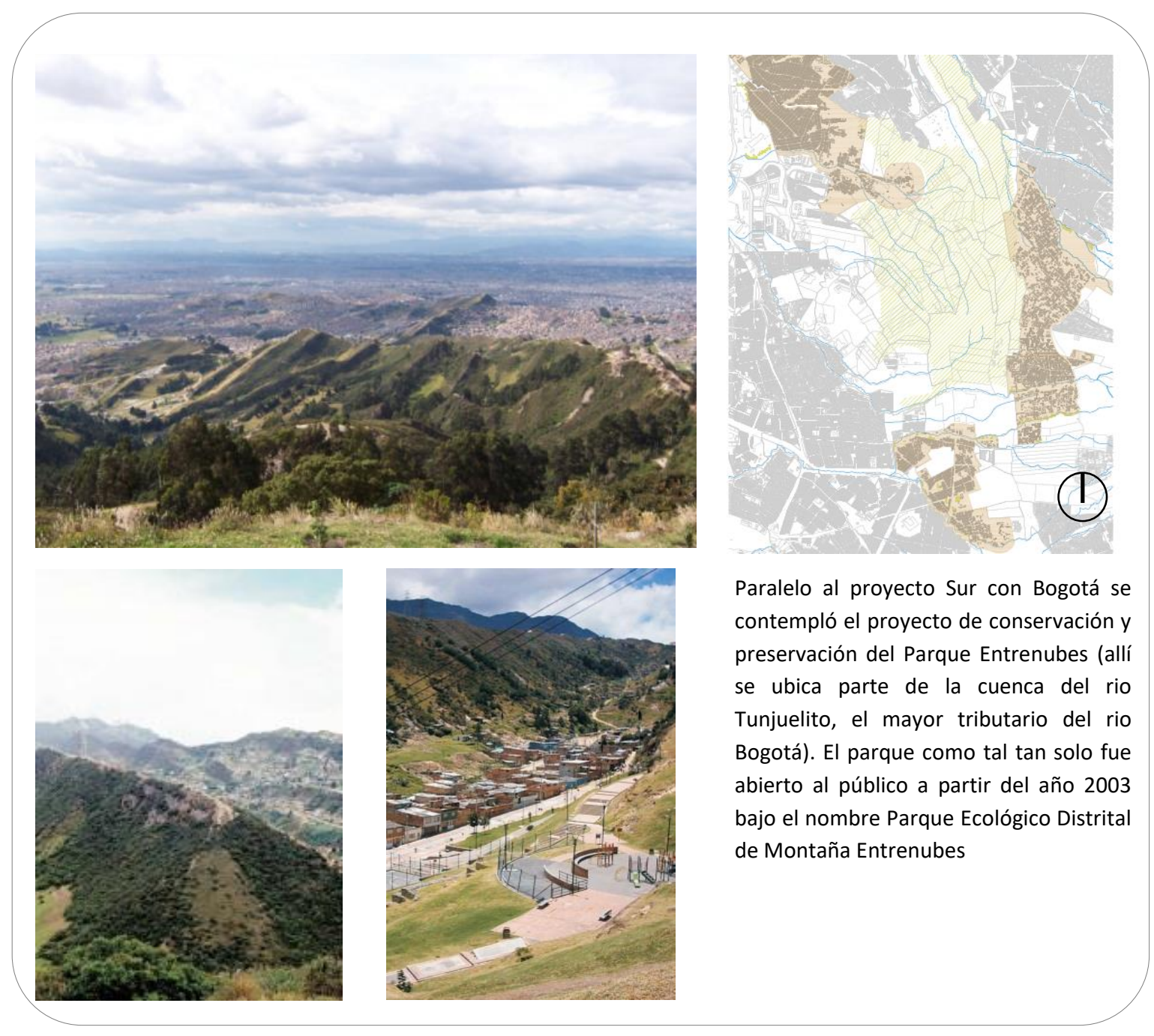




\section{Cronograma}

1997: Surge la idea del Proyecto de Mejoramiento Integral de Barrios 'Sur con Bogotá", propuesta por el Departamento Administrativo de Planeación Distrital y la Empresa de Acueducto y Alcantarillado de Bogotá para fortalecer los procesos de habilitación y legalización de barrios como requisito para iniciar acciones de mejoramiento barrial.

1997 enero a diciembre: Acuerdos de participación y gestión de recursos

Para la financiación de la propuesta se considera la posibilidad de gestionar recursos de la cooperación internacional y se vincula a la Presidencia de la República, a través de la "Consejería para el Desarrollo Territorial y de Santa Fé de Bogotá".

1998 enero a junio: Formulación del Proyecto.

Estudio de factibilidad, que definió la propuesta de intervención y al mismo tiempo constituyó el punto de partida para la cooperación internacional con el Gobierno Alemán a través Kreditanstalt fiir Wiederaufbau 1(1W - (Banco para la Reconstrucción de Alemania).

1998 julio-diciembre: Preinversión

Se consolidaron los principios y la conceptualización del Proyecto, se gestionaron las primeras contrapartidas con las entidades distritales, destacándose la estructuración de la Unidad de Gestión como instrumento para la planeación, coordinación, gestión, seguimiento y control del Proyecto.

1999 mediados fase de implementación

Ejercicio de coordinación institucional y participación comunitaria que garantice la ejecución y sostenibilidad de obras y proyectos y la inversión financiera programada por parte del Distrito (80\%) y el gobierno Alemán (20\%). 2002 El distrito recibió una segunda donación del Gobierno Alemán, lo que generó una segunda fase de inversión y permitió ejecutar todas las obras previstas.

2003: Se delega en el Gerente de la Caja de Vivienda Popular la representación del Distrito.

2003 diciembre: originalmente prevista la fase de ejecución.

2004 Encuesta de Opinión por parte de la Alcaldía Mayor de Bogotá y La Empresa de Acueducto y Alcantarillado de Bogotá.

2005 marzo. Finalización de la fase de intervención

\section{Problemas en la zona antes de la intervención}

Uno de los problemas más graves que se presentaban en las zonas de intervención del Proyecto SUR con Bogotá era el alto nivel de violencia y la baja seguridad ciudadana, que afectan la convivencia de las comunidades y perjudica la sostenibilidad de la intervención. En los diagnósticos participativos promovidos por la administración distrital en el marco de los procesos de planeación participativa, los representantes de las comunidades han asignado la más alta prioridad a la lucha contra la violencia y al manejo de los conflictos en los barrios como parte fundamental del proceso de mejoramiento urbano.

La administración respondió a ese reclamo de las comunidades con la creación de una acción específica dentro del componente de desarrollo social dirigida a la promoción de la convivencia seguridad ciudadana. Simultáneamente se gestionó ante el Gobierno Alemán recursos adicionales para fortalecer la línea de convivencia y seguridad ciudadana, constituyéndose ésta como un proyecto en paralelo denominado "Sur de Convivencia".
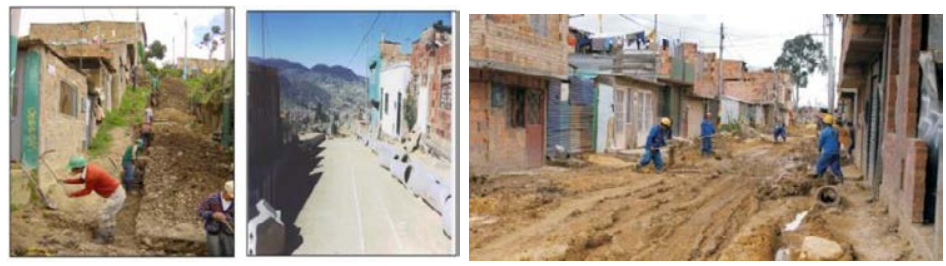

Historia de los barrios Las Fiscalas "Yo vivo en el sector Fortuna. E1 sector Fortuna era un terreno montañoso y llegó un Señor Trino García y urbanizó este terreno. Empezaron a vender unos lotes y estos lotes nos enva, alcantarillado y unas redes de luz o sea con luz perio todo pirata. Somos mas o menos ciento y pico de personas viviendo aqui y en este momento estamos padeciendo por la legalización de nuestro sector porque como allá se dividieron de la Junta de La Fiscala Centro y otros sectores, entonces nos separamos del sector y resulta que ahorita nosotros quedamos sin legalizar el sector. Estamos en tramite para la legalización del terreno y también porque hubo una parte para mitigación de alto riesgo que ja arreglaron este problema y en este momento tampoco contamos con alcantarillado, ni agua o sea digamos acometidas de agua, ni telefono y otras cosas que necesita un sector como el de aca y esperamos el apoyo del Proyecto SUR para que para que asi nos salgan los servicios que necesitamos." 


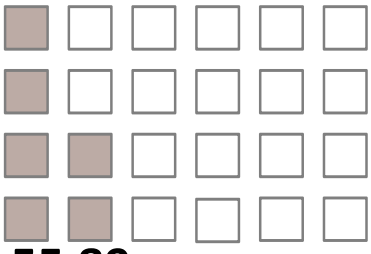

$55,89_{\text {viv/ha }}$

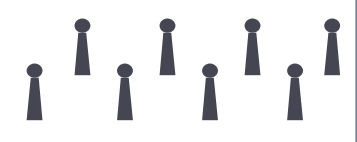

312,78 hab/ha

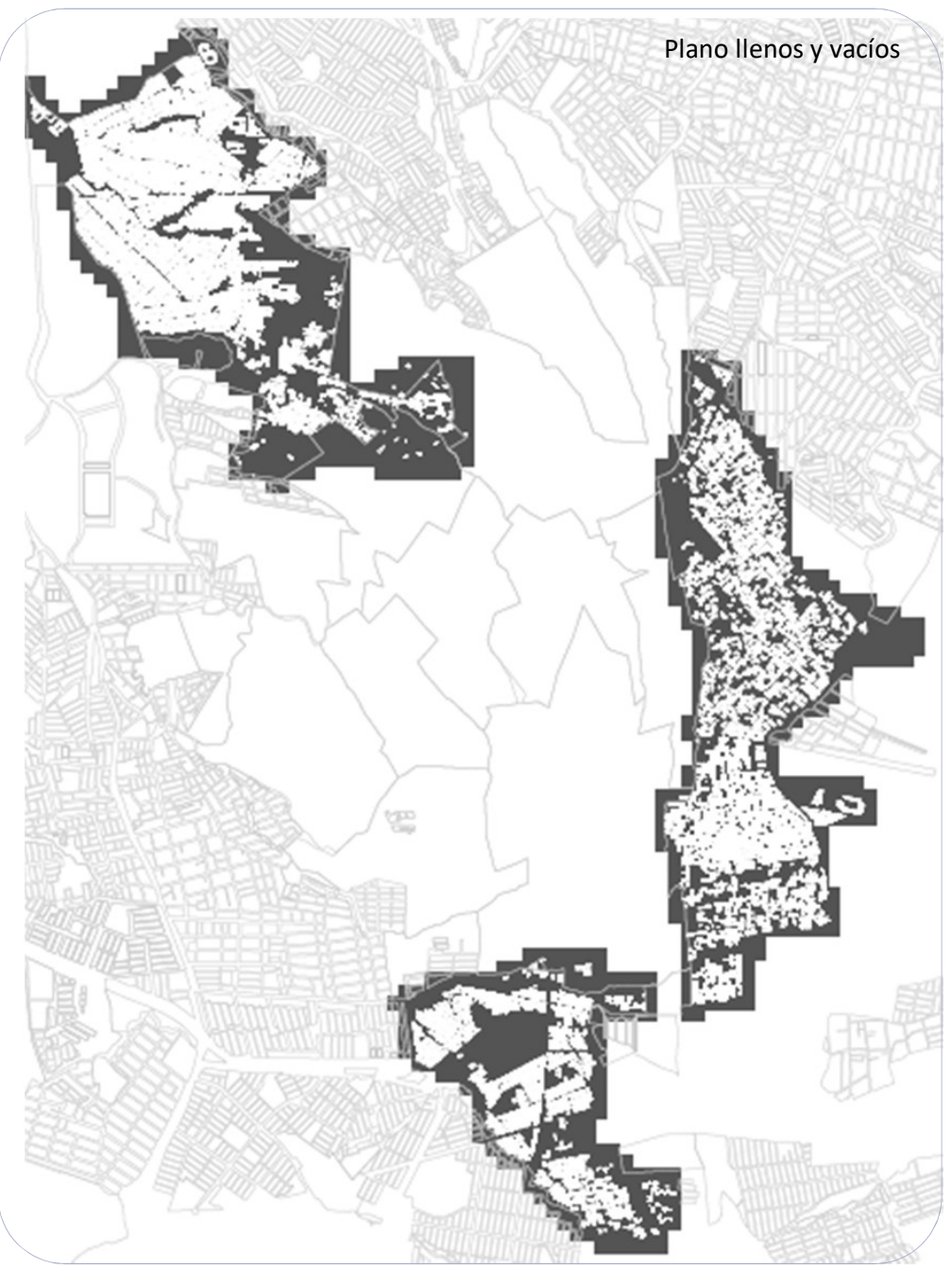

102 Cesiones

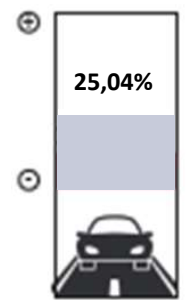

Malla vial

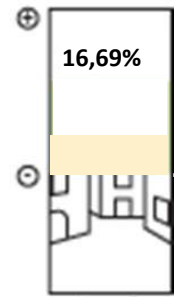

Espacio público

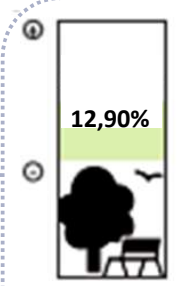

Zonas verdes Zom

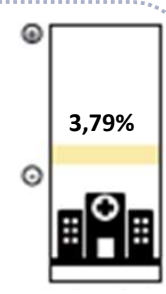

Equipamientos
La cesiones, si como tal se pueden llamar en un proyecto de origen marginal, son muy deficientes a nivel de espacio público, especialmente en equipamientos, y estándar según la normativa a nivel de malla vial.
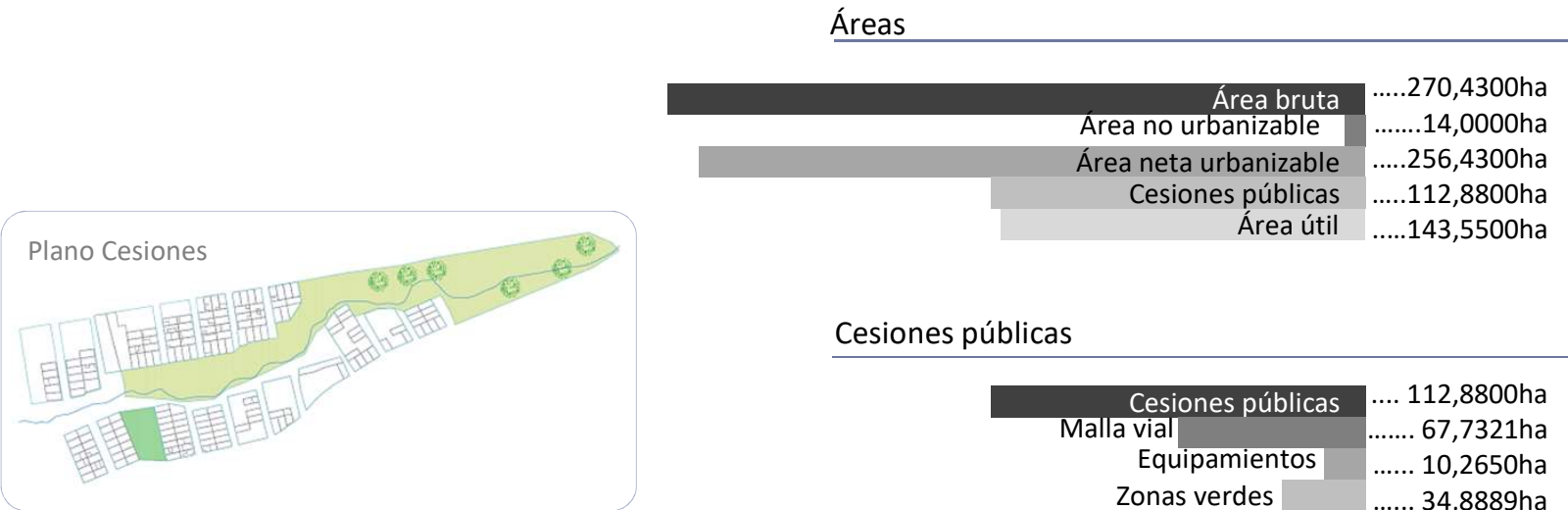

Cesiones públicas

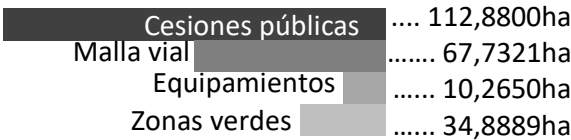




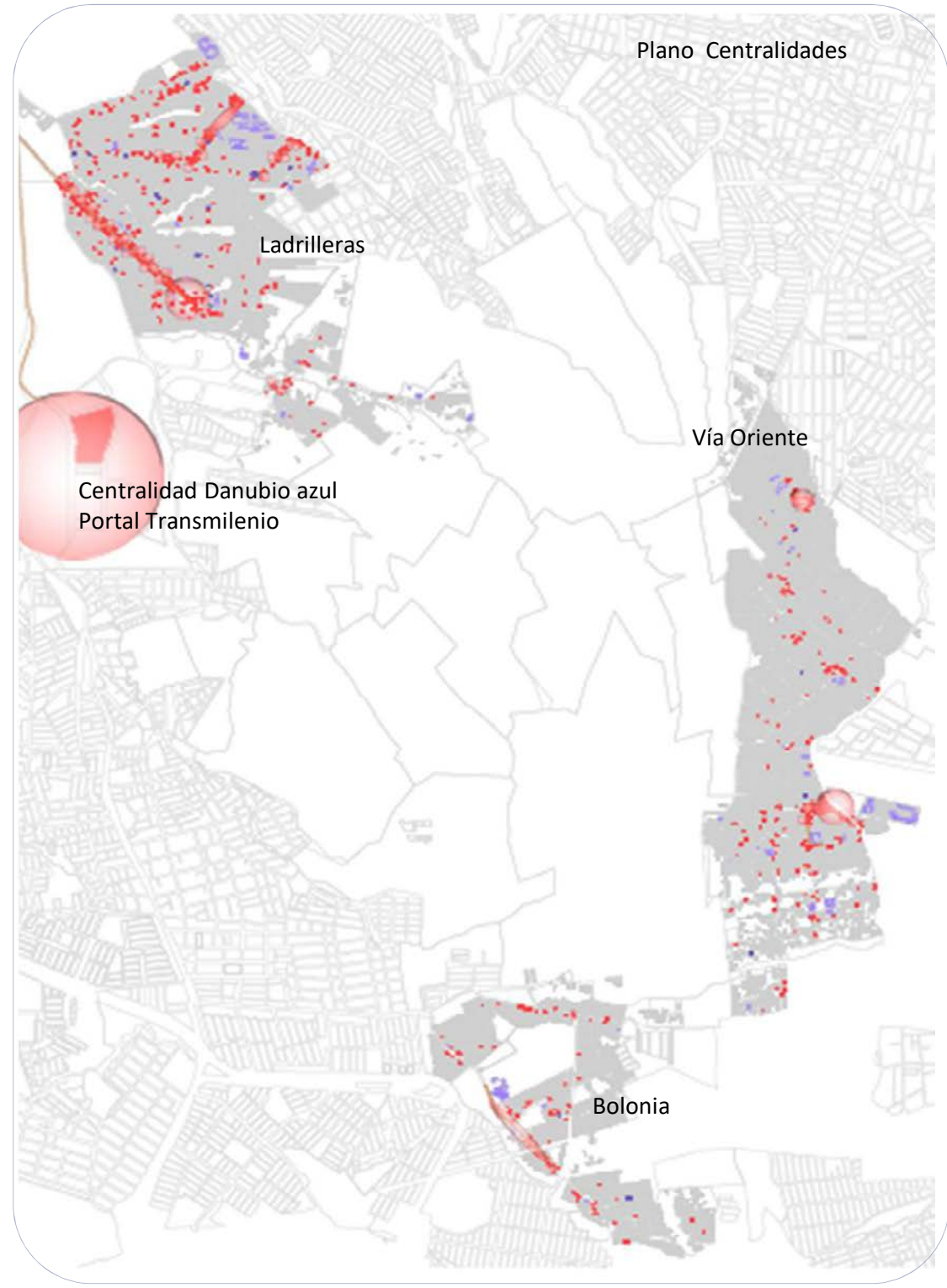

El proyecto no cuenta dentro de su territorio con centralidades establecidas desde Planeación Distrital.

Existe, por un lado, una centralidad a escala de ciudad establecida con el portal de buses del sistema de transporte masivo Tranmilenio y un centro comercial a una distancia considerable de las tres zonas del proyecto: Via Oriente, Ladrilleras ; y Bolonia.

Y por otro lado, pequeñas centralidades a escala zonal establecidas por la propia población con el establecimiento de comercio dentro de sus propias viviendas.

\section{Tiempos de desplazamiento a la centralidad Danubio Azul}
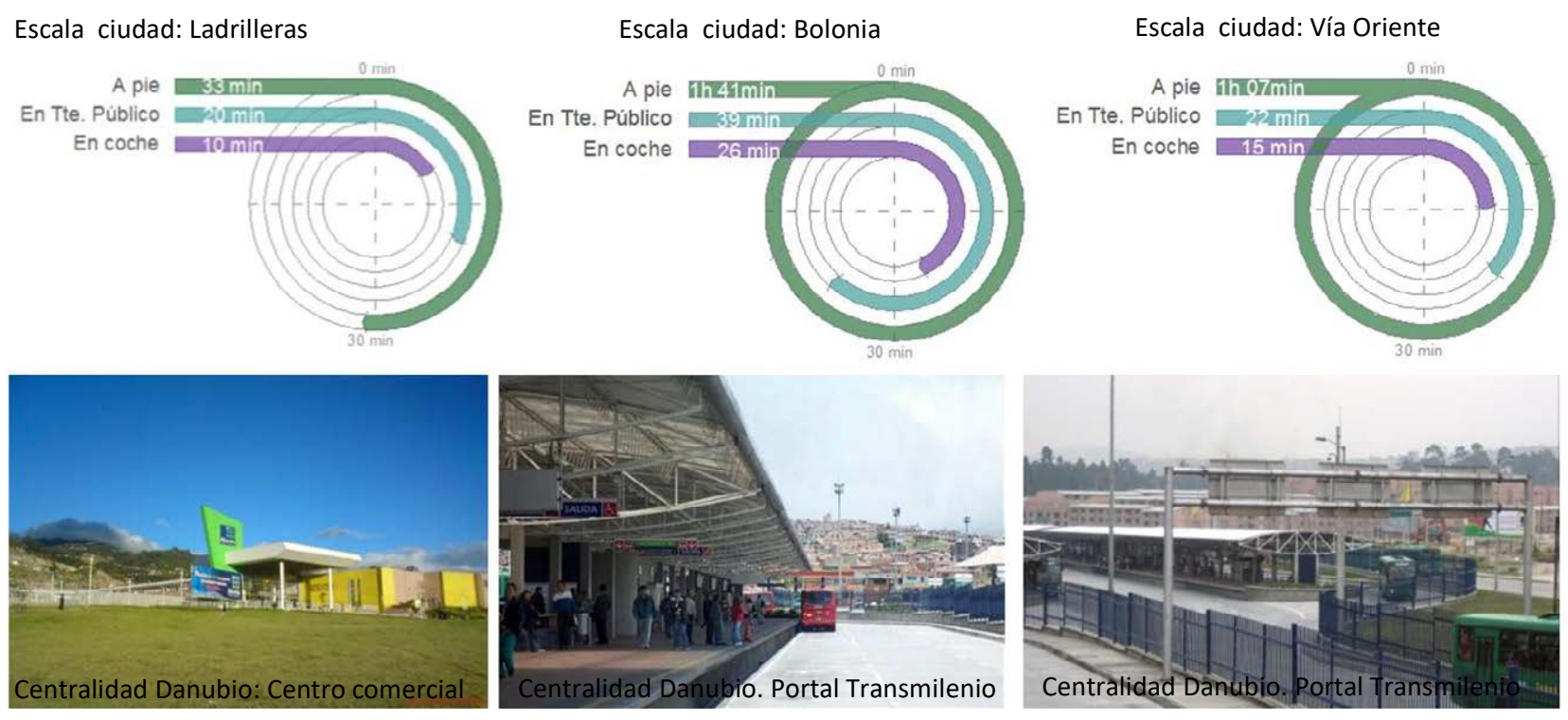

Según los criterios establecidos sobre los tiempos de desplazamiento a pie y en transporte público, se hace evidente que las centralidades cuentan con una accesibilidad muy baja a nivel peatonal y media a nivel de transporte público. Como se constata en el indicador siguiente, las tres zonas cuentan con un sistema de alimentadores del sistema de Transmilenio que depositan a la población justo en el portal ubicado en la Centralidad Danubio Azul. 


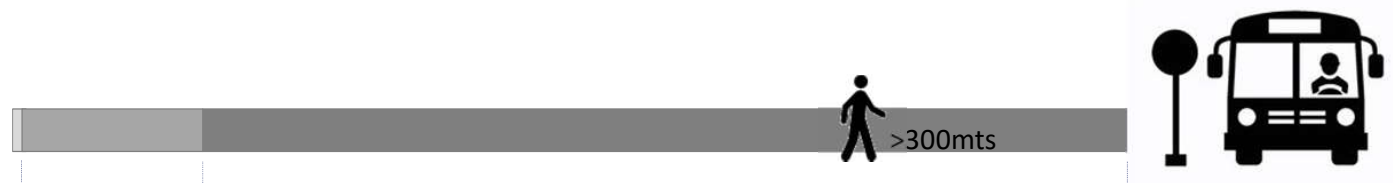

$1,34 \% \quad 10,73 \%$

$87,93 \%$

La accesibilidad al sistema de transporte público en cualquiera de las tres zonas es muy deficiente, especialmente en la zona de Bolonia en donde tan solo se cuenta con dos paradas de autobus en el perímetro del proyecto. En ese caso particular los habitantes deben caminar $1,8 \mathrm{~km}$ para llegar a la parada (distancia muy superior a la considera como máximo de $300 \mathrm{mts}$ a cerrorer).

Adicionalmente, como se ha señalado ya en otros proyectos. Todos los recorridos señalizados para estas zonas son por medio de alimentadores. Esto significa que para que un habitante de la zona quiera utilizar el sistema de transporte público y quiera desplazarse por la ciudad en él, debe tomar, el alimentador, llegar hasta el portal y una vez allí tomar el bus que requiera. Todos estos cambios significan tiempo y recursos invertidos. Las posibilidades de acceder de forma igualitaria en cuanto a trabajo, oportunidades o servicios, no puede ser la misma para una habitante que tarde mas de una hora en legar al centro o una hora y media a u centro de negocios de la ciudad.

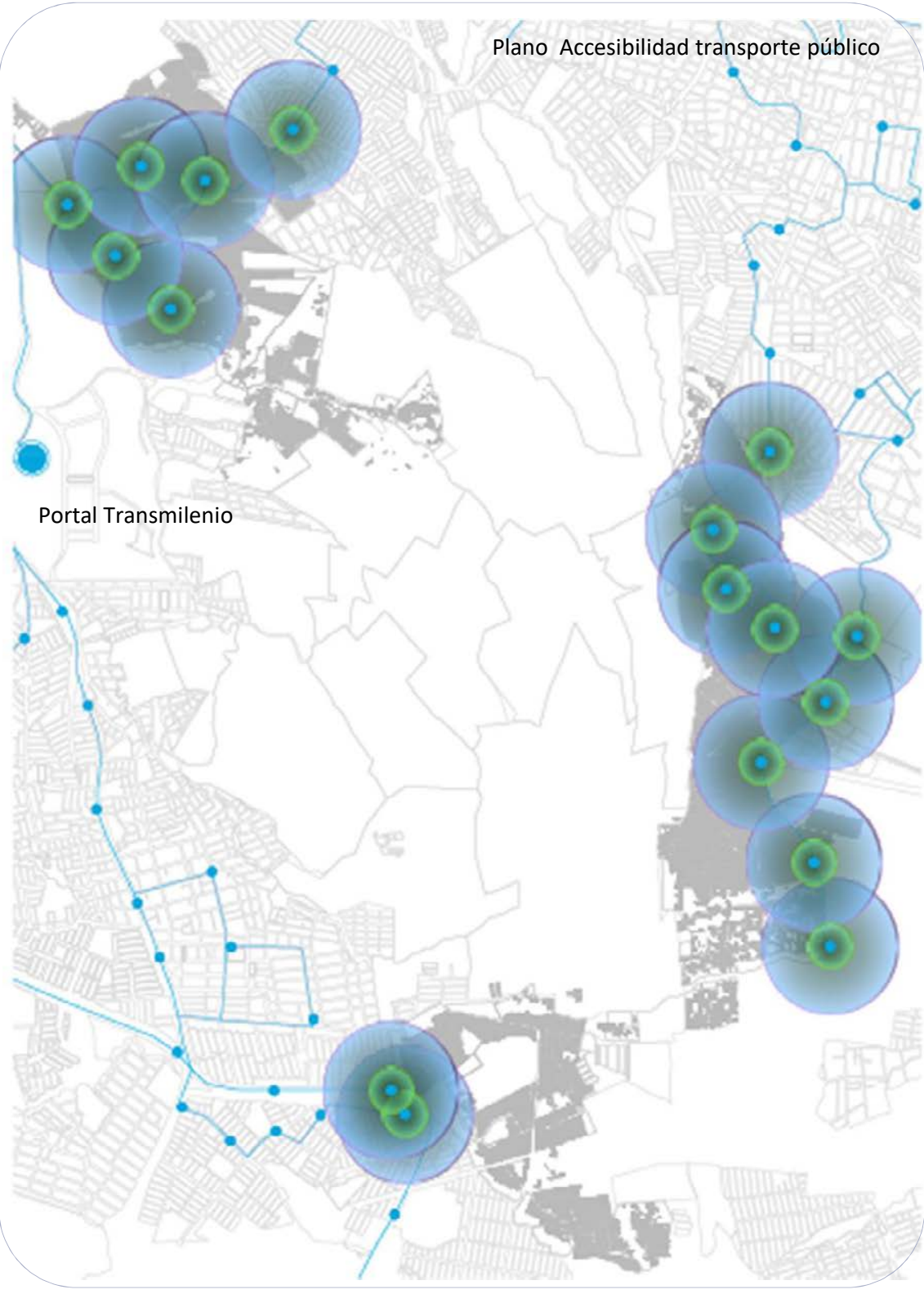

Tipología Paradas de autobuses
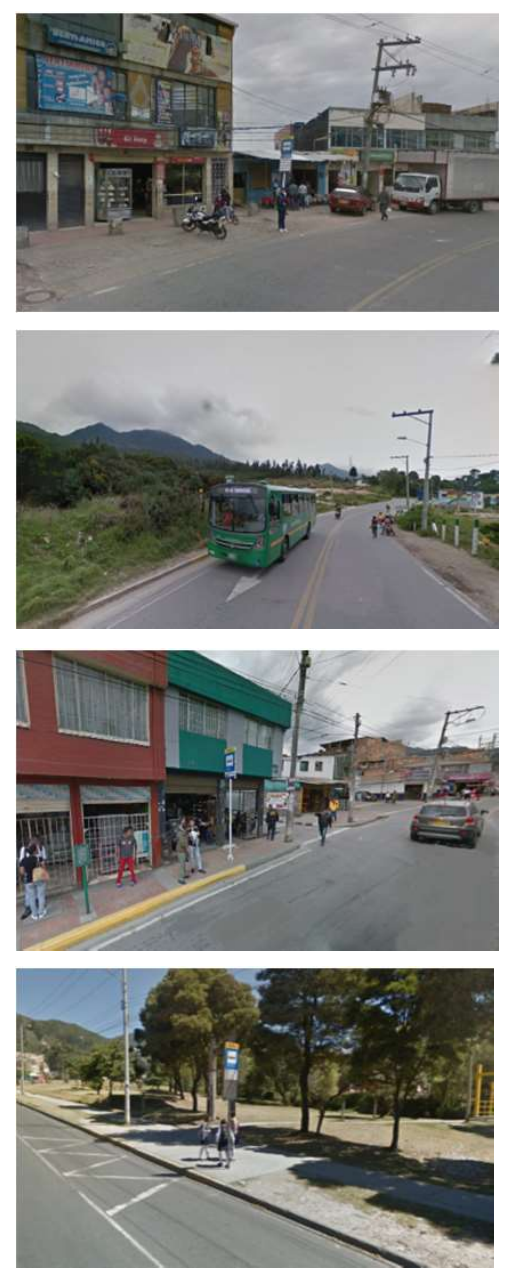
Pendiente

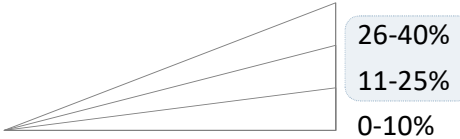

Acceso a escala de ciudad
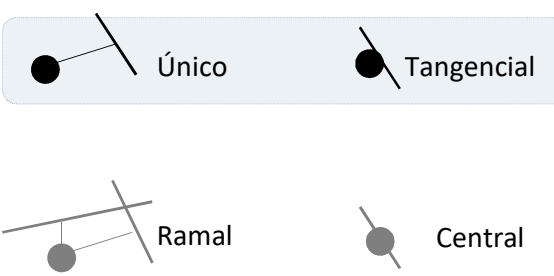

Conexión a escala de barrio
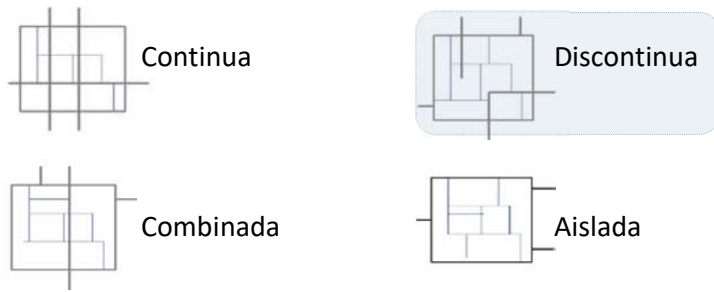
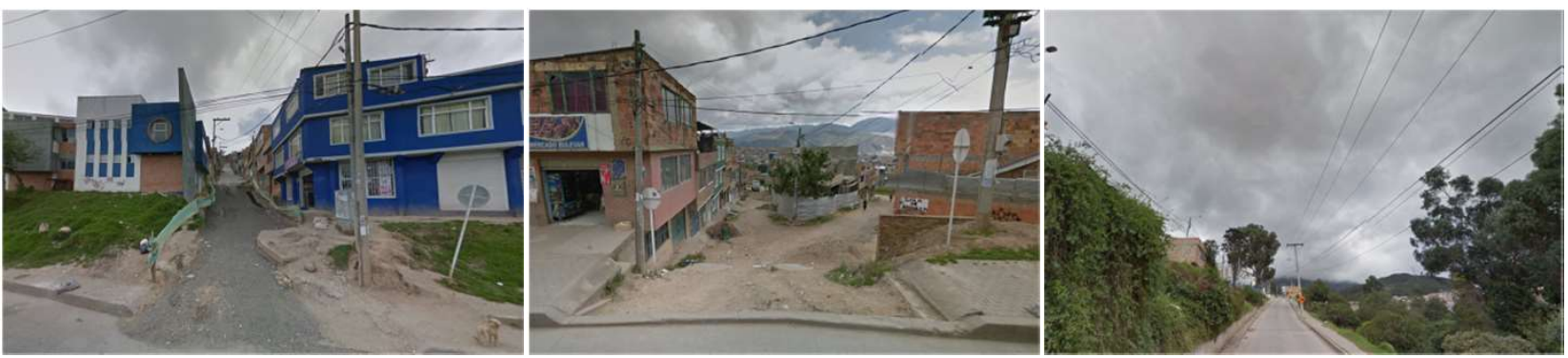

Conexión calles vehiculares

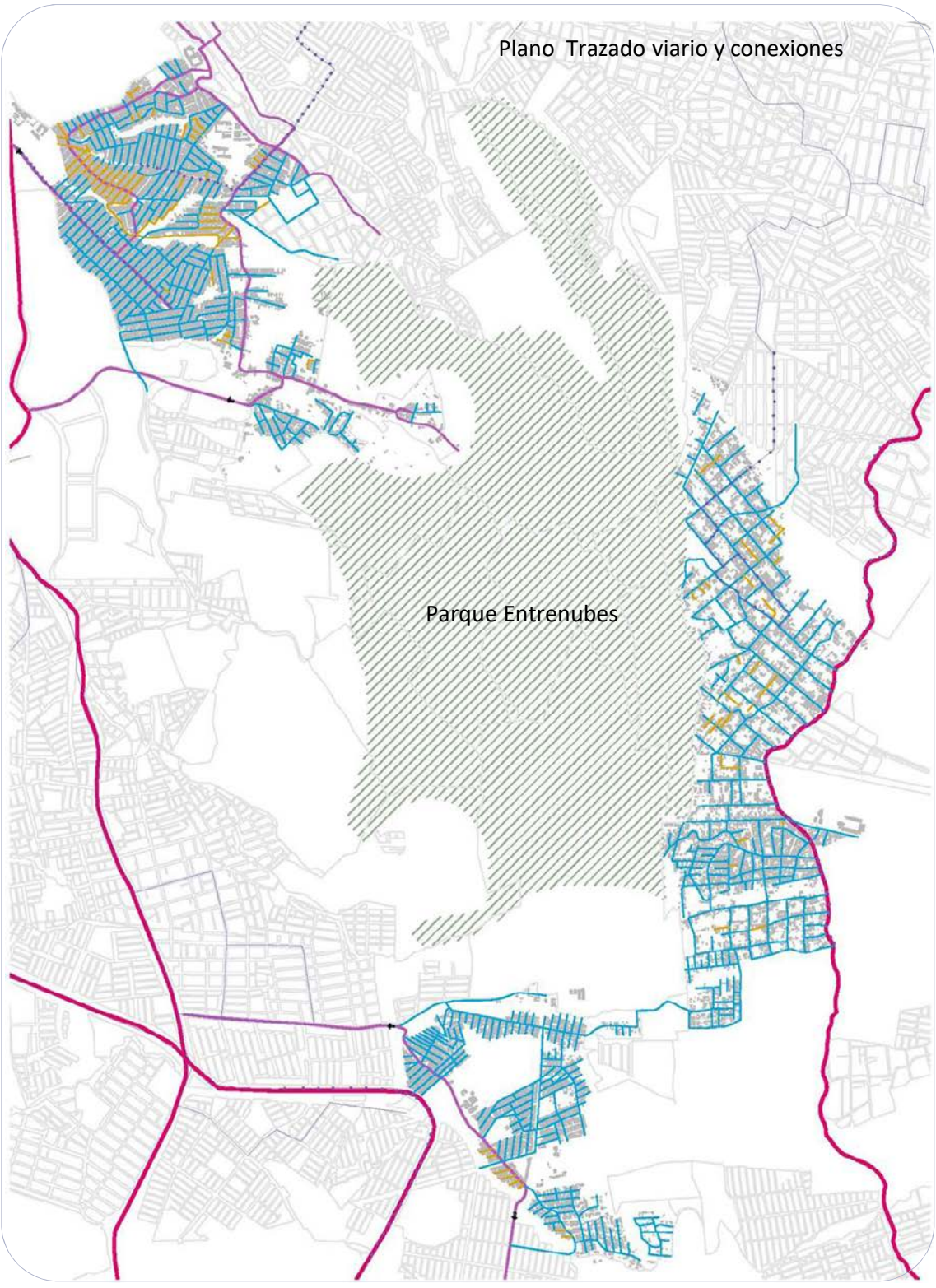

El proyecto Sur Con Bogotá, en cualquiera de sus tres zonas, se encuentra conectada a la ciudad por medio de una única vía principal. De ella a su vez se desprenden las vías locales en forma de ramal.

Dicha única conexión hace los trayectos de los habitantes de unas distancias considerables y les genera un aislamiento con el resto de la ciudad.

Hay que señalar adicionalmente que las tres zonas se encuentran separadas entre sí por el Parque Entrenubes, el cual cuenta con una topografía abrupta. 


\section{VÍA VEHICULAR}

Pavimentada

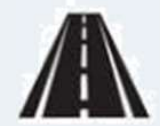

$67,77 \%$
No Pavimentada

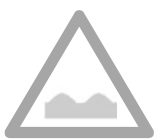

$32,23 \%$

VÍA PEATONAL

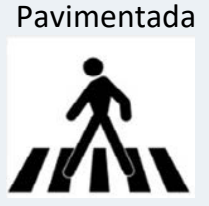

$62,65 \%$
No Pavimentada

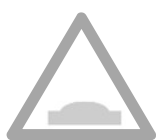

$37,35 \%$

Es estado de las vías en el proyecto Sur Con Bogotá es, en términos generales, bastante deficiente. Poco mas de la mitad de las vías vehiculares o peatonales están pavimentadas. No obstante, hay que reconocer que allí en donde se han mejorado el estado de las mismas o se han pavimentado por primera vez la ejecución se ha intentado hacer con todos las especificaciones de diseño, dimensiones y materiales que la Cartilla de Espacio Público de la ciudad de Bogotá contempla.

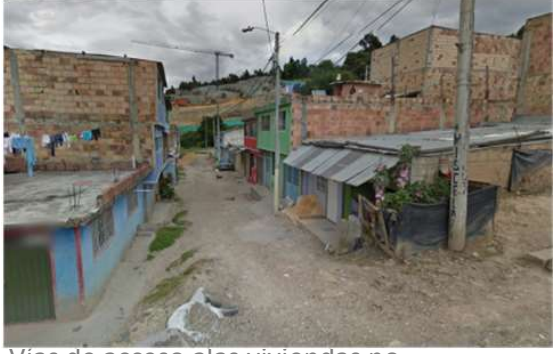

Vias de acceso alas viviendas no pavimentadas

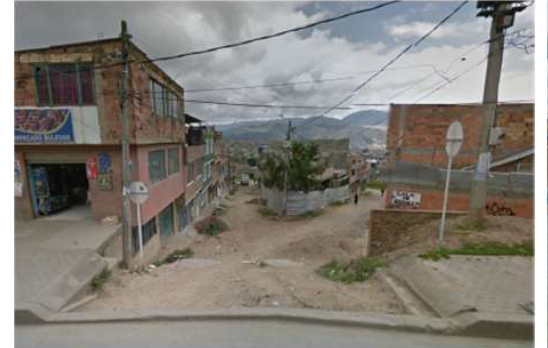

Vía principal pavimentada y vías secundarias no

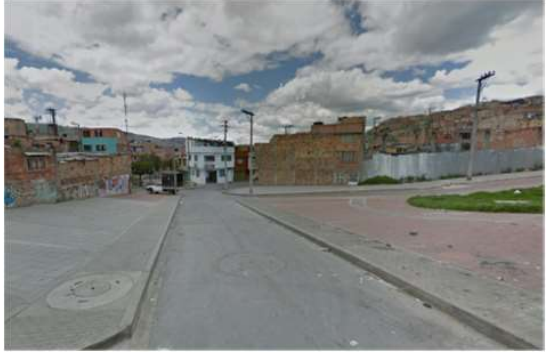

Vía construidas en el mejoramiento

\section{EQUIPAMIENTOS ESCALA BLOQUE-VECINDARIO}
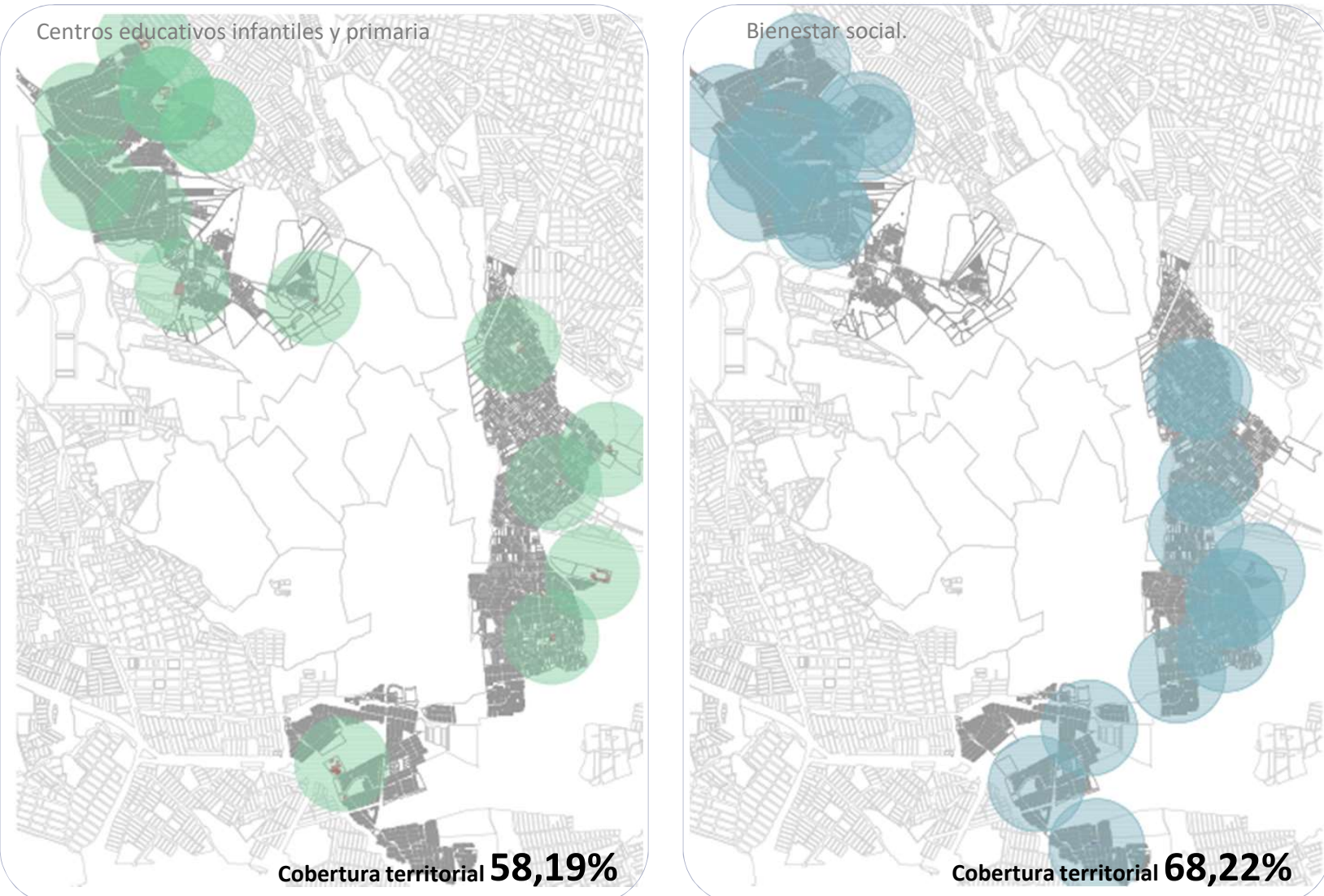


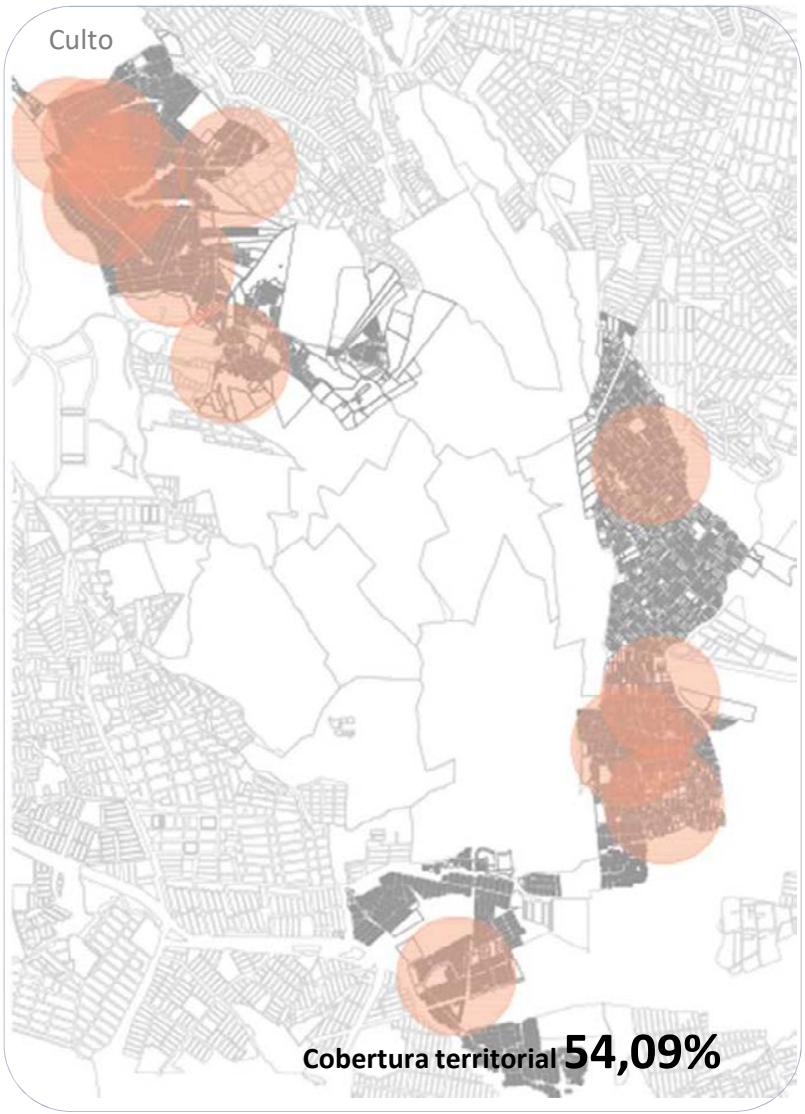

\section{Centros educativos}

La cobertura de los centros educativos a nivel territorial es apenas eficiente a nivel de educación primaria e insuficiente a nivel de secundaria. No sobra señalar que esta cobertura no es constante en las tres zonas: la zona de Ladrilleras, la que mas consolidada esta de las tres, es la zona con mejor cobertura. La zona de Bolonia, la menos consolidada y mas reciente en su formación, es la que peor cobertura tiene en todos los tipos de equipamientos y de comercio.

\section{Centros de bienestar social}

Este tipo de equipamiento es el que mas se construye en cualquiera de las tres zonas. Su explicación se debe a que ésta es generada por la propia comunidad en un intento por compensar aquellos equipamientos que el Estado aun no les ha construido en la zona. Bajo este tipo de edificaciones se encuentran comedores sociales, jardines infantiles, salones comunales, casa vecinales o casas de encuentro.

\section{Centro de salud}

Con respecto a los centros de salud, estos son casi inexistentes en todo el proyecto. Existen dos pequeños centros de atención de día en la zona de Ladrilleras y absolutamente nada mas. La población debe, en caso de urgencia, recorrer grandes distancias para llegar al hospital mas cercano.
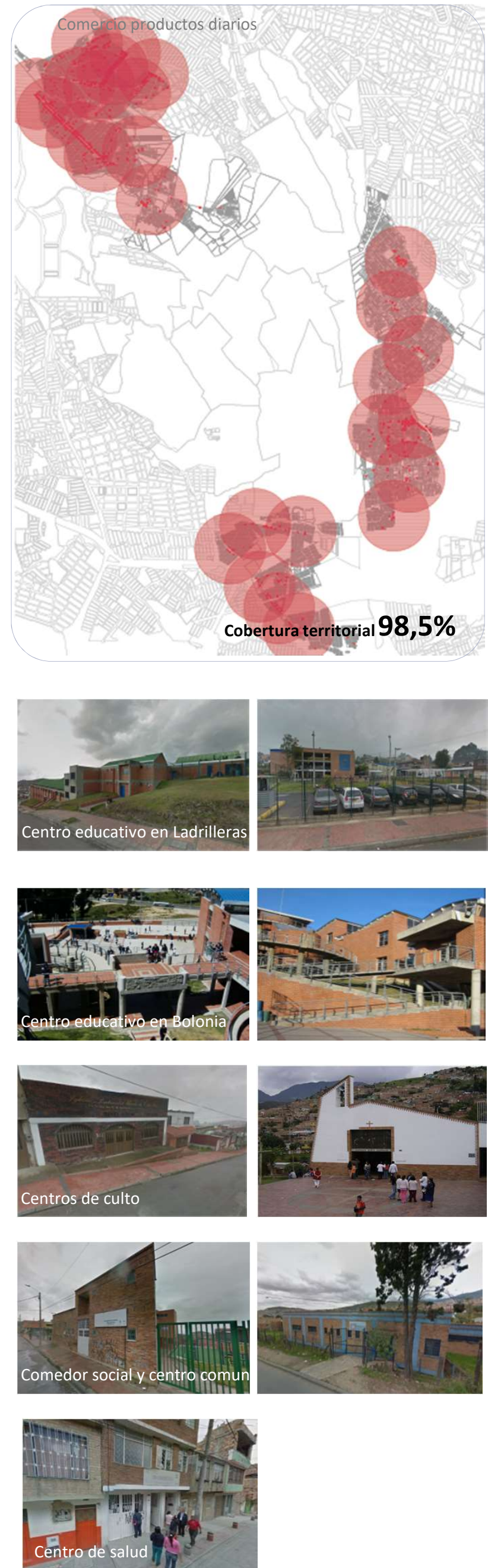

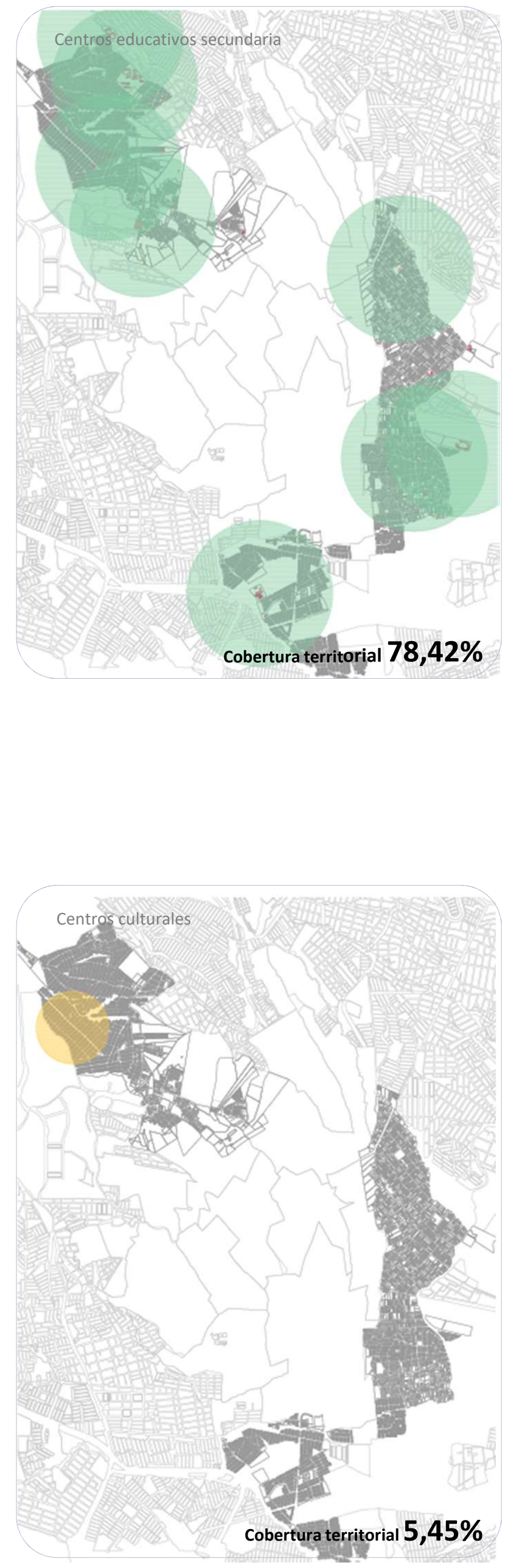

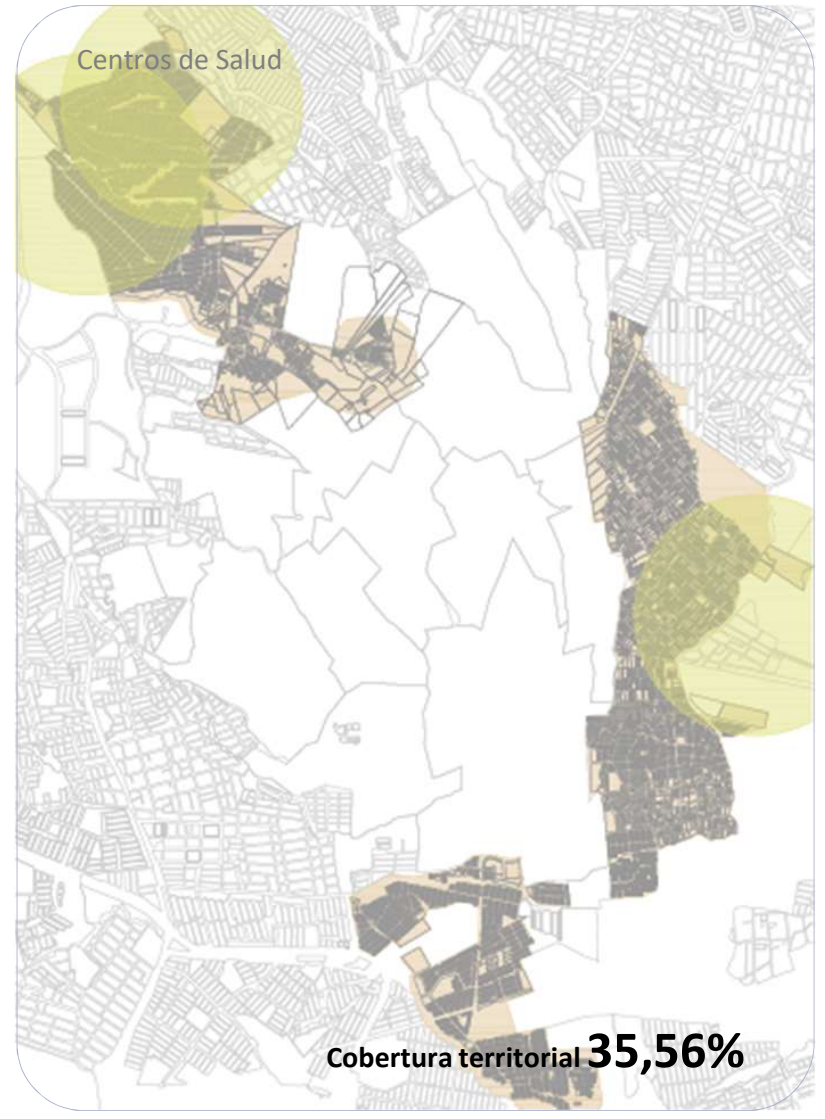

\section{Comandos de atención inmediata}

Estos equipamientos de seguridad, denominados comúnmente en Colombia: CAI, son unidades policiales estratégicamente ubicadas en los perímetros urbanos para vigilar sectores con mayores posibilidades de problemas de orden público. Su creación y ubicación esta determinada para "contar con una adecuada, inmediata y oportuna capacidad de respuesta".

En el Proyecto las tres zonas cuentan con este tipo de equipamientos, especialmente Ladrilleras en donde hay zonas con un Cai cada 500mts.
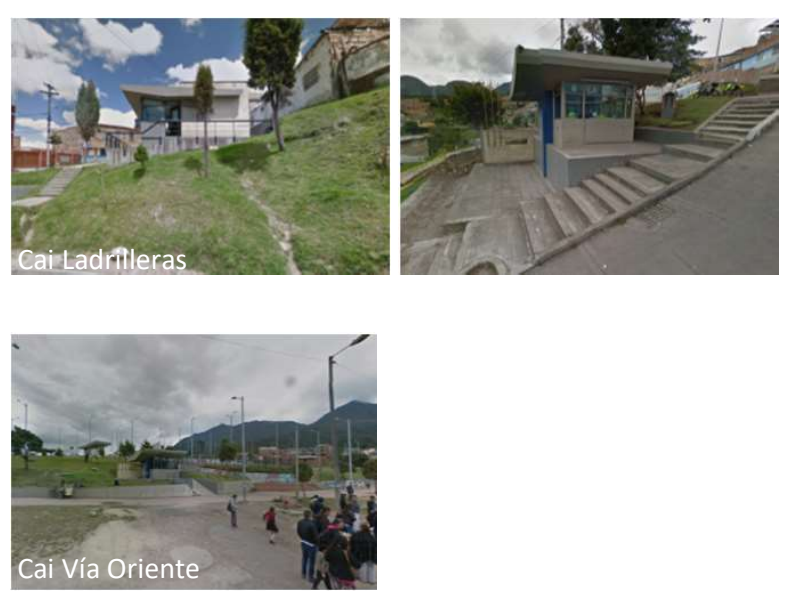


\begin{tabular}{|l|l|}
\hline$>300 \mathrm{mts}$ & $<100 \mathrm{mts}$ \\
\hline
\end{tabular}

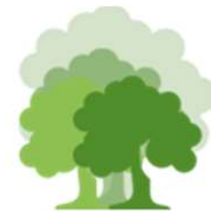

Accesibilidad baja 11,15\% Accesibilidad media 45,07\% Accesibilidad alta 43,78\%

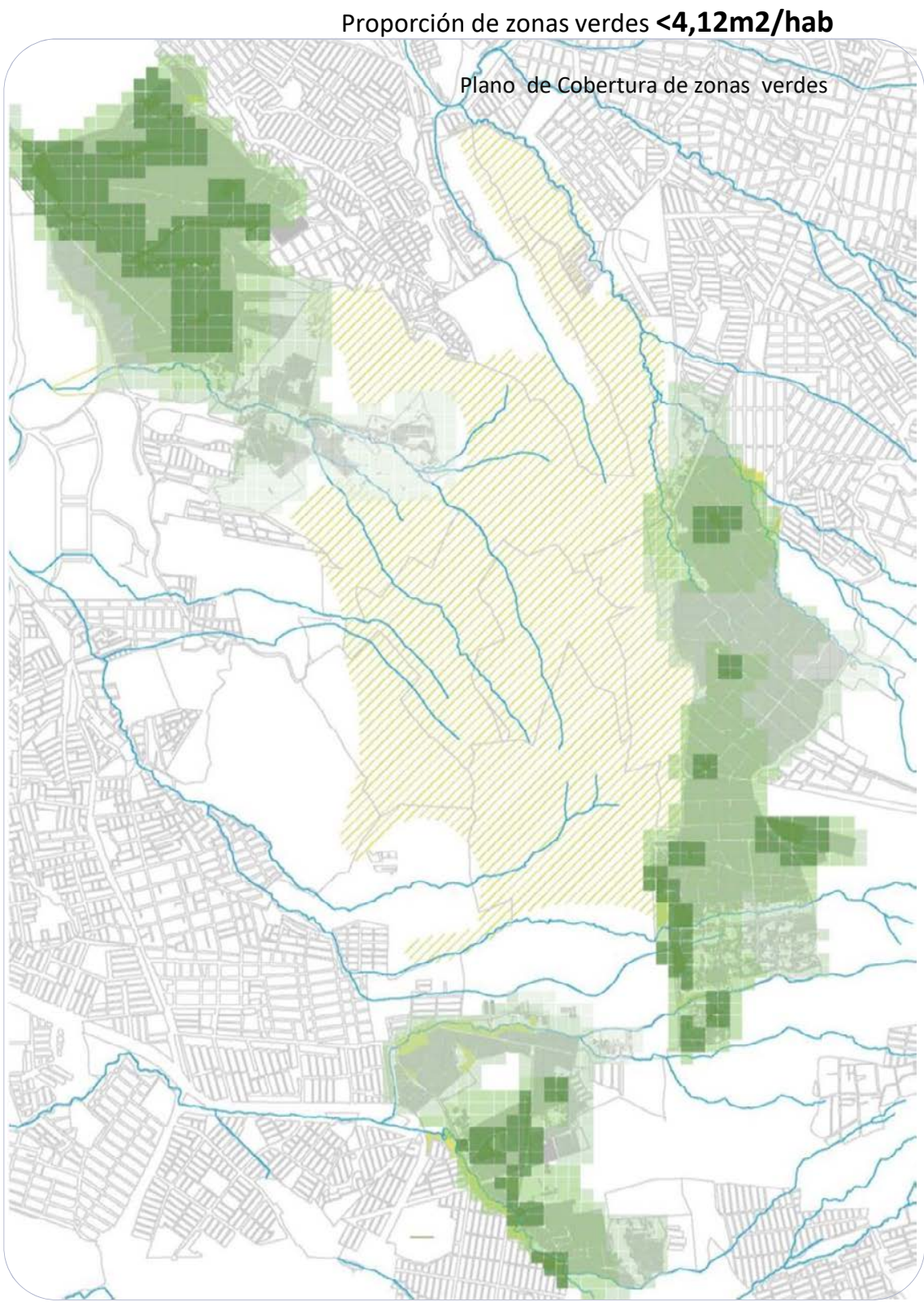

Una de las mayores intervenciones que se ha realizado a nivel de espacio público en el proyecto Sur Con Bogotá es en la construcción diversas zonas verdes, plazas o zonas recreativas.

El déficit en espacio público efectivo de la zona sur de la capital era de suma importancia. Se contaba con tan solo 2,51m2/hab. Con la ejecución del proyecto se alcanzaron niveles nunca antes obtenidos en estas zonas de la ciudad.
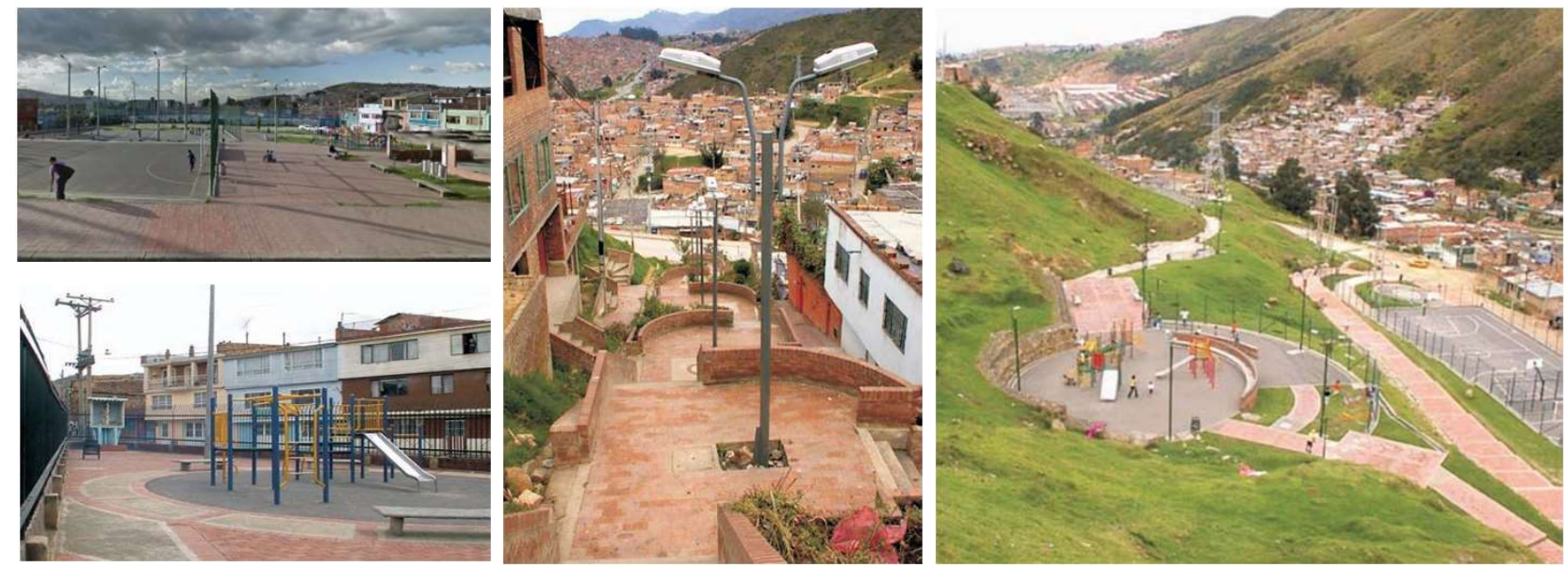


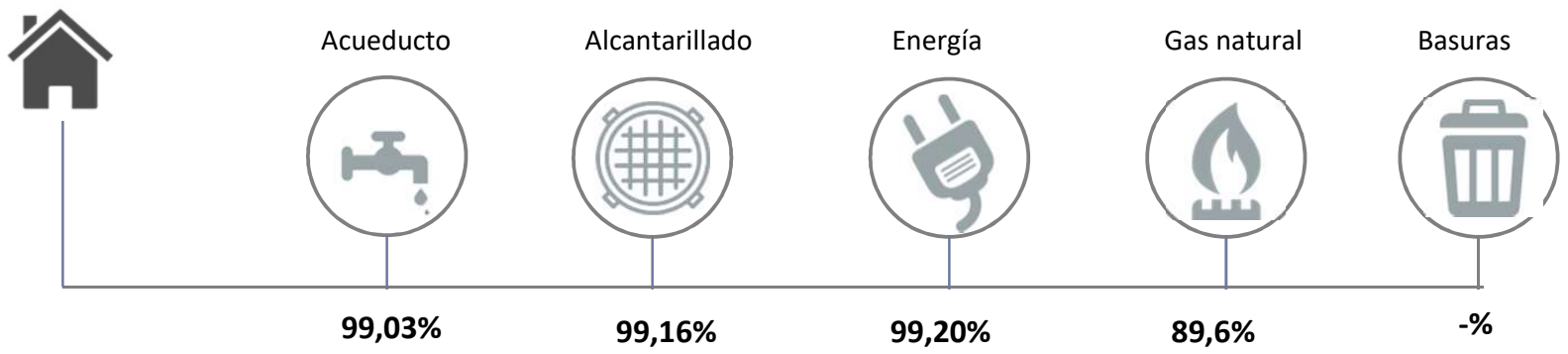

La cobertura de servicios domiciliarios, como se ha mencionado para la ciudad de Bogotá, es bastante completa. Así lo es para el proyecto Sur Con Bogotá. Los servicios de agua, electricidad y alcantarillados están prácticamente garantizados para toda la población. El gas natural, a su vez, si bien no tiene una cobertura del $99 \%$ o del $100 \%$, si tiene una cobertura alta. No llega aun a aquellas zonas de canteras o consolidación media o baja de reciente ubicación.

Con respecto al servicio de la recogida de basuras, no se encontraron datos específicos pare el proyecto. Con los recorridos a las zonas, sin embargo se pudo observar que existen problemas con los centros de acopio y con la limpieza de las calles o las parcelas baldías.

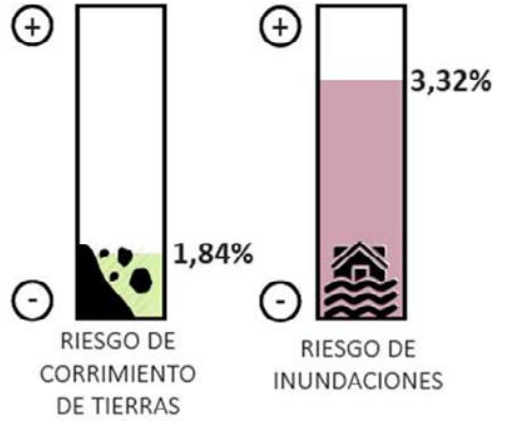

I11 Morfo-tipología

Conjunto habitacional y vivienda
Estabilización de laderas - recuperación de una zona erosionada Con el proyecto se recuperan 5 hectáreas de ladera para mitigar los riesgos de deslizamiento de tierras en zonas donde esta ubicada la población. Para ello se construyen algunos taludes o se reubican a las familias en otras zonas de la ciudad.

\section{Recuperación ambiental: arborización de rondas y zonas erosionadas}

En el proyecto se propone la recuperación de $\mathbf{9}$ has de las quebradas de Bolonia, Santa Librada, El Muerto, Verejones, Nutria y Olla del Ramo. Adicionalmente, se promueven actividades de capacitación de la comunidad sobre el manejo y la normatividad de las rondas de quebrada. Para ello se permite a la comunidad participar en el diseño de las zonas verdes residuales.
Unidades habitacionales construidas

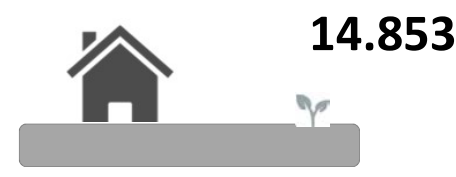

Viviendas unifamiliares

Número de parcelas
Ocupación de la manzana y tipología de la vivienda

El proceso de ocupación en Sur con Bogotá es de origen marginal (o ilegal) en toda su extensión, salvo por algunas parcelas propiedad del Estado en donde se encuentran los equipamientos educativos. La mitad del territorio es de tipo clandestino y la otra mitad de invasión.

Dicha ocupación tiene una relación directa con el proceso de configuración de las parcelas y las viviendas, la mayoría son de carácter orgánico adecuándose a las condiciones topográficas del territorio.

Con respecto a las edificaciones, todas las viviendas son de baja altura (aun cuando en su desarrollo progresivo pueden llegar a alcanzar hasta 5 niveles). Los materiales con los que están construidas estas viviendas son en su mayoría estables ( ladrillo, hormigón, piedra, etc), especialmente en la zona de ladrilleras. 


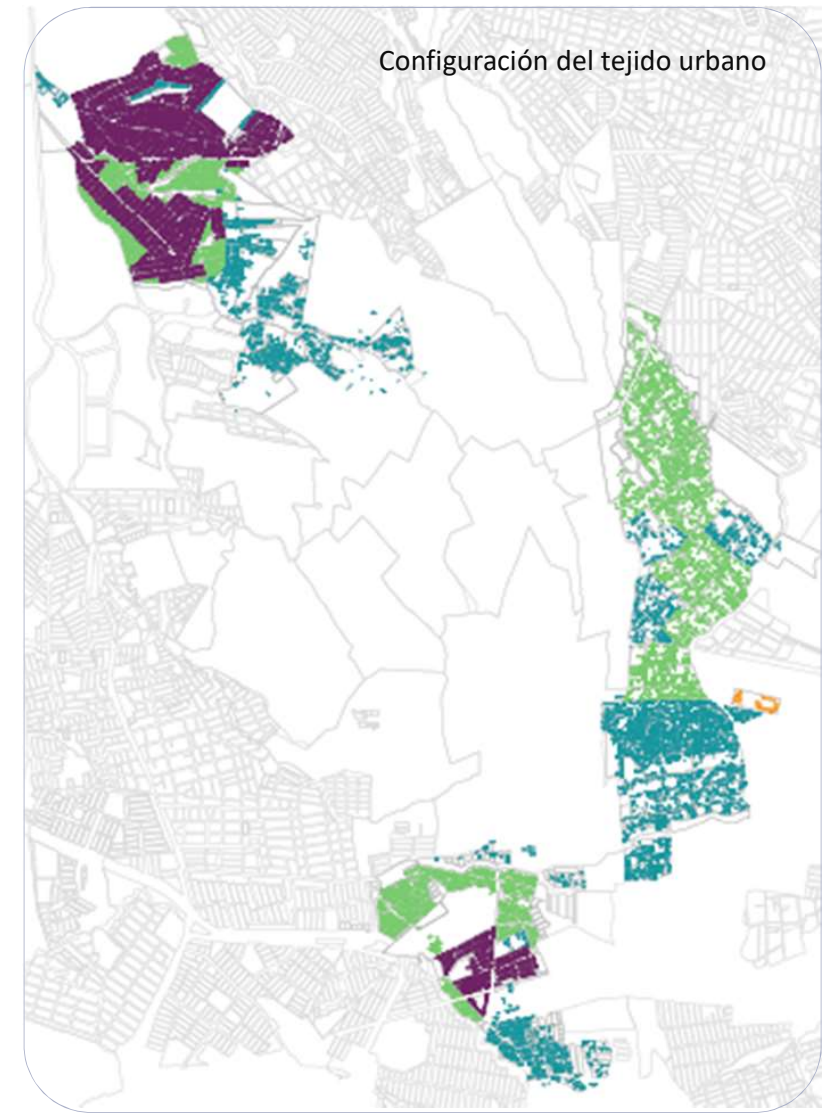

Marginal Mixto Oránico Peticular Orgánico Mixto $O$ Reticular

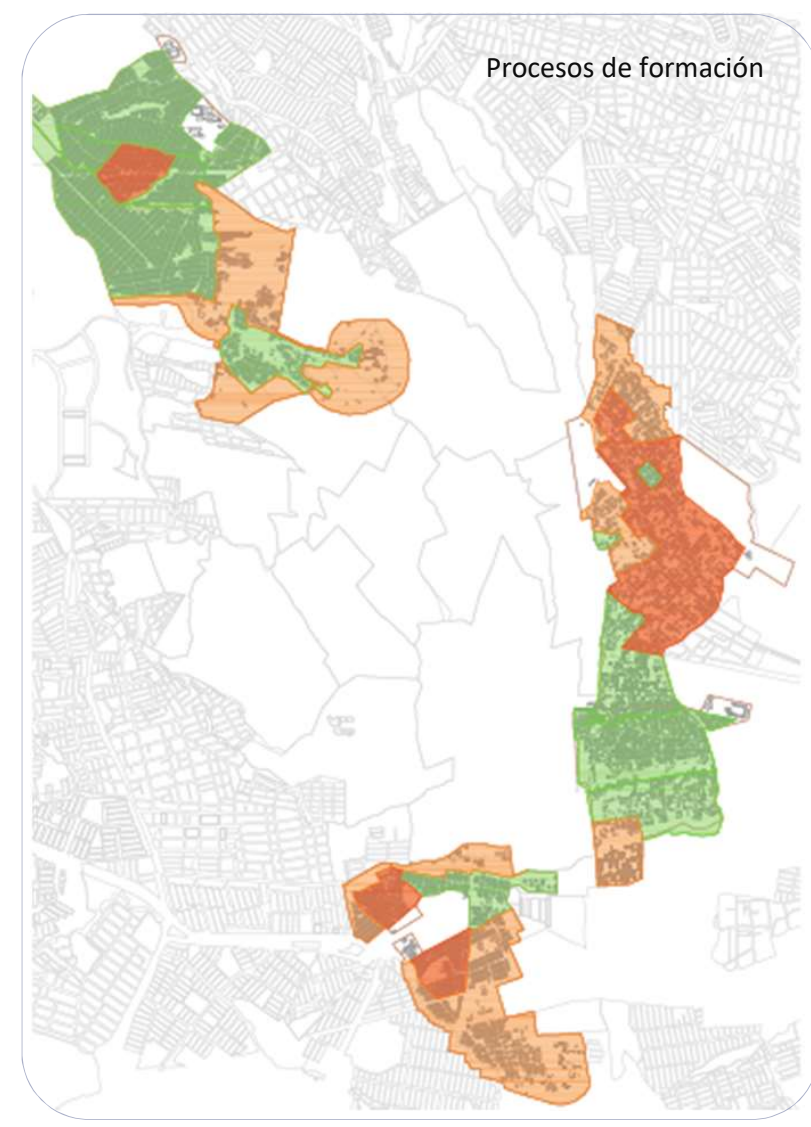

Clandestino Invasión Invasión

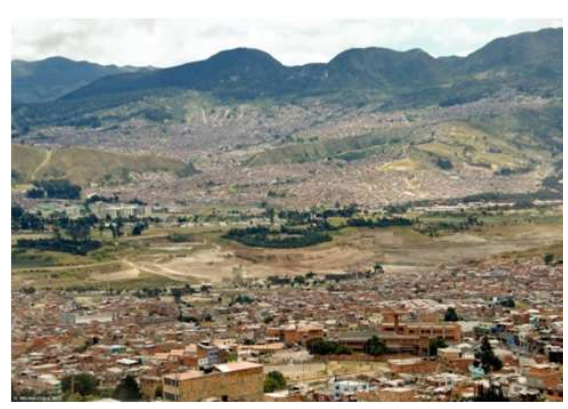

Sector Ladrilleras
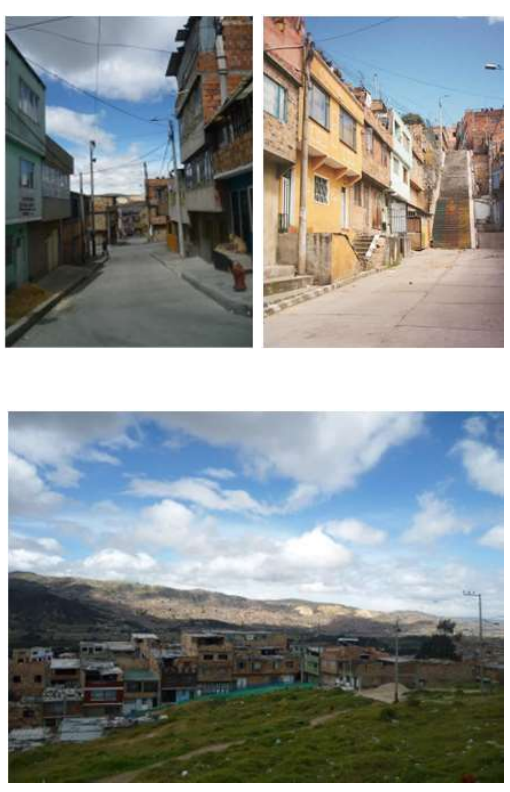
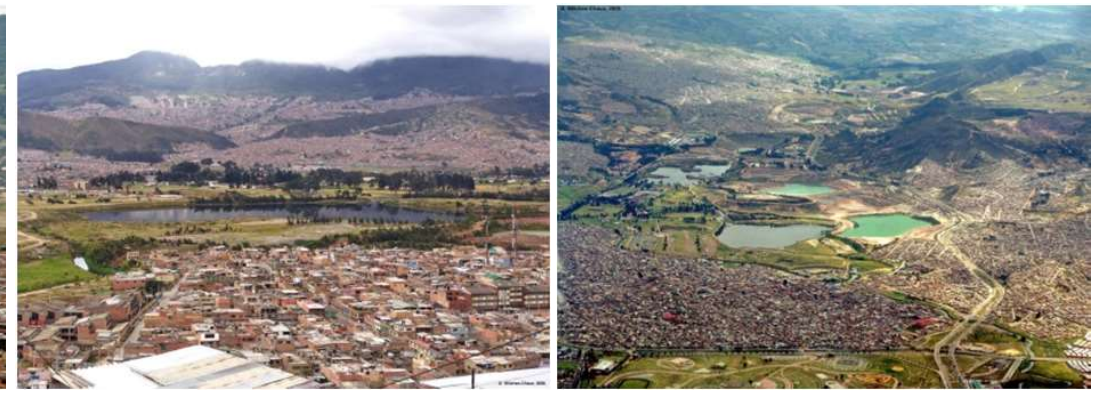

Sector Bolonia
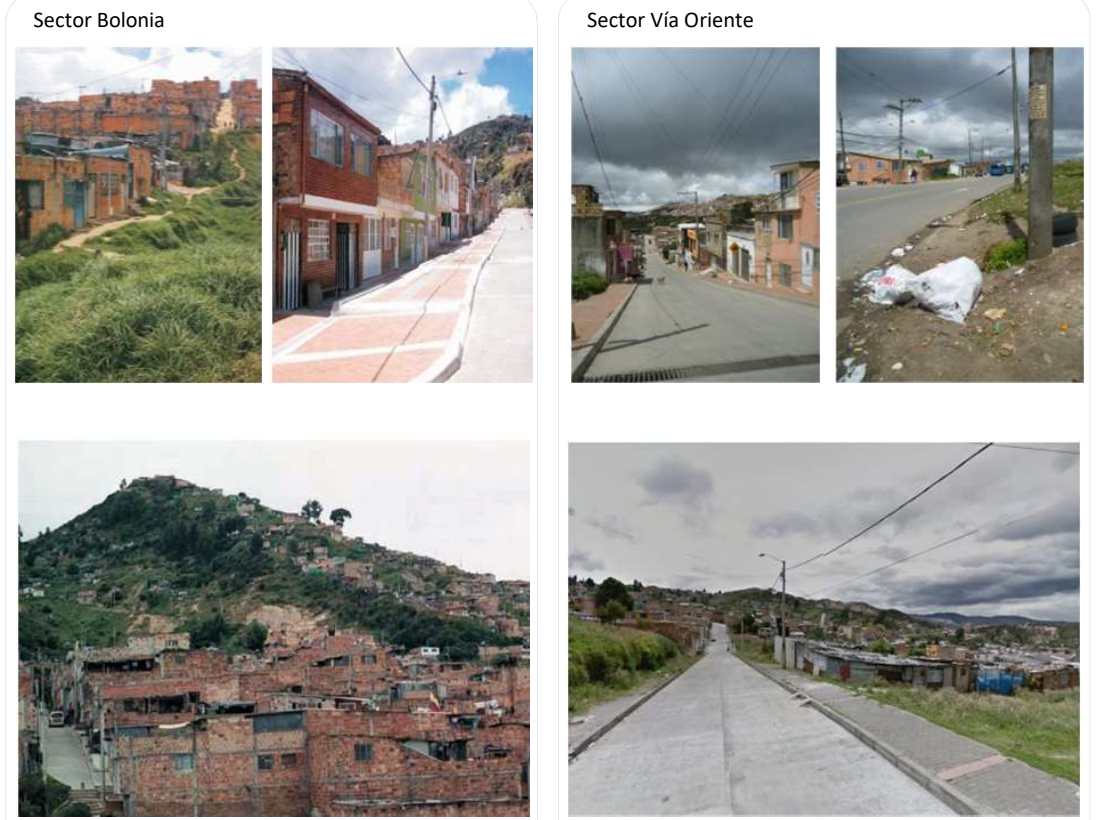


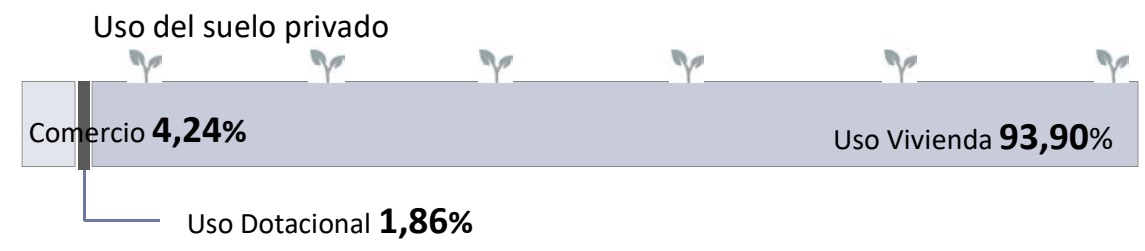

El Proyecto Sur Con Bogotá, como la mayoría del territorio de origen marginal de la capital presenta un alto porcentaje de uso residencial y un muy bajo porcentaje de uso dotacional. Las zonas de comercio de productos diarios, en cambio, se encuentran relativamente proporcionada en el territorio. Estas edificaciones comerciales han sido todas desarrolladas por la propia población, en la parte delantera de sus viviendas $u$ ocupando toda su parcela. Dicho uso ha configurado la jerarquía de las vías y las propias centralidades.

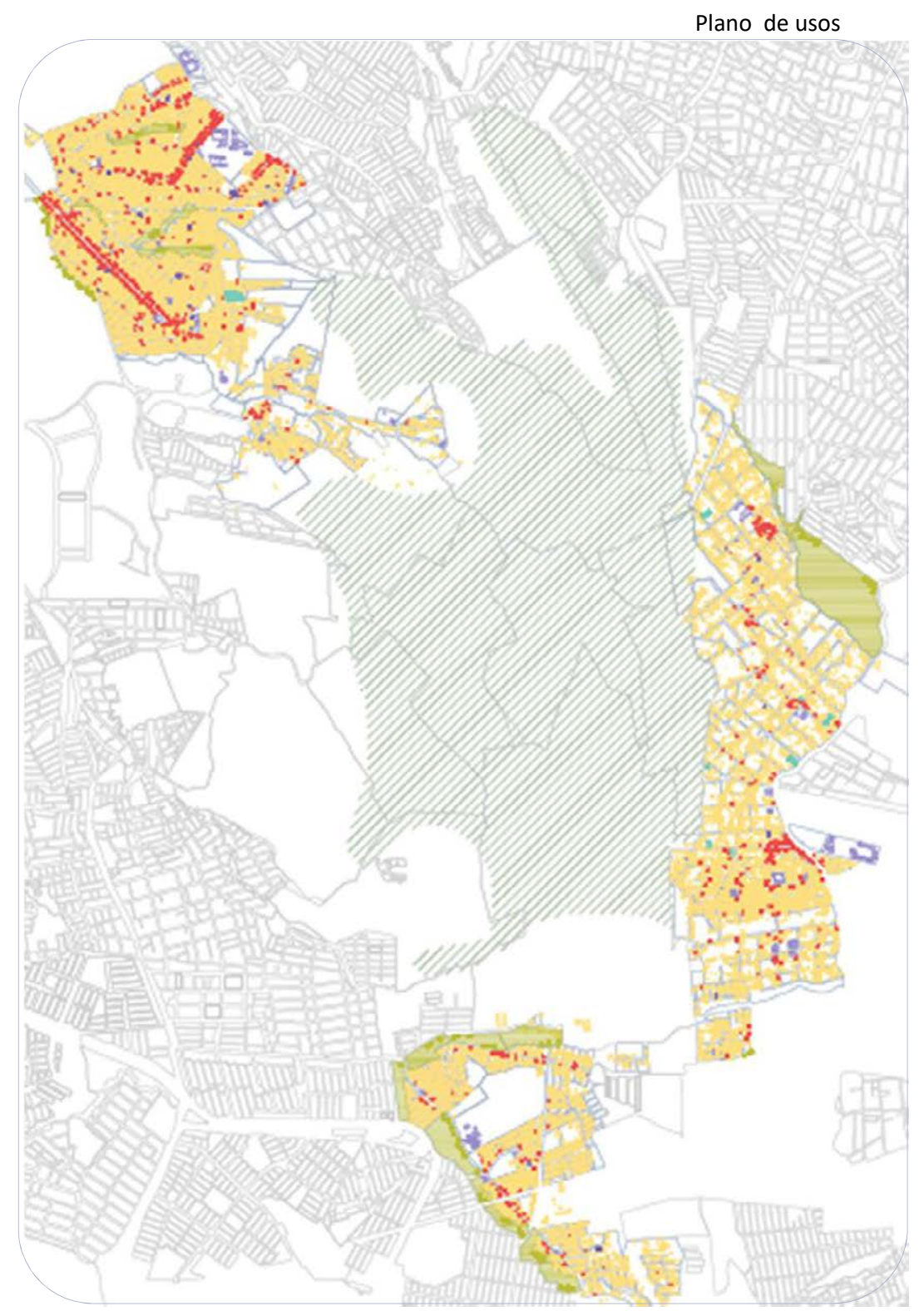

\section{Mezcla de rentas}

La población objeto del proyecto Sur con Bogotá en su mayoría es de estrato socioeconómico 1 y 2 (sus condiciones económicas son relativamente bajas: ingresos familiares hasta $3 \mathrm{smmlv}$ ). Aun después de la intervención, presenta un déficit importante en su calidad de vida, en los procesos de organización comunitaria y en el grado de satisfacción por las condiciones de su territorio.

El origen de la población es diverso: Hay población desplazada, población propia de la ciudad que se ha asentado allí por voluntad o por falta de oportunidades o posibilidades y población de otras ciudades o del campo que solo ha podido llegar a instalarse en esta zona de la ciudad.

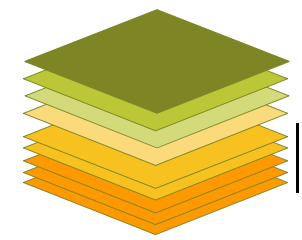




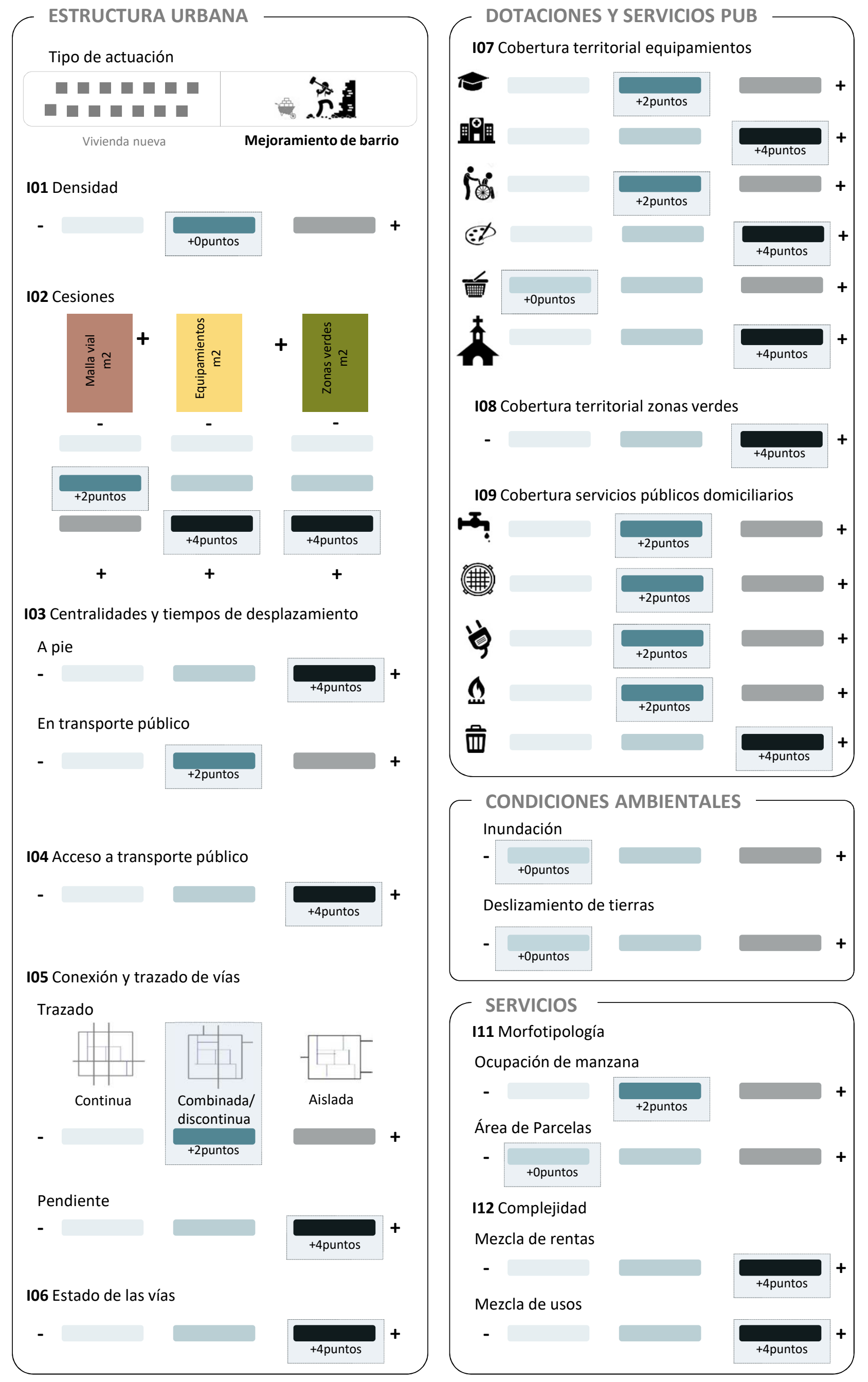




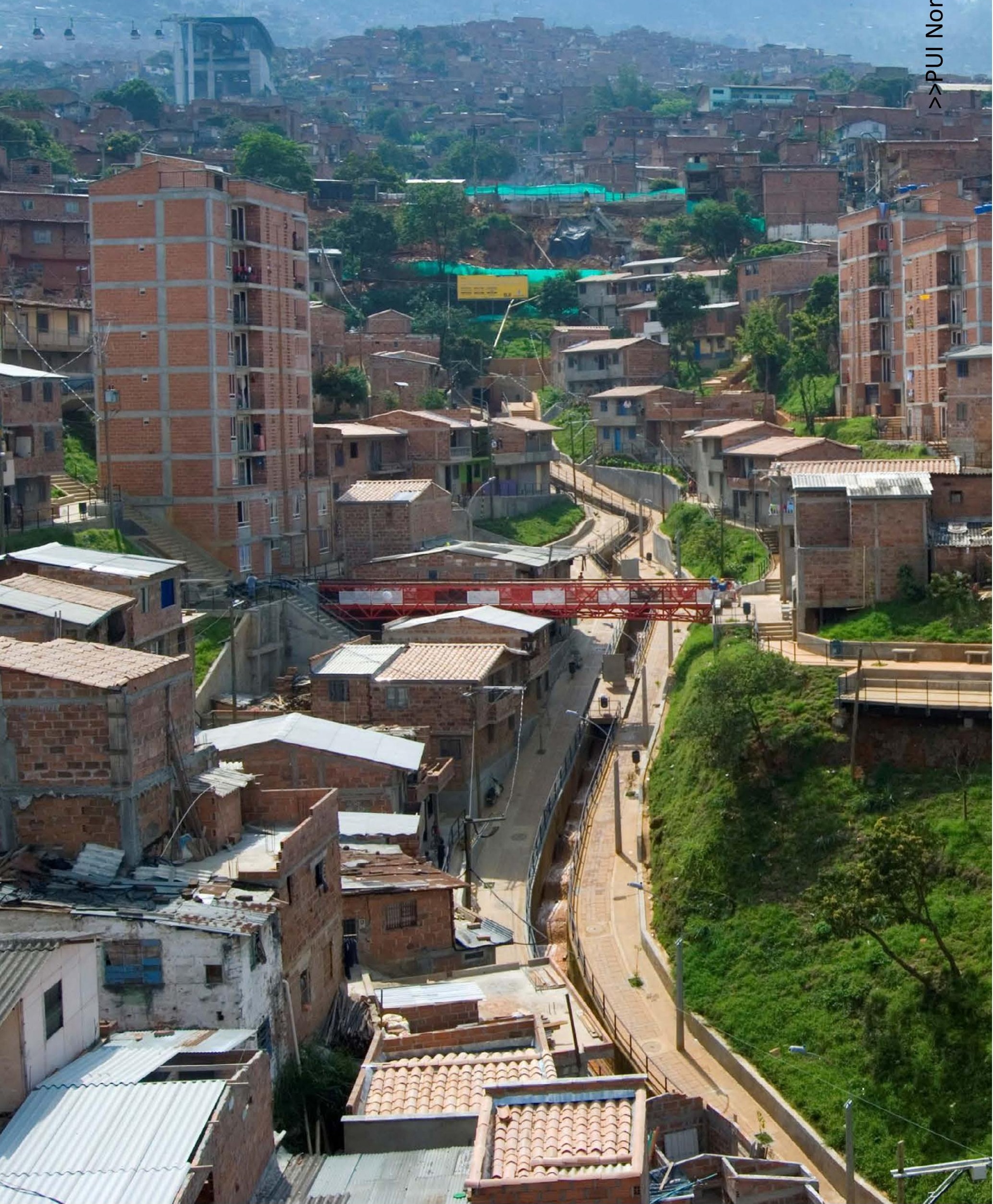




\section{PUI Nororiental - Medellín}

El Proyecto Urbano Integral Nororiental fue un plan de intervención urbana, del año 2004 al 2007, que contemplaba acciones físicas, sociales e institucionales con el objetivo de resolver las problemáticas territoriales de esta zona marginal de la ciudad de Medellín (comuna 1 y 2 ). Su elección obedecía a la identificación de la zona por tener los más bajos índices de calidad de vida (ICV), índices de desarrollo humano (IDH) y el mayor número de homicidios para inicios del año 2000. Su objetivo era, aprovechando la construcción de metrocable ${ }^{130}$, realizar una intervención integral que mejorara las condiciones de movilidad y a su vez, recuperara el espacio público, construyera equipamientos y adelantara proceso de regularización y mejoramiento del entorno, la vivienda y la condición de vida de los habitantes.

El proyecto benefició a más de 150.000 habitantes de estrato socioeconómico 1 y 2 de once barrios de las dos comunas nororiental. En él se construyeron equipamientos colectivos tales como el parque biblioteca España, depósitos de buses, estaciones de policía, salas de navegación por Internet, un centro de desarrollo empresarial (CEDEZO), la adecuación y mejoramiento de determinados comedores escolares, centros de salud, centros educativos y escenarios deportivos como la cancha de futbol granizal. También se adecuaron los espacios públicos con la construcción de 14 plazas y plazoletas (se pasó de $1 \mathrm{~m}^{2} / \mathrm{hab}$. a 1,48m²/hab.). Se realizaron acciones en conservación, rehabilitación y prevención ambiental (Incremento del 991.56 \% en nueva arborización, de 154 a 1.527unidades). Y finalmente se promovió la continuidad en la movilidad peatonal a partir de la conexión entre vías (4 paseos peatonales $23.893 \mathrm{~m} 2$ ) y la construcción de 4 puentes peatonales.

En el componente social, además se contó con la participación comunitaria, a través de Talleres de Imaginarios, para involucrar a la población en la formulación de los proyectos: desde la identificación de problemas hasta la aprobación de los mismos. Durante la intervención, se crearon también algunas plazas de trabajo temporal en cada obra de construcción para subsanar la carencia de oportunidades laborales de la población.

Finalmente, en el componente interinstitucional se intentó coordinar y articular las diferentes acciones de todas las dependencias del municipio: las secretarías municipales y los entes descentralizados, para la realización de las diferentes labores. Así mismo, se promovió alianzas intersectoriales con el sector privado, las ONG, los organismos nacionales e internacionales y las diferentes organizaciones comunitarias.

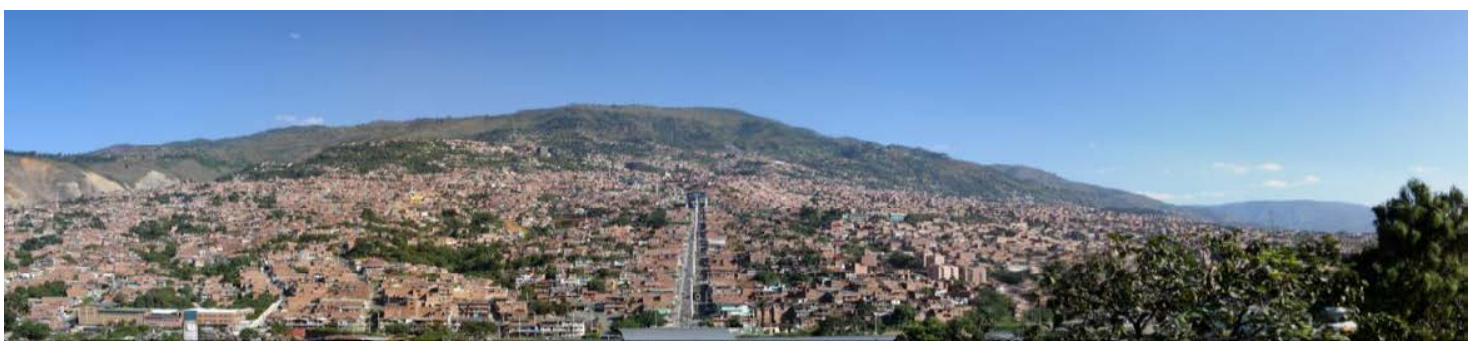

${ }^{130}$ Con la construcción del metrocable la administración esperaba que: “ se modificaran las condiciones socioeconómicas de los habitantes de la zona pues los desplazamientos que realizarían las personas demandarían menos tiempo y menos costo. [... ] Este sistema de transporte establecería una fuerte presencia en el territorio por parte de la administración, regularía las formas de relación con el paisaje y fomentaría hábitos de vida cotidiana mejorando la calidad de vida de las comunidades. (EDU 2011:54) 


\section{Localización}

El Proyecto Urbano Integral Nororiental está localizado en un sector periférico de la ciudad de Medellín en las comunas 1 y 2 . Abarca una superficie de 184 hectáreas extendidas a lo largo del área de influencia de las estaciones del metrocable ${ }^{131}$ (Andalucía, Popular y Santo Domingo Savio). La zona inició su proceso de desarrollo en los años cincuenta con residencias informales de familias obreras $y$ grupos inmigrantes del área rural como consecuencia de los fenómenos de violencia. Su crecimiento, como consecuencia de dicha marginalidad, fue la de un territorio desequilibrado con una deficiente estructura vial, una baja cobertura de equipamientos y servicios y un escaso espacio público.

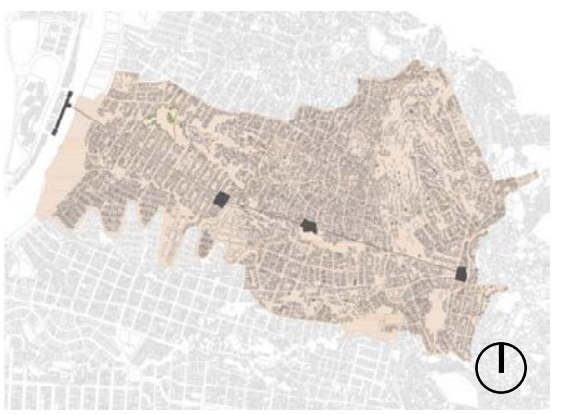

Sistema de metro de Medellín

\section{Área de intervención Andalucía}

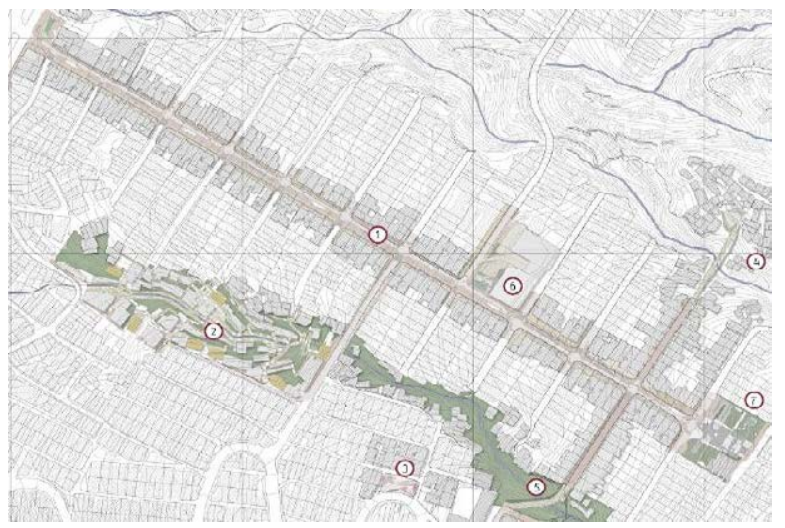

(1) Paseo urbano calle 107

(2) Consolidación habitacional Juan Bobo

(3) Parque de la Imaginación

(4) Puente Mirador

(5) Puente de la Paz

(6) Centralidad Andalucía

(7) Estación Andalucía

\section{Área de intervención Popular}

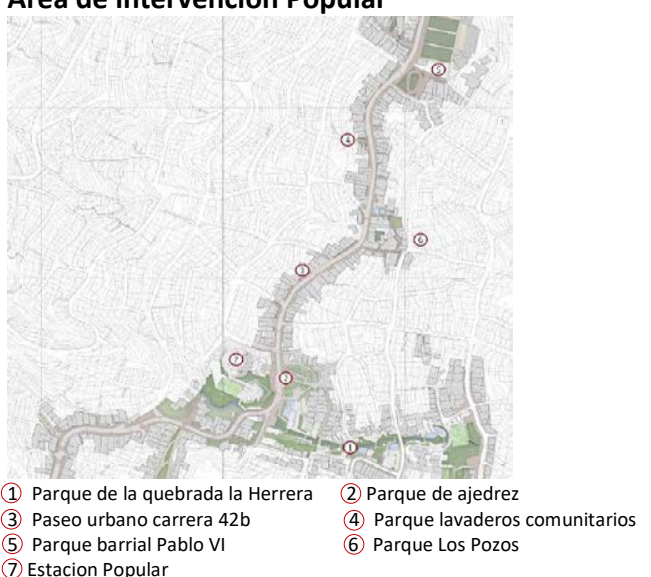

Área de intervención Santo Domingo

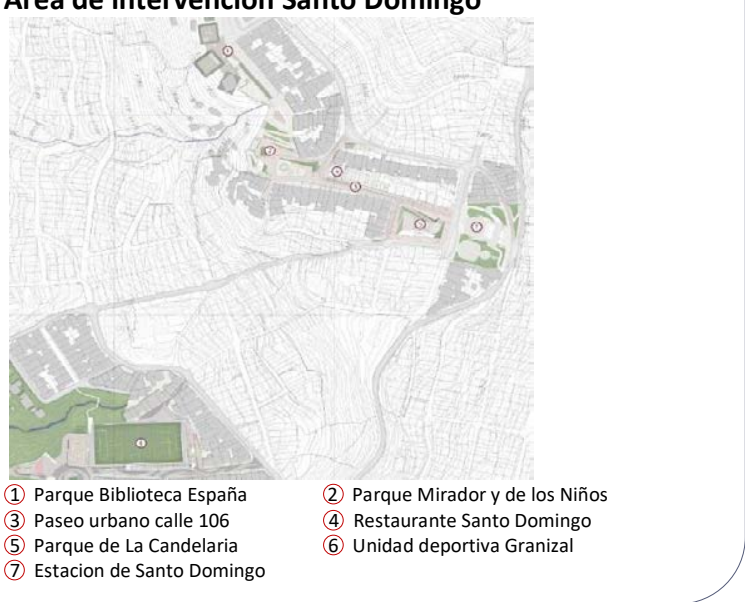

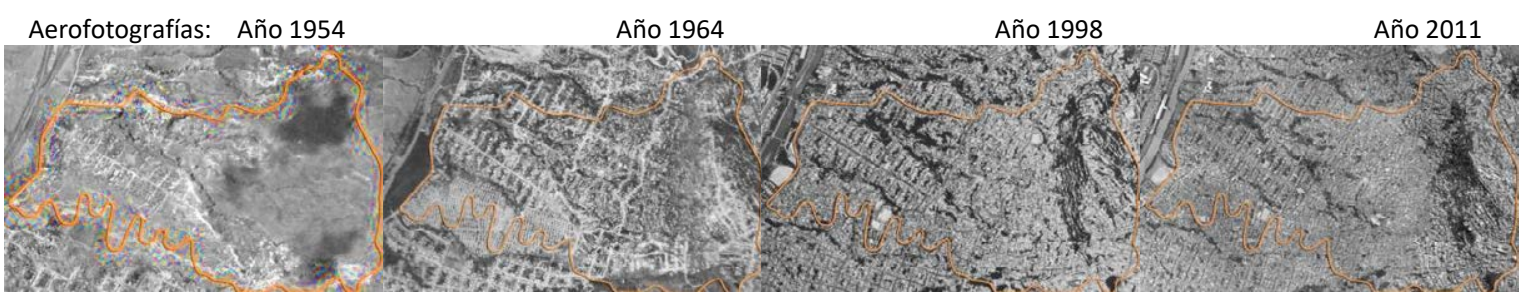

131 En 1999 el Metro de Medellín (Empresa de Transporte Masivo del Valle de Aburra) definió la necesidad de estudiar alternativas de expansión con sistemas de mediana capacidad. De igual forma el Plan de Ordenamiento Territorial -POT- (1999) incorporó en sus lineamientos el sistema de transporte masivo compuesto por el Metro y los corredores complementarios que ordenarían la movilidad y actuarían como estructurantes principales de la ciudad. En 1999 se presentó la alternativa de construir un sistema de cable aéreo que integraría al barrio Santo Domingo Savio con el sistema Metro, cerrando el anillo vial exterior propuesto para Medellín. (EDU 2011:53) 


\section{Modelo de ciudad propuesto y construido}

El modelo de ciudad propuesto para la zona de intervención se presentó bajo el Plan Maestro PUI Nororiental. En este se planteó dos grupos de actuaciones: uno denominado Mejoramiento del espacio público, movilidad y construcción; y el segundo Adecuación de servicios comunitarios. Su finalidad era generar directrices urbanas y arquitectónicas para el diseño y la ejecución del proyecto; éste modelo debía ser replicable en futuros proyectos de la ciudad.

Los objetivos fundamentales del proyecto fueron:

+Fortalecer las organizaciones comunitarias, a través de la capacitación de líderes, la realización de actividades informativas para la comunidad, de monitoreo y evaluación del proyecto.

+Promover adecuadas intervenciones del Estado, a partir de la conformación de un comité directivo municipal, la formación de mesas de trabajo con entidades públicas para lograr acuerdos con este sector, así como con el privado y académico y la gestión para la participación de las entidades nacionales y los agentes de cooperación internacional.

+Adecuar el espacio público, dándole nueva cualidad mediante el mejoramiento de calles y la construcción de parques y plazoletas.

+Fomentar la continuidad en la movilidad peatonal, a partir del plan de puentes peatonales y vehiculares.

+Adecuar nuevos equipamientos colectivos, con la construcción de bibliotecas públicas, depósitos de buses, estaciones de policía, salas de navegación y centros de desarrollo empresarial; con especial énfasis en el mejoramiento de algunos centros educativos, restaurantes escolares, centros de salud, y escenarios deportivos.

+Promover programas habitacionales, mediante la regularización, legalización, mejoramiento y construcción de edificios mixtos, vivienda de borde, vivienda en interior de manzana abierta y el plan terrazas.

+ Mitigar el desgaste del ambiente, por reforestación, adecuación de áreas para la educación ambiental, renovación de fauna y flora; la construcción de sistemas de recolección y tratamiento de aguas residuales, obras de control a la erosión, el manejo de residuos sólidos, la recuperación de corrientes de agua; y la reubicación de viviendas ubicadas en zonas de alto riesgo hidrológico, así como campañas de prevención, vigilancia y control sobre las cuencas de las quebradas.
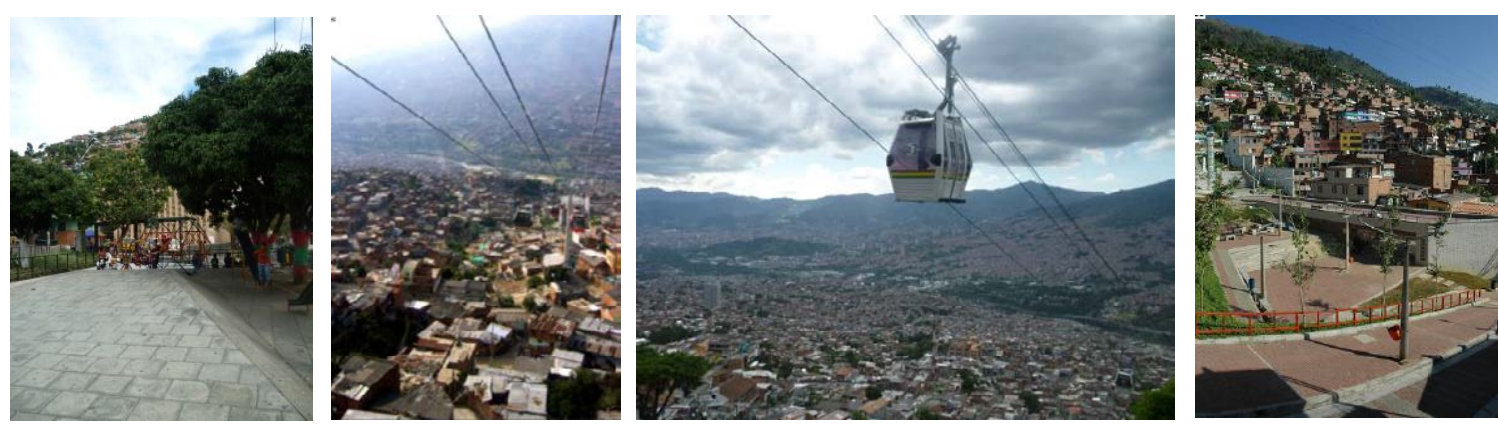


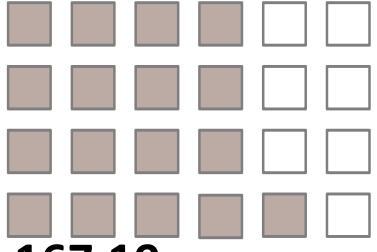

167,19 viv/ha

Zona Andalucía 300viv/ha

Zona Popular 230viv/ha

Zona Santo Domingo 30viv/ha

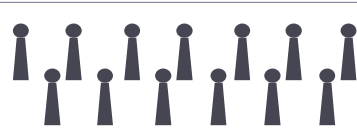

543hab/ha

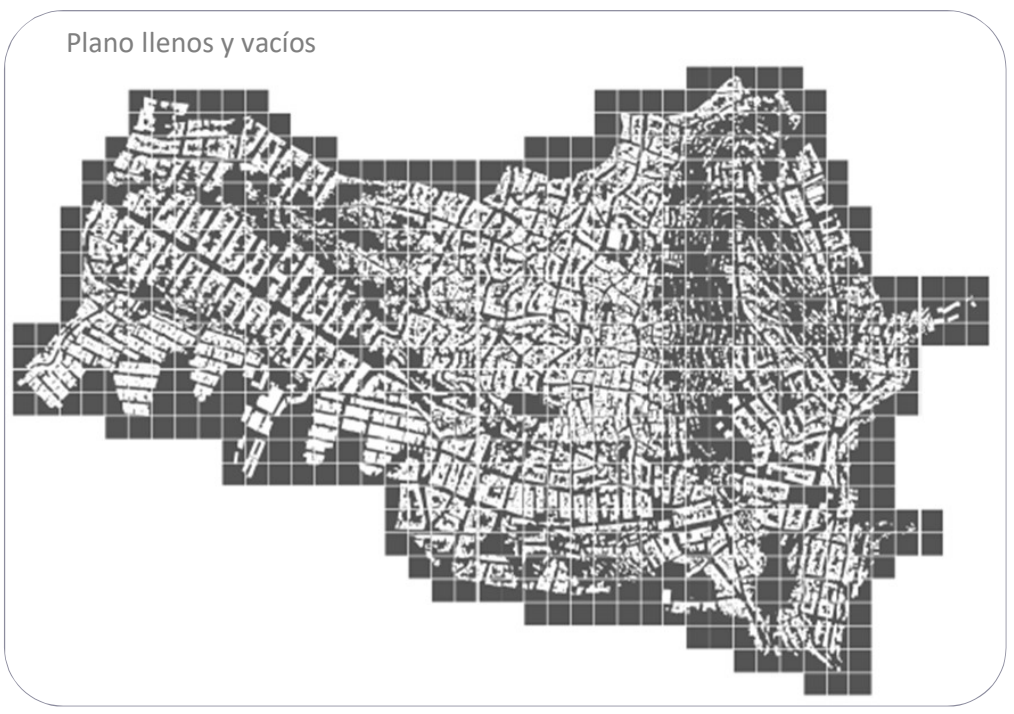

102 Cesiones

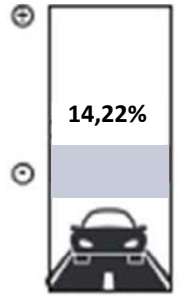

Malla vial

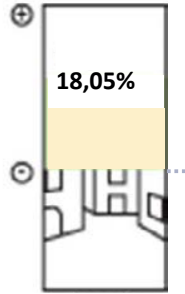

Espacio público

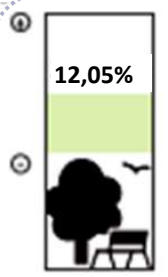

Zonas verdes

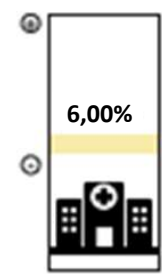

Equipamientos
Cesiones de espacio público
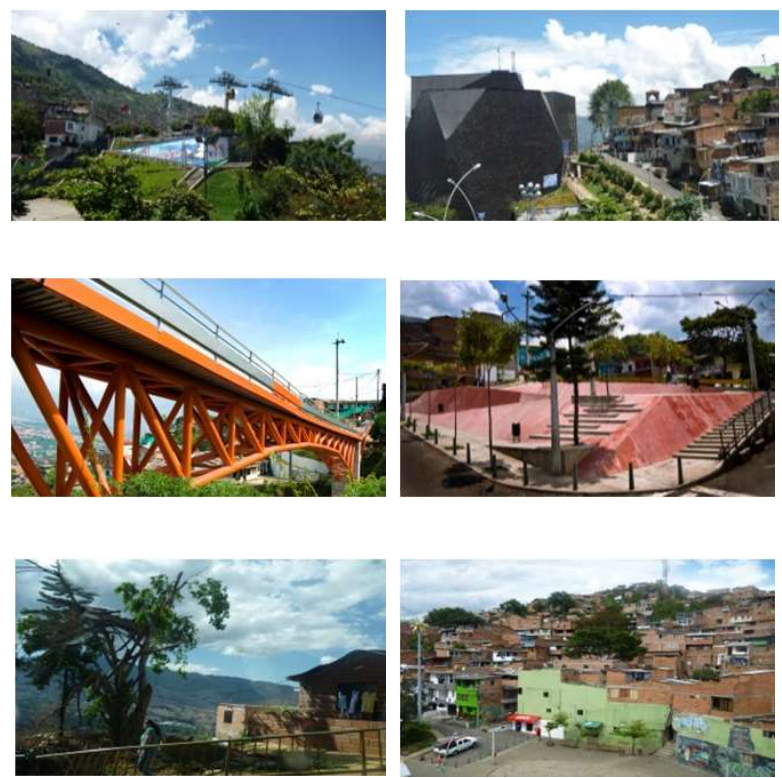

La cesiones conseguidas en PUI Nororiental a nivel de espacio público y malla vial alcanzan prácticamente las requeridas por ley en un proyecto de vivienda nueva planeado ( $14,5 \%$ para malla vial, $7,5 \%$ para equipamientos y $15,5 \%$ para zonas verdes del área bruta del desarrollo habitacional).

Dichas áreas fueron posibles en el proyecto gracias a la recuperación del espacio público, a la reubicación de viviendas sobre zonas de quebradas y espacio público y a la reconstrucción, pavimentación y adecuación de varias vías vehiculares y peatonales.

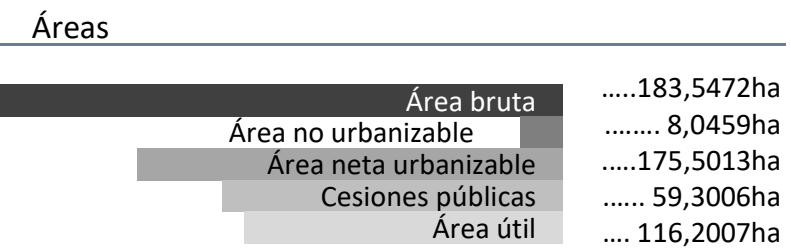

Cesiones públicas

\begin{tabular}{c|c}
\hline Cesiones públicas & ... 102,0297ha \\
\hline Malla vial & $\ldots . . .26,1592 \mathrm{ha}$ \\
Equipamientos & $\ldots . . .11,0121$ ha \\
Zonas verdes & $\ldots . . .22,1293 \mathrm{ha}$
\end{tabular}




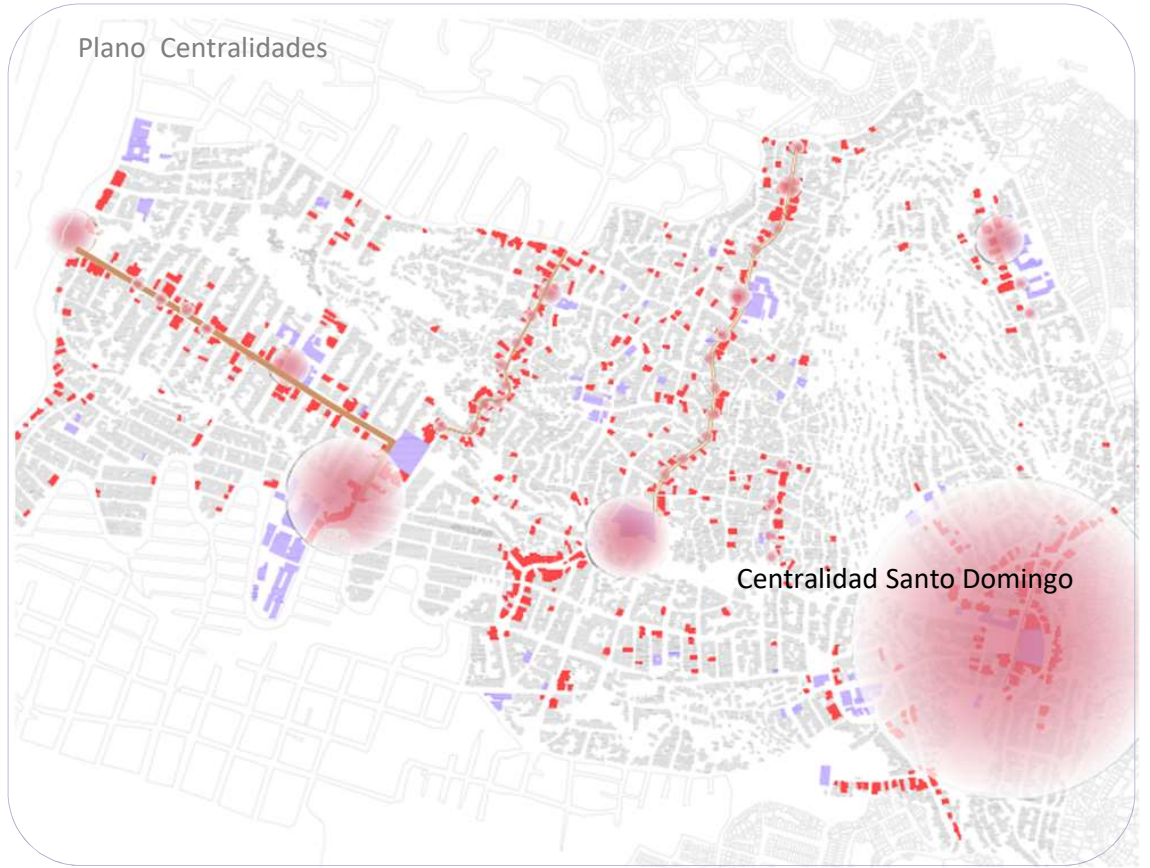

A partir del Plan Maestro propuesta para la realización del PUI Nororiental se definieron tres áreas de intervención. Andalucía, Popular y Santo Domingo, las cuales corresponden a las estaciones del sistema Metrocable como centralidad estratégica.

La de mayor importancia, la de escala de ciudad, es la centralidad de Santo Domingo.
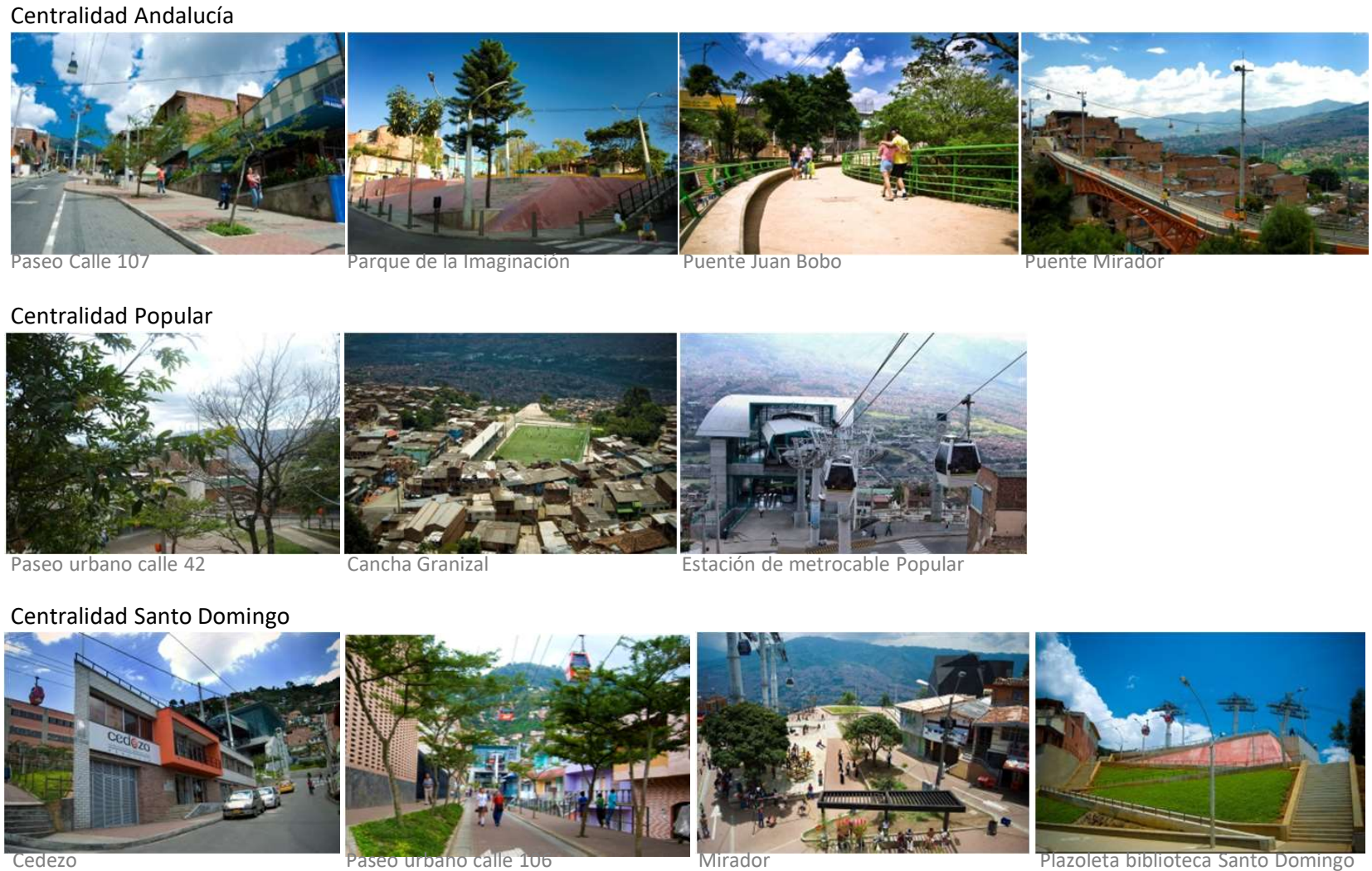

\section{Tiempos de desplazamiento a la centralidad más cercana}

Escala Ciudad: Centralidad Santo Domingo

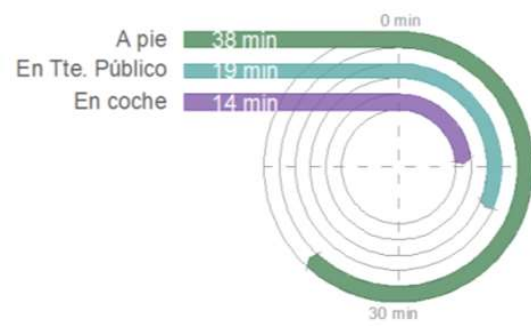

Escala Zonal: Centralidad Andalucía

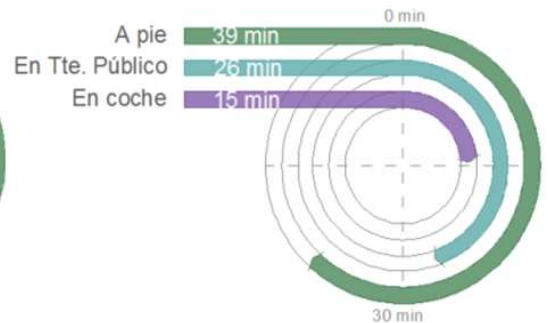

Escala Local: Centralidad Popular

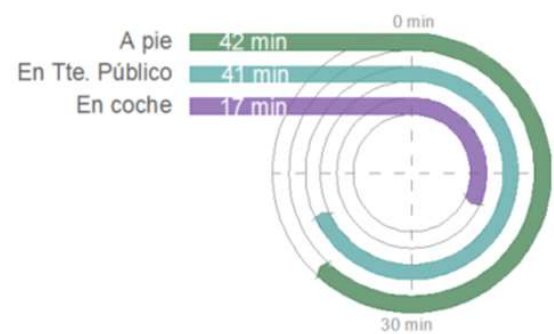

Según los criterios establecidos sobre los tiempos óptimos de desplazamiento a pie, éste proyecto cuenta con unas condiciones deficitarias; todos los trayectos superan los $30 \mathrm{~min}$. En cambio, el tiempo óptimo de desplazamiento en transporte público a la centralidad de Santo Domingo es adecuado y a las otras dos centralidades es correcto o normal. 


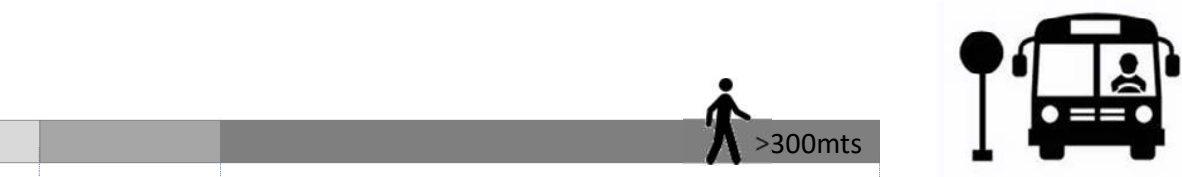
$4,98 \% \quad 33,36 \%$
$61,66 \%$

La accesibilidad al transporte público en el PUI Nororiental es considerablemente deficiente si se tiene en cuenta la totalidad de su territorio. Si bien como se mencionaba en el indicador anterior, los tiempos de desplazamiento en transporte público son eficientes, esta condición se ve desmejorada para acceder a estos transporte a nivel peatonal. Mas del $60 \%$ del territorio no es accesible a menos de 5 min caminando por parte de la población.
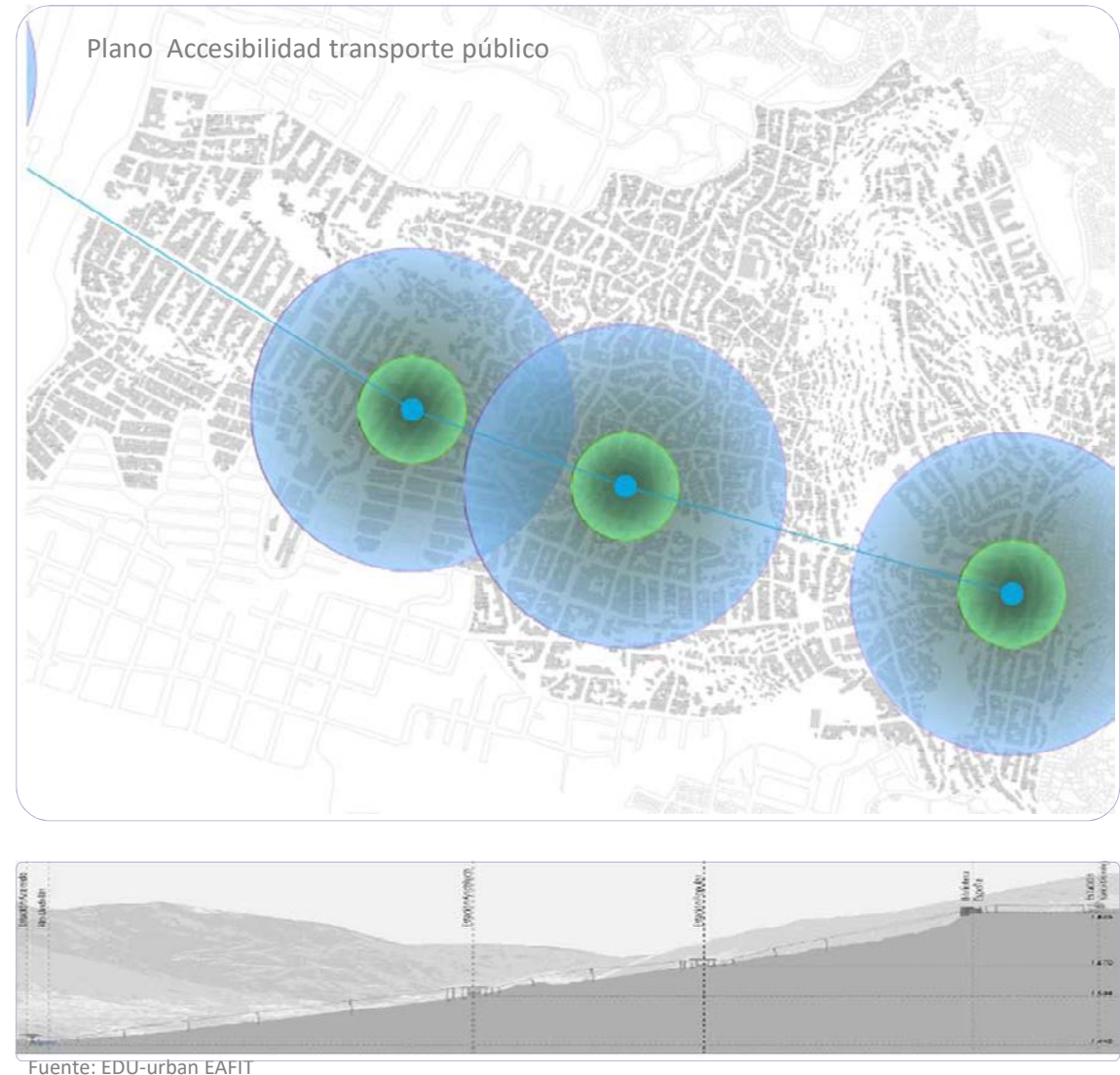

Fuente: EDU-urban EAFIT
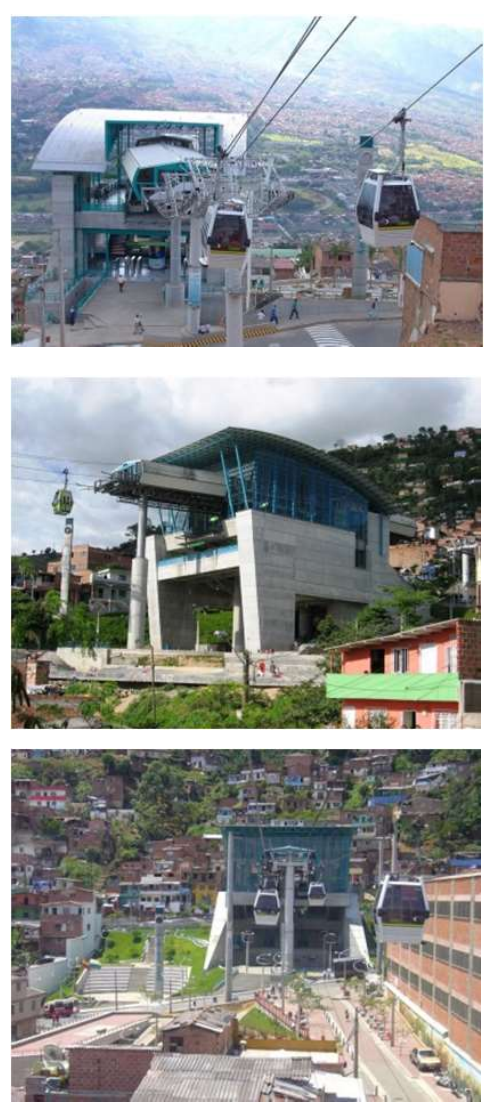

Movilidad

\section{Conexiones y trazados de vías}

Las conexiones y los trazados viarios han sido el resultado de las particulares condiciones topográficas de I terreno y de los diferentes procesos de ocupación del territorio.

El desnivel desde el extremo occidental del proyecto (cercano al norde del rio Medellín) al extremo oriental ( estación de Santo Domingo es de 405 metros ( se inicia con $1440 \mathrm{msnm}$ y finaliza en $1845 \mathrm{msnm}$ ) 
Pendiente

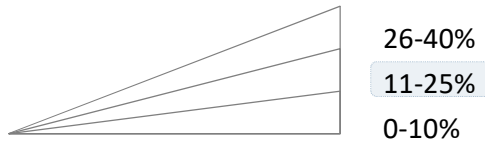

Acceso a escala de ciudad
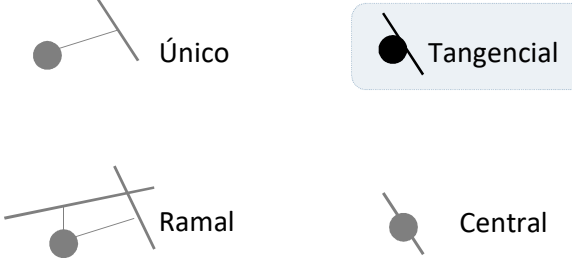

Conexión a escala de barrio
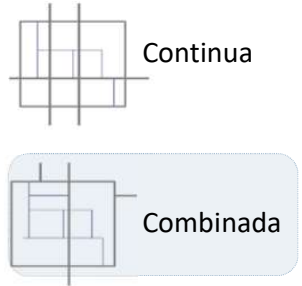
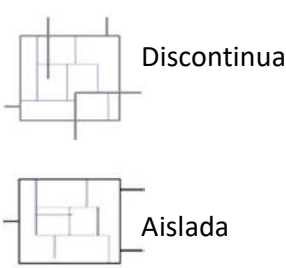

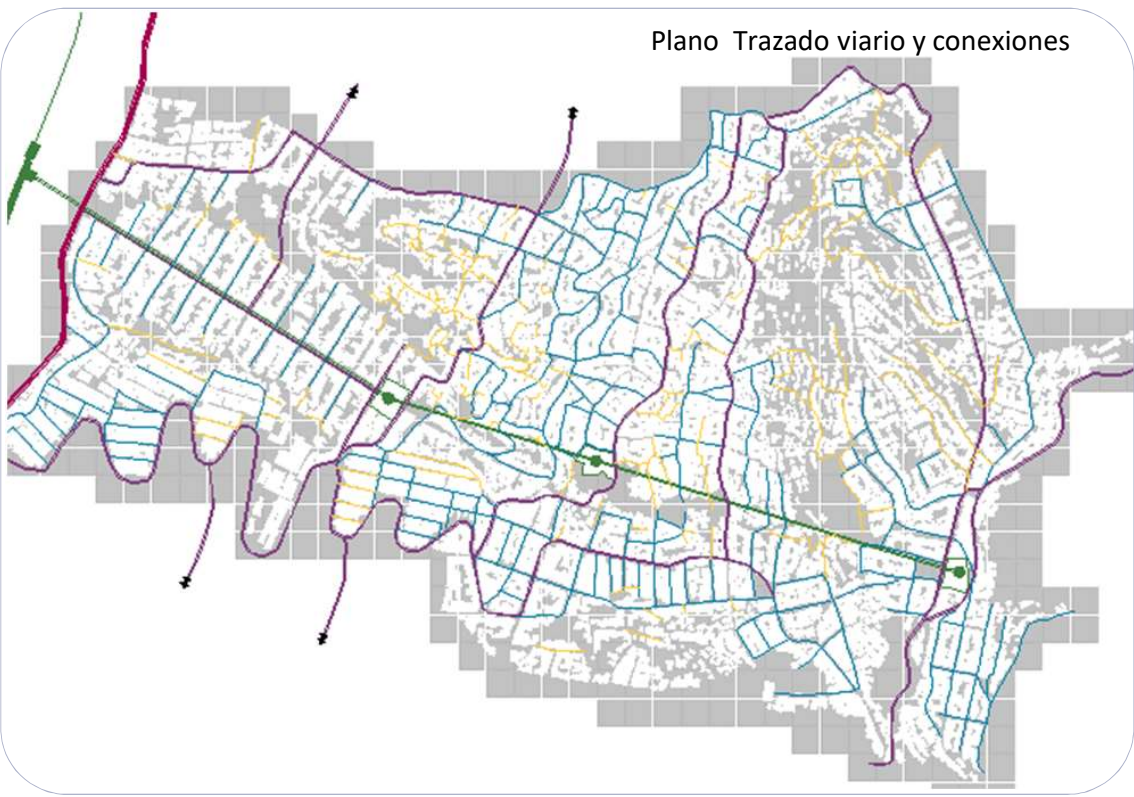

Dadas las condiciones topográficas antes comentadas el trazado viario se realiza, en su mayoría, a contrapendiente. Dicha situación genera tres tipos de trazados viales: lineal, en red y arbóreo.

El lineal se presenta tan solo en la parta de Andalucía y es allí en donde se generan la mayor cantidad de conexiones con la ciudad. Los otros dos tipos de trazados, de carácter mas irregular, presuponen un eje principal y unas ramificaciones que solo se relacionan entre sí . La conexión con el contexto y la ciudad es muy deficiente en este tipo de trazado.

\section{Estado de las vías}

\section{VÍA VEHICULAR}

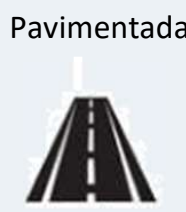

$97,67 \%$
No Pavimentada

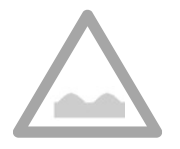

$2,33 \%$

\section{VÍA PEATONAL}

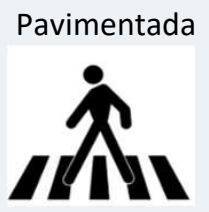

$81,20 \%$
No Pavimentada

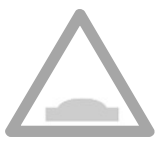

$18,80 \%$

El proyecto cuenta, hasta el periodo de análisis, con la mayoría de las vías vehiculares y peatonales pavimentadas. En el mejoramiento de barro se ha procurado no solo adecuar las vías aledañas a las estaciones del metrocable sino mejorar, dentro de los recursos disponibles, las vías de todo el proyecto.
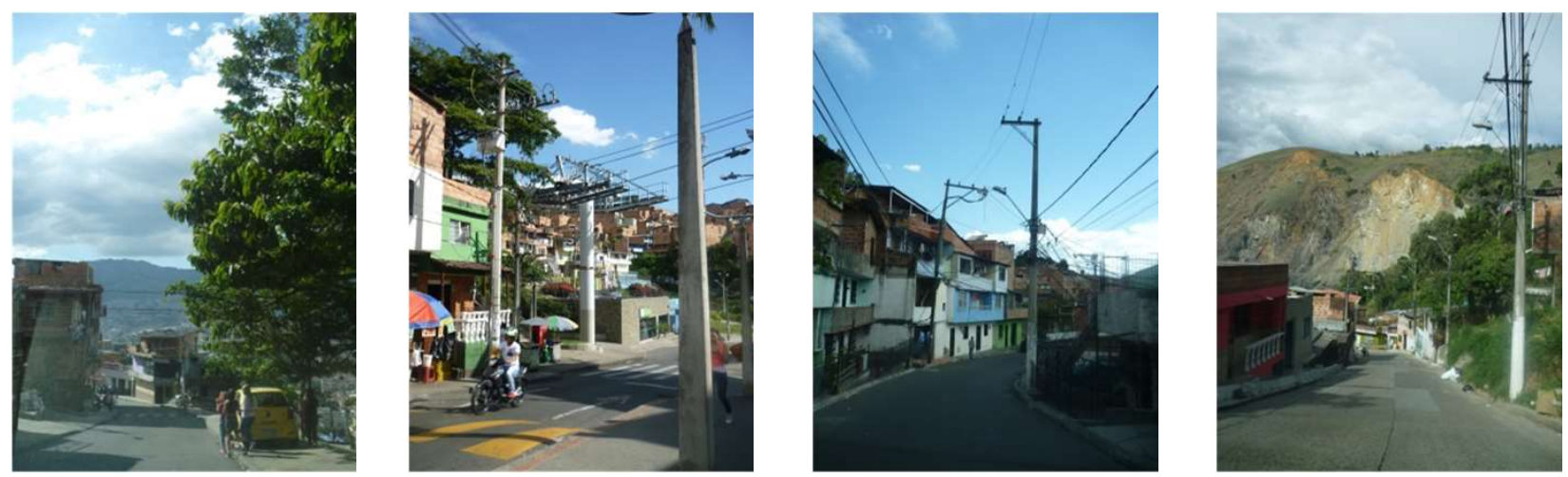


\section{EQUIPAMIENTOS A ESCALA BARRIO-VECINDARIO}
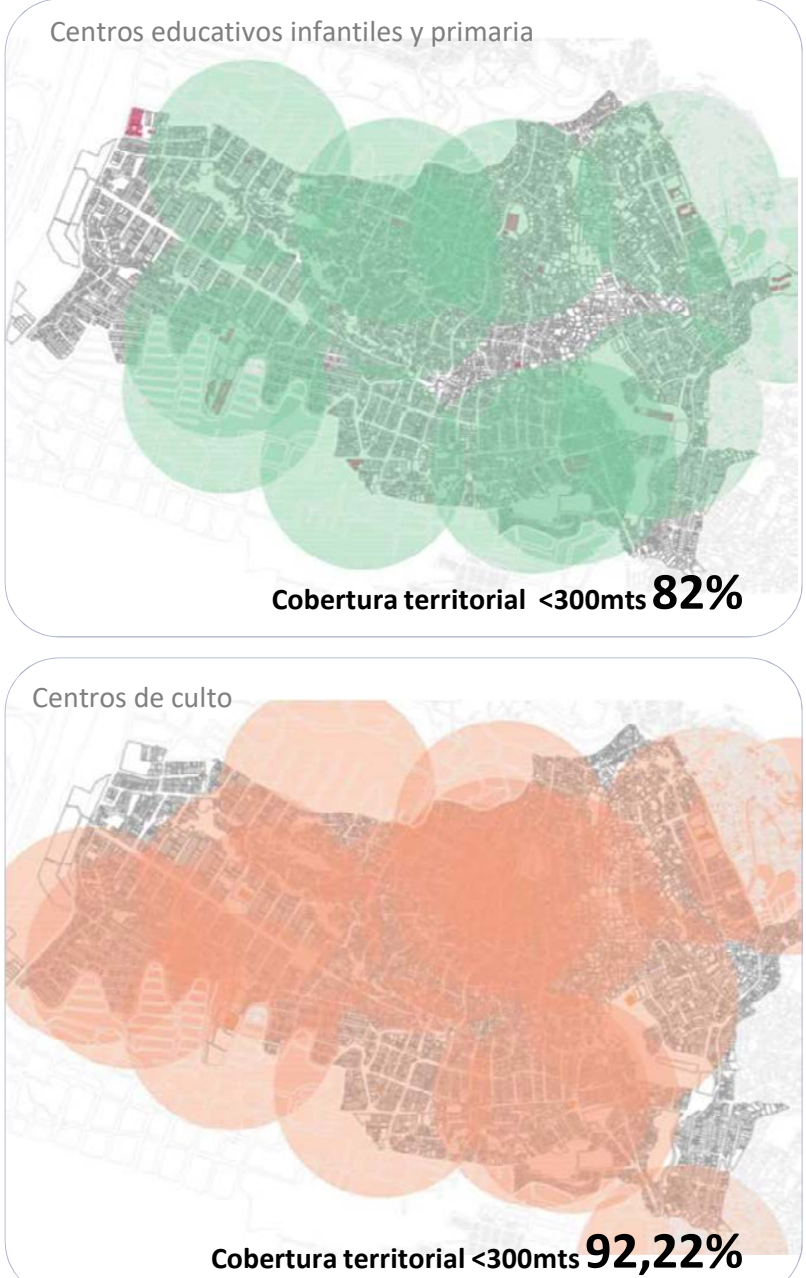

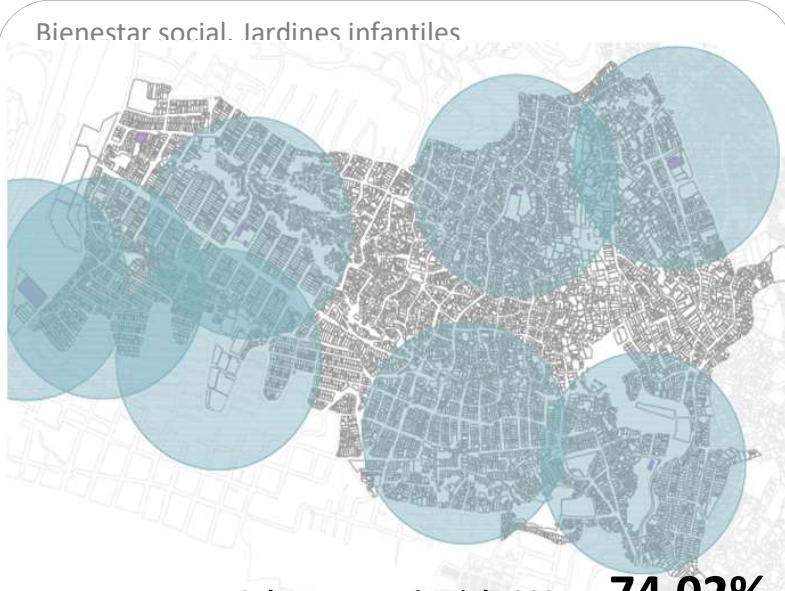

Cobertura territorial $<300 \mathrm{mts} 74,02 \%$

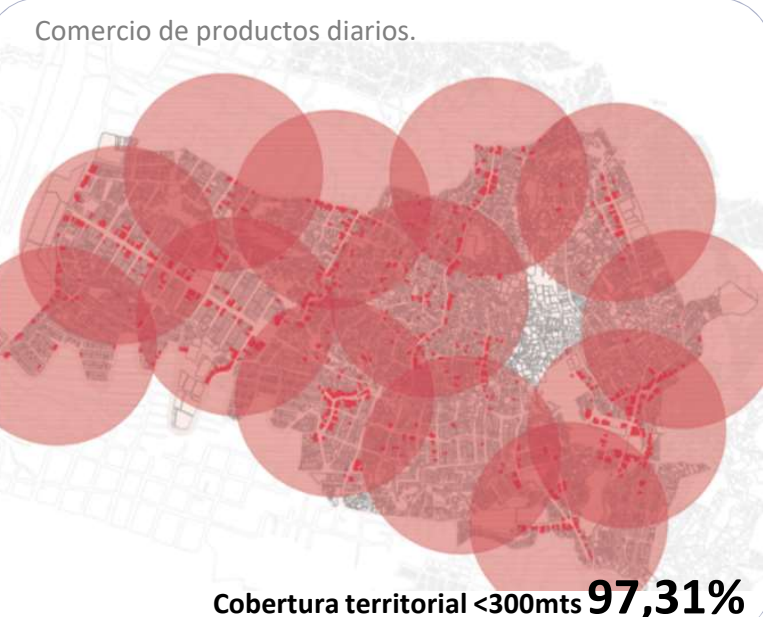

\section{Centros educativos}

La cobertura actual de los centros educativos a nivel territorial es relativamente buena tanto a nivel de secundaria como a nivel de primaria y preescolar. Sin embargo, tan solo el $61 \%$ de la población cuenta con un titulo de educación primaria y un 30\% con un grado de bachillerato aprobado. Esto evidencia que en paralelo a la construcción de este tipo de equipamientos se debe capacitar e informar a la población de los beneficios que la educación trae.

\section{Centros de bienestar social}

El proyecto cuenta con una red proporcionada de jardines infantiles a lo largo de todo su territorio. Sin embargo, este es prácticamente el único equipamiento de bienestar social, el proyecto tan solo cuenta adicionalmente con dos casas juveniles. No se encuentran ningún otro tipo de prestación social.

Una problemática asociada a estos equipamientos es la inadecuada planeación de los mismos y su deterioro, reflejado además en la insatisfacción por parte de la comunidad, la poca disponibilidad de espacios y en algunos casos el mal uso de estos espacios.

\section{Centro de salud}

El déficit mas importante en todo el proyecto se encuentra en los equipamientos de salud. Tan solo existen dos unidades de atención primaria que no dan cobertura a los 100.000 habitantes del proyecto.

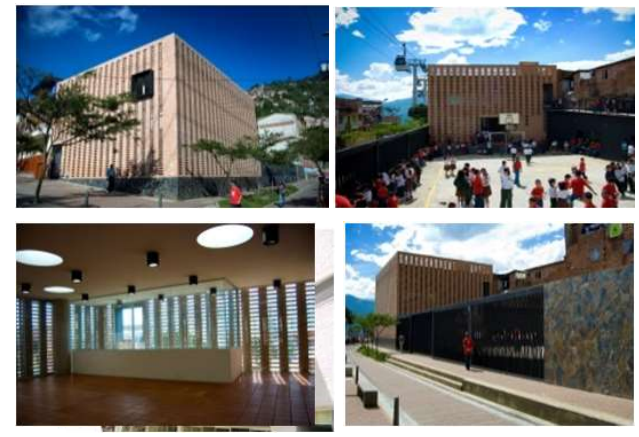

Centro educativo La Candelaria

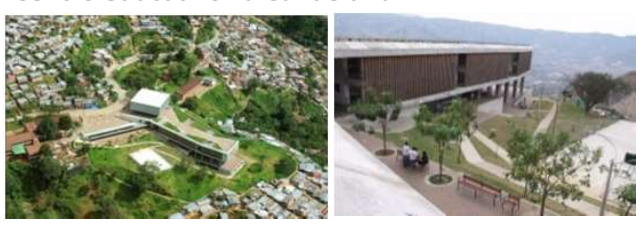

Centro educativo Antonio Derka
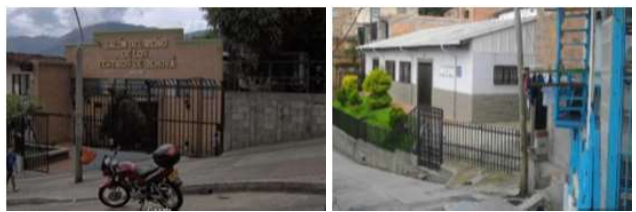

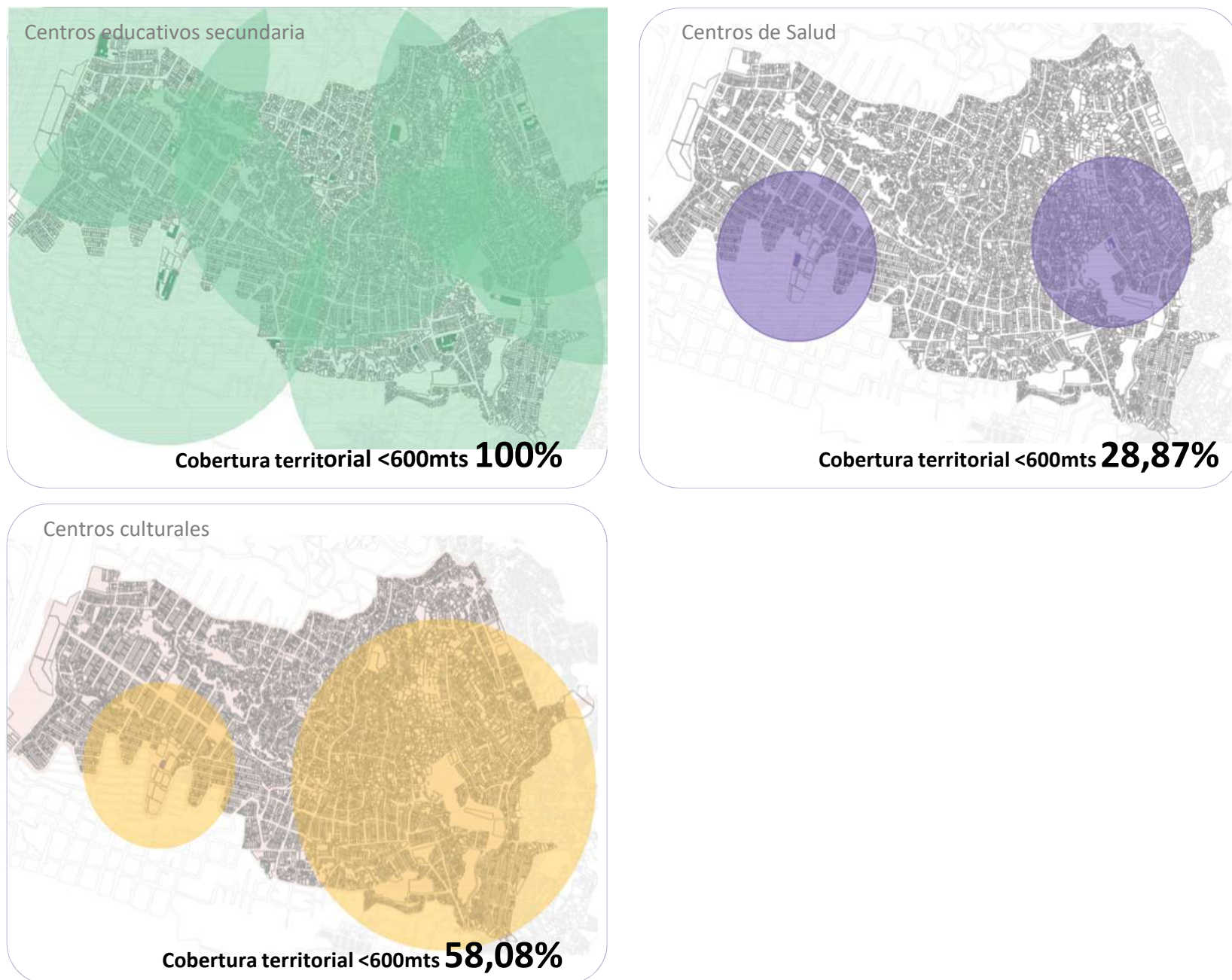

\section{Centros culturales}

Con respecto a los equipamientos culturales, se identifican tan solo dos edificaciones en todo en proyecto: la biblioteca España y la escuela de música. Éstas, por supuesto, no son suficientes para cubrir las demandas culturales de la población y se han convertido en los espacios más solicitados en las tres franjas del territorio.

La biblioteca España, ganadora de varios premios internacionales de arquitectura (XVI Bienal Panamericana de Arquitectura de Quito y VI Bienal Iberoamericana de Arquitectura en Lisboa 2008) y símbolo de resiliencia del proyecto, en la actualidad se encuentra fuera de uso por parte de la población por problemas de mantenimiento y uso en sus materiales de construcción. Ésta ha debido ser prácticamente reconstruida en su fachada.
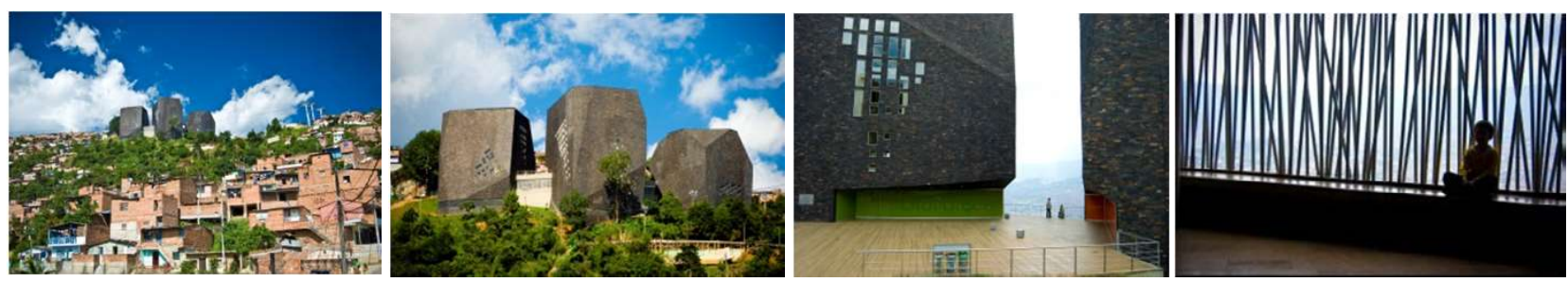

Recortes de prensa sobre el estado actual de la Biblioteca
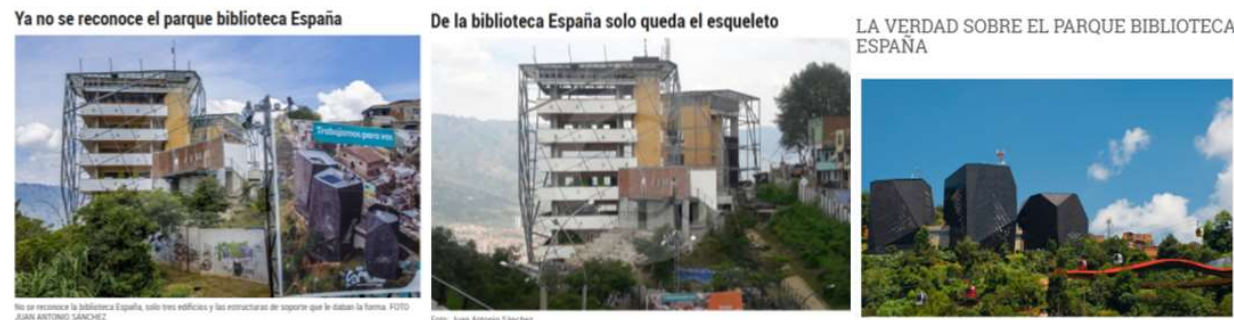

El deterioro amenaza la Biblioteca España, un ESPANA
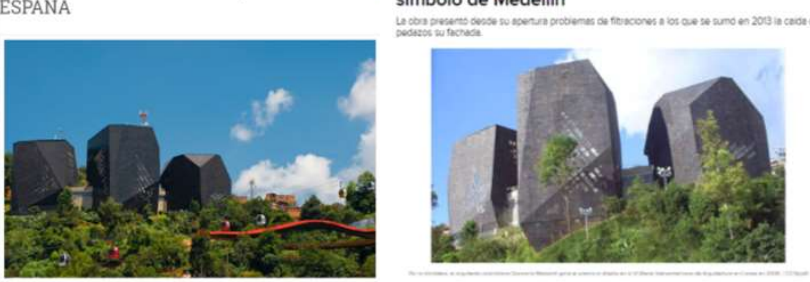


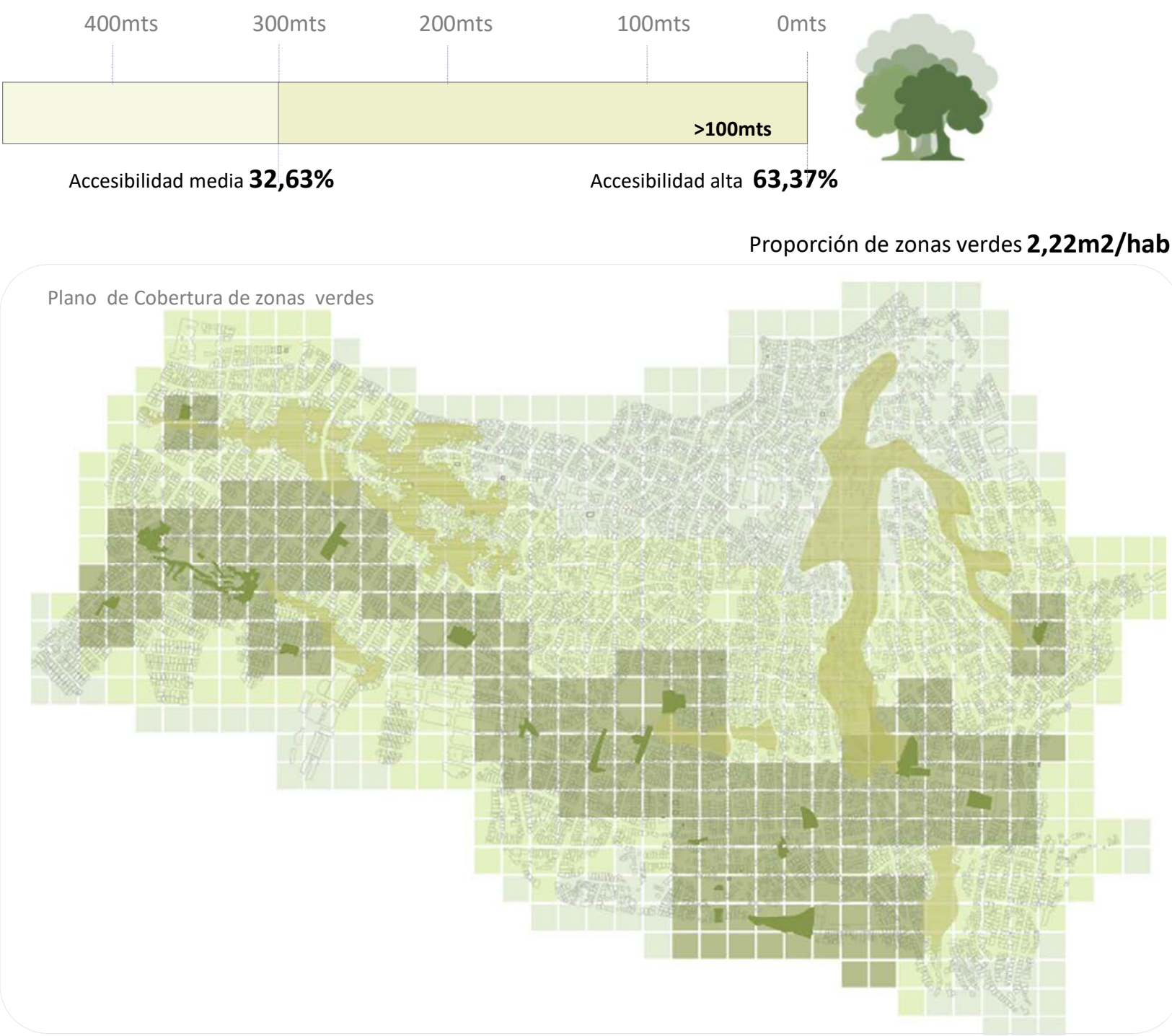

En el componente de mejoramiento ambiental del proyecto se ejecutaron una serie de obras tales como parques, plazas, zonas verdes y vías peatonales que dotaron al territorio de una proporción mas elevada de espacio público por habitante ( se paso de $1,3 \mathrm{~m} 2 / \mathrm{hab}$ a $2,22 \mathrm{~m} 2 / \mathrm{hab}$ ). En total se construyeron $5.087 \mathrm{~m} 2$ de espacio público, este sobretodo realizado en las áreas de influencia de las estaciones del metrocable y de las rondas de rio.

Las zonas verdes del interior de la manzanas en cambio no fueron modificadas ni mejoradas dentro del programa. Estas ya altamente densificadas y colmatadas están ahora sufriendo, debido a la intervención del MIB, en una nueva densificación. No en vano, de los seis estudios de caso analizados éste proyecto es una de los mas densificados y el mayor a nivel de los de mejoramiento de barrio.
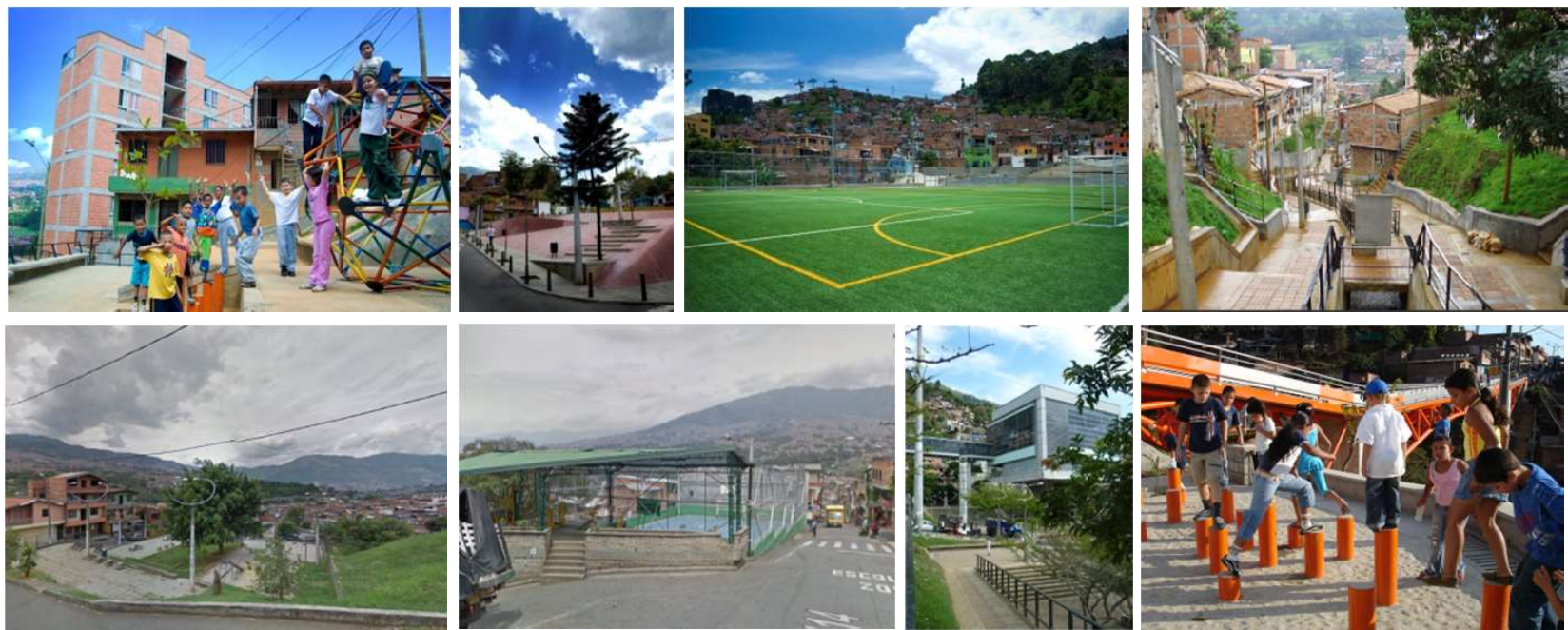


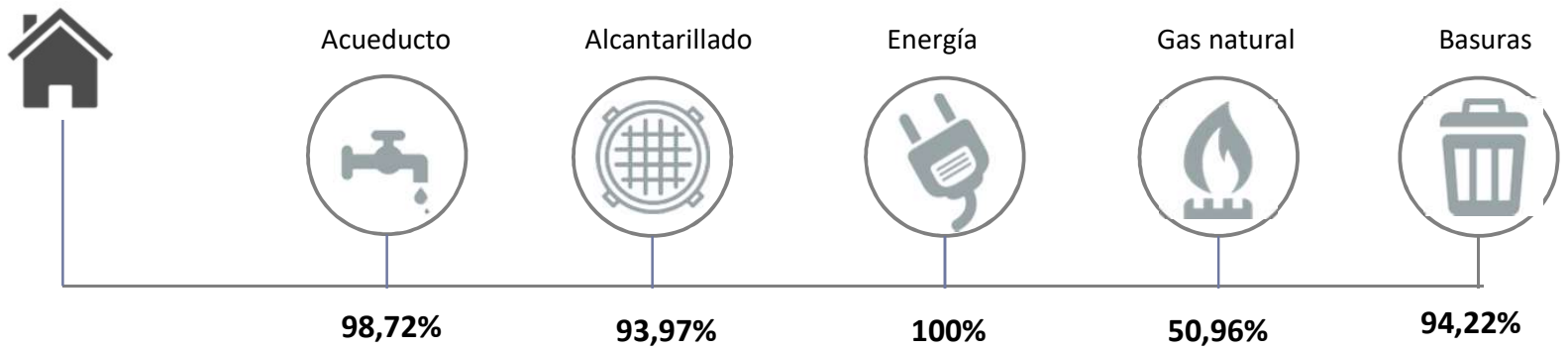

Una de las prioridades en el PUI Nororiental fue la de atender los desequilibrios ambientales del proyecto por medio de un plan de recuperación, reposición y distribución de redes de acueducto y alcantarillado, saneamiento del recurso hídrico y construcción de sistemas de drenaje para las viviendas, especialmente aquellas situadas en bordes de rio. Gracias a ello se logró una cobertura casi total en acueducto y alcantarillado.

El servicio de gas natural en cambio, no ha sido preocupación por parte del Estado y no llega aun a prácticamente la mitad del territorio. La explicación, según las entidades encargadas se debe a la topografía del terreno.

\section{Condiciones geotécnicas. Riesgos}
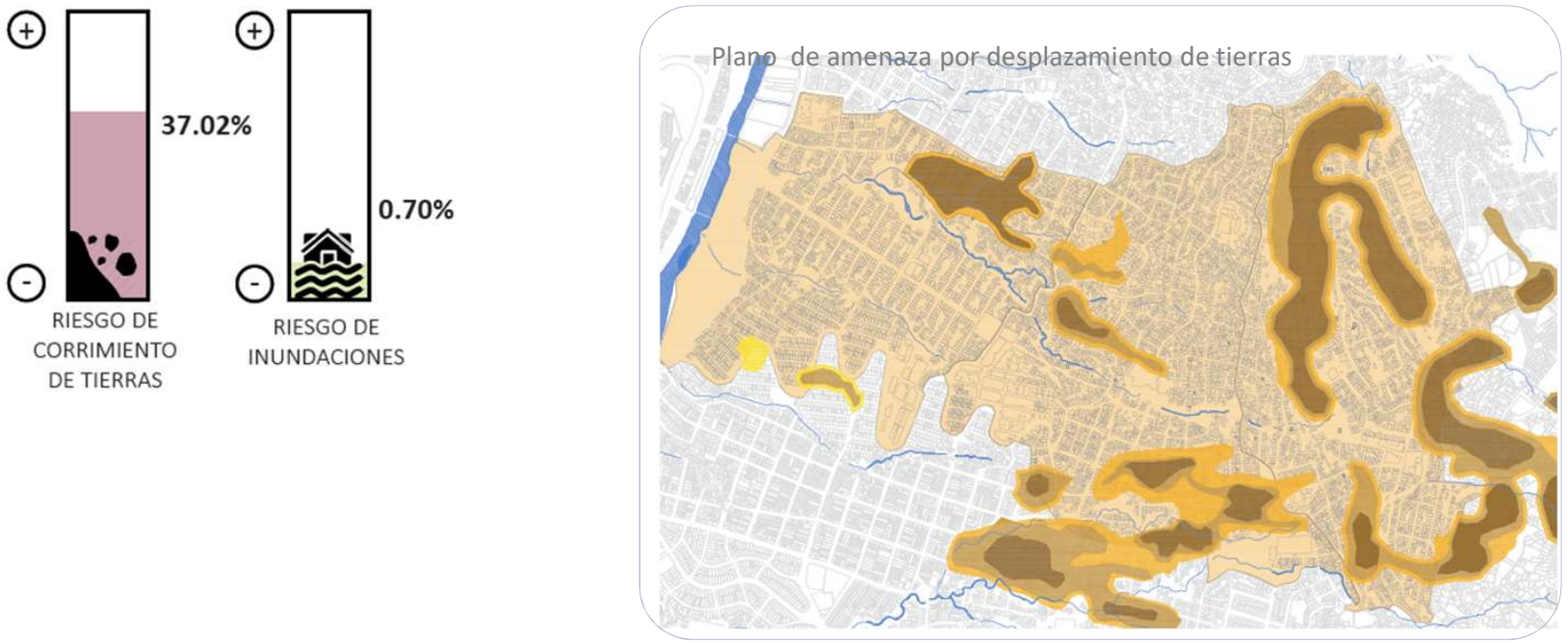

Unidades habitacionales construidas
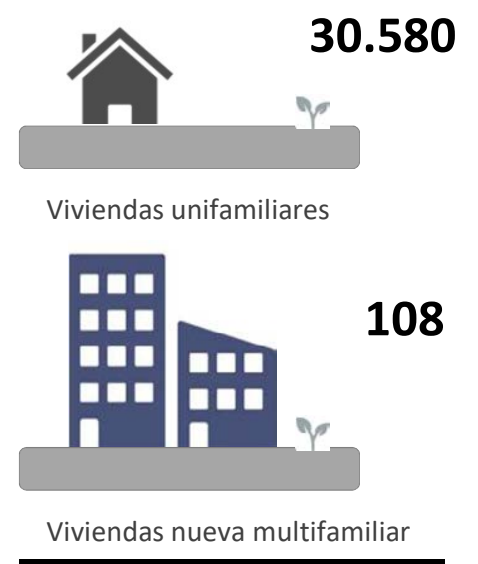

Total $=\mathbf{3 0 . 6 8 8}$ viviendas
Ocupación de la manzana y tipología de la vivienda

El proceso de ocupación de la zona Nororiental de Medellín es de origen marginal (o ilegal) en toda su extensión. Su formación inicio en la parte baja (comuna 2 ) en los años 50 y 60 y la parte alta en los años 80 . Se termino de consolidar en los años 90 pero tan solo fue en le año 2002 cuando se propuso su regularización y legalización urbanística. Un tercio de su territorio es de tipo clandestino y los otros dos tercios restantes de invasión

Su proceso de configuración es de carácter orgánico o mixto en la mayoría del territorio adecuándose a las condiciones topográficas del territorio.

Con respecto a las edificaciones, las mayoría de las viviendas son de baja altura salvo por el proyecto habitacional en la quebrada Juan Bobo. El $33,08 \%$ de las viviendas son de 1 nivel y el $42,93 \%$ de dos niveles, el $23,99 \%$ restante corresponden a edificaciones de 3 niveles o mas. Los materiales con los que están construidas estas viviendas son en su mayoría estables ( ladrillo, hormigón, piedra, etc). 

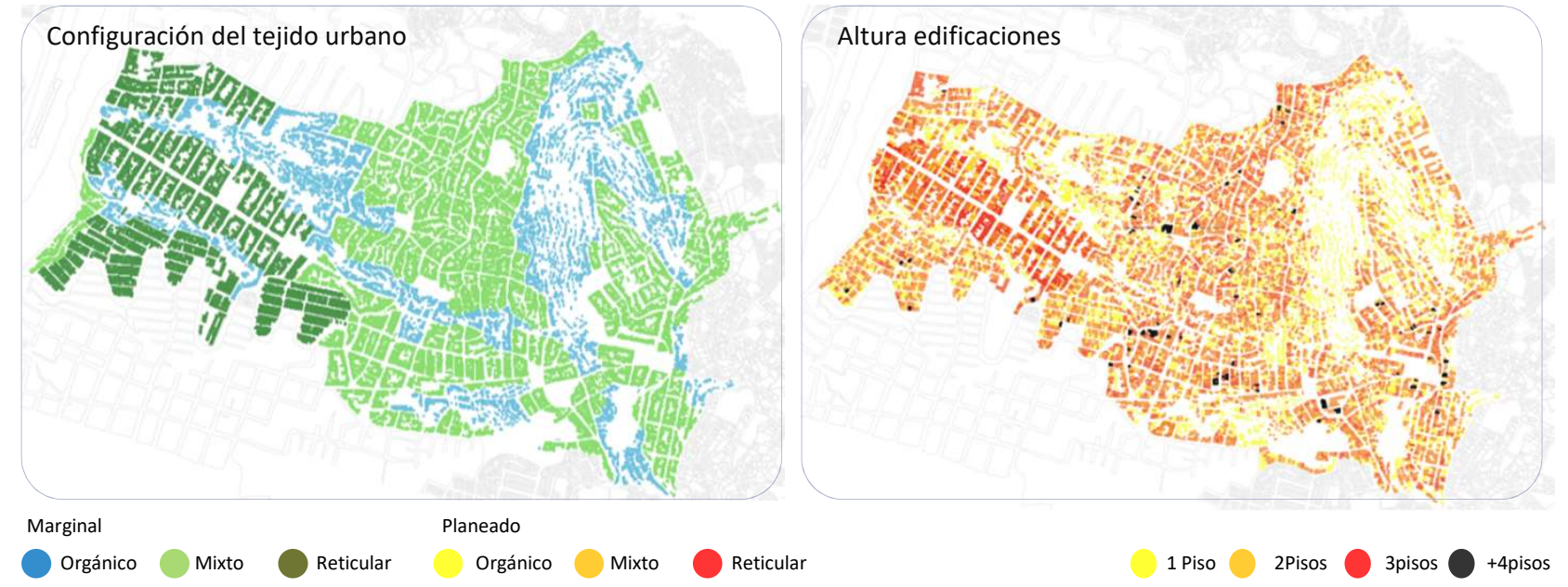

\section{Viviendas tipo PUI Nororiental}

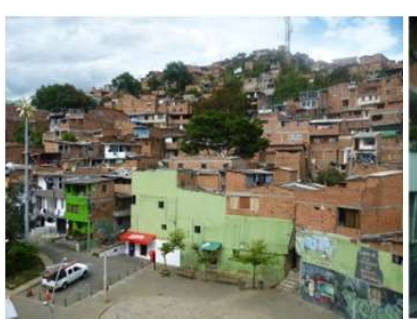

Tamaño de parcelas

85-100m2promedio

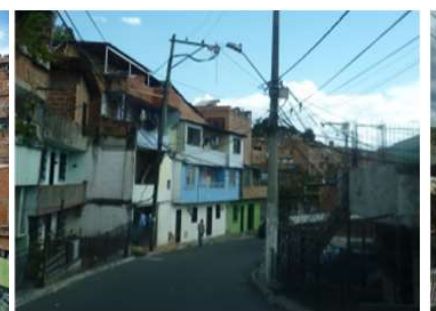

Marginal reticular
$8 \times 14,5=116 \mathrm{~m}^{2}$

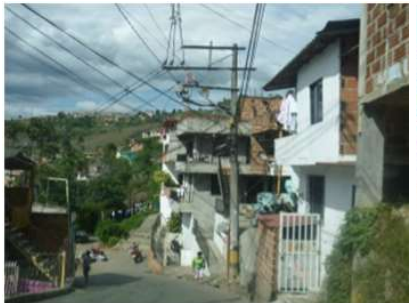

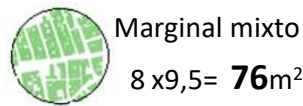
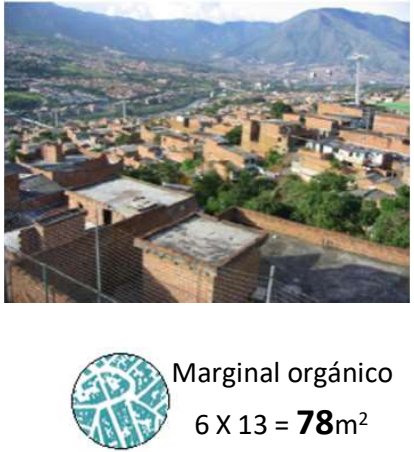

\section{Consolidación habitacional quebrada Juan Bobo}

Una de las problemáticas habitacionales más representativas encontradas en esta zona nororiental de la ciudad de Medellín, estuvo asociada a la ocupación de quebradas y zonas ambientales por parte de la población. Allí se evidenciaba viviendas en zonas de alto riesgo, construcciones inadecuadas (las familias vivían en hacinamiento crítico: $29 \mathrm{~m} 2 /$ viv, 4,2 hab/viv.), malas condiciones espaciales y estructurales, poca salubridad y una conexión fraudulenta o inexistente de los servicios públicos (50\% de las unidades habitacionales tenían acueducto en fraude, 35\% energía en fraude, $100 \%$ de las viviendas tenían el alcantarillado de forma informal). Ante ello la administración decide entonces actuar en una parte puntual del territorio (barrios Villa Niza y Andalucía )y consolidar un proyecto habitacional denominado "Consolidación Habitacional en la Quebrada Juan Bobo". La premisa del proyecto era tirar las viviendas que se encontraran sobre la quebrada sin desalojar a la población existente, construir vivienda nueva y coordinar programas de mejoramiento de vivienda propia para la población que pudiera acceder económicamente al programa.

Para el plan de vivienda nueva se decidió construir pequeños edificios, 8 en total, de 6 o 7 niveles con dos unidades habitacionales por nivel, cada una de ellas de $46-48 \mathrm{~m} 2$. (área menor a la de las viviendas tipo del PUI Nororiental).

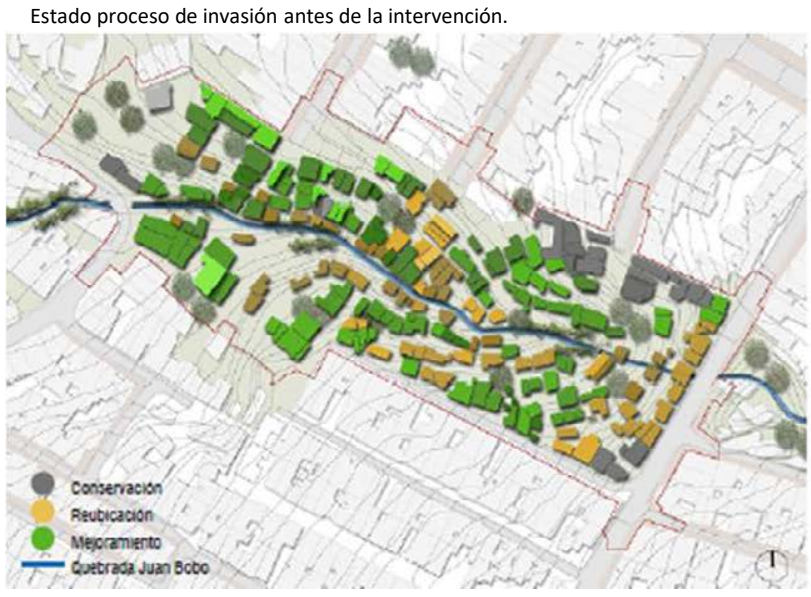

Tamaño de parcelas

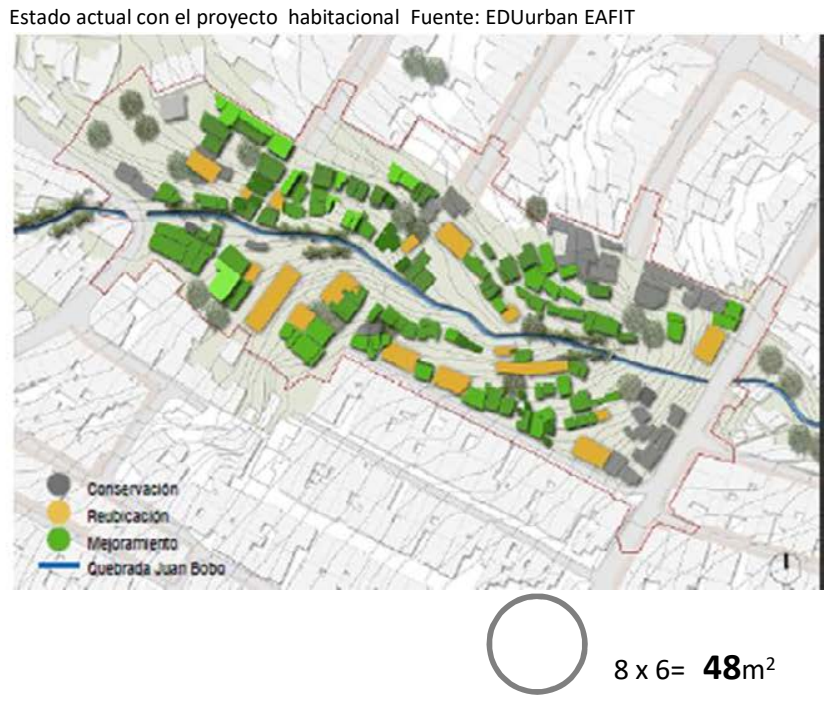



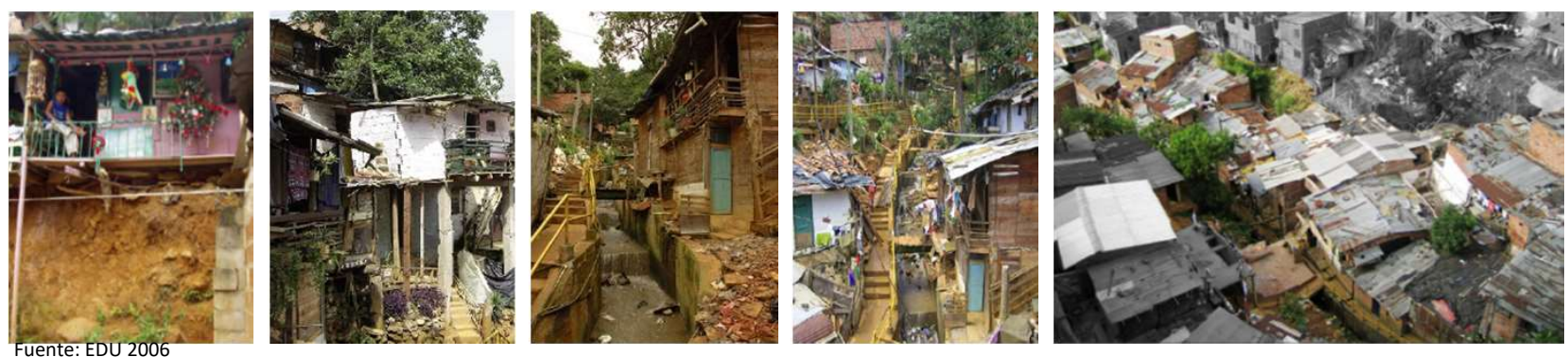

\section{Fotografías con el proyecto de vivienda nueva}
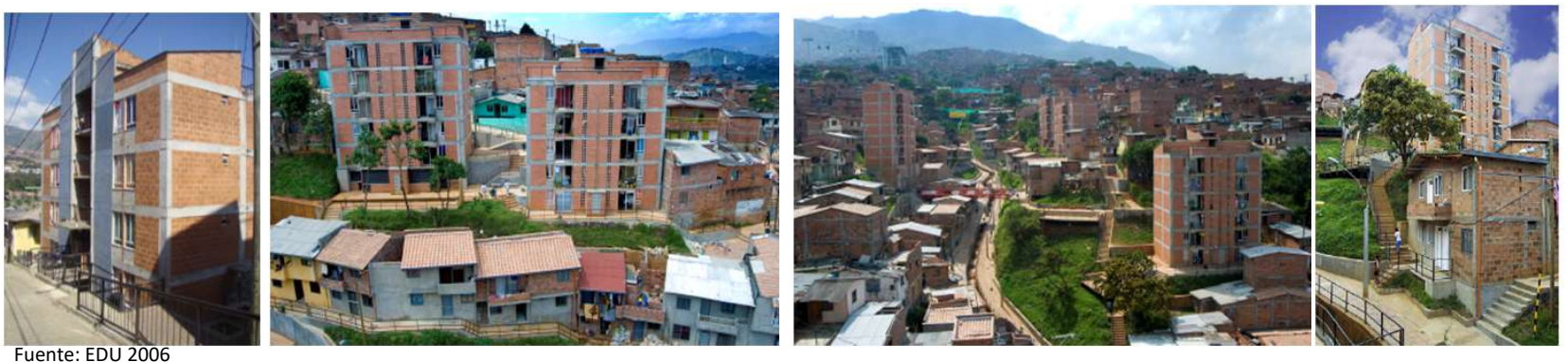

\section{Complejidad}

Conjunto habitacional v vivienda

Uso del suelo privado

Comercio 4,36\% Uso Vivienda $\mathbf{9 3 , 4 1 \%}$

Uso Dotacional 2,21\%

EI PUI Nororiental presenta un alto porcentaje de uso residencial y un muy bajo porcentaje de uso dotacional aunque su reparto territorial este relativamente bien distribuida. Las zonas de comercio de productos diarios, en cambio, se encuentran concentradas en las vías principales del proyecto. Éstas vías principales, vale mencionar, son las vías de continuidad dentro del PUI y con los barrios del contexto.

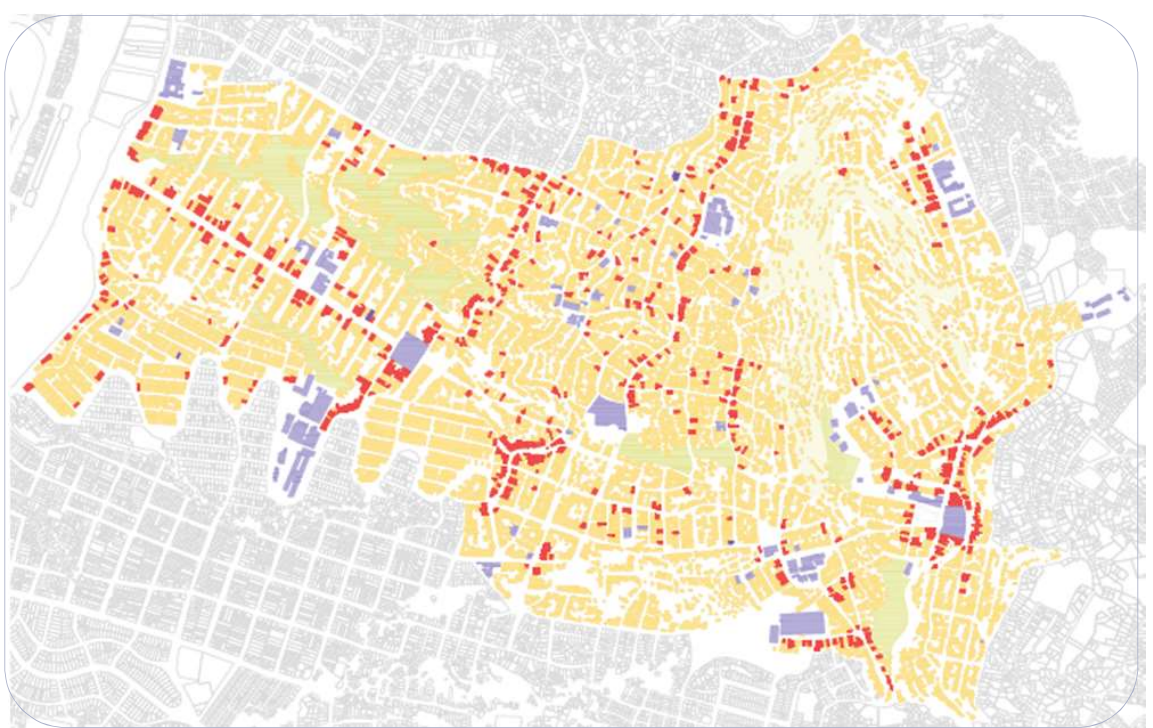

Fotografías de viviendas con comercio en primera planta
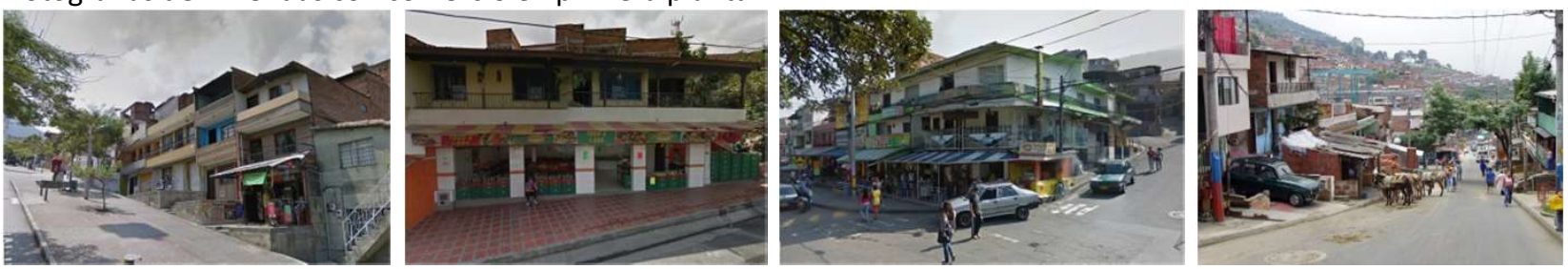

Con respecto a la población del área de intervención de la comuna N.01, Popular, ésta erpresenta el $47 \%$ del total de la población de la comuna; y la población de los cuatro barrios de intervención de la Comuna N.o2 el $41 \%$ de la comuna. Como ya se ha mencionado, toda ella es de origen socioeconómico bajo, principalmente estrato 1 (18\%) y estrato 2 ( $57 \%)$. Su origen es por general de población que migro a la ciudad en búsqueda de mejores condiciones laborales. 


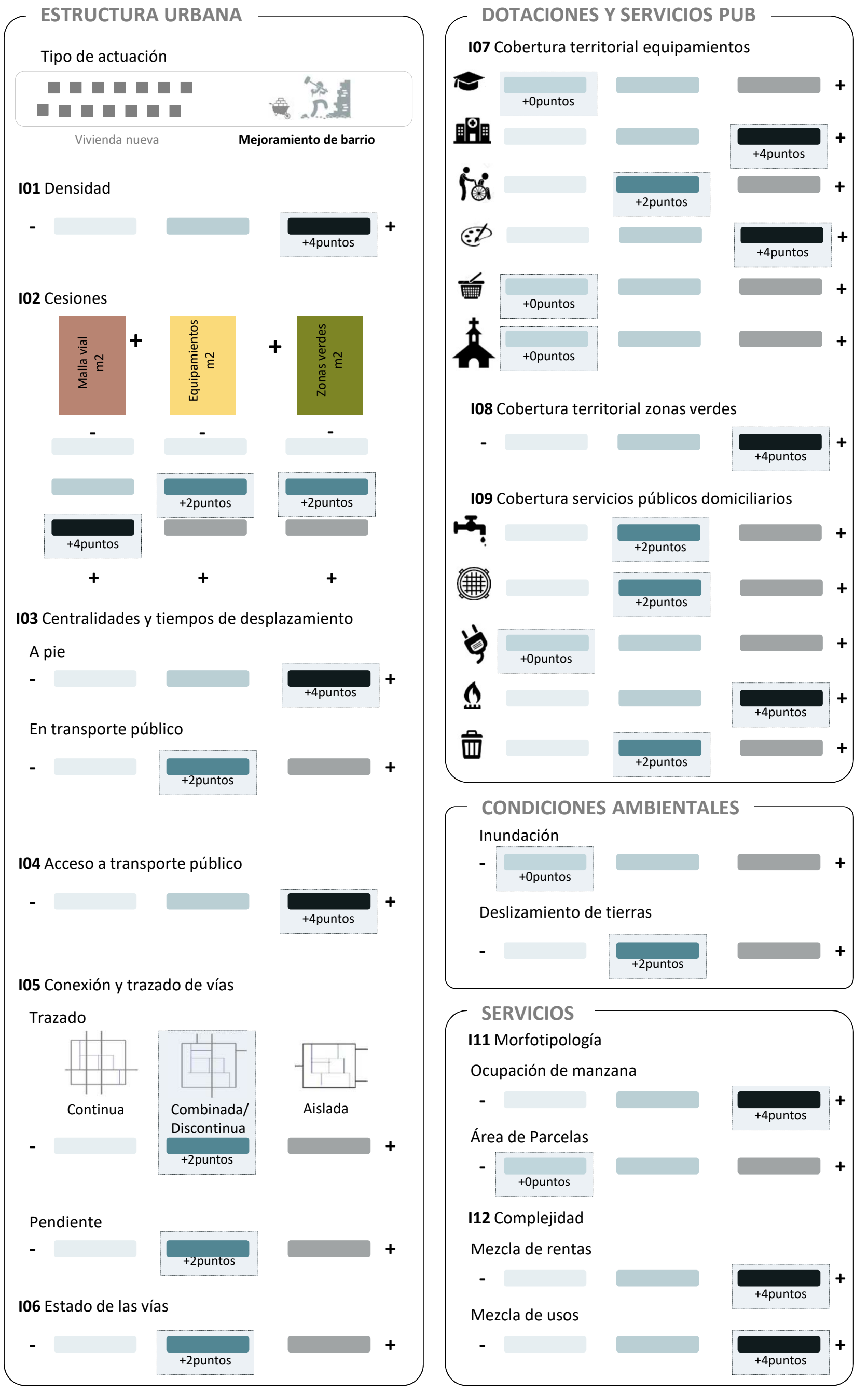



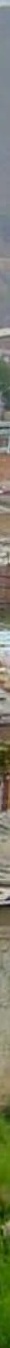


\section{MIB El Lucero - Bogotá}

El Mejoramiento de Barrio en la UPZ El Lucero nació como un proyecto de intervención prioritaria en el año 2009, en el marco de las directrices del POT de Bogotá. Su área de actuación surgió con el fin de integrar física, social y territorialmente las comunidades allí asentadas en sectores de alto grado de vulnerabilidad.

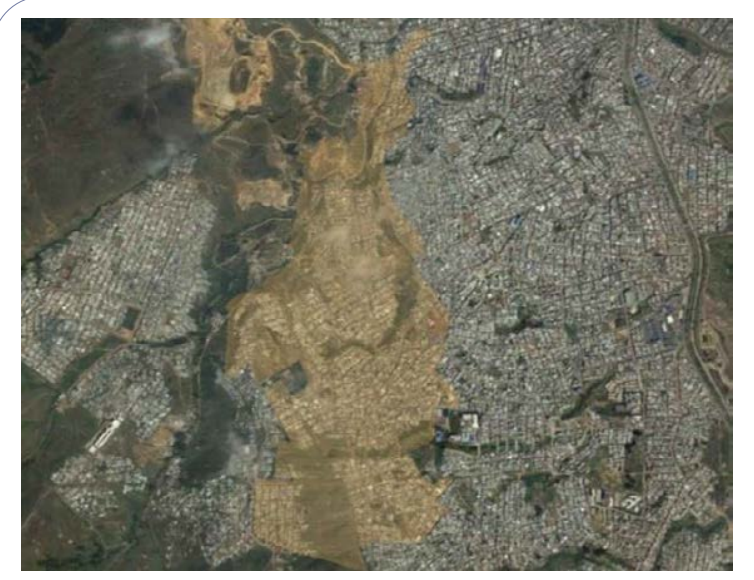

La UPZ está ubicada en el extremo Nororiental de la localidad de Ciudad Bolívar en Bogotá. Tiene una extensión de 581,61ha y una población de 229.216 habitantes lo que la convierta en la zona más densa de la localidad.
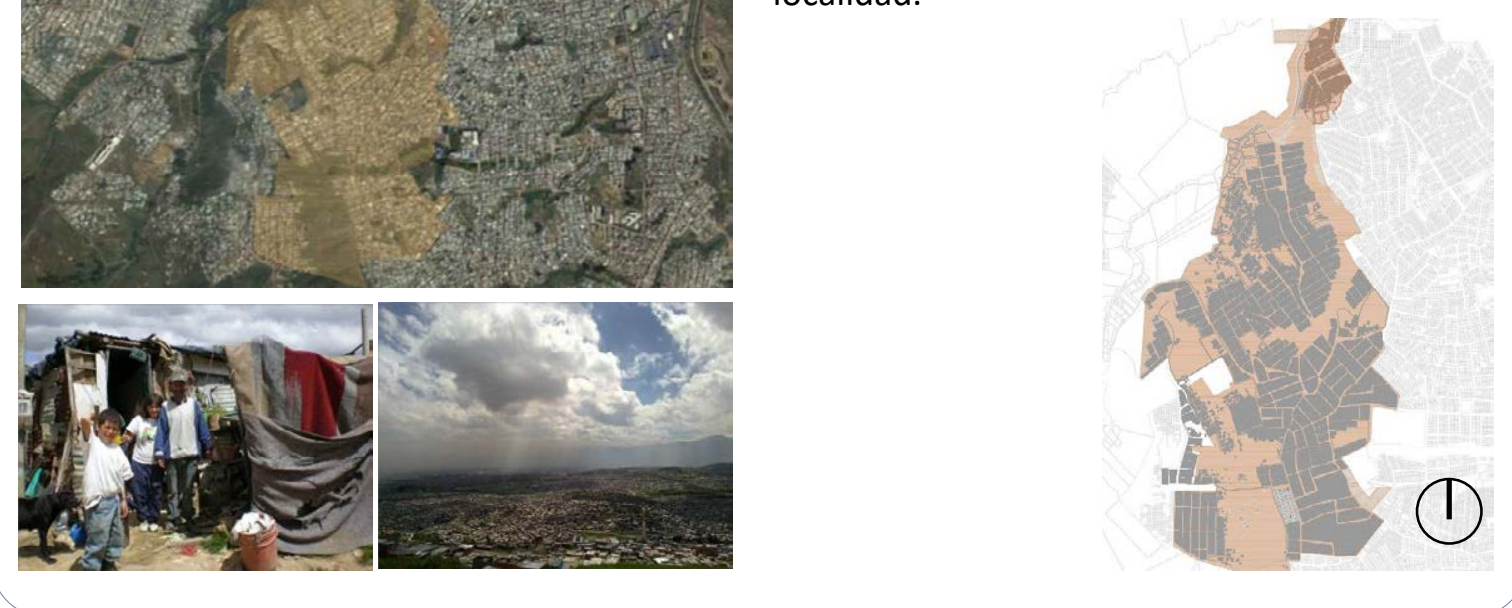

El Lucero es un sector periférico de la ciudad con uso residencial predominante de estratos 0 , 1 y $2(22,6 \%, 61,5 \%$ y $15,9 \%$ respectivamente). Antes de la intervención en la zona se observaban deficiencias en servicios públicos, accesibilidad, equipamientos y espacio público, deterioro de las áreas de la estructura ecológica y precariedad de títulos y de habitabilidad de las viviendas. Además, los hogares existentes presentaban un nivel de pobreza (41\%) y de miseria $(12,4 \%)$ elevado con problemas relacionados de convivencia y seguridad (violencia, maltrato intrafamiliar, presencia de actores armados y consumo de sustancias psicoactivas entre otras).

La vocación del programa MIB se centró entonces en dos variantes la física y la social. En la física se mejoró la accesibilidad con la pavimentación de 31 segmentos viales, se recuperaron parques y zonas verdes, se construyeron equipamientos, se recuperaron las zonas hídricas y rondas de rio y se mejoraron los escenarios de vivienda de algunos hogares. En lo social se fortaleció las condiciones de seguridad y convivencia a través del Programa Sur de Convivencia con las diferentes entidades distritales que actúan en la zona. Dicha experiencia interinstitucional le otorgó en reconocimiento de "Buenas Prácticas en el Mejoramiento del Hábitat" del distrito en el año 2014. 


\section{Modelo de ciudad propuesto y construido}

El proyecto de mejoramiento de barrio El Lucero fue una de las primeras experiencias de intervención de la administración distrital enfocado en un modelo de planificación por zonificación física y temporal (UPZ). Los criterios que se tuvieron en cuenta y los objetivos del programa, según el decreto 440 de 2004 el cual reglamenta la zona, fueron:

+ Vivienda: proponer un programa de mejoramiento de vivienda dado que en esta UPZ se hace necesario mejorar en las condiciones estructurales de 14.377 viviendas, reasentar a 6.751 familias, titular a 12.339 parcelas y reconocer a 26.822 nuevas edificaciones de 1 y 2 niveles.

+Redes de servicios: realizar acciones prioritarias para la continuación de redes troncales (interceptadores) y para la continuación de redes locales de acueducto, alcantarillado sanitario y alcantarillado pluvial.

+Movilidad: Consolidar los ejes de la malla vial arterial y los corredores de movilidad local para que sirvan de conectores con el área delimitada como Operación Estratégica Río Tunjuelo Centralidad Danubio. Acción necesaria dado que la mayoría de las vías están en mal estado o no existen, lo cual dificulta la movilidad y afecta la calidad de vida de los habitantes, ocasionando problemas asociados como deficiente acceso a servicios públicos domiciliarios, dificultad en el acceso a los equipamientos, las centralidades de la localidad y de la ciudad; la ausencia de andenes y/o de construcción irregular al lado de la vía principal genera dificultades en el flujo de tráfico vehicular, causando inseguridad y riesgo en el desplazamiento de los habitantes de estos barrios.

+Equipamientos: Por un lado, reestructurar y mejorar las instalaciones de los equipamientos de educación, salud y bienestar Social. Y por otro lado, construir parques vecinales como los de México, San Rafael, La Alameda, Gibraltar.

+Zonas verdes Según la norma reglamentaria de la UPZ en términos del Sistema de Espacio Público, esta UPZ cuenta con 2,09 $\mathrm{m}^{2} / \mathrm{hab}$., sobre el promedio de la ciudad que corresponde a $4.7 \mathrm{~m}^{2} / \mathrm{hab}$., la norma propone llegar a $6 \mathrm{~m}^{2} / \mathrm{hab}$.,

+Condiciones ambientales: Realizar acciones de mantenimiento, protección y preservación ambiental, para la consolidación del área de Ronda del Río Tunjuelito y Quebrada de Limas. Reasentar a la población allí localizada.
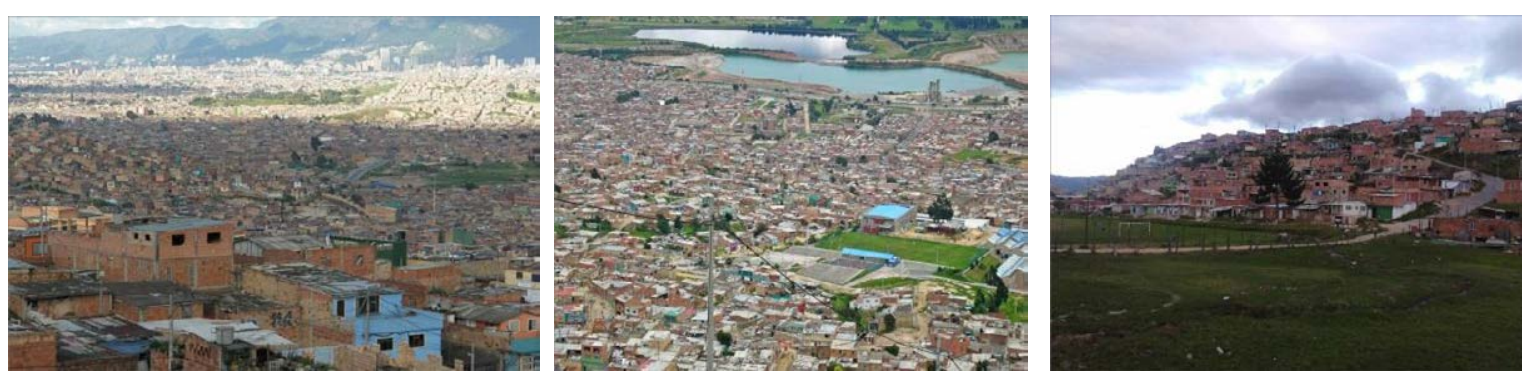

Aerofotografías de la zona 


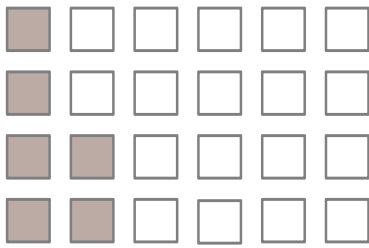

67,53viv/ha

API El Lucero 49,24viv/ha

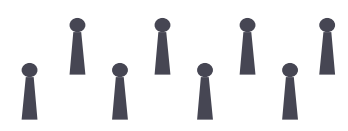

229,37hab/ha

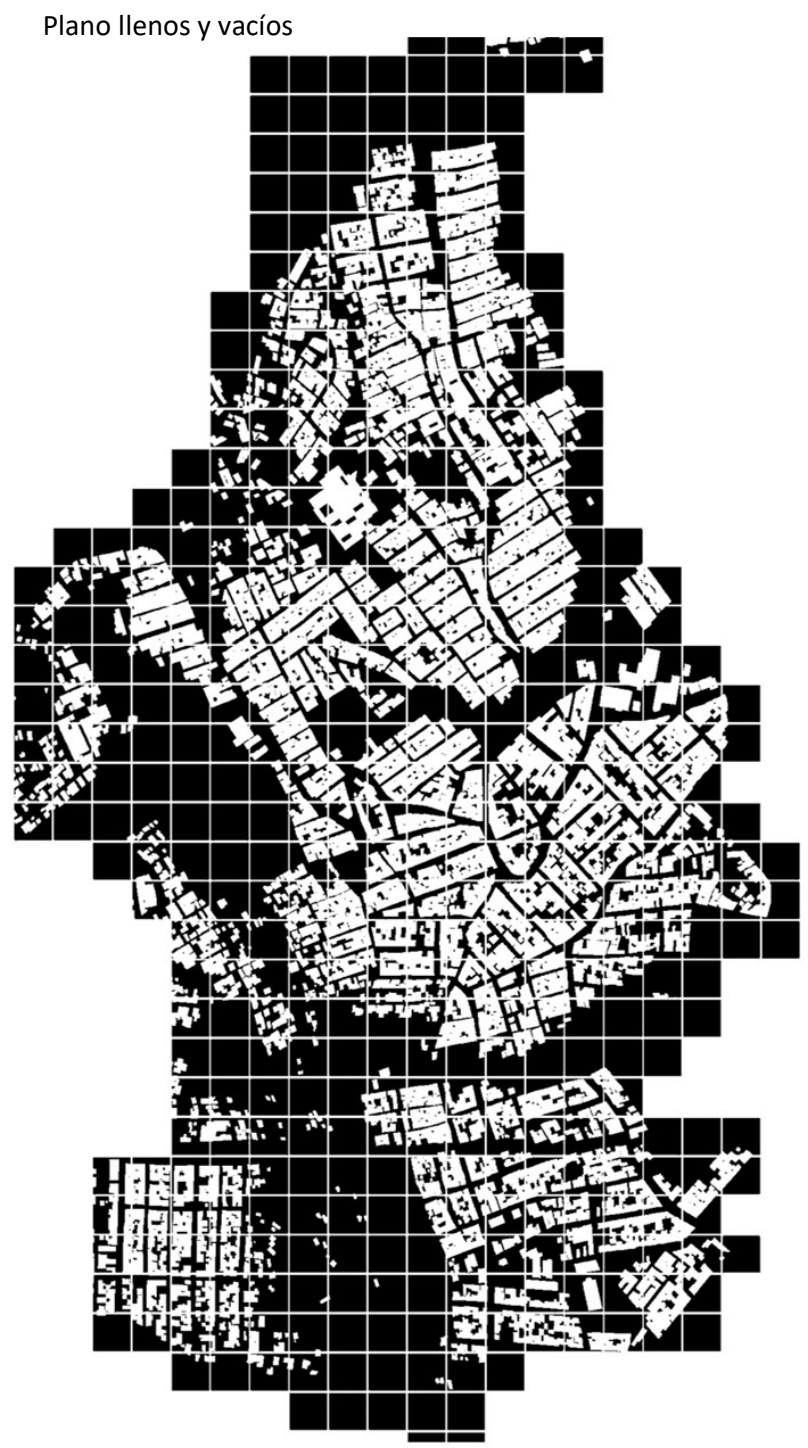

102 Cesiones

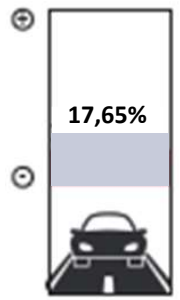

Malla vial

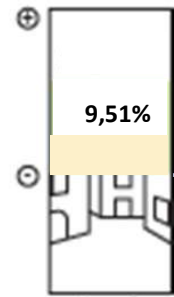

Espacio público

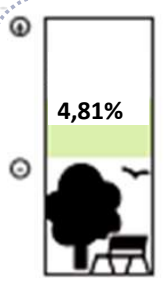

Zonas verdes

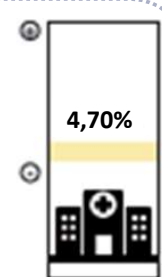

Equipamientos

Las área no construidas dispuestas como cesiones en El Lucero son muy deficientes tanto a nivel de espacio público (equipamientos y zonas verdes) como de malla vial. Ninguna cumple con los estándares mínimos deseables establecidos

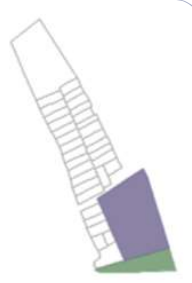

Áreas

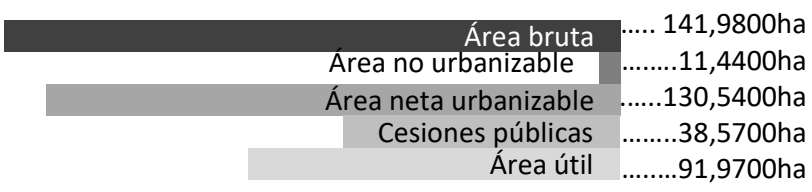

Cesiones públicas

\begin{tabular}{c|c} 
Cesiones públicas & ........ 38,5700ha \\
Malla vial & $\ldots . . .25,0670 \mathrm{ha}$ \\
Equipamientos & $\ldots . . . .66,6730 \mathrm{ha}$ \\
Zonas verdes & .........6,8353ha
\end{tabular}




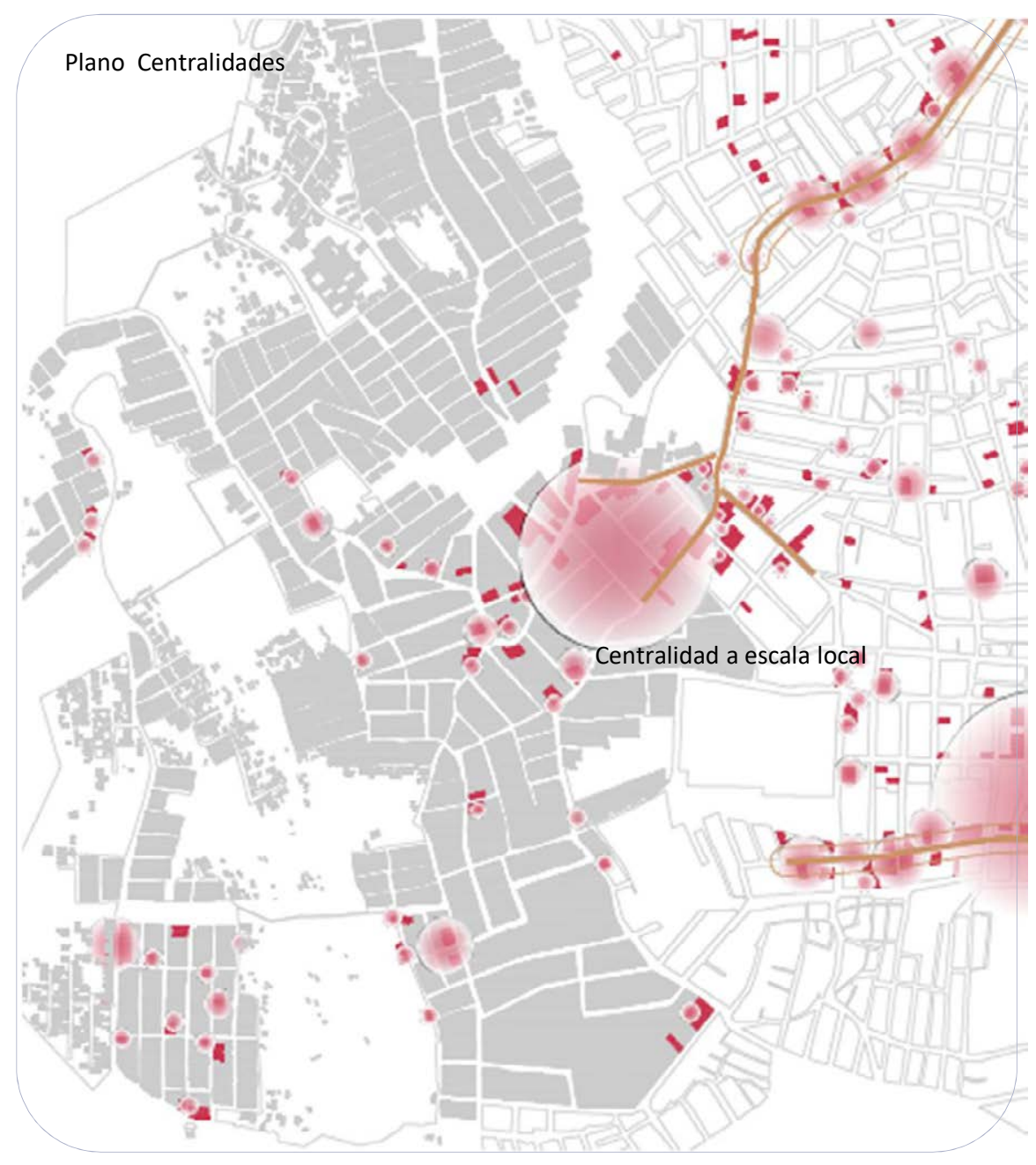

El proyecto no cuenta dentro de su territorio con centralidades establecidas desde el POT.

Existe una pequeña centralidad a nivel local que se ha configurado gracias al comercio de productos diarios que la gente ha ido instalando en la calle (venta ambulante) $o$ en sus propias viviendas en las primeras plantas.

Centralidad local
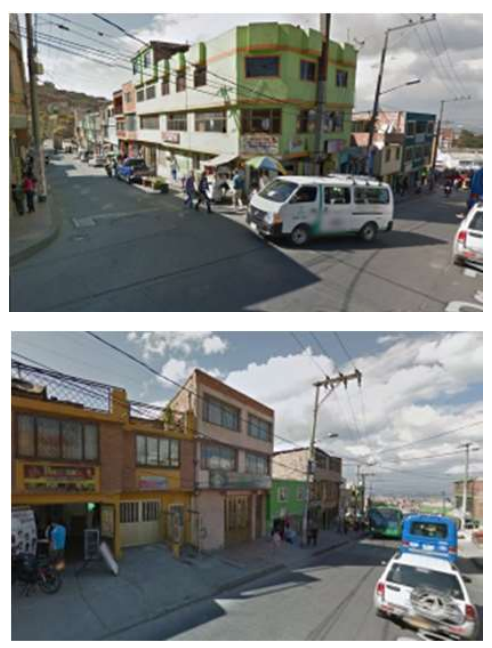

Tiempos de desplazamiento a la centralidad Danubio Azul

Escala ciudad: Centralidad Danubio

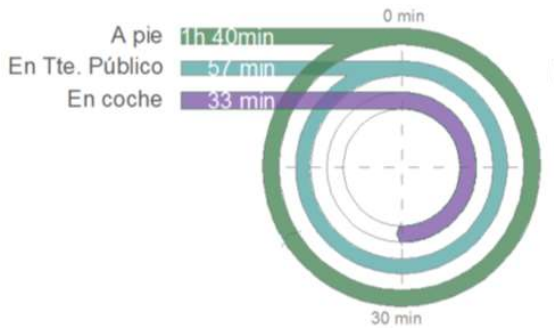

Escala local: Centralidad propio proyecto

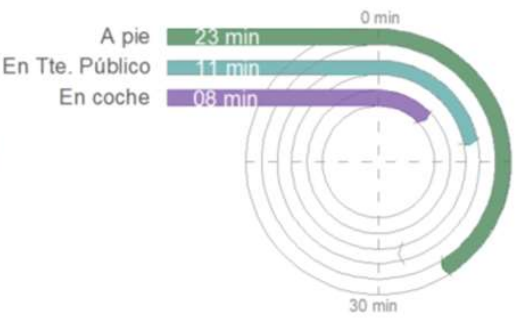

Escala local: Centralidad afueras del proyecto

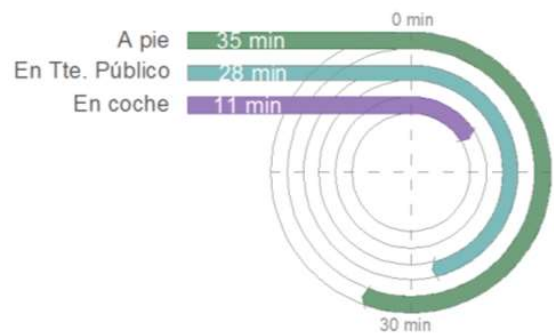

Según los criterios establecidos sobre los tiempos de desplazamiento, es evidente que la única centralidad existente por fuera del proyecto es prácticamente inaccesible a pie y con un trayecto muy largo en transporte público. No en vano la población ha creado sus propias centralidades gracias a la modificación de sus viviendas para poder resolver sus necesidades lo mas próximo posible a su hogar.

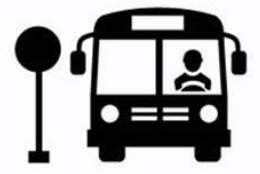



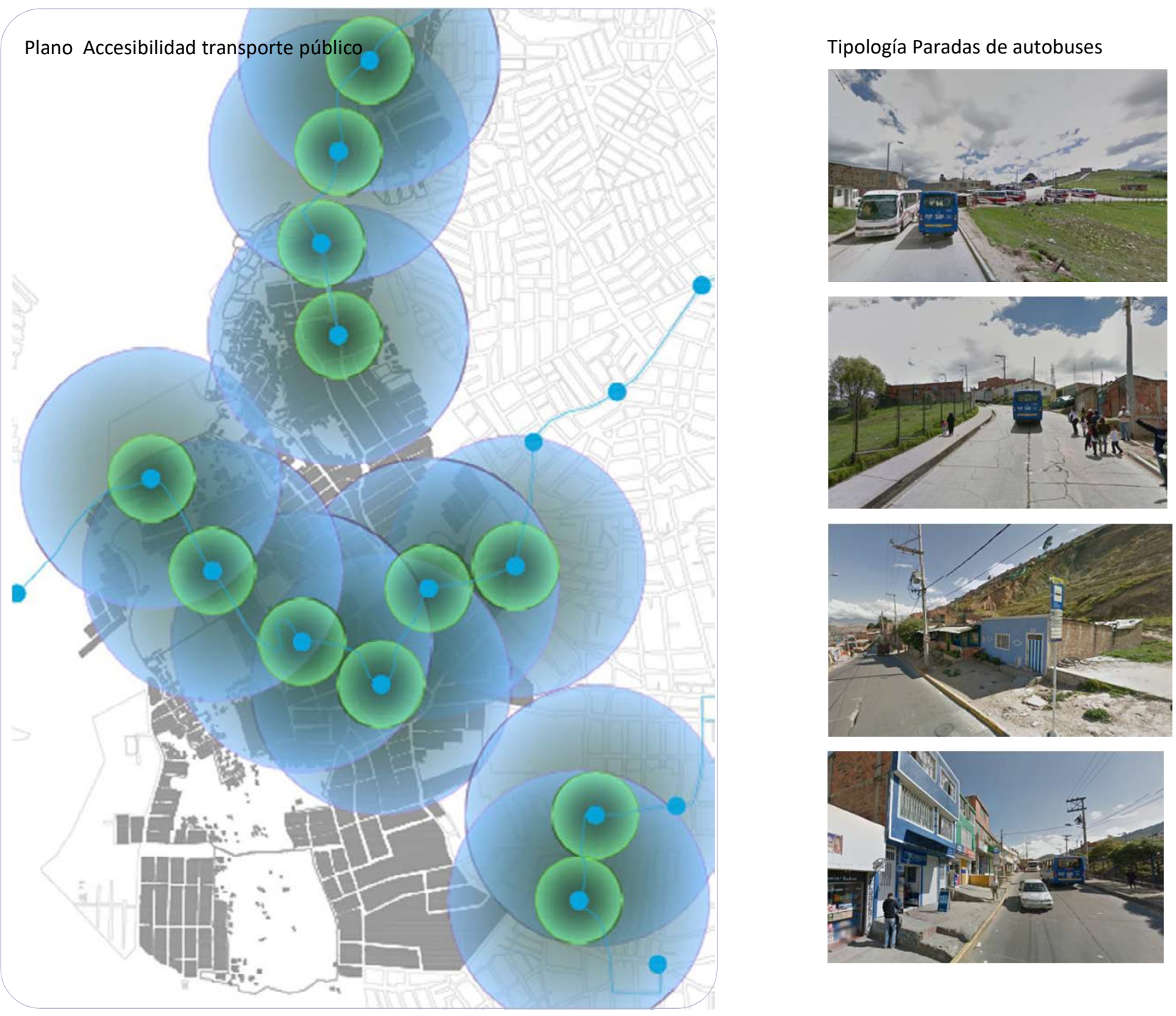

La accesibilidad al sistema de transporte público es de carácter medio. El 51,87\% del territorio cuenta con paradas de autobús (alimentador de I sistema de Transmilenio) entre $100 \mathrm{mts}$ y $300 \mathrm{mts}$ de distancia de las viviendas. El esto del territorio debe desplazarse con el sistema tradicional, no organizado, de transporte. Dicha condición genera, como ya se había planteado en los otros estudios de caso con igual situación, una posición de desventaja para la población que debe gastar tiempo y recursos para llegar hasta un portal de Transmilenio o al centro mismo de la ciudad.

\section{Conexiones y trazados de vías}

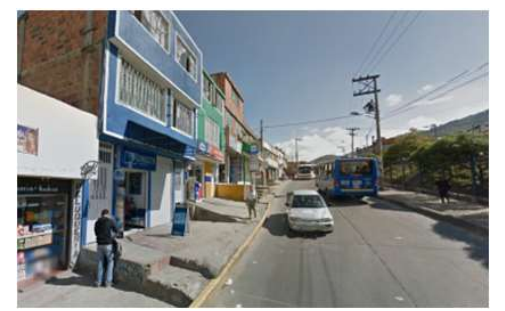

Pendiente

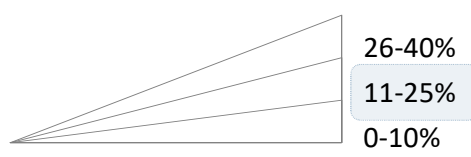

Acceso a escala de ciudad
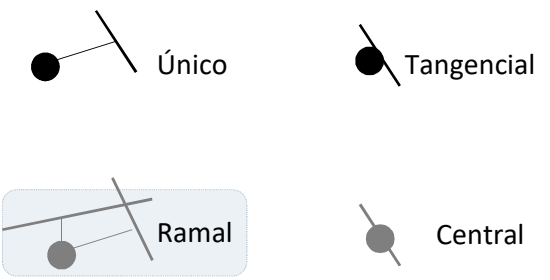

Conexión a escala de barrio
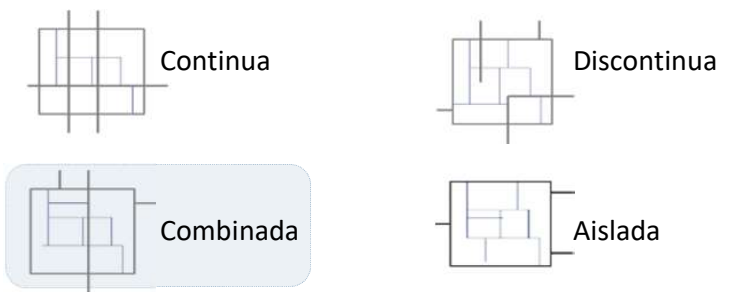

El proyecto El Lucero cuenta con una malla vial insuficiente, desarticulada y sin continuidad. La avenida Boyacá es la vía principal y es la única que le da acceso al barrio por medio de dos vías en ramal. Su perfil, el de las dos vías, es estrecho, presenta comercio y ventas ambulantes a lo largo de todo su recorrido, lo que las hace unas calles congestionadas.

La topografía del proyecto en moderada, con pendientes en su mayoría entre $11 \%$ y $25 \%$. No obstante hay una zona de alta pendiente, mayores de $60 \%$, que esta tratando de ser desalojada por parte de la administración para convertirla en un parque público. 


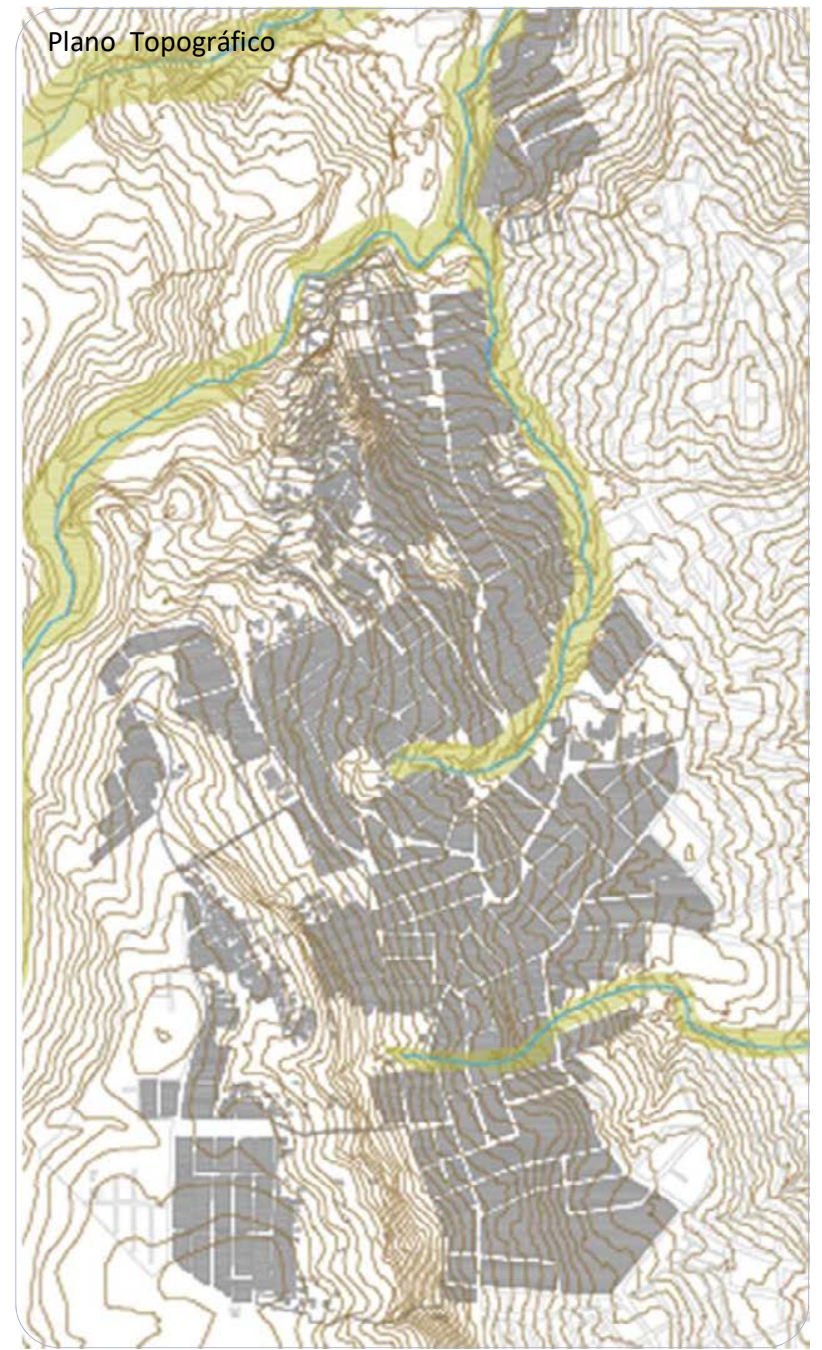

\section{Estado de las vías}

\section{VÍA VEHICULAR}

Pavimentada

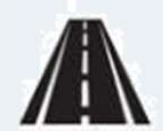

$56 \%$
No Pavimentada

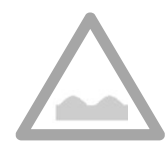

$44 \%$

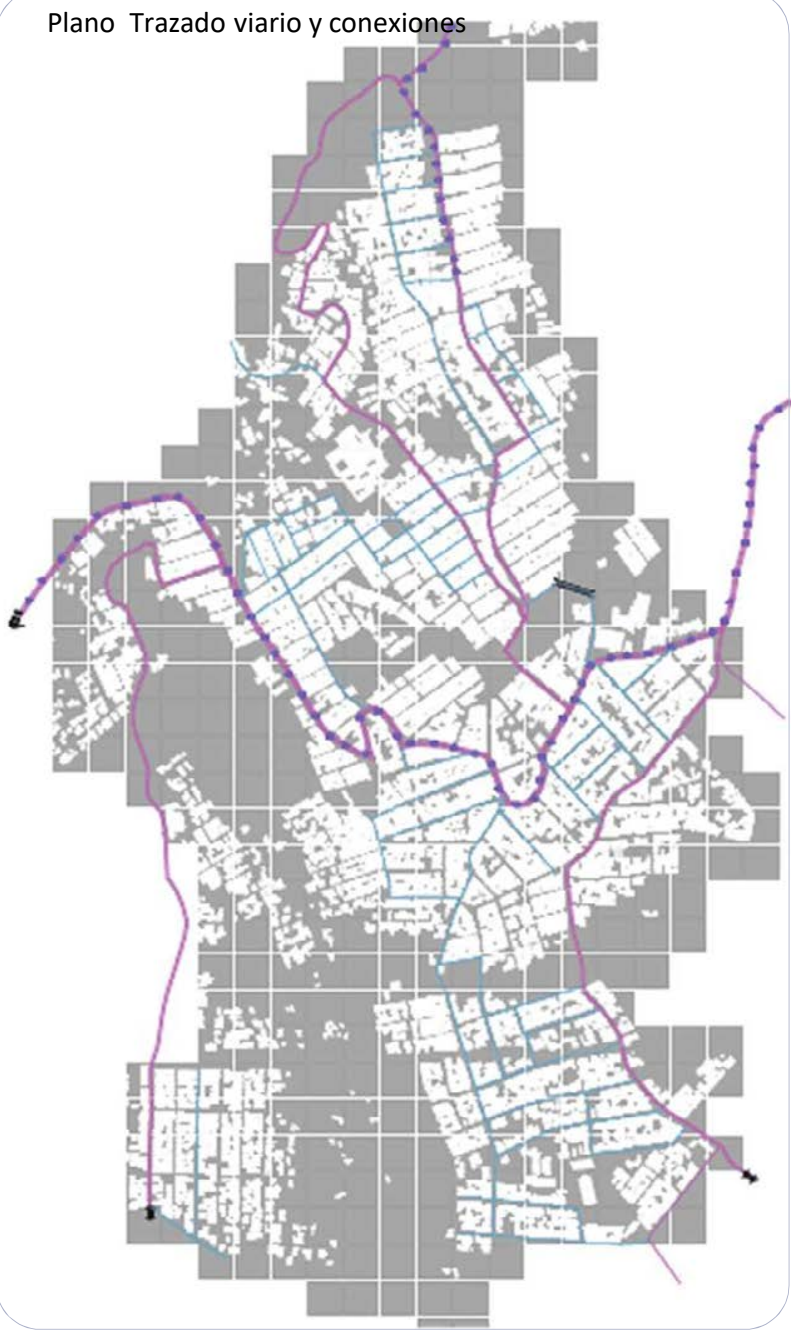

Movilidad

\section{VÍA PEATONAL}

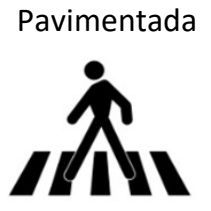

$26 \%$
No Pavimentada

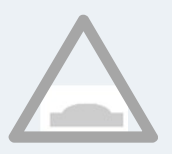

$74 \%$

En general en el proyecto, lasa vías vehiculares y peatonales se caracterizan por encontrarse en mal estado, en parte debido al paso del transporte público y a las difíciles condiciones del terreno. Algunas calles y andenes han sido, sin embargo objeto de mejoramiento.
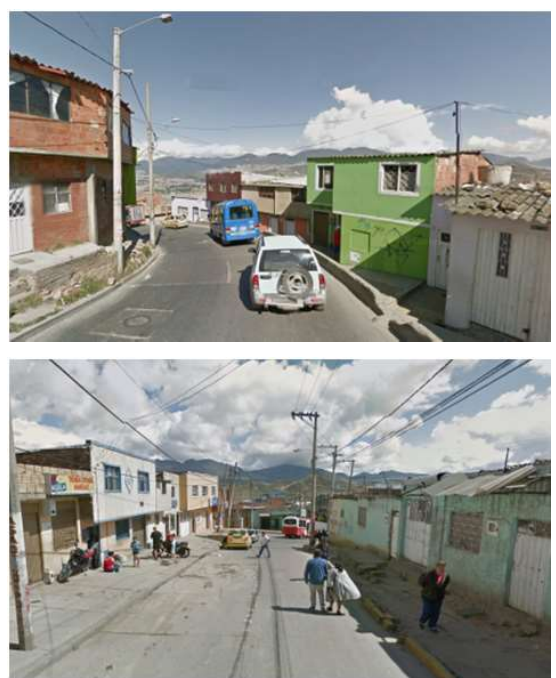
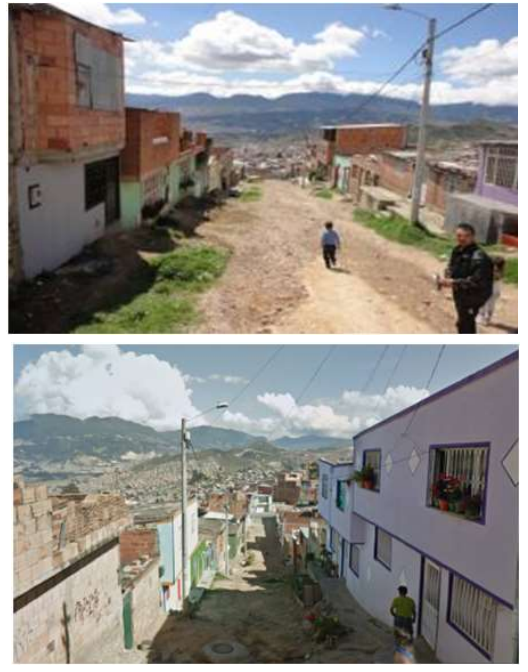

Vía construidas en el mejoramiento
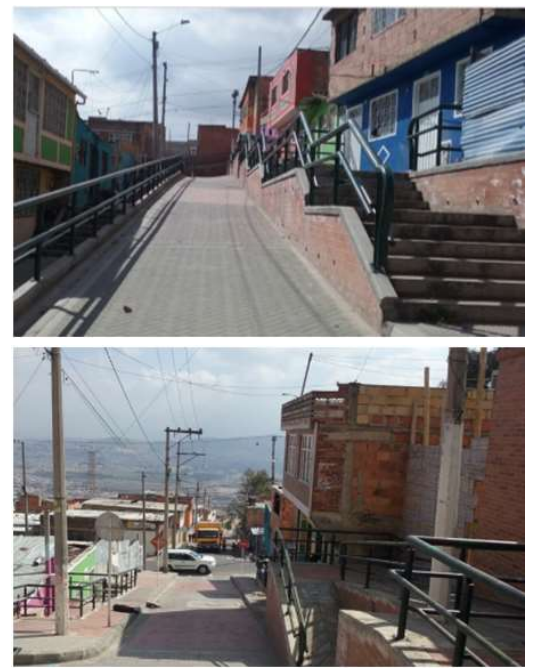


\section{EQUIPAMIENTOS ESCALA BLOQUE-VECINDARIO}
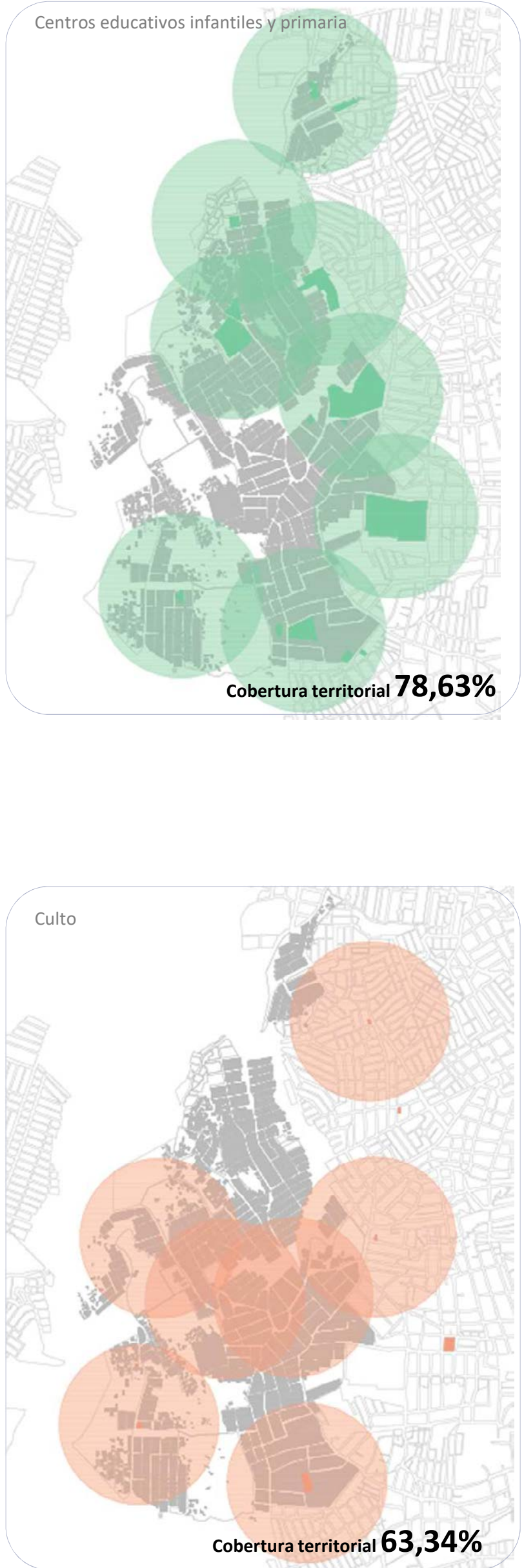
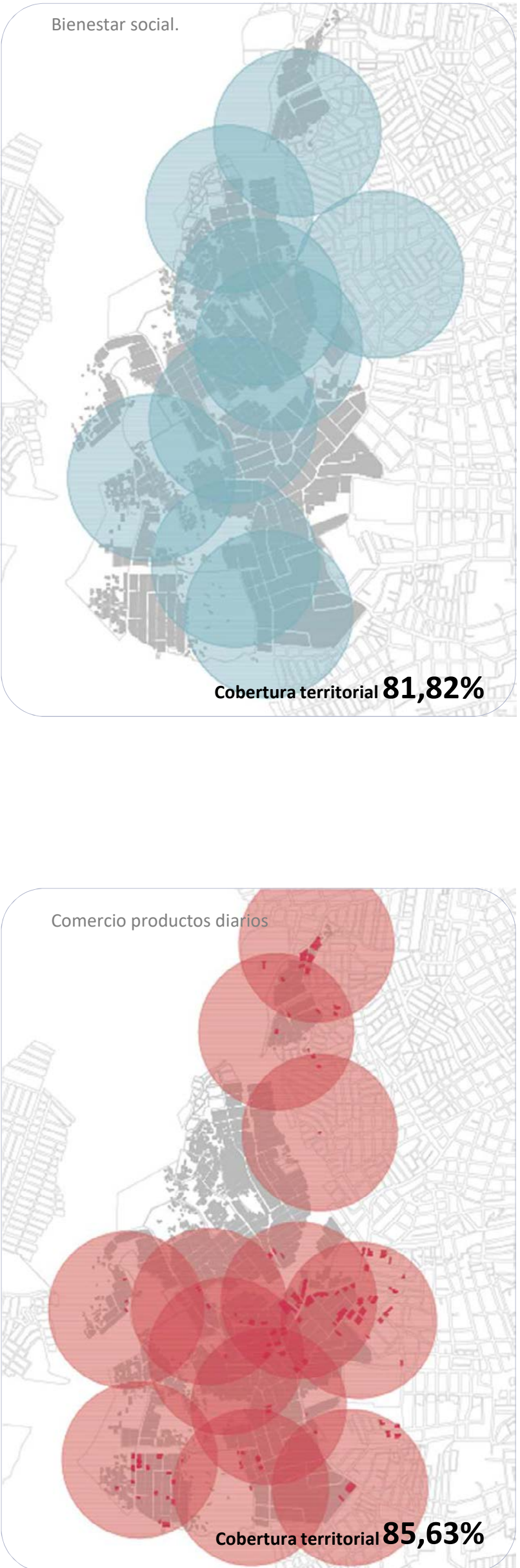


\section{Centros educativos}

La cobertura de los centros educativos a nivel territorial es apenas eficiente a nivel de primaria y óptima a nivel de secundaria. Sin embargo, dicha cobertura territorial no refleja la cobertura en cupos educativos, que para la zona es de 20.943 y la demanda de 51.516. Es necesario construir prácticamente el doble de instituciones académicas.

\section{Centros de bienestar social}

Los equipamientos de bienestar social están representados en el proyecto únicamente por salones comunales. Estos creados por la población no se encentran todos en buen estado.

\section{Centro de salud}

Con respecto a los centros de salud, la cobertura a nivel territorial solo se da en la mitad de su área de desarrollo. La UPZ Lucero cuenta con un hospital de segundo nivel, dos UBAS, 1 UPA y 1 CAMI. Además se encuentran dieciséis instituciones prestadoras de servicios de carácter privado. El inconveniente es que no todas estas edificaciones se encuentran dentro del área de mejoramiento y por lo tanto requiere de un desplazamiento grande de la población para acceder a ellas.

\section{Centros de culto}

Los equipamientos de tipo religiosos, como en los otros proyectos analizados, siguen teniendo una presencia importante en el territorio, mas aun en aquel desarrollado de forma marginal. MIB El Lucero, no es la excepción y la cobertura territorial de este tipo de equipamientos es mayor al $50 \%$.

\section{EQUIPAMIENTOS ESCALA BARRIO-ZONAL}

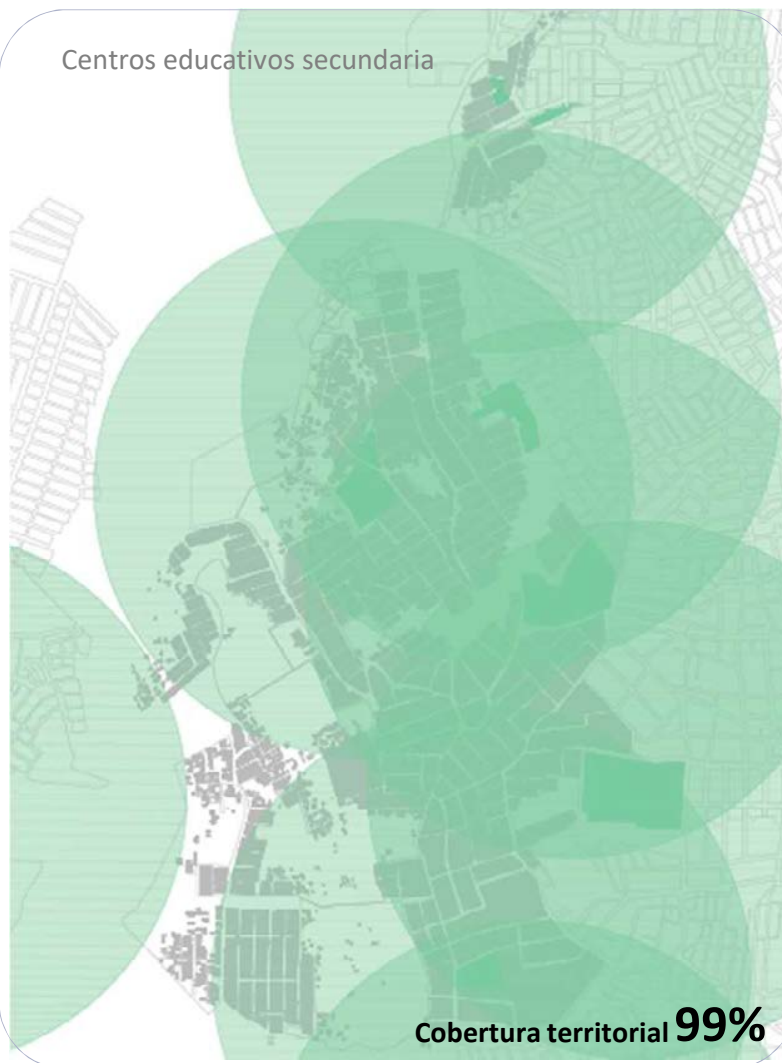

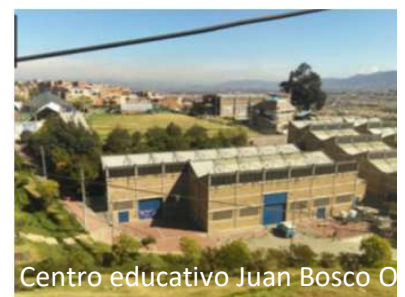
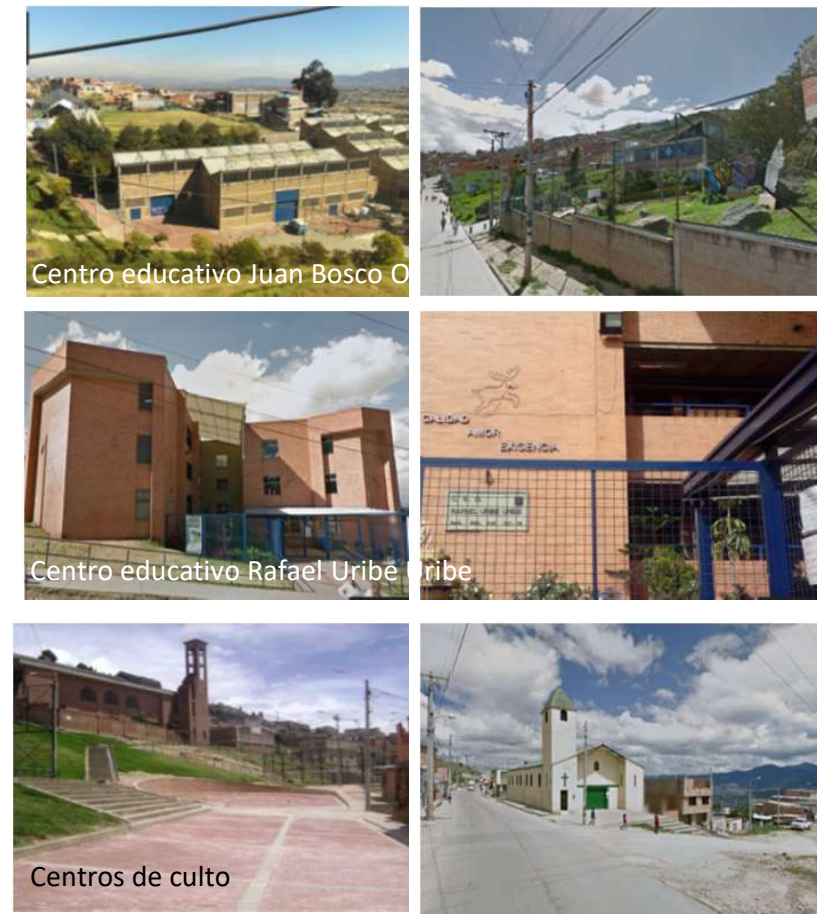

Centros de culto
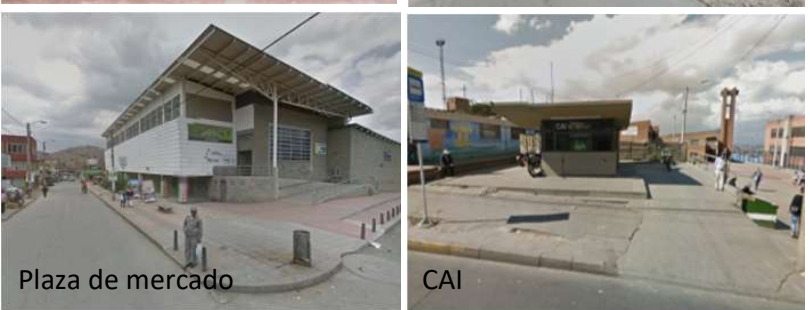

Centros de Salud

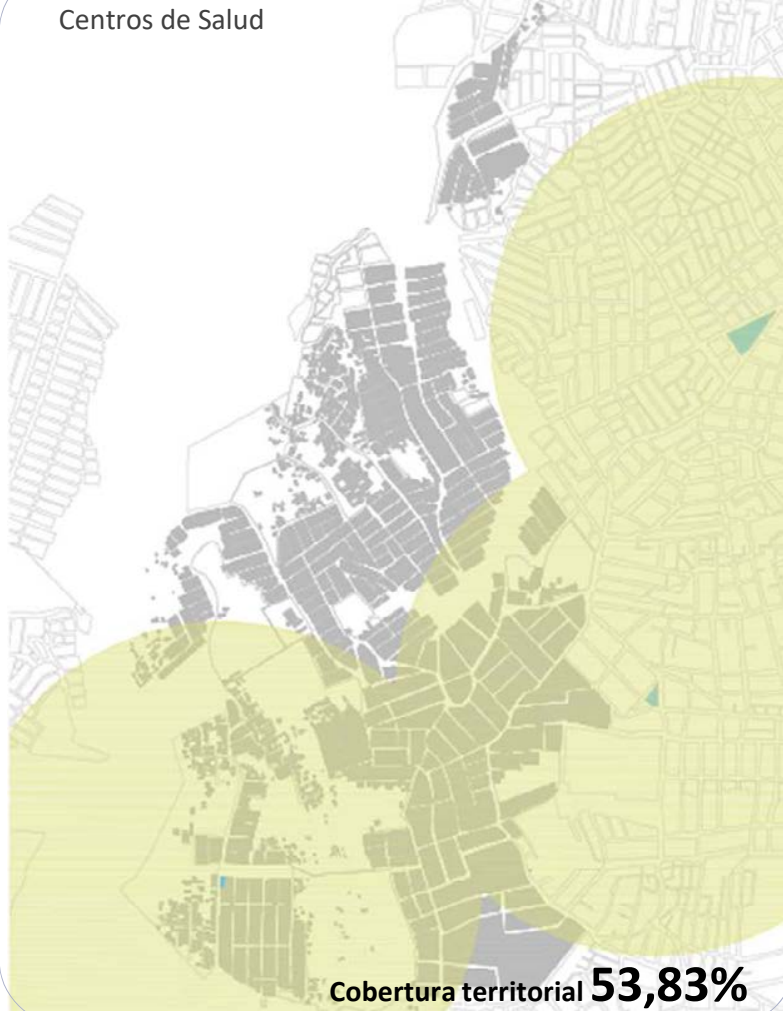




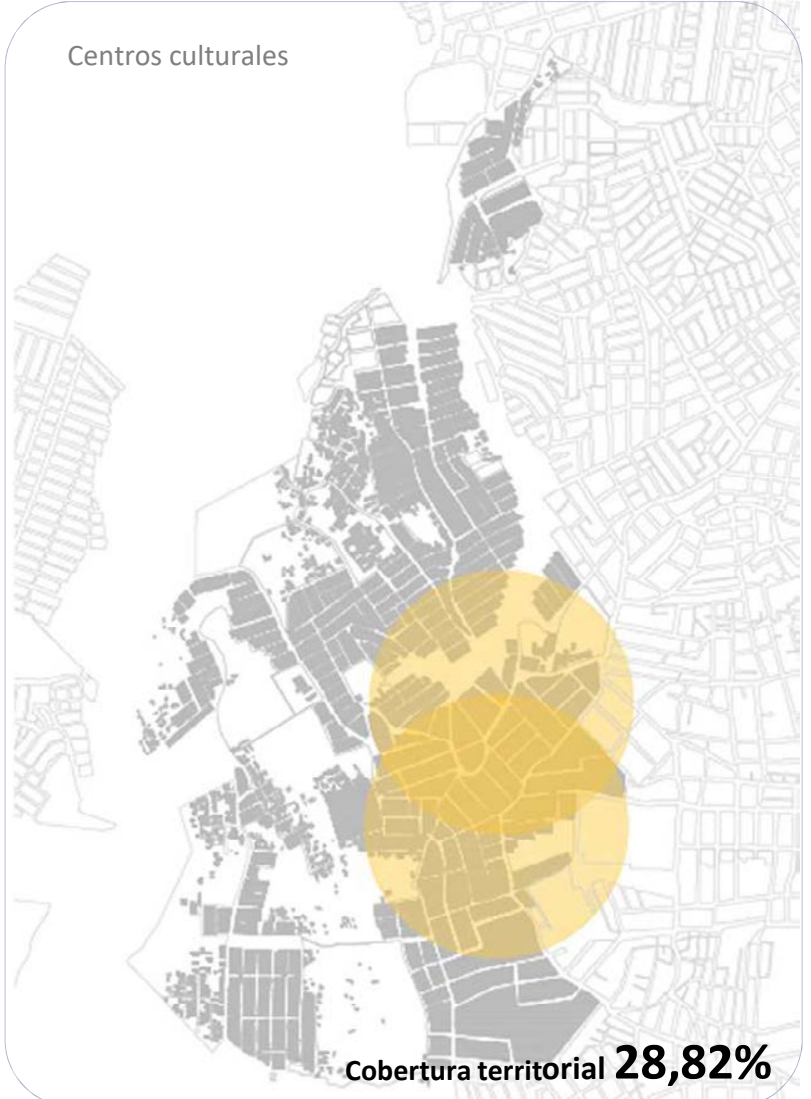

\section{Centros Culturales}

Uno de los equipamientos mas deficitarios, por lo general, en las zonas de periferia de la ciudad de Bogotá, son los equipamientos de cultura, tales como bibliotecas, teatros, ludotecas, etc. Mib El Lucero no es la excepción, tan solo cuenta con dos edificaciones de este uso: son dos pequeñas ludotecas insertadas en la primera planta de dos viviendas particulares.

108 Cobertura zonas verdes

\section{0 - 300mts}

Accesibilidad media $\mathbf{1 1 , 9 8 \%}$
$<100 \mathrm{mts}$

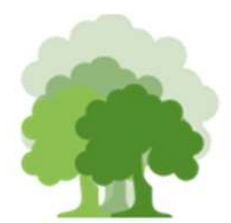

Uno de los proyectos que tiene la administración en El Lucero, es la recuperación del espacio público por medio de apropiación de los moradores pintando sus propias fachadas. Para ello, la administración inició contratando a unos pintores para que realizaran unos murales que sirvieran de “inspiración“ a la población.
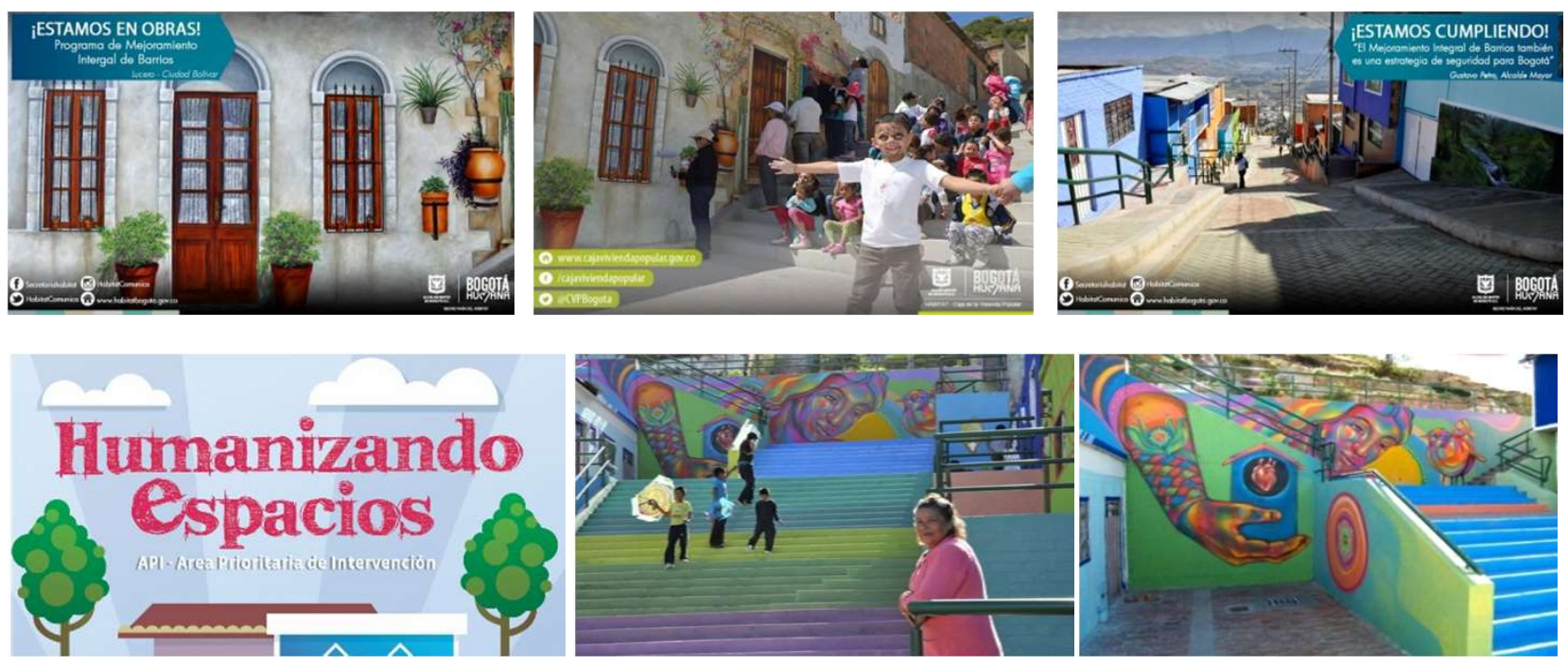


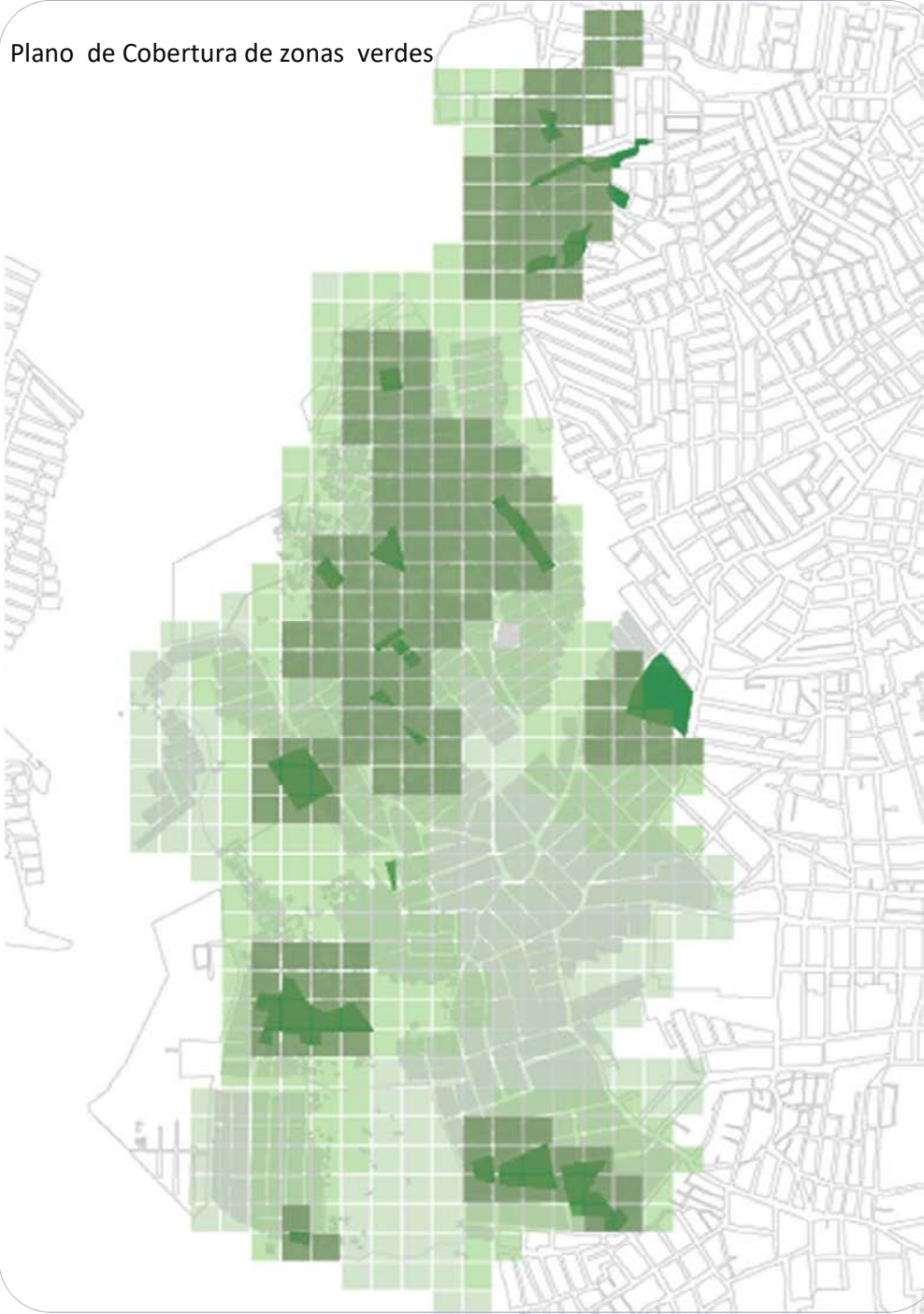

El espacio público que presenta el proyecto El Lucero es insuficiente (en relación a los metros cuadrados por habitante) y se encuentra deteriorado. Sin embargo, su cobertura a nivel territorial es de nivel medio. El sector tiene un alto porcentaje de parcelas baldías y terreno para zonas verdes que no han sido del todo desarrolladas; lo que ha generado un uso desfavorable con un alto nivel de basuras.
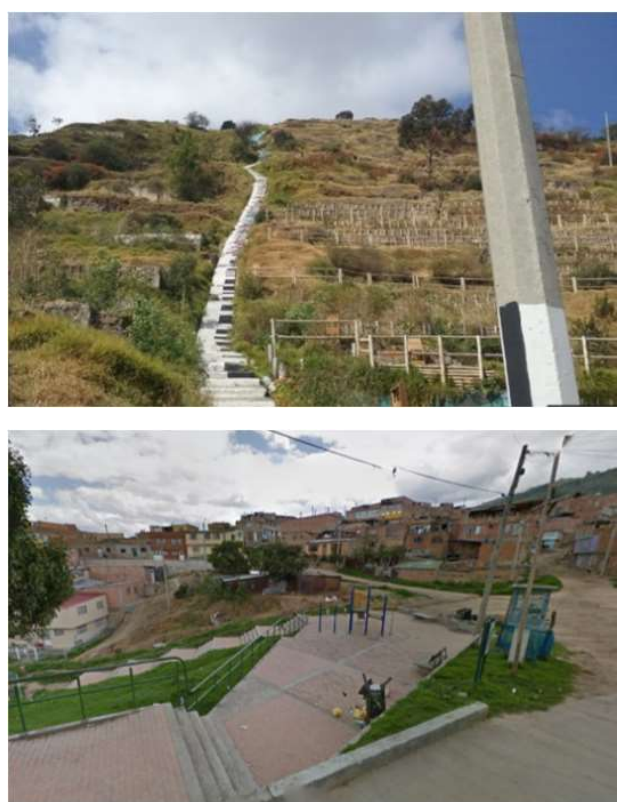

Proporción de zonas verdes 2,09m2/hab

\section{Cobertura de servicios públicos domiciliarios}
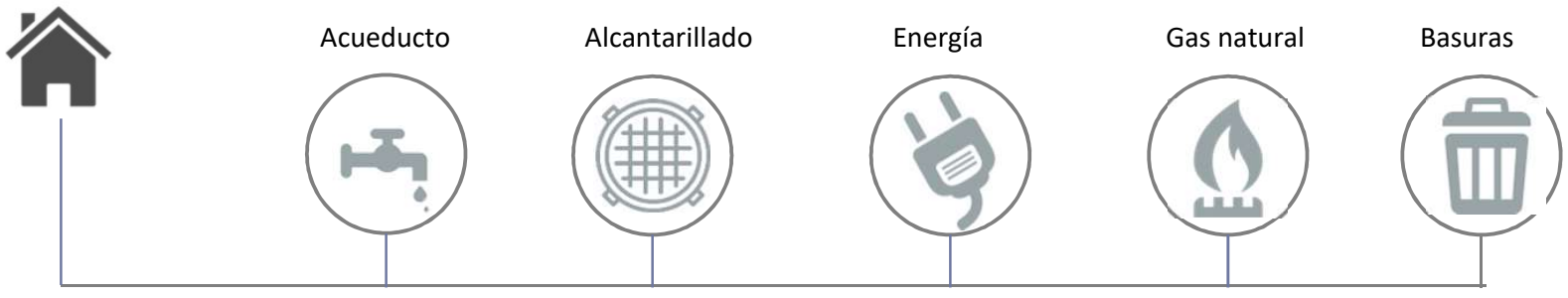

$99,40 \%$

$91,30 \%$

$100 \%$

$73,91 \%$

$60.86 \%$

En general, los barrios legalizados cuentan con la totalidad de redes de acueducto y energía, pero cuentan con algunas deficiencias en las redes de alcantarillado pluvial y sanitario. Por otra parte, para los barrios ubicados en la parte más alta del MIB y que aún están en proceso de legalización (Mirador de Quiba III, Tabor Alta Loma, El Eden Sector el Paraíso, La Puerta del Paraíso) existen deficiencias en la prestación de los servicios de acueducto y/o alcantarillado y aún no cuentan con la totalidad o ninguna de las redes. Esta situación obedece a que estos barrios se encuentran por encima o muy cerca de la cota máxima de servicio de acueducto y el Acueducto de Bogotá, con la infraestructura actual, no puede garantizar la prestación del servicio. Además, estos desarrollos, en su mayoría, se encuentran en zonas de alta pendiente con afectaciones por alto riesgo.

La recolección de basuras, en cambio es un servicio bastante deficiente pues solo pasa a recoger los desechos tres días a la semana y no en todo el territorio. Existen barrios, los más altos de la UPZ (Cordillera Sur, Villas del Progreso, Villas del Diamante, Villa Gloria, Tierra Linda y La Esmeralda Sur), que dadas las condiciones topográficas del sector y que la totalidad de las vías aún no están pavimentadas, son de difícil acceso del carro recolector. Condiciones similares y con mayor restricción por no estar legalizados, se presenta en los barrios Mirador de Quiba III, Tabor Alta Loma, El Eden Sector el Paraíso, La Puerta del Paraíso. 


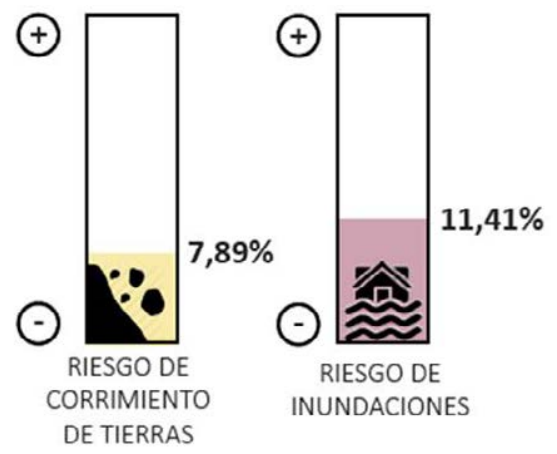

I11 Morfo-tipología

Unidades habitacionales construidas

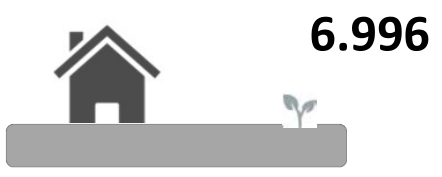

Viviendas unifamiliares

Número de parcelas

8.745
Riesgo por deslizamiento de tierras. La UPZ el Lucero se encuentra ubicada en una zona de amenaza sísmica intermedia, lo que le confiera una posibilidad del $8 \%$ de riesgo por deslizamiento. El terreno tiene una pendiente predominante en la parte occidental con viviendas de origen marginal y procesos inestables de invasión alrededor de las quebradas El Zanjón y la Ladera.

Riesgo por inundación. Dada las mismas condiciones de invasión de viviendas sobre el cause de las quebradas antes mencionadas, El Lucero presenta áreas de amenaza media por inundación.

Contaminación El área presenta un alto porcentaje de contaminación (basura y materiales de construcción) que deterioran el espacio público y las zonas verdes.

Conjunto habitacional y vivienda

Ocupación de la manzana y tipología de la vivienda

La configuración del tejido residencial en El Lucero se caracteriza por ser de origen marginal en su totalidad, salvo por algunas parcelas adquiridas, posteriormente al asentamiento por parte de la administración para la construcción de equipamientos. De dicha configuración, un porcentaje importante $(90 \%)$ ha sido desarrollada por una formación de tipo invasión.

Todos los barrios del Mib han sido legalizados salvo por 1 (barrio Las Manitas). La fecha de legalización de la mayoría de barrios oscila entre el año 1992 y el año 2000.

Tamaño de parcelas

$90 \mathrm{~m} 2-150 \mathrm{~m} 2$ promedio
Marginal reticular $7 \times 12,85=90 \mathrm{~m}^{2}$
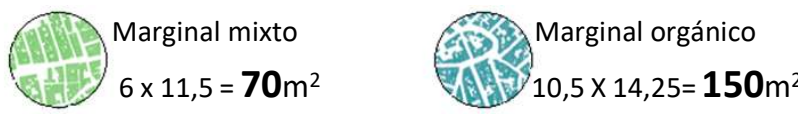
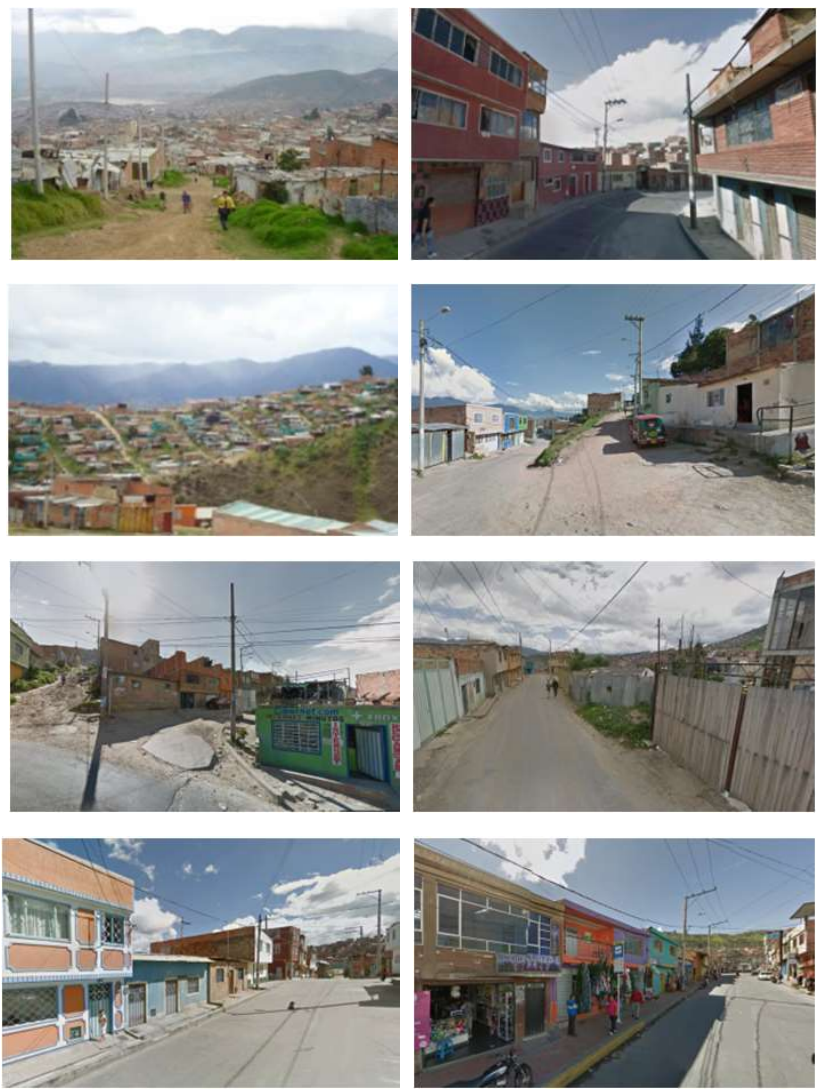

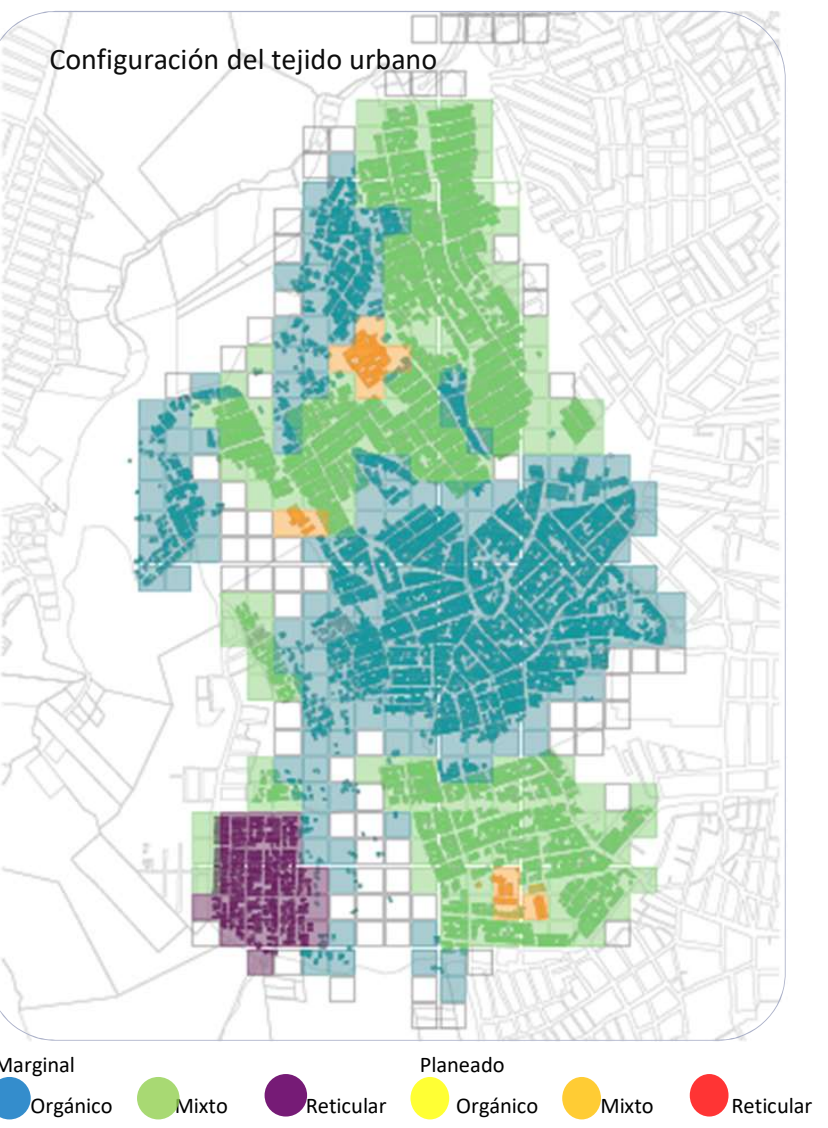




\section{Niveles de consolidación}

En general puede afirmarse que los barrios más antiguos de la UPZ, que corresponden a los ubicados en la zonas planas y en las laderas de menor pendiente, se encuentran medianamente consolidados. El porcentaje de predios ocupados y construidos de estos barrios es del $90 \%$; las viviendas están construidas con niveles entre uno y dos pisos, estructuras de en concreto y ladrillo y cubiertas en placa.

En los barrios más jóvenes y aquellos que aún están en proceso de conformación, y que corresponden a los que están ubicados en las zonas más altas y de mayor pendiente de la UPZ, el porcentaje de consolidación es menor (alrededor del 70\%). En estos barrios se encuentran viviendas con estructura de ladrillo y concreto de un piso, pero también es muy frecuente encontrar viviendas construidas con materiales provisionales (tuguriales) como cartón, madera y zinc, situación evidente en aquellos desarrollos que están tramitando su legalización.

\section{I12 Complejidad}

Uso del suelo privado
Comercio $2,13 \%$
Uso Dotacional $\mathbf{2 , 1 4 \%}$

EI Proyecto MIB El Lucero presenta un alto porcentaje de uso residencial, como la mayoría del territorio de origen marginal de la capital, y un muy bajo porcentaje de uso dotacional. Sorprendentemente, el uso comercial también es relativamente bajo. Lo que convierte la zona en un área prácticamente dormitorio en donde la gente mas que desarrollar su vida y satisfacer sus necesidades, simplemente hace su vida al interior de la vivienda. Todo lo ajeno a ella se realiza en otros territorios de la ciudad.

Hay que recordar que esta es una zona olvidada por el Estado con un alto porcentaje de vandalismo e inseguridad con constante presencia de pandillas, robos, atracos y hurtos según la población habitante.

\section{Comercio ambulante}
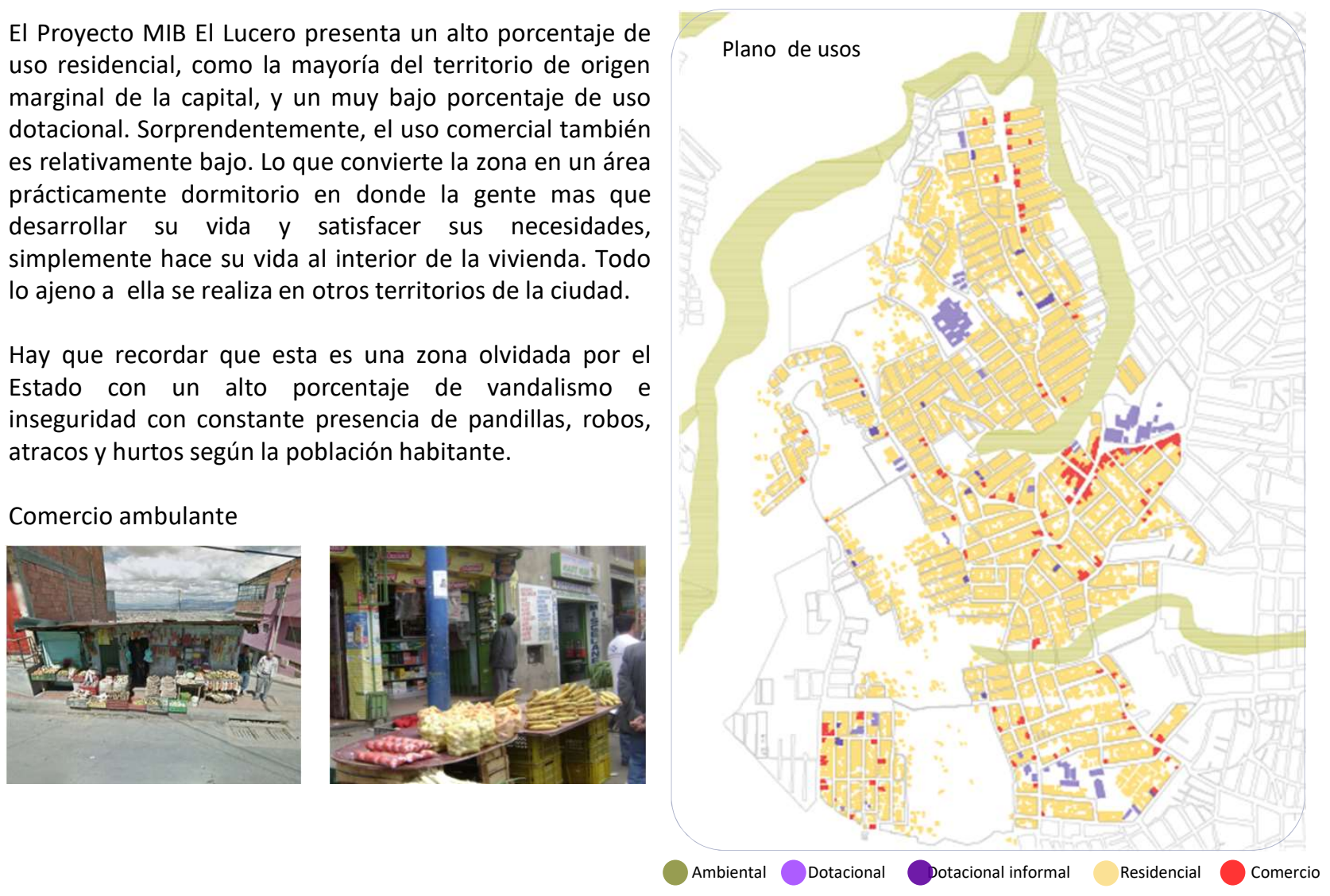

\section{Mezcla de rentas}

La población de El Lucero es predominantemente de estrato 1 con condiciones de pobreza bastante elevadas y perpetuadas en el tiempo. Provienen de departamentos como del Tolima, Pereira, Valle, Gacheta y Pacho Cundinamarca, inmigrantes de hace mas de treinta años que llegaron a poblar en forma precaria los primeros barrios de la parte mas plana de la UPZ u otros habitantes vienen de distintos sectores de Bogotá que por razones económicas se vieron obligados a desplazarse a este sector de la ciudad (Monografía Secretaria de Gobierno, Localidad de Ciudad Bolívar, 2004)

Su condicione socioeconómica es bastante precaria. Según la percepción de los representantes de las JAC, , en el 50\% de los barrios, por lo menos existe una necesidad básica insatisfecha, en el 17.3\% se percibe que hay mas de dos NBI visiblemente ubicadas en los barrios altos y barrios en zonas afectadas por ronda de quebrada o riesgo. Un $32.6 \%$ de los lideres manifestaron que en sus barrios algunos ubicados en la parte baja de la UPZ, no presentan NBI. 


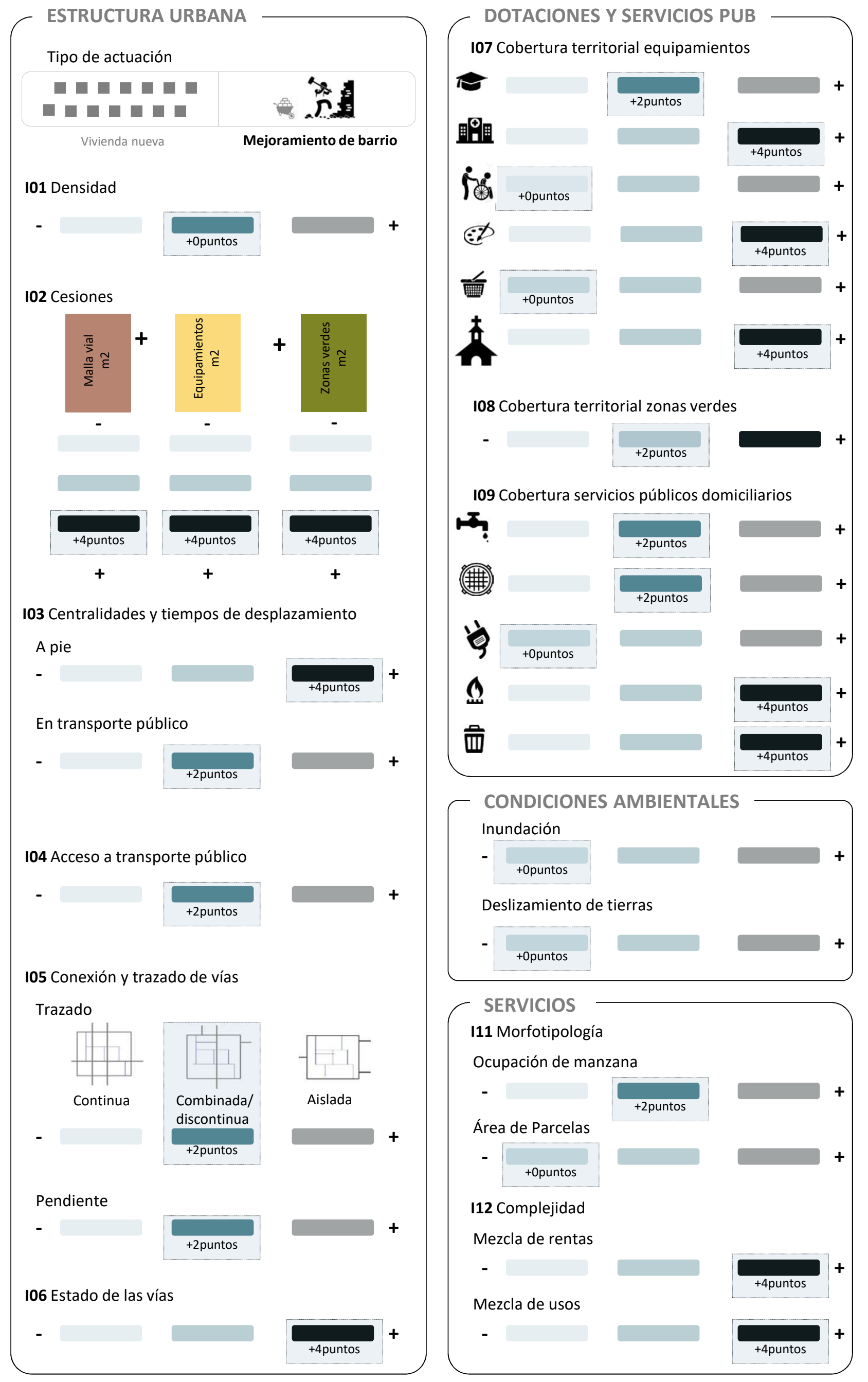




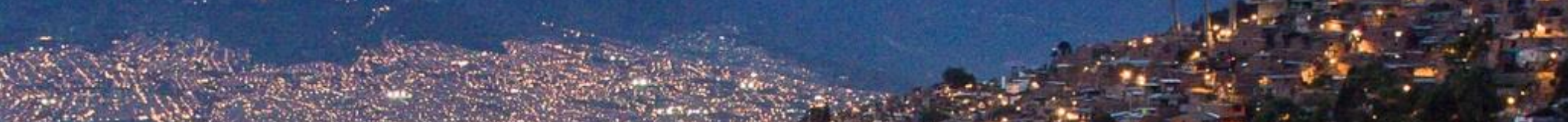

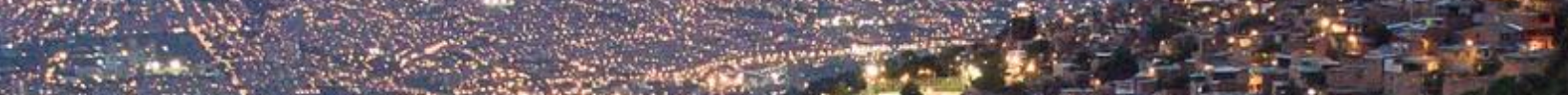

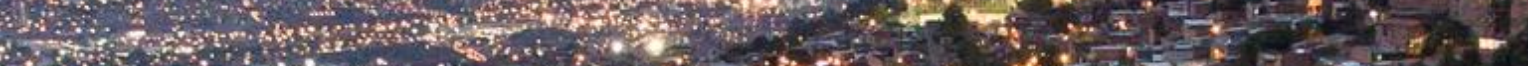

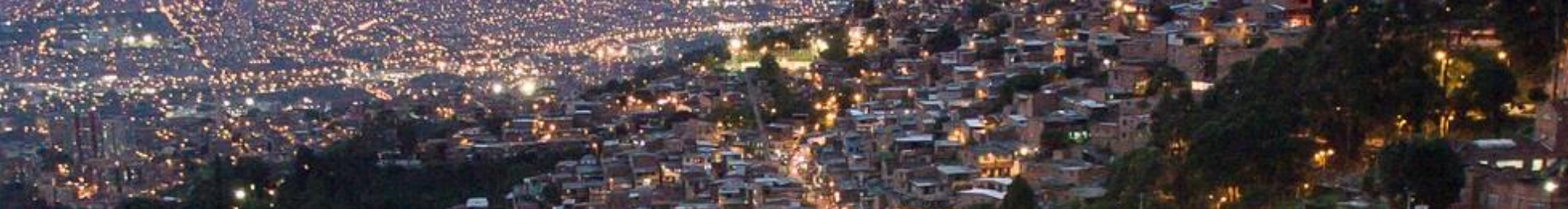
$\therefore \quad \frac{2}{20}$

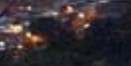

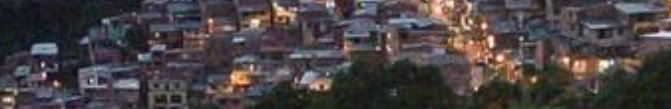

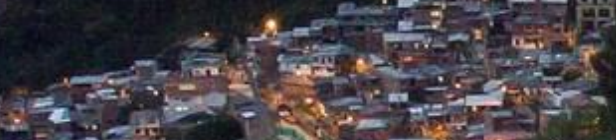
Het.

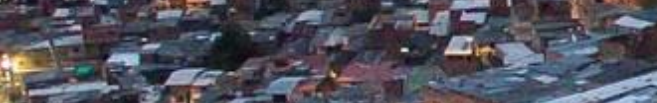

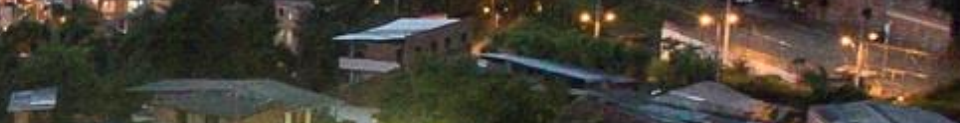
....

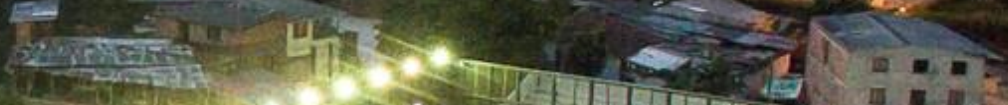
(S): mas $13-\cos 304$

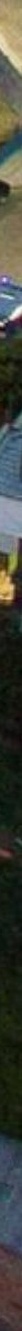




\section{PUI Centroriental - Medellín}

El proyecto urbano de regularización y legalización de las comunas 8 y 9 , denominado PUI Centroriental está ubicado en la zona oriental parte alta de la ciudad de Medellín. Se enmarca dentro del programa de "Mejoramiento Integral de Barrios" del POT de la ciudad cuya perspectiva de intervención se "orienta a brindar igualdad de oportunidades de desarrollo social y económico a los diversos grupos humanos, mediante la gestión político administrativa y las actuaciones urbanísticas públicas y privadas para elevar la calidad de vida de sus moradores". (Resolución 0065 de 2009)

La intervención de ésta zona inició en el año 1998 bajo el programa PRIMED fase II (19982003), terminó de consolidarse con el Acuerdo Municipal 46 de 2006, Acuerdo 409 de 2007 y finalmente la Resolución 0065 de 2009. Para dicho momento, el Municipio de Medellín ya era dueño de más del $51 \%$ del área a regularizar y podía abarcar grandes obras en el territorio.

En cuanto a las actuaciones físicas, éstas han estado dirigidas a la mejora y creación del espacio público, como eje estructurante del territorio, a la edificación de equipamientos, a la construcción de una red vial (que conecte la zona a la única vía de acceso) y a la recuperación de los sistemas orográficos e hidrográficos. Adicionalmente se ha propuesto un conjunto habitacional para delimitar el borde urbano con en 1376 parcelas de vivienda nueva y 1014 nuevos bloques multifamiliares. Para el periodo 2010, la ejecución del proyecto tan solo iba en el 50\%. En la actualidad, 2019, el proyecto cuenta con un tranvía, y dos líneas de metrocable.

Las actuaciones sociales han estado centradas en promover la participación ciudadana para garantizar la inmersión de la población en las nuevas obras físicas desarrolladas.

Finalmente, en cuanto a las actuaciones de las entidades del Municipio se han articulado las diferentes acciones de todas las dependencias: las secretarías municipales y los entes descentralizados, para la posible sostenibilidad del proyecto. Así mismo, se ha promovido como en el PUI Nororiental, la alianzas intersectoriales con el sector privado, las ONG, los organismos nacionales e internacionales y las diferentes organizaciones comunitarias para obtener así mayores recurso económicos.

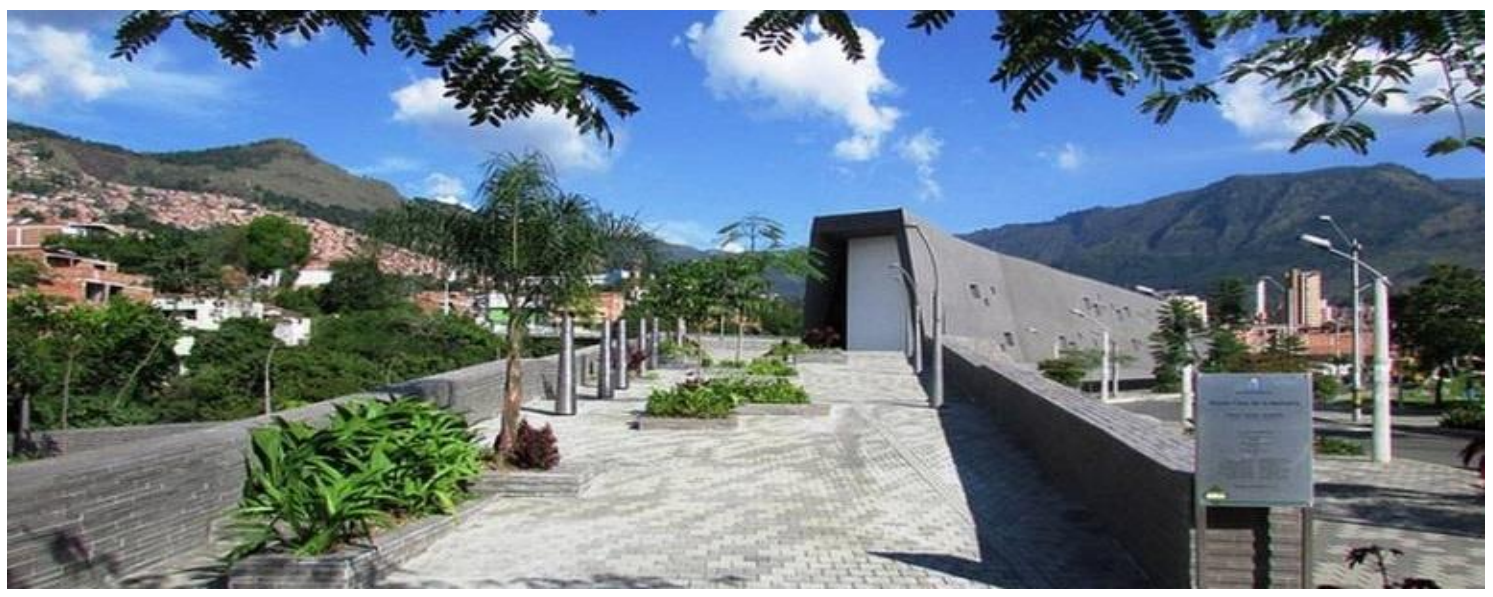

Museo Casa de la Memoria 


\section{Localización}

El Proyecto Urbano Integral Centroriental está localizado en un sector central (borde) de la ciudad de Medellín en las comunas 8 y 9. Abarca una superficie de $\mathbf{1 4 9 . 2 6}$ hectáreas y está compuesto por los barrios La Sierra, Villa Turbay, Juan Pablo II, Ocho de Marzo, Villa Liliam, Las Estancias, Barrio de Jesús. Éstos últimos tres barrios están separados del resto por la quebrada Santa Elena, fuerte condición ambiental que genera una división importante en el territorio. Antes de la intervención no había prácticamente comunicación entre dichos barrios. Otra circunstancia para el desarrollo y localización de los barrios, como se mencionó, es la carretera que comunica Medellín con Rio Negro. Ésta atraviesa todo el territorio en cuestión y es la que ha marcado el desarrollo de los barrios.
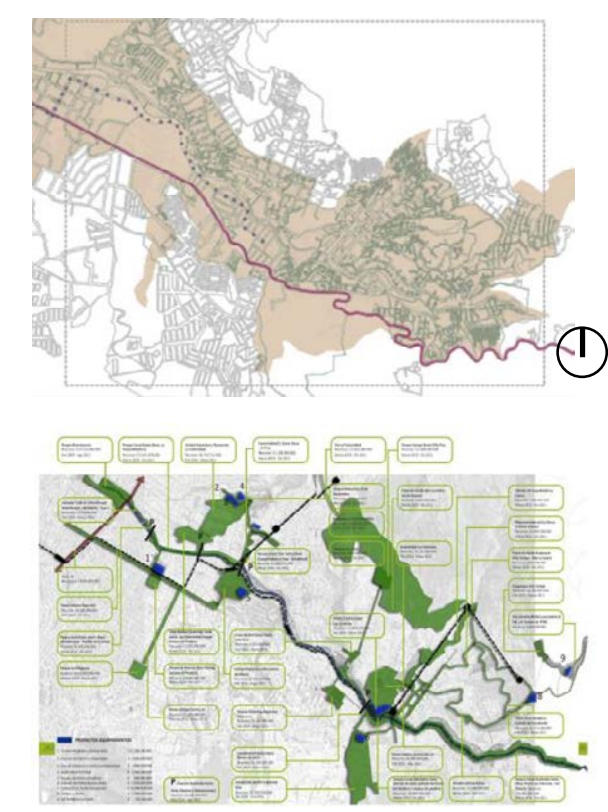

\section{Modelo de ciudad propuesto y construido}

El Proyecto Urbano Integral de la zona centroriental de Medellín está encaminado a la regularización urbanística de las comunas 8 y 9 de la ciudad mediante la definición de acciones prioritarias para el mejoramiento de las condiciones de las viviendas y el entorno de la zona. Su intervención ha buscado consolidar un modelo de ocupación de gestión pública con actuaciones urbanísticas de carcater públicas y privadas, que garanticen así su supuesta correcta ejecución.

Como modelo ha partido de reconocer la comunidad allí asentada como motor para el mejoramiento integral de ese territorio, propiciando para ello su participación, el fortalecimiento de los lazos comunitarios y la gestión para una construcción de un hábitat mas democrático e incluyente como lo denomia la administración.

El espacio público ha sido tomado como el eje estructurante del territorio a partir del cual se mejora la conectividad dentro de la zona y de ésta con la ciudad. Se han valorado los suelos de protecciónpor medio de la recuperación y aumento las zonas verdes y se han construidos equipamientos de calidad.

Los principios fundamentales, basados en la ley 388 de 1997 y del POT de Medellín, para esta actuación han sido:

+Respeto por la construccion social del hábitat con una intervención que propicie una integración socio-espacial de los asentamientos humanos allí instalados y se respete la dignidad humana.

+Protección a los moradores garantizando el derecho a la vivienda digna por medio de la regularización de sus parcelas o viviendas, el acompañamiento a programas de mejoramiento 
de vivienda, el reasentamiento en sitio propio o en otra zona de la ciudad y ayuda a la creación de actividades económicas.

+Recuperación y mejoramiento paisajístico de los suelos de protección, conformados por las zonas de riesgo, las zonas de protección ambiental, los retiros de quebrada y las áreas de borde urbano-rural, que se localizan dentro del área de planificación, a través de acciones de manejo con criterios de sostenibilidad ambiental y resignificación urbana para incorporarlos al Sistema de Espacio Público del Municipio, de manera que contribuyan a elevar los estándares de espacio público.

+Reducir los problemas de contaminación y degradación del recurso hídrico, mediante la eliminación de descargas directas e indirectas de aguas contaminadas en el sistema de drenaje de las microcuencas, a través de la construcción de colectores que permitan mejorar la calidad del recurso agua.

+ Generar nuevas centralidades de carácter vecinal en los barrios La Sierra y Villa Lilliam que complementen la centralidad barrial existente en el barrio Las Estancias, con el fin de fortalecer lugares de convocatoria ciudadana, mediante la generación de espacios públicos y equipamientos.
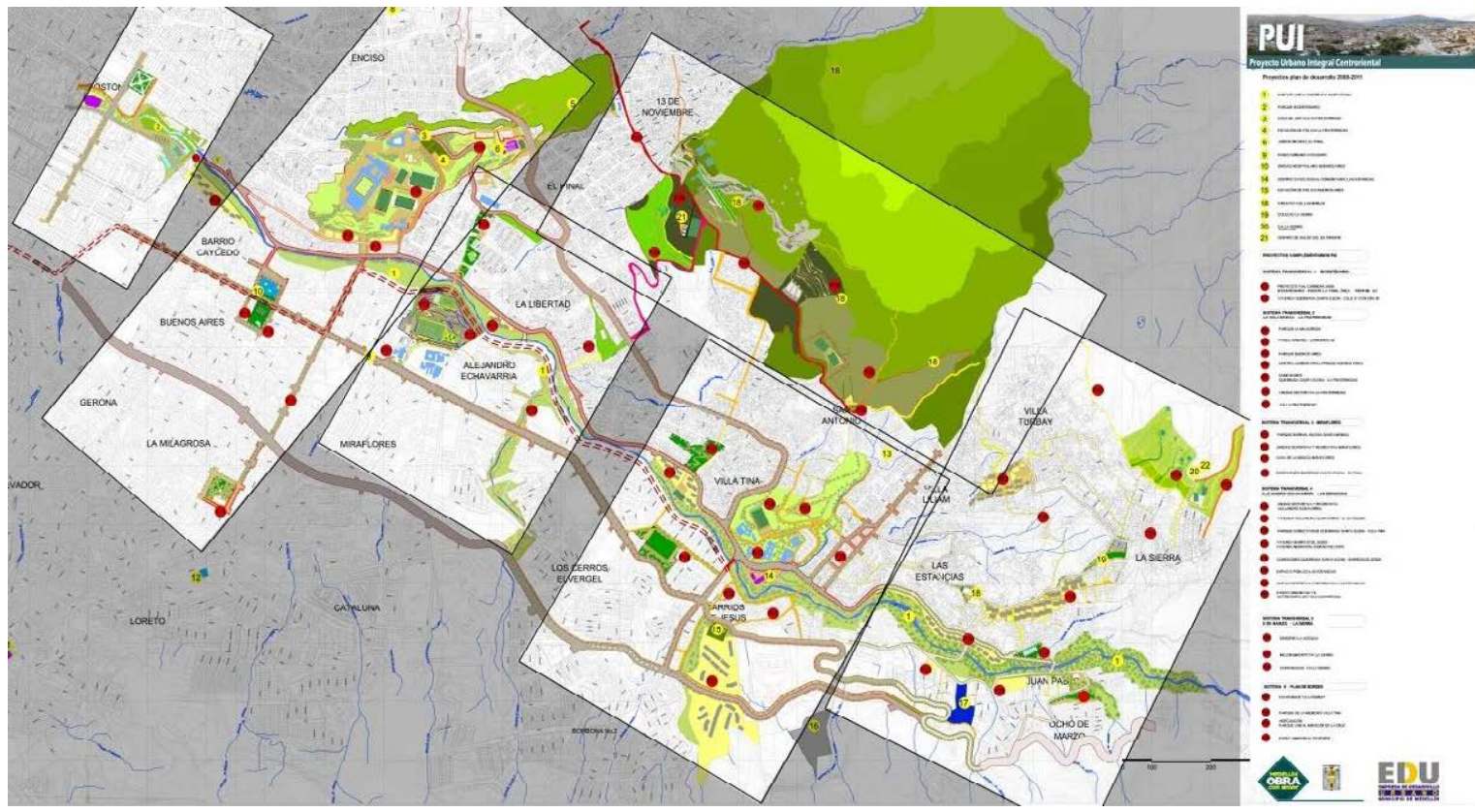

Proyecto urbano PUI Centroriental. 


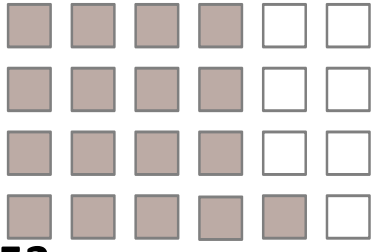

\section{3 viv/ha}

Zona baja 100viv/ha

Zona alta 30viv/ha

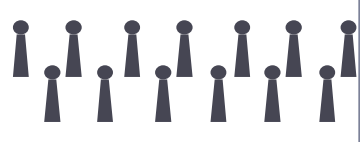

235 hab/ha

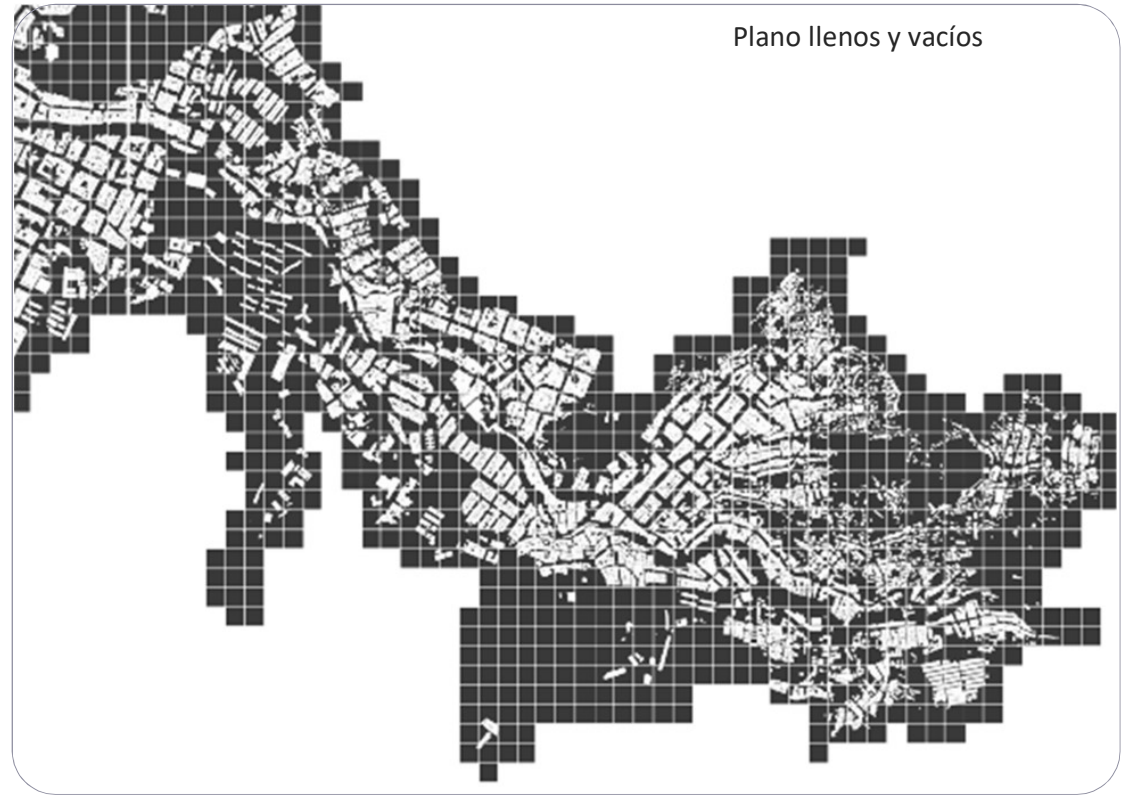

102 Cesiones

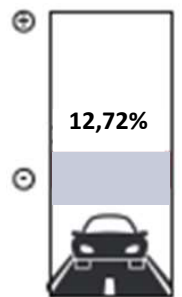

Malla via

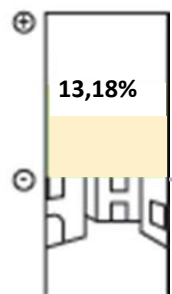

Espacio público

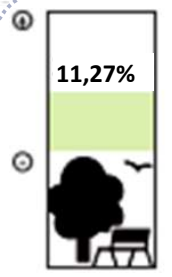

Zonas verdes

Zonas verdes

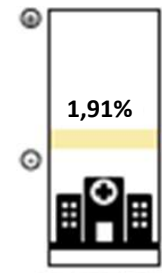

Equipamientos
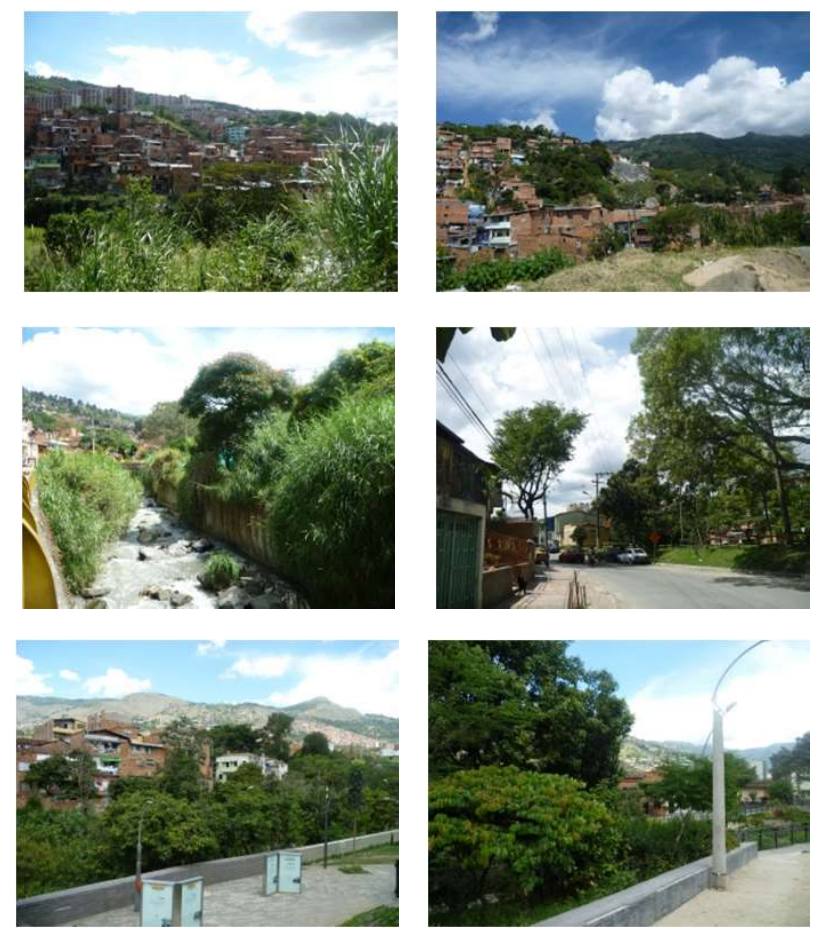

La cesiones logradas en PUI Centroriental a nivel de espacio público y malla vial no llegan aun a los valores establecidos por ley en un proyecto de vivienda nueva planeado (14,5\% para malla vial, $7,5 \%$ para equipamientos y $15,5 \%$ para zonas verdes del área bruta del desarrollo habitacional).

Quedan muchas vías por construir, especialmente en la parte alta de las comunas 8 y 9 en donde existen senderos peatonales en tierra como forma de acceso a las viviendas. Sin embargo, es en las cesiones de espació público, en equipamiento mayoritariamente, que faltan por liberar 10 ha para llegar a un mínimo deseado.
Áreas

\begin{tabular}{|c|c|}
\hline Área bruta & ........ 149,26na \\
\hline Área no urbanizable & ............ 77,91ha \\
\hline a url & ........... 71,35ha \\
\hline Áre & 3267 ha \\
\hline
\end{tabular}

Cesiones públicas

\begin{tabular}{cr}
\hline Cesiones públicas & ............ 38,68ha \\
\hline Malla vial & ........... 18,99ha \\
Equipamientos & $\ldots \ldots . . . . .2,864 \mathrm{ha}$ \\
\hline Zonas verdes & $\ldots . . . .16,83 \mathrm{ha}$
\end{tabular}




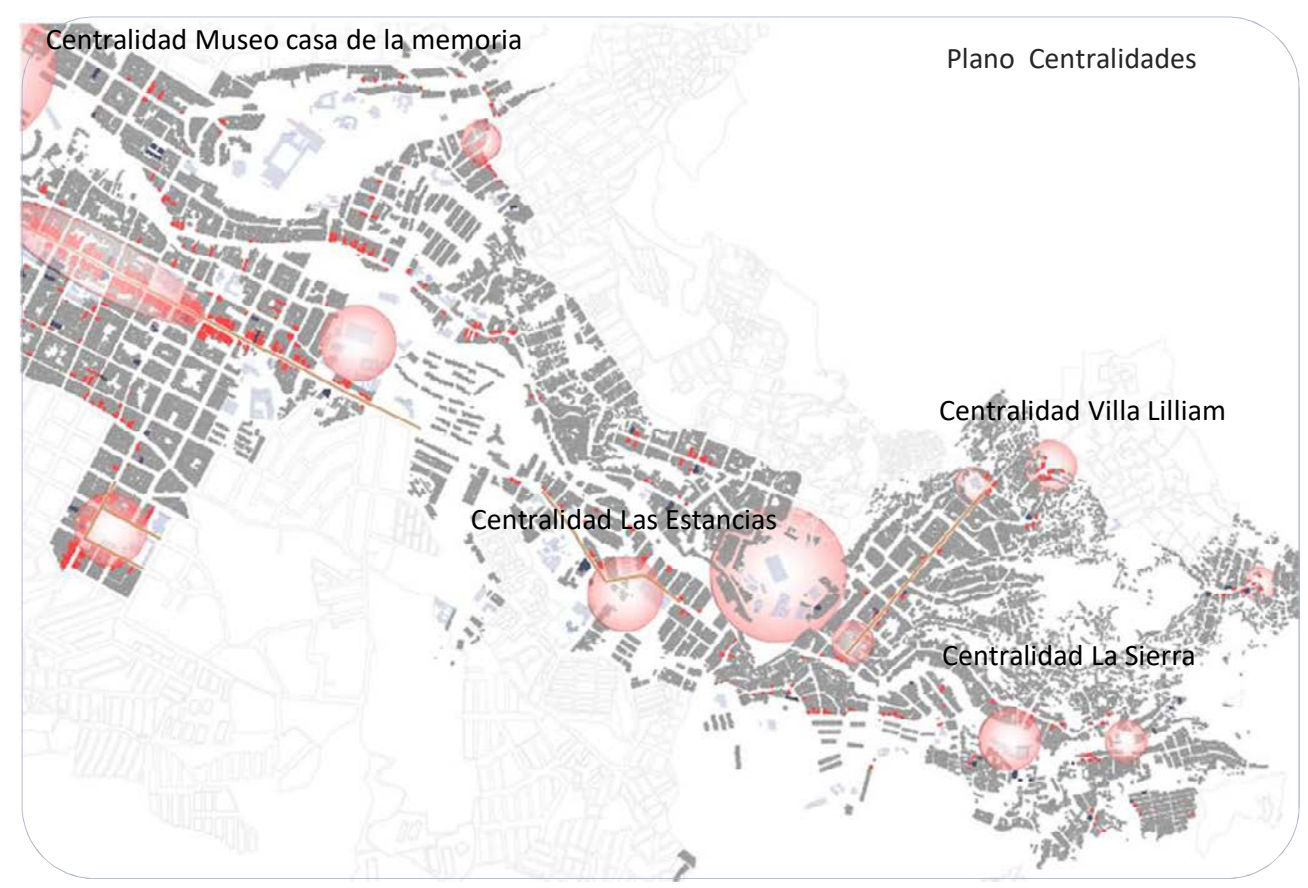

Las centralidades planteadas en el área centroriental son tres: dos del nivel barrial en los barrios la Sierra y Villa Lilliam (Guayaquilito), una de carácter zonal en las Estancias.

La centralidad de Villa Lilliam es reconocida por la comunidad como tal (gran dinamismo comercial) y por medio del POT se le reconoce a nivel normativo.

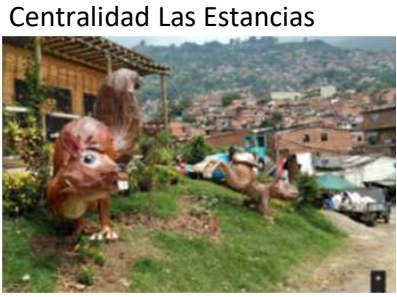

Cerro de los valores

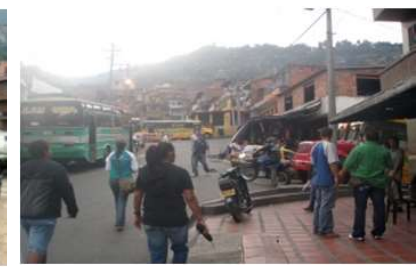

Calle 52

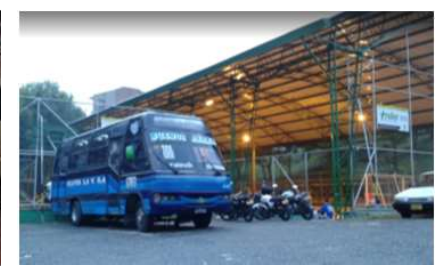

Cancha de fútbol Las Estancias

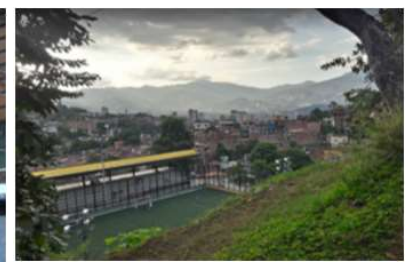

Cancha sintética Las Estancias

Centralidad Museo Casa de la Memoria

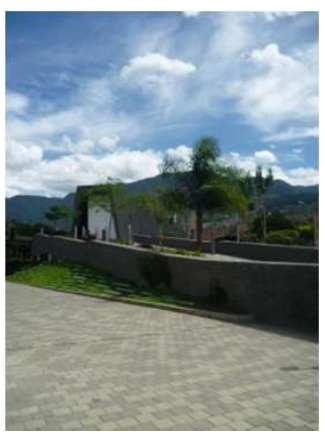

Museo Casa de la Memoria

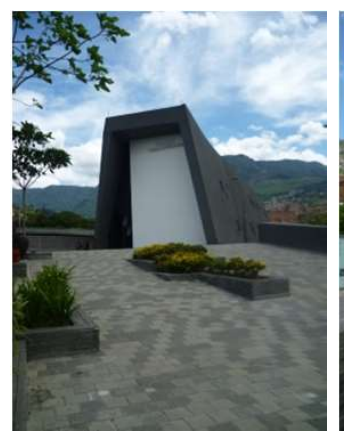

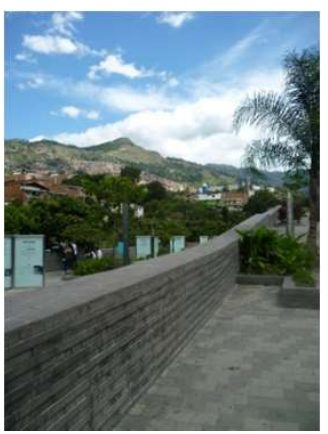

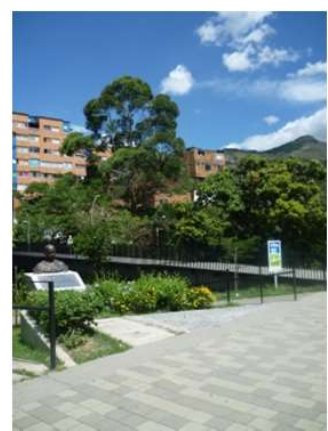

Parque bicentenario

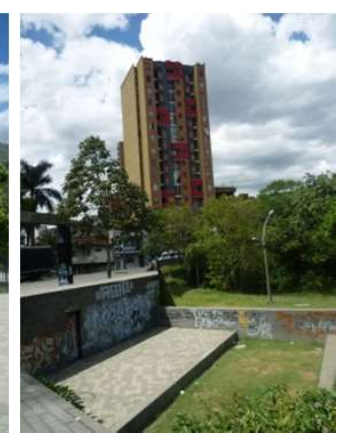

\section{Tiempos de desplazamiento a la centralidad más cercana}

Escala Ciudad: Museo Casa de la memoria

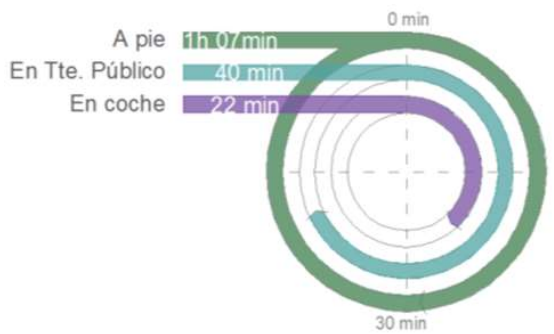

Escala Zonal: Centralidad La Estancia

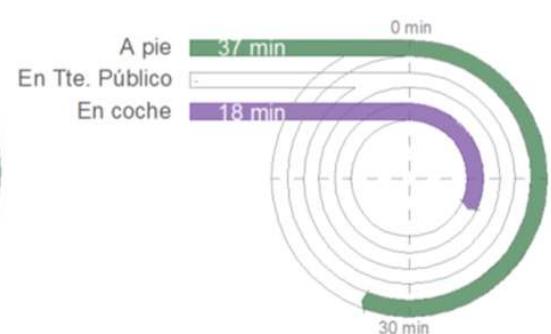

Escala Local: Centralidad La Sierra

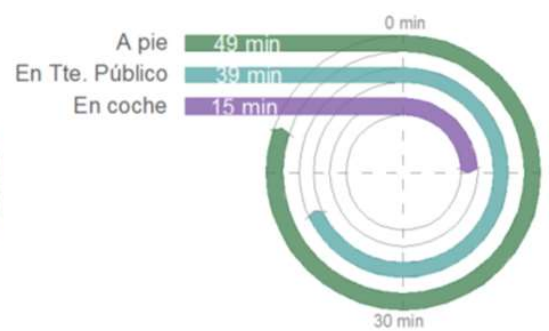

Según los criterios establecidos sobre los tiempos óptimos de desplazamiento a pie, éste proyecto cuenta con unas condiciones deficitarias; todos los trayectos superan los $30 \mathrm{~min}$. En cambio, el tiempo de desplazamiento en transporte público a las diferentes centralidades esta entre el límite de correcto y deficitario. Ahora bien no se puede acceder en todos los casos con un medio de transporte publico motorizado. La centralidad Casa de la Memoria es la única centralidad consolida dentro del tejido urbano de la ciudad; sin embargo es la mas lejana de las viviendas construidas en el perímetro del tratamiento. 


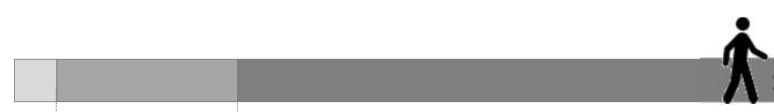

$>300 \mathrm{mts}$

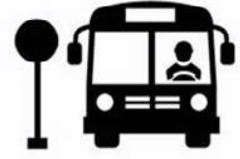

$63,81 \%$

La accesibilidad al transporte público en el PUI Centroriental es considerablemente deficiente. Tan solo un $5 \%$ de la población tiene una para de transporte público a menos de $100 \mathrm{mts}$ de su vivienda. Esas paradas de transporte público son además relativamente recientes (construidas en el año 2016) que fue cuando se entregó la primea línea de tranvía o metro ligero en la ciudad de Medellín. Este sistema de transporte constituye el primer tranvía moderno de Latinoamérica, con una longitud de $4,3 \mathrm{~km}$ y pendiente de hasta el 12,5\%, según datos administrativos (EDU). Recorre, en su mayor parte, la zona urbana del tradicional eje vial de la calle Ayacucho, en la zona centro oriental de la Ciudad de Medellín.
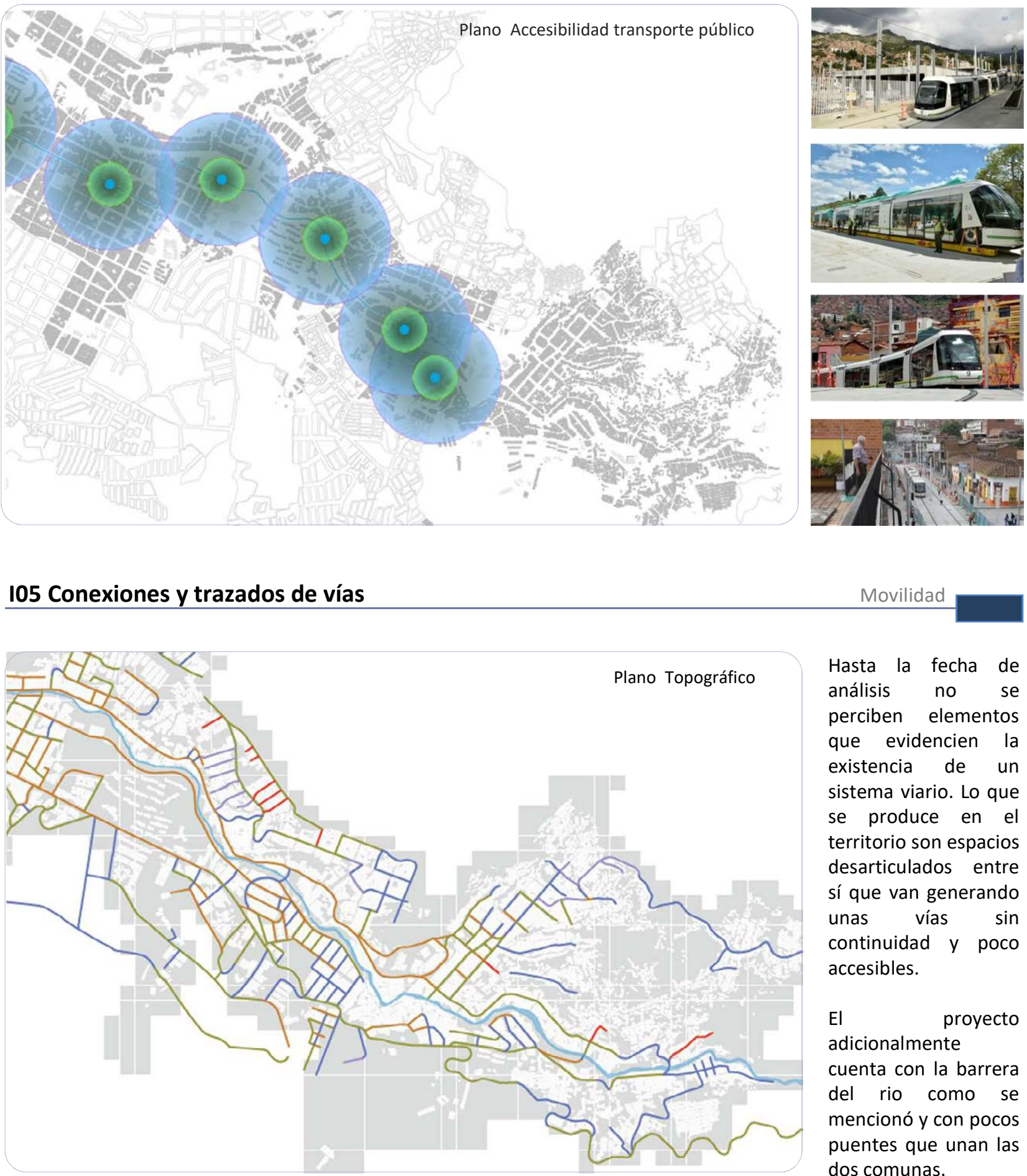

Hasta la fecha de análisis no se perciben elementos que evidencien la existencia de un sistema viario. Lo que se produce en el territorio son espacios desarticulados entre sí que van generando unas vías sin continuidad y poco accesibles.

El adicionalmente cuenta con la barrera del rio como se mencionó y con pocos puentes que unan las dos comunas. 
Pendiente

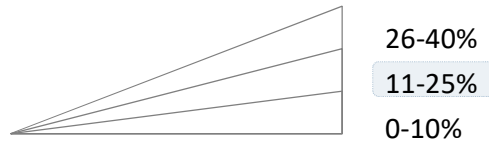

Acceso a escala de ciudad

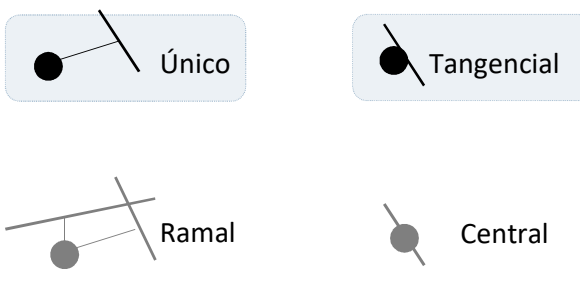

Conexión a escala de barrio
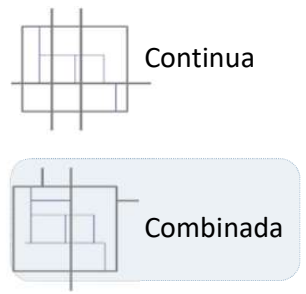
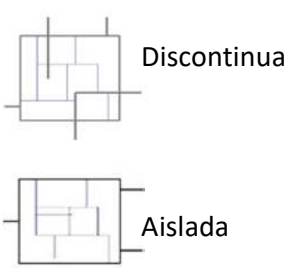

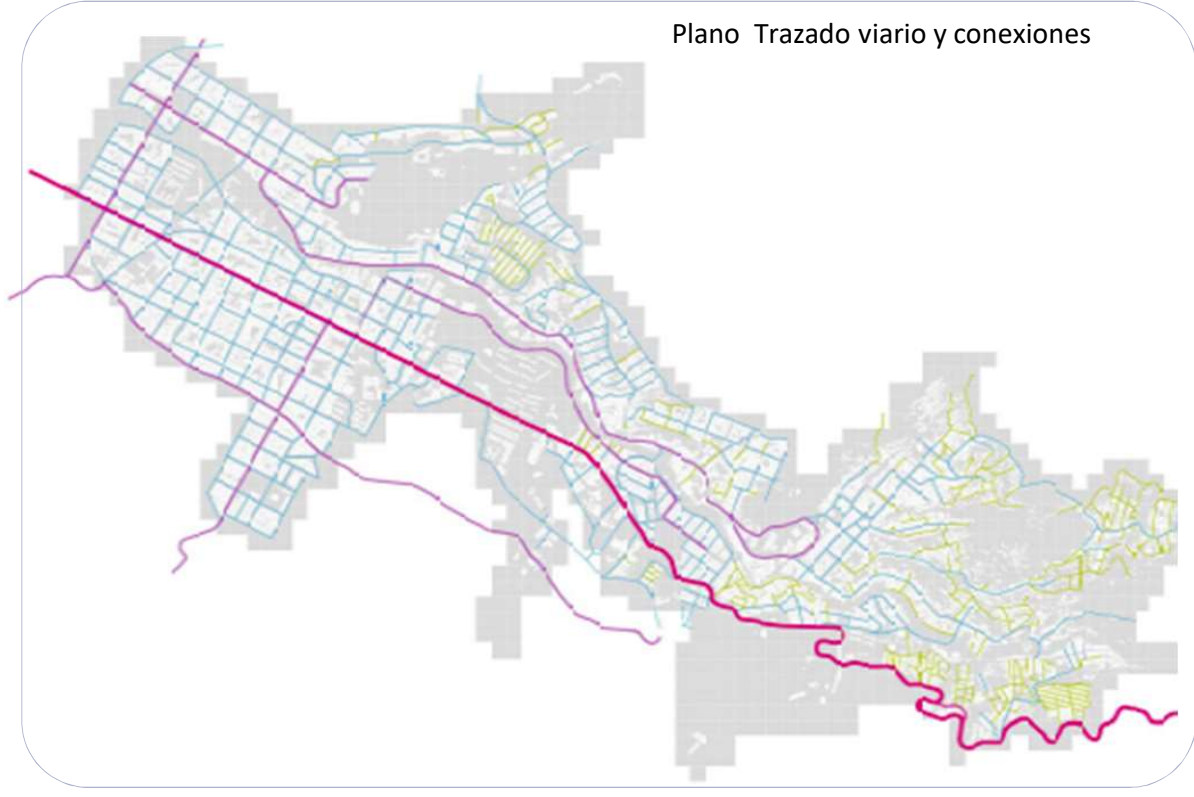

La conexión de ciudad es principalmente de carácter urbano central y tangencial. A nivel de barrio los accesos son combinados. Las conexiones varían según la consolidación del barrio y la topografía. En la parte baja del proyecto las conexiones son continuas, en la parte media y alta son combinadas 0 discontinuas.

Existe una barrera geográfica o ambiental, la quebrada Santa Helena que hasta la fecha divide el proyecto, y su circulación en dos partes aisladas prácticamente entre si en la parte media y baja.
106 Estado de las vías

\section{VÍA VEHICULAR}

Pavimentada

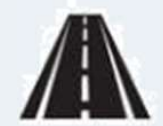

$83,84 \%$
No Pavimentada

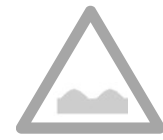

$16,16 \%$

Movilidad

\section{VÍA PEATONAL}

Pavimentada

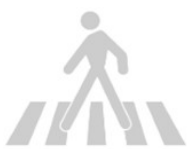

No Pavimentada

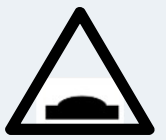

El estado de las vías, como todo el proyecto en sí mismo, depende del grado de consolidación de los barrios. En la parte baja todas las vías peatonales y vehiculares se encuentran pavimentadas y en la parte alta casi el $80 \%$ no se encuentra pavimentado.
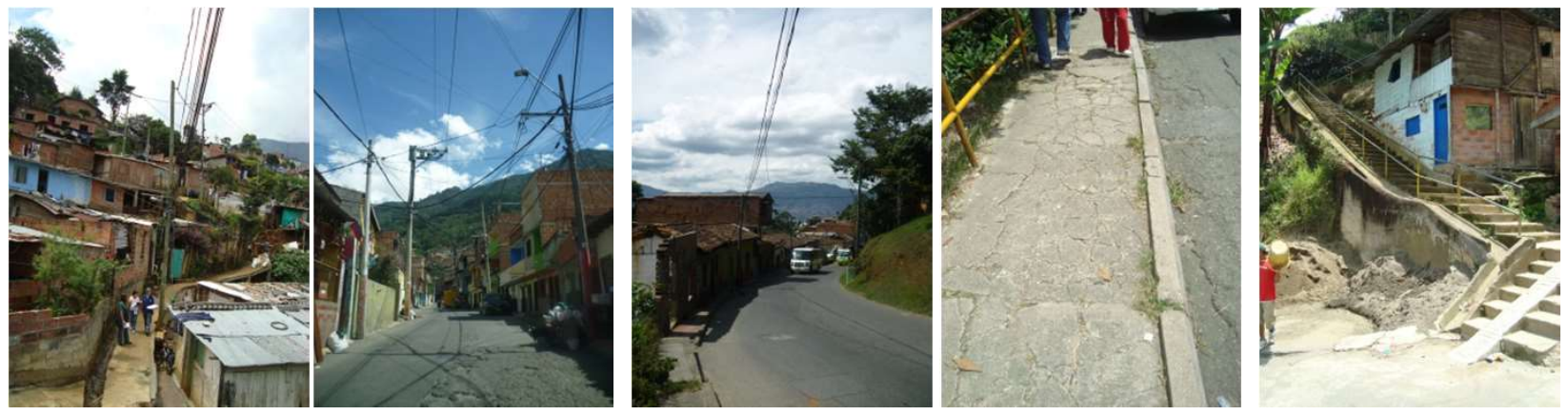


\section{EQUIPAMIENTOS A ESCALA BLOQUE-VECINDARIO}
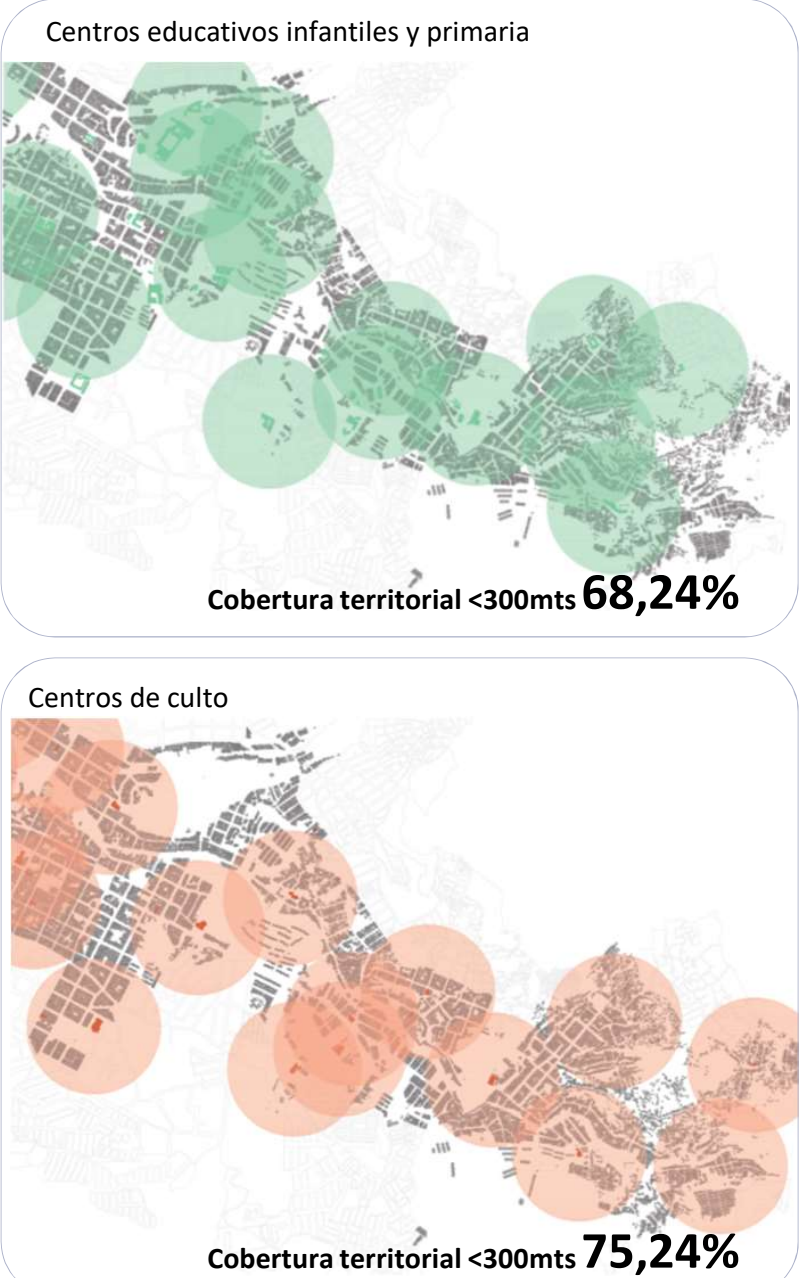

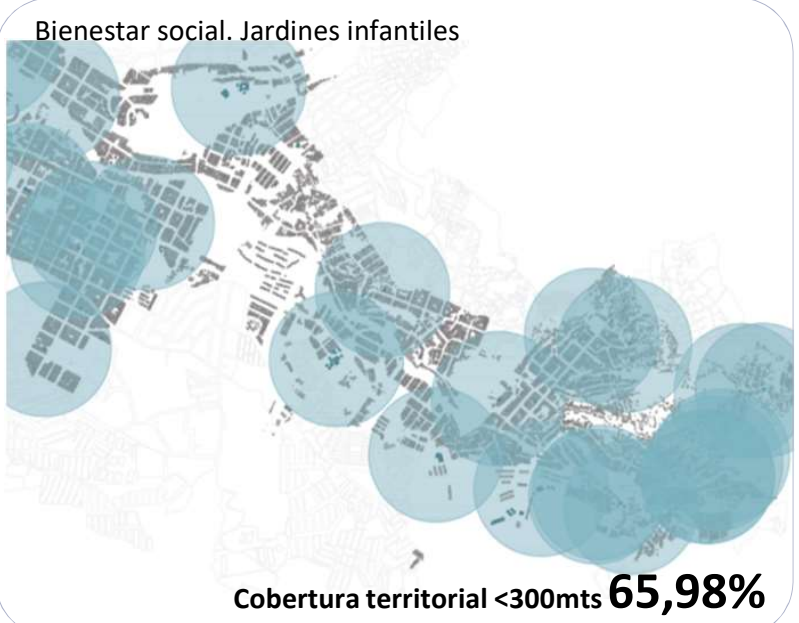

Comercio de productos diarios

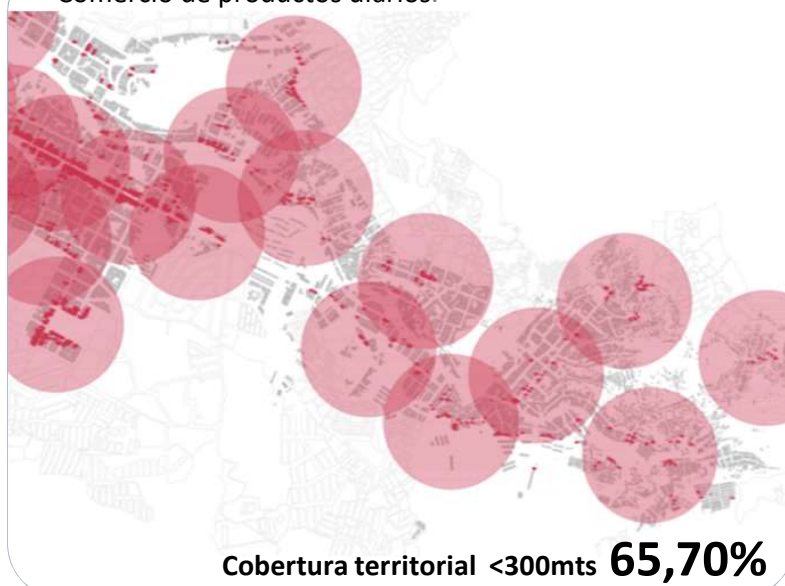

\section{Centros educativos}

La cobertura actual de los centros educativos con respecto al cupo para la población en edad de estudiar está cubierta pero las condiciones de las edificaciones, según diagnóstico realizado por la administración misma (Documento técnico de soporte - resolución $n^{\circ} 0065$ de 2009) éstas no cumplen con las áreas mínimas de aulas (normativa $56 \mathrm{~m} 2$; aulas encontradas de $35 \mathrm{~m} 2$ ), hay ausencia de ambientes escolares tipo $B$ y tipo $C$ a los que se refiere el Decreto 409 de 2007 y existe un déficit de espacio para la recreación de los alumnos (normativa $30 \mathrm{mts} \times 18 \mathrm{mts}$ ).

\section{Centros de bienestar social}

El proyecto cuenta con una red proporcionada de jardines infantiles, gracias a aquellas instalaciones informales creadas por la población. Esta condición se refleja claramente en el territorio, entre menor es el estrato social y mayor el grado de precariedad mayor es la cantidad de este tipo de equipamientos.

La zona cuenta también con cinco comedores sociales y dos estaciones de Policía.

\section{Centro de culto}

Este equipamiento, prácticamente de carácter informal, es el que mayor cobertura tiene en el territorio. La población allí donde no tiene un centro de culto, construye uno.

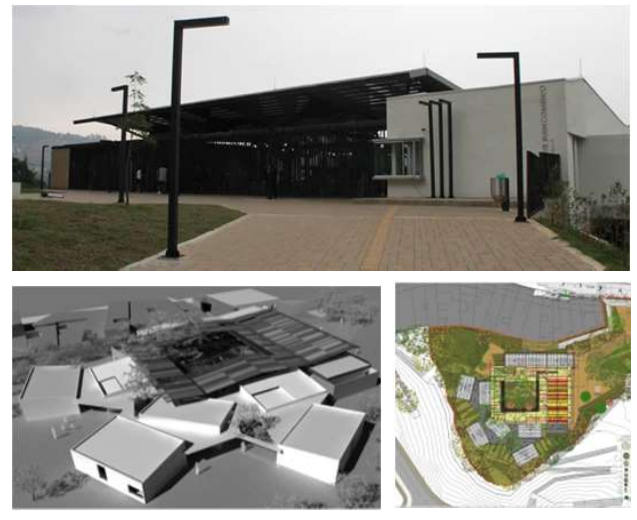

Jardín infantil Buen comienzo El Pinal
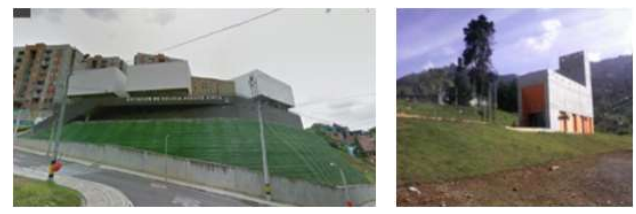

Centros de policía

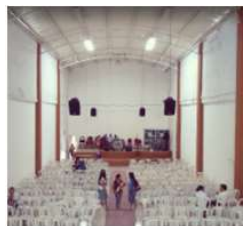



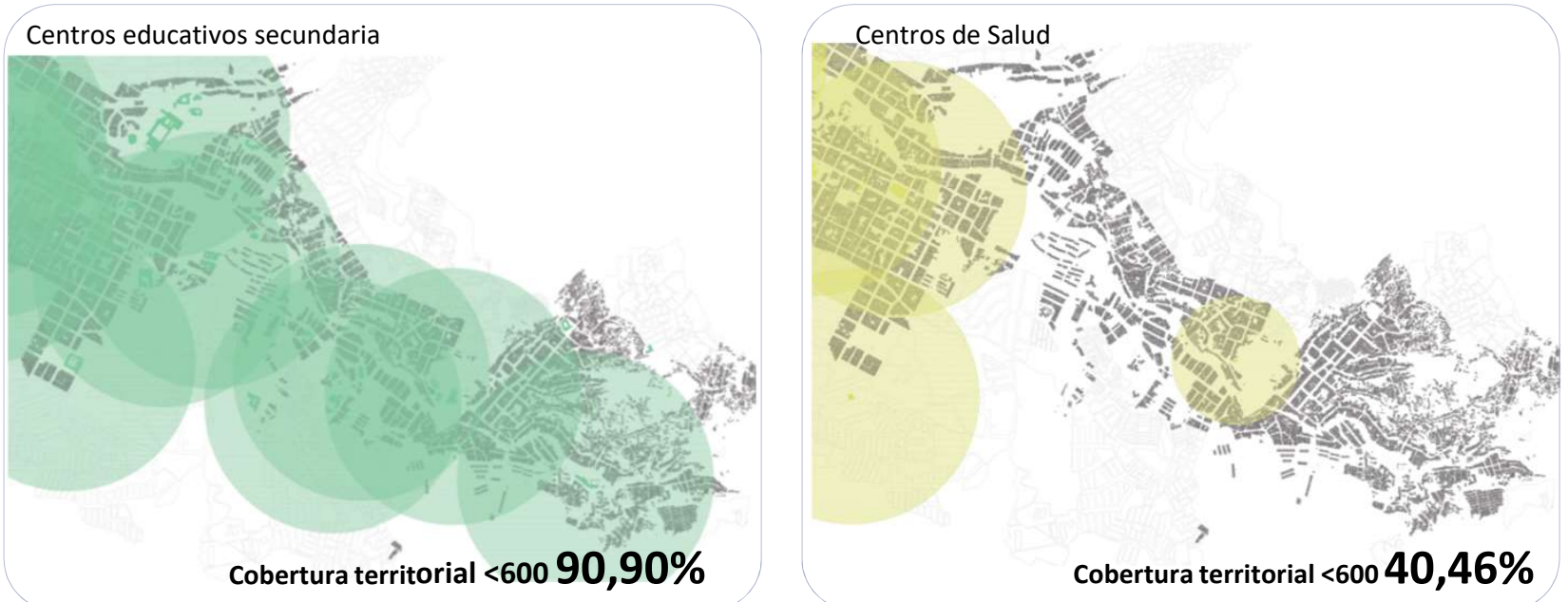

Centros culturales

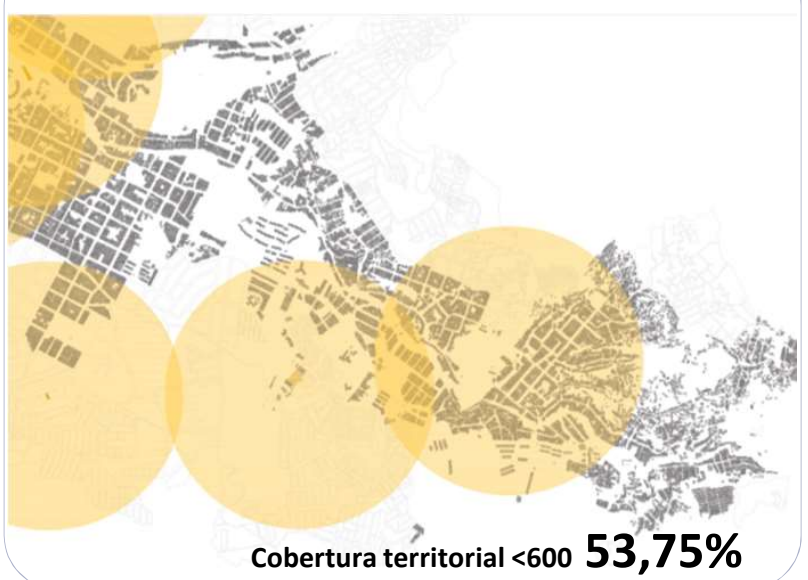

\section{Centros educativos}

Los equipamientos educativos de carácter zonal (secundaria, bachillerato y universidad) son los equipamientos de mayor importancia y los que mayor cobertura tienen en el territorio. El 100\% de la población en edad de estudiar estuvo o esta matriculado. El problema en este tratamiento radica en las condiciones poco adecuadas de la infraestructura. Las áreas mínimas de las aulas, los espacios de recreación y los espacio con ambientes escolares diferentes a las aulas no cumplen la norma.

Existe un instituto universitario denominado Instituto Tecnológico Metropolitano de escala ciudad que tiene como una orientación tecnológica, de carácter pública y de orden municipal. Su origen remonta al año 1944 con el Consejo de Medellín creó en Instituto Obrero Municipal con el propósito de brindar formación a la clase trabajadora de la ciudad que para aquel entonces era principalmente industrial.

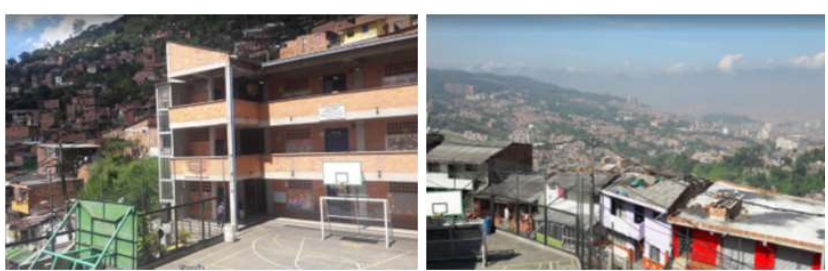

Instituto educativo Villa Turbay
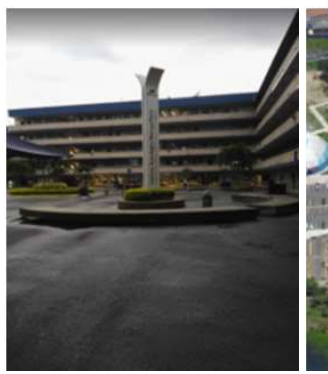

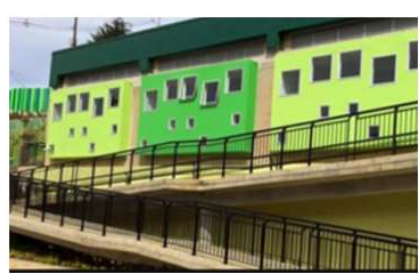

Instituto educativo Villa Turbay
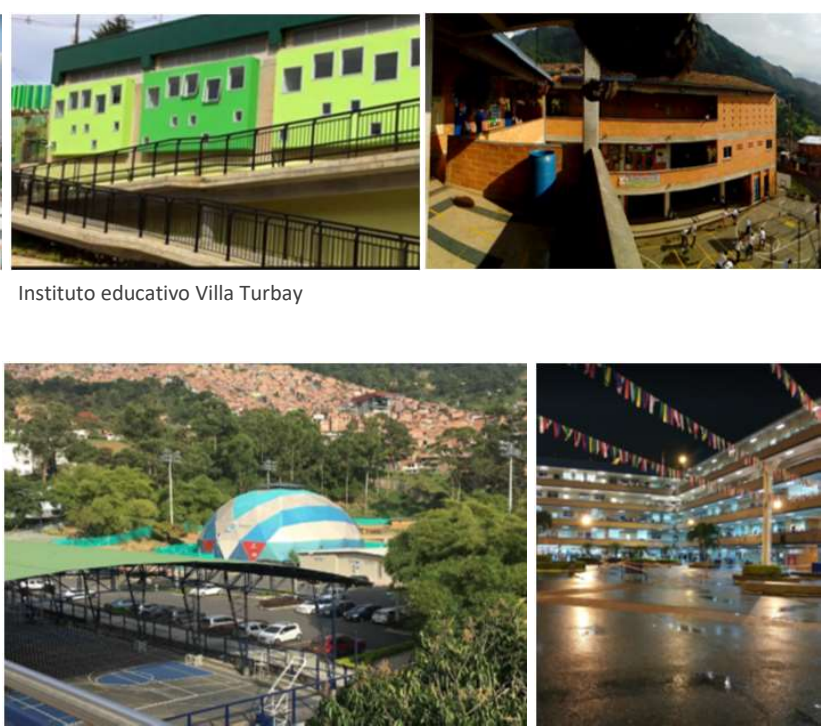


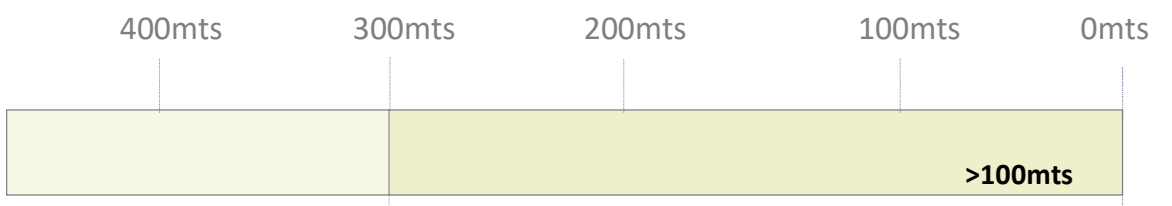

Accesibilidad media $\mathbf{2 6 , 8 6 \%}$

Accesibilidad alta $\mathbf{7 3 , 1 4 \%}$

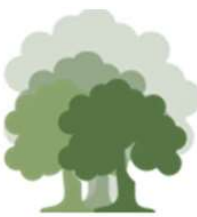

Proporción de zonas verdes 4,78m $2 /$ hab

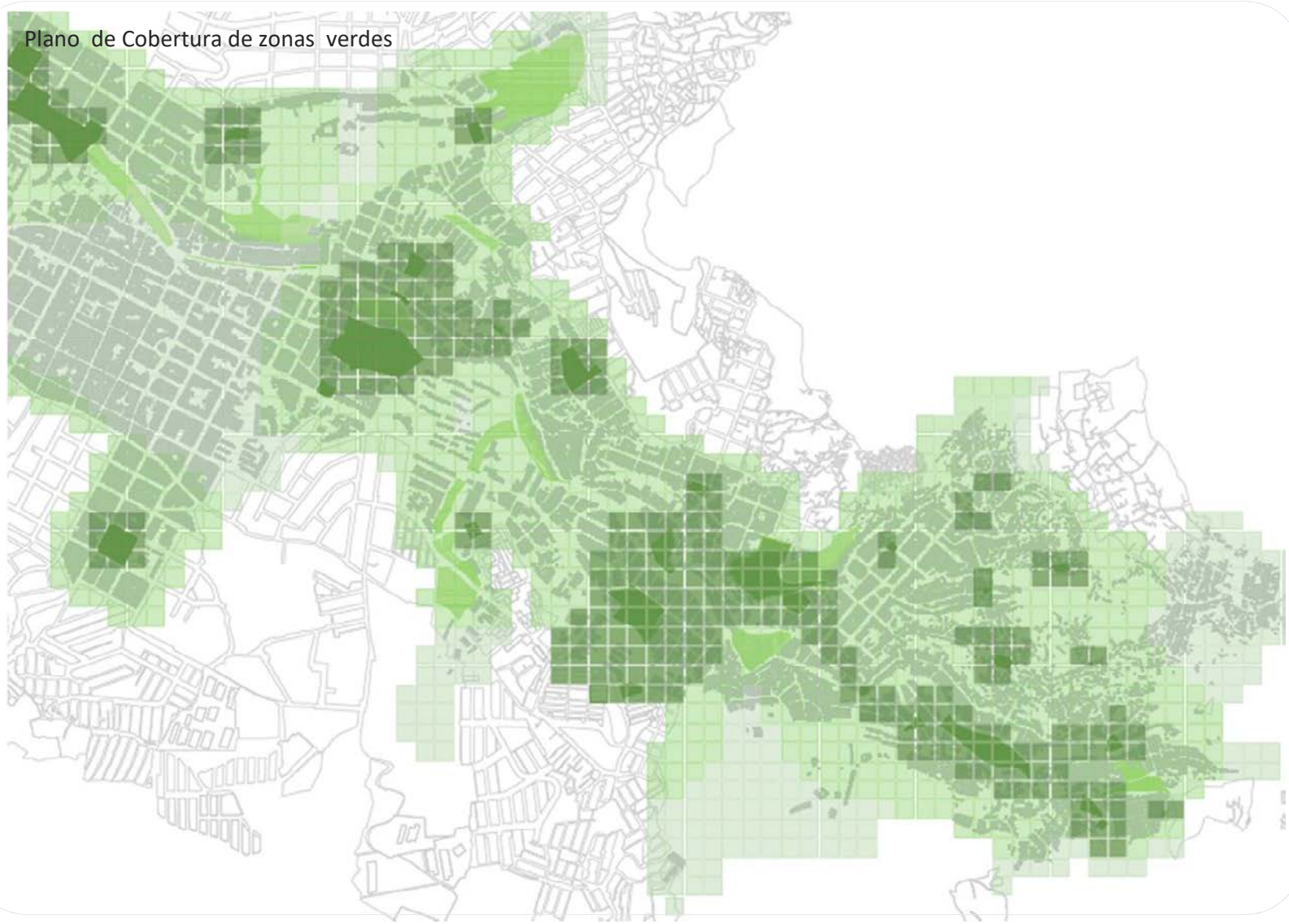

En PUI Centroriental se busca la consolidación de un sistema que articulara el espacio público artificial (parques infantiles, placas polideportivas, zonas verdes) con el sistema natural de quebradas (Santa Elena, La Castro, La Mica, la Santa Lucía, La Seca, La Salada y la Mediagua), y las zonas de protección (Área de amortiguamiento del Parque Ecológico Piedras Blancas, borde urbano - rural y zonas de riesgo). Hasta el año 2010 se había pasado de un índice de espacio público por habitante de $0.38 \mathrm{~m} 2 /$ hab a $4,78 \mathrm{~m} 2 / \mathrm{hab}$.
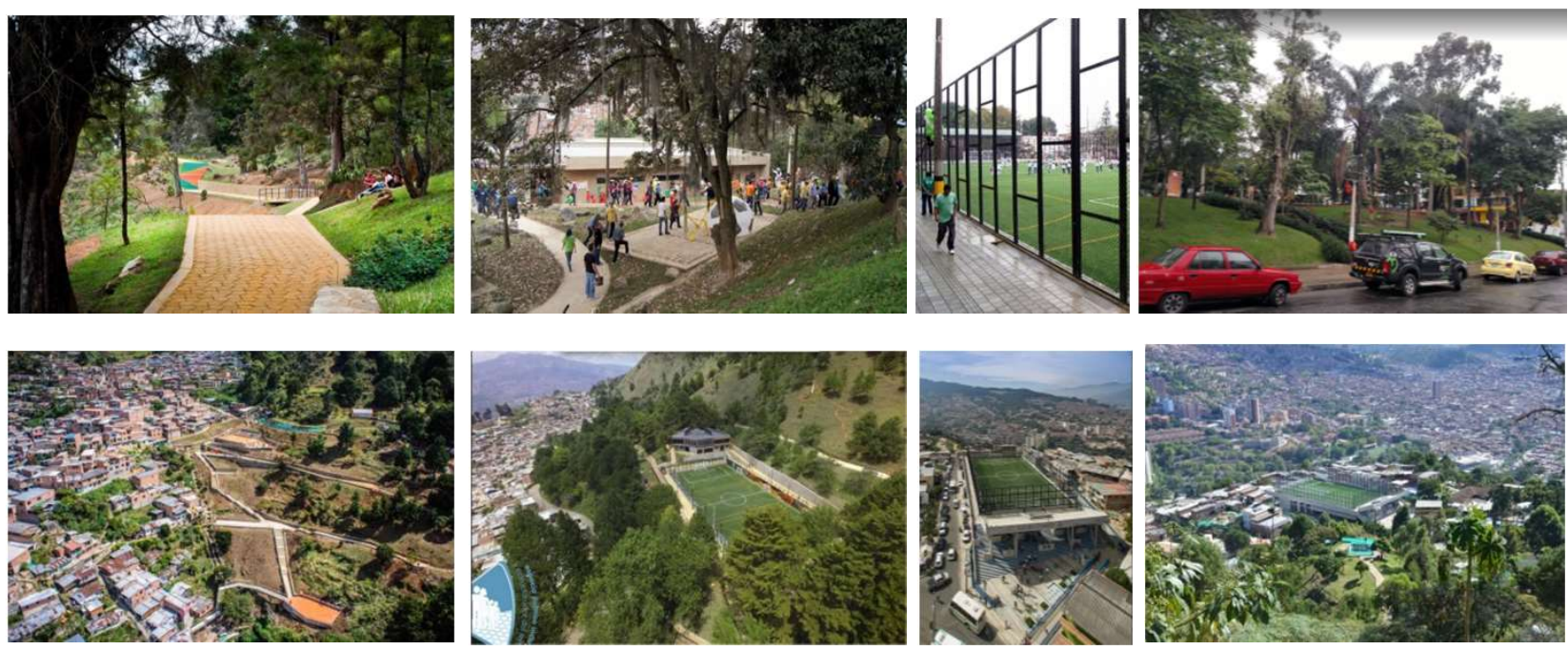


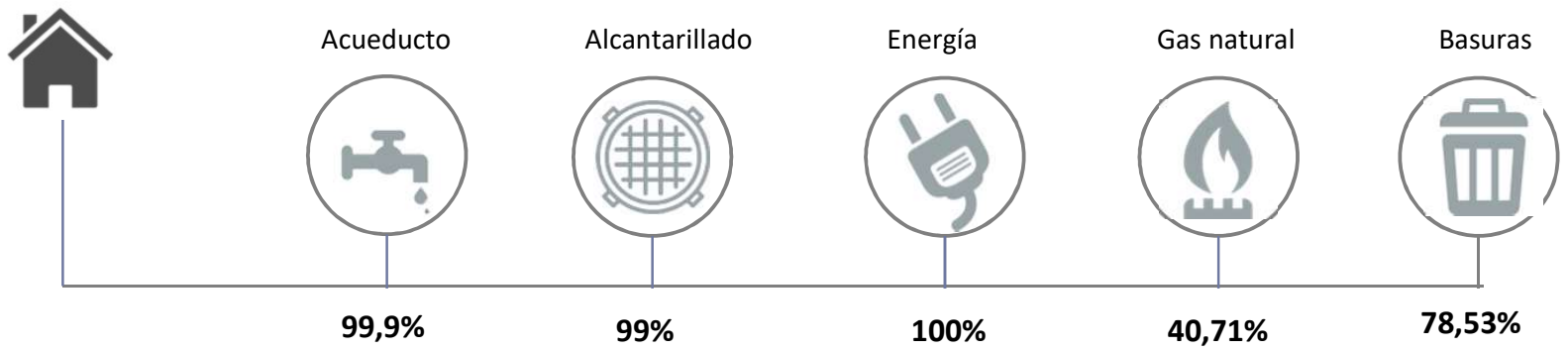

El proyecto cuenta en su totalidad con una cobertura prácticamente del $100 \%$ en acueducto, alcantarillado, energía eléctrica y recolección de basuras. por parte de las empresas prestadoras de servicios. Sin embargo no existe disponibilidad o dotación de redes de servicio en algunas áreas, en especial para el suministro de gas natural.

Con respecto a las basuras, su mayor problemática esta dada por el vertimiento de desechos en las cuencas y microcuencas. Tan solo hasta el año 20062007 se construyeron los alcantarillados Brisas de Oriente en el barrio Ocho de Marzo y sectores aledaños a la Calle $55 \mathrm{HH}$ con Carrera 6 en Villa Turbay, quedando pendientes por dotar los restantes 7 sectores.

\begin{tabular}{|c|c|c|}
\hline Energía & Cobertura del100\% & $\begin{array}{l}\text { Problemas en la calidad del servicio (regular y mala) en un } \\
3,5 \% \text { de las viviendas. Otro porcentaje similar tiene el servicio } \\
\text { suspendido }\end{array}$ \\
\hline Acueducto & $100 \%$ & $\begin{array}{l}\text { Problemas en la calidad del servicio (regular y mala) en un } \\
3,5 \% \text { de las viviendas. Otro porcentaje similar tiene el servicio } \\
\text { suspendido }\end{array}$ \\
\hline Alcantarillado & $100 \%$ & \\
\hline Gas natural & $\begin{array}{l}\text { Comuna } 8 \text { 25,77\% } \\
\text { Común } 955,45 \%\end{array}$ & \\
\hline \multirow[t]{2}{*}{ Basuras } & & $12,64 \%$ tienen una mala calidad \\
\hline & & $8,83 \%$ Ilevan las basuras a un basurero publico \\
\hline
\end{tabular}

\section{I10 Condiciones geotécnicas. Riesgos} Condiciones ambientales
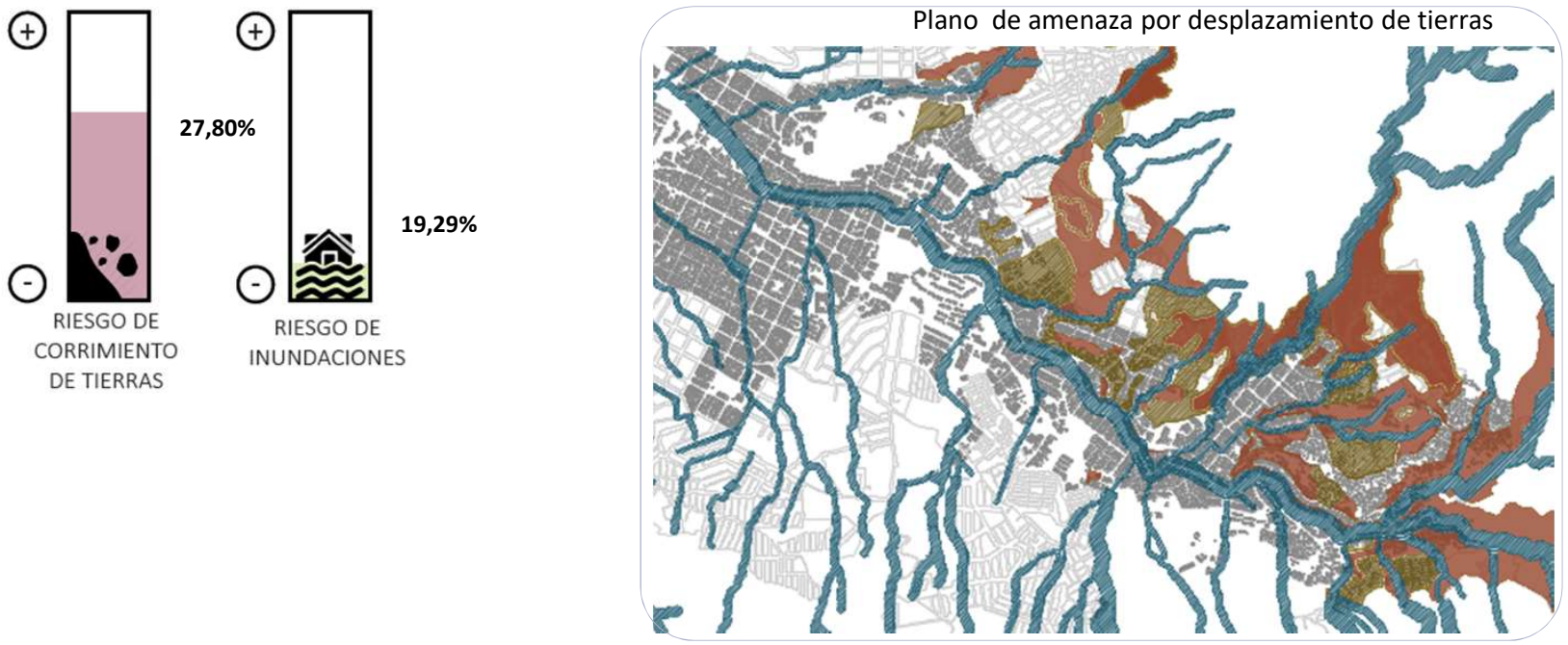

El área de planificación está conformada por 149.26 Ha de las cuales $52.2 \%$ son suelos de protección, que actualmente están siendo utilizados como área para vivienda, vías, cultivos de café, plátano y como áreas de rastrojo, ya que para la población es una referencia lejana y no existe una apropiación del concepto.

Asociado al estado del recurso agua, las fuertes pendientes, el grado de urbanización, de intervención antrópica y las técnicas inadecuadas de modelamiento del terreno, reflejan el uso inadecuado e insostenible del recurso suelo, principalmente en áreas determinadas como de amenaza alta, por inestabilidad. La situación se vuelve crítica al reconocer que el $85 \%$ de las viviendas de las ubicadas en suelo apto, presentan un grado de vulnerabilidad medio, que hace que no estén preparadas para soportar las fuerzas de la naturaleza 
Unidades habitacionales construidas

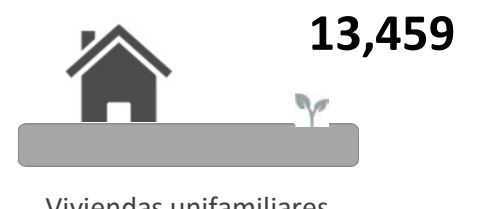

Viviendas unifamiliares

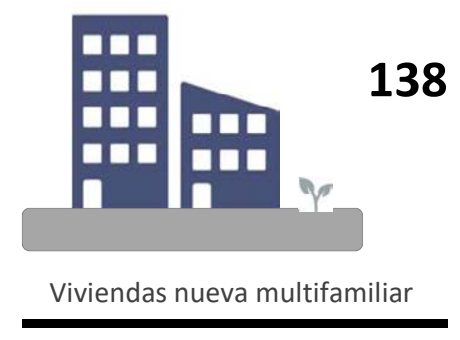

Ocupación de la manzana y tipología de la vivienda

El proceso de ocupación de la zona Nororiental de Medellín es de origen formal en su parte baja, cercana al centro de la ciudad y de origen marginal (o ilegal) en toda su extensión superior. Su desarrollo inicia con el antiguo camino que comunicaba a Medellín con Rio Negro hacia 1938. Dicho camino bordeaba la quebrada Santa Elena, que junto con la quebrada la Castro, fueren quienes marcaron el desarrollo de expansión de las viviendas. Estas generaron un acelerado crecimiento de los espacios residenciales, localizados en llanuras de inundación de las quebradas, nunca comunicados entre sí.

Su proceso de configuración es de carácter orgánico o mixto en la mayoría del territorio adecuándose a las condiciones topográficas del territorio. Se evidencia una localización inicial de las viviendas sin "planeamiento alguno", sin espacios para zonas verdes, equipamientos o infraestructura.

Total $=13,597$ viviendas

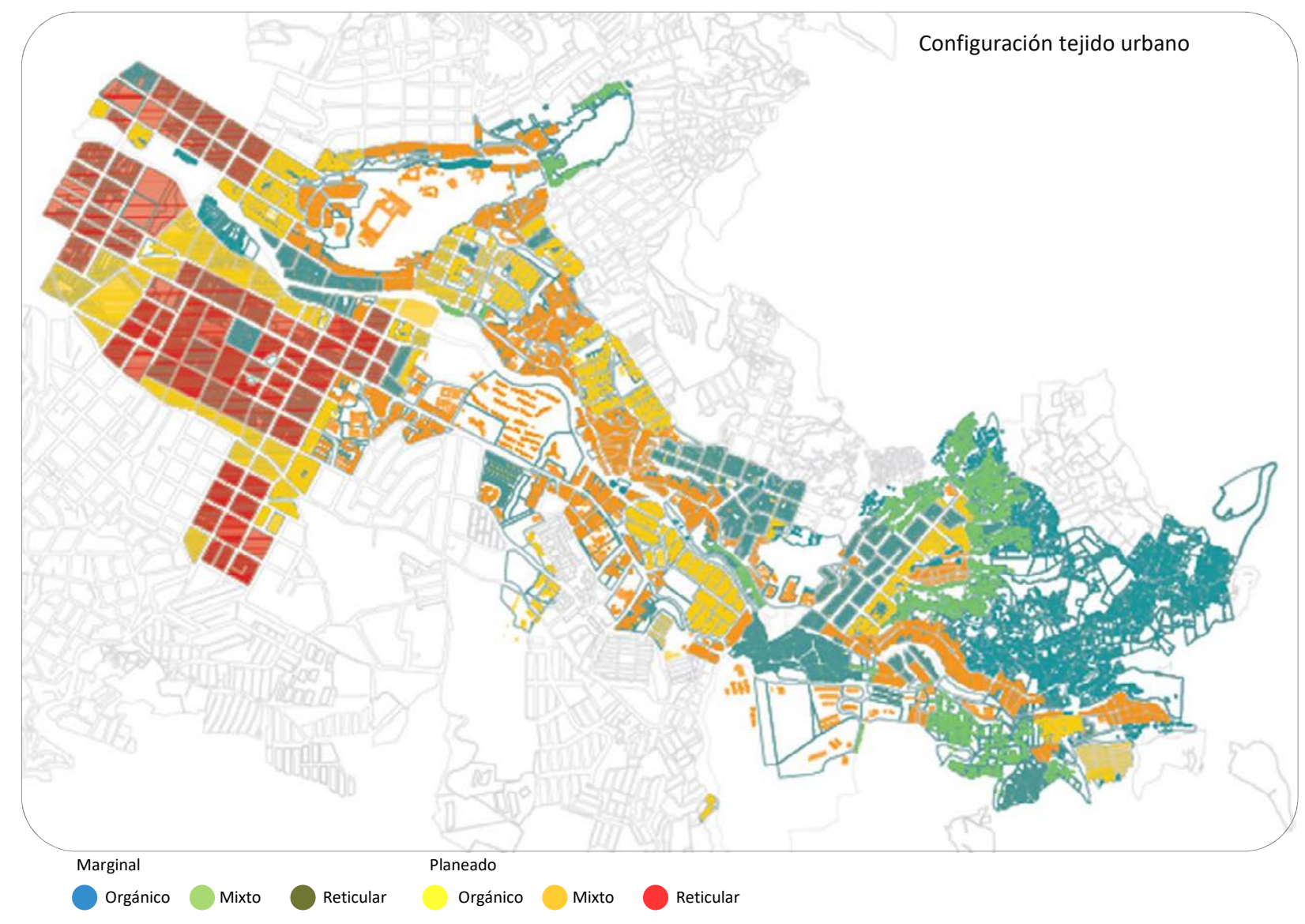

Viviendas tipo PUI Centroriental

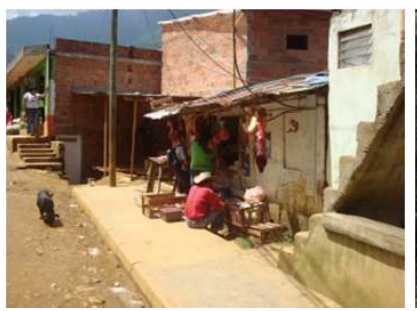

Tamaño de parcelas

100-150m2promedio

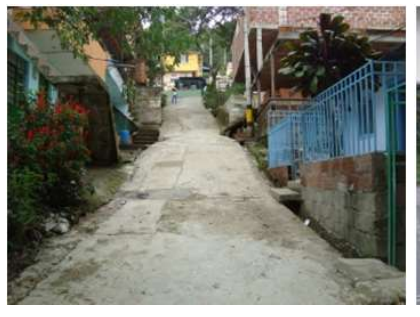

Planeado reticular $6 \times 25=116 \mathrm{~m}^{2}$

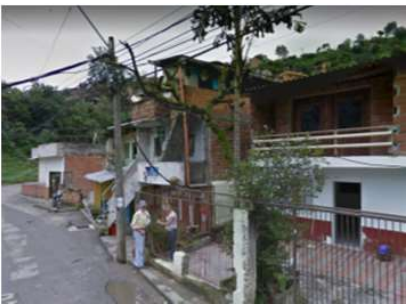

Planeado mixto $7 \times 16,4=115 \mathrm{~m}^{2}$

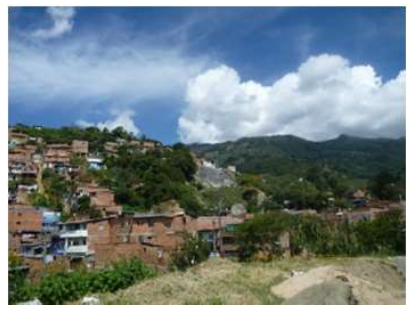

Planeado orgánico $6 \times 16,5=100 \mathrm{~m}^{2}$

Marginal orgánico $7 \times 15,5=85 m^{2}$ 
Uso del suelo privado

Comercio 2,54\% Uso Vivienda $\mathbf{9 5 , 9 9 \%}$

Uso Dotacional $\mathbf{1 , 4 5 \%}$

EI PUI Centroriental presenta un alto porcentaje de uso residencial. Tan solo un $5 \%$ del territorio esta destinado a usos dotacionales, comerciales o ambientales.

A diferencia de los otros proyectos, éste cuenta con pocas áreas comerciales que tan solo están reunidas sobre tres ejes principales. Su carácter es de comercio de productos diarios y en su mayoría ha sido desarrollado por la población misma.

Las dotaciones principales de este proyecto son las canchas de futbol.

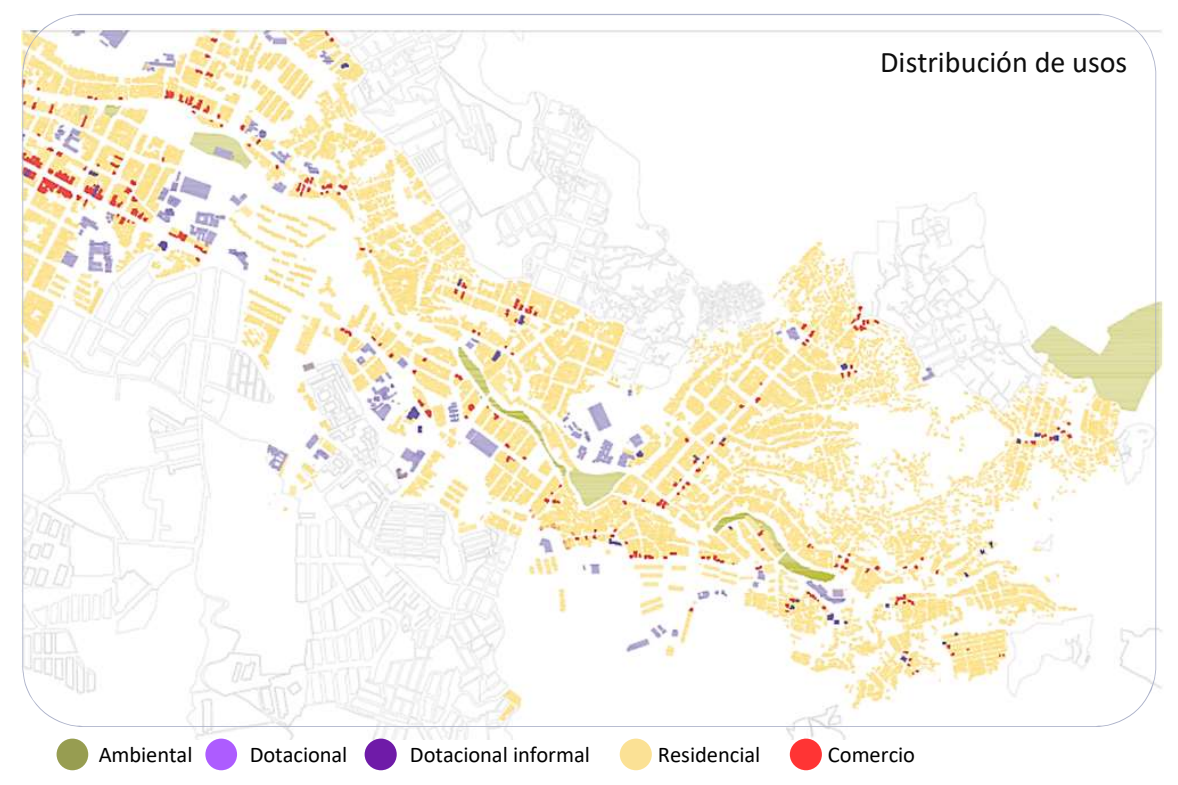

Fotografías de viviendas con comercio en primera planta
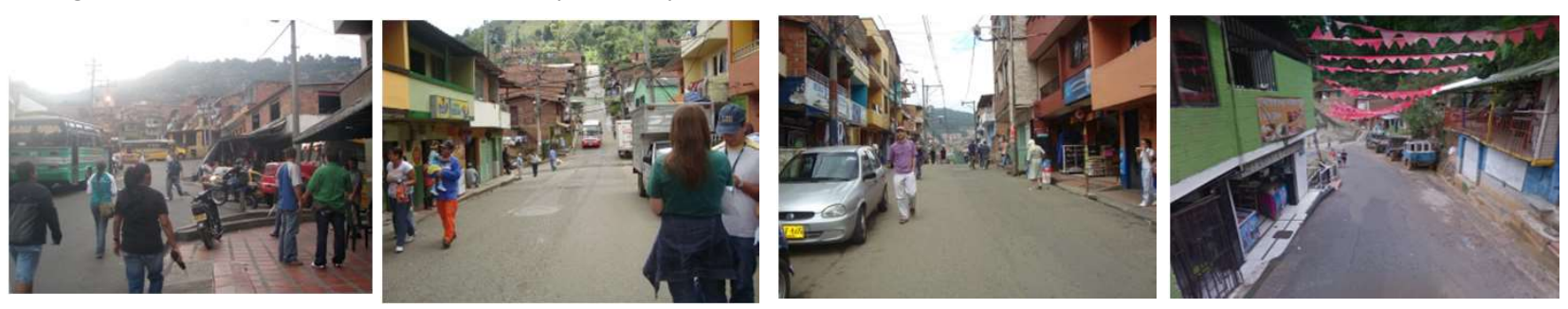

EI PUI Centroriental es el proyecto que más mezclas social abarca. Cuenta con un pequeño porcentaje de población de clase media ( $2 \%$ estrato 4 ), un gran porcentaje de clase pobre en sus umbrales más altos ( $33 \%$ estrato 3 y $45,55 \%$ estrato2) y un porcentaje menor de clase baja baja (19,54\% estrato 1$)$. Dicha población según su estrato socioeconómico tiene una ubicación muy concreta en el territorio: entre menor sean su estratificación más lejana será su ubicación frente al centro de la ciudad y más hacia la montaña, el cerro, estará ubicada.

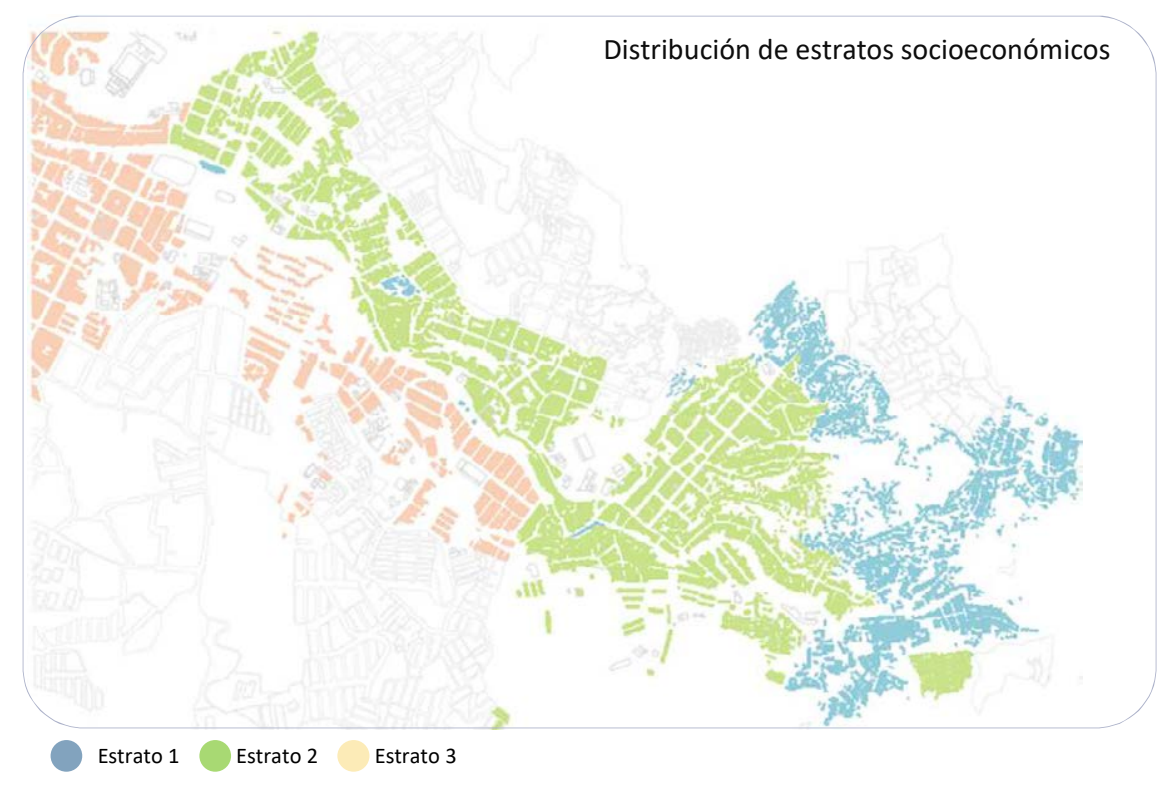




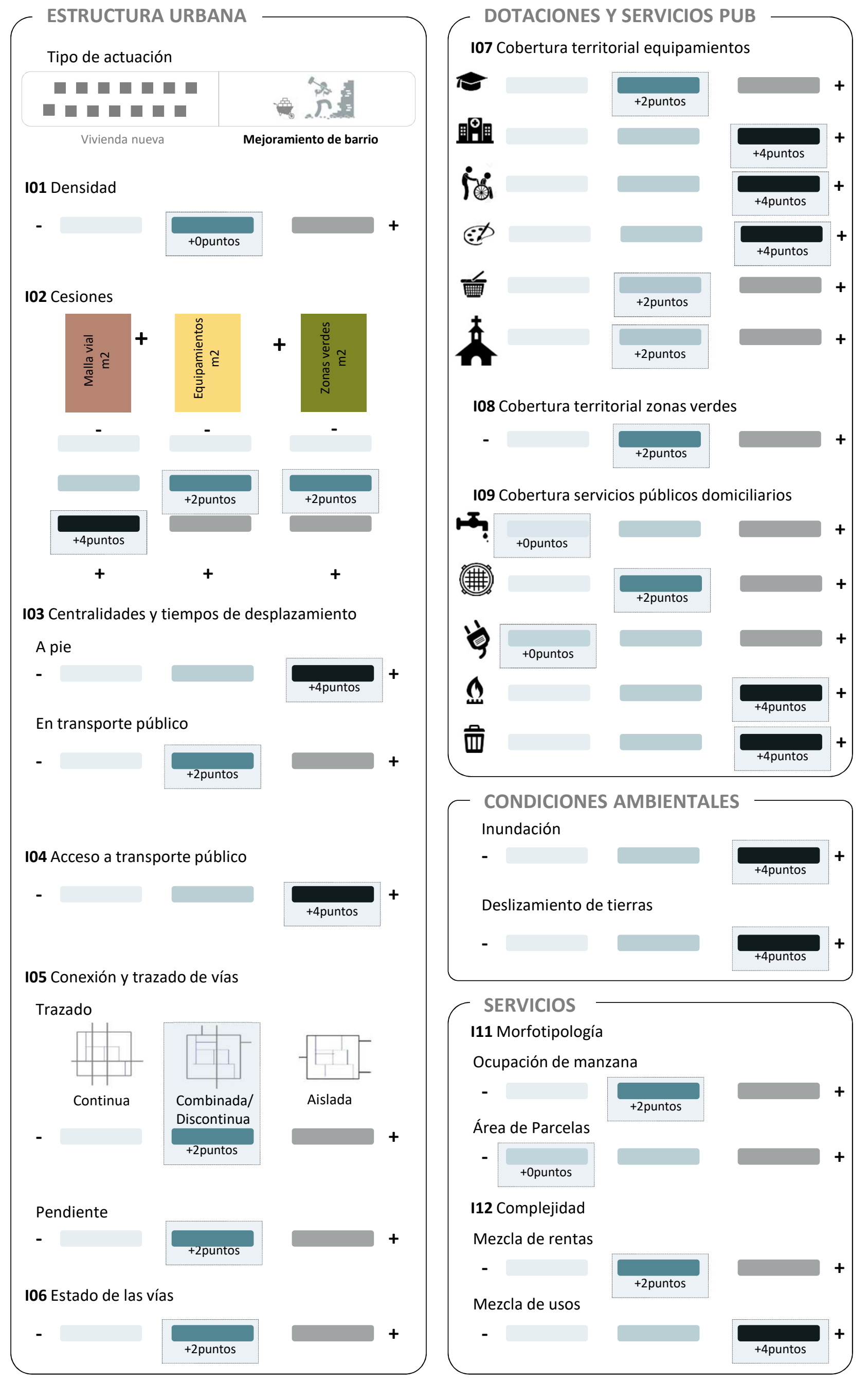




\section{INFORMES INSTITUCIONALES}

ALCALDÍA DE BOGOTA (2004) Encuesta de opinión sobre los resultados del Proyecto Sur con Bogotá. Bolonia-Ladrilleras-Vía oriente. Alcaldía mayor de Bogotá - Caja de Vivienda Popular.

ALCALDÍA MAYOR DE BOGOTÁ (2005) Diseño, desarrollo e implementación de un sistema de indicadores para el programa de Mejoramiento Integral de Barrios PMIB, SI-PMIB de la CAJA DE LA VIVIENDA POPULAR. Bogotá

ALCALDÍA MAYOR DE BOGOTÁ (2011) Una Reflexión sobre la producción de vivienda social en Bogotá 1998-2010. Secretaría Distrital del Hábitat. Metrovivienda. Bogotá

BANCO INTERAMERICANO DE DESARROLLO -BID (2013) Anexo 2 Indicadores de la Iniciativa Ciudades Emergentes y Sostenibles. Bajo la coordinación y supervisión de Carolina Barco, Luis Manuel Espinoza, David Maleki y Rebecca Sabo.

CENTRO DE ESTUDIOS DEL HÁBITAT POPULAR- CEHAP (1989) La calidad espacial urbana de los barrios para sectores de bajos ingresos en Medellín. Universidad Nacional de Colombia Sede Medellín, Facultad de Arquitectura. Centro de Investigaciones, Medellín

COALICIÓN INTERNACIONAL DEL HÁBITAT - HIC (2004) Indicadores de resultados e impactos. Metodología de aplicación en proyectos participativos del hábitat popular. Investigadores Rodríguez, M - Buthet, C - Scavuzzo, J - Taborda,

COMISIÓN ECONÓMICA PARA AMÉRICA LATINA Y EL CARIBE -CEPAL (2014) Aplicación de indicadores de sostenibilidad urbana la vivienda social. Documento elaborado en el marco de las Primeras Jornadas de Planificación Económica y Social 2013 organizadas por el instituto latinoamericano y del caribe de Planificación Económica y Social (ILPES). Santiago de Chile.

DEPARTAMENTO ADMINISTRATIVO DE PLANEACIÓN - DAP (2006) Documento técnico de soporte del Plan de Ordenamiento Territorial (Acuerdo 46/2006). Medellín

DEPARTAMENTO ADMINISTRATIVO DE PLANEACIÓN - DAP (2009) Documento técnico de soporte Resolución No. 0065 de 2009 Proyecto urbano Cor-Alta de regularización y legalización urbanística para los barrios La Sierra, Villa Liliam, Villa Turbay, Las Estancias, Juan Pablo II, Ocho de Marzo y Barrios de Jesus. Medellín

DEPARTAMENTO ADMINISTRATIVO DE PLANEACIÓN - DAP (2012) Plan Parcial de desarrollo en suelo de expansión: Pajarito. Documento técnico de soporte. Medellín

DEPARTAMENTO NACIONAL DE PLANEACIÓN (2007) Pobreza y servicios públicos domiciliarios. Misión para el diseño de una estrategia para la reducción de la pobreza y la desigualdad (MERPD) En red: https://www.dnp.gov.co/Portals/O/archivos/documentos/DDS/Pobreza/En_Que_Vamos/SERV ICIOS\%2OPUBLICOS.pdf [Consultado: 18/02/2014]

DANE (2005) Censo General 2005

DANE (2007) Encuesta de calidad de vida - Bogotá 2007. Bogotá 
DANE (2011) Encuesta multipropósitos - Bogotá 2011. Bogotá

DEFENSORIA DEL PUEBLO (2009) El derecho a una vivienda digno y adecuada en la constitución, la jurisprudencia y los instrumentos Internacionales de Derechos Humanos. Bogotá. Programas ProSeDHer.

DEFENSORIA DEL PUEBLO (2012) El derecho a una vivienda digna y adecuada. Evaluación de las condiciones del componente lugar en proyectos de vivienda de interés social (VIS) y viviendas de interés prioritario (VIP), en la ciudad de Bogotá. Bogotá. Programas ProSeDHer.

EMPRESA DE DESARROLLO URBANO - EDU (2002) Convocatoria al sector privado. Participación en el desarrollo de Ciudadela Nuevo Occidente. Resumen Ejecutivo. Documento inédito. Medellín

EMPRESA DE DESARROLLO URBANO - EDU (2011) Modelo de transformación urbana. Proyecto urbano integral en la zona nororiental y consolidación habitacional en la quebrada de Juan Bobo. Con participación de Agencia Francesa de Desarrollo y Universidad EAFIT. Medellín.

MVDP (2005) Formulación y aplicación de la ley 388 de 1997 en Colombia. Una práctica colectiva hecha realidad. Ministerio de Ambiente, Vivienda y Desarrollo territorial, UN Hábitat Colombia, PNUD Y Fedevivienda.

MINISTERIO DEL AMBIENTE, VIVIENDA Y DESARROLLO TERRITORIAL (2003) Recopilación de normas sobre vivienda. Dirección del Sistema Habitacional. Bogotá.

MINISTERIO DE DESARROLLO ECONÓMICO (1998) Metodología de diseño y evaluación de proyectos de vivienda de interés social. Viceministerio de Desarrollo Urbano. Dirección de vivienda, suelos y construcción. Bogotá.

ONU- COMITÉ DE DERECHOS ECONÓMICOS, SOCIALES Y CULTURALES (1991) Observación General No. 4. El derecho a una vivienda adecuada. Doc. e/1991/

PNUD (2015) Informe de Desarrollo del Milenio. Informe 2015. Naciones Unidad. Nueva York

SECREATERÍA DISTRITAL DEL HÁBITAT - SDHT (2009) Caracterización de la UPZ 51 Los Libertadores, Equipo de Gestores Locales de San Cristóbal, diciembre de 2007. Bogotá.

UN_HABITAT (2012) Urban Planning for city leaders. Nairobi, Kenya.

UN_HABITAT (2004) Indicadores Urbanos según la Agenda Habitat (ONU-HABITAT) Observatorio Urbano Global (GUO) - Rolac

UNIVERSITY COLLEGE LONDON. (2006) Suelo urbano y vivienda para la población de ingresos bajos. Estudios de caso: Bogotá-Soacha-Mosquera; Medellín y Área Metropolitana. Development Planning Unit - DPU

\section{PUBLICACIONES SOBE LA MATERIA}

ALGUACIL, Julio (1998) Calidad de Vida y Praxis urbana. Nuevas iniciativas de gestión ciudadana en la periferia social de Madrid. Edición publicada en el año 2000 por el Centro de Investigación Sociológica. Universidad Complutense de Madrid. 
ALVAREZ, Eva: FERNÁNDEZ GÜEL, José y SMITH, Harry (2015) Instruments for analysing urban conflicts in the global south: the case of urban transformation processes in Dakar. Revista Habitat International 49. Pág. 187-195.

APRIL-GNISET, Jacques (1992) La Ciudad colombiana. Banco popular. Bogotá.

BALLEN, Sergio (2009) Vivienda social en altura. Tipologías urbanas y directrices de producción en Bogotá. En revista Punto Aparte. Universidad Nacional de Colombia. Facultad de Artes. Bogotá

CAMINOS, Horacio y GOETHERT, Reinhardt (1985) Elementos de Urbanización. Editorial Gustavo Gili, Barcelona

CAPEL, Horacio (1998): "Una bibliografía para el estudio de la ciudad" Bilbio 3W. Revista Bibliográfica de Geografía y Ciencias Sociales. [En línea]. Barcelona. Universidad de Barcelona, No. 114, 17 de septiembre de 1998. http://www.ub.edu/geocrit/b3w-114.htm Recuperado: Septiembre de 2016

CAPEL, Horacio (2002): La morfología de las ciudades. Vol.I Sociedad, cultura y paisaje urbano. Barcelona: Ediciones del Serbal (Colección La Estrella Polar).

CAPEL, Horacio (2003): "A modo de introducción: los problemas de las ciudades. Urbs, civitas y polis". Número 3 de la Colección Mediterráneo Económico: "Ciudades, arquitectura y espacio urbano." Instituto de Estudios Cajamar

CASTELLS, Manuel (1979) Ciudad, democracia y socialismo. 2da ed. Siglo XXI Editores, México

CEBALLOS, Olga Lucía (2005) La evolución del planeamiento urbano en la configuración del espacios público del área periférica de Bogotá. Revista Bitácora No. 09 Pág. 17-26. Bogotá.

CEBALLOS, Olga Lucía, TARCHOPULOS, Doris y SALDARRIAGA, Alberto (2008) Vivienda social en Colombia: Una mirada desde su legislación. 1918-2005. Editorial Pontificia Universidad Javeriana. Bogotá

CEBALLOS, Juan Carlos (2016) ¿Los Macroproyectos de Vivienda Masiva solucionan los problemas de habitabilidad? Un acercamiento a la experiencia de Medellín con Ciudadela Nuevo Occidente. Universidad Nacional de Colombia. Sede Medellín.

CIUDADES PARA UN FUTUTO MÁS SOSTENIBLE. (2006). Proyecto de mejoramiento de barrios SUR con Bogotá (Colombia). Consultado en:

http://habitat.aq.upm.es/bpal/onu06/bp1323.html [21/06/2014]

CHOPLIN, A. (2017). Repenser les quartiers précaires pour penser la ville. En A. Deboulet, Repenser les quartiers précaires (pp. 265-269). Paris: Agence Française de Développement.

ECHEVERRÍA RAMIREZ, María Clara y RINCON PATIÑO, Análida (2000) Ciudad de territorialidades: polémicas de Medellín. Centro de Estudios de Hábitat Popular CEHAP de la Universidad Nacional de Colombia Sede Medellín

ESCALLON, Clemencia (2016) Cartilla de Indicadores. Observatorio de vivienda Departamento de Arquitectura. Universidad de los Andes. Bogotá 
EZQUIAGA, José María (1997) El proyecto del alojamiento: criterios de diseño, Revista oficial del Colegio de Arquitectos de Madrid, ISSN 0213-9391, № 30, 1997, pág. 6. Madrid

FIQUE, Luis Fernando (2006): Vivienda social en Colombia. Políticas públicas y habitabilidad en los años noventa. En revista Punto Aparte. Universidad Nacional de Colombia. Facultad de Artes. Bogotá

FRESNEDA, Oscar (1997) Déficit habitacional. Propuesta para su medición. Viceministro de Vivienda, Desarrollo Urbano y Agua Potable, Bogotá

FRESNEDA, Oscar (1998) Índice de calidad de vida. Sistema de necesidades alienadas. Cuadernos de Investigación y Estudios Monográficos. Observatorio de Cultura Urbana - IDCT. Bogotá.

HARVEY, David (1973) Urbanismo y desigualdad social. Siglo XXI de España Editores, S.A. Título original: Social Justice and the City. 7ạ edición.

HARVEY, David (2012) Rebel Cities: From the right to the city to the urban revolution. London. Verso

HERNÁNDEZ-AJA, Agustín (1997) La ciudad de los ciudadanos. Ministerio de Fomento Madrid

HERNÁNDEZ-AJA, Agustín (2006) Parámetros Dotacionales para la Ciudad de los Ciudadanos. Instituto Juan Herrera, Madrid.

HERNÁNDEZ-AJA, Agustín y SIMÓN-ROJO, M, (2011) Calidad de vida y medio ambiente urbano. Indicadores locales de sostenibilidad y calidad de vida urbana. Informe de la construcción. Volumen 63, EXTRA, 41-49

LOPEZ DE LUCIO, Ramón (1995): Los nuevos ensanches de Madrid: la morfología residencial de la periferia reciente 1985 - 1993. Gerencia Municipal de Madrid. Ayuntamiento de Madrid. Coautor con Hernández Aja, Agustín.

LOPEZ DE LUCIO, Ramón. (2004): “Morfología y características de las nuevas periferias. Nueve paisajes residenciales en la región Urbana de Madrid." Revista Urban 9 (invierno/ primavera): pág. 56-80

LOPEZ DE LUCIO, Ramón. (2012): Vivienda colectiva, espacio público y ciudad: evolución y crisis en el diseño de tejidos residenciales, 1860-2010. Editorial Nobuko. Madrid

MAX-NEEF, Manfred. ELIZALDE, Antonio. HOPENHAYN, Martín (2010) "Desarrollo a escala humana una opción para el futuro". Developement dialogue, número especial. CEPAUR y Fundación Dag Hammarskjöld. Suecia. 1986

MEJÍA-ESCALANTE, Mónica (2012) "Habitabilidad en la vivienda social en edificios para población reasentada. El caso de Medellín, Colombia" publicado en la revista EURE Vol. 38, No. 114, pág. 203-227.

MESA ESCOBAR, Julio (2012) Los lugares del hábitat como espacio de realización de los políticos y de la política pública a través del habitar: Una propuesta teórica para el análisis del hábitat en la Ciudadela Nuevo Occidente. Tesis de grado para optar al título de Magister en Hábitat. Universidad Nacional de Colombia. Sede Medellín. 
MONTANER, Josep Ma'; MUXÍ, Zaida y FALAGÁN, David (2011) Herramientas para habitar el presente. La vivienda del siglo XXI. Master laboratorio de la vivienda del siglo XXI. Universidad Politécnica de Catalunya. Barcelona.

REESE, Eduardo (2010) Presentación: "Urbanismo, configuración de la ciudad y mercados del suelo: efectos sociales y espaciales" en el Programa de Creación de Capacidades Institucionales Locales en Gestión del Suelo. Medellín.

MESA ESCOBAR, Julio (2012) Los lugares del hábitat como espacio de realización de los políticos y de la política pública a través del habitar: Una propuesta teórica para el análisis del hábitat en la Ciudadela Nuevo Occidente. Tesis de grado para optar al título de Magister en Hábitat. Universidad Nacional de Colombia. Sede Medellín.

MOSER, Caroline (1998) The Asset Vulnerability Framework: Reassessing Urban Poverty Reduction Strategies. WorldDevelopment 25(1). Pág. 1-19

ROMERO, Carolina (2013) El proyecto sur con Bogotá: Una estrategia de inclusión territorial y social. En revista Bitácora 23 (2). Universidad Nacional de Colombia

RINCÓN, Patricia (2006): Bogotá y sus modalidades de ocupación del suelo. Análisis de los procesos de re-densificación. En revista Punto Aparte. Universidad Nacional de Colombia. Facultad de Artes. Bogotá

PANERAI, Philipe (1999) Análisis Urbano. Titulado originalmente Analyse Urbaine. Edition Parenthèses. Marsella.

PERLMAN, J. (2017). Repenser les quartiers précaires: concepts et conséquences de la marginalité. En A. Deboulet, Repenser les quartiers précaires (pp. 41-60). Paris: Agence Française de Développement.

RUEDA, Salvador (1996) Habitabilidad y calidad de vida. Cuadernos de Investigación Urbanística No. 42. Escuela Técnica Superior de Arquitectura de Madrid.

RUEDA, Salvador (2012) Plan de Indicadores de Sostenibilidad Ambiental de la actividad Urbanística de Sevilla. Ayuntamiento de Sevilla.

SALDARRIAGA, Alberto, FONSECA, Lorenzo. (1982) Evaluación arquitectónica de los proyectos de vivienda hechos por el Estado en los últimos 20 años: Formulación y aplicación de un método en dos barrios de Bogotá. Bogotá: Universidad Nacional de Colombia, Centro de Estudios Ambientales, CEAM.

SAMPER, German (2003) La evolución de la vivienda. Colección Somosur. Editorial Escala, Bogotá.

SOLÀ-MORALES, Manuel (1997) Las formas de crecimiento urbano. Edicions de la Universitat Politècnica de Catalunya, SL. Barcelona

SOLÁ-MORALES, Manuel (2008) De cosas urbanas. Gustavo Gili, Barcelona.

TARCHÓPULOS, Doris y CEBALLOS, Olga (2003). Calidad de la vivienda dirigida a los sectores de bajos ingresos en Bogotá. En Prensa, Bogotá, Pontificia Universidad Javeriana, Instituto Colombiano para el Desarrollo de la Ciencia y la Tecnología (COLCIENCIAS), Banco Interamericano de Desarrollo, Centro Editorial Javeriano (CEJA). 
TARCHÓPULOS, Doris y CEBALLOS, Olga (2005). Patrones urbanísticos y arquitectónicos en la vivienda dirigida a los sectores de bajos ingresos en Bogotá. Bogotá, Pontificia Universidad Javeriana, Instituto Colombiano para el Desarrollo de la Ciencia y la Tecnología (COLCIENCIAS), Banco Interamericano de Desarrollo, Centro Editorial Javeriano (CEJA).

TORRES, Carlos Alberto, RINCÓN, John Jairo Y VARGAS, Johanna (2009) Pobreza Urbana y Mejoramiento integral de barrios en Bogotá. Hábitat y vivienda. Universidad Nacional de Colombia. Vicerrectoría Académica. Bogotá.

TORRES, Carlos Alberto y RINCÓN, John Jairo (2011) Suelo urbano y vivienda social en Bogotá: la primacía del mercado y el sacrificio del interés general, 1990/2010. Universidad Nacional de Colombia. Vicerrectoría Académica. Bogotá.

TORRES, Carlos Alberto (2012) Producción y transformación el espacio residencial de la población de bajos ingresos en Bogotá en el marco de las políticas neoliberales (1990 -2010). Premio Iberoamericano de Tesis de Investigación sobre vivienda sustentable. Infonavit Redalyc

VIVIESCAS, Fernando (1985) La calidad espacial urbana de los barrios para sectores de bajos ingresos en Medellín. Informa final de investigación para el Programa de Estudios de Vivienda en América Latina. Peval. Universidad Nacional de Colombia Sede Medellín

VELÁSQUEZ, Carlos (2011) Diagnóstico comunitario barrio Villa Turbay. Comuna 8 de Medellín. Mesa Interbarrial de desconectados. Corporación Paz y Futuro. Medellín.

VIDAL FERNÁNDEZ, Fernando (2009) Pan y rosas: fundamentos de exclusión social y empoderamiento. (Cáritas Española. Ed) Madrid: Fundación FOESSA.

\section{REFERENCIAS WEB}

Agustín Codazi Visor: http://geoportal.igac.gov.co:8888/siga_sig/Agrologia.seam

Buenas prácticas: http://habitat.aq.upm.es/dubai/98/bp490.html

Bogotá como vamos: http://bogotacomovamos.org

Departamento Administrativo Nacional de Estadística http://www.dane.gov.co/

Medellín como vamos: http://medellincomovamos.org

Medellín, las 10 mejores prácticas http://www.acimedellin.org/laboratoriomedellin/

Ministerio de Vivienda:

http://www.minvivienda.gov.co/Vivienda/ProyectoVISyVIP/Paginas/default.aspx

\section{- Bogotá}

Alcaldía Bogotá: http://www.alcaldiabogota.gov.co/sisjur/index.jsp

Secretaría del Hábitat Bogotá, Colombia: http://www.habitatbogota.gov.co/sdht/index.php

Instituto de Desarrollo Urbano: http://www.idu.gov.co

Secretaría Distrital de Planeación: http://www.sdp.gov.co/portal/page/portal/PortalSDP

Secretaría Distrital de Planeación. Estadísticas: http://portales.sdp.gov.co/section-192837.jsp

Secretaría Distrital de Planeación planoteca:

http://portel.bogota.gov.co/portel/libreria/php/frame_detalle_scv.php?h_id=23772 
Portal de mapas Bogotá: http://mapas.bogota.gov.co/geoportal/

Camacol Cundinamarca: http://www.camacolcundinamarca.co/

Metrovivienda: http://www.metrovivienda.gov.co/

Caja de vivienda popular: http://www.cajaviviendapopular.gov.co/

\section{- Medellín}

Alcaldía de Medellín: http://www.medellin.gov.co/irj/portal/medellin

Portal de viviendas VIS y VIP http://www.viviendasmedellin.com

Camacol Antioquia: http://camacolantioquia.org.co/

Portal de planos Medellín: http://poseidon.medellin.gov.co/geonetwork/srv/es/main.home

Instituto Social de Vivienda y Hábitat de Medellín: http://www.isvimed.gov.co

Departamento Administrativo de Planeación de Antioquia: http://www.antioquia.gov.co

Comfenalco Antioquia: http://www.comfenalcoantioquia.com

Empresa de Desarrollo Urbano: http://www.edu.gov.co/index.php/inicio.html 
API: $\quad$ Área prioritaria de intervención

AUI: $\quad$ Actuaciones urbanas integrales

BID: $\quad$ Banco Interamericano de Desarrollo

CAl: $\quad$ Comando de atención inmediata (policía)

CDESC: $\quad$ Comité de Derechos Económicos, Sociales y Culturales de las Naciones Unidas

CEPAL: Comisión económica para América Latina y el Caribe

DANE: Departamento Administrativo Nacional de Estadística

DAP: $\quad$ Departamento administrativo de Planeación. Medellín.

DNP: $\quad$ Departamento Nacional de Planeación

DPAE: $\quad$ Dirección de Prevención y Atención de Emergencias

EDU: $\quad$ Empresa de Desarrollo Urbano

IDH: Índice de Desarrollo Humano

ICV: $\quad$ índice de Calidad de vida

INSVIMED: Instituto de vivienda de Medellín

MAVDT: $\quad$ Ministerio de ambiente, vivienda y desarrollo territorial

MIB: $\quad$ Mejoramiento integral de barrio

ODS: $\quad$ Objetivos de Desarrollo Sostenible

OMS: $\quad$ Organización Mundial de la Salud

ONU: $\quad$ Organización de Naciones Unidad

PND: $\quad$ Plan Nacional de Desarrollo

POT: $\quad$ Plan de Ordenamiento Territorial

PUI: $\quad$ Proyectos Urbanos Integrales

SISBEN: $\quad$ Sistema de Identificación de Potenciales Beneficiarios de Programas Sociales

SDHT: $\quad$ Secretaría Distrital del Hábitat

SDP: $\quad$ Secretaría Distrital de Planeación

SFV: $\quad$ Subsidios familiar de vivienda

SMMLV: $\quad$ Salario mínimo mensual legal vigente que representa el ingreso devengado por los trabajadores.

UPZ:

Unidad de Planeación zonal

VIS: $\quad$ Vivienda de Interés social

VIP: $\quad$ Vivienda de interés prioritario

VN: $\quad$ Vivienda nueva 
Tabla 01 Comparación criterios de selección estudios de caso

Pág. 29

Tabla 02 Déficit de vivienda por estratos socioeconómicos en Bogotá, año 2000 .......................... Pág. 35

Tabla 03 Crecimiento asentamientos marginales por décadas Bogotá ............................................ Pág. 36

Tabla 04 Costo de vivienda (Tipo 1) Ciudadela el Porvenir, Bogotá ................................................. Pág. 44

Tabla 05 Costo de vivienda (Tipo 1) Ciudadela Nuevo Occidente, Medellín..................................... Pág. 44

Tabla 06 Soporte económico familias estudios de caso ................................................................. Pág. 50

Tabla 07 Procedencia población residente estudios de caso .......................................................... Pág. 51

Tabla 08 Equipamientos por UPZ Bogotá. Año 2005 ..................................................................... Pág. 57

Tabla 09 Distancia y tiempo de desplazamiento malla vial por estratos. Bogotá 2005 .................... Pág. 60

Tabla 10 Comparativo disposiciones normativas sobre tamaño de la vivienda social...................... Pág. 65

Tabla 11 Normas generales sobre los programas de vivienda social ............................................. Pág. 71

Tabla 12 Dimensiones del concepto Calidad de Vida ..................................................................... Pág. 78

Tabla 13 Principios de Higiene de la vivienda OMS ....................................................................... Pág. 83

Tabla 14 Derechos y obligaciones sobre la calidad de la vivienda ................................................. Pág. 87

Tabla 15 Densidades de población. Comparativa estudios de caso .............................................. Pág. 160

Tabla 16 Número de personas por vivienda. Comparación estudios de casos ............................... Pág. 161

Tabla 17 Porcentaje de la población en hacinamiento crítico. Comparación estudios de casos ...... Pág. 161

Tabla 18104 Proximidad de paradas de transporte público. Comparativa estudios de caso............ Pág. 165

Tabla 19106 Estado de las vías. Comparativa estudios de caso ..................................................... Pág. 167

Tabla 20107 Cobertura territorial de equipamientos. Comparativa estudios de caso .................... Pág. 168

Tabla 21107 Oferta educativa MIB El Lucero .................................................................................. Pág. 169

Tabla 22107 Oferta educativa PUI Centroriental ............................................................................. Pág. 170

Tabla 23107 Comparación de indicadores (POT) en Instituciones educativas PUI Centroriental .... Pág. 170

Tabla 24108 Zonas verdes. Comparativa estudios de caso .............................................................. Pág. 174

Tabla 25109 Cobertura servicios domiciliarios. Comparativa estudios de caso .............................. Pág. 175

Tabla 26 I11 Morfo-tipología: Etapas del proceso de formación ..................................................... Pág. 179

Tabla 27 I11 Grado de consolidación, materiales y alturas de las viviendas de los barrios de origen

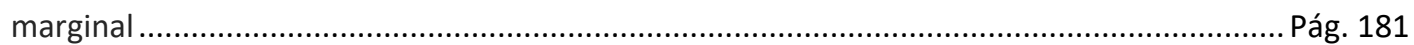

Tabla 28112 Comparativa diversidad de usos entre los seis estudios de caso.............................. Pág. 187

Tabla 29 Análisis relativo a la escala de ciudad ......................................................................... Pág. 188

Tabla 30 Análisis relativo a la escala de barrio-zona ................................................................. Pág. 189

Tabla 31 Análisis relativo a la escala de bloque-vecindario ........................................................... Pág. 191

Tabla 32 Entrevista realizada a residente de Ciudadela Nuevo Occidente ...................................... Pág. 193

Tabla 34 Entrevista realizada a docentes sobre Ciudadela Nuevo Occidente................................. Pág. 194

Tabla 33 Encuesta de opinión a los residentes del Proyecto MIB Sur con Bogotá.......................... Pág. 195

Tabla 35 Entrevista realizada a población residente en PUI Centroriental ..................................... Pág. 196 
Gráfico 01 Modelo de análisis básico

Pág. 22

Gráfico 02 Distribución porcentual de las formas de producción en materia de vivienda social ...

Pág. 34

Gráfico 03 Viviendas por tipo según estrato. Comparativa año 2004 y 2011

Pág. 39

Gráfico 04 Comparación costos de vivienda producción formal y marginal periodo de 15 años ..... Pág. 45

Gráfico 05 Sistema de Indicadores de UN-Hábitat (2004).

Pág. 91

Gráfico 06 Iniciativa de Ciudades Emergentes y Sostenibles del BID (2013).....

Pág. 95

Gráfico 07 Indicadores de Sostenibilidad Urbana Salvador Rueda - CEPAL

Pág. 97

Gráfico 08 Indicadores de Resultados e Impactos. HIC-AL (2004)

Pág. 100

Gráfico 09 Sistema Único de Monitoreo de Impacto. PMIB-CVP Bogotá (2005) ........................... Pág. 101

Gráfico 10 Sistema de Indicadores. РОT Medellín 2005

Pág. iError! Marcador no definido.

Gráfico 11 Metodología de diseño y evaluación de proyectos de vivienda de interés social. MINISTERIO

DE DESARROLLO ECONÓMICO (1998)

Pág. 108

Gráfico 12 Indicadores del modelo de evaluación realizado por la Defensoría del Pueblo. Bogotá (2012

Pág. iError! Marcador no definido.

Gráfico 13 Propuesta de indicadores en Calidad de la vivienda dirigida a los sectores de bajos ingresos en

Bogotá. TARCHÓPULOS, Doris y CEBALLOS, Olga (2003).

Pág. ¡Error! Marcador no definido.

Gráfico 14 Marco comparativo sobre ámbito destacado por cada iniciativa.

Pág. 118

Gráfico 15 Modelo de análisis

Pág. 123

\section{ÍNDICE DE PLANOS}

Plano 01 Ubicación casos de estudio Bogotá y Medellín

Pág. 24

Plano 2 Localización de asentamientos de origen marginal en Bogotá y Medellín. Acumulado año 2010 ...

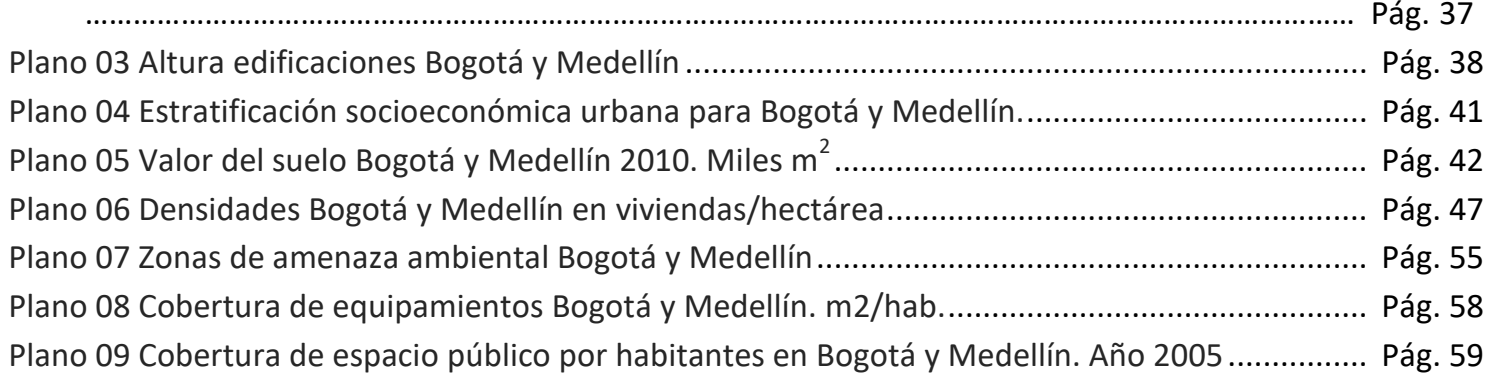

